\title{
DOCUMENTO
}

\section{RELATÓRIO DA EQUIPE DE ASSESSORIA DO PLANEJAMENTO DO ENSINO SUPERIOR (EAPES) - ACORDO MEC-USAID}

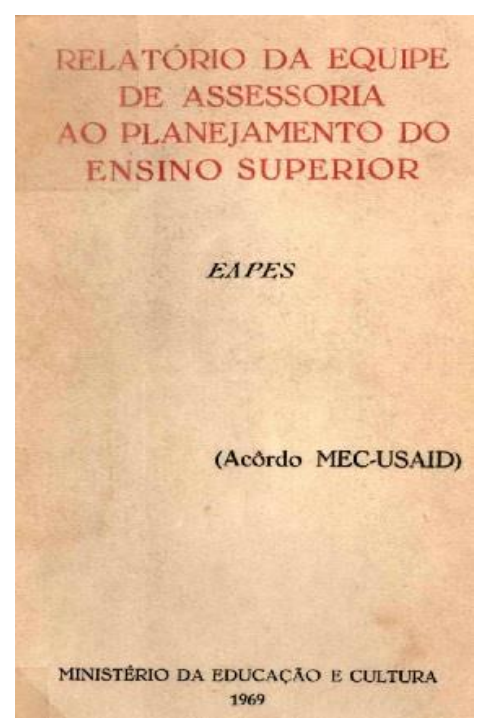

\author{
Zuleide S. Silveira \\ Universidade Federal Fluminense \\ Niterói, RJ, Brasil \\ DOI: https://doi.org/10.22409/mov.v7i14.47208
}

\section{Apresentação}

No Brasil dos anos 1960, ao terem início os trabalhos da reforma universitária, contava-se com um conjunto de subsídios, desde os estudos produzidos no plano internacional como, o Relatório Atcon - La Universidad Latino Americana Clave para un enfoque conjunto del desarrollo coordinado social, económico y educativo en América Latin, de 1961, e a mesa redonda Higher Education and Latin American Development, promovida pelo Banco Interamenricano de Desenvolvimento e realizada, no ano 1965, em Assunção, Paraguai, passando pelo conjunto de formulações da ainda genesíaca política de ciência e tecnologia (C\&T), até o Relatório Meira Mattos, os Acordos entre o Ministério da Educação e Cultura e a Agência Internacional dos Estados Unidos para o Desenvolvimento (MEC-USAID) e o Relatório da Equipe de Assessoria ao Planejamento do Ensino Superior (EAPES), entre outros. 


\section{movim nto \\ rograma de pós-graduação \\ faculdade de educação \\ ano 7 - número 14 - Edição Especial - 2020}

A reforma universitária, promovida pelo governo empresarial-militar, por meio da Lei ㄲo 5.540/1968, fixou normas de organização e funcionamento da graduação e pós-graduação, com base no modelo norte-americano de ensino superior, instituindo, entre outras medidas, o sistema de créditos, o regime semestral de curso com fragmentação curricular, a organização da universidade por departamentos especializados, além de dar continuidade à instrumentalização da pesquisa científico-tecnológica, "impulsionada pela CAPES e CNPq", direcionada por substanciais recursos do [Fundo Nacional de Desenvolvimento Científico Tecnológico/Fundo de Financiamento de Estudos e Projetos e Programas] FNDCT/FINEP" (LONGO, 2009, p. 5).

Embora tenha sido implantada sob a égide do Al-5, de 1968, a reforma universitária foi iniciada com a outorga do Decreto-Lei ํㅡㄴ 53, de 18 de novembro de 1966, que veio fixar os princípios e as normas de organização das universidades federais e distinguir a pesquisa básica da pesquisa aplicada, e, ainda, do DecretoLei oㅡ 252, de 28 de fevereiro de 1967, normatizador do antecessor Decreto-Lei no 53/66. Na prática, ela se desenvolvia desde os governos populistas a exemplo do trabalho da Comissão Supervisora do Plano dos Institutos (COSUPI), constituída para reformular o ensino de engenharia, por meio da Portaria ํo 102, de 28 de janeiro de 1958 (CUNHA, 1983).

Os referidos Decretos-Leis já respondiam aos Acordos MEC-USAID, assinados, desde os anos 1950, entre os governos brasileiro e estadunidense para

\footnotetext{
1 Nos anos 1950, as universidades públicas, já, vinham sendo consideradas peças-chave na construção da política científico-tecnológica nacional, quando foi criado o primeiro organismo destinado ao desenvolvimento da pesquisa, o Conselho Nacional de Pesquisa (CNPq), por meio da Lei $n^{\circ} 1.310$ de 15 de janeiro de 1951. A finalidade do CNPq foi assim definida: promover investigação científica e tecnológica por iniciativa própria e em cooperação com outras instituições do país e do exterior. É, também, desta época a criação da Comissão de Aperfeiçoamento de Pessoal de Nível Superior (CAPES), por meio do Decreto no 29.741 de 11 de julho de 1951, com vistas a assegurar o aperfeiçoamento de pessoal de nível superior no país, técnicos e cientistas, para atender à demanda potencial e crescente do desenvolvimento nacional. A Capes e o CNPq, complementando um ao outro, criaram as condições para a política pública de ciência e tecnologia na década seguinte. A principal diretriz era a de formar infraestrutura técnico-científica e massa crítica capazes de desenvolver matérias-primas e aumentar a produtividade industrial (SILVEIRA, $2011 ; 2020)$.
} 


\section{movim nto \\ revista de educação do \\ programa de pós-graduação \\ faculdade de educação \\ ano 7 - número 14 - Edição Especial - 2020}

estabelecer intercâmbio de conhecimentos técnicos, elaboração de planos e ações respeitantes ao desenvolvimento econômico do Brasil e à ampliação e reestruturação do sistema educacional brasileiro.

É neste contexto que, em 1965, Flávio Suplicy de Lacerda, ministro da educação e cultura, Stuart Van Dyke, Diretor da USAID no Brasil, Deolindo Couto, presidente do Conselho Federal de Educação (CFE) e Faria Góis, representante do Brasil para a Cooperação Técnica - Ponto IV, assinam o acordo para a reestruturação do sistema nacional de ensino superior e estabelecem a criação de um quadro de técnicos especialistas em planejamento educacional, formado por cinco brasileiros e cinco norte-americanos. Quadro de técnicos este que originou a Equipe do Planejamento do Ensino Superior (EPES), depois, denominada Equipe de Assessoria do Planejamento do Ensino Superior (EAPES).

O documento Relatório da Equipe de Assessoria do Planejamento do Ensino Superior (EAPES) - Acordo MEC-USAID, que ora incorporamos ao Dossiê 55 anos de Pós-Graduação no Brasil, apresentado oficialmente em 29 de agosto de 1968 e publicado em 1969, teve seu conteúdo e suas concepções mantidas pelo Grupo de Reforma Universitária, criado por Decreto n 62.937, de 2 de julho de 1968, pela relação estreita mantida entre aquela Equipe e o Grupo.

Nas suas quase setecentas páginas o Relatório não é apenas uma informação circunstanciada do trabalho desenvolvido pela EAPES. Nele é possível capturar as contradições pelas quais operam o desenvolvimento capitalista e a produção do conhecimento novo e inovador, bem como as disputas internas à Equipe e as concepções de organização e funcionamento das instituições de ensino superior, atualmente constituídas como um sistema articulado e hierarquizado de ofertas formativas de curta, média e longa duração.

Como a educação, na visão da Equipe, é requisito do desenvolvimento econômico capitalista, sendo dele coetânea e a ele ajustável, há uma convergência substantiva e inegável entre desenvolvimento econômico e desenvolvimento cultural. Não sem razão Antonio Gramsci aponta que uma reforma intelectual e 


\section{movim nto \\ revista de educação do \\ programa de pós-graduação \\ faculdade de educação \\ ano 7 - número 14 - Edição Especial - 2020}

moral não pode deixar de vincular-se a um programa de refirma econômica (GRAMSCI, 2007, p. 19).

A verdade é que existe enorme descontentamento com os sistemas existentes, e por isso se critica tudo, o ensino, os professores, os reitores, a cátedra vitalícia, a desvinculação entre a Universidade e a sociedade. Quase toda a gente se mostra disposta a declarar que o ensino no Brasil, e até no mundo, é obsoleto, anacrônico, ultrapassado, alienado, medieval. E a conclusão é que se impõe uma reforma radical e urgente do ensino. Todas essas críticas valem como meias verdades. Porque a solução não está apenas na reforma do ensino, mas numa reforma mais ampla da sociedade toda, dos jornais, do rádio, da televisão, dos métodos de trabalho, do funcionalismo todo, civil e militar, enfim, de nossas concepções de vida, da própria atmosfera filosófica da cultura ocidental. A luta contra os defeitos do sistema brasileiro de educação deverá ser uma luta em que esteja empenhado não apenas o Governo, mas a família brasileira, e sobretudo professores e alunos (BRASIL, 1969, p.32).

Trata-se, pois, de modificar a visão de parcela significativa da sociedade, particularmente a classe média, sobre o trabalho, a formação da força de trabalho para a inserção dependente, associada e subalterna ao processo de internacionalização da economia/tecnologia. Afinal, era momento de aplicar a Teoria do Capital Humano às políticas educacionais a serem promovidas pelo regime ditatorial.

A EAPES, ao examinar os problemas do ensino superior brasileiro toma a universidade norte-americana como modelo e estabelece uma relação estreita e linear entre educação e desenvolvimento econômico. Para a Equipe os gastos com a educação representam um investimento lucrativo na formação do capital humano, contudo, haveria que se entender que o governo federal dispõe de parcos recursos para priorizar a educação em seus investimentos, tornando-se necessário, por conseguinte, conclamar a sociedade civil organizada em torno do empresariado para resolver o problema do financiamento da educação:

A importância de determinado grau de ensino não se mede pela verba orçamentária. Educação nacional é um movimento de responsabilidade coletiva e solidária, conforme o têm proclamado inúmeros educadores brasileiros, como Anísio Teixeira e Carlos Pasquale. Tanto em suas raízes mais profundas quanto em suas especializações mais altas, a educação é o reflexo das forças íntimas que animam a sociedade. Não é o resultado apenas de esforços, mais ou menos espasmódicos, da classe política. A educação é talvez a expressão mais característica da vida de uma sociedade. E mesmo sem a escola pública, já houve áreas no Brasil em que não se encontrava um único analfabeto (BRASIL, 1969, p. 26). 


\section{movim nto \\ programa de pós-graduação \\ faculdade de educação \\ ano 7 - número 14 - Edição Especial - 2020}

Além deste aspecto, que trazia em seu bojo o incentivo à explosão de cursos na rede particular de ensino e a aproximação entre Estado, universidade e empresa privada, à universidade voltada para o desenvolvimento capitalista caberia potencializar as aptidões ou vocações humanas, diversificando a oferta formativa no nível superior de ensino.

Materializa-se, assim, nos trabalhos da EAPES, a proposta de Anísio Teixeira (1988) que toma como paradigma o modelo norte-americano de universidade moderna. Tal universidade, ao se construir a serviço do Estado e voltada para a solução de problemas, busca a formação de diferentes capacidades de trabalho: "um ensino relativamente simples e prático para a obtenção de graus correspondentes ao B.A. e ao B.S. americanos, e outro, rigoroso e exigente, para a obtenção de graus correspondentes ao M.A., M.S. e Ph.D." (BRASIL, 1969, p. 29).

A educação superior nos Estados Unidos - undergraduated - tem seus cursos distribuídos em áreas acadêmicas, caracterizados segundo sua duração: cursos superiores de curta duração (Associated Degrees) e Licenciaturas (Bachelors Degrees). Os diplomas conferidos aos concluintes dos cursos da área das ciências humanas e sociais são os de Bachelors Arts (B.A.) e os concluintes da área das ciências exatas recebem o Bachelors Science (B.S.). Seguindo o mesmo critério de divisão por área do conhecimento, os cursos de mestrado conferem os títulos de Master of Arts (M.A.) aos mestres formados na área das ciências humanas e sociais; e de Master of Science (M.S.) na área das ciências exatas. Há, ainda, o Master of Fine Arts (MFA), que engloba os cursos de Fotografia e Teatro, e o Master in Business Administration (MBA), mestrado profissional, com duração de, apenas, dois anos. Outros mestrados como o de jornalismo possuem, apenas, um ano de duração. Quanto aos cursos de doutorado, existem os profissionais que conferem o título de Professional Doctore, que ao contrário do doutorado acadêmico - research doctore (Ph.D.) -, não exige geração de 


\section{movimento \\ revista de educação do \\ programa de pós-graduação \\ faculdade de educação \\ ano 7 - número 14 - Edição Especial - 2020}

conhecimento novo por meio de pesquisa, tendo como exigência, apenas, o desempenho do doutorando em disciplinas e estágio.

$\mathrm{Na}$ realidade, o modelo de funcionamento e estrutura do ensino superior proposto pela EAPES, em franca oposição aos supostos cursos de longa duração e obsoletismo do conhecimento, é o que veio a ser materializado, no Brasil, a partir da segunda metade dos anos de 1990.

No que concerne o aumento do número de matrículas na rede privada de ensino, a EAPES vislumbra o que veio se materializar no Programa de Crédito Educativo (CREDUC), criado em 1975. Ao CREDUC veio se juntar o Fundo de Financiamento Estudantil (FIES), no ano 1999, e o Programa Universidade para Todos (PROUni), em 2004.

Quanto às Universidades particulares, deve ser estimulada sua fundação, prestandoIhes os governos auxílios, a fim de assegurar nela vagas para os alunos pobres. Mas só em casos extremos, verdadeiramente excepcionais, deverá o Governo encampálas ou federalizá-las, assumindo destarte a totalidade de seus encargos financeiros. Os recursos governamentais disponíveis devem ser empregados, sobretudo, no alargamento das Universidades oficiais existentes, pelo menos por enquanto. Em vez de fundar novas escolas ou encampar as particulares, o Governo deve aumentar a lotação de suas escolas superiores tradicionais (BRASIL, 1969, p.63).

A questão da ciência e tecnologia, tornada objeto de política governamental, foi explicitada no Plano Estratégico de Desenvolvimento que deu origem ao FNDCT, criado em 1969, com a finalidade de dar apoio financeiro aos programas e projetos desenvolvimento científico e tecnológico, contando com o apoio do BID.

Entretanto, bem antes da criação do FNDCT, a EAPES já evocava o ensino superior, particularmente a pós-graduação, a exercer papel estratégico na produção de C\&T e no processo de formação de pessoal altamente qualificado em regime de colaboração solidária entre Estado, empresa privada, e universidade.

Há que elaborar-se um programa de pós-graduação voltado para a solução de alguns dos mais graves problemas que dificultam o progresso brasileiro: a carência de pessoal docente de nível superior, o imperativo da abertura de novas fronteiras no domínio da pesquisa científica e de formação de pesquisadores de alto nível, a exigência de manter a investigação científica do país em nível compatível com os padrões científicos internacionais e, finalmente, a necessidade de um trabalho de 'reciclagem' para atualização de conhecimentos e técnicas dos profissionais graduados em escolas superiores. Urge assim promover uma política nacional de amplo incentivo à pesquisa científica nos diversos domínios do saber, a qual possa 


\section{movim nto \\ revista de educação do \\ programa de pós-graduação \\ faculdade de educação \\ ano 7 - número 14 - Edição Especial - 2020}

contar com o apoio solidário do trinômio Estado-Universidade-Empresa, de modo que atenda aos imperativos da segurança, da ciência e da produtividade" (BRASIL, 1969, p.175).

O princípio da autonomia universitária é visto "como força criadora da ciência, da técnica e dos valores mais altos da cultura universal", que afirmada na individualidade institucional, "assegura a liberdade na busca permanente de soluções pedagógicas sempre mais aperfeiçoadas" junto à empresa privada. Desse modo, a autonomia didática, administrativa, financeira e disciplinar, mais do que um simples status jurídico, deve ser visto como um atributo da comunidade universitária ao se associar de modo subordinado ao setor empresarial.

Para encerrar a apresentação do Documento, intitulado Relatório da Equipe de Assessoria do Planejamento do Ensino Superior (EAPES) - Acordo MEC-USAID, torna-se necessário evidenciar que, a concepção de universidade nele propugnada e suas orientações, cuja racionalidade instrumental ${ }^{2}$ se sobrepõe à racionalidade crítica e criadora, vêm marcando todo o processo de contrarreforma da educação superior, em curso, nesta temporalidade neoliberal.

Espera-se, pois, que a sua publicação venha contribuir para 0 aprofundamento de estudos em torno do tema da Educação Superior.

\section{Referências}

BRASIL. Ministério da Educação e Cultura. Relatório da Equipe de Assessoria ao Planejamento do Ensino Superior (Acordo MEC-USAID). Brasília: MEC: EAPES, $1969 . \quad$ Disponível em: http://www.dominiopublico.gov.br/download/texto/me002109.pdf

CUNHA, Luiz Antonio. A universidade crítica: o ensino superior na República Populista. Rio de Janeiro: Francisco Alves, 1983.

FERNANDES, Florestan. Universidade Brasileira: reforma ou revolução? São Paulo: Alfa-Ômega, 1975.

\footnotetext{
2 A universidade é vista, tão somente, como fator de desenvolvimento e de mudança dos padrões de dependência nos limites do capital (FERNANDES, 1975).
} 


\section{movim nto \\ programa de pós-graduação \\ faculdade de educação \\ ano 7 - número 14 - Edição Especial - 2020}

GRAMSCI, Antonio. Cadernos do cárcere. v.3. Maquiavel; Notas sobre o Estado e a política. 3.ed. Rio de Janeiro: Civilização Brasileira, 2007.

LONGO, Waldimir Pirró; DERENUSSON, Maria Sylvia. FNDCT, 40 anos. Revista Brasileira de Inovação. Campinas: UNICAMP; FINEP, v. 8, no 2, 2009, pp. 515533.

SILVEIRA, Zuleide Simas da. Concepções de educação tecnológica na reforma da educação superior: finalidades, continuidades, e rupturas - estudo comparado Brasil e Portugal (1995-2010). Tese (Doutorado em Educação). Niterói: UFF, 2011. Disponível em: https://marxismo21.org/wpcontent/uploads/2015/07/TESE-FINAL-Zuleide-Silveira.pdf

SILVEIRA, Zuleide S. concepção burguesa de educação tecnológica, desenvolvimento econômico e política de ciência, tecnologia e inovação. Revista Trabalho, Política e Sociedade, v. 05, n. 08, p. 95-117, jan.-jun., 2020.

TEIXEIRA, Anísio. Educação e universidade. Rio de Janeiro: EdUFRJ, 1988.

\section{SOBRE A AUTORA}

ZULEIDE S. SILVEIRA é doutora em educação pela Universidade Federal Fluminense (UFF), com doutoramento intercalar na Universidade de Lisboa e mestra em Educação pela Universidade Federal Fluminense (UFF), professora da Faculdade de Educação e dos Programas de PósGraduação (lato sensu e stricto sensu) em Educação da Universidade Federal Fluminense, coordenadora do Grupo de Pesquisa Estado, Trabalho, Educação e Desenvolvimento: pensamento crítico latinoamericano e tradutibilidade de Antonio Gramsci (GPETED/UFF), editorachefe da Movimento-Revista de Educação da UFF e membro do Fórum da Gestão do Ensino Superior nos Países e Regiões de Língua Portuguesa, com sede em Lisboa.

E-mail: zuleidesilveira@gmail.com

Recebido em: 18.11.2020

Aceito em: 20.11.2020 


\section{RELATÓRIO DA EQUIPE DE ASSESSORIA AO PLANEJAMENTO DO ENSINO SUPERIOR}

\section{EAPES}

(Acôrdo MEC-USAID)

MINISTÉRIO DA EDUCAÇÃO E CULTURA 1969 


\title{
MINISTÉRIO DA EDUCAÇÃO E CULTURA
}

\author{
DIRETORIA DO ENSINO SUPERIOR
}

\author{
RELATÓRIO DA EQUIPE \\ DE ASSESSORIA AO PLANEJAMENTO DO ENSINO SUPERIOR \\ - E A P E S - \\ (Acordo MEC-USAID)
}

Professores:

$$
\begin{aligned}
& \text { José Fernando Domingues Carneiro } \\
& \text { Laerte Ramos de Carvalho } \\
& \text { Osmar Ferreira } \\
& \text { Rubens d'Almada Horta Porto }
\end{aligned}
$$

Rio de Janeiro, 30 de junho de 1968. 
«A influência da instrução geral sobre os interesses econômicos, sobre a situação financeira e, até, em um grau pasmoso, sobre a preponderância internacional e a grandeza militar dos Estados, é, presentemente, uma dessas verdades de evidência excepcional, que a história contemporânea atesta com exemplos admiráveis e terríveis lições.»

«Se quereis sair das detestáveis tradições, que não conhecem outro recurso para aumentar a renda, senão multiplicar os impostos, cumpre fecundar a nação nas fontes vivas de sua riqueza: na sua inteligência e nas suas qualidades morais, que do desenvolvimento do ensino dependem primordial e absolutamente. Este o mais produtivo emprego das forças do erário nacional, cujos recursos, despendendo-os neste ramo de serviços, não consumis, antes capitalizais a juros multiplicáveis ao infinito.» 


\title{
APRESENTAÇÃO
}

\author{
"Uma palavra serena num debate apaixonado". \\ LEONEL FRANCA (em O Divórcio)
}

Não será exagerado dizer que o problema universitário está, hoje, entre os três ou quatro mais graves que lançam o seu desafio a administradores e a homens públicos de todo o mundo.

Bom é que assim seja.

Porque na tranquilidade dos ambientes universitários não isentos i o;?; certeza da paixão pela verdade e do entusiasmo pelo bem comum todos os angustiados problemas que se põem hoje a Humanidade encontrarão aquela atmosfera de luminosa serenidade a que se referia $o$ sábio LEONEL FRANCA (membro do Primeiro Conselho Nacional de Educação, até sua morte); e que permitirá a procura, dolorosa e extenuante, sem dúvida, da verdade esquiva.

No Brasil, país novo e ainda titubeante na procura dos rumos que o hão de levar a seus destinos gloriosos, é natural que as elites. não suficientemente amadurecidas, encontrem dificuldades maiores $c$ mais rudes obstáculos, a sua difícil tarefa de definir um sentido exato. para a evolução mais adequada do nosso processo social e econômico.

Ora. a Universidade - se possui com certeza outras finalidades - tem como uma das suas principais missões a de preparar lideres que sejam capazes de sentir, no turbilhão das aspirações mal definidas do povo, as diretrizes certas que o conduzam pelas estradas luminosas do futuro que merece.

A verdade, porém, é que hoje, em quase todo o mundo, a Universidade não se está mostrando à altura dessa tremenda tarefa.

Daí os inevitáveis e universais conflitos entre os moços que sentem a necessidade de uma solução, mas não a enxergam, na sua natural inexperiência; e os mais antigos, cuja prudência não lhes permite sugerir respostas improvisadas e cujas naturais tendências para a manutenção da lei e da ordem dificultam-lhes. às vezes, a visão mesma do problema angustiante.

A essa pesada missão de compreender o mundo contemporâneo $e$ de ajudá-lo a se encontrar a si mesmo, no encontro dos seus destinos, junta a Universidade outras a que não poderá fugir. 
O preparo da elite dirigente e a elaboração do pensamento que a norteie não bastam, se não houver executantes de alto nível que façam com que esse pensamento se encarne, na execução realista de um plano de vida nacional.

E é o que as instituições universitárias procuram conseguir com o preparo de profissionais superiores, indispensáveis a execução dos programas mais altos que tenham origem nos campos bem semeados das Universidades.

A essa múltipla tarefa não se esquivou o Governo.

E por diferentes caminhos tem buscado, a duras penas, dar aos problemas universitários brasileiros uma solução brasileira.

Uma das modalidades que tentou foi a da organização de uma Equipe de Assessoria que ajudasse os técnicos dos quadros normais da Administração na feitura de um plano realista (talvez melhor: de um diagnóstico) para o nosso ensino superior.

A equipe, reformulada por três ou mais vezes, em face das dificuldades pessoais dos que a compunham, contou sempre com a competência, o sadio patriotismo dos professores e técnicos que nela trabalharam.

Contou, também, numa colaboração eficaz e, às vezes mal entendida, com o concurso de outra equipe, esta constituída de cinco notáveis professores norte-americanos que, em virtude de Convênio financiado pela USAID no Governo do honrado Presidente Marechal HUMBERTO CASTELLO BRANCO, vieram trazer à busca da solução do problema $c$ subsídio valioso de sua incontestável experiência.

Nunca se pretendeu, como o terão pensado alguns mal informados, que a êles se quisesse dar uma posição antipática do magister que dixit c não permite réplica. Foram eles próprios os primeiros a reconhecer, com realismo e como afirmam no seu relatório preliminar, que "as sensíveis e profundas diferenças de temperamento e de mentalidade" existentes entre o meio brasileiro e o meio norte-americano "condicionam necessariamente e forçam soluções diversas e eventualmente contraditórias".

$\hat{E}$ certo, contudo, que existe um substratum humano comum a todos os povos: e é nessa base de humanismo essencial que a colaboração dos ilustres representantes das Universidades americanas pôde trazer aos mestres brasileiros contribuição muito valiosa, que é de estrita justiça aqui assinalar.

O Relatório da Equipe de Assessoria do Planejamento do Ensino Superior (EAPES) que agora se publica \{incluídos Os trabalhos originais dos professores estrangeiros) dá, nas suas quase setecentas páginas, uma notícia circunstanciada dos estudos feitos e das contribuições apresentadas. 
Nele se verá de início um histórico da Equipe atual (a EAPES) e da que a antecedeu (a EPES).

Em seguida, examinam-se as relações entre educação e desenvolvimento. Não se considerará apenas o assunto no sentido estrito que se dá, às vezes, à expressão "desenvolvimento", considerando-o, na forma simplista do autor da Wealth of Nations como um quarto elemento do capital fixo das nações, ao lado da "terra melhorada pela drenagem e pelos fertilizantes". . Encara-se aí a Educação num plano mais alto e, digamo-lo, menos terra a terra, como fator que leve ao desenvolvimento integral do homem brasileiro em terras do Brasil. $E$ verifica-se o modo como as despesas correspondentes têm sido consideradas nos nossos orçamentos públicos ou particulares.

Cabem no mesmo grupo as considerações sobre as relações entre a "cultura geral e a cultura profissional"._ E, apenas para mostrar que às vezes é possível dizer coisas sérias sorrindo, vale citar um trecho do Relatório quando pergunta: "como iremos medir a importância econômica da Casa Grande e Senzala, de GILBERTO FREYRE $O U$ $d a$ Rosa do Povo. de CARLOS DRUMMOND DE ANDRADE ?"...

Ao estudar, em seguida, mais detidamente os "recursos para a Educação", o Relatório mostra que, ao contrário do que às vezes se terá dito, as nossas falhas educacionais não se devem apenas ao fato de serem mal gastos os recursos destinados a fins educativos.

$O$ que há, sobretudo, é que esses recursos são deficientíssimos.

Nem é de admirar que assim aconteça, se se lembra, como o Relatório o observa, que em 1966, o orçamento total da União foi de 4.700 milhões de cruzeiros novos, quando a cidade de Nova York tinha para despender anualmente, na mesma ocasião, mais de 8.000 milhões (quer dizer: pouco mais terá tido o Brasil do que a metade do que coube a Nova YORK!)

Estuda-se depois um pouco do que tem sido a história do ensine superior e universitário em nosso país. Segundo o Relatório, as nossas Escolas superiores mais antigas são as duas de Medicina criadas em J808, em Salvador e no Rio de Janeiro, e a de Engenharia, que se iniciou dois anos mais tarde na capital do país.

Quanto a Universidades — sete vezes seculares $\mathrm{cm}$ outras terras - entre nós só teriam começado na do Paraná, em 1912, e na do Rio de Janeiro, em 1920.

Aborda depois e assinala alguns dos problemas que se vêm pondo aos que estudam o novo ensino superior:

a) a "Fundação" que poderá ser um fator na solução, mas que está longe de se apresentar como panaceia que ponha o "doente" curado de todos os males:

b) o "mercado de trabalho profissional" sobre o qual, aliás, está este Ministério, em colaboração com a Fundação Getulio Vargas, promovendo um inquérito de surpreendentes resultados; 
c) sobre a relação entre a Universidade e o ensino superior $(o$ qual não é senão um, c talvez não o mais importante dos objetivos universitários);

d) sobre a questão cruciante do processo de admissão às escolas pelo clássico 'vestibular" (que poderá - o que é muito discutível, aliás - selecionar os melhores alunos, mas seguramente não escolherá os melhores futuros profissionais);

e) a revisão dos currículos, quando hoje já se começa a pôr $\mathrm{cm}$ dúvida a necessidade mesmo de currículos-padrões;

f) a instituição do sistema departamental, no intuito de criar subunidades que contribuam para fortalecer uma unidade mais geral:

g) a instituição da pós-graduação, ótima ideia, ainda muito mal definida e que poderia ser gravemente prejudicada com péssima e ameaçadora aplicação;

h) as difíceis relações entre Estado. Universidade e Empresa;

i) enfim, uma série de problemas que percorrem mais ou menos todo o horizonte da educação universitária e superior em nosso pais.

$O$ Relatório é fruto de um trabalho de equipe; e traduz, naturalmente, a média das opiniões dos que cooperaram na Assessoria.

Não tem pretensão de ser obra perfeita: tem, contudo, o valor que. sem falsa modéstia, deve ser assinalado, representar o esforço consciente, refletido, ponderado de quantos nele colaboraram.

Ao entregá-lo ao estudo dos competentes c dos interessados, é justo que se manifeste ao Departamento de Imprensa Nacional o reconhecimento sincero de todos pela maneira como se desincumbiu com zelo c perfeição, da parte gráfica do Relatório.

NOTA IMPORTANTE - Do relatório, ora publicado e apresentado oficialmente cm 29 de agosto de 1968, foi, antecipadamente, dada ciência ao Grupo de Reforma Universitária, criado por Decreto $\mathrm{n}^{\circ}$ 62.937, de 2 de julho de 19(68; e. posteriormente, muitas das sugestões nele contidas se transformaram em decisões do Governo, vivamente empenhado na Reforma do Ensino Superior no Brasil. 


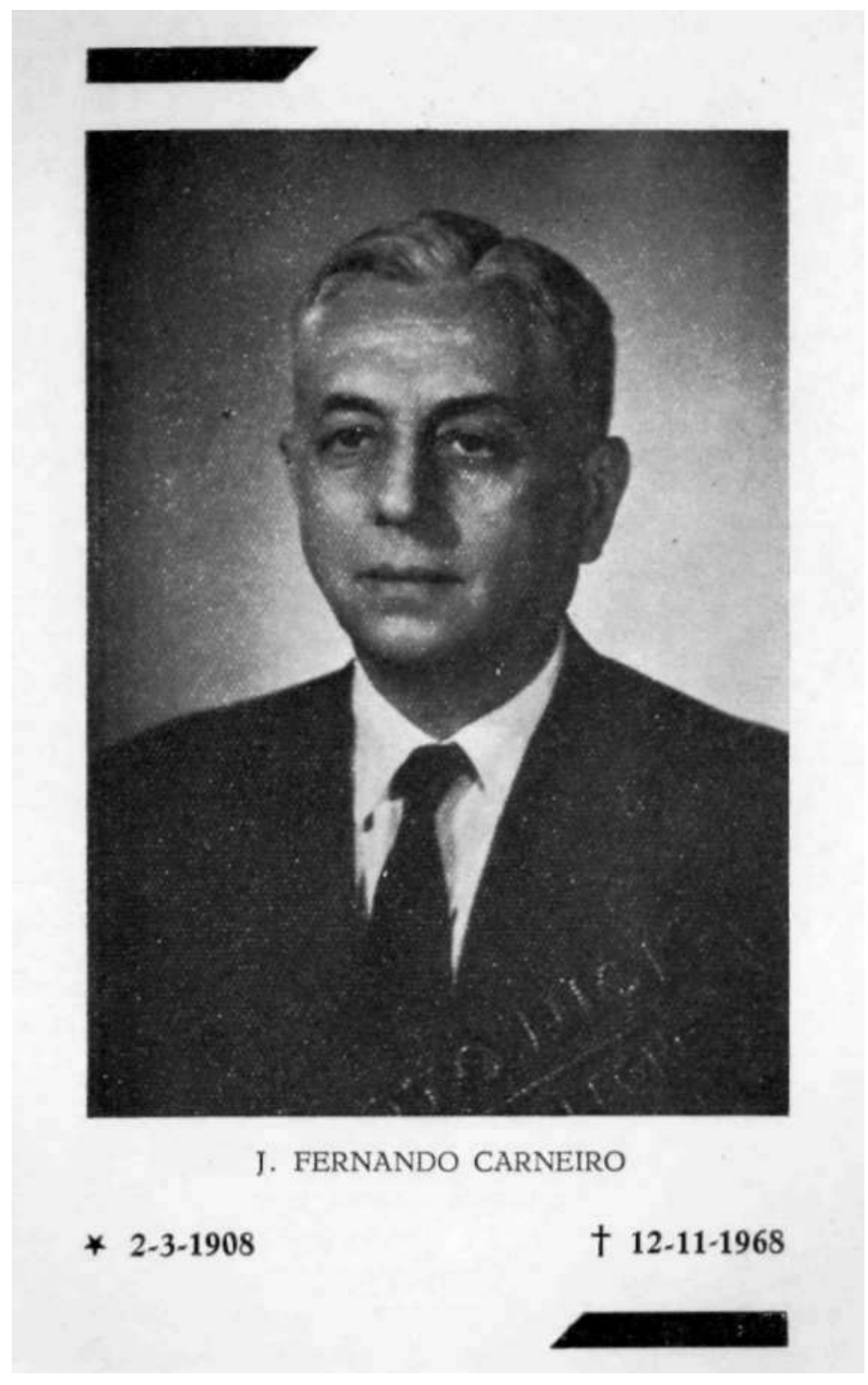




\title{
"IN MEMORIAM"
}

\author{
PROF. JOSÉ FERNANDO DOMINGUES CARNEMO \\ $2.3 .1908-\mathrm{t} \quad 12.11 .1968$
}

Esperou-a serenamente.

Quando sentiu-a aproximar-se, olhou-a nos olhos, e sorriu-lhe aquele misterioso sorriso que tinha para os amigos.

Porque a Morte não foi para êle uma intrusa, ou uma estranha.

Como médico, estava habituado a encontrá-la cada dia.

Como cristão convicto, sabia que, ao invés de aparecer como a catástrofe final que assusta a quase todos, era apenas um episódio. uma simples passagem, dolorosa, quem sabe. mas tão rápida, do tempo ã eternidade.

Parece mesmo, segundo narram as crónicas, que êle marchou ao encontro da grande ceifadora.

Sentindo em Porto Alegre - na sua clarividência clínica - que era Ela que chegava, e estando em pane o elevador do Hospital da Cirurgia Torácica, que com raro brilho dirigia, subiu - sabe Deus - (só Êle o saberá) - com que esforço cardíaco - dois lances de escada para procurar o sacerdote que lá estava em permanência.

Com êle, preparou-se para a passagem definitiva.

E, menos de uma hora depois. J. Fernando Carneiro ficava inconsciente, para vir a morrer, como vivera; silenciosamente, tranquilamente, cristãmente.

Assim desaparecia do cenário intelectual de nossa terra uma de suas mais belas e altas expressões.

O jeito, discreto e tímido que era o seu, não terá permitido ao juizo primário das multidões despreparadas, sentir nele os fulgores de uma inteligência excepcional e criadora.

Todos, porém, quantos tiveram o privilégio de seu convívio, sabem com que luminosa clareza êle sabia todo um mundo de coisas.

Era acima de tudo um scholar, um humanista. 
Era mestre na sua especialidade, na ciência médica. A sua tese sôbre Tuberculose e Gravidez fêz época. Seus estudos sobre a cirurgia do tórax mostram como era atilado o seu saber, num ramo ainda tão novo da Medicina.

Não era, porém, um especialista de antolhos. E sua curiosidade, seu carinho pelas cousas do espírito estendiam-se a toda uma extensa gama colorida de temas intelectuais.

Assim é que, para abrir os olhos distraídos que só admiram aos que se sabem fazer admirar, escreveu uma Apresentação de Jorge de Lima, na qual estuda, quase o diríamos clinicamente, a lírica admirável e profundamente brasileira do poeta da Nega Fulo.

Numa obra de vários colaboradores, faz uma bela Evocacão de Gcorges Bernanos , mostrando o génio daquele que, seu grande e particular amigo, foi, talvez, o maior romancista francês deste século.

Num de seus derradeiros trabalhos, estuda a difícil Psicologia do Brasileiro , mostrando mais uma vez como o seu espírito voltado para as coisas universais aterrava raízes profundas na alma de nossa gente.

Vale a pena ler seu Discurso de Paraninfo do curso de Medicina, pelo que tem de saboroso e de sábio.

Foi esse homem admirável que, no crespúsculo já de sua vida, trouxe uma inestimável e marcante, para não dizer excepcional, colaboração à Equipe de Assessoria e Planejamento do Ensino Superior (EAPES-MEC).

É com emocionado carinho que aqui lhe manifestamos o nosso reconhecimento sincero - nós todos seus colegas de Equipe, seus auxiliares tão carinhosamente por êle tratados; e a nossa imorredoura e fraternal saudade.

RUBENS PORTO

Agosto - 1969

Nota biobibliográfica do Prof. J. FERNANDO CARNEIRO, em anexo. 


\section{NOTA BIOGRÁFICA DO PROF. JOSÉ FERNANDO DOMINGUES CARNEIRO}

- nascido em Fortaleza (Estado do Ceará) em 2 de março de 1908.

- curso secundário feito no Ginásio Municipal de Lorena (São Paulo) e concluído em 1925 - obteve o Prémio Artigas, instituído pelo Governo uruguaio para o aluno que obtivesse melhores notas durante o curso secundário, no respectivo Ginásio.

- formado em Medicina pela Faculdade Nacional de Medicina (Rio de Janeiro) em 1931.

- Professor contratado de Tisiologia da Faculdade de Medicina de Porto Alegre a partir de 1954.

- Doutor em Medicina e Docente livre pela Faculdade de Medicina de Porto Alegre, a partir de 1960.

- Catedrático de Tisiologia da Faculdade de Medicina de Porto Alegre, a partir de 1967.

— Tisiologista do ex-IAPC (hoje INPS), desde 1940.

\section{CURSOS FREQUENTADOS NO ESTRANGEIRO}

- Curso Pós-Graduação Full-Time no Instituto of Diseascs of the Chest, em Londres, 1953.

Curso de Pós-Graduação no Cheshire Joint Sanatorium, em Market Drayton, em maio de 1953.

- Curso de Pós-Graduação no Instituto of Diseases of the Chest, em Londres, 1964.

\section{ESTÁGIOS}

- Estágio no Brompton Hospital for Consumption and Diseases of the Chest. em Londres, em 1943, como bolsista do British Council.

- Estágio no Brompton Hospital for Consumption and Diseases of the Chest, em Londres, em 1953, como bolsista do Conselho Nacional.

- Viagem de estudos realizada em 1964:

— Estágio de três meses (janeiro, fevereiro e março) no Brompton Hospital for Consumption and Diseases of the Chest, em Londres.

— Estágio de um mês no Serviço do Prof. KOURILSKI (Hospital Saint Antoine) em Paris, maio.

- Estágio de um mês no Tuberulose Forchungsinstitut Borstcl, Borstel Uber, Bad Odesloe, Alefiianha, junho.

— Estágio de uma semana no Serviço do Prof. John Crofton (City Hospital) em Edimburgo, Escócia, julho. 


\section{PRÉMIOS MÉDICOS}

- Prémio Clemente FerReira, da Sociedade Brasileira de Tuberculose, em 1945.

- Premio OTÁVIO MANGABEIRA, do Instituto Brasileiro para Investigação da Tuberculose, pelo seu trabalho Aneurismas Ventriculares de Etiologia Tuberculosa, em 21 de fevereiro de 1959.

- Premio SOCIEDAde RIOGRANDENSE DE TUBERCUlose E DOENÇAS DO TÓRAX, instituído para o melhor trabalho sul-riograndense apresentado ao XI Congresso Nacional de Tuberculose, realizado em novembro cie 1961, em Porto Alegre. Foi premiado o trabalho Valor da pesquisa direita do bacilo no escarro para o diagnóstico da cura da tuberculose pulmonar tratada.

\section{ALGUMAS ATIVIDADES FORA DA MEDICINA}

- Prcs'dente da Comissão de Consolidação das Leis de Imigração, nomeado pelo Presidente do então INIC, em 1955. Os demais membros da Comissão foram ORLANDO VALVERDE C Padre FERNANDO BASTOS dAviLA.

- Frequentou o Ciclo de Estudos das Bases para o Estabelecimento de uma Doutrina de Segurança Nacional, realizada pela ADESG no período de 14.9.64 a 24.10.64, em Porto Alegre.

- Presidente da Comissão Organizadora do $1^{\circ}$ Colóquio de Estudos TeutoBrasileiros, realizado em Porto Alegre, de 24 a 30 de julho de 1963, sob os auspícios da Universidade Federal do Rio Grande do Sul, com a participação de representantes dos Estados c de diferentes paises.

- Conferencista convidado pela Escola Superior de Guerra, onde falou em 1966, sobre Psicologia do Povo Brasileiro.

- Conferencista convidado em 1965, 1966 e 1967 para pronunciar conferencia sobre Saúde Pública c Segurança Nacional no $2^{\circ}, 3^{\circ}$ e $4^{\circ}$ Ciclo de Estudos promovidos pela ADESG em Porto Alegre, resoectivamente em 1965, 1966 e 1967.

Falecido em Porto Alegre, Rio Grande do Sul, cm 12 de novembro de 1968. 


\section{NOTA BIOBIBLIOGRÁFICA DE JOSÉ FERNANDO DOMINGUES CARNEIRO}

Antropofagia entre os indígenas do Brasil, publicado pelo MEC, cm 1946.

Catolicismo, Evolução e Reação, Livraria AGIR Editora, em 1947.

"Imigração e Colonização do Brasil", publicação avulsa $\mathrm{n}^{\circ} 2$ da Faculdade Nacional de Filosofia - Universidade do Brasil, em 1950.

"Rui Barbosa", "Conferências", publicação da Casa Rui Barbosa, em 1954.

Apresentação de Jorge de Lima. Livraria AGIR Editora, em 1955.

Conversa amarga. Organização Simões Editora, em 1958.

"Eutanásia", publicação do Instituto de Filosofia da Universidade do Rio Grande do Sul, em 1959.

Karl von Koserítz. pelo Instituto Estadual do Livro, Porto Alegre, em 1959.

"A luta antituberculosa no Brasil", em Anais da Faculdade de Medicina de Porto Alegre, em 1959.

Tuberculose e Gravidez (tese de Docência livre), para a Universidade Federal do Rio Grande do Sul, em 1959.

Evolução e Ensino da Tisiologia, Livraria do Globo, em 1960.

Discurso de Paraninfo, na Universidade Federal do Rio Grande do Sul, cm Porto Alegre, em 1962.

'Psicologia do BrasileiTo", em revista Organon, no ${ }^{\circ}$, FFUF do Rio Grande do Sul (e em avulso), em 1967.

Evocação de Georges Bernanos (com outros). Editora Vozes, em 1968. 


\section{ÍNDICE}

\section{TOMO I}

Págs.

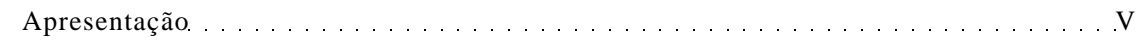

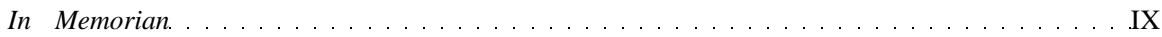

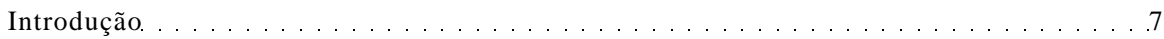

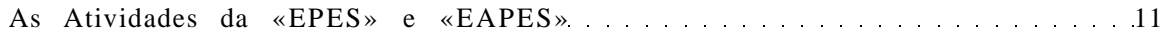

I - Prolegômenos e Acordos . . . . . . . . . . . . . . . . . . 11

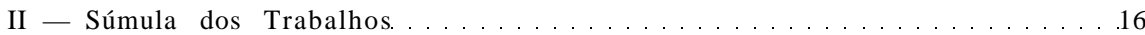

III - Aspectos Administrativos . . . . . . . . . . . . . . . . . . . . 20

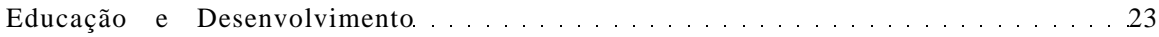

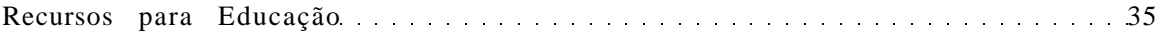

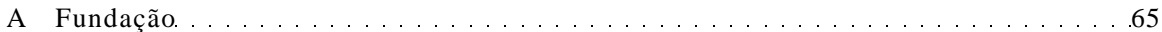

O Mercado de Trabalhe Profissional ..............................

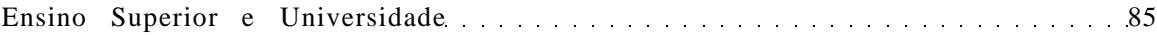

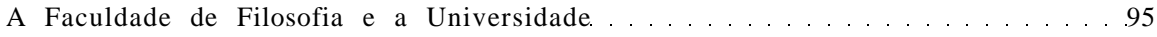

A Faculdade de Filosofia e a Formação do Magistério ............ 99

A Universidade e a Lei de Diretrizes e Bases. . . . . . . . . . . . . . . . . 107

A Expansão do Ensino Superior . . . . . . . . . . . . . . . . . . . . 113

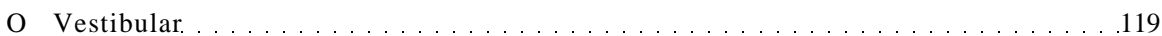

A Revisão dos Currículo; . . . . . . . . . . . . . . . . . . . . . . 153

A Instituição do Sistema Departamental . . . . . . . . . . . . . . . 155

A Organização dos Cursos Integrados . . . . . . . . . . . . . . . . . 171

A Criação, na Administração Centra! de Serviços de Aconselhamento

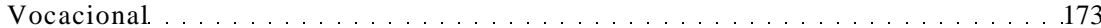

A Redefinição do Período Letivo ..................................... 175

O Papel do Trinômio Estado-Universidade-Emprésa . . . . . . . . . . . . . . . 177

A Instituição de Cursos de Pós-Graduação . . . . . . . . . . . . . . . . . . . . . 179

Uma Comissão Permanente de Assessoramento - a DASu. . . . . . . . . . 181

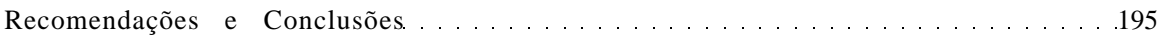

Apreciação Sumária dos Trabalhos da Equipe Americana . . . . . . 197

TOMO 11

ANEXOS - Integra dos Trabalhos da Equipe Americana, textos em português. em inglês e outros trabalhos. 


\section{TOMO I}

\section{INTRODUÇÃO}

A Equipe de Assessoria ao Planejamento do Ensino Superior EAPES - apresenta agora o resultado dos trabalhos que pôde realizar.

Acredita ter conseguido mais do que fora lícito esperar, pois o tempo de que dispôs foi bastante curto: menos de um semestre.

Por outro lado, quantos já tenham estudado o assunto, sabem como, em nossa terra, a documentação que a êle se refere é desigual, escassa sobre certos dados, copiosa sobre certos aspectos e às vezes até contraditória.

Juntando a tudo isso a complexidade extraordinária da questão e o fato de estar posta de novo em debate toda a problemática educacional, no Brasil como alhures, compreende-se quão extensa e árdua era a tarefa; e pode-se avaliar o que representa de esforço continuado, de pesquisa cuidadosa, de ponderada reflexão o que se conseguiu, em tão pouco tempo, realizar.

Evitou a Equipe limitar-se a uma simples reunião de opiniões diversas, de pareceres divergentes. Tentou fazer obra una e coerente. Seria despropositado tratar da universidade com uma multiplicidade de concepções que viriam dificultar ainda mais o entendimento do assunto.

Foi justamente uma das missões mais difíceis da Equipe, a de procurar distinguir, nos depoimentos diversos, o que neles havia de realmente comum, uma vez que todos visavam a um só e mesmo objetivo: reformular, entre nós, o conceito e a concepção da Universidade e do ensino superior.

Procuramos fazer surgir da diversidade das opiniões uma Universidade ideal, para cuja gradativa obtenção possam ser reunidos os esforços de todos quantos se interessam pela solução real do difícil problema.

Observe-se, aliás, que na realidade não havia apenas um. problema a equacionar: múltiplas eram as questões discutidas e discutíveis.

Que papel deve a Universidade desempenhar no desenvolvimento do País, rompendo aquele «soberbo isolamento» que para ela sonhavam alguns dos eleitos e aristocratas da cultura? 
Que recursos serão necessários para tornar realidade uma solução que não pode ser apenas mais um volume na vasta e empoeirada prateleira dos projetos que nunca passaram de projetos?

Definidos os recursos necessários, onde buscá-los, entre as aperturas reais ou simplesmente alegadas, que se procuram opor muitas vezes aos programas educacionais no País?

Será a Fundação uma fórmula, mais ou menos mágica, que. com sua varinha de condão, transforme e multiplique a escassez das verbas e das contribuições destinadas ao ensino?

Será ela a libertadora dos grilhões burocráticos, administrativos e políticos, que entravam, segundo muitos, toda a ação verdadeiramente criadora na obra universitária?

Para que a educação represente de fato um elemento propulsor do desenvolvimento econômico, como reagirá em relação a ela o mercado de trabalho, exigindo ou recusando os egressos da escola? Entre nós não raro se confunde o chamado ensino superior com o desejado ensino universitário. Pergunta-se: a Universidade é apenas um aglomerado de faculdades, mais justapostas do que integradas? Ou será ela antes um processo inverso, isto é, algo uno que se diversifica em faculdades várias?

Como se põe realmente o nevrálgico problema das Faculdades de Filosofia? Qual é nelas a função puramente cultural e qual a função. realmente importante, de uma espécie de escola normal superior, em que se prepara o magistério para o ensino de nível médio?

Uma vez que não se pode, cartesianamente, fazer tábua-rasa do que já existe, que lições se aproveitam da tentativa, em larga escala. traduzida na Lei de Diretrizes e Bases?

Como se deve expandir o ensino superior? Como será mais útil controlar essa expansão, evitando paradoxos como este, por exemplo, de sobrarem médicos nos grandes centros e não haver médico algum em centenas de municípios do interior? Como este, de faltarem engenheiros para a indústria em expansão e um terço dos engenheiros formados não exercerem Engenharia?

De que modo abrir as escolas superiores aos que a ela se candidatam? Serão os chamados «vestibulares» o meio adequado para escolher, não apenas os mais capazes no momento, mas sobretudo os mais aptos no futuro? Feita a escolha, como encarar o problema dos «excedentes», em torno do qual tanto rumor se faz?

Admitido o aluno à escola, será que esta lhe fornece, através de seus currículos, os meios capazes de prepará-lo profissionalmente, e de prepará-lo para o ensino ou para pesquisa? 
Que pensar do sistema departamental, que para muitos é a fórmula para estabelecer a integração do ensino e da pesquisa e evitar o desperdício dos esforços e recursos pedagógicos?

Como deveríamos conceber os «cursos integrados»?

Dada a importância da vocação no sucesso de qualquer atividade. não será de prever a criação ou a intensificação de serviços de aconselhamento vocacional, para orientar a ignorância ou a ingenuidade tão frequente nos que procuram a Universidade?

Como definir o período letivo, de modo que seja realmente «letivo» e «período», ao invés de se batizar com essa expressão o que não passa de algum semestre espalhado pelos doze meses do ano e sem a correspondente carga horária?

E o grave problema da intercomunicação de Estado, Universidade e Empresa, e o da participação solidária na vida da comunidade?

Dada a extensão prodigiosa da gama de conhecimentos e a sua rápida evolução no tempo, como atender a uma e a outra com os chamados «cursos de pós-graduação», estimulando-lhes a indispensável difusão e impedindo, ao mesmo tempo, a proliferação de cursos de inferior qualidade?

Não seria também o caso de examinar a possibilidade de tornar permanente a ação vigilante de uma comissão de assessoramento, capaz de sugerir eficazmente à administração do ensino um sentido dinâmico e criador?

São estes, entre muitos, os problemas que estudamos, valendo-nos da colaboração de inúmeros técnicos no assunto, bem como dos ilustres educadores americanos que nos vieram trazer o concurso de sua experiência e de seu conhecimento.

Esperamos ter cumprido satisfatoriamente nossa tarefa.

Valha ela como um elemento a mais na tentativa de solução daquele que é talvez o desafio mais grave lançado hoje à capacidade realizadora dos dirigentes nacionais. 


\section{AS ATIVIDADES DA "EPES" E "EAPES"}

\section{I _ PROLEGÔMENOS E ACORdos}

Acordos entre o Governo do Brasil e a USAID para assessoramento americano aos técnicos brasileiros encarregados de estudar uma reforma de ensino superior.

1. Parece-nos conveniente, antes de fazer rapidamente o estudo dos trabalhos resultantes do Acordo entre o MEC e a USAID. apresentar um ligeiro resumo histórico relativo ao assunto, desde os seus primórdios, em 1950, até o momento atual (julho de 1968).

Fa-lo-emos numa enumeração cronológica, que poderá ser explicitada com a documentação que acompanha este relatório.

Temos assim:

1.1 - 19 de dezembro de 1950 - Acordo geral entre os Governos do Brasil e dos Estados Unidos para estabelecer «o intercâmbio de conhecimentos técnicos e a cooperação em atividades correlatas» visando a «contribuir para um desenvolvimento equilibrado e coordenado dos recursos econômicos e da capacidade produtiva do Brasil». O Acordo foi feito por meio de uma troca de notas entre o Ministro do Exterior do Brasil Raul Fernandes e o Embaixador dos Estados Unidos Herschell V. Johnson, e constitui, no género, o primeiro documento que liga o incentivo cultural externo (troca de conhecimentos) ao desenvolvimento econômico do país.

1.2 - 30 de maio de 1953 - «Acordo sobre Serviços Técnicos Especiais entre ó Governo dos Estados Unidos e o do Brasil» (Ministro João Neves da Fontoura e Embaixador Walter M. Wahnsley) estabelecendo o fornecimento pelo Governo americano ao Governo brasileiro «de serviços técnicos e especializados em qualquer setor de atividades que se relacione com o desenvolvimento econômico do Brasil», «sempre que este o solicitar e (o Governo americano) concordar». Este Acordo completa o de dezembro de 1950. 
de junho de 1965 - Acordo entre a USAID, o Ministério da Educação («atuando através da DESu») e o representante do Brasil para a Cooperação Técnica (Ponto IV). Este Acordo tem como finalidade «a elaboração de uma série de planos exequíveis para a ampliação e reestruturação do sistema nacional de ensino superior» e medidas correlatas; inclusive a «criação de um quadro de técnicos em planejamento educacional brasileiro» e «o contrato pela USAID com instituição técnica competente dos E.U.A., de 5 assessores educacionais (americanos! para trabalhar com o grupo de educadores brasileiros. durante um período de 24 meses». Assinaram este Acordo, muitas vezes designado especialmente como «MEC-USAID». o Ministro Flávio Suplicy de Lacerda. o Diretor da USAID no Brasil, Stuart Van Dyke, o Presidente do CFE, Prof. Deolindo Couto ( $«$ ad referendum» do plenário do Conselho) e o Prof. Faria Góis (Ponto IV).

de junho de 1965 - O Acordo é enviado ao Conselho Federal de Educação para opinar. Pareceres do Conselho Federal de Educação:

«... somos de parecer que nenhum impedimento existe contra a participação do Conselho no convênio proposto». as) José Barreto Filho (Presidente), Newton Sucupira (Relator), Péricles Madureira de Pinho, António Almeida Júnior e Abgar Renault.

Parecer 604/65, da Câmara de Planejamento, aprovado em 15/6/65:

«... cabe a esta Câmara opinar favoravelmente quanto ao mérito, por envolver solução de alto interesse.»

as) Clóvis Salgado (Presidente), Celso Kelly (Relator) e José Borges dos Santos. Foi feita a ressalva de que a execução dos projetos dele resultantes «sejam dependentes do seu aproveitamento pelos órgãos competentes do ensino brasileiro», como o CFE, os Conselhos Universitários e em última instância o Ministro da Educação». O Convênio resultante é de 23 de junho de 1965.

de setembro de 1965 - Termo Aditivo ao Acordo de junho de 1965. especificando que os 5 educadores brasileiros previstos neste Acordo terão seus nomes submetidos à ratificação do $\mathrm{CFE}$, ao $\mathrm{q}$ ual serão também submetidos «os planos e recomendações apresentados pela EPES, Equipe de Planejamento de Ensino Superior». Esse Termo foi assinado pelo Ministro Flávio Suplicy de Lacerda, pelo Diretor da USAID no Brasil. Stuart Van 
Dyke, pelo Presidente do CFE. Prof. Deolindo Couto, e pelo Prof. Joaquim Faria Góis Filho, Representante do Brasil junto ao Ponto IV.

16 - janeiro de 1966 - A USAID informa ao Diretor do Ensino Superior que as negociações «para designar os componentes americanos da Equipe de Planejamento do Ensino Superior estão praticamente concluídas».

1.7 - 7 de janeiro de 1966 - Carta do Diretor da DESu, Professor Raimundo Moniz de Aragão, ao Diretor do Departamento de Recursos Humanos da USAID no Brasil, Dr. Rosson L. Cardwell, manifestando o interesse na «chegada dos 5 educadores americanos» cuja «indicação foi cometida ao Midwest Consortium». e dizendo que «está tomando as providências que lhe competem, entre as quais o recrutamento de elementos brasileiros, de alto nível, que participarão do programa, os quais serão, em maioria, professores universitários».

1.8 - 18 de janeiro de 1966 - Seção I do Diário Oficial - Despacho do Presidente da República para o Ministério da Educação e Cultura:

Autorização para efetuar despesas decorrentes dos Convênios firmados entre o MEC e a USAID, «visando a proporcionar assistência técnica aos Conselhos e Secretarias Estaduais de Educação, no preparo e reformulação. em articulação com as Universidades brasileiras, do Ensino Superior do País».

1.9 - Os estudos para a criação de um órgão que execute o Acordo são feitos pelo Diretor do Ensino Superior, juntamente com os Professores Roberto Figueira Santos e Paulo Ernesto Tolle.

1.10 - 3 de agosto de 1966 - A Diretora da DESu, Profa. Ester de Figueiredo Ferraz, envia ao CFE uma lista de nomes para constituírem a EPES: Professores Roberto Figueira Santos, José Gomes de Campos, Fernando Correia Rebelo, Paulo Ernesto Tolle e Flávio Penteado Sampaio, e mais outros colaboradores: Profs. Rubens Mário Garcia Maciel, Newton Sucupira, Valnir Chagas, Peri Pinto Dinis da Silva, Lindolfo de Carvalho Dias, José Artur Rios, Alberto Luís Coimbra e Heloísa Biasoto Mano.

1.11 - 4 de agosto de 1966 - Aprovadas as indicações pelo CFE, comunica a Diretora da DESu que «não puderam as pessoas em sua maioria aceitar o convite que lhes foi dirigido, «devido à exigência da dedicação integral e ao salário reduzido». 
1.12 - 1966/1967 - Indicação pela USAID, de acordo com o Midwest Consortium, dos educadores americanos previstos no Acordo «MEC-USAID»: Profs. Henry W. Hoge. John D. Ryder, J. M. Klotsche e John M. Hunter.

1.13 - 3 de fevereiro de 1967 - Portaria do Ministro Raimundo Moniz de Aragão aprovando as Instruções para o funcionamento da Equipe de Planejamento do Ensino Superior (EPES) e integrando nela «os termos do Acordo de 23/6/1965». As Instruções declaram que a «EPES contará com, pelo menos, 5 educadores brasileiros, capazes de realizar os trabalhos neles previstos».

1.14 - 2 de março de 1967 - Portarias designando o Prof. Paulo Ernesto Tolle e mais os membros do CFE, Profs. Roberto Figueira Santos, Valnir Chagas, Rubens Mário Garcia Maciel e Newton Sucupira para prestarem serviços na EPES «em regime de tempo parcial, sem salários e recebendo jetons de $\mathrm{NCr} \$ 30,00$ » por sessão (e diárias quando fora da residência) .

1.15 - 2 de março de 1967 - Portaria designando a Prof' Maria Aparecida Pourchet Campos para prestar serviços na EPES (já vinha trabalhando no assunto desde 26 '1 67) sem receber qualquer salário.

1.16 - 14 de março de 1967 - Portaria designando o Prof. Gastão Dias Veloso para integrar como sénior a EPES a tempo parcial e salário mensal de $\mathrm{NCr} \$ 500.00$.

1.17 - fevereiro c março de 1967 - Contratação do Pessoal Administrativo: Edi Salvador Canetti, Secretário-Geral (salário mensal de NCr\$ 600,00); Renée Carasso, Estenógrafa bilíngue (salário mensal de NCr\$ 600,00); Jacques Rocha Veloso, Tradutor Bibliotecário (salário mensal de .... NCr\$ 500,00); Hilda Cirino Rockenbach, Doméstica (salário mínimo) e Heyder Cirino Rockenbach. Servente (salário mínimo) .

1.18 - março de 1967 - Relatório da Diretora da DESu. Professora Ester de Figueiredo Ferraz, dando as informações resumidas nos itens anteriores sobre a contratação de pessoal; informando que «anteriormente a DESu» contratou o Prof. José Artur Rios e equipe do Instituto de Estudos para o Desenvolvimento Social e Econômico - INED. para realizar um levantamento geral relativo às Universidades do Brasil.

1.19 - 9 de maio de 1967 - Novo «Convênio da Assessoria ao Planejamento do Ensino Superior» assinado pelo Ministro 
Tarso Dutra, pelo Diretor da USAID no Brasil. Ministro Stuart Van Dyke, pelo CFE (Prof. António Ferreira de Almeida Júnior) e pelo Representante do Brasil no Ponto IV (Prof. Joaquim Faria Góis Filho), que reformula o anterior. O Convênio declara que «o MEC delega à DESu atribuição para executar o Convênio» e concorda em designar «pelo menos 4 educadores brasileiros de alto nível para constituir o Grupo Permanente de Planejamento junto à DESu». O Convênio substituiu o de 23 de junho de 1965 (item 1.4) e era para ter vigência até 30 de junho de 1969 «podendo ser cancelado pela DESu e pela USAID mediante comunicação prévia com antecedência de 30 dias».

1.20 - maio c junho de 1967 - Nomeação da Equipe de Assessoria ao Planejamento do Ensino Superior-EAPES (substituindo a EPES), integrada pelos Professores Ernesto Luís de Oliveira Júnior, Heitor Herrera, João Paulo de Almeida Magalhães, Paulo Accioly de Sá e Rubens dAlmada Horta Porto.

1.21 - maio. junho c julho de 1967 - Demitem-se sucessivamente da Equipe os Profs. João Paulo de Almeida Magalhães (18/5/67), Heitor Herrera (6/7/67), Paulo Accioly de Sá (30/6/67) e Ernesto Luís de Oliveira Júnior (19 de julho de 1967).

.22 - O Prof. Rubens d'Almada Horta Porto, que se manteve a pedido do Sr. Ministro da Educação e Cultura, solicita a nomeação de uma nova Equipe brasileira, e reitera sua necessidade junto à DESu, o que é feito em 23 de janeiro de 1968.

1.23 - janeiro de 1968 - Nomeação da $3^{\mathrm{a}}$ Comissão brasileira composta dos Professores Hermínio Pessoa, José Fernando Domingues Carneiro, Laerte Ramos de Carvalho. Osmar Ferreira e Rubens d'Almada Horta Porto. Dela se afastou o Prof. Hermínio Pessoa, em 3/6/68, por motivos particulares.

2. O atual Governo, com anuência da USAID/Brasil, resolveu alterar, ampliar e substituir o Convênio original, depois de aprofundado estudo, cm que ficou patente que nada havia contra os interesses nacionais.

3. As alterações e a ampliação e substituição do Convênio original obedeceram à necessidade de:

a) colocar o convênio dentro das diretrizes da Nova Política Educacional Brasileira; 
b) concretizar os compromissos do Governo Brasileiro na Carta de Punta del Este; anterior;

c) dirimir algumas interpretações erróneas provocadas pelo texto

d) estudar a experiência positiva de outros centros educacionais;

e) resolver os problemas técnicos e administrativos que estavam dificultando o convênio, para colocá-lo em funcionamento efetivo.

4. A finalidade do Convênio de Assessoria ao Planejamento do Ensino Superior, esclarecendo mais uma vez, é a de assessorar otrabalho da Diretoria nos seus esforços para atingir a expansão e o aperfeiçoamento, a curto e a longo prazo, do sistema de ensino superior brasileiro, através de processo de planejamento que torne possível a preparação e a execução, por parte das autoridades brasileiras, de programas com o objetivo de atender às crescentes necessidades deste setor.

5. Isto significa que:

a) o Ministério criará um Grupo Permanente de Planejamento, composto unicamente de educadores brasileiros;

b) somente às autoridades brasileiras caberá determinar, com» sempre, a politica e as normas da Educação, aprovar ou não todos os planos elaborados, e executá-los quando aprovados;

c) o Ministério, através da USAID/Brasil, contratará com instituição norte-americana de alto nível pelo menos quatro educadores para funcionarem na qualidade, e somente nesta qualidade, de Assessores de Grupo Permanente de Planejamento;

d) o resultado do trabalho não será o produto de apenas um grupo de brasileiros, mas também serão convocados para o debate os professores e os estudantes, os grupos, entidades e organizações do país interessados nos problemas de ensino superior;

e) o trabalho final não incluirá nenhum padrão universitário, porque, em matéria de educação, numa sociedade em desenvolvimento, não devem existir fórmulas fixas, sob pena de provocar o colapso do progresso. Todo o planejamento só deve levar em conta o contexto sócio •-econômico em que se insere, não só para merecer aquele nome, mas também para ser real e efetivo. Assim, se um padrão houvesse, este só poderia ser brasileiro.

\section{II - SÚMULA DOS TRABALHOS}

1. À 1 Comissão brasileira, composta dos Professores Gastão Dias Veloso, José Gomes de Campos, Maria Aparecida Pourchet Campos. Paulo Ernesto Tolle e Roberto Figueira Santos, couberam as atividades iniciais dos estudos, inclusive a definição de sua posiçãono estudo geral de Reforma, a ser feito com a colaboração americana. 
1.1 - Do que ela fêz consta relato sucinto na Exposição do Prof. José Gomes de Campos em 15 de março de 1967,

2. À 2 Comissão brasileira, integrada pelos Professores Ernesto "Luís de Oliveira Júnior, Heitor Herrera, João Paulo de Almeida Magalhães, Paulo Accioly de Sá e Rubens d'Almada Horta Porto, apesar de sua atividade ter sido muito curta, conseguiu realizar uma série de trabalhos de real valor. Convém citar alguns deles:

2.1 - O Prof. João Paulo de Almeida Magalhães apresentou algumas considerações iniciais sobre o modo como a Comissão poderia considerar a Reforma Universitária.

2.2 - O Prof. Heitor Herrera ofereceu um roteiro para os trabalhos da Comissão, contendo esquematicamente:

2.2.1 - análise da situação;

2.2.2 - determinação dos objetivos;

2.2.3 - análise das características do ensino superior no Brasil;

2.2.4 - previsão para os próximos 10 anos;

2.2.5 - lista de problemas a serem estudados.

2.3 -- O Prof. Rubens ('Almada Horta Porto realizou varies trabalhos:

2.3.1 - coordenou todo o interessante conjunto de dados estatísticos relativos ao ensino superior no Brasil;

2.3.2 - fêz análise da obra realizada pelas instituições de ensino superior em nosso país, relacionada com toda a problemática do assunto;

2.3.3 - promoveu reuniões com professores da Universidade do Espírito Santo;

2.3.4 - promoveu reuniões com professores da PUC-Rio;

2.3.5 - examinou o problema das rendas e do reforço financeiro para a educação superior.

2.4 - O Prof. Ernesto Luís de Oliveira Júnior colaborou com:

2.4.1 - várias exposições verbais sobre assuntos de interesse da Comissão;

2.4.2 - estudos escritos sobre definição de Universidade;

2.4.3 - estudo sobre o problema da Fundação;

2.4.4 - idem, sobre a carreira do magistério;

2.4.5 - idem, sobre as chamadas «conexões e medidas de amparo social aos alunos»; 
2.4.6 - estudo sobre o Serviço Nacional de Exames Comparativos;

2.4.7 - idem, sobre a articulação entre a Universidade e o meio exterior;

2.4.8 - - idem, sobre o problema de proliferação das Universidades .

2.5 - O Prof. Paulo Acciohj de Sá realizou trabalhos de dois tipos:

2.5.1 - Promoveu reuniões com:

» 2.5.1.1 - a comissão encarregada em São Paulo de estudar a reforma das Universidades paulistas, discutindo o assunto com os respectivos membros;

2.5.1.2 - a comissão que em Curitiba estava preparando a reforma universitária local, estabelecendo com ela proveitoso diálogo;

2.5.1.3 - o Reitor Prof. Roberto Figueira Santos e Vice-Reitor Prof. H. Sobral, da Universidade da Bahia, examinando os estudos lá realizados sobre a matéria;

2.5.1.4 - o Diretor, o Vice-Diretor e um grupo de professores da Escola de Engenharia da Universidade Federal do Rio de Janeiro, com eles discutindo os assuntos universitários;

2.5.1.5 - professores da Universidade do Espírito Santo encarregados do estudo da reforma das Universidades.

2.5.2 - Apresentou uma série de trabalhos escritos sobre:

2.5.2.1 - os objetivos da comissão;

2.5.2.2 - visitas feitas a várias comissões de reforma, em Universidades do país;

2.5.2.3 - opiniões emitidas pelos professores de Engenharia sobre a reforma.

2.5.2.4 - Em colaboração com o Prof. Rubens d'Almada Horta Porto, apresentou uma série de sugestões sobre problemas de que a reforma deve cogitar: função da Universidade na comunidade, objetivos próprios, composição, carreira do magistério, admissão à Universidade, tempo integral etc. 


\section{TRABALHOS ANEXADOS A ESTE RESUMO}

3. Além dos estudos a que nos referimos e dos quais fizemos uma coleção separada, juntamos uma série de trabalhos cuja consulta parece realmente interessante a quem deseje conhecer melhor o assunto MEC-USAID.

3.1 - Em primeiro lugar, os trabalhos apresentados pela Comissão de professores americanos, trabalhos a que nos referimos detalhadamente, inclusive com resumo de cada um, em outro relatório.

3.2 - Uma «informação» sintética, reportando ao The Meditevranean Regional Project.

3.3 - Uma conferência do Prof. James Perkins, Presidente da Cornell University, na Conferência Internacional sobre a Crise Mundial de Educação. Trata-se de trabalho de grande interesse, no qual, depois de se mostrar que a crise educacional é uma crise mundial e não restrita a qualquer país, se examina:

a) o que se faz quando se educa;

b) o modo como se deve estruturar e administrar as instituições educacionais;

c) o problema de professores e alunos (centro do processo educativo);

d) a questão do conteúdo do ensino e dos métodos mais adequados a sua transmissão;

e) os recursos indispensáveis à manutenção do sistema e o modo de usá-los;

/) a cooperação internacional, que se impõe, uma vez que o problema - como se disse - transcende as fronteiras de qualquer país.

3.4 - Considerações à margem do Convênio da Assessoria ao Planejamento do Ensino Superior, mostrando por que, na sua primeira fase, êle não tinha elementos que lhe permitissem funcionar.

3.5 - Atos oficiais sobre o assunto (inclusive resoluções do Conselho Federal de Educação).

3.6 - Um resumo sobre a United States Agcncy fov International Devclopment.

3.7 - Um catálogo de parte de duas centenas de «projetos» e do Acordo de assistência técnica realizada entre o Brasil e os Estados Unidos.

3.8 - Muitos outros trabalhos, cujo resumo seria impossível nesta rápida síntese que estamos tentando. 


\section{PALESTRAS REALIZADAS NA EAPES}

4. A partir de fevereiro de 1968, a EAPES realizou diversas reuniões e palestras, todas com a finalidade de analisar os problemas do Ensino Superior e de apresentar recomendações para solucioná-los.

Foram convidados os seguintes professores:

Florindo Vila Alvarez - Problemas do Ensino de Administração.

Mauro Viegas e Ângelo Murgel — Problemas do Ensino de Arquítetura.

José Leme Lopes - Problemas do Ensino de Medicina.

Américo Piquet Carneiro - Problemas do Ensino de Medicina.

Paulo Accioly de Sá - Problemas do Ensino de Engenharia.

José Hilário - Problemas do Ensino de Medicina.

Gladstone Chaves de Melo e Hélio Drago Romano - Problemas do Vestibular.

Maximiniano Carvalho da Silva - Reforma da Universidade Federal Fluminense.

(Esta palestra contou com a presença dos Professores José Artur Rios, Nelson Libânio e José Carlos de Melo e Sousa) . geral.

Carlos Mascaro e Jaime de Abreu - Problemas de ensino em

Rubens Maciel. Newton Sucupira, Valnir Chagas, do Conselho Federal de Educação, Edson Nery da Fonseca e Rubens Borba de Morais (da Universidade de Brasília) — Problemas de Reconhecimento de novas Faculdades.

Padre Laércio D. Moura, Reitor da PUC-Rio - Reforma da PUC-Rio.

Isaac Kerstenetsky e Flávio Sampaio Penteado - Mercado de Trabalho.

\section{III - ASPECTOS ADMINISTRATIVOS}

Pessoal Administrativo (antes da gestão Tarso Dutra)

1.2.67 - Edi Salvador Canetti - Secretário-Geral - Salário mensal, $\mathrm{NCr} \$ 600,00$

1.2.67 - Jacques Rocha Veloso - Tradutor Bibliotecário - Salário mensal, NCr\$500,00

1.2.67 - Hilda Cirino Rockenbach - Doméstica - Salário mensal, NCr\$ 105,00 
1.3.67 - Heyder Lehar Cirino Rockenbach - Mensageiro-Servente - Salário mensal, NCr\$ 105,00

103.67 - Renée Carasso - Estenógrafa bilíngue - Salário mensal NCr\$ 600,00

Pessoal Administrativo (depois da gestão Tarso Dutra)

30.3.67 - May Robertson de Figueiredo Lázaro - Dactilógrafa Salário mensal, NCr\$ 137,50

18.5.67 - Darcila Helena Anesi de Lalor - Secretária bilíngue Salário mensal, NCr\$500,00

16.67 - Margarida Queiroz — Secretária bilíngue - Salário mensal, $\mathrm{NCr} \$ 500,00$

Em 24-7-67 foi dispensada, a pedido, Darcila Helena Anesi de Lalor, e em 1-10-67 foi aproveitada nesta mesma vaga a Dactilógrafa May Robertson de Figueiredo Lázaro.

Em janeiro de 1968, os funcionários, autorizados pelo Diretor do Ensino Superior, tiveram os $20 \%$ de aumento concedidos pelo Governo para o funcionalismo da União.

Em 12-2-68 foi dispensada, a pedido, Renée Carasso, não sendo preenchida sua vaga.

\section{SEDES}

1 Sede $-11^{9}$ andar da Casa do Estudante do Brasil, onde não chegou a funcionar, por ter sido cedida ao DASP, conforme ofício $\mathrm{H} \gg 442$, da DESu.

$2^{1}$ Sede - Provisória - na Academia Nacional de Medicina, por gentileza do Prof. Cruz Lima, seu Presidente.

3 Sede - Rua Honório de Barros, 41 - 8' andar - apto. $801-$

16-3-67 - Edifício Massangana - O aluguel é de $\mathrm{NCr} \$ 1.500,00$ (hum mil e quinhentos cruzeiros novos), mais as taxas e condomínios, o que totaliza cerca de NCr\$2.000,00 (dois mil cruzeiros novos). 


\section{EDUCAÇÃO E DESENVOLVIMENTO}

A educação é não apenas uma responsabilidade social mas também fator de desenvolvimento. Já Adam Smith, em seu livro famoso. "publicado pela primeira vez em 1776, considerava a educação como um encargo social, uma responsabilidade tão importante quanto a de criar e conservar as vias de comunicação.

«The expense of the institutions for education and religious instruetions is likewise, no doubt, beneficiai to the whole society, and may, therefore, without injustice, be defrayed by general contribution of the whole society.»

Em vernáculo: «A despesa com as instituições educacionais e com instrução religiosa resulta, indubitavelmente, em benefícios para toda a sociedade, e pode, portanto, sem injustiça, ser custeada pela contribuição geral de toda a sociedade.»

Adam Smith considerava a educação parte do capital fixo, ao lado de 1) maquinaria; 2) edifícios; 3) terra melhorada por drenagem e fertilizantes.

«Fourthly, of the acquired and useful abilities of ali the inhabitants or members of the society. The acquisition of such talents, by the maintenance of the acquirer during his education, study, or apprenticeship, always costs a real expense, which is a capital fixed an realized, as it were, in his person. Those talents, as they make a part of his fortune, so do they likewise of that of the society to which lie belongs. The improved dexterity of a workman may be considered in the same light as a machine or instrument of trade which facilitates and abridges labour, and which, though it costs a certain expense, reapys that expense with a profit.»

Em vernáculo: «Em quarto lugar (consta o capital fixo), das aptidões úteis adquiridas por todos os habitantes ou por membros da sociedade. A aquisição de tais habilitações, através do sustento do

\footnotetext{
1 Adam Smith, An Inquiry into the Nature and Causes of the Wea'th of Nations - Encyclopxdia Brtannica, Ins. Great Books of the Western World, vol. 39. The University of Chicago, 1952.
} 
adquirente durante o período de sua educação, estudo e aprendizado, representa sempre um dispêndio real, que é um capital fixo, mas como que realizado em sua pessoa. Esses talentos, na medida em que fazem parte da fortuna pessoal, fazem também parte da fortuna da sociedade a que pertence o discente. A melhorada destreza de um operário pode ser comparável à de uma máquina ou instrumento de comércio que facilita e abrevia o trabalho, e que, embora custe dinheiro, paga com lucro a despesa. »

E Alfred Marschall, ${ }^{2}$ ainda no século passado, em seus Princípios de Economia, livro 4, cap. $6, \S 7^{\circ}$, considerava a educação um investimento nacional. Nada menos do que isso. Mas só recentemente essa ideia empolgou os economistas, que, estendendo o conceito, perceberam também que as despesas com saúde pública podem repercutir na renda nacional, incrementando-a.

Foi também baseado na noção do valor da educação, que Rui Barbosa, ainda no século passado, elaborou seu plano de reforma da instrução pública. Para êle, ${ }^{3}$ a educação popular era «a mais criadora de todas as forças econômicas, a mais fecunda de todas as medidas financeiras».

Como se vê, o reconhecimento da importância da educação como fator de desenvolvimento e meta de governo não é cousa dos nossos dias.

Quando a produção bruta sobe, e quando se procura analisar os fatores de produção (mão-de-obra, capital investido, etc), verifica-se algumas vezes que o aumento havido não pode ser explicado apenas pelos citados fatores. Aparece aquilo que muitos economistas chamam de resíduo. Então se conclui que esse resíduo, aparentemente não explicável, foi devido ao fator qualitativo, ao know-how, que é de natureza cultural. Esse incremento da produção, além de tudo quanto é imputável ao «trabalho adicional»e ao «capital adicional», credita-se à educação.

Nos Estados Unidos, segundo o Órgão Nacional de Pesquisa Econômica de Nova York, houve, no período de 1899 a 1953, um crescimento da produção total três vezes maior do que o crescimento dos fatores trabalho, terra e capital. Destarte, dois terços do crescimento não puderam ser atribuídos ao aumento dos fatores trabalho, terra e capital, mas sim a melhoramentos técnicos, administrativos e à melhor educação dos trabalhadores.

2 Ver Alfred Marschall, Princípios de Economia, trad. de Manuel de Torres, Madrid, Aguillar, 1948.

3 Ver Rui Barbosa, Obras Completas, vol. X, tomo 1, pág. 143 (1883), Ministério da Educação e Saúde, 1947.

4 Ver Salomon Fabricant, Economic Progrcss and Economic Change, 34' relatório anual do N.B.E.R., N.Y., apud Planificação da Educação e seus Problemas Econômicos e Sociais, MEC, 1967. 
$\mathrm{Na}$ Ucrânia, igualmente, em dois períodos estudados, atribuiu-se 31 por cento do crescimento da produção industrial ao aumento do capital e do trabalho e 57 por cento a outros fatores.

Muitos estudos vêm sendo feitos seguindo esse critério, sendo famoso o relatório Denison (Edward Denison), ao qual Schreiber dedica um capítulo em seu livro. ${ }^{6}$

O resíduo atribuível à educação não significa necessariamente educação universitária, nem sequer, pelo menos diretamente, aperfeiçoamento do ensino profissional. Significa, sem dúvida, progresso técnico e melhor organização, e pode-se imaginar que esse progresso ocorra dentro da empresa, e que independa da situação do sistema nacional de ensino. De qualquer sorte, educação no contexto desenvolvimentista representa um processo social, e está longe de ser sinónimo apenas de instrução escolar.

Por isso mesmo, cabe perguntar, os gastos com a educação, mais particularmente com o ensino escolar, representam um investimento lucrativo, ou um prejuízo?

É óbvio que a educação não é apenas fator de desenvolvimento, mas fator essencial ao desenvolvimento. Ela o acompanha, nele se ajusta e se integra. Se o precede, não o saberíamos dizer, nem vem muito ao caso. Há uma convergência substantiva entre desenvolvimento econômico e desenvolvimento cultural, que não pode ser negado.

As considerações acima são muito interessantes e poderíamos ampliá-las, mostrando quanto o valor humano, o capital humano vem crescendo de importância no processo de desenvolvimento. Sem qualquer exagero, poderíamos dizer que o gasto feito para melhorar o elemento humano representa o mais rendoso dos investimentos. Mas para que fazer tais considerações, repisar o óbvio, no caso como o do Brasil, onde o problema não é de educação para o desenvolvimento, longe disso, nem sequer de educação para a segurança nacional, mas onde realmente a educação é problema de salvação pública! Nesta altura temos que enfrentar uma calamidade pública, pois outro nome não pode merecer uma situação como a nossa, bem ilustrada pelas cifras existentes de analfabetismo, de abandono prematuro, tanto da escola primária quanto da secundária, e de estrangulamento do ensino universitário.

Estabelecida a necessidade dos investimentos educacionais, tanto como medida de salvação pública quanto para corresponder às necessidades do desenvolvimento, caberiam algumas perguntas suplementares.

\footnotetext{
5 Ver A. G. Frank, General Productivity in Soviet Agricnlture and Industct): The Ukraíne, 1928-1955, Journal of Politicai Economg, dezembro de 1958, apud Planificação da Educação e seus Problemas Econômicos e Sociais, MEC, 1967.

6 Ver Jean-Jacques Servan Schreiber, Le Defi Américain, Paris, Denoel, 1967.
} 
Que percentagem do produto nacional bruto deve ser invertido em educação? Estabelecida por sua vez essa percentagem - que foi fixada em 4 por cento para os países latino-americanos, tanto na Declaração de Punta dei Este quanto em Santiago do Chile - pergunta-se se devemos aplicar os recursos disponíveis indiscriminadamente, nos diversos setores da instrução pública, ou aplicá-los preferencialmente em setores específicos?

Conforme dissemos, os gastos com a educação representam investimento lucrativo, mas a prazo variável. Ao que parece, o lucro do investimento educacional é tanto mais imediato quanto mais avançada a fase em que se encontra a nação. Haverá situações em que o lucro do investimento só tardiamente se fará sentir.

Cumpre aos planejadores, ao destinar recursos para determinado empreendimento, calcular o chamado custo de oportunidade, ou seja, avaliar a alternativa que foi sacrificada em virtude da destinação escolhida.

Por isso, no que se refere à aplicação dos dinheiros disponíveis para a educação em países subdesenvolvidos, com mercados ainda restritos, as opções na sua aplicação se tornam cada vez mais delicadas. Quanto mais atrasada a nação, menor será a faixa de erro permissível. Este é, aliás, um dos dramas das nações subdesenvolvidas, que possuem elites dirigentes subdesenvolvidas. Destas elites, que detêm o poder e sabem captar a imaginação popular, exatamente delas se exige maior objetividade e maior competência.

Nossa convicção é que, quanto mais elementar o ensino de que se carece, mais importante êle é. Fundamentalmente, precisamos combater o analfabetismo, secundariamente, propiciar ensino médio e, em terceira instância, ensino universitário. Mas deste raciocínio não se conclui que o investimento federal deva necessariamente seguir essa linha de prioridade. A importância de determinado grau de ensino não se mede pela verba orçamentária. Educação nacional é um movimento de responsabilidade coletiva e solidária, conforme o têm proclamado inúmeros educadores brasileiros, como Anísio Teixeira e Carlos Pasquale. Tanto em suas raízes mais profundas quanto em suas especializações mais altas, a educação é o reflexo das forças íntimas que animam a sociedade. Não é o resultado apenas de esforços, mais ou menos espasmódicos, da classe política. A educação é talvez a expressão mais característica da vida de uma sociedade. E mesmo sem a escola pública, já houve áreas no Brasil em que não se encontrava um único analfabeto.

Feitas estas ressalvas, devemos assinalar que o ensino primário tem recebido o maior quinhão, conforme se vê, apreciando em seu conjunto a destinação das verbas federais, estaduais, municipais e particulares. Os dados mais recentes que temos à mão nos são oferecidos por J. Torfs e referem-se ao ano de 1961. 
Ensino Primário. . . . . . . .

No Programa de Dispêndios em Educação para 1967 até 1976, verifica-se que o ensino superior deverá ou deveria receber menos recursos que o ensino primário e médio, conforme se vê do quadro abaixo, que elaboramos com base nos dados oferecidos no volume Educação e Mão-de-obra.

PROGRAMA DE DISPÊNDIOS EM EDUCAÇÃO

VALORES EM Cr\$ 1.000.000 DE 1966

\begin{tabular}{|c|c|c|c|}
\hline A N O & PRIMÁRIO & MÉDIO & SUPERIOR \\
\hline 1967. & \multirow{10}{*}{$\begin{array}{r}729.422 \\
773.036 \\
825.339 \\
871.321 \\
949.106 \\
990.377 \\
1.049 .095 \\
1.087 .733 \\
1.176 .935 \\
1.232 .665\end{array}$} & \multirow{10}{*}{$\begin{array}{r}608.866 \\
669.299 \\
747.611 \\
836.224 \\
929.115 \\
1.012 .589 \\
1.159 .941 \\
1.265 .017 \\
1.386 .258 \\
1.506 .213\end{array}$} & \multirow{5}{*}{$\begin{array}{l}346.363 \\
388.148 \\
398.642\end{array}$} \\
\hline 1968 & & & \\
\hline 1969. & & & \\
\hline 1970. & & & \\
\hline 1971. & & & \\
\hline 1972. & & & \multirow{5}{*}{$\begin{array}{l}470.309 \\
506.686 \\
651.420 \\
691.201 \\
623.684\end{array}$} \\
\hline 1973. & & & \\
\hline 1974. & & & \\
\hline 1975. & & & \\
\hline 1976. & & & \\
\hline & 9.685 .029 & 10.121 .033 & 4.635.213 \\
\hline
\end{tabular}

FONTE: Plano Decenal de Educação.

7 Jacques Torfs, «.Receitas e Despesas com o Ensino no Brasil», Revista Brasileira de Estudos Pedagógicos, vol. 46, out.-dez. 1966.

8 Educação e Mão-de-Obra, vol. 1, Anexo C, Ministério do Planejamento, 1967. 
Embora não esteja sendo cumprido o Plano Decenal, o conjunto das cifras serve para ilustrar o entendimento do problema das atividades educacionais, em seus níveis primário, médio (ginasial e colegial) e superior, por alguns «estrategistas» do nosso progresso.

São os orçamentos estaduais, e não os municipais, que mais contribuem para o ensino primário, conforme se vê do quadro a seguir, também retirado do trabalho de J. Torfs. ${ }^{9}$

DESTINO DAS RECEITAS PRIMÁRIAS DO ENSINO EM 1961

\begin{tabular}{|c|c|c|c|c|c|}
\hline & UNIÃO & ESTADOS & MUNICÍPIOS & $\begin{array}{c}\text { PAR- } \\
\text { TICULARES }\end{array}$ & TOTAL \\
\hline \multicolumn{6}{|l|}{ Primario } \\
\hline & 8.0 & 70.0 & 6.0 & 16.0 & 100.0 \\
\hline Médio. & 27.0 & 30.0 & 1.0 & 42.0 & 100.0 \\
\hline Superio & 70.0 & 18.0 & & 12.0 & 100.0 \\
\hline
\end{tabular}

A tendência de alguns municípios ricos é até a de inverterem dinheiro em educação superior. Em Taubaté, por exemplo, há uma Universidade municipal, a primeira do Brasil. Nos municípios que constituem o A B C (Santo André, São Bernardo e São Caetano) está em formação, bem adiantada, uma Universidade intermunicipal, cujos professores perceberão salários superiores aos das Universidades federais.

No âmbito universitário, acerca do qual nos compete opinar, de pronto se levanta a questão de saber o que é mais importante para o desenvolvimento econômico do Brasil: mais cultura geral, ou melhor formação profissional? Devemos tornar o ensino universitário mais acessível, mais fácil, mais popular, ou concentrar recursos para formar elites mais capazes e conscientes? O que é preferível: muitos engenheiros de padrão médio, ou poucos engenheiros de altíssimo padrão? Será melhor ter médicos em abundância, embora de qualidade inferior, ou número bem menor de médicos, de esmerada e refinada cultura? Em outras palavras, devemos educar pensando sobretudo no mercado de trabalho ou educar pensando sobretudo em incrementar a cultura em si mesma, e no que ela tem de universal?

9 Ver Jacques Torfs, «Receitas e Despesas com o ensino no Brasil», em Revista Brasileira de Estudos Pedagógicos, a" 104, out.-dez., 1966. 
Há pessoas que gostam de ver antinomias onde elas não existem, de provocar quarelas tão abstratas quanto aquela famosa acerca do sexo dos anjos, e com isso se distraem, perdem tempo e fazem os outros perder o seu.

Parece-nos muito difícil, na análise do desenvolvimento econômico, desagregar e «medir» separadamente esses dois fatores, cultura geral e cultura profissional. Tratando da cultura geral, como iremos medir a importância econômica de Casa Grande e Senzala, de Gilberto Freyre, ou de Rosa do Povo, de Carlos Drummond de Andrade? Pelas horas de trabalho que esses livros asseguraram aos gráficos que os compuseram, ou pelo lucro que eles deram aos seus autores ou editores? O valor das obras reduzir-se-á a esse tipo de avaliação? Poderíamos. nesta mesma linha, multiplicar exemplos indefinidamente.

Se há problemas dificeis de resolver, há, em compensação, algumas coisas que podem ser afirmadas com segurança. Uma delas é que o ensino no Brasil não vem formando, em número suficiente, nem profissionais capazes, nem profissionais técnicos de elevada cultura geral. Poder-se-ia dar como exemplo o caso dos nossos engenheiros civis, situados muitas vezes longe das necessidades práticas, e, por outro lado, não suficientemente preparados para se comunicarem com a problemática teórica universal, enfim, com a verdadeira cultura. Einstein provavelmente não saberia consertar um aparelho de rádio. mas sua alta capacidade matemática veio a ter enormes consequências práticas. $\mathrm{O}$ engenheiro civil que estamos tentando figurar não saberia consertar um aparelho de rádio, nem poderia acompanhar as elucubrações de um Poincaré ou de um Einstein. É exatamente esse tipo intermediário que devemos evitar, fora da órbita prática e fora da órbita científica. $\mathrm{O}$ engenheiro é o homem que está fazendo o mundo de hoje, pelo menos a infra-estrutura material da presente civilização. Temos necessidade premente de bons engenheiros. E o que é o bom, o verdadeiro engenheiro? O Prof. Paulo Sá o definiu muito bem, quando disse: «é aquele que faz por 1 dólar o que os outros fazem por 2». É tão premente a necessidade de bons engenheiros, que hoje alguns especialistas em educação universitária consideram que o diploma de engenheiro deve ser revalidado de 10 em 10 anos, tal a velocidade do progresso tecnológico. Precisamos então, com urgência, impedir a proliferação desses doutores que ficam num certo limbo, nem teórico nem prático.

E aqui deparamos com um problema vocacional que deve ser resolvido pela Universidade. É indispensável que se propiciem condições para o desenvolvimento das diversas aptidões humanas e que se atenda à diversidade de níveis vocacionais, em cada matéria. Devemos então criar um ensino relativamente simples e prático para a obtenção de graus correspondentes ao B.A. e B.S. americanos, e outro, rigoroso e exigente, para a obtenção de graus correspondentes ao M.Â., M.S. e Ph.D. 
No que se refere à Medicina, a resposta deve ser particularizada. Seu ensino deve ser prático e teórico a um tempo, e deve ser rigoroso. Um médico de segunda classe vale menos que um charlatão. E é mais perigoso. Medicina, ou é excelente ou nada vale.

Não há porque fabricar médicos em 3 anos, ou mesmo em 4 anos. $\mathrm{O}$ que se pode formar em 4 e até em 3 anos são bacteriologistas excelentes, biologistas, farmacêuticos de primeira classe, enfermeiras de alto padrão e outros especialistas, cuja presença é indispensável ao funcionamento dos hospitais e faculdades e ao exercício moderno da Medicina.

Ainda com referência à falsa antinomia entre cultura geral e cultura especializada, cabem algumas afirmações, a primeira das quais será afirmar o valor eugênico, ortopédico e terapêutico (perdoem-nos esses adjetivos) das ideias universais. Devemos estudar o presente e valorizar os elementos da conjuntura, é certo. Entretanto, se uma valorização excessiva do concreto particular que se observa em cada momento histórico poderia afigurar-se fecunda em resultados práticos, ela seria, em verdade, paralisante. E, sobretudo, seria ilusória. Segundo Harold Rugg, «nem uma só vez, em século e meio de história nacional, o currículo escolar coincidiu com a dinâmica da vida americana». ${ }^{10}$ Isso nos Estados Unidos da América, que possui o menos rígido dos sistemas de ensino até hoje elaborados.

Não pretendemos, citando Rugg, aconselhar o alheamento da Universidade à sociedade, mas apenas controlar a neurose dos homens que pretendem dançar sempre a música da hora que passa. Talvez ninguém melhor que Ortega y Gasset, " ao estudar a obra e a personalidade de Toynbee, haja apontado, com tanta eloquência, o valor fundamental da educação em si, independentemente de seu aggiornamento:

«Digamos ahora brevísimas palabras sobre la otra noticia: ser Toynbee un egrégio helenista de Oxford. Yo no sé si estas sencillas palabras les dicen algo; yo no sé si les despertarán la adecuada expectativa. Se trata, a mi juício, de uno de los hechos más admirablemente extraordinários de la edad contemporânea. Desde el siglo XVIII, ejerció Inglaterra su preponderância o hegemonia sobre el mundo occidental. Durante el siglo XIX, Inglaterra extiende ese predominio a todo el planeta. No hay, creo, punto de la tierra donde no tuviese asuntos. 1968.

10 Ver Taime de Abreu, em Problemas Brasileiros de Educação, Rio, Lidador,

11 José Ortega y Gasset, «Una Interpretación de Ia Historia Universal», Revista de Occidente, Madrid, 1960, págs. 34/36. 
Para llevar estos y dirigirlos, para regentar la vida inglesa $y$ sus ubicuos intereses, Inglaterra necesitaba muchos hombres aptos, capaces de la más concreta lucha con cosas, situaciones y hombres, en Europa como en Ásia, en Oceania y en África. Por otra parte, el inglês había valido siempre como hombre práctico por excelência y a ello se atribuía su triunfo y aventajamiento. Pues bien: como se las arreglo Inglaterra para tener a su disposición esos numerosos equipos de los que podríamos llamar «jefes de asuntos»? Pues hizo esto: en cada generación escogió los mejores muchachos de las clases superiores y los confino en Oxford para que allí se dedicasen a aprender griego y a practicar deportes como hicieron los griecos. Eso es todo. Reconocerán que el hecho es fenomenal y de sobra inesperado. Cuando en mis mocedades tuve de él conocimiento y percibí la descomunal paradoja que representaba, busque por todas partes una explicación de ella, pêro no la encontre en ninguna, y entonces, tiempo adelante, conociendo un poço mejor el génio de Inglaterra, que es, a la vez, magnifico y heteróclito, tuve que improvisarme una explicación para mi propio uso, que transmito a ustedes con la adecuada reserva. Creo, sin embargo, que quienes conozcan el peculiar modo de ser hombre que llamamos «ser inglês» $\mathrm{y}$, por conocerlo, lo sientan desde su interioridad y admiren ciertos dones sin par que en él hay - mezclados ciertamente con no poças cosas menos gratas — juzgarán verosímil mi ensayo de esclarecimento a aquel exorbitante enigma. Helo aqui: los educadores, sobre todo cuando van inspirados por un afán de practicismo, piensan que lo que hay que hacer con los muchachos es prepararlos dei modo más concreto posible para la vida tal cual es, desejando a un lado todas las disciplinas y modos que parecen ornamentales, suntuarios y supérfluos. Pêro es el caso que la vida histórica tiene la condición de cambiar constantemente. La historia es permanente iaquietud y mutación. De modo que si se educa a un muchacho preparándolo concretamente para la vida tal cual es hoy, cuando llega a adulto se encuentra con que la vida tiene otra figura, y cuando más practicamente preparado estuviese para la anterior más desajustado queda para la que tiene que vivir y en que tiene que actuar. Es lo que he llamado el anacronismo constitutivo de la usual pedagogia. Dispara a la nueva generación sobre un blanco que cuando va a llegar a él lo han quitado ya y está en otra parte. Pues bien, Inglaterra, yo no sé si con una conciencia plenamente clara de ello o más bien con 
la certera penumbra de un instinto, resueive esta contradicción inversamente: hace que durante unos anos su mejor juventude se vaya a vivir a Atenas en el siglo de Péricles, es decir que, en vez de adaptaria a un tiempo presente, la proyecta fuera de todo tiempo, ya que el siglo de Péricles es una fecha irreal, un tiempo imaginário, convencional y paradigmático, que se cierne idealmente sobre todo tiempo preciso. Dentro de esa Grécia irreal son educados los jóvenes en las formas esenciales dei vivir, esto es, se preparan en ellos puras disponibilidades que permiten una adaptación a las más diversas ocasiones concretas, por lo mismo que no están de antemano adscritas especialmente a ninguna. Ya los biólogos nos habían ensenado que un organismo muy diferenciado, de estructura estrictamente ajustada a un médio, queda indefeso cuando el médio cambia, mientras que un animal informe, sin órganos, como la ameba, tiene el poder de crearse en cada situación los órganos provisórios que necesita. Si ha menester de acercarse ai alimento, emite de su plasma una prolongación o pseudópodo, que funciona como un pie, la hace caminar y, una vez utilizado, tranquilamente reabsorve. El gran biólogo von Uexkiill formula esto diciendo: Struktur hommt Stmkturbildung, tener estructura impide crear estructura. A mi me parece genial esta solución inglesa a la contradicción constitutiva de la usual pedagogia. El práctico inglês, precisamente porque es autenticamente práctico sabe que, a veces, lo más práctico es no parecerlo.»

Tal concepção do ensino foge bastante aos conceitos em voga. A verdade é que existe enorme descontentamento com os sistemas existentes, e por isso se critica tudo, o ensino, os professores, os reitores, a cátedra vitalícia, a desvinculação entre a Universidade e a sociedade. Quase toda a gente se mostra disposta a declarar que o ensino no Brasil, e até no mundo, é obsoleto, anacrónico, ultrapassado, alienado, medieval. E a conclusão é que se impõe uma reforma radical e urgente do ensino.

Todas essas críticas valem como meias verdades. Porque a solução não está apenas na reforma do ensino, mas numa reforma mais ampla da sociedade toda, dos jornais, do rádio, da televisão, dos métodos de trabalho, do funcionalismo todo, civil e militar, enfim, de nossas concepções de vida, da própria atmosfera filosófica da cultura ocidental. A luta contra os defeitos do sistema brasileiro de educação deverá ser uma luta em que esteja empenhado não apenas o Governo, mas a família brasileira, e sobretudo professores e alunos.

Para a correção dos defeitos existentes, muito poderiam contribuir os estudantes, não há negar. Deles dependerá em grande parte levar 
o ensino médio e superior a servir às necessidades do nosso desenvolvimento econômico, social e político.

Em verdade, não podemos esperar tudo da escola, do ensino público ou particular. E sem querer negar os defeitos existentes e sem querer absolver os professores relapsos ou incompetentes, devemos lembrar que o educando é o principal agente da educação. Quando este quer aprender, êle o consegue, apesar das falhas do sistema educacional. Por outro lado, nenhum sistema de ensino, por melhor que seja, será capaz de proporcionar cultura na ausência de uma cooperação ativa e vigilante do educando.

A cultura depende em primeiro lugar do aluno; depois, da família; depois, do ambiente cultural da sociedade; finalmente, um pouco das escolas, que não foram feitas para ensinar tudo, ao contrário do que se imagina. Mas sempre o educando será o agente principal da educação. Esta retumbante descoberta de alguns autores modernos tem longas, veneráveis barbas brancas.

Escreveu Santo Tomás de Aquino:

«Homo docens solumodo exterius ministerium adhibet, sicut medicus sanans; sed sicut natura interior est principalis causa sanationis, ita et interius lúmen intellectus est principalis causa scientiae.»

Em vernáculo: «O homem que ensina realiza apenas uma obra exterior, assim como o médico quando cura; mas, assim como a natureza interior é a causa principal da cura, assim também a luz interior da inteligência é a causa principal da ciência.» (Summa Theologica, I, qu. 117, art. 1, ad 1).

E já muito antes havia escrito Santo Agostinho:

«Quis tam stulte curiosus est, qui filium suum mittat in scholam, ut quid magister cogitei discat? At istas omnes disciplinas quas se docere profitentur, ipsiusque virtutis atque sapieníiae, cum verbis explicaverint [magistri], tum illi qui discipuli vocantur, utrum vera dieta sint, apud semetipsos considerant, interiorem scilicet illam veritatem pro viribus intuentes. Tunc ergo discunt».

Em vernáculo: «Quem haverá tão estúpido que mande o filho à escola para que êle aprenda o que pensa o professor? Depois que os mestres explicaram, com palavras, todas essas disciplinas que dizem lecionar, inclusive as referentes à virtude e à sabedoria, então é que os chamados discípulos vão, consigo mesmo, considerar se são verdadeiras as coisas ensinadas, contemplando, na medida de suas forças intelectuais, a verdade interior. Aí então é que aprendem». (De Magistro, cap. XIV) 
Em resumo, o que pretendemos é fazer um reparo àqueles que de certa maneira imaginam que o homem seja feito de fora para dentro e que vivem clamando por uma organização perfeita de ensino que dispense de certa maneira o esforço individual e na qual seja possível adquirir-se cultura por simples imersão.

Mais uma vez reafirmamos não ser nosso intento advogar estruturas universitárias rígidas. Propugnamos uma estrutura universitária plástica, mas sem o esquecimento da base humanística e sem o culto da novidade pela novidade.

Aliás, observa-se que nos Estados Unidos se procura, cada vez mais, alargar a base humanística e científica das Universidades e evitar a especialização prematura.

A posse de ideias gerais, o conhecimento dos grandes valores da vida, da Filosofia e da História constitui necessidade fundamental. Quanto mais alguém se especializa, mais precisão tem de inserir seus conhecimentos particulares dentro de um contexto mais amplo e universal.

Para um engenheiro não ficar manietado, estreito, êle precisa ler romances e ouvir música. Se não o fizer, será incapaz de inventar um saca-rôlhas.

Por outro lado, é indispensável que os homens que lidam com ideias gerais aprendam algum ofício técnico ou manual. A Filosofia conduzirá à loucura seus cultores, se estes não souberem aplicar corretivos ao permanente exercício da introspecção e do raciocínio abstrato. O filósofo, para conservar a saúde mental, precisa desenvolver alguma atividade artesanal.

Se os homens são engenhosos em procurar antinomias onde elas não existem, antinomias cerebrinas, a vida se encarrega de simplificar as coisas, e de mostrar a harmonia dos tons complementares, das formas contrastadas, enfim, dos antagonismos aparentes. Por vezes se propõe uma opção entre isto ou aquilo, quando a solução mais rica será isto e aquilo. 


\section{RECURSOS PARA EDUCAÇÃO}

Os documentos que tratam das despesas com educação no Brasil insatisfatórios. Contra isso reclamou, entre outros, um perito da UNESCO, Jacques Torfs. ${ }^{1}$

Mas com razoável segurança, três coisas podem ser afirmadas.

Primeiro, há desproporção entre nossas necessidades, ou, se quiserem, aspirações e nossos recursos. Não há dúvida que as necessidades educacionais do Brasil estão muito além da capacidade nacional de investimento público e particular neste setor.

Segundo, embora levando em conta a pobreza do país, a taxa de educação, ou seja, a relação entre as despesas totais de educação e o produto interno bruto, vem sendo inferior ao que poderia e deveria ser. Nunca atingimos a cifra de 4 por cento, que foi proclamada como necessidade imperiosa em reuniões pan-americanas, tanto em Punta del Este quanto em Santiago do Chile.

Terceiro, os insuficientes recursos atribuídos à Educação vêm sendo mal gastos. Este último ponto já foi repisado inúmeras vezes, tanto pelo atual Ministro do Planejamento, Sr. Hélio Beltrão, quanto por seu antecessor, o Embaixador Roberto de Oliveira Campos. Como o Ministério do Planejamento vem atribuindo à Educação parcela menor que a desejada, seus titulares tornaram-se os maiores críticos de nossas falhas educacionais.

Com referência à primeira das três afirmativas, gostaríamos de esclarecer que, ao falar na pobreza nacional, estamos referindo-nos à situação do país tal como se nos apresenta no momento. Sabemos quão falhas são as estatísticas nacionais. Mas nos recusamos a assumir a atitude de certos economistas que declaram não saber a quanto montam os recursos reais do Brasil e por isso. dizem, não podem opinar. Declaram que há homens cujas riquezas não se sabe exatamente a quanto montam, e acrescentam que destarte ignoram qual a carga tributária que o povo, pobre ou rico, poderá ainda suportar.

Jacques Torfs, Revista Brasileira de Estudos Pedagógicos, $\mathrm{n}$ 104, outubrodezembro de 1966. 
Dizem mais, e ninguém o contesta, que a quantidade de recursos a serem empregados em Educação depende de opções como a de saber o que consideramos mais importante: se Educação ou Agricultura; se Educação ou Forças Armadas, e assim por diante. Mas o que se verifica em realidade é que os recursos ora existentes não chegam para satisfazer às necessidades da Educação, nem da Agricultura, nem da mineração e assim sucessivamente. Objetar-se-á que cada um deve viver dentro de suas posses. Sabemos disso, e reconhecemos que a alocação de recursos para a Educação representa uma opção governamental ante os objetivos nacionais, e sabemos que a alocação de recursos na Educação para seus diferentes ramos e níveis representa outra opção que deve ser feita. Mas não podemos perder tempo com certos jogos com que alguns estudiosos gostariam de entreter-se. Perguntam como definiremos as «necessidades» educacionais, e quais serão as «necessidades» verdadeiras do país. O Brasil, responderemos, precisa de educação primária universal, já e já, precisa de educação secundária, que deverá tornar-se também universal, o mais cedo possível, e precisa - sem aviltar — de ensino universitário, tanto para atender à pressão social quanto para corresponder ao seu desenvolvimento. Aliás, a Constituição Federal, em seu art. 168, impõe o ensino obrigatório dos 7 aos 14 anos, o que inclui o ensino primário e ginasial. A Constituição em vigor exige mais do que o «Plano Nacional de Educação» elaborado em 1962 pelo Conselho Federal de Educação.

Dir-se-á que os alvos apontados no Plano Nacional da Educação e na Constituição Federal são desejos (wants) e não necessidades (nceds). Responderemos que não é só a economia que dita as necessidades humanas, como não é ela que explica toda a História. Há desejos que transcendem os condicionamentos econômicos da existência, mas que, em virtude de seu significado moral e político, devem ser considerados pelo homem público. A História não é um robot movimentando-se segundo prévia programação, com seus mecanismos de [eed-back, impecavelmente construídos. Sem chegar ao delírio, podemos ter aspirações e até necessidades superiores às nossas possibilidades.

Para encerrar a digressão e consubstanciar nossa afirmativa, feita de maneira intencionalmente vaga, apresentamos as cifras comparativas da renda per capita dos diferentes países da América. Embora defeituosas, bem o sabemos, para alguma coisa elas devem servir. Veríamos então o lugar modestíssimo que ocupamos, mesmo dentro da América Latina. 
QUADRO 1

ESTIMATIVA DA RENDA «PER CAPITA», 1965 PAÍSES DÓLARES

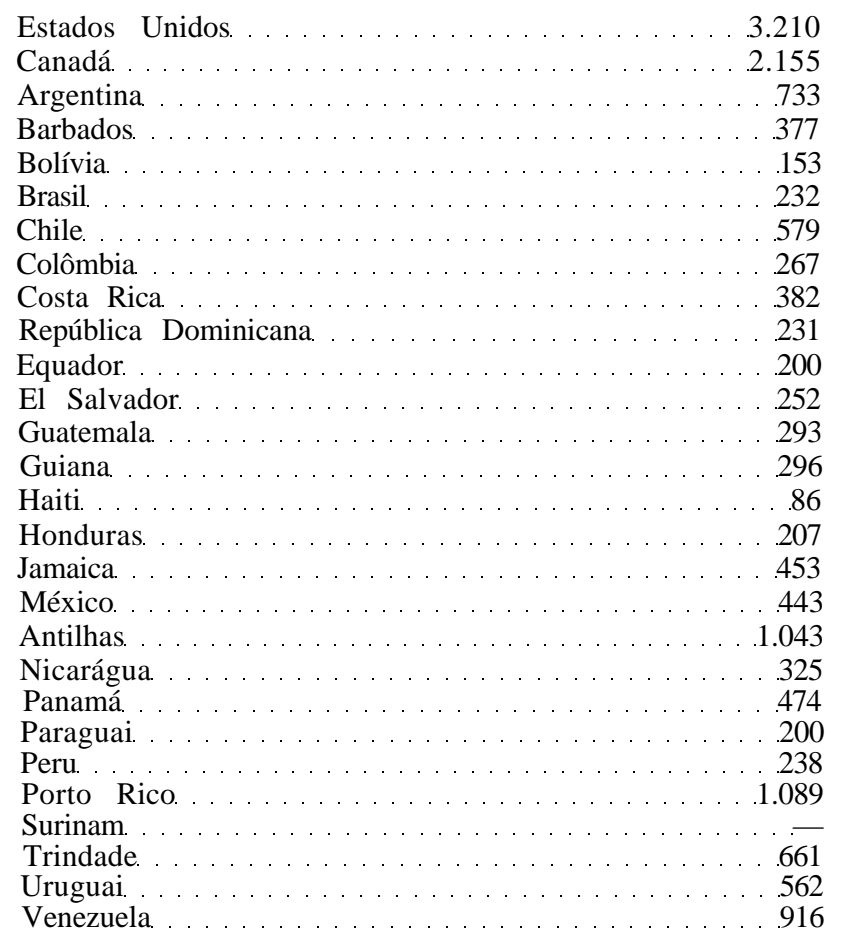

Nosso pais, segundo prognósticos, no ano 2000, não terá atingido sequer a fase industrial, em que a renda per capita deverá ser de 600 a 1.500 dólares. Com os recursos existentes, e se não formos capazes de desmentir certos prognósticos que vêm sendo divulgados, jamais poderemos enfrentar de cabeça erguida o ano 2000. Lá chegaremos falando uma língua só, usando um alfabeto adequado, e, entretanto, larga parte da população continuará absolutamente iletrada, a despeito das facilidades assinaladas.

Para se ter ideia da pobreza nacional, bastará dizer que o orçamento total da União em 1966 foi de 4.719.085.180 cruzeiros novos. Em período equivalente, ou seja de $1^{\circ}$ de julho de 1965 a 30 de junho de 1966, o orçamento da cidade de Nova York ${ }^{2}$ foi de 3.7744.733.084 dólares (total expenditures), ou seja 8.304.412.785 cruzeiros novos, ao câmbio da época, que era de NCr\$2,20 o dólar.

FONTE: Yearbook of National Arcounts Statistics, 1966. 
O orçamento da União é inferior ao de uma cidade que não possui encargos militares contra inimigos externos e que não precisa sustentar um corpo diplomático no exterior.

A comparação aparentemente arbitrária que apresentamos serve para ilustrar a escassez dos recursos federais para enfrentar vários problemas, entre os quais o da Educação, que é realmente oneroso, dos mais onerosos que se possa imaginar. É necessário que se tenha plena consciência de que Educação custa muito dinheiro.

Ao compararmos as imensas tarefas que teremos forçosamente de enfrentar, se quisermos eliminar as grandes carências do atendimento escolar, nos três níveis de ensino, com os escassos recursos orçamentários disponíveis, torna-se patente a enorme desproporção entre a magnitude dos objetivos a atingir e a insuficiência dos meios de que dispomos para alcançá-los. Para citar um único exemplo: na II Conferência Nacional de Educação, que se reuniu em Porto Alegre em abril de 1966, o Diretor do Instituto Nacional de Estudos Pedagógicos demonstrou que somente o programa de construção e equipamento das salas de aula indispensáveis à expansão da rede de estabelecimentos de ensino primário, como decorrência do programa de escolarização compulsória estabelecido no Plano Nacional de Educação, exigiria nada menos de 1.875 bilhões de cruzeiros antigos em seis anos, o que representaria a média de 312 bilhões de cruzeiros antigos por exercício. A fim de que se tenha uma ideia do que esta última quantia representa, basta considerar que o custeio de um sistema de escolarização de 10,275 milhões de crianças existentes em 1964 exigiria recursos da ordem de 292,270 bilhões de cruzeiros «importância superior à soma da totalidade de recursos do Fundo Nacional do Ensino Primário (46,932 bilhões) e da totalidade dos recursos que os Estados (218,208 bilhões) e os Municípios (27 bilhões) estavam obrigados a destinar à manutenção e desenvolvimento do ensino...» (II Conferência Nacional de Educação, MEC/INEP, 1967, pág. 60).

A verdade é que o desafio educacional é muito mais grave. $\mathrm{O}$ programa de escolarização compulsória exige mais de 320.000 salas de aula. E há mais: para atender, em 1970, 13,5 milhões de crianças de 7 a 11 anos e 4,5 milhões de 12 a 14 anos serão necessários mais de 500 mil professores diplomados.

Jacques Lambert, ${ }^{4}$ no seu livro Os Dois Brasis, analisa o problema brasileiro de escolarização obrigatória sob aspecto demográfico, e demonstra que, em relação à população ativa, o encargo brasileiro com a educação compulsória é cerca de quatro vezes mais pesado que o da França, pois, para cada criança em idade escolar, existem no Brasil

3 II Conferência Nacional de Educação, INEP/MEC, 1967, pág. 60.

4 Jacques Lambert, Os Dois Brasis, INEP/MEC, 1959. 
121 indivíduos ativos, enquanto na França, para cada criança, existem 432 indivíduos ativos. «Poucos países, conclui Jacques Lambert, consagram ao ensino percentagem tão alta do seu orçamento, mas, em face de tal composição por idade, é totalmente impossível fornecer a toda população um ensino satisfatório; em iguais condições, nenhum país, aliás, o conseguiu. Quando o número das crianças é muito grande em relação ao dos adultos, torna-se necessário que o ensino seja breve e muito barato, ou então que seja proporcionado a uma parte apenas da população».

De qualquer forma, dentro das possibilidades existentes, o Brasil vem invertendo em Educação menos do que deveria, segundo todos os parâmetros.

Nem sempre será lícito comparar a situação do Brasil com a de outras nações em grau de desenvolvimento diferente. Mas às vezes essas comparações podem ser elucidativas e ilustrativas. Com os enormes recursos de que dispõem, os Estados Unidos empregam 6,7\% do seu PNB em Educação e $3 \%$ em Pesquisa. O Brasil emprega no máximo 3,5\% em Educação e 0,1\% em Pesquisas.

Outras fontes de informações dão para a contribuição americana percentagem inferior à citada, apenas $4,6 \%$, mas a cifra correta colhida em boa fonte é a de $6,7 \%{ }^{5}$ A taxa brasileira de $3,5 \%$ foi fornecida pelo Ministro Hélio Beltrão em entrevista ao Jornal do Brasil de 15/5/68 e $O$ Globo de 19/6/1968. Ignoramos em que informes o Sr. Ministro se baseou para encontrar cifra tão favorável, porque, segundo dados do Escritório de Pesquisa Econômica Aplicada do Ministério do Planejamento, as cifras do PIB eram bem mais baixas em passado recente, como se vê, transcrevendo o quadro a seguir $\left(\mathrm{n}^{\circ} 2\right)$ oferecido em Educação (I) sob o Quadro $n^{\circ} 46$ :

QUADRO 2

DESPESAS COM EDUCAÇÃO NO BRASIL E PIB

\begin{tabular}{|c|c|c|c|}
\hline A N O & $\begin{array}{l}\text { DESPESAS COM EDUCAÇÃO } \\
\text { (Cr\$ bilhões correntes) }\end{array}$ & $\begin{array}{c}\text { PIB } \\
\text { (Cr\$ bilhões correntes) }\end{array}$ & $\begin{array}{c}\text { DESPESAS } \\
\text { COMO \% DO } \\
\text { PIB }\end{array}$ \\
\hline 1960. & 66,5 & $2.396,8$ & 2,8 \\
\hline 1961. & 102,6 & $3.475,1$ & 3,0 \\
\hline 1962 & 177,1 & $5.435,6$ & 3,3 \\
\hline 1963. & 270,1 & 9.619 .8 & 2,8 \\
\hline 1964. & 532,3 & $18.726,2$ & 2,8 \\
\hline
\end{tabular}

5 U.S. Department of Health, Education and Welfare, Digest of Educational Stntistics, 1966. Government Printing Office, 1966, Washington, D.C., pág. 18. 
Mesmo assim, a taxa ainda seria inferior à de países como a União Soviética $(7,1)$, o Canadá $(4,5)$ e o Japão $(5,3)$, mas superior à de países como a Nicarágua $(1,3)$ e o Paraguai $(1,15)$, onde, entretanto, as taxas de escolarização primária são mais favoráveis que as do Brasil.

Dir-se-á que não tem maior sentido comparar os gastos do Brasil com os gastos de nações altamente desenvolvidas. Mas se, como dizem, a Educação é fator de desenvolvimento, então para que a diferença entre o Brasil e, digamos, os Estados Unidos se mantenha constante a nossa taxa de educação deveria ser igual à taxa norte-americana. Se gastarmos menos, o incremento de desenvolvimento nacional será menor que o incremento do desenvolvimento norte-americano, e o gap aumentará. Só haverá um meio de reduzir o enorme gap entre um país desenvolvido e um país subdesenvolvido: é este último gastar em Educação percentagem maior de seu PIB que o antagonista. Esse raciocínio simples e até ingénuo não é de todo verdadeiro (porque o desenvolvimento não é função apenas de Educação), mas serve ao menos para mostrar não ser de todo desproporcionada a comparação entre nossos educadores e os gastos de outros povos vanguardeiros. É óbvio que, além de gastar mais, precisamos gastar bem, pois de outra maneira estaríamos agravando o círculo vicioso do subdesenvolvimento.

Além do mais, tudo indica que na taxa de Educação de 3,5\% fornecida pelo atual Ministro do Planejamento, se houver erro, será para mais e não para menos. O embaixador Roberto de Oliveira Campos (O Globo, 31-1-1968) reconhece que ela se baseia em «estimativas reconhecidamente precárias.» Calcula-se o PNB para a Educação multiplicando por 100 o produto da divisão entre o que se gasta com Educação (dividendo) com o valor bruto das mercadorias e serviços produzidos pela economia de um país (divisor). No Brasil, devemos suspeitar do numerador e do denominador da fração, sobretudo deste último, porque o grau de organização econômica ainda é baixo, sendo razoável supor que muitos itens econômicos sejam negligenciados. Muitos serviços e bens fogem ao mercado, sendo por isso ignorados. Toda a agricultura de subsistência entra nessa categoria. Os serviços de informação estatística são reconhecidamente deficientes, inclusive seu pessoal. Há alguns anos, Henry Spiegel ${ }^{6}$ calculou que o PNB brasileiro fosse muito provavelmente o dobro das cifras oficialmente oferecidas. Acredita-se que a situação haja melhorado, mas não está completamente corrigida. No que diz respeito à contribuição federal, verifica-se que ela é menor do que poderia ser. É sabido que a Constituição Federal de 1946 estabelecia em seu art. 169 que fossem aplicados para manutenção e desenvolvimento do ensino (veja-se bem, do ensino, e não da educação) $10 \%$, pelo menos, dos recursos orçamentários da União e $20 \%$, pelo menos, dos recursos orçamentários dos Estados e Municípios.

\footnotetext{
6 Henry W. Spiegel The Brazilian Economy: Chronic In[lation and Sporadic industrialization, Filadélfia, Blokiston Co., 1949.
} 
Com base naquela disposição constitucional, a LDB, em seu art. 92, determinou que a União aplicasse $12 \%$, no mínimo, de sua receita de impostos e os Estados, e Distrito Federal e os Municípios 20\%-, no mínimo.

O princípio da vinculação de despesas para fins específicos não foi consagrado pela Constituição Federal vigente, que diz em seu art. 65, 6 33: «Ressalvados os impostos únicos, e as disposições desta Constituição e de leis complementares, nenhum tributo terá a sua arrecadação vinculada a determinado órgão, fundo ou despesas. A lei poderá, no entanto, instituir tributos cuja arrecadação constitua receita do orçamento de capital, vedada sua aplicação no custeio de despesas correntes». Surge o problema de saber se, com isso, fica ou não revogado o art. 92 da LDB. Poder-se-ia pensar que a vinculação deixa de ser imperativo da lei constitucional, mas continua ainda válido o dispositivo da lei ordinária, até que seja explicitamente revogado. Não nos pronunciaremos em assunto que foge totalmente à nossa esfera de competência. O certo é que a União, em suas dotações, jamais obedeceu em sua plenitude ao mínimo legal estipulado pela LDB, mas procurou aproximar-se da exigência. Os Estados, contudo, respeitaram-na exemplarmente, o que não ocorreu com os Municípios, que se mostraram, de modo geral, incapazes de cumpri-la.

As informações mais recentes que obtivemos, graças à gentileza do Ministério do Planejamento, mostram que a contribuição dos Estados continua superando a contribuição federal e municipal reunidas.

São dados preliminares e não oficiais do IPEA, sujeitos ainda a retificação, mas absolutamente válidos em suas linhas gerais. Com essa ressalva e com os agradecimentos da Equipe de Assessoria ao Planejamento do Ensino Superior - EAPES - que representou a contrapartida brasileira no acordo MEC/USAID para o ensino superior, aí estão os dados mencionados: 


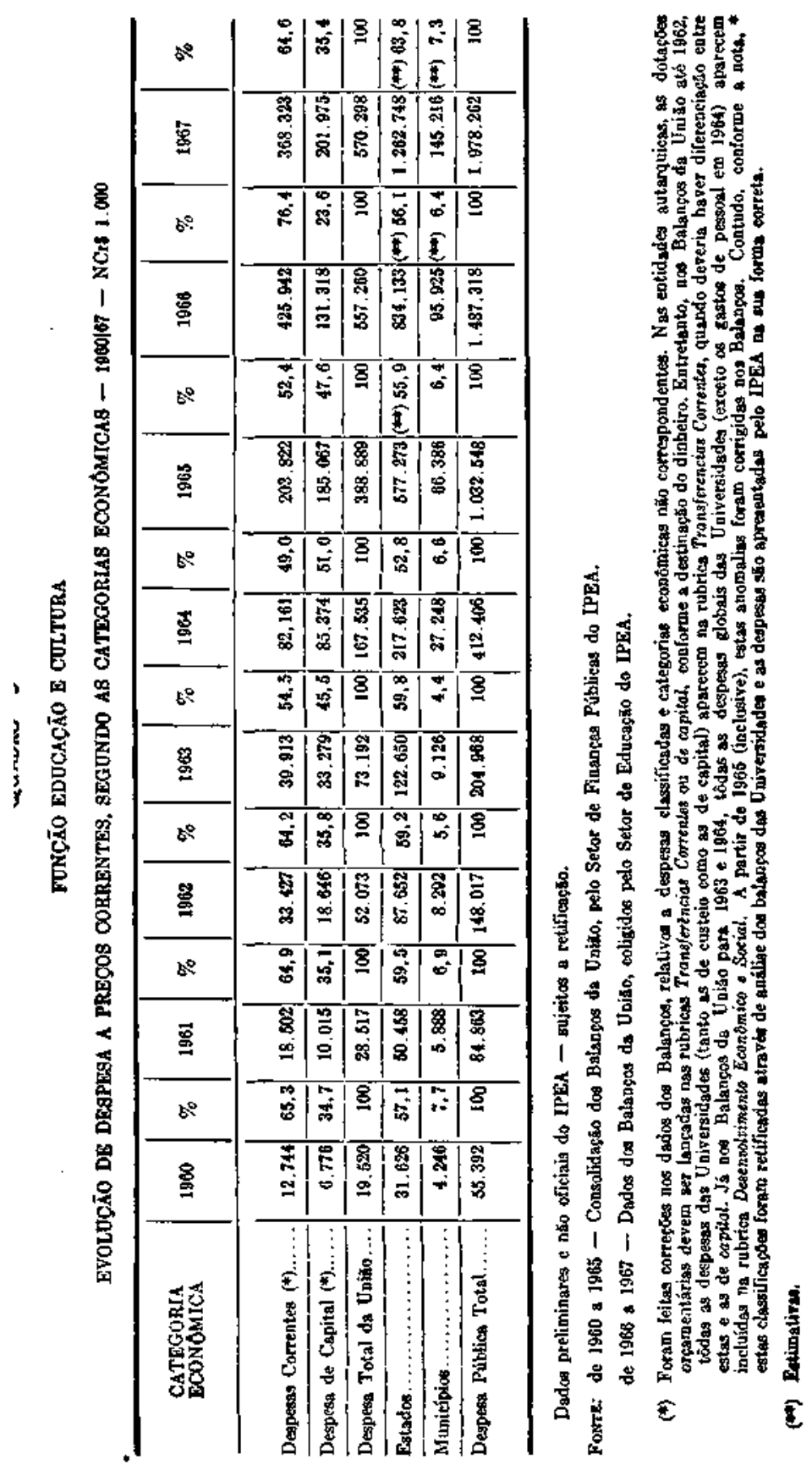


Do quadro se conclui que o investimento dos Estados em Educação durante o período de 1960 a 1967 superou de muito a soma dos investimentos feitos pela União e pelos Municípios.

QUADRO 4

INVESTIMENTOS EDUCACIONAIS

de 1960 a $1967 \mathrm{~cm}$ NCr\$ 1.000

Estados

União

3.184 .163

Municípios

362.327

Total

5.303 .774

Revogado ou não o art. 92 da Lei de Diretrizes e Bases, o certo é que vem caindo a percentagem destinada à Educação no orçamento federal, conforme se vê, combinando dados publicados pelo IPEA $^{7} \mathrm{e}$ pelo Conselho de Reitores ${ }^{8}$.

QUADRO 5

DESPESAS DA UNIÃO COM EDUCAÇÃO COMO PERCENTAGEM DA RECEITA

\begin{tabular}{|c|c|}
\hline ANOS & $\%$ \\
\hline 1963. & 9,2 \\
\hline 1964 & $.11,5$ \\
\hline 1965 & 11,0 \\
\hline 1966. & 9,7 \\
\hline 1967. & 8,7 \\
\hline 1968 & 7,7 \\
\hline
\end{tabular}

Esses dados fornecidos pelo Conselho de Reitores foram considerados defeituosos. Afirmou-se que o percentual em relação ao orçamento federal pouco significa, só sendo importante o cálculo feito em relação ao PIB. Entretanto, o cálculo em relação à receita de impostos revela mais e melhor do que a chamada taxa de educação a prioridade que o Governo Federal dá aos problemas educacionais.

A verdade é que a contribuição da União vem caindo. Após um esforço maior feito em 1965 e ainda mantido em 1966, houve uma espécie de íefrigeração. Mesmo elaborando um quadro de receita da União com exclusão da parcela referente ao imposto único sobre energia elétrica, minerais e combustíveis e lubrificantes, observa-se uma queda na contribuição federal. Nesse demonstrativo, com receita amputada, a percentagem gasta com Educação subirá, é claro, mas, mesmo lançando mão desse artifício, verifica-se queda da contribuição federal. A percentagem de gastos com Educação seria então a seguinte, a partir de 1963:

' ^ Plano Decenal de Desenvoltamente Econômico e Social - Educação (I) Diagnóstico Preliminar, Ministério do Planejamento, EPEA, 1966.

8 Conselho de Reitores das Universidades Brasileiras, Conjuntura Atual das Universidades Brasileiras, UFSC, Florianópolis, Out/1967. 


\section{QUADRO 6}

PERCENTAGEM DA RECEITA GASTA COM EDUCAÇÃO, EXCLUÍDO DA RECEITA O IMPOSTO ÚNICO SOBRE ENERGIA ELÉTRICA, MINERAIS, ETC.

ANOS

1963.

1964.

1965.

1966.

1967.
PERCENTAGEM

10,2

O imposto único, em questão, destina-se todo ao Ministério de Minas e Energia. Até 1963, tratava-se de imposto único sobre energia elétrica; a partir de 1964, passou a ser imposto único sobre energia elétrica e minerais e, a partir de 1968, temos o imposto único sobre energia elétrica, minerais do país e combustíveis e lubrificantes.

Acrescentem-se às aperturas das verbas federais de Educação os cortes de verbas e os atrasos na liberação das que não foram cortadas. No Fundo de Contenção para o exercício financeiro do ano de 1968, estabelecido pelo Decreto n» 62.316, o corte sofrido pelo Ministério da Educação e Cultura foi dos mais elevados, ou seja 15\%-, como se vê no demonstrativo abaixo:

\section{QUADRO 7}

FUNDO DE CONTENÇÃO - 1968

\section{O R G A O S}

Ministerio da Fazenda.

Ministerio do Interior.

Ministerio da Educacao e Cultura

F6rgas Armadas.

Ministerio da Agriculture

Ministerio da Saude.

Ministerio dos Transposes

Ministerio das Minas e Energia

Ministerio do Trabalho e Previdencia Social

Ministerio das Comunicacoes.

PrcsidSncia da Republica.

Ministerio da Justica.

Ministerio do Planejamento.

Ministerio das Relacoes Exteriores

Ministerio da Industrie e Comercio.

TOTALL

\begin{tabular}{|c|c|}
\hline NCr\$ 1.000 & $\%$ \\
\hline & 30,0 \\
\hline & 15,4 \\
\hline & 15,0 \\
\hline & 10,0 \\
\hline & 8,1 \\
\hline & 4,1 \\
\hline & $\begin{array}{l}5,0 \\
3,6\end{array}$ \\
\hline & 3,6 \\
\hline & 2.1 \\
\hline & 1.6 \\
\hline & 1,3 \\
\hline & 0,7 \\
\hline & 0,6 \\
\hline & 0,1 \\
\hline 600.000 & 100 \\
\hline
\end{tabular}


$\mathrm{Na}$ publicação citada do Conselho dos Reitores, verifica-se que em 1967 a contribuição percentual do MEC para o Fundo de Reserva ultrapassa a de qualquer outro Ministério, como se vê abaixo:

QUADKC 8

DEMONSTRAÇÃO DA INCIDÊNCIA DO FUNDO DE RESERVA DE 1967 NOS MINISTÉRIOS

SUBANEXO
DO
ORÇAMENTO/67

4.04.00

4.05 .00

4.06 .00

4.07 .00

4.08 .00

4.09 .00

4.10.00

4.11 .00

4.12 .00

4.13 .00

4.14 .00

4.15 .00

4.16.00

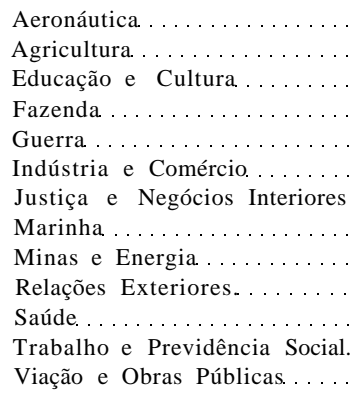

TOTAL

\author{
DOTAÇÃO \\ ORÇAMENTO/67 \\ LEI n.o 6.169/66
}

FUNDO RESERVA

DECRETO-LEI n. ${ }^{\circ} 81$

$\begin{array}{rrrr}419.974 .504 & 24.134 .000 & 6,7 \\ 222377,216 & 25.241 .000 & \mathbf{1 1 , 3} \\ 604644.282 & 69.341 .000 & 11,4 \\ 2.082013 .580 & 36.438 .000 & 1,7 \\ 643.684 .346 & 20.267 .000 & 3.1 \\ 14,901.072 & 476.000 & 3,2 \\ 78916.577 & 4.356 .000 & 5,5 \\ 353673.600 & 8.343 .000 & 2,3 \\ 262,568.436 & 17.710 .000 & 6,7 \\ \mathbf{1 0 0} 204.915 & 2.774 .000 & 2,7 \\ 239449.509 & 24.251 .000 & 10,1 \\ 75.543 .770 & 880.000 & 1.1 \\ 1.115,599.582 & 82.670 .000 & 7,4 \\ & & \\ 6.213 .551 .479 & 316.881 .000 & \mathbf{5 , 0 0}\end{array}$

Será sempre preferivel analisar antes as despesas realmente feitas, e não as dotações orçamentárias. E é importante, para a compreensão de certas agruras por que passa o Ministério da Educação, comparar os dinheiros realmente recebidos no curso de alguns anos, mas procedendo antes ã correspondente correção monetária. Inflacionada para o valor da moeda em 1967, a contribuição federal a partir de 1963, teremos o seguinte quadro:

QUADRO 9

DESPESAS FEDERAI: COM A EDUCAÇÃO

\begin{tabular}{cc|c}
\hline ANOS & $\begin{array}{c}\text { Gastos com Educação } \\
\text { em milhões de cruzeiros } \\
\text { antigos }\end{array}$ & $\begin{array}{c}\text { Valores inflacionados } \\
\text { para } 1967 \text { em } \\
\text { NCr\$ } 1.000\end{array}$ \\
\hline 1963 & 73.192 & \\
1964 & 167.535 & 389.733 \\
1965 & 388.889 & 467.452 \\
1966 & 557.260 & 690.744 \\
& 570.298 & 570.710 \\
\hline
\end{tabular}


Houve queda acentuada em 1967, pois várias despesas do 4' trimestre foram liberadas em 1968. Exemplo típico são as verbas destinadas às Universidades.

Os cruzeiros gastos em 1963 e 1964 diferem dos apresentados no vol. Educação I, publicado pelo EPEA (Ministério do Planejamento), Quadro 37, entre págs. 90 e $93,{ }^{9}$ em virtude de correções posteriormente feitas.

No caso particular do ensino superior vimos, em outro trabalho, como os estrategistas do nosso desenvolvimento ofereceram a este ramo de ensino contribuição relativamente modesta. Para o decénio de 1967 a 1976 foram destinados 4.635.213.080 de cruzeiros novos ao ensino superior, contra 10.121.033.000 de cruzeiros novos destinados ao ensino médio (ginasial e colegial) e 9.685.029.000 destinados ao primário. ${ }^{10}$

A falta real de recursos para Educação, sobretudo a superior, pode ser compensada, parcialmente, mercê de empréstimos suaves, combinados com doações.

No campo do financiamento muito poderia ser feito através de estímulos fiscais para a inversão de dinheiro na criação de Universidades. Já se falou em sudenizar a Educação. Também se vem propondo a criação de um Banco Nacional de Educação, e essa ideia já constitui objeto de um projeto de lei (Projeto n" 1.391, de 1968, da deputada Sra. Júlia Steinbruck) . Acerca da criação de Banco de Educação, temos algumas críticas a fazer, resultantes de um receio básico, qual seja o de que êle venha a ajudar mais ao rico que ao pobre, como tantas organizações sociais, que acabam sempre, no Brasil, favorecendo uma minoria de privilegiados.

O movimento financeiro do Banco Nacional da Habitação, cujo êxito bancário e operacional serve de estímulo a um Banco de Educação, é canalizado para os grandes empreiteiros, enfim, para aquelas firmas construtoras que têm capacidade de enfrentar a complexa burocracia do Banco e que podem oferecer sólidas garantias hipotecárias. O pequeno construtor não tem acesso aos seus favores. Assim, caso venha a ser criado um Banco de Educação, será quase inevitável que êle passe a agravar o processo de seletividade não-pedagógica do ensino no Brasil.

Nossos problemas educacionais devem ser tratados sobretudo com recursos internos e melhor aproveitamento das disponibilidades já existentes. Numa exposição feita perante a EAPES, na vigência do Acordo MEC/USAID para o ensino superior (extinto em 30/6/1968),

Educação (I). Dagnóstico Preliminar, Plano Decenal de Desenvolvimento Econômico e Social, Ministério do Planejamento, 1966.

10 Educação e Mão-de-Obra, vol. 1, tomo VI, Plano Decenal de Desenvolvimento Econômico e Social, Ministério do Planejamento, 1967. 
o Prof. J. M. Hunter (do Departamento de Economia da Michigan State University) mostrou a pouca ou nenhuma vantagem dos empréstimos externos. O empréstimo externo não aumenta os recursos internos de que a Educação depende, como professores e materiais de construção. Uma vez que a moeda estrangeira deverá ser convertida em cruzeiros, será mais econômico emitir papel. Os efeitos de nossos cruzeiros sobre a economia nacional serão aproximadamente os mesmos, quer venham de um empréstimo externo, quer venham da Casa da Moeda. Só em determinados casos, como seja para compra de equipamentos, o empréstimo externo tem alguma serventia.

Podemos aceitar doações, sobretudo em equipamentos, ou então empréstimos muito suaves.

Um dos empréstimos educacionais mais recentes foi o do BID, de 25,000.000 de dólares, destinados a 9 Universidades brasileiras, a saber:

Universidade Federal do Rio de Janeiro

Universidade de Brasília

Universidade Estadual de São Paulo

Universidade Federal de Minas Gerais

Universidade Rural do Estado de Minas Gerais

Universidade Federal do Ceará

Universidade Federal de Pernambuco

Pontifícia Universidade Católica do Rio de Janeiro

Universidade Federal da Bahia

Alguns dados sobre o empréstimo, extraídos do Diário Oficial e $11 / 1 / 1968$.

Montante do empréstimo: até US\$ 25,000.000 ou seu equivalente em outras moedas que façam parte do Fundo de Operações Especiais do BID.

Pagamento do empréstimo: 43 prestações semestrais sucessivas, a partir de 30/11/1971.

Juros: semestrais sobre os saldos devedores, de $2,25 \%$ ao ano, contados a partir da data dos respectivos desembolsos. Serão pagos em 31 de maio e 30 de novembro de cada ano, começando em 31/5/1968.

Comissão de serviço: o mutuário pagará ainda, semestralmente, e sobre os saldos devedores, comissão de serviço de $0,75 \%$ ao ano, contada a partir da data dos respectivos desembolsos, paga na mesma data estabelecida para os juros.

Comissão de compromisso: sobre o saldo não desembolsado do montante máximo (US\$ 25 milhões), o mutuário pagará uma comissão de compromisso de $0,5 \%$ ao ano, contada após 60 dias da assinatura deste contrato. Será paga na mesma data do pagamento dos juros.

$\mathrm{O}$ auxílio internacional ao ensino frequentemente assumiu caráter ainda mais benigno que esse do empréstimo do BID. 
A USAID, somente em doações para Educação, que é uma de suas atividades mais modestas, despendeu 65 milhões de dólares no Brasil, entre 1945 e 1965.

\section{DOAÇÕES DA USAID AO ENSINO NO BRASIL 11 $1945-1966$}

\begin{tabular}{|c|c|c|}
\hline & & US\$ \\
\hline Ensino & Primário. & 57.391 .000 \\
\hline Ensino & Secundário. & 2.260 .000 \\
\hline Ensino & Superior. & 5.533 .000 \\
\hline
\end{tabular}

Parece ser decisão da USAID substituir totalmente o sistema de doações pelo de empréstimos suaves.

O problema da contribuição internacional vem sendo bem estudado pelo Instituto de Pesquisa Econômica Aplicada, IPEA, do Ministério do Planejamento. De 1960 a 1965, as dotações recebidas pelo Brasil atingiram o montante de 59 milhões de dólares, como se vê na relação abaixo fornecida pela IPEA:

\section{US\$}

\begin{tabular}{|c|c|}
\hline USAID. & 43.038 .610 \\
\hline BID. & .4 .000 .000 \\
\hline Fundação Ford & 10.405 .400 \\
\hline UNESCO . . . & 606.010 \\
\hline UNICEF. & 970.400 \\
\hline OIT. & .19 .800 \\
\hline Programa Ampliado de Assistência Técnica & 193.600 \\
\hline
\end{tabular}

TOTAL 59.233 .820

Retirando do Quadro 3 os gastos educacionais do Brasil (União, Estados e Municípios) referentes aos anos de 1960 a 1965 e convertendo esses gastos em dólares, sempre levando em conta a taxa de câmbio, obteremos um total de US\$ 2.062.664.000. Os gastos da União foram de US\$ 754.178.000.

Nessa quantia devem estar incluídos os US\$ 59.233.820 da contribuição das diferentes agências americanas. Se assim fôr, a contribuição americana terá sido de 2,8 por cento. Terá sido de 2,9 por cento na hipótese contrária.

A contribuição das diferentes agências americanas representa por sua vez 8,5 por cento da contribuição federal ao ensino, se a quantia

11 Nas doações estão incluídos os salários dos funcionários americanos que trabalharam nos projetos, através dos quais a doação foi concedida.

12 Plano Decenal — Educação I - Diagnóstico Preliminar, 1966. 
de USS 59.233.820 estiver incluída nos gastos federais, ou 7,9 por cento, se a quantia referida não houver sido incluída.

As doações da Fundação Ford entre 1959 e 1967 montaram a mais de 15 milhões de dólares, como se vê no quadro a seguir:

\section{FUNDAÇÃO FORD}

Total de Doações em US\$ - Novembro de 1959 a junho de 1967 (não incluem Despesas Administrativas)

Ciência e Tecnologia.

\section{US\$} $\%$

Ciências Naturais.

Tecnologia

$$
3.617 .500 \text { (10 doações) }
$$

$1 \cdot 174.640$ ( 3 doações)

Ciências Sociais

Economia e Desenvolvimento Econômico

Administração Pública e Ciência Política.

Administração de Empresas

2.148 .000 ( 8 doações $)^{\mathrm{u}}$

4.792 .140

Direito e Desenvolvimento

$$
\begin{array}{cc}
1.160 .400 & (4 \text { doações }) \\
605.000 & (2 \text { doações }) \\
485.000 & (1
\end{array}
$$

Agricultura.

Pesquisa de Produção de Alimentos.

Desenvolvimento Agricola Universitário.

Economia Agrícola

Educação Vocacional em Agricultura

Educação c Humanidades.

Educação Primária.

$$
\begin{array}{r}
700.000 \quad(2 \text { doações }) \\
1.070 .000 \quad(2 \text { doações }) \\
630.000 \quad(2 \text { doações }) \\
1.100 .000 \quad(1 \text { doação })
\end{array}
$$

Educação Secundária ....

Educação Superior

240.000 ( 2 doações)

1.454 .800 (13 doações)

565.500 ( 2 doações)

População.

476.500 ( 1 doação)

Biologia Reprodutiva

(53 doações)

15.427.340

TOTAL DE DOAÇÕES.

.(53 doaçôs)

476.500

Nem sempre tem sido possível receber as contribuições vindas de fora, em virtude de desentrosamento, acerca dos quais não nos cabe emitir julgamentos. A título ilustrativo, veja-se como era ou teria sido, ou talvez ainda venha a ser, um empréstimo da USAID de US\$ 25.000.000, destinados ao ensino secundário:

Montante fornecido pela USAID - US\$ 25.000.000.

O Governo Brasileiro se compromete a aplicar igual quantia, tendo em vista alcançar os objetivos previstos no Acordo. O equivalente em cruzeiros desta quantia deverá ser depositada no Banco do Brasil.

Valor total do projeto - US\$ 50.000.000.

U Esta quantia inclui a doação de US\$ 140.000, destinada à SUDENE, e que deve ser relacionada no item Agricultura. 
O projeto já está basicamente estruturado, embora ainda não se tenha chegado a um acordo quanto a sua forma final. Os estudos tinham término previsto para 1» de maio de 1968 e o convênio deveria ser assinado a 15 de junho de 1968.

Dentre os objetivos, destacam-se:

1. Ampliar o sistema de ensino médio público em 4 Estados: Bahia, Espírito Santo, Minas Gerais, Rio Grande do Sul, o que inclui a construção de novas escolas.

2. Aprimorar o treinamento de professores para o nível médio em todo o país.

3. Ampliação e melhoria dos atuais seis Centros de Treinamento de Professores em ciências.

4. Criação de novos Centros de Treinamento de Professores de Matérias Técnicas Educacionais e ampliação dos já existentes. Estes professores lecionam matérias, tais como artes industriais, agricultura, práticas comerciais, economia doméstica, etc.

5. Distribuição de bolsas de estudo.

O projeto concentrará seus esforços basicamente no nível ginasial e unicamente nos ginásios vocacionais, ou ginásios voltados para o trabalho, não incluindo, portanto, os ginásios industriais, comerciais, etc.

O empréstimo de US\$2 25 milhões da USAID deverá ser pago com um prazo de carência de 10 anos. O prazo total, para que o Governo brasileiro pague o empréstimo, é de 40 anos, devendo esse pagamento ser feito em dólares e com juros de aproximadamente $0,5 \%$ ao ano.

A parte brasileira será utilizada com correção monetária. Assim, cada parcela dos 25 milhões de dólares - correspondentes à parte brasileira - que fôr aplicada, deverá sê-lo na base do câmbio da época de sua aplicação.

As instituições que receberem o auxílio da USAID estão isentas de qualquer pagamento, ficando o Governo Federal responsável pelo pagamento do empréstimo à USAID .

Esses eram os termos do empréstimo. Mas a contribuição brasileira a esse projeto foi cortada pelo Ministério do Planejamento e destarte a USAID, automaticamente, deveria retirar sua oferta. Acreditamos que esteja havendo no momento esforço bilateral por parte das autoridades brasileiras e norte-americanas para solucionar favoravelmente o caso.

Em virtude das contenções, cortes, atrasos no pagamento de verbas para a Educação e rejeição de projetos de empréstimo, compreende-se que altas personalidades do Ministério do Planejamento tenham vindo a público, com bastante frequência, criticar o funcionamento do ensino no Brasil. Declara o Embaixador Roberto de Oliveira Campos 
30/1/1968): «É tão escandalosamente baixo o rendimento do investimento federal no ensino superior, que seria imprudente expandir o dispêndio sem corrigir as causas do desperdício.» $\mathrm{E}$ ainda: «O Brasil não gasta absurdamente pouco em Educação, gasta absurdamente

E por isso entende S. Excia. que, «antes de lacrimejarmos sobre Carência de verbas para a Educação, há que corrigir, em primeiro luaar o enorme desperdício embutido em nosso atual nível de dispêndio.»

Em entrevista ao jornal do Brasil (15/5/1968), o Ministro Hélio Beltrão externou ponto de vista análogo.

Realmente, há muito que corrigir no Brasil, não só em matéria de aproveitamento de recursos destinados à Educação, mas também à agricultura, à rede ferroviária nacional e aos demais ministérios, autarquias sociedades de economia mista, e fundações que, afinal, formam ou expressam a realidade nacional. A crítica que merecem as altas autoridades brasileiras em Educação não tem caráter específico, ao que tudo indica. Mas sobre elas, particularmente, é que se vêm concentrando as criticas.

Tentaremos, mais adiante, apontar as principais causas do desperdício financeiro em matéria de Educação.

Antes, queremos assinalar a existência de boa fonte de recursos para a instrução primária, que é o salário-educação, criado pela Lei n 4.440 , de 27 de outubro de 1964.

O art. 170 da atual Constituição consagra o salário-educação da Lei $\mathrm{n}^{\circ} 4.440$ e estendeu o disposto no art. 168, alínea III, da Constituição de 1946, que obrigava as empresas de mais de 180 empregados a manter ensino primário gratuito. Agora, são todas as empresas, mesmo com menos de 100. A obrigatoriedade se estendeu a todas as empresas. E onde houver mais analfabetos, haverá mais dinheiro. Assim, dispõe o art. $4^{\circ}$ da Lei $n^{\circ} 4.440$, de 27 de outubro de 1964:

«Art. $4^{\circ}$ As contribuições recolhidas nos Estados, no Distrito Federal, e nos Territórios, deduzida a parcela de meio por cento relativa às despesas de arrecadação. serão depositadas dentro de sessenta (60) dias, sob pena de responsabilidade civil e penal, pelos Institutos de Aposentadoria e Pensões no Banco do Brasil S. A., em duas contas distintas:

a) $50 \%$ a crédito do Fundo Estadual de Ensino Primário ou, na inexistência deste, em conta vinculada ao «desenvolvimento do ensino primário», a crédito do respectivo Governo, para aplicação no próprio Estado, de conformidade com o $\S 1^{\circ}$ deste artigo;

b) $50 \%$ em conta vinculada ao Fundo Nacional do Ensino Primário, como reforço de seus recursos e para aplicação em todo o território nacional, na conformidade 
e segundo os mesmos critérios de distribuição estabelecidos pelo Conselho Federal de Educação $\left(\S 2^{\circ}\right.$ do art. 92 da Lei n 4.024, de 20 de dezembro de 1961), o qual levará em conta, sobretudo, a razão direta dos índices de analfabetismo .

$\S 1$ Os recursos de que trata a letra a deste artigo serão aplicados nos Estados, e no Distrito Federal, de acordo com planos estabelecidos pelos respectivos Conselhos Estaduais de Educação, e, nos Territórios, de conformidade com os critérios que forem fixados pelo Conselho Federal de Educação.

$\S 2^{\circ}$ Durante os três primeiros anos de vigência desta lei, $40 \%, 50 \%$ e $60 \%$, respectivamente, dos recursos do salário-educação serão obrigatoriamente aplicados em despesas de custeio e o restante em construções e equipamentos de salas de aula. Nos anos seguintes, a percentagem atribuída a construções e equipamento será fixada pelo Conselho Federal de Educação.»

Estima-se que o salário-educação recolhido pelo INPS venha a atingir em breve a cifra de $\mathrm{NCr} \$ 200.000 .000$, ou pouco mais. Enquanto o Ministério da Educação estimou a arrecadação do salárioeducação para $1968 \mathrm{em} \mathrm{NCr} \$ 90.000 .000$, a previsão do INPS ascendeu a $\mathrm{NCr} \$ 177.251 .000,00$. As cifras reais do salário-educação equivalem a $1 / 4$ do orçamento federal para Educação, e são três vezes maiores que a dotação do Fundo do Ensino Primário.

Em sua mensagem ao Congresso, na abertura da Sessão Legislativa de 1968. declarou o Marechal Costa e Silva: «As transferências de recursos federais aos Estados e Municípios, para a expansão e manutenção da rede escolar primária, superaram a cifra de NCr\$29.000.000,00, nela incluídos cerca de $\mathrm{NCr} \$ 15.000 .000,00$ da quota federal do salário-educação.» Segundo estamos informados, existe ainda retido, em poder do INPS, um saldo de $\mathrm{NCr} \$ 72.885 .640,72$ referentes aos exercícios de 1966 e 1967.

A Lei $n^{\circ} 4.440$, imaginada por Carlos Pasquale, vem proporcionando bons recursos, como se vê.

Nenhum recurso tributário, entretanto, será suficiente para promover a Educação, em seus diferentes níveis, se não se criar uma vontade cívica de educação, uma consciência nacional de sua importância e utilidade. E é isso que falta para suprir as insuficiências em recursos financeiros e para corrigir certas lamentáveis distorções no uso dos dinheiros públicos.

Deixando de lado o problema das motivações, o certo é que são procedentes muitas das críticas do Embaixador Roberto de Oliveira Campos. Vemos com espanto os recursos educacionais serem esbanjados na edificação de Reitorias suntuosas e na construção de palácios universitários, com enorme desperdício de espaço. A capacidade ociosa de certos edi- 
ficios na Ilha do Fundão e no campus universitário da Universidade de São Paulo ilustra nossa afirmação. A mesma coisa se observa no $\mathrm{Pa}$ á É incrível que na época atual ainda haja quem tente impressionar os outros com obra de fachada.

Explica-se depois a anomalia, assinalada por António Dias Leite (Jornal do Brasil, 16 de junho de 1968), da ausência do vidro de álcool e presença do microscópio eletrónico, ou da relativa abundância de salas de aula e escassez de giz e de papel de mimeógrafo.

Recordamo-nos do saudoso Professor António Austregésilo, quando lembrava que os índios brasileiros, ornamentados embora com cocares e plumas multicores, em verdade continuavam nus.

Por isso mesmo, merece louvor, entre outros, o campus da Uniersidade de Campinas, onde se erguem edifícios com seus tetos de concreto aparente, chão de cimento vermelho, canalização exposta, paredes de fibra vegetal, e o exemplar aproveitamento da área construída. Igual louvor merece a Faculdade de Engenharia Industrial (FEI) de São Bernardo do Campo, da PUC de São Paulo.

Infelizmente, ainda impera em nossas Universidades, em virtude de sua organização em escolas separadas, o sistema de recursos materiais divididos e pessoal multiplicado. Os Decretos-leis ns. 53, de 1966, e 252, de 1967, procuraram, ainda em vão, corrigir esse desperdício.

Não há negar, portanto, repetimos, a procedência de muitas críticas, embora não de todas. Como exemplo ilustrativo da ressalva, citaremos aquela crítica de que no Brasil o número de professores é excessivo. Realmente, em 1965, tínhamos 30.162 professores para 155.781 universitários, o que representa 1 professor para 5,16 alunos. Nos Estados Unidos da América temos 1 professor para 8,74 alunos, conforme se vê ${ }^{15}$ dividindo o número de estudantes (4.234.092) em 1963-64 pelo número de professores (494.514). Em 1967 passamos a ter 213.741 universitários, e é certo que o número de professores não cresceu proporcionalmente, mas não temos dados precisos.

Se quiséssemos fazer um desses paradoxos à Bertrand Russell, quando diz que a parte pode ser igual ao todo, diríamos que 8,74 alunos são menos de 5,12 alunos. Os professores universitários brasileiros são em sua quase totalidade de tempo parcial, enquanto os americanos são em sua quase totalidade de tempo integral. Além de computar o número de professores, cumpre verificar certas peculiaridades, como saber se trabalham ou não em tempo integral e qual o salário que recebem. Calculando o número de alunos em relação ao professor-hora-salário, ver-se-á que o número de professores no Brasil está longe de ser excessivo.

S:nopse Estatística do Ensino Superior, 1964/65. SEEC-MEC, Rio de
Janeiro. Of Educational
Washington,
1966. Statisfics, U.S. Government Printing Office. 
O título de professor é estimulante do amor próprio, mas seu tratamento social vem sendo deprimente, sobretudo nos últimos tempos. Esse contraste gera ressentimentos naturais, e é necessário que se lhe ponha paradeiro, a bem de todos.

Os defeitos apontados não constituem desculpa, é bom frisar-se, para o descumprimento da legislação oficial, que destina ao ensino superior 3,6 por cento da arrecadação federal de impostos. E determina mais a Lei de Diretrizes e Bases em seu art. 82, que os recursos destinados às Universidades «terão a forma de dotações globais, fazendo-se no orçamento da Universidade a devida especificação.» Corroborando e reforçando esse artigo, reza o art. 65 da atual Constituição Federal em seu $\S 1^{\circ}$ : «A inclusão, no orçamento anual, da despesa e receita dos órgãos de administração indireta será feita em dotações globais e não lhes prejudicará a autonomia na gestão de seus recursos, nos termos da legislação específica.»

Mas muito pouco do que manda a lei é cumprido no Brasil, até pelos órgãos oficiais. Ainda recentemente, o Reitor Raimundo Moniz de Aragão (Jornal do Brasil, 16 de junho de 1968) lamentava «a prática, pelo Congresso, de elaborar orçamentos analíticos, especificando dotações até para cadeiras,» o que vem arruinar a autonomia financeira das Universidades .

Diante de tais abusos, compreende-se o brado de três educadores brasileiros (Edília Coelho Garcia, Dom Lourenço de Almeida Prado, O. S. B., e Leônidas Sobrino Porto), membros do Conselho Estadual de Educação do Estado da Guanabara, pedindo que o Poder Público cumpra as leis existentes.

O brado desses ilustres educadores é compreensível e lógico. Realmente, antes de pensar na mudança da legislação, devemos exigir o cumprimento das leis ditas em vigor, que, apesar de algumas falhas, não são más.

E aqui voltamos a repisar uma afirmação anterior. A Nação, como um todo, deve lutar em prol da Educação, que não se divide apenas nos três níveis da lei, ou seja, primário, secundário e superior. Não basta exigir dos governos verbas maiores; as forças vivas da Nação, que valem sempre mais que os governos, devem empenhar-se numa luta geral e inteligente para corrigir os vários aleijões educacionais do Brasil, que não se resumem no analfabetismo, simples manifestação ou expressão de doença mais grave do espírito de uma sociedade. Há um postulado que não deve ser esquecido: num país em que a metade da população é analfabeta, a outra metade andará também muito próxima disso. Não nos esqueçamos quão exíguo é o tempo que permanecem na escola primária a maioria daqueles que nela um dia se matricularam.

Embora a Constituição diga (item II do $\S 3^{1 ?}$ do art. 168) que «o ensino dos sete anos aos quatorze anos é obrigatório para todos e gratuito nos estabelecimentos primários oficiais», a média real de permanência na 
escola primária não atinge a dois anos. ${ }^{16}$ Entretanto, o ensino primário, ao menos durante quatro anos, deveria ser ministrado e exigido por todos os setores responsáveis da sociedade, por suas forças civis, militares e religiosas diferentes partidos políticos, pelas sociedades artísticas e esportivas pelos jornais e pelas associações de comércio e de indústria. a Luta contra o analfabetismo não poderá circunscrever-se ao problema de dotações orçamentárias. Deve representar esforço nacional conjunto. Pena é que venha sendo tão descurada a ação da imprensa falada e escrita no processo educacional. Há hábitos nacionais deploráveis, contra os auais jamais se viu uma ação coordenada e desinteressada da imprensa. Se propuséssemos, por exemplo, que os jornais e estações de rádio e de televisão iniciassem pregação contra o hábito brasileiro de escarrar no chão nossa proposta seria tomada como pilhéria ou impertinência, ou futilidade. Se assim fôr, teremos exemplo de como aquela metade que sabe ler continua analfabeta, em larga medida, inclusive os seus doutores. O excesso de salivação do nosso povo é espantoso, e ninguém pensa com amor e passando por cima das divergências ideológicas, em corrigir esse hábito. E vários outros. Como já se disse tantas vezes, há analogia entre o trabalho do educador e o trabalho do médico. Não lhe cabe apenas ministrar instrução de acordo com os programas oficiais. Corrigir hábitos e costumes vulgares e condenáveis, que já não correspondem às necessidades e motivações da vida civilizada, é ainda tarefa sua. E tarefa para a qual se espera a colaboração daqueles que não são oficialmente professores. E só assim, conjugando esforços, enfrentaremos de cabeça erguida os desafios que o futuro nos reserva.

Não só deixa a imprensa falada e escrita de dar a contribuição esperada, mas contribui algumas vezes, sobretudo a imprensa falada, para agravar o processo de abastardamento da cultura e do sentimento público. Não se deve inferir dessa declaração que sejamos partidários da criação de uma televisão explicitamente educativa, nem de proibir-se a atividade particular no rádio e na televisão. Aqui, como em tantos outros pontos, a solução inglesa se nos afigura a mais simples, natural e engenhosa. Existe na Inglaterra a televisão governamental, a BBC, com dois canais permanentes, proporcionando uma variedade de programas diários, cada qual melhor, e correspondendo amplamente e sem qualquer faccionismo político ou religioso as necessidades do público, inclusive as necessidades culturais. Além disso, permite-se a TV privada, a qual, ante essa dupla (dois canais) concorrência da TV oficial, se vê forçada a elevar seus padrões e a usar com grande parcimônia o anúncio. Através da BBC, foi possível na Inglaterra corrigir até erros de pronúncia vigentes em algumas regiões do país.

\footnotetext{
16 Ver, entre outros, Jaime de Abreu em Problemas Brasileiros de Educação, Rio, Lidador, 1968.
} 
É inacreditável que, para atender aos altos objetivos da Educação e do desenvolvimento nacional, não lance mão o Governo de um recurso tão poderoso quanto a televisão. Mas aqui se impõem algumas cautelas, quando se atenta na má qualidade de certos locutores oficiais. Os erros de pronúncia que cometem já fazem parte do anedotário carioca. Se a situação melhorou recentemente, isto se deve a artistas e locutores vindos de emissoras particulares. Ah! Brasil! Tão desconcertante.

Ainda dentro do contexto de recursos para a Educação, seja-nos permitido aludir ao problema da gratuidade do ensino universitário. Se a Educação tem de ser, no Brasil, esforço nacional solidário, projeto total da comunidade, como situar dentro desse critério o problema da gratuidade?

A Lei Magna (art. 168, § 3, item III) diz que o ensino médio e superior, nos estabelecimentos federais, será gratuito «para quantos, demonstrando efetivo aproveitamento, provarem falta ou insuficiência de recursos».

Entretanto, a gratuidade indiscriminada vigora praticamente em todos os estabelecimentos oficiais de ensino superior. Será isso um bem ou um mal?

Num país ainda em desenvolvimento, a gratuidade indiscriminada é um mal, porque limita a expansão do ensino oficial e não corrige o caráter seletivo, do ponto de vista financeiro, da escola superior.

A despeito de gratuita, ou quase gratuita, a educação superior vem sendo, em países como o Brasil, apanágio de uma minoria. Numa pesquisa feita por Bertran Hutchinson ${ }^{17}$ em 1960, abrangendo 500 alunos do primeiro ano da Universidade de São Paulo, foi encontrada a seguinte distribuição por classes econômicas:

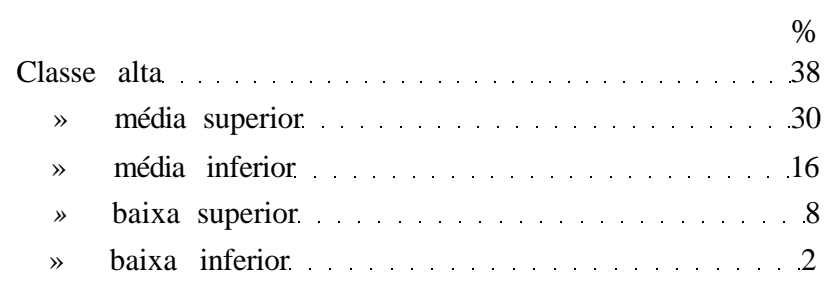

Somente $10 \%$ dos alunos, como se vê, pertenciam à classe mais humilde (baixa superior e inferior).

Foi tentada pelo CBPE uma caracterização sócio-econômico dos universitários em 10 capitais brasileiras (Fortaleza, Salvador, Recife, Belo Horizonte, Niterói, Rio de Janeiro, São Paulo, Curitiba, Porto Alegre e Brasília), utilizando-se para classificação a escala de Bertran Hutchinson,

17 Ver Nádia Franco da Cunha, Vestibular na Guanabara, MEC, 1968. 
baseada no prestígio social das ocupações dos universitários, seus pais e irmãos. O prestigio social desfrutado pelas diferentes profissões tem o valor de classificação de nível econômico. Seis são as ocupações da escala citada (sem habilidades manuais e com semi-habilidades manuais, nível 1; habilidade manual, nível 2; inspeção, supervisão e outras ocupações não manuais, de padrão baixo, nível 3; inspeção, supervisão e outras ocupações não manuais de padrão alto, nível 4; dirigentes e executivos, nível 5; profissionais e administradores, nível 6).

O estudo foi extenso e foram analisadas as peculiaridades dos primeiranistas de Medicina, Ciências Econômicas e Direito. Verificou-se, em resumo, que a maioria dos primeiranistas pertence à classe média e alta. Comparando estudantes de Medicina com os alunos das demais modalidades do ensino superior, verificou-se que:
« $1^{\circ}$, a percentagem de estudantes de Medicina que trabalham é três vezes menor:
$2^{\circ}$, é maior a proporção de alunos das escolas médicas que recebem ajuda monetária da família;
$3^{\circ}$, uma proporção mais alta de primeiranistas de Medicina alegou ter frequentado cursos vestibulares;
$4^{\circ}$, a percentagem de estudantes de Medicina que prestou dois ou mais concursos de habilitação é sensivelmente maior.»

Quanto aos primeiranistas de Direito, verificou-se haver entre eles «maior percentagem de alunos mais velhos, casados, vivendo com os pais ou cônjuge, dedicados simultaneamente ao trabalho e ao estudo e não recebendo ajuda monetária do grupo doméstico».

Não é nossa intenção resumir essa pesquisa, ${ }^{18}$ do mais alto interesse, mas queremos deixar assinalada sua existência.

Outro approach, ou, como se diz também, com uma palavra de mau gosto - enfoque - do problema pode ser dado analisando a composição racial da Universidade, como foi feito por August James Rogers III, da Michigan State University, em trabalho ainda em andamento. A pesquisa na região Norte do Brasil e no Espírito Santo está completa, faltando ainda a apuração dos dados referentes à Guanabara e Santa Catarina.

De modo geral, pardos e negros dispõem de menores recursos financeiros que os brancos, e assim se explica como e por que, na pesquisa citada, resumida no Quadro 10, se encontrou, entre os graduados de nível secundário, uma percentagem de brancos maior que a da população geral, subindo ainda essa percentagem entre os graduados de nível universitário.

\footnotetext{
Caracterização Socio-Economica do Estudante Brasileiro - CBPE, Série 8. [U:sas c Monografias, vol. 3, 1968.
} 
QUADRO 10

PERCENTAGENS DA COMPOSIÇÃO RACIAL DA POPULAÇAO TOTAL. Dos GRADUADOS DE NÍVEL SECUNDÁRIO E DE NÍVEL UNIVERSITÁRIO BRASIL -1960

\begin{tabular}{|c|c|c|c|}
\hline Á R E A & $\begin{array}{l}\text { POPULAÇÃO MAIOR } \\
\text { DE } 19 \text { ANOS }\end{array}$ & $\begin{array}{l}\text { GRADUADOS } \\
\text { DE NÍVEL } \\
\text { SECUNDÁRIO }\end{array}$ & $\begin{array}{c}\text { GRADUADOS } \\
\text { DE NÍVEL } \\
\text { UNIVERSITÁRIO }\end{array}$ \\
\hline \multicolumn{4}{|l|}{ REGIÃO NORTE } \\
\hline Brancos. & 24.6 & 64.3 & 75.8 \\
\hline Pretos. & 4.5 & 1.1 & 0.1 \\
\hline$\ldots \ldots \ldots \ldots$ & 70.9 & 34.6 & 24.1 \\
\hline \multicolumn{4}{|l|}{ ESPÍRITO SANTO } \\
\hline Brancos & G1.3 & 88.8 & 93.5 \\
\hline Pretos $\ldots \ldots \ldots$ & 12.1 & 1.4 & 0,3 \\
\hline Outros & 26.6 & 9.8 & 6.2 \\
\hline \multicolumn{4}{|l|}{ GUANABARA } \\
\hline$\ldots \ldots \ldots \ldots \ldots \ldots$ & 72.5 & 95.0 & 97.5 \\
\hline$\therefore \ldots \ldots \ldots \ldots$ & 10.4 & 1.0 & 0.5 \\
\hline Outros. & 17.1 & 4.0 & 2.0 \\
\hline \multicolumn{4}{|l|}{ SANTA CATARINA } \\
\hline Brancos & 94.1 & & \\
\hline Pretos & 3.0 & & \\
\hline Outros & 2.9 & & \\
\hline
\end{tabular}

Através de um sistema de seleções, algumas justas e outras injustas, convenientes umas e inconvenientes outras (sirvam de exemplo os famosos «cursinhos» pré-vestibulares) é que alguns poucos conseguem ingressar nas escolas superiores. Em 1954 tínhamos 2.954 .475 alunos no primeiro ano primário, dos quais apenas 535.712 alcançaram o quarto ano. No ano seguinte, matricularam-se na primeira série ginasial apenas 297.904, dos quais somente 103.705 atingiram a terceira série colegial. Destes, matricularam-se em curso superior apenas 45.774. De modo geral, ${ }^{19} \mathrm{em} 1.000$ crianças matriculadas na primeira série primária, apena.s 13 conseguem alcançar a primeira série de nível superior. Considere-se ainda que as 1.000 crianças que se matriculam na escola primária já reJaneiro.

19 Sinopse Estatística do Ensino Superior 1965/1964. MEC. IBGE, Rio de 
presentam uma primeira seleção. Para 1.000 que ingressam na primeira série primária, há mais de 500 que nem isso conseguiram. ${ }^{20}$ A meditação acerca destes fatos deveria ser suficiente para dar ao universitário brasileiro a noção, a um tempo, de sua importância e de sua responsabilidade. A noção, sobretudo, de seus deveres. Os estudantes frequentemente se esquecem que, dentro da pobreza de países como o Brasil ou da riqueza de países como o Canadá, eles são privilegiados da sorte. $\mathrm{O}$ fato de entrarem na Universidade significa vantagem e privilégio, tanto maior quanto mais pobre a nação a que pertencem.

A Universidade é sustentada com os recursos de todos, inclusive dos pobres. No que se refere ao imposto de renda, verifica-se que no Brasil a contribuição dos mais pobres supera a dos ricos. Vejam-se os dados a esse respeito, colhidos em boa fonte. ${ }^{2 \mathrm{I}}$ Nos Estados Unidos, em 1962, 54 por cento dos contribuintes com renda baixa pagavam 13 por cento do imposto de renda. Os classificados no nível de renda alta, ou seja, 11 por cento, contribuíram com 50 por cento da arrecadação; e os de renda média, constituídos de 35 por cento dos contribuintes, pagavam 37 por cento do total arrecadado. Enquanto isso, no Brasil, em 1963, 51 por cento dos contribuintes com renda baixa, pagavam 31,5 por cento do imposto de renda; os classificados como de renda alta, ou seja, 6 por cento, contribuíram com 24,5 por cento da arrecadação; e os de renda média, constituídos por 43 por cento dos contribuintes, pagavam 44 por cento do total arrecadado.

No quadro a seguir (pág. 60) pode-se contemplar melhor a diferença entre o Brasil e os Estados Unidos.

É óbvio, que, se prevalecesse a tese de gratuidade generalizada, ocorreria um agravamento desse regime discriminatório. Como dizem os já citados membros do Conselho Estadual de Educação do Estado da Guanabara, Professora Edília Coelho Garcia, D. Lourenço de Almeida Prado, O. S. B., e Leônidas Sobrino Porto:

«Na verdade, a gratuidade indiscriminada do ensino médio e superior não aumenta as oportunidades de educação e sim as diminui. Propiciada aos que teriam recursos para pagar integralmente, impede o acesso de um número igual de estudantes que não poderiam pagá-la. Concedida aos que poderiam pagar parcialmente seus estudos, impede que outros, na proporção do que poderia ser pago, tenham igual oportunidade.

A luta pela gratuidade geral do ensino, a nosso ver, é a luta inconsciente em muitos, consciente e ardilosa em alguns, seja para manutenção de um status melhor para Valnir Chagas, Articulação da Escola Média com a Superior, Documenta 79,
dezembro de 1967.

21 Estudos de Administração Fiscal, Fundação Getúlio Vargas, 1967. 


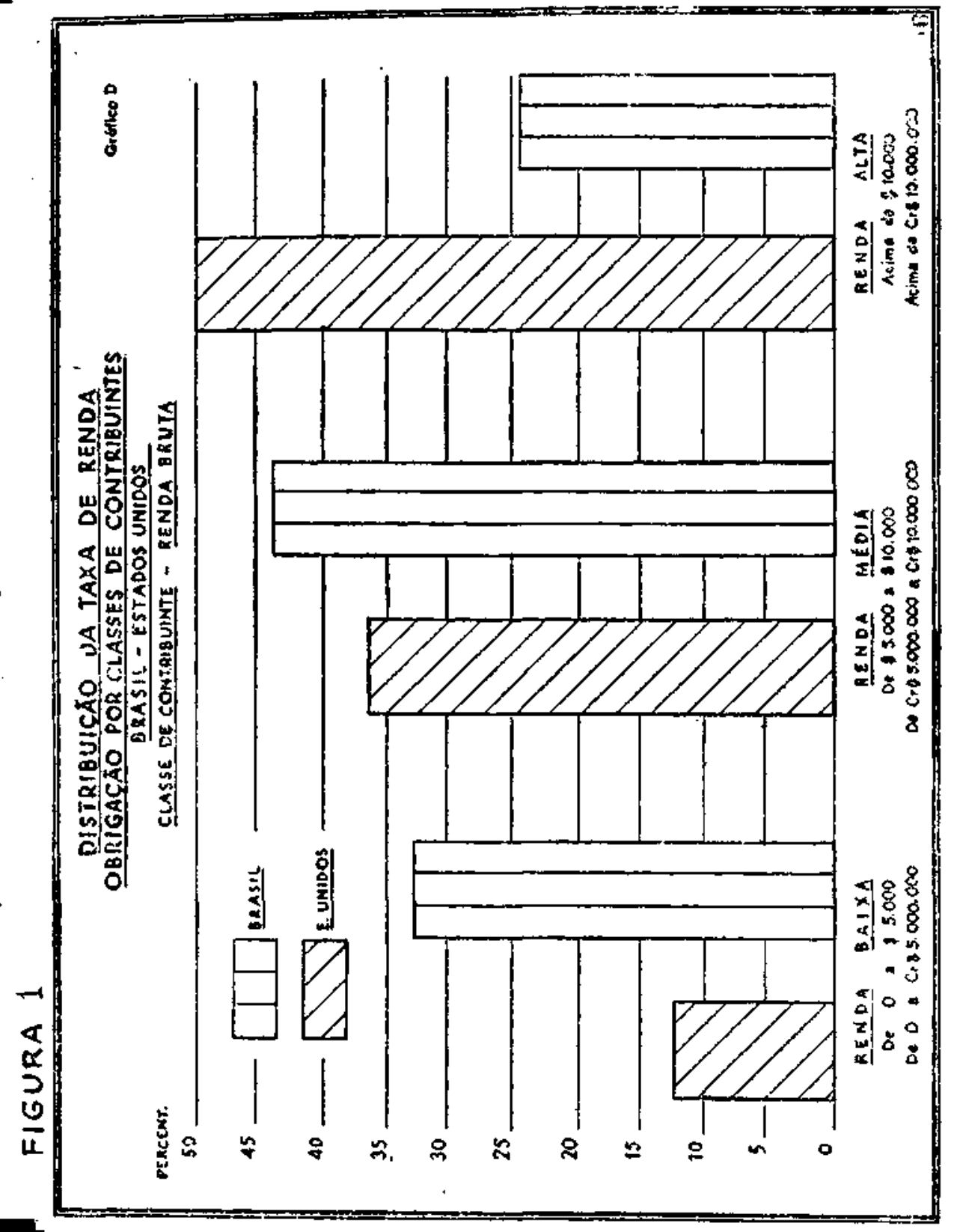


uma minoria privilegiada, seja para acentuar distorções sociais, dentro do objetivo de incitar quanto possa favorecer as reações e conflitos no convívio social.»

Lutando pela gratuidade total do ensino, alguns professores vêm apontando a crescente contribuição oficial à causa do Ensino e da Pesquisa nos Estados Unidos, e oferecem dados interessantes, mas nem sempre bem interpretados. E alguns já falam em encampação de Universidades norte-americanas pelo Governo. Realmente, o número de estudantes matriculados nas Universidades públicas supera hoje o número de matriculados nas Universidades privadas. Em 1965, para 1.967.471 de universitários matriculados em instituições privadas, havia 3.999.940 matriculados em instituições públicas, num total, portanto, de 5.967.411. ${ }^{22}$ Daí não se segue, entretanto, que as Universidades particulares desejam ser encampadas. Observe-se primeiro que está crescendo o número de jovens; segundo, que uma proporção maior passa a concluir o curso secundário; e terceiro, que uma proporção crescente de jovens deseja frequentar a Universidade. Enquanto isso ocorre, as Universidades particulares decidiram não estender suas matrículas, e assim os governos adotaram a política da expansão de suas próprias Universidades e criação de novas. Estabeleceram redes de instituições com sucursais e júnior colleges. Para não ter uma quantidade muito grande de jovens procurando vagas não-existentes, o poder público resolveu criar facilidades, aceitando deliberadamente, em alguns casos, a queda da qualidade. Com isso, não decresceu o prestígio das Universidades particulares.

O auxílio federal a qualquer escola, sob a forma de empréstimo ou de doação, em geral auxílio à pesquisa, implica cessação de qualquer discriminação racial porventura existente na escola.

Acrescentem-se a isso dois fatores: o primeiro é que as Universidades públicas são estaduais ou municipais, nunca federais; o segundo é que, tanto na Universidade pública (isto é, estadual ou municipal) quanto na particular, o aluno deve pagar anuidade.

Nas Universidades particulares, a anuidade chega às vezes a 2.000 dólares $(=\mathrm{NCr} \$ 6.440,00)$. Nas Universidades estaduais, a contribuição do estudante é menor. Assim, na Michigan State University, para dar exemplo ilustrativo, o estudante residente no Estado de Michigan (in-state student) paga 354 dólares $(=\mathrm{NCr} \$ 1.139,88)$ apenas, e o estudante provindo de outros Estados (out-of-statc student) paga 1.020 dólares $(=\mathrm{NCr} \$ 3.284,40)$.

Essa contribuição estudantil representa em bloco aproximadamente 20 a 25 por cento dos custos do ensino, no caso das Universidades particulares. Tomando as despesas totais do ensino universitário público e particular nos Estados Unidos para 1961-1962, no valor de 7,5 bilhões de dólares, e a contribuição estudantil, no valor de 1,5

\footnotetext{
${ }^{2}$ - Digest of Educational Statistics. U.S. Government Printing Office,. Washington. 1966
} 
bilhões de dólares, verifica-se que esta última cobriu 20 por cento dos gastos com o ensino. Não é muito, mas é alguma coisa. Num país de alta renda per capita, é possível esperar do estudante uma contribuição desta ordem, correspondente a 20 por cento das despesas de manutenção, mas seria utopia esperar o mesmo no caso de um país como o Brasil. Estudando a renda per capita do Estado de Michigan, ${ }^{23}$ o Prof. John M. Hunter verificou corresponder a contribuição estudantil à Universidade a 11 por cento dessa renda. Aplicando o critério ao Brasil, a anuidade do estudante brasileiro deveria ter sido no ano de 1964 de apenas NCr\$25,00. Em termos de 1968, corrente, essa importância corresponderia ao máximo a $\mathrm{NCr} \$ 50,00$, quantia irrisória, que não aliviaria em quase nada os encargos governamentais com Universidades. Basicamente, pode-se afirmar que, excetuades casos individuais, é óbvio, a contribuição geral de universitário brasileiro terá de ser, necessariamente, muito inferior à do estudante norteamericano.

Para o caso brasileiro, no momento, será necessário cumprir o disposto na Constituição Federal, quando diz que o ensino oficial ulterior ao primário será gratuito «para quantos, demonstrando efetivo aproveitamento, provarem falta ou insuficiência de recursos» (art. 168, $\S 3$ ", item III). Para estes, não há dúvida, o ensino deverá ser financiado pelo Estado. E para os demais? Em princípio, pensamos que o estudante que pode pagar deve pagar. Apenas, como verificar a situação, com rigor e justiça? Seria utópico pensar na possibilidade de uma justiça perfeita e acabada. E poder-se-ia também objetar que os remediados e até os ricos têm tanto direito à gratuidade quanto os pobres. Afinal, as famílias ricas pagam seus impostos, pelo menos em teoria, e para corrigir desigualdades existe explicitamente o chamado imposto de renda. Se não funciona adequadamente, que se lute pelo seu aprimoramento, e com urgência. Mas esse assunto fugiria ao plano do nosso trabalho. Em relação às escolas superiores federais. já existe uma tradição de gratuidade, que não pode ser ignorada. E quanto ao futuro, embora algo remoto, a tendência é que o Estado. à medida que seus recursos forem crescendo, venha a assumir o encargo total do ensino nos níveis primário, secundário e superior. A instauração progressiva da gratuidade do ensino médio e do ensino superior, convém lembrar, figura no art. 13 do Pacto Internacional relativo aos Direitos Econômicos, Sociais e Culturais, que faz parte do Pacto Internacional dos Direitos do Homem, assinado na Assembleia Geral das Nações Unidas a 16 de dezembro de 1966, por 66 votos contra 2 e 38 abstenções. ${ }^{24}$ O Brasil assinou o pacto, sem qualquer restrição.

\footnotetext{
23 Digest of educational stntistics. U.S. Governant Prinfnçj Office, Washington, 1966.

24 Revue de la Comission Internacional de furisies, Revue VIII. $\mathrm{n}^{\circ}$ 1, Été, 1967.
} 
Neste interregno, considerando expectativas e hábitos já entranhados em nosso país, a solução razoável parece-nos ser a de manter a gratuidade ou quase gratuidade reinante nos estabelecimentos oficiais de ensino. E vamos além: para os estudantes com capacidade intelectual acima da média, e comprovada a insuficiência de recursos, deverá o Estado neles investir, fornecendo-lhes bolsas individuais de alimentação e de alojamento. A Constituição, no item III do § 3" do art. 168, fala era bolsas de estudo, exigindo «o posterior reembolso. no caso do ensino de grau superior». Entendemos que no fornecimento desses auxílios deve haver bastante rigor no que diz respeito ao mérito intelectual dos candidatos. Mas, quanto ao reembolso, a exigência se nos afigura desarrazoada, no regime de inflação em que vivemos e de mercado c!e trabalho pouco favorável. Um pagamento posterior com correção monetária será impraticável.

Quanto às Universidades particulares, deve ser estimulada sua fundação, prestando-lhes os governos auxílios, a fim de assegurar nela vagas para os alunos pobres. Mas só em casos extremos, verdadeiramente excepcionais, deverá o Governo encampá-las ou federalizá-las, assumindo destarte a totalidade de seus encargos financeiros. Os recursos governamentais disponíveis devem ser empregados sobretudo no alargamento das Universidades oficiais existentes, pelo menos por enquanto. Em vez de fundar novas escolas ou encampar as particulares, deve o Governo aumentar a lotação de suas escolas superiores tradicionais. As escolas particulares devem lutar pela própria subsistência, mobilizando recursos de fontes não governamentais, entre os quais as anuidades, modestas embora, de uma boa parte de seus alunos. As escolas particulares superiores passarão a ser os veículos próprios para assegurar uma contribuição adicional dos ricos à causa do ensino público.

Maneira bastante semelhante de ver o problema é a que foi consagrada em São Paulo na Constituição Estadual, que diz, no seu art. 124:

«A Educação é direito de todos e dever do Estado e visará ao desenvolvimento integral da personalidade humana e à sua participação na obra do bem comum.

$\S 1^{\circ}$ O Estado ministrará e difundirá o ensino em todos os graus.

$\S 2^{\circ} \mathrm{O}$ ensino oficial será gratuito em todos os graus.

$\S 3 "$ Respeitadas as leis que o regulem, o ensino é livre à iniciativa particular, que será amparada pelo poder público quando destinado às classes menos favorecidas».

O ensino poderá ser totalmente gratuito, como já ocorre em alguns países, quando o orçamento nacional o permitir. Nesse dia abençoado. todos exigiremos que o Governo assuma a responsabilidade total pela 
manutenção das Universidades. Lembramos apenas o valor relativo das palavras. Em verdade, nada é gratuito. Alguém paga. Na Inglaterra são gratuitos os serviços médicos, porque a população os paga sob a forma de um imposto, aliás bastante pesado. Na Holanda e na Bélgica os governos têm recursos, vindos dos contribuintes, para manter todas as escolas das diferentes denominações religiosas. Assim, há variedade de escolas, e todas sustentadas pelo Estado, que é afinal sustentado pelo povo.

Qualquer que seja o regime, será necessário assegurar recursos à Educação, dentro das possibilidades existentes, é óbvio. Lembramos a frase de um escritor que as gerações modernas desconhecem, para gáudio dos inimigos ostensivos ou mascarados da democracia:

«A pior de todas as espécies de avareza é negar-se ao ensino os instrumentos do progresso».

Mas por que falaria assim o grande brasileiro? Porque, segundo êle, ${ }^{25}$ «a produção é um efeito da inteligência: está, por toda a superfície do globo, na razão direta da educação popular. Todas as leis protetoras são ineficazes para gerar a grandeza econômica do país; todos os melhoramentos materiais são incapazes de determinar a riqueza, se não partirem da educação popular, a mais criadora de todas as forças econômicas, a mais fecunda de todas as medidas financeiras.» 


\section{A FUNDAÇÃO}

A transformação das Universidades federais em Fundações vem sendo objeto de acalorados debates. Assim sendo, a EAPES não poderia furtar-se a opinar sobre o assunto, embora o faça em termos sucintos.

Inicialmente, convém distinguir entre a Fundação como pessoa jurídica de direito privado, tal como ela é prevista no Código Civil Brasileiro, e a Fundação como órgão público de administração indireta, Acerca da Fundação de direito privado, nada há que discutir, e sua validade é ponto pacífico. O debate diz respeito à Fundação como órgão público de administração indireta.

Já as autarquias haviam sido criadas como entidades ou pessoas de direito público, independentes do Governo central, desvinculadas portanto do sistema orçamentário, afastados dos controles do Legisla. tivo e do Tribunal de Contas, e livres das restrições e critérios oficiais para a admissão e remuneração do seu pessoal. Entretanto, como lembrou o Conselheiro Afonso Almiro, Ex-Diretor-Geral do Ministério da Fazenda, em lúcida exposição perante a Confederação Nacional do Comércio:

«Em 1952, o novo Estatuto dos Funcionários Públicos (Lei $\mathrm{n} " 1.711$, de 28 de outubro) incluiu em suas disposições gerais (art. 252, $\mathrm{n}^{9}$ II) uma determinação no sentido de que o regime jurídico aplicável aos funcionários da administração centralizada fosse extensivo aos servidores das autarquias. Era o primeiro obstáculo que se levantava contra as facilidades vigentes e, por isso, chegou a ser vetado. O Congresso entretanto rejeitou o veto do Governo, mantendo o dispositivo.

Também as tomadas de contas e os controles econômicos financeiros passaram a ser exigidos com mais rigor.

Perderam assim as autarquias as vantagens que justificaram a sua criação.

Foi quando começaram a se desenvolver e a se multiplicar as chamadas sociedades de economia mista.

Tais sociedades, organizadas pelo Governo, sob a forma jurídica de sociedades anónimas, tinham a participação minoritária de particulares. 
Embora a origem dessas sociedades possa ser encontrada ao longo da História, pois já em 1599 a Inglaterra criava a Companhia das índias Orientais, e logo em 1602 a Holanda fundava a Companhia das índias Ocidentais, ambas com a participação de pessoas alheias ao Estado, e, entre nós, a primeira sociedade mista foi o Banco do Brasil. organizado pelo alvará de 12 de outubro de 1808, do Príncipe Regente, o seu desenvolvimento é recente e se deve à preocupação de proporcionar ao Governo meios e processos, à margem das fórmulas rígidas impostas à administração centralizada, capazes de permitir a livre expansão de sua atividade intervencionista.

Com isso, a máquina administrativa centralizada ia sendo, cada vez mais, postergada, na medida em que as suas atribuições iam sendo delegadas às novas sociedades mistas. Por meio destas, o Estado passou a absorver os setores da produção e da distribuição, fazendo com que as esferas reservadas ao consumo se subordinassem aos postulados impostos pelo império das suas decisões econômicas .

Mas, se o fundamento jurídico-doutrinário alegado para a criação dessas sociedades de economia mista era o mesmo que justificava a criação das autarquias, ou seja, a faculdade que tem o Estado de intervir nos setores econômico e social, verdadeiras razões criadoras e impulsionadoras dessa tendência governamental eram sempre. salvo raríssimas exceções, a deficiência, a rigidez e o mau funcionamento da máquina administrativa centralizada.

Esta máquina administrativa - cada vez mais desprestigiada e desaparelhada; tolhida pela malfadada e permanente insuficiência de verbas orçamentárias; emperrada e ineficiente pelos excessivos e inoperantes controles; desestimulada e mal remunerada pelo regime de pessoal, que dificulta o ingresso dos mais capazes, quer nivelando vencimentos sob critérios injustos, quer aproximando cada vez mais os mais modestos aos mais elevados cargos, quer, ainda, anulando carreiras - tem sido a principal causa das anomalias que tentamos descrever, pelo que expressa de fatores negativos prejudicando a dinâmica do Estado.

E isto porque é mais fácil para o Governo, que deseja realizar ou ao qual se apresentam problemas setoriais ou conjunturais requerendo soluções urgentes, é mais fácil, por incrível que possa parecer, criar ura novo organismo paraestatal do que dinamizar a máquina. administrativa centralizada. 
E assim, buscando fórmulas mais flexíveis e operantes, portanto com patriotismo e, até certo modo, se não com acerto, pelo menos, com a melhor intenção e espírito público, vai-se avolumando e hipertrofiando a estrutura administrativa.

Mas também as sociedades de economia mista começaram a ser também controladas, embora timidamente. A Comissão de Defesa dos Capitais Nacionais, por exemplo, foi criada no Ministério da Fazenda (Decretos ns. 41.427, de 25 de abril de 1957, 47.811, de 23 de abril de 1960, e 50.916, de 6 de julho de 1961, e Decretolei $\mathrm{n}^{9} 147$, de 13 de fevereiro de 1967, art. 39) com o fim de zelar «pela defesa dos interesses da União nas sociedades de que sejam acionistas o Tesouro Nacional, autarquias federais ou outras sociedades de economia mista».

Talvez por coincidência, mas o fato é que, a partir de então, começam a se multiplicar as empresas estatais.

Estas são sociedades anónimas, constituídas com capital inteiramente do Estado, e integradas por pessoas jurídicas de direito público.

Aqui já se torna mais flagrante a diferenciação que se impõe entre a intervenção econômica doutrinariamente aceita e a estatização socializante. Naquela o Estado intervém para controlar, para corrigir distorções ou para suprir deficiências; nesta, na estatização, o Estado substitui a iniciativa privada, tomando o seu lugar, numa concorrência desnecessária e espúria.

E então verifica-se, com inevitável pessimismo, que se processa entre nós uma estatização sutil, crescente e abrangente, que se desenvolve sem fixação doutrinária, sem qualquer orientação filosófica ou pensamento político, e mais, que contraria o sentimento unânime da Nação e os princípios democráticos orientadores de nossa formação e se processa como decorrência do mau funcionamento da máquina administrativa centralizada.

A causa de tudo isso está, portanto, na busca ansiosa e justificada de solução para problemas unicamente administrativos .

Claro que é estranho e inadequado o caminho escolhido. Mas a imaginação criadora prossegue inquieta. E já temos nova receita salvadora. São as Fundações.

O velho instituto do nosso Direito Civil, que exigia para sua criação que o seu instituidor, por escritura pública ou testamento, fizesse doação especial de bens livres e especificasse o fim a que se destinava, foi modificado na sua essência e incorporou-se ao direito público. 
As Fundações instituídas por lei têm hoje os mais variados fins, e encontramos as que exercem atividades culturais, administrativas, técnicas, industriais, jornalísticas, de serviços urbanos, etc.

Mas o que cumpre assinalar e repetir é que todo esse movimento conturbador dos quadros administrativos do Pais tem servido principalmente para hipertrofiar a ação governamental e desprestigiar cada vez mais a administração centralizada.

Em última análise, essa alteração no terreno da estrutura jurídica das entidades criadas e mantidas pelo Poder Público expressa, irrecusavelmente, uma deformação do sistema de organização e funcionamento dos órgãos estatais, e nas Fundações, a questão passa a ter apenas $o$ aspecto formal de utilização de nomes e apelidos. Recentemente, pelo Decreto-lei n" 200, de 25 de fevereiro de 1967, que dispõe sobre a organização da administração federal e estabelece diretrizes para a Reforma Administrativa, foi tentada uma consolidação legal, emprestandose uma definição a cada um daqueles institutos.

Assim, o art. $5^{9}$ considera, para os fins daquela lei:

I - Autarquia - o serviço autónomo, criado por lei, com personalidade jurídica, património e receita próprios, para executar atividades típicas da Administração Pública, que requeiram, para seu melhor funcionamento, gestão administrativa e financeira descentralizada.

II - Empresa Pública - a entidade dotada de personalidade jurídica de direito privado, com património próprio e capital exclusivo da União ou de entidade de Administração Indíreta, criada por lei para desempenhar atividades de natureza empresarial que o Governo seja levado a exercer por motivos de conveniência ou contingência administrativa, podendo tal entidade revestir-se de qualquer das formas admitidas em direito.

III - Sociedades de Economia Mista - a entidade dotada de personalidade jurídica de direito privado, criada por lei para o exercício de atividade de natureza mercantil, sob a forma de sociedade anónima, cujas ações com direito de voto pertençam, em sua maioria, à União ou à entidade da Administração Indireta.»

As Fundações se apresentam ainda de tal maneira diversificadas e imprecisas, que o citado decreto-lei não usou sequer tentar uma definição, dispondo apenas no $\S 2^{\circ}$ do art. $4^{\circ}$, que «Equiparam-se às Empresas Públicas, para os efeitos desta lei, as Fundações instituídas em vir- 
tude de lei federal e de cujos recursos participe a União, quaisquer que sejam suas finalidades.»

Mais adiante diz o Sr. Afonso Almiro, cujo trabalho estamos transcrevendo longamente, porque expressa ponto de vista com o qual nos sentimos solidários:

«Pode-se mesmo afirmar que o Poder Público, criando autarquias, as sociedades de economia mista, as empresas estatais $e$ as Fundações, fica, pouco a pouco, à mercê das entidades que criou, tal o seu crescimento, tal a força das suas decisões, tal o volume do seu capital, tal o vulto dos seus orçamentos, tal o campo de sua atuação, tudo aos poucos absorvendo as atribuições e as prerrogativas da Administração Centralizada.

E as entidades assim criadas, organizadas e dirigidas pelo Poder Público, paradoxalmente se hipertrofiando, passaram a asfixiar a Administração Pública Centralizada que é, justamente, o meio operante, o instrumento de ação do próprio Poder Público, retirando dele, assim, todo o poder de decisão e toda a forca de comando.

O mundo atravessa uma fase de transição doutrinária e tecnológica que atinge e revoluciona o Direito Administrativo e a ciência da administração.

Não devemos agravar ainda mais a crise decorrente da revisão de princípios e de conceitos, com a criação desordenada de organismos estatais.

A falta de coordenação e cooperação entre estes novos órgãos, aliada ao desaparelhamento das repartições centralizadas e ao desprestígio da função pública, afeta, frontalmente, o Poder Nacional».

Como norma de Governo, devemos apresentar essas restrições a ideia da Fundação em si. Mas entendemos que ela possa representar uma solução a curto prazo para problemas de administração universitária. Nesse sentido, compreende-se o atrativo que essa solução possa exercer sobre o espírito dos administradores. Conforme vimos, a Fundação representa tentativa de corrigir, em determinados casos, defeitos mais gerais da Administração Pública. Essas soluções de emergência em prazo longo acabam mostrando suas desvantagens, e o próprio Poder Público se vê compelido a legislar em sentido contrário e corretivo.

Quanto ao receio manifesto em alguns setores da opinião pública de que a transformação das Universidades em Fundação seja um primeiro passo para entregá-las ao controle de potências estrangeiras, êle nos parece tão extravagante e tão afastado da realidade dos fatos, 
que não perderemos tempo em comentá-lo, reconhecendo embora que êle traduz uma situação grave de angústia.

Não tem também fundamento o receio de que, adotada a fórmula Fundação, venha o Governo a eximir-se de suas responsabilidades financeiras para com as Universidades. Em verdade, o que se vê é o contrário. O Governo da República e os Governos dos Estados subvencionam fartamente até algumas Fundações de direito privado.

A Universidade de Brasília é uma Fundação. Também o são as Universidades do Amazonas, do Maranhão e de Sergipe, e a Universidade do Estado da Guanabara, à qual estão vinculados, por lei constitucional do Estado, recursos do orçamento anual da Guanabara. É portanto uma Fundação de direito público, cuja vida depende de dotações ânuas do Governo. Nenhuma dessas Fundações se desnacionalizou, ou foi abandonada pelo Poder Público.

São estes os subsídios que a EAPES julga oportuno oferecer para o exame de matéria tão relevante para os destinos do ensino superior no Brasil. 


\section{O MERCADO DE TRABALHO PROFISSIONAL}

A estruturação da Universidade em bases que se possam considerar racionais exige que se dê especial atenção ao capítulo relativo ao Mercado de Trabalho Profissional. Na medida em que a Universidade estiver preparando e formando professores, técnicos, cientistas e profissionais imediatamente destinados às necessidades do desenvolvimento do país, estará cumprindo suas finalidades específicas. O universitário, ao mesmo tempo que se prepara para ser membro útil à sociedade, através da carreira que escolheu, deverá, ao mesmo passo, encontrar nessa carreira o meio de ganhar a vida e de prover às necessidades da família. Daí o cuidado especial que merece, na estrutura da Universidade, o estudo do mercado de trabalho profissional, sobretudo para a organização das carreiras e dos respectivos currículos. Como na vida, deve haver na Universidade cursos que aparecem e desaparecem, cursos que diminuem, conforme as previsões das necessidades. Essas necessidades serão conhecidas através de um bom serviço de pesquisa de mercado profissional. «O planejamento educacional, em sua perspectiva moderna, deve ser precedido do planejamento da mão-de-obra. O plano de mão-de-obra se inicia por um diagnósticoque mostre a evolução passada e a situação presente da força de trabalho, segundo ocupação, nível educativo, sexo, idade, condições de emprego e setores de atividade». ' O passo seguinte será o estudo» meticuloso das projeções de demanda espontânea, ou de ocupação programada, consoante o esquema de tratamento dos recursos humanos adotado por opção: o das oportunidades abertas ou da educação orientada por concentração em níveis ou áreas que o planejamento econômico indique prioritárias em determinado período. Conforme pondera o Prof. Eduardo Celestino Rodrigues: ${ }^{2}$

«País pobre, devemos formar pessoal de nível superior dentro das necessidades do mercado de emprego e não desperdiçar recursos como atualmente fazemos. Se os norte-americanos agem assim, que dizer de nós, ainda com a pecha de subdesenvolvidos, a formar universitários em modalidades sem colocação no mercado?

1 Arlindo Lopes Corrêa, «Economia da Educação, Revista Indústria c Produtividade. junho de 1968.

2 O Estado de São Paulo, 18/8/68, pág. 48. 
Desperdiçamos tempo e dinheiro, quando temos pressa e somos pobres. $\hat{E}$ a estratégia do desperdício.

Damo-nos ao descabido luxo de não orientar os universitários para as necessidades reais do País, quando é baixo o número de formados em Universidade, no mercado de trabalho, conforme demonstra o quadro abaixo:

\begin{tabular}{|c|c|c|}
\hline Países & Ano & $\begin{array}{l}\text { População } \\
\text { superior cor } \\
\text { força de tr }\end{array}$ \\
\hline Estados Unidos. & .1960 & 11,9 \\
\hline URSS ........ & .1959 & 3,8 \\
\hline Japão. & .1961 & 3,7 \\
\hline Itália. & 1959 & 3,0 \\
\hline França. & .1961 & 2,9 \\
\hline Grécia & 1951 & 2,3 \\
\hline Colômbia & 1960 & 1,9 \\
\hline Espanha & 1960 & 1,7 \\
\hline México. & .1960 & 1,4 \\
\hline Portugal. & 1960 & 4 \\
\hline Iugos-lávia. & .1960 & 1,3 \\
\hline Turquia. & 1950 & 0,9 \\
\hline Brasil & 1960 & 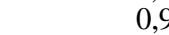 \\
\hline Eg:to. & .1947 & 0 \\
\hline Índia & .1951 & 0,8 \\
\hline Paquistão. & 1961 & 0,4 \\
\hline Tailândia & .1960 & \\
\hline Tanganica & 1960 & \\
\hline
\end{tabular}

FONTE: Estudos APEC — julho de 1966.

Uma reflexão importante, que vale como advertência, aparece na revista The Economist:

«A entrada da América Latina no que se convencionou chamar a terceira etapa do processo de industrialização está sendo dificultada pelo restrito poder aquisitivo da massa de consumidores, como também pela falta de mão-de-obra qualificada. Para países como a Argentina, Brasil e México, que iniciaram a quarta etapa de sua industrialização, isto é, uma etapa decisiva para a substituição de importações por produtos nacionais, o risco maior estaria em desembocar numa situação de crescente dependência relativamente às técnicas estrangeiras, pelo menos nas indústrias mais dinâmicas, a menos que se dê resposta adequada a esse problema através de uma política de ciência e tecnologia efetiva».

O ensino superior no Brasil se caracteriza historicamente pelo traço 'da culturalização e não da tecnificação das profissões. No nosso ensino superior nunca houve caráter verdadeiramente universitário, orientado

3 The Economist, 3-5-1968 (Documento). 
para o binómio «ciência e tecnologia» (excetuados os casos da Medicina e Engenharia) . A preocupação sempre foi o diploma, que, não obstante, habilita seu detentor a exercer legalmente uma profissão. Daí a tendência a seguir as carreiras mais tradicionalmente procuradas, aquelas em que geralmente há excedentes na demanda de matrículas escolares, como as de Direito, de Engenharia e de Medicina. O Direito, até há pouco tempo líder nas estatísticas, vem progressivamente perdendo lugar nas preferências. É que aos poucos se desperta uma consciência de que não é possível seguir apenas uma carreira; de que necessário se faz seguir uma carreira reclamada pela sociedade. Entretanto, ainda aqui predomina um traço antigo: são mais procuradas as carreiras de mais prestígio. Por outro lado, há exemplos flagrantes do afirmado: a carência de enfermeiras no país, ou de técnicos agrícolas. As Escolas de Enfermagem raramente preenchem $50 \%$ de suas vagas: no entanto, há enorme necessidade de enfermeiras. Na Universidade Fluminense havia este ano (1968) 30 vagas na Escola de Enfermagem, e não se apresentou nenhuma candidata. As poucas escolas agrícolas existentes no país não figuram entre as que lutam com o problema de excedentes.

A opinião da maioria dos jovens que estão cursando os últimos anos das Faculdades, para as especialidades de Medicina, Economia, Direito. Engenharia, Química, Odontologia, Farmácia, Psicologia, Filosofia e Letras, é a de que o mercado de trabalho, onde muitos procuram competir, está sendo reduzido de ano para ano, numa economia que não logra alcançar melhor ritmo de desenvolvimento.

Essa opinião é baseada em várias constatações sobre o mercado de empregos, que apontam, entre outros problemas, o baixo número de vagas, remuneração insuficiente para diversas especializações, alto custo das instalações de consultórios e escritórios, falta de financiamento, falta de assessoramento da Universidade. Em alguns casos, a realidade não é bem esta, pois há um fenômeno parecido com o efeito estroboscópico na ótica visual, isto é, por causa do número crescente de aspirantes a empregos, parece que as rodas do mercado de trabalho estão girando para trás.

De modo geral, segundo pesquisas já realizadas pela Fundação Getúlio Vargas (e também pela experiência dos acadêmicos), o mercado de trabalho é mais favorável às profissões técnicas do que às humanísticas, e, menos ainda, aos cientistas. Estes últimos, além do pequeno número de colocações de alto nível oferecidas na estrutura do trabalho, têm que enfrentar o problema da baixa remuneração. Nos últimos anos, inclusive, vem-se registrando uma tendência para a emigração desses especialistas, em busca não só de melhores níveis de remuneração mas também e, talve: principalmente, de melhores condições técnicas de trabalho.

O problema das condições técnicas pode ser visto por mais de um aspecto. Por exemplo: a) ambiente ou clima de trabalho e pesquisa que, para muitos profissionais de vocação, é mais importante do que os 
resultados financeiros imediatos; b) profissionalização do trabalho, em regime de crescente socialização dos investimentos e resultados; c) alto custo das instalações para os que preferem a modalidade de trabalho em regime de profissão liberal. Ilustra esta opção a montagem de um consultório dentário, incluindo salas, móveis e equipamentos, que orça por cerca de NCr\$35.000,00, enquanto um gabinete médico, para clínica geral, anda pelos NCr\$15.000,00. No caso de se incluírem equipamentos de cirurgia e Raios X, aquele custo ultrapassa os NCr\$ 100.000,00. Mesmo para montar um escritório de advocacia, é necessário importância superior a NCr\$ $10.000,00$, e ainda assim, se não forem luxuosas ns instalações.

Financiamento existe, mas nem todos podem aceitá-lo: para móveis e outros equipamentos, o pagmento é em seis e até doze prestações, e para materiais técnicos, tais como aparelhos científicos e técnicos, em 60 e 90 dias.

É voz corrente entre os estudantes de Direito que o grande mercado de trabalho para os novos advogados é o de títulos financeiros e as companhias de crédito e investimento, bem como o será em breve o novo ramo da advocacia de empresas ou negócios, moderna ampliação do campo do Direito Comercial. Neste campo de atividades a iniciação geralmente se faz através da integração em equipes já formadas, com escritórios conhecidos, ou através da atuação em firmas comerciais e industriais, geralmente na função de consultores. O ramo do Direito Trabalhista começa a ser um segmento promissor para os bacharéis em Ciências Jurídicas e Sociais.

Embora com razoável possibilidade de iniciar a vida profissional com acesso a uma clientela em constante crescimento, segundo os acadêmicos e também velhos profissionais, a advocacia é talvez a especialidade liberal que tem mais profissionais exercendo atividades alheias à carreira. O magistério, os quadros burocráticos da Administração Pública e dos organismos de classe são naturalmente hoje o grande desaguadouro do enorme contingente de profissionais legalmente habilitados em Direito.

No setor das Ciências Humanas, um campo ultimamente em expansão é o da Psicologia, com maior utilização dos profissionais pelas empresas brasileiras, e também com o aparecimento de muitas organizações especializadas no exame psicológico de candidatos a empregos. No que diz ao Magistério, o mercado de trabalho é considerado desestimulante, não tanto pela falta de colocações, mas pela baixa remuneração que, de modo geral, é oferecida. A maioria dos professores só consegue aceitável nível financeiro através do acúmulo de diversos empregos, possibilidade que existe para os mais antigos, mas raramente para os recémformados.

Profissões que vêm registrando aumento do número de oportunidades são as Ciências Econômicas e Administrativas, e a Química. Quanto a esta última, há falta de profissionais para a Química Inorgânica, ramo de atividade que apresenta crescimento muito grande no Brasil, como em 
todo o mundo. Os profissionais - poucos - dessa especialidade que saem das Universidades podem, inclusive, ter esperança de colocação no exterior.

Para os engenheiros químicos e eletrotécnicos o emprego geralmente parece antes da conclusão do curso. Há grande procura desse tipo de profissionais, e nas seções de anúncios de classificados dos jornais aro é o dia em que não são feitas ofertas de empregos. Esta procura

técnicos leva as empresas privadas a colaborar com as escolas, ofeecendo estágios práticos e geralmente contratando os estudantes mais capazes.

Nos demais ramos da Engenharia, a naval também vem-se desenvolvendo aceleradamente, enquanto a civil, ligada ao setor de construção (o que mais cresce no País) apresenta agora grande número de oportunidades, um pouco em função da política habitacional do Governo. Embora a remuneração neste caso seja considerada baixa, ${ }^{4}$ é certo que a estruturação deste segmento profissional tende a beneficiar-se com os crescentes planos de obras urbanísticas e rodoviárias, que a urbanização das populações obriga, em um país cuja população rapidamente se aproxima dos 100 milhões.

A Engenharia Econômica e a Engenharia de Produção são novos aspectos da profissão, reclamados à medida que se expande e se sofistica nosso parque industrial.

Num trabalho da natureza deste, é preciso ter sempre em conta o caráter temporário dos valores estatísticos e a relatividade das afirmações. Só para determinada faixa de tempo se pode falar em demanda de mãode-obra. por exemplo, no período em que estamos pensando, de 1968 a 1975. Daí a necessidade de serviços permanentes na Universidade, que orientem os órgãos responsáveis pela instituição de carreiras e pela propaganda dos cursos, como o observatório meteorológico nos orienta diariamente sobre as condições do tempo. $\mathrm{O}$ alcance desses prognósticos não só se expressará em termos de programação da capacitação profissional das novas gerações, mas também revelará a necessidade de retreinamento e atualização de recursos humanos anteriormente qualificados, os quais podem representar séria obsolecência, pelo impacto da acelerada mudança tecnológica nos sistemas econômicos de produção e comercialização de bens e serviços.

«Evidentemente, são as necessidades objetivas da produção que geram, em primeira mão, os problemas de formação profissional, entendida esta em seu sentido genérico.

Entretanto, as modalidades específicas de formação, tanto da mão-de-obra menor como da adulta, devem desenvolver-se,

\footnotetext{
" «Estudantes vêem mercado de trabalho caindo a cada ano», Correio da Manhã, 19-6-1968.
} 
em cada região, de acordo com suas características demográficas, econômicas e sociais.

Assim, a distribuição etária da população se reflete diretamente na composição da força de trabalho; a extensão alcançada pelo sistema regional de educação básica determina a duração e os programas de aprendizagem do menor para as atividades industriais; o processo de tecnificação das atividades agropecuárias influi sobre o tipo de mão-de-obra adulta disponível para a industrialização».

Parece que um dos equívocos da estrutura educacional brasileira tem sido a tendência à padronização de currículos, cursos e escolas, como se o Brasil fosse uniforme e estável. As diferenças regionais são diferenças altamente sensíveis na composição do mercado de trabalho.

«Efetivamente, segundo dados conhecidos, a proporção de «engenheiros por milhão de habitantes» varia, em alguns países da Europa e da América do Norte, de 2.500 a 4.000, ao passo que no Brasil está em torno de 500. Sabendo-se que nas indústrias de transformação a relação técnicos-engenheiros oscila, naqueles países, entre 3 e 5, resulta, na pior das hipóteses, numa proporção de 7.550 a 12.000 técnicos por milhão de habitantes. No Brasil, a relação técnicos-engenheiros, mesmo nas regiões mais industrializadas, é igual a 1, dando, pois, em resultado, a média de 500 técnicos por milhão de habitantes.

... Segundo levantamentos efetuados nos diferentes setores industriais, a carência de técnicos é mais acentuada nas empresas siderúrgicas, metalúrgicas, mecânicas e de material elétrico. No estado atual de desenvolvimento das regiões mais industrializadas do País, é razoável admitir-se a necessidade mínima, de «dois técnicos para cada engenheiro», o que corresponde à média de 1.000 técnicos por milhão de habitantes».

Recentemente se introduziram nos principais centros urbanos do país cursos de «Engenharia de Operações» (Engineecing Technicians), o que deverá lentamente corrigir a distorção da utilização do Engenheiro em funções intermediárias. Não seria lícito pretender encontrar muitos engenheiros no interior, onde o trabalho é predominantemente agrícola e artesanal.

O mesmo não ocorre com os médicos, necessários em toda parte. Se não os encontramos no interior, é por outras razões, sobretudo de caráter econômico-social, as quais, aliás vêm sendo abundantemente estudadas .

5 ítalo Bologna, SENAI, monografia apresentada ao I Congresso Íbero-Ameri(.dno de Promoção Profissional de Mão-de-Obra, Madrid, maio-junho, 1967.

6 Id-, ibidem. 
O problema do mercado de mão-de-obra categorizado está evidentemente ligado às necessidades sócio-econômicas específicas do meio.

Relativamente são poucos no Brasil os estudos que ligam o mercado de trabalho com o ensino superior. O que de mais especializado encontramos foi o estudo feito no Plano Decenal de Desenvolvimento Econômico e Social, tomo VI, sob a rubrica «Educação e Mão-de-Obra», do Ministério do Planejamento e Coordenação Econômica, de março de 1967, sob forma de ensaio preliminar.

Sintetizando os dados oferecidos por este documento, podemos ter o panorama geral das principais profissões de nível superior, relacionadas com as previsões das necessidades de mercado até 1976, ano-meta.

Outro estudo de demanda de mão-de-obra especializada de nível superior nos é dado pela Secretaria-Geral do MEC. O quadro, que a seguir reproduzimos, é demonstrativo da ocorrência das matrículas no Ensino Superior nos últimos 10 anos, de 1958 a 1967. As matrículas, como se poderá observar, continuam a crescer consideravelmente, assinalando, para o decénio um incremento de $153 \%$, passou de 84.481 para 231.741 o número de matriculados nos diversos cursos de formação de nível superior. Em relação ao ano anterior, o incremento foi de $18,7 \%$, ou seja, mais 33.632 universitários.

\section{CURSOS DE FORMAÇ̃̃o}

Filosofia, Ciencias e Letras

Direito. .

Engenharia

Administração e Economia

Medicina.

Odontologia

Agricultura

Servico Social

Farmacia

Arquitetura e Urbanismo.

Artistica.

Medicina Veterinaria

Enfermagem

Outros.

TOTAL

\begin{tabular}{|c|c|c|c|}
\hline \multicolumn{2}{|l|}{1958} & \multicolumn{2}{|c|}{$\begin{array}{llll}1 & 9 & 6 & 7\end{array}$} \\
\hline NÚMERO & $\%$ & NÚMERO & $\%$ \\
\hline 17.372 & 20,6 & 51.289 & 24,0 \\
\hline 22.302 & 26,4 & 42.499 & 19,9 \\
\hline 9.672 & $11 . .4$ & 30.894 & 14,4 \\
\hline 6.812 & 8,1 & 29.020 & 13,6 \\
\hline 10.535 & 12,5 & 20.295 & 9,5 \\
\hline 5.145 & 6.1 & 7.413 & 3,5 \\
\hline 1.627 & 1,9 & 5.195 & 2,4 \\
\hline 1.265 & 1,5 & 3,630 & 1,7 \\
\hline 1.583 & 1,9 & 3.122 & 1. 5 \\
\hline 1.720 & 2,0 & 2.817 & 1,3 \\
\hline 1.797 & 2,1 & 2.729 & 13 \\
\hline 763 & 0,9 & 2.356 & 1.1 \\
\hline 1.653 & 2,0 & 1.538 & 0,7 \\
\hline 2.235 & 2,6 & 10.944 & 5,1 \\
\hline 84.481 & $100,0_{-}$ & 213.741 & 100,0 \\
\hline
\end{tabular}

FONTE: Análise do Ensino no Brasil — Estudo Preliminar.

Éste quadro revela em síntese que a distribuição pelos vários cursos em sofrendo profunda alteração, com ocorrência de aumento de interesse 
pela Engenharia, Administração, Economia e pelos cursos profissionalizantes das Faculdades de Filosofia. Ciências e Letras, os quais de 20,6\% em 1958, passaram a constituir, no fim do decénio, $24,4 \%$ da população universitária, com decréscimo percentual das matrículas no curso de Direito. Quanto à matrícula nos cursos de Filosofia, Ciências e Letras, a preferência cabia aos cursos de Letras, com 10.330 alunos matriculados. ou 23,1\%, seguindo-se Pedagogia, com 9.094, ou 20,3\%; História, com 4.446, ou 9,9\%; Ciências Sociais, com 3.647, ou 8,1\%; Filosofia, com 3.157, ou 7,0\%; Geografia, com 2.686, ou 6,0\%; Matemática, com 2.618, ou 5,8\%; História Natural, com 2.212, ou 4,9\%; Biologia, com 1.322, ou 3,0\%; Física, com 1.157, ou 2,6\%, e Química, com 857, ou 1,9\%.

Com referência ao ensino de Engenharia, desde 1960 as matrículas dos cursos especializados ultrapassaram as do curso de Engenharia Civil. devido aos novos mercados de trabalho que têm surgido no país através das indústrias do petróleo, siderúrgica, naval, automobilística e manufatureira em geral.

Os cursos de Administração e Economia tiveram quadruplicadas suas matrículas nos últimos anos, com perspectivas de manter essa progressão, o que é extremamente grave, particularmente em Economia, no que concerne à qualidade do ensino.

As matrículas no curso de Medicina se mantiveram estacionárias durante vários anos, vindo a dobrar, graças à ação do Governo Federal, no período 64/67.

No tocante à Medicina, verifica-se insuficiência de médicos em relação à população geral, havendo 1 médico para 3.672 brasileiros, numa área de 8,5 milhões de quilómetros quadrados. Dir-se-á que não existe falta de médicos nos grandes centros, e é verdade. Mas isso nos leva à terceira conclusão; não basta haver demanda teórica de mão-de-obra para orientar a escolha profissional universitária. Antes, é necessário atender a uma série de outras complexas condições reclamadas para o exercício da profissão, e para que os jovens, na faixa etária da opção, se sintam seguros quanto à escolha feita.

Algumas lições importantes podem ser tiradas das poucas pesquisas neste particular realizadas. A ocorrência e matrículas de engenheiros em cursos especializados evidencia a importância dos novos mercados na dinamização e no interesse dos cursos superiores. É a principal lição. Os diversos índices de matrículas nos cursos de Filosofia, Ciências e Letras mostram, sem dúvida, uma alienação de comportamento de nossa população universitária com relação às reais necessidades do país. É a segunda lição.

Além desses trabalhos oficiais que acabamos de utilizar, devemos citar alguns outros, que trazem significativa contribuição ao estudo do problema. 
O Instituto Universitário de Pesquisas do Rio de Janeiro, da Sociedade Brasileira de Instrução, realizou, neste particular, dois importantes trabalhos.

a) através de convênio com a Coordenação de Aperçoamento do Pessoal de Ensino Superior (CAPES), um intitulado: Demanda de Engenheiros, Expansão das Novas Unidades Produtivas, 1966/1973.

b) através de convênio com a Diretoria do Ensino Superior do MEC, um intitulado: Análise da Demanda de Profissionais Químicos no Brasil - Relatório Geral das Atividades em 1965 da Comissão do Planejamento da Formação de Químicos.

A Fundação Getúlio Vargas, pioneira em tantas iniciativas no campo da Administração, do Ensino e da Pesquisa, tem realizado vários estudos neste campo, sendo de citar especialmente a pesquisa realizada mediante acordo com o Ministério da Educação e Cultura, sob a direção do Professor Joaquim Faria Góis Filho e do Engenheiro Roberto Hermeto Corrêa da Costa, sob o título: $O$ Trabalho de Engenheiros e Técnicos da Indústria c a sua Formação.

Aliás, a Fundação Getúlio Vargas acaba de enriquecer seu organograma com uma unidade nova, cuja área de atividades inclui precisamente - o mercado profissional: chama-se CETRHU, Centro de Estudos e Treinamento em Recursos Humanos. Neste momento, o Professor Paulo Sá, sobejamente conhecido por seus trabalhos de Engenharia, Administração e Pesquisa, está concluindo, para o referido Centro, um exaustivo trabalho sobre Demanda de Engenheiros.

Não podemos deixar de fazer referência ao trabalho do Professor Rogers sobre Rendimento das Diversas Profissões, bem como ao do Professor B. Hutchinson. Mobilidade $c$ Trabalho, dadas as implicações que os mesmos têm com a demanda de mão-de-obra.

$\mathrm{Na}$ tentativa de apresentar uma relação evidentemente incompleta das instituições que realizam estudos sobre profissionais de nível superior e mercado profissional, podemos ainda citar: 'Superior ${ }^{\circ}$

CAPES - Coordenação c Aperfeiçoamento de Pessoal de Nível

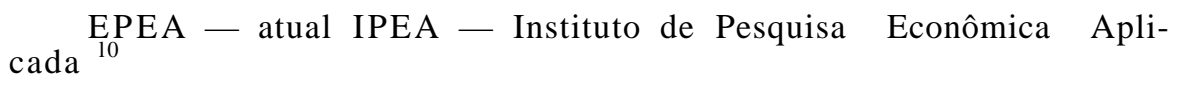

A. J. Rogers III, Rendas Profissionais e Retornos Econômicos do Investimento no Ensino Superior — Tese de Doutoramento.

8 B. Hutchinson, Mobilidade $c$ trabalho, Rio de Janeiro, 1960.

Remeto o interessado à leitura de A Formação de Pessoal de Nível Superior e o Desenvolvimento Econômico, de Américo Barbosa de Oliveira e José Zacarias Sá Carvalho.

10 Ver Educação I - Diagnóstico Preliminar - Dois Anexos, in fine Anexo 1

- Pesquisas sobre Economia da Educação - Anexo II - Projetos existentes. 


\section{FUNDAÇÃO FORD}

\section{UFES - Universidade Federal do Espírito Santo}

\section{Social}

ABPES - Associação Brasileira de Programação Econômica e-

ICS - Instituto de Ciências Sociais, da Universidade Federal do Rio de Janeiro

SENAI -- Serviço Nacional de Aprendizagem Industrial

DEPARTAMENTO NACIONAL DE MÃO-DE-OBRA, do Ministério do Trabalho e Previdência Social.

Grande parte do planejamento educacional até agora realizado no Brasil tem por base o chamado man power approach, técnica que consiste essencialmente em determinações setoriais de futuras exigências de mãode-obra qualificada, e a partir destas estimativas ealculam-se os necessários recursos educacionais.

$\mathrm{O}$ método se baseia em suposições limitantes quanto à tecnologia atual e futura, e também quanto à futura produção de bens e serviços. O mercado de trabalho ou é ignorado ou supõe-se que êle forçosamente se ajustará às previsões dos planejadores.

$\mathrm{Na}$ tentativa de melhorar essas previsões, fêz-se um estudo sobre os rendimentos de diversas profissões e sobre os custos universitários necessários para formar os vários tipos de pessoal qualificado (médicos, advogados, engenheiros, etc). Também foram investigadas as influências de fatores como sexo, raça, religião e classe de ocupação. Os dados para o nosso estudo provêm do VII Recenseamento Geral do Brasil (1960), cujos resultados começaram a ser divulgados no ano passado, presentemente estando disponíveis os que se referem aos Estados do Espírito Santo, Amazonas, Pará, Acre, Maranhão, Piauí, Santa Catarina e Guanabara, mais os territórios da Região Norte. Estes dados incluem a declaração dos rendimentos auferidos, bem como as usuais informações demográficas e educacionais. A realização de entrevistas individuais indicou que os dados sobre rendimentos representam uma boa aproximação dos verdadeiros rendimentos em 1960 auferidos pelas pessoas na sua principal ocupação. Portanto, correspondem aos rendimentos provenientes do «trabalho» resultante de qualificações profissionais, mas não correspondem aos rendimentos provenientes de propriedades ou outras fontes não relacionadas com a principal ocupação.

É de notar-se que as estatísticas do SFPT do M.T.P.S. revelam a existência de elevado número de micro-empreendimentos, nos setoressecundário e terciáro dos maiores centros, onde os proprietários desenvolvem todo o trabalho com a ajuda de familiares e sem emprego depessoal especializado.

As estimativas dos custos para a formação universitária nas várias Faculdades foram obtidas em relatório do Ministério da Educação e 
Cultura e do Ministério do Planejamento e Coordenação Econômica, sendo aos dados desses relatórios adicionados os rendimentos não recebidos pelos estudantes e provenientes de profissões que poderiam ter sido exercidas, mas não o foram por incompatibilidade com a frequência às aulas. O retorno para cada profissão é calculado por subtração .do rendimento médio obtido pelos graduados de nível secundário aos rendimentos auferidos pelo grupo profissional em questão, para cada grupo etário incluído no período normal de vida de trabalho. Os custos para a formação universitária são considerados como investimento .que produz este retorno recebido, que é maior do que o retorno alcançado pelas pessoas que só têm instrução secundária. O retorno líquido é expresso por uma «taxa de juros» sobre as despesas (isto é, investimentos) educacionais, a fim de facilitar comparações entre os investimentos realizados pelo indivíduo e/ou pela sociedade, nas diferentes categorias profissionais, bem como comparações com outros investimentos alternativos fora da área educacional. Assim, se uma pessoa (ou uma sociedade) investiu a mesma quantia em dinheiro num empreendimento não educacional, ela teria que receber, durante toda vida, uma taxa de juros igual à «taxa de retorno» que recebeu como resultado de sua formação em nível superior, para que aquele investimento fosse tão compensador quanto o investimento em Educação.

Este estudo nos dá um retrato de como estava funcionando em 1960 o mercado de trabalho para as diversas profissões. A partir deste retrato, podem ser determinadas muitas pressões econômicas com que se defrontam os graduados universitários. Se o presente estudo fôr realizado também para o restante do País, e posteriormente repetido, utilizando-se os dados do Recenseamento de 1970 (que esperamos estarem disponíveis em 1972), e se forem comparadas as taxas dos retornos nestes dois períodos, poderão também ser estimadas muitas das forças dinâmicas da Economia.

$\mathrm{O}$ rate-of-return approach não substitui o man power approach, mas, sim, o complementa. Por exemplo: seria correto dizer-se que o País «precisa» de mais agrónomos e, portanto, que deveriam ser fornecidos mais recursos educacionais para formar agrónomos. Entretanto, se, para graduação em Agronomia, o custo para o indivíduo e a capacidade intelectual dele exigida forem mais ou menos semelhantes aos da formação de um engenheiro, e se o mercado oferecer ao agrónomo um terço do rendimento auferido por um engenheiro, é duvidoso que baste, para resolver o problema, um aumento do número de escolas de Agronomia e de seus recursos. O mercado de trabalho também precisa ser tomado em consideração. $O$ ensino não é um «bem grátis», quer para a sociedade, quer para o indivíduo. Mesmo se não forem cobradas taxas ou anuidades, o rendimento não recebido pelo estudante universitário representa para êle e para a sociedade um 
custo ponderável, sob a forma de capacidade produtiva perdida. O método da taxa de retorno considera explicitamente estes custos em relação aos benefícios individuais e sociais oferecidos pelo mercado.

Ao fa;er-se o diagnóstico da Educação brasileira, a Divisão de Planejamento da Secretaria Geral do MEC, em documento recentíssimo. enumera cinco problemas principais na área do ensino superior: a) escassez de vagas em cursos profissionais considerados prioritários para o desenvolvimento; b) preferência por certos cursos, em detrimento de outros, o que condiciona o crescimento desordenado da rede de escolas superiores; c) ausência de planejamento nas escolas, para utilização dos recursos humanos, instalações e equipamentos, o que gera capacidade ociosa; d) diversificação inadequada dos currículos para qualificação múltipla conforme às necessidades do mercado de trabalho; e) deficiência qualitativa do ensino, não raro decorrente do precário sistema de financiamento da entidade escolar e da baixa remuneração do corpo docente. " $O$ documento se refere à diversificação inadequada dos currículos para qualificaçãção múltipla conforme às necessidades do mercado de trabalho. Vem a propósito repetir aqui a observação do Prof. Arlindo Lopes Corrêa, para quem «enfocado como uma indústria de prestação de serviços, o sistema educacional, depois de ser estudado em suas relações com os demais setores econômicos, está sendo vasculhado no sentido de buscar-se e aprimorar sua eficiência interna.» ${ }^{12}$

Caberia talvez aqui repetir o velho refrão de que «Deus vende os bens do mundo a preço do esforço». E acrescentaríamos que o esforço dos recursos humanos há de ser tão rentável, pelo menos quanto se espera o sejam os esforços por investimento de recursos de capital.

Forçoso é reconhecer, entretanto, que ainda estamos muito longe de dispor de elementos válidos, completos e atualizados num campo tão importante para a racionalização da Universidade, quanto este que diz respeito à ligação dinâmica de seus cursos com as necessidades domercado e do desenvolvimento econômico. Os planos de desenvolvimento econômico e social do País exigem, como é óbvio, levantamentos

11 Programa Estratégico de Desenvolvimento - Área da Educação 1968/70, publicação mimeografada do MEC, maio de 1968.

Arlindo Lopes Corrêa, ob. cit. 
e análises de uma série de dados, sem os quais não podem ser traçados, nem podem ser fixadas as metas viáveis de sua execução nos prazos estabelecidos.

Nosso esforço consistiu, sobretudo, em não deixar o relatório sem pelo menos uma palavra em assunto de capital importância para a Universidade poder realizar suas finalidades essenciais de centro propulsor de cultura e tecnologia, peças fundamentais do desenvolvimento, como deixamos claro no começo deste trabalho.

Tarefa utilíssima seria a de se fazer, neste particular, e quanto antes, o mais completo levantamento das organizações que aqui ou no estrangeiro se dedicam a estudos e pesquisas de mercado profissional de nível superior, bem como da bibliografia existente.

Seria lícito afirmar que uma das funções precípuas da Comissão Permanente de Assessoramento da DESu, cuja necessidade tantas vezes se fêz sentir no decorrer dos trabalhos, será a de estar a par das flutuações desse específico mercado de trabalho, para fornecê-las às Universidades, através de seu Departamento de Programação e Currículos, pondo-se para tanto em contato com todas as instituições aqui relacionadas e com outras, atuais e futuras. Seria mesmo de desejar a elaboração de um «dicionário» de profissões e ocupações (que já têm outros países), o qual poderia ser encomendado a uma instituição capaz de brindar-nos com esse importante instrumento de referência, para o estudo das profissões e do mercado profissional.

Como se viu, não existe ainda no país nenhuma instituição que, por si ou em conexão com outras, realize satisfatoriamente estudos de mercado profissional. Por outro lado, não se pode admitir que a situação continue assim, pois não é possível planejar um programa racional de ensino superior sem conhecer as necessidades do mercado. Como consideramos o período coberto pelo plano do IPEA - tempo bastante para, incentivados aos estudos de mercado profissional, esperar pelo urgente instrumento de planejamento que ora nos falta sugerimos que por enquanto se tomem como base os estudos do Plano Decenal e do Diagnóstico Preliminar, do Ministério do Planejamento. 


\section{ENSINO SUPERIOR E UNIVERSIDADE}

Com o Decreto $\mathrm{n}^{\circ} 19.851$, de 11 de abril de 1931, iniciou-se o processo de estruturação, em moldes universitários, do ensino superior brasileiro. A ideia de Universidade, entretanto, que foi o impulso modelador das instituições criadas a partir de 1931, é bem anterior a esta data e, segundo alguns autores, remonta ao último quarto do século XVI. ' O Estatuto das Universidades Brasileiras representou uma média de aspirações «um estado de equilíbrio entre tendências opostas, de todas consubstanciando os elementos de possível assimiliação pelo meio nacional, de maneira a não determinar uma brusca ruptura com o presente, o que tornaria de adaptação difícil ou improvável, diminuindo, assim, os benefícios que dele poderão resultar de modo imediato». ${ }^{2}$ Esta linha de moderação e equilíbrio, «de transações c compromissos entre as várias tendências, correntes e direções de espírito», marcou sem dúvida orientação nova, mais larga do que a adotada em 1920 com a Universidade do Rio de Janeiro.

Não será difícil reconhecer, nas diretrizes fixadas no Estatuto, o propósito de corrigir as limitações do modelo adotado em 1920 e de, ao mesmo tempo, traduzir algumas das concepções comuns sustentadas

Valmir Chagas, A Luta pela Universidade no Brasil, MEC/UFRGS, Gráfica da Universidade, 1967; Serafim Leite, S. J., História da Companhia de Jesus no Brasil, tomo I, Lisboa, Livraria Portugália, 1938. págs. 97-98. Sobre o valor dos títulos concedidos pelo Colégio da Bahia, ver Fernando de Azevedo, A Cultura Brasileira, Editora Universidade de Brasília, 4' ed., 1963. pág. 522. nota 13. A propósito dos movimentos para a criação de Universidades no Brasil, ver Ernesto de Souza Campos, Educação Superior no Brasil, Rio de Janeiro. MEC, 1940, e História da Universidade de São Paulo, São Paulo, 1954; Roque Spencer Maciel de Barros, «A Ilustração Brasileira e a ideia da Universidade», Boletim da F.P. CL. da U.S.P., São Paulo, 1959; Jorge Nagle, Educação e Sociedade no Brasil (1920-1929), 2 vols. (mimeografado), Araraquara, 1966. Fonte: Primitivo Moacir. A Instrução e o Império (subsidio para a história da educação no Brasil), Comp. Editora Nacional, 3 vols., 1936-1938; A Instrução e as Províncias, Comp. Editora Nacional, 3 vols., 1937-1940; A Instrução e a República (subsídios para a história da Educação no Brasil), publicação do INEP, 1941-1942. Depois de algumas tentativas, no Império e na República, a instituição universitária surge com a Universidade de Manaus, em 1909; Universidade do Paraná, em 1912; Rio de Janeiro, em 1920; e Minas Gerais, em 1927.

Exposição de Motivos do Ministro Francisco Campos, Diário Oficial de 15 de abril de 1931. 
por cientistas e educadores ilustres nos inquéritos coordenados por Fernando de Azevedo e pela Associação Brasileira de Educação.

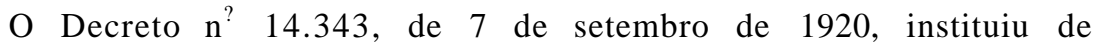
fato uma Universidade mais nominal do que real. Agruparam-se, sob a direção do presidente do Conselho Superior do Ensino, na qualidade de Reitor e do Conselho Universitário, «com atribuições previstas no respectivo regulamento», três escolas profissionais: Escola Politécnica, Faculdade de Medicina e Faculdade de Direito, todas do Rio de Janeiro. O Conselho Universitário passou a funcionar como um Colegiado, no qual se reuniram o Reitor, com voto de qualidade, os diretores e seis professores catedráticos, «sendo dois de cada Congregação, eleitos em escrutínio secreto, por maioria absoluta de votos».

As duas escolas oficiais, a Politécnica e a Faculdade de Medicina, continuaram com autonomia didática e administrativa (art. $3^{\text {? }}$ ), e a Faculdade de Direito deveria, de acordo com o art. $4^{\circ}$, «prover todas as despesas exclusivamente com as rendas do respectivo património, sem outro auxilio oficial ou vantagem para os professores, além dos que lhe são outorgados pelos seus estatutos».

Não houve, como se vê, preocupação de estabelecer uma estrutura universitária, com serviços de ensino e pesquisa comuns e integradas. O cuidado foi só o de agrupar escolas sob a direção de uma Reitoria e de um Colegiado com reduzidíssimo poder deliberativo, pois as escolas continuavam com autonomia didática e administrativa.

A maior falha do modelo universitário de 1920 reside, sem dúvida. no fato de se organizar uma Universidade pela reunião de três escolas profissionais e sem nenhuma preocupação que visasse à criação de um Centro de Pesquisas e Ensino de Ciências Fundamentais não Aplicadas e de Filosofia, Letras e Artes.

3 Fernando de Azevedo, A Educação Pública em São Paulo. Problemas $t$ Discussões. Inquérito de $O$ Estado de São Paulo, em 1926; Brasiliana, vol. 9S. Comp. Editora Nacional. São Paulo, 1937; $2^{\mathrm{a}}$ ed., in A Educação na Encruzilhada. Edições Melhoramentos. São Paulo, 1950; O Problema Universitário Brasileiro. Inquérito promovido pela Seção de Ensino Técnico e Superior do Ministério d;i Educação, A Encadernadora S.A., Rio, 1929.

4 Decreto $\mathrm{n}^{\circ}$ 14.343, in História da Universidade de São Paulo, de Ernesto de Sousa Campos, São Paulo, pág. 36.

5 Idem, ibidem, pág. 37.

6 «Não errarei afirmando, pois, que a Universidade do Rio de Janeiro está, apenas, criada in nomine, e, por esta circunstância, se ache, ainda, longe de satisfazer o desideratum do seu Regimento: «estimular a cultura das ciências; estreitar, entre os professores, os laços de solidariedade intelectual e moral e aperfeiçoar os métodos de ensino». Constituída pela agregação das três Faculdades preexistentes, de Engenharia, de Medicina e de Direito, do Rio de Janeiro, nem ao menos têm elas a sua localização comum ou próxima. Vivem apartados e como alheios uns dos outros os três institutos que a compõem, sem laço de ligação, além do Conselho Universitário, cujos membros procedem das três Faculdades». Relatório do Reitor Ramiz Galvão, apud Jorge Nagle, ob. cit., pág. 396. 
O modelo de 1920 teve, todavia, o mérito de suscitar o debate em torno do problema universitário. José Augusto assinalava que a solução proposta no Brasil contrariava a tendência histórica de substituir a Universidade profissional pela Universidade científica: «É certo. dizia que a organização do saber em vista das atividades práticas não pode deixar de estar dentro dos planos universitários, mas estes. coroamento de todo o sistema da pública educação, não podem deixar de visar as mais altas conquistas da inteligência, elaborando, ensinando e difundindo a ciência».

\section{O MODELO DE 1931}

Estas inúmeras manifestações convergiram para uma ideia de Universidade na qual os estudos não aplicados das Ciências e das Letras exerceriam um dos papéis mais relevantes do trabalho universitário de elaboração, ensino e difusão de cultura. O Decreto $\mathrm{n}^{\circ}$ 19.851, que dispõe sobre a organização do ensino superior brasileiro, e o de $\mathrm{n}^{\circ}$ 19.852, que organizou a Universidade do Rio de Janeiro, ambos de 11 de abril de 1931, instituíram o novo modelo de estrutura universitária, com a admitida criação da Faculdade de Educação, Ciência e Letras.

O Decreto $\mathrm{n}^{\circ}$ 19.851, Estatuto das Universidades Brasileiras. determina «que o ensino superior no Brasil obedecerá, de preferência. ao sistema universitário, podendo ainda ser ministrado em institutos isolados...»

A Mensagem que acompanhou o projeto explicitou os propósitos que nortearam a concepção da estrutura universitária então instituída. Âs diretrizes do modelo universitário de 1931. de acordo com a Mensagem ministerial, podem ser resumidas nos seguintes pontos:

\section{Universidade e institutos isolados}

O ensino superior está organizado em Universidades e, em caráter transitório, em escolas isoladas. «A Universidade constituirá, assim, ao menos como regra geral, em estado de aspiração, enquanto durar o regime transitório de institutos isolados, a unidade administrativa e didática que reúne, sob a mesma direção intelectual e técnica, todo o ensino superior, seja de caráter utilitário e profissional, seja o puramente científico e sem aplicação
imediata. ..»

Apud Jorge Nagle, ob. cit., pág. 399.

8 Mensagem, Diário Oficial, de 15 de abril de 1931. Todas as citações que se seguem são transcrições da Mensagem aos projetos consubstanciados nos Decretos ns. 19.850, que criou o Conselho Nacional de Educação. 19.851. que dispôs sobre a organização do Ensino Superior, e 19.852, que dispôs sobre a organização da Universidade do Rio de Janeiro. 
Objetivo cultural e objetivo profissional

A Universidade traduzirá, na sua finalidade, a superação do modelo representado pela simples reunião de escolas profissionais, pela conciliação dos objetivos culturais ou profissionais, aparentemente antinômicos. Visará «assim a Universidade ao duplo objetivo de equipar tecnicamente as elites profissionais do país e de proporcionar ambiente propício às vocações especulativas e desinteressadas, cujo destino, imprescindível à formação da cultura nacional, é o da investigação e da ciência pura».

Transmissão e criação de conhecimentos

A Universidade não se restringirá à função do ensino e da difusão de conhecimentos: cabe-lhe essencialmente o papel de renovar, criar e abrir novos caminhos na busca do saber. A «Universidade não é apenas uma unidade didática, pois que a sua finalidade transcende ao exclusivo propósito do ensino, envolvendo preocupações de pura ciência e de cultura desinteressada...»

\section{Universidade e solidariedade comunitária}

A Universidade, igualmente, não se reduz ao mero cumprimento das exigências especificamente escolares. $\mathrm{O}$ que a distingue é o fato de ser uma comunidade, «uma família intelectual e moral» de professores e alunos, unida pelos laços de solidariedade que se fundamentam nos mesmos interesses e aspirações.

\section{Universidade e extensão universitária}

A Universidade deve ser uma comunidade aberta e levar à sociedade os elementos do seu trabalho por intermédio dos serviços de extensão universitária. «A extensão universitária se destina a dilatar os benefícios da atmosfera universitária àqueles que não se encontrem diretamente associados à vida da Universidade, dando, assim, maior amplitude e mais larga ressonância às atividades universitárias que concorrerão, de modo eficaz, para elevar o nível da cultura geral do povo, integrando, assim, a Universidade na grande função educativa que lhe compete no panorama da vida contemporânea, função que, só ela, justifica, ampla e inteiramente, pelos benefícios coletivos resultantes, o sistema de organização do ensino sobre base universitária».

Universidade e desenvolvimento econômico e cultural

A Universidade, como núcleo de formação de pessoal, deve corresponder às necessidades do aperfeiçoamento 
técnico e científico e às exigências do crescimento economico e do progresso cultural. «Na organização das Universidades brasileiras dominou, de modo precípuo e fundamental, o critério de prover às atuais necessidades de nosso aperfeiçoamento técnico e científico, não deixando, porém, de ser atendidas, em dispositivos destinados a execução oportuna, parcial e progressiva, as exigências de desenvolvimento, ampliação e adaptação do sistema universitário, de acordo com o crescimento econômico e cultural do pais».

\section{Universidade e heterogeneidade}

A Universidade, respeitadas as linhas gerais de sua estruturação, não se constitui num único padrão uniforme. O Estatuto «se limita a instituir em linhas gerais o modelo de organização administrativa e didática para as Universidades federais e equiparadas, admitindo, porém, variantes, desde que orientadas por condições e circunstâncias cuja interferência, na organização e objetivos do ensino universitário, seja de manifesta utilidade. Em um país de tão amplas proporções territoriais como o Brasil e constituído de tantas zonas geográficas e econômicas de caracteres tão acentuadamente definidos, é da maior utilidade permitir, mesmo no interesse do enriquecimento formal e material da organização universitária, que esta se deixe influenciar e modelar pelos múltiplos fatores de ordem econômica, geográfica e espiritual de cuja incidência se compõe a fisionomia própria ou a característica diferencial de cada uma de nossas regiões. A organização universitária esposada pelo projeto não padece dos vícios de intolerância e rigidez. que tornariam difícil ou precária a sua adaptação à diversidade de circunstâncias do ambiente brasileiro. Ela se distingue e recomenda, ao contrário, pela flexibilidade das suas linhas e pela capacidade de adaptação resultante da amplitude e da liberdade dos seus planos administrativos e didáticos».

9 «As Universidades estaduais ou livres poderão ser equiparadas às Universidades federais para os efeitos da concessão de títulos, dignidade e outros privilégios universitários, mediante inspeção prévia pelo Departamento Nacional de Ensino e ouvido o Conselho Nacional de Educação.

Parág. único. O Ministro da Educação e Saúde Pública fixará, cm instruções especiais, o processo de inspeção prévia e quais os elementos mínimos de ordem material e financeira necessários à equiparação.

a $\mathrm{r}$ t $13 \mathrm{As}$ universidades estaduais e livres equiparadas ficarão sujeitas à fiscalização do Governo Federal, por intermédio do Departamento Nacional de 


\section{Universidade e autonomia}

A Universidade, no que se refere ao seu status jurídico, será orientada de modo que alcance, como uma conquista, plena autonomia didática e administrativa. $\mathrm{O}$ projeto, «pelas tendências manifestas que revela, se deixa orientar pelo critério da autonomia administrativa e didática das Universidades. Seria, porém, de todo ponto inconveniente e mesmo contraproducente para o ensino, que, de súbito, por uma integral e repentina ruptura com o presente, se concedesse às Universidades ampla e plena autonomia didática e administrativa. A autonomia requer prática, experiência e critérios seguros de orientação. Ora, o regime universitário ainda se encontra entre nós na sua fase nascente, tentando os primeiros passos e fazendo os seus ensaios de adaptação. Seria de mau conselho que nesse período inicial e ainda embrionário, rudimentar, da organização universitária, se tentasse, com risco de graves danos para o ensino, o regime da autonomia integral.

«Este o motivo pelo qual o projeto preferiu a orientação prudente e segura da autonomia relativa, destinada a exercer uma grande função educativa sobre o espírito universitário que, na sua prática, adquirirá a experiência e o critério indispensáveis a uma autonomia mais ampla, seja no terreno administrativo, seja no domínio didático. Com a experiência, poderá o quadro da autonomia ir se alargando de maneira gradual e progressiva, até que, finalmente, com o desenvolvimento da capacidade e da envergadura do espírito universitário, venha a reunir sob a sua autoridade todos os poderes de governo do grande agrupamento administrativo, técnico e didático que constitui a Universidade. A autonomia integral será, assim, obra e conquista do espírito universitário, amadurecido, experiente e dotado do seguro e firme sentido de direção e de responsabilidade, ao invés de constituir uma concessão graciosa e

Ensino, que verificará a fiel observância de todos os preceitos legais e estatutários que regem a organização e o funcionamento da Universidade e dos institutos que a compuseram solidários e estritamente responsáveis pela eficiência do ensino neles ministrado.

Parág. único. A equiparação das Universidades estaduais ou livres poderá ser suspensa enquanto não fo-em sanadas graves irregularidades porventura verificadas no funcionamento, e será cassada por decreto do Governo Federal, desde que, mediante prévio inquérito e ouvido o Conselho Nacional de Educação, ficar comprovado que não mais preenchem os seus fins». Equiparação das Universidades, Cap. II, arts. 12, 13 e parág. único do Decreto $\mathrm{n}^{\circ} 19.851$, de 11 de abril de 1931. 
extemporânea, destinada antes a deseducar do que a formar, no centro universitário, o senso de organização de sociedade e de governo.»

\section{Núcleo constitutivo mínimo das Universidades}

A Universidade será constituída pela reunião de três dos seguintes institutos de ensino superior: Faculdade de Direito, Escola Politécnica, Faculdade de Medicina e Faculdade de Educação, Ciências e Letras. «O projeto exige, para que se constitua a Universidade, a incorporação de pelo menos três institutos de ensino superior, entre os mesmos incluindo os de Direito, Medicina e Engenharia, ou, ao invés de um deles, a Faculdade de Educação, Ciências e Letras».

\section{Governo da Universidade}

O projeto organiza a administração superior da Universidade, criando a Reitoria, o Conselho Universitário, o Conselho Técnico-Administrativo e redefinindo as atribuições do Diretor e das Congregações. «O Reitor e o Conselho Universitário constituem os órgãos supremos da direção técnica e administrativa da Universidade, raros sendo os assuntos, quase exclusivamente de ordem financeira e puramente administrativa, que dependem da decisão do Ministro da Educação». A criação do Conselho Técnico-Administrativo visou dotar a administração da unidade de um órgão que pudesse cooperar com o diretor, como peça central, na solução de todos os problemas técnicos, administrativos e didáticos da vida do instituto.

$1^{\circ}$ O exame atento dos dispositivos do Decreto $\mathrm{n}>19.851$, que definem as atribuições dos órgãos da administração universitária, indica o cuidado de assegurar o caráter de uma administração colegiada. Confrontem-se, por exemplo, as atribuições do Reitor com as do Conselho Universitário, e as do Diretor com as do Conselho Técnico-Administrativo.

ESTATUTO DAS UNIVERSIDADES BRASILEIRAS

Art. 18. Constituem atribuições do Reitor: seus estatutos.

I - representar e dirigir a Universidade, velando pela fiel observância dos tário;

II - convocar e presidir a Assembleia Universitária e o Conselho Universi-

III - assinar, conjuntamente com o respectivo diretor do instituto universitário, os diplomas conferidos pela Universidade;

IV - administrar as finanças da Universidade;

$\mathrm{V}$ - nomear, licenciar e demitir o pessoal administrativo da Reitoria;

VI - superintender os serviços da Secretaria-geral e os serviços anexos; 
VII - nomear ou contratar professores, de acordo com resoluções do Conselho Universitário;

VIII - exercer o poder disciplinar;

IX - desempenhar todas as demais atribuições inerentes ao cargo de reitor, de acordo com os dispositivos estatutários e com os moldes gerais do regimento universitário.

Art. 23. Constituem atribuições do Conselho Universitário:

I - exercer, como órgão deliberativo, a jurisdição superior da Universidade;

II - organizar a lista tríplice para o provimento do cargo de reitor;

III - eleger o seu vice-presidente;

IV - elaborar o regimento interno do Conselho e da Universidade;

$\mathrm{V}$ - aprovar os regimentos internos, organizados para cada um dos institutos universitários, pelos respectivos conselhos técnico-administrativos;

VI - deliberar sobre quaisquer modificações do estatuto da Universidade, de acordo com os altos interesses do ensino;

VII - aprovar modificações dos regulamentos de cada um dos institutos da Universidade, atendidas as restrições constantes deste estatuto;

VIII - aprovar as propostas dos orçamentos anuais dos institutos universitários, remetidos ao reitor pelos respectivos diretores;

IX - organizar o orçamento de despesas da Reitoria e suas dependências fixando as quotas anuais com que deve contribuir para esse orçamento cada um dos institutos universitários;

$\mathrm{X}$ - autorizar as despesas extraordinárias não previstas nos orçamentos dos institutos universitários, que atendam a necessidades do ensino;

XI - aprovar a prestação de contas, de cada exercício, feita ao reitopelos diretores dos institutos universitários;

XII - resolver sobre a aceitação de legados e donativos, e deliberar sobre a administração do património da Universidade;

XIII - autorizar acordos entre os institutos universitários e sociedades industriais, comerciais ou particulares para a realização de trabalhos ou pesquisas;

XIV - autorizar o contrato de professores para a realização de recursos nos institutos universitários;

XV - organizar o quadro dos funcionários administrativos da Reitoria e dos institutos universitários e autorizar a nomeação de pessoal extranumerário dentro da.» verbas disponíveis;

XVI - resolver sobre os mandatos universitários para a realização de cursos de aperfeiçoamento ou de especialização, por iniciativa própria ou por proposta de qualquer instituto da Universidade;

XVII - organizar, de acordo com proposta dos institutos da Universidade, os curses e conferências de extensão universitária;

XVIII - deliberar sobre assuntos didáticos de ordem geral e aprovar iniciativas ou modificações no regime do ensino, não determinadas era regulamentos, propostas por qualquer dos institutos da Universidade, atendidas as condições em que se exercita a autonomia universitária.

XIX - decidir sobre a concessão do título de professor honoris causa;

$\mathrm{XX}$ - criar e conceder prémios pecuniários ou honoríficos destinados a estimular e recompensar atividades universitárias;

XXI - deliberar, em grau de recurso, sobre a aplicação de penalidades, de acordo com os dispositivos do regimento interno da Universidade; 
XXII - deliberar sobre providências destinadas a prevenir ou corrigir atos de indisciplina coletiva, inclusive sobre o fechamento de cursos e mesmo de qualquer instituto universitário;

XXIII - deliberar sobre questões omissas deste estatuto ou do regimento interno da Universidade e dos institutos universitários;

Art. 28. Constituem atribuições do diretor de cada instituto universitário:

I - entender-se com os poderes superiores sobre todos os assuntes que interessem ao instituto e dependam de decisões daqueles;

II - representar o instituto em quaisquer atos públicos e nas suas relações com outros ramos da administração, instituições científicas e corporações particulares; inslituto;

III - assinar, conjuntamente com o reitor, os diplomas expedidos pelo

$$
\text { IV - fazer parte do Conselho Universitário; }
$$

$\mathrm{V}$ - assinar e expedir certificados dos cursos de aperfeiçoamento e de especialização;

VI - convocar e presidir as reuniões do Conselho Técnico-Administrativo e da Congregação;

VII - executar e fazer executar as decisões dos órgãos administrativos da Universidade;

VIII - dirigir a administração do instituto, de acordo com os diapositivos regulamentares e com decisões do Conselho Técnico-Administrativo e da Congregação;

IX - fiscalizar a fiel execução do regime didático, especialmente no que respeita à observância de horários e programas, à atividade de professores, docentes livres, auxiliares de ensino e estudantes;

$\mathrm{X}$ - manter a ordem e a disciplina em todas as dependências do instituto. e propor no Conselho Técnico-Administrativo providências que se façam necessárias;

XI - superintender todos os serviços administrativos do instituto;

XII - remover de um para outro serviço os funcionários administrativos. de acordo com as necessidades ocorrentes;

XIII - conceder férias regulamentares;

XIV - dar posse aos funcionários docentes e administrativos;

$\mathrm{XV}$ - nomear os docentes livres, auxiliares de ensino extranumerários;

XVI - informar o Conselho Técnico-Administrativo sobre quaisquer assuntos que interessem à administração é ao ensino;

XVII - apresentar anualmente ao reitor relatório dos trabalhos do instituto, nele assinalando as providências indicadas para a maior eficiência do ensino,

XVIII .- aplicar as penalidades regulamentares.

Art. 30. Constituem atribuições do Conselho Técnico-Administrativo:

I - reunir-se em sessões ordinárias pelo menos uma vez por mês, e, extraordinariamente, quando convocado pelo diretor;

II - emitir parecer sobre quaisquer assuntos de ordem didática que hajam de ser submetidos à Congregação;

III - rever os programas de ensino das diversas disciplinas, a fim de verificar se obedecem às exigências regulamentares;

IV - organizar horários para os cursos oficiais, ouvidos os respectivos professores, e atendidas quaisquer circunstâncias que possam interferir na regularidade da frequência e na boa ordem dos trabalhos didáticos;

$\mathrm{V}$ - autorizar a realização de cursos previstos no regulamento e dependentes de sua decisão, depois de rever e aprovar os respectivos programas; 
VI - fixar anualmente o número de alunos admitidos à matrícula nos cursos seriados;

VII - fixar, ouvido o respectivo professor e de acordo com os interesses do ensino, o número de estudantes das turmas a seu cargo;

VIII - deliberar sobre as condições de pagamento pela execução de cursos remunerados;

IX - organizar as comissões examinadoras para as provas de habilitação dos estudantes;

$\mathrm{X}$ - constituir comissões especiais de professores para o estudo de assuntos que interessem ao instituto;

XI - autorizar a nomeação de auxiliares de ensino e a designação de docentes livres como auxiliares do professor dos cursos normais;

XII — organizar, ouvida a Congregação, o regimento interno do instituto, submetendo-o a aprovação do Conselho Universitário;

XIII - elaborar, de acordo com o diretor, a proposta de orçamento do instituto;

XIV - encaminhar à Congregação, devidamente informada e verificada a procedência dos seus fundamentos, representações contra atos dos professores.

Parág. único. O Conselho Técnico-Administrativo terá como presidente o diretor do instituto, que será substituído nas suas ausências ou impedimentos eventuais pelo membro do Conselho mais antigo no magistério. 


\section{A FACULDADE DE FILOSOFIA E A UNIVERSIDADE}

A criação das Faculdades de Filosofia, Ciências e Letras no início da década de 30 correspondeu ao desejo generalizado de atenuar as limitações notórias de um ensino voltado preponderantemente para o desenvolvimento da ciência aplicada e para a formação profissional. Embora possuíssemos já este tipo de escola, o certo é que somente com o Decreto $\mathrm{n}^{9} 19.851$ a Faculdade de Filosofia adquiriu status legal de escola universitária, com objetivos claramente definidos. $\mathrm{Na}$ Exposição de Motivos de 1931, o Ministro reconhecia as limitações do modelo de 1920, ao justificar a criação e a remodelação das escolas superiores de Artes e a instituição de Faculdades de Educação, Ciências e Letras. «Esta última particularmente», assinala a Mensagem, «pela alta função que exerce na vida cultural, é que dá, de modo mais acentuado no conjunto de institutos reunidos em Universidades, o caráter propriamente universitário, permitindo que a vida universitária transcenda aos limites do interesse puramente profissional, abrangendo, em todos os seus aspectos, os altos e autênticos valores de cultura, que à Universidade conferem o caráter e atributo que a definem e individualizam, isto é, a Universidade».

A esta finalidade tipicamente universitária das Faculdades de Educação, Ciências e Letras se acrescentou outra, não menos relevante: a de preparar o pessoal do magistério secundário. A Mensagem justificou o caráter «especial e misto» da nova instituição, lembrando que não se podia esquecer, «na primeira tentativa que se fêz de instituir no Brasil um Instituto de Alta Cultura, que nos povos em formação, como o nosso, a alta cultura não pode ser organizada de uma vez, integralmente e de maneira conclusiva. Para que um Instituto dessa ordem vingue entre nós, torna-se indispensável resultem de sua instituição benefícios imediatos, devendo a sua inserção no meio nacional fazer-se exatamente nos pontos fracos ou nas lacunas da nossa cultura, de maneira que o seu crescimento seja progressivo e em continuidade com as nossas exigências mais próximas e mais imperativas». A posição da Faculdade de Educação, Ciências e Letras no quadro da Universidade ficou assim precisamente definida como centro de altos estudos, de cultura desinteressada, mas com «papel eminentemente utilitário e prático»: A formação do pessoal do magistério secundário e normal. Apesar do inegável avanço alcançado, em relação ao modelo de 1920, a estrutura proposta nos Estatutos não estabeleceu, como 
devia, a efetiva integração das escolas na nova Universidade. O' art. 9" do Decreto $n^{\circ} 19.851$ assim dispunha: «As Universidades gozarão de personalidade jurídica e de autonomia administrativa. didática e disciplinar nos limites estabelecidos pelo presente decreto, sem prejuízo da personalidade jurídica que tenha ou possa ser atribuída pelos Estatutos Universitários a cada um dos institutos componentes da Universidade». A Universidade nessas condições tornou-se uma federação de federação de escolas. Houve, sem dúvida, preocupação de alcançar o que hoje chamaríamos de integração universitária. Mas a integração almejada se situou mais no plano da vida social universitária do que das atividades académicas. O Título XIII do Estatuto é todo êle dedicado ao estabelecimento de condições e estímulos para a organização da vida universitária. «As Universidades brasileiras, solidárias nos mesmos propósitos e aspirações de cultura, devem manter ativo intercâmbio de entendimento e de cooperação, a fim de que eficazmente contribuam para a grande obra nacional que lhes incumbe realizar».

«Entre os institutos de qualquer Universidade deverá haver permanente contato, facilitado em reuniões coletivas, nas quais os corpos docente e discente possam encontrar ambiente agradável e propício à orientação e renovação dos ideais universitários. Mas, além disso, as Universidades devem vincular-se intimamente com a sociedade, e contribuir, na esfera de sua ação, para o aperfeiçoamento do meio». Neste capítulo, o Estatuto prevê, com riqueza de pormenores, a organização da vida universitária, tanto do seu corpo docente, quanto do discente. Os órgãos estudantis nele estabelecidos, depois de longo período em que permaneceram completamente esquecidos, foram restaurados pela Lei n' 4.440 , de 27 de outubro de 1964. modificada posteriormente pelo Decreto-lei no 228, de 28 de fevereiro de 1967.

Todavia, assinalado foi o empenho que se fêz em São Paulo para implantar a estrutura de uma Universidade integral. A Faculdade de Filosofia, Ciências e Letras, criada no governo de Armando Sales de Oliveira em 1934, não foi concebida, na ideia dos fundadores da Universidade de São Paulo, apenas como centro de alta cultura e como escola destinada à formação do pessoal do magistério secundário. Esta formação, de acordo com o Estatuto de 25 de janeiro de 1934, que criou a Universidade de São Paulo, deveria ser realizada por intermédio do Instituto de Educação. Os cursos da Faculdade de Filosofia (note-se, Filosofia e não Educação, como consta do Decreto n' 19.851), Ciências e Letras não tinham nenhum caráter profissionalizante. A separação dos cursos de formação cultural ou científica e do curso de formação pedagógica, caracterizada pela existência de duas escolas distintas, diferencia o modelo universitário paulista e o distingue nitidamente do modelo instituído, no plano federal, em 1931. A relevância do papel claramente atribuído à nova escola, é expressa nos próprios termos do decreto que criou a Universidade de São Paulo (Decreto $\mathrm{n}^{9}$ 6.283, de 25 de janeiro de 1934). 
A concepção dos fundadores da Universidade de São Paulo foi realmente de alcance mais profundo. A integração universitária apresentou-se como a ideia de fazer da Faculdade de Filosofia, Ciências e Letras a base e a cúpula do organismo universitário. Júlio de Mesquita Filho, principal incentivador e um dos fundadores da Universidade de São Paulo, traz-nos, neste sentido, depoimento de grande valor histórico. Em discurso proferido por ocasião da solenidade de formatura dos Licenciados de 1945, ao tratar do problema do planejamento da Cidade Universitária, o ilustre jornalista teceu as seguintes considerações: «Desde que a sua estrutura arquitetônica seja concebida de acordo com os princípios gerais que vimos enunciando, a Cidade Universitária tornaria possível a centralização das cátedras que se destinam ao ensino das matérias chamadas básicas, isto é, daquelas que se dedicam às ciências puras, como a Matemática, a Química, a Botânica, a Biologia Geral, a Zoologia, a Filosofia, a Anatomia etc. No pensamento do fundador desta Faculdade e no de seus companheiros de luta, seriam desagregadas das diferentes escolas em que são obrigatoriamente ministradas, para passar a ser exclusivas de uma Faculdade central: da Faculdade a que pertenceis, alma mater do organismo que, por definição, deve dedicar-se aos chamados altos estudos desinteressados, os quais são a finalidade precípua de uma Universidade realmente digna desse nome, a cuja volta se agrupariam os demais institutos profissionais.

«Para que este pensamento adquira nitidez maior, vejamos um exemplo concreto: admitamos que a Química, a Física, a Biologia Geral e a Zoologia fossem matérias ensinadas nos cursos não somente da Faculdade de Filosofia, Ciências e Letras, onde procurariam seus diplomas os que se destinassem ao doutoramento em Ciências, mas ainda nas de Medicina, Farmácia e Odontologia. Pois bem, segundo a concepção que presidiu à redação do Decreto de 25 de janeiro de 1934, seriam elas eliminadas desses diferentes institutos, para que tanto os alunos de Medicina quanto os de Farmácia e Odontologia as cursassem na Faculdade de Filosofia, Ciências e Letras. Da mesma maneira, os que se destinam à Escola Politécnica deixariam de cursar nela a Análise Matemática, a Física, a Química, para segui-las nas respectivas subseções dedicadas às mesmas disciplinas da Faculdade de Filosofia, Ciências e Letras. Outro tanto aconteceria com a Economia Política, que seria ministrada exclusivamente nesta Faculdade, onde os alunos de Direito deveriam cursá-la. Assim, as Faculdades dedicadas à formação de profissionais de Medicina, Farmácia, Odontologia, Engenharia, Direito, Agricultura etc., veriam seus cursos reduzidos exclusivamente às cadeiras práticas e técnicas propriamente ditas.

«Poderia estender-se a regra acima mesmo às Escolas do Exército e da Marinha. O desconhecimento e quase divórcio existente entre os civis e militares em nosso país tem sido a causa de um trágico mal entendido entre os primeiros e as classes armadas. A desconfiança mútua e, às vezes, até a prevenção, fazendo com que uns formem juízo falso 
dos outros, quase sempre injusto, desapareceriam por completo se, no período universitário, os estudantes da Escola Militar ou da Escola Naval e de outros estabelecimentos universitários tivessem a oportunidade de um convívio estreito que se daria na Faculdade de Filosofia, Ciências e Letras, através dos cursos de Matemática, Física e Química e mais disciplinas indispensáveis às carreiras de armas.

«Cremos não serem necessárias mais extensas explanações, para que quantos tenham o hábito de meditar sobre assuntos do ensino aprendam o imenso alcance de uma tal sistematização. Para estes não escapará a significação decorrente do fato de submeterem os alunos que se destinam a diferentes especialidades a uma formação científica básica uniforme, a um convivio sob o mesmo teto e, portanto, à ação contínua do mesmo espírito formativo. A passagem da totalidade do corpo discente pela Faculdade de Filosofia, Ciências e Letras dar-lhe-ia uma percepção nítida e tangível daquele espírito universitário a que acima nos referimos e que se definiu como sendo a própria consciência da unidade do saber humano e da colaboração de todos na obra comum em prol do progresso, tanto da terra em que nascemos, como da ciência em si mesma. A permanência de uma Faculdade, cujo trato diferencial seria o caráter desinteressado dos estudos que nela se fariam, teria ainda, e forçosamente como resultado, a imediata elevação de nível geral de cultura de todos quantos se dedicassem às chamadas profissões liberais, o que não deixaria de ser imensa conquista, sobretudo nos países da América, onde o progresso material excessivamente fácil teve como consequência uma orientação demasiado pragmática e superficial da cultura. Além disso, não devemos desprezar os efeitos benéficos de desenvolvimento do espírito de solidariedade que os acompanharia quando lhes coubesse constituir, de alto a baixo da hierarquia social, os quadros dirigentes da nacionalidade».

1 Júlio de Mesquita Filho, Palestra, publicada em o Estado de São Paulo. 


\section{A FACULdAde de FILOSOFIA E A FORMAÇÃo DO MAGISTÉRIO}

Na estrutura universitária de 1931, como assinalamos, a Faculdade de Educação, Ciências e Letras deveria corresponder ao duplo objetivo de preparar trabalhadores intelectuais nos diversos domínios do conhecimento e de formar os professores de ensino secundário. Vimos que, de acordo com o pensamento do Ministro Francisco Campos, o «caráter especial e misto» deste tipo de escola resultava da necessidade de conferir-lhe, juntamente com as suas funções de cultura, «papel eminentemente utilitário e prático». Assim, o Decreto $\mathrm{n}^{\circ}$ 19.852, de 11 de abril de 1931, expressamente dispunha no seu art. 210: «O diploma de licenciado em educação conferirá ao candidato o direito de lecionar as ciências da educação nos estabelecimentos de ensino secundário». Parágrafo único: «Os diplomas de licenciados nas demais seções da Faculdade ' conferirão o direito de lecionar as respectivas disciplinas nos cursos secundários, quando obtiver o candidato os certificados que forem exigidos da Seção de Educação.

1 «Art. 199. Na Faculdade de Educação, Ciências e Letras serão organizadas progressivamente as seguintes seções:

a) seção de educação;

b) seção de letras;

c) seção de ciências.

I

«Art. 206. A frequência e habilitação nos cursos seriados da Faculdade de Educação, Ciências e Letras conferirá diplomas de acordo com os seguintes itens:

I - Seção de Educação:

a) licenciados em educação.

II - Seção de Ciências:

a) licenciados em ciências matemáticas;

6) licenciados em ciências físicas;

c) licenciados em ciências químicas;

d) licenciados em ciências naturais.

III - Seção de Letras:

a) licenciados em letras;

6) licenciados em filosofia;

c) licenciados em história e geografia;

d) licenciados em línguas vivas.

«Art. 305. No empenho de elevar, quanto possível, a capacidade didática dos atuais membros do magistério secundário da República, o Ministério da Educação e Saúde Pública, por intermédio do Departamento Nacional de Ensino, providenciará, 
A Faculdade de Filosofia, Ciências e Letras da Universidade de São Paulo, a primeira escola oficial deste tipo que se instalou no Brasil, obedeceu a planos que ainda hoje nos surpreendem. Convém lembrar, neste sentido, a solução dada ao problema na constituição do seu corpo docente. As áreas de estudo e de pesquisa a serem instaladas e desenvolvidas na nova escola eram praticamente inexploradas no Brasil. Impunha-se, portanto, evitar os descaminhos da improvisação cultural e ao perigo do autodidatismo. Entre formar nas Universidades europeias o pessoal docente indispensável ao funcionamento da escola e contratar professores destas mesmas Universidades, os fundadores da Faculdade de Filosofia optaram pela segunda solução, por ser de alcance prático mais imediato e mais multiplicador nos seus efeitos.

no caso de ginásios federais, e realizará acordo com os ginásios e outros estabelecimentos equiparados de ensino secundário, a fim de que, anualmente, parte do professorado respectivo possa realizar cursos de aperfeiçoamento na Faculdade de Educação, Ciências e Letras.»

3 Fernando de Azevedo, in A Cultura Brasileira, Edições Melhoramentos, São Paulo, fornece um quadro preciso da situação em que se encontrava, há alguns anos, o corpo docente da Faculdade de Filosofia, Ciências e Letras: «Os cursos na Faculdade de Filosofia, Ciências e Letras de São Paulo, fundada em 1934, foram inaugurados, nesse ano, por professores estrangeiros contratados na França, Itália e Alemanha. Eram ao todo 13 professores, dos quais 6 franceses, 4 italianos e 3 alemães. Em 1935, Etienne Borne, contratado para a Filosofia, foi substituído por Jean Maugúé, que rege essa cadeira até hoje; a P. Arbousse Bastide, professor de Sociologia, desde 1934, veio reunir-se em 1935, Claude Levi-Strauss, etnólogo francês, a quem sucedeu Roger Bastide, em 1938, e que é atualmente professor e um dos diretores da Escola Livre de Altos Estudos, em Nova York, nos Estados Unidos. O Prof. Ernst Marcus, de Zoologia, foi contratado em 1936, para substituir Ernst Breslau, que falecera em maio de 1935; Picrre Monbeig foi incumbido, em 1935, do curso de Geografia Física e Humana, em lugar de Pierre Deffontaines, que se retirara para Europa, depois de um ano de permanência em São Paulo, e a Robert Garric sucedeu em 1935 o Prof. Pierre Hourcade, substituído, três anos depois, por Alfred Bonzon, atual professor de Língua e Literatura Francesa. Entre os professores contratados, nos dois primeiros anos da Faculdade, encontrava-se grandes nomes como Luigi Fantappié, italiano, na Análise Matemática; Cleb Wathagin, russo de nascimento, naturalizado italiano, na Física; Heinrich Rheimboldt, alemão, na Química, Ernst Breslau, na Zoologia, Félix Rawitschcr, também alemão, na Botânica, e Robert Garric, francês, na Literatura, entre outros. Em 1935, foi contratado em Portugal, para a cadeira de Filologia Portuguesa, o Prof. Francisco Rebelo Gonçalves (1935-36), a quem sucedeu, em 1938, o Professor Fidelino Figueiredo. A História da Civilização Americana esteve, de 1936 a 1940, a cargo do Prof. Paul Vanorden Shaw, norte-americano. Em 1942, encontravam-se ainda, ministrando cursos na Faculdade de Filosofia de São Paulo, 22 professores estrangeiros, dos quais seis desde o primeiro ou segundo ano de sua fundação. Passaram por essa Faculdade, desde 1934, — sem contar os assistentes de laboratórios, 45 professores estrangeiros, provenientes de diversos países. Embora menor o movimento de professores e estudantes brasileiros que estiveram no estrangeiro para cursos de aperfeiçoamento e de especialização, foi constante o interesse pelas bolsas e viagens de estudos. De 1937 a 1942, obtiveram bolsa de estudos 11 licenciados, dos quais 3 por duas vezes. Fizeram cursos especiais na França dois estudantes, na Inglaterra um, na Itália um, e sete nos Estados Unidos, para onde se dirigiu a corrente de estudantes, depois que a Segunda Guerra Mundial tornou extremamente difícil a permanência, para estudos, em países europeus.»A Cultura Brasileira, pág. 755. 
Infelizmente, as resistências que se ergueram impediram que a Faculdade de Filosofia exercesse desde o seu inicio o papel científico e cultural que lhe fora destinado. «Neste regime em que os problemas suscitados pela sociedade - assinala Fernando de Azevedo - continuavam entregues aos práticos sem técnica e aos técnicos sem ciência», e em que dominava o interesse prático e utilitário do «profissionalismo», cultivado através de mais de um século de. escolas superiores, de tipo profissional, não se compreendia facilmente que o estudo e o emprego das ciências aplicadas dependiam do conhecimento e dos progressos das ciências puras».

A transformação política de 1937 alterou os rumos da Universidade paulista e de sua Faculdade de Filosofia. Em 1938, o Instituto de Educação foi fechado por decreto da Interventoria e os professores foram relotados no quadro docente da Faculdade de Filosofia. A nova ordem unitária e autoritária que se implantou no país transformou o regime de equiparação, tradicional no sistema educacional brasileiro e consagrado na legislação de 1931, no regime de padronização uniforme, de estilo napoleónico. O currículo da Faculdade de Filosofia e até os próprios exames vestibulares tiveram de obedecer às normas emanadas do Ministério da Educação. Perdeu-se assim, sob as pressões hostis do próprio ambiente universitário, reforçadas por uma legislação imposta de fora para dentro, heteronômicamente, a ideia de fazer-se da Faculdade de Filosofia, Ciências e Letras o núcleo fundamental, a alma mater da organização universitária nacional. Soam falsas, portanto, quando situadas em função de uma visão retrospectiva do desenvolvimento das Faculdades de Filosofia, as elevadas e esperançosas palavras do então Ministro Gustavo Capanema: «A Faculdade Nacional de Filosofia, constituindo dentro da Universidade do Brasil um grande centro de estudos, processados com disciplina e vigor, em todos os domínios da cultura intelectual pura, há de ser, pelos tempos afora, a grande força de animação, de enriquecimento e de orientação de nossos trabalhadores intelectuais. E desta forma, transcendendo os estreitos limites do ensino, entrará ela a influir, de modo mais amplo, no destino da cultura nacional».

E soam falsas, porque a finalidade eminentemente cultural e universitária da escola foi gradualmente relegada a um plano secundário e adjetivo, na mesma medida que avultava o seu caráter profissionalizante.

$\mathrm{Na}$ Exposição de Motivos que encaminhou o projeto que se transformou no Decreto-lei $\mathrm{n}^{\circ} 1.190$, o Ministro Capanema justificou a organização da Faculdade Nacional de Filosofia, «estabelecimento federal padrão do ensino destinado à preparação do magistério secundário», fundamentando-se nas três seguintes razões: «Em primeiro lugar, é o ensino secundário que recebe considerável benefício. Fala-se muito na decadência de nosso ensino secundário. Mas é um falar excessivo

4 Ob. cit.. $4^{\text {a }}$ ed., pág. 747. 
e injusto. Nunca foi de primeira ordem esta modalidade de ensino em nosso país. E hoje êle está melhor do que em qualquer outro tempo, melhor na sua organização, na sua disseminação, na sua realização. Ótimo não é, e não o será somente pelo efeito de reformas de lei e regulamentos, pela mudança dos programas, pela mais abundante e complexa montagem das instalações escolares. Tais coisas, certamente necessárias e valiosas, não resolverão jamais o penoso problema da educação secundária. Neste terreno, a renovação certa, útil e vital só poderá partir de uma base primeira, a saber, a preparação de vasto corpo de professores, cientes da disciplina do currículo e mestres no ofício de ensino». ${ }^{5}$ «Em segundo lugar, o decreto-lei, ora apresentado, vem concorrer para a melhoria do ensino primário. Sabemos, de fato, que as escolas normais, existentes em todo o país, não primam, no maior número dos casos, pela excelência do seu corpo docente. Há por certo professores doutos e operosos, mas em número escasso. E aí está a causa principal do incompleto preparo com que deixam os bancos escolares as normalistas a que é entregue a educação da infância em todo o país. Ora, só podemos elevar o nível do nosso ensino primário pela preparação cada vez mais apurada dos seus professores. E esta preparação não será perfeita enquanto não fôr de primeira ordem o corpo de professores das escolas normais. $\mathrm{O}$ decreto-lei, objeto destas considerações, visa a tal objetivo, fixando, a partir de 1943, a obrigatoriedade do diploma de licenciado para o exercício do magistério normal». «Em último lugar, diremos que a Faculdade Nacional de Filosofia, cujos fundamentos ora se fixam, virá contribuir, da maneira mais decisiva, para aumentar e aprofundar a cultura nacional, no terreno filosófico, científico e literário. Somos, neste particular, um país de autodidatas. Os nossos pesquisadores e escritores são, em geral, trabalhadores isolados, que formam a própria cultura com o mais angustioso esforço, desprovidos de assistência de mestres experimentados, da colaboração de colegas da mesma vocação e dos recursos técnicos imprescindíveis ao eficiente trabalho intelectual. Estamos, porém, longe de ser uma nação produtora de cultura. A nossa produção filosófica, científica e literária pode ser numerosa e brilhante, pode ser motivo de nossa ufania e vaidade, mas, como nos dizia há tempo o Prof. Georges Dumas, da Sorbonne, não corresponde aos dons prodigiosos com que a natureza dotou a nossa inteligência. A Faculdade Nacional de Filosofia, constituindo, dentro da Universidade do Brasil, grande centro de estudos, processados com disciplina e vigor, em todos os domínios da cultura intelectual pura, há de ser, pelos tempos afora, a grande força de animação, de enriquecimento e de orientação de nossos trabalhadores intelectuais. E, desta forma, transcendendo os estritos limites do ensino, entrará ela a influir, de modo mais amplo, no destino nacional». Não há, como se vê, nenhuma palavra sobre a função estruturalmente universitária que a Faculdade Nacional de Filosofia deveria exercer

\footnotetext{
Exposição de Motivos publicada no Diário Oficial de 25 de abril de 1939. As transcrições que se seguem são da mesma Mensagem.
} 
como órgão naturalmente destinado à integração dos cursos básicos e gerais das escolas profissionais. A sua finalidade cultural seria realizada «dentro da Universidade», mas sem nenhuma articulação funcional, no plano dos estudos com os demais institutos. Há mais ainda. No Decreto de 1931, os cursos de formação pedagógica são distintos dos cursos de formação cultural e científica. Esta separação tornou-se ainda mais acentuada no modelo universitário paulista de 1934: o curso pedagógico, de caráter profissional, era ministrado pelo Instituto de Educação.

$\mathrm{Na}$ organização consagrada pelo Decreto-lei $\mathrm{n}^{\circ} 1.190$, de 4 de abril de 1939, a formação do magistério passou a ser parte integrante das Faculdades de Filosofia: "Art. $1^{\circ}$ A Faculdade de Filosofia, Ciências e Letras, instituída pela Lei $\mathrm{n}^{\circ} 452$, de 5 de julho de 1937, passa a denominar-se Faculdade Nacional de Filosofia. Serão as seguintes as suas finalidades:

a) preparar trabalhadores intelectuais para o exercício das altas atividades culturais de ordem desinteressada ou técnica;

b) preparar candidatos ao magistério secundário ou normal;

c) realizar pesquisas nos vários domínios da cultura que constituem objeto do seu ensino». $\mathrm{O}$ Decreto foi ainda mais longe ao conferir regalias aos licenciados.

Art. $5^{\circ}, \S 1^{\circ}$, do Decreto $\mathrm{n}^{\circ}$ 6.283, de 25 de janeiro de 1934: «A licença para o magistério secundário será concedida pela Universidade somente ao candidato que, tendo se licenciado em qualquer uma das seções em que se especializou na. Faculdade de Filosofia, Ciências e Letras, haja concluído o curso de formação pedagógica no Instituto de Educação.»

1 Decreto $\mathrm{n}^{\circ}$ 1.190, de 4 de abril de 1939, Capitulo XIII. Das regalias conferidas aos diplomados.

Art. 51. A partir de 1 de janeiro de 1943 será exigido:

a) para o preenchimento de qualquer cargo ou função do magistério secundário ou normal, em estabelecimento administrado pelos poderes públicos ou por entidades particulares, o diploma de licenciado correspondente ao curso que ministre o ensino da disciplina a ser lecionada;

6) para preenchimento dos cargos ou funções de assistentes de qualquer cadeira, em estabelecimentos destinados ao ensino superior da Filosofia, das Ciências, das Letras ou da Pedagogia, o diploma de licenciado corresponde ao curso que ministre o ensino da disciplina a ser lecionada;

c) para o preenchimento dos cargos de técnicos de educação do Ministério da Educação, o diploma de bacharel em Pedagogia.

$\S 10^{\circ}$ A aplicação dos preceitos deste artigo se restringe aos diplomas expedidos por estabelecimento federal ou reconhecido.

$\S 2 .^{\circ} \quad$ As exigências constantes deste artigo deixarão de vigorar sempre que ficar demonstrada a inexistência de candidatos legalmente habilitados.

$\S 3 .^{\circ}$ O prazo fixado no presente artigo poderá ser restringido pelos poderes públicos para o efeito da admissão dos docentes dos estabelecimentos de ensino, que administrarem.

Até a data marcada neste artigo, os diplomas de licenciados serão considerados o principal título de preferência para o provimento dos cargos e funções do magistério, com que se relacionarem. 
A tendência profissionalizante dos cursos das Faculdades de Filosofia, acentuada a partir de 1939, transparece nos índices de matrículas registrados. O número de escolas cresceu extraordinariamente. Assinalam as estatísticas duas Escolas de Filosofia em 1929; 8 em agosto de 1968, elas somam 14. A maioria, entretanto, não se integra em Universidade.

No período compreendido entre 1933 e 1938, as matrículas nos cursos de bacharelado das Faculdades de Filosofia, Ciências e Letras passaram de 9 para 655 alunos. Em 1942, a matrícula geral nestes cursos alcançou 2.631 alunos. E assim, num índice de crescimento expressivo, nos anos de 1947, 1952, 1957, 1962, o número de matrículas registrado foi, respectivamente, o seguinte: $2.881,4.480,8.127,15.800$, 24.170. ${ }^{9}$ Entre 1962 e 1967, a matrícula geral nos cursos de bachare-

Art. 52. A lei federal, estadual ou municipal fixará quais os demais cargos ou funções públicas, cujo preenchimento exija a apresentação dos diplomas de que trata a presente lei.

Parágrafo único. Caberá à lei federal determinar a data a partir da qual será exigido o diploma de licenciado, obtido nos termos da presente lei, para o preenchimento dos lugares de professores catedráticos dos estabelecimentos destinados ao ensino superior da Filosofia, das Ciências, das Letras e da Pedagogia.

8 A sinopse retrospectiva do ensino no Brasil, 1871-1954, indica que havia no Brasil, em- 1929, duas unidades escolares de Filosofia, Ciências e Letras; de 14 de Direito; 58 de Medicina, Odontologia e Farmácia; 16 de Engenharia e 22 de Agronomia e Veterinária. Fonte: Sinopse Retrospectiva do Ensino no Brasil, 1871-1954, MEC, Serviço de Estatística da Educação e Cultura, Rio de Janeiro, 1954. As duas unidades registradas seriam provavelmente cursos livres de Filosofia e não cursos de Filosofia, Ciências e Letras. Nair Fortes Abu-Merhy, em relatório apresentado nos encontros regionais dos Educadores Brasileiros, caracterizou quatro fases da história das Faculdades de Filosofia no Brasil e indica a Faculdade de Filosofia, Ciências e Letras de São Bento e o Instituto Superior de Educação anexo, localizado em São Paulo, e fundados em 1908, como «precursores do modelo que ora possuímos». Nair Fortes Abu-Merhy, As Faculdades de Filosofia e a Formação do Magistério, Rio de Janeiro, 1960 (mimeografado), pág. 8.

Na Mensagem dirigida ao 'Congresso Nacional em 1927, o Presidente Washington Luís, analisando o esforço de 38 anos de vida republicana, afirma o seguinte: «Em 1888, havia 8.157 escolas, com uma matrícula de 258.800 alunos, e em 1926 se encontram 25.000 escolas, com a matricula de 1.455 .000 alunos. Além das escolas especializadas do Exército e da Marinha, havia apenas, em 1888, as Academias de Direito de São Paulo e do Recife, as Faculdades de Medicina do Rio e da Bahia, a Escola Politécnica do Rio e a de Minas em Ouro Preto. Hoje permanecem os mesmos institutos, porém com maior capacidade e melhor eficiência, e mais as Escolas de Direito de Manaus, do Pará, do Maranhão, do Ceará, da Bahia, de Niterói, do Distrito Federal, de Minas Gerais, do Paraná, de Porto Alegre; e mais as Escolas de Medicina de Porto Alegre, do Paraná, de Belo Horizonte, de São Paulo; mais as Escolas de Engenharia de Pernambuco, da Bahia, duas em São Paulo, Mackenzie e Escola Politécnica, de Belo Horizonte, do Paraná, de Porto Alegre, de Juiz de Fora; mais 13 escolas de Farmácia e Odontologia. Tínhamos seis, hoje temos 35». Apud Jorge Nagle, ob. cit., pág. 450.

9 Este número representa a soma de matriculas em cursos de bacharelado e licenciados. 
lado e licenciados passou de 24.170 para 51.289 alunos. ${ }^{10}$ Já em 1964. o «Curso de Filosofia, pela primeira vez no Brasil, passou a congregar a maior parcela da população universitária, isto é, 32.396 ou 22,8\%, cabendo o segundo lugar ao curso de Direito ou 21,8\%, que há muitos anos mantinha a posição de vanguardeiro dos cursos superiores relativamente ao número de universitários matriculados; em seguida o de Engenharia com 14,2\%, o de Economia com $10 \%$.

O quadro seguinte (pág. 106) evidencia a evolução das matrículas nos principais ramos de especialização, no período entre 1953 e $1967 .{ }^{12}$

10 Fonte: Sinopse Retrospectiva do Ensino no Brasil, 1871-1954, págs. 26 e 27.

11 Sinopse Estatística do Ensino Superior, MEC, Serviço de Estatística da Educação e Cultura, 1963-64.

12 Fontes: Sinopse Estatística do Ensino Superior, MEC. Serviço de Estatística da Educação e Cultura, 1963-64, CAPES, Boletim n. ${ }^{\circ}$ 183, fevereiro de 1968. 


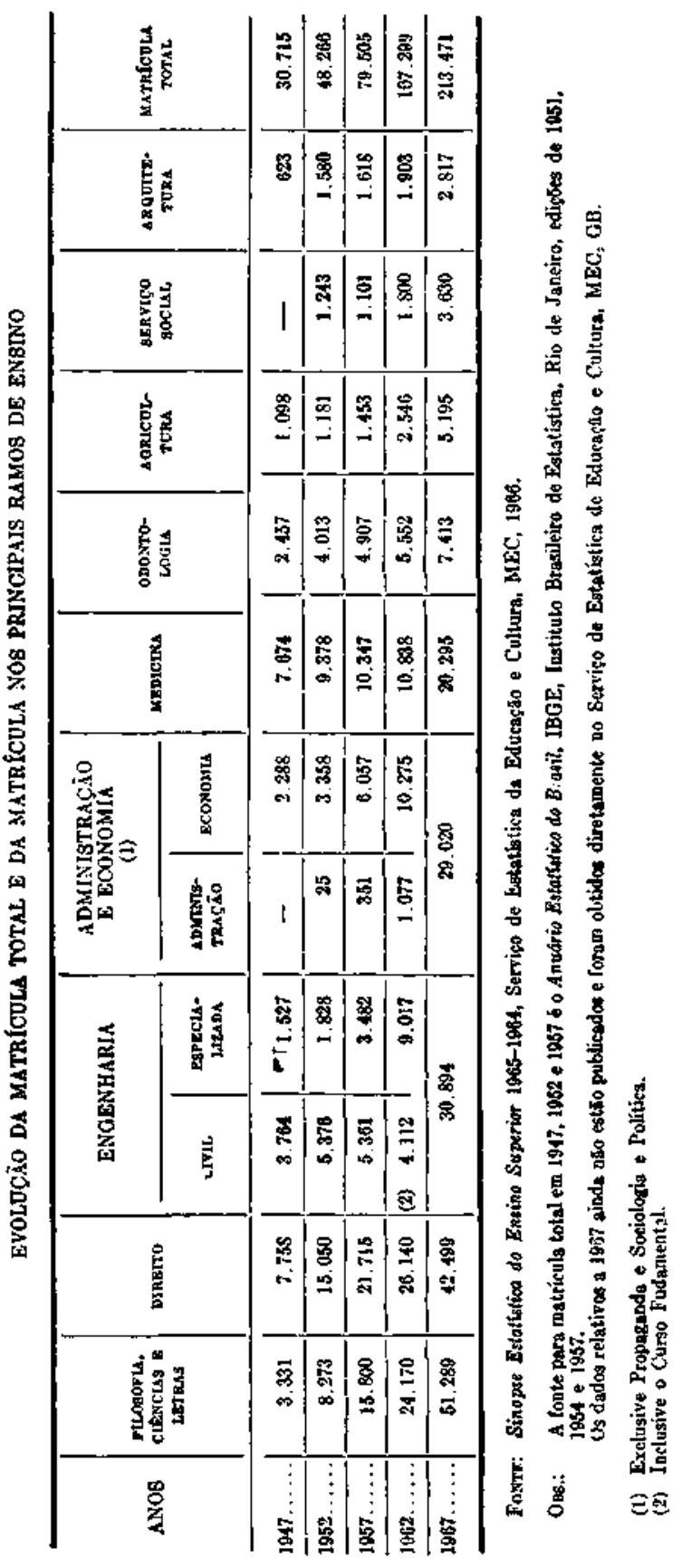




\section{A UNIVERSIDADE E A LEI DE DIRETRIZES E BASES}

Os elevados propósitos que inspiraram os Decretos ns. 19.851 e 19.852, ambos de 1931, não foram suficientes para organizar, em moldes universitários, o sistema de ensino superior brasileiro. Criaram-se Universidades sem nenhuma funcionalidade integradora. As escolas isoladas, cuja existência foi reconhecida como transitória, tornaram-se a regra comum da expansão do ensino de nível universitário. O estabelecimento de padrões, ao invés de dificultar, facilitou a multiplicação de escolas. Depois, sob a pressão dos interesses regionais, veio, como numa reação em cadeia, o processo intensamente progressivo de federalização de institutos isolados e de Universidades. Até o advento da Lei de Diretrizes e Bases, o sistema de ensino superior brasileiro permaneceu estruturalmente dentro das normas básicas da legislação de 1931. As modificações ocorridas na legislação posterior e até mesmo as inovações introduzidas pela Lei de Diretrizes e Bases de 1961 não alteraram a estrutura fundamental de nossas instituições escolares.

É preciso mencionar, porém, a tentativa de reformulação empreendida pela Comissão Supervisora do Plano dos Institutos (COSUPI), constituída, em caráter experimental, pela Portaria $\mathrm{n}^{\circ} 102$, de 28 de janeiro de 1958, e consolidada pelo Decreto $\mathrm{n}^{\circ} 49.355$, de 28 de novembro de 1960. A COSUPI preconizava a transformação da Universidade, tendo em vista as necessidades da era tecnológica. «A Universidade da era tecnológica... não pode ser uma reunião de escolas profissionais; precisa ser constituída de organismos de dois tipos: a) Institutos, em cada um dos quais será feito o estudo, o ensino e a pesquisa em dado ramo dos conhecimentos humanos; $b$ ) Escolas ou Faculdades, em cada uma das quais serão ministrados os conhecimentos e as práticas necessárias ao exercício de determinada profissão e ao processo das técnicas ligadas a essa atividade».

O programa de reestruturação das Universidades sugerido pela COSUPI visava à instauração de um novo conceito de Universidade. de feitio científico e tecnológico, nos moldes das diretrizes seguidas, a partir de 1945, no Centro Técnico de Aeronáutica e no Instituto Técnico de Aeronáutica de São José dos Campos. Convém assinalar que a vinculação da pesquisa aos Institutos, proposta no programa da

Ernesto Luis de Oliveira Júrvor, Objetivos da Comissão Supervisora <!o Plano dos Institutos (COSUPI), Associação da Revista Cientifica, Rio de Janeiro, 1961. 
COSUPI, foi posteriormente consagrada no $\S 2^{\circ}$ do art. 79 da Lei de Diretrizes e Bases, o que implica a ideia de uma esdrúxula separação entre ensino e atividades de pesquisas. ${ }^{2}$ A reformulação do conceito de docência e de cadeira de magistério, assim como o estabelecimento de novo conceito de educação universitária constituíram os objetivos fundamentais propostos pela COSUPI. Assinale-se, entretanto, que no conjunto das propostas para a reformulação da estrutura universitária não se encontra nenhuma sugestão sobre departamento, o que é, a nosso ver, a pedra angular, a célula básica, de uma estrutura universitária mais flexível e mais ajustada às exigências do trabalho de ensino e de pesquisa e a que melhor corresponde às necessidades do aperfeiçoamento do pessoal docente dentro dos quadros escalonados da carreira do magistério.

Os recursos financeiros distribuídos pela COSUPI retratam a importância do esforço governamental e dos propósitos oficiais no sentido de alterar a fisionomia da estrutura universitária nacional: em 1958 foram aplicados 230 milhões de cruzeiros; em 1959, 590 milhões; em 1960, 915 milhões; em 1961, 915 milhões e em 1962, 1.180 milhões.

No ano em que foi aprovada a Lei de Diretrizes e Bases (1961), a situação universitária brasileira revelou três tendências características de integração, finamente assinaladas por Valnir Chagas num trabalho publicado no número do mês de julho de 1961 da revista Educação $e$ Ciências Sociais. A primeira era representada pelas necessidades decorrentes do planejamento das cidades universitárias: a unificação de serviços idênticos que se encontrassem dispersos nas escolas existentes. A reunião das cadeiras de Química, distribuídas pelas diversas escolas e faculdades componentes da Universidade, é exemplo das possíveis vantagens de uma concentração no espaço, que elimina a duplicação desnecessária de laboratórios, equipamentos e bibliotecas. A segunda tendência foi a que se concretizou na Universidade de Brasília, com os Institutos Centrais (observe-se a coincidência com a nomenclatura proposta pela COSUPI), destinados a servir de suporte aos estudos básicos à complementação não profissionalizante e aos cursos de pós-graduação; e com as faculdades, que seriam as escolas ou cursos de formação profissional. A terceira tendência seria representada pelo retorno à ideia original das Faculdades de Filosofia «como base e cúpula da Universidade». A Faculdade de Filosofia, Ciências e Letras da atual Universidade Federal do Ceará ilustra esta última tendência. Basta ver que seu Regimento alinha como primeiro objetivo:

«funcionar como escola básica de toda a Universidade, juntamente com os Institutos de Ciências, destinados a

2 Valnir Chagas, «A Reforma Universitária e a Faculdade de Filosofia», in Educação e Ciências Sociais, ano V, vol. 9, n. ${ }^{\circ}$ 17, maio-agôsto, 1961, Rio de Janeiro, pág. 161. 
ministrar o ensino fundamental dos cursos de formação da própria Faculdade e das demais unidades de educação profissional de Universidade». ${ }^{3}$

A Lei de Diretrizes e Bases, sancionada em dezembro de 1961, poderia ter contribuído para a reformulação do ensino universitário brasileiro, se os dispositivos que nela figuram referentes ao ensino superior fossem inspirados por uma ideia mais adequada dos objetivos e da estrutura de uma autêntica Universidade. A verdade, porém, como já assinalou Valnir Chagas, é que, enquanto as modificações introduzidas no âmbito do ensino primário e médio traduziram positivas conquistas que o debate e a experiência aconselhavam, na esfera do ensino superior não se encontra nenhum dispositivo de efeito comparável. Limitou-se a consagrar «tudo o que se pretendia fosse modificado». Faltou alma e anseio renovador. A Universidade, concebida como mera reunião de escolas (art. 79), a dispensa dos requisitos estabelecidos no caput do artigo mencionado, com a finalidade de propiciar a «criação de Universidades rurais e outras de objetivo especializado» ( $\S 1^{\circ}$ do art. 79), a fragmentação da unidade funcional do ensino-pesquisa, a caracterização dos Institutos como órgãos de pesquisa e a oficialização de um tipo de colégio universitário nos moldes dos atuais «cursinhos» orientados para os exames vestibulares, tudo isto representou imenso retrocesso na formulação adequada dos problemas mais urgentes da Universidade brasileira.

A Lei de Diretrizes e Bases, no seu Título IX, Cap. I, depois de definir o objetivo do ensino superior (art. 66), dispõe que o «ensino superior será ministrado em estabelecimentos agrupados ou não em Universidades, com a cooperação de institutos de pesquisa e centros de treinamento profissional» (art. 67) . Fixou-se assim, como regra, como norma geral, o que até então vinha sendo, de acordo com o Decreto $\mathrm{n}^{9}$ 19.851, de abril de 1931, a exceção legalmente consentida: «o ensino superior no Brasil obedecerá, de preferência, ao sistema universitário, podendo ainda ser ministrado em institutos isolados. ..»

3 Apud Valnir Chagas, ob. cit., págs. 75-76. A propósito do papel das Faculdades de Filosofia, afirma neste ensaio Valnir Chagas: «Quando, portanto, se vai transformar em cediço lugar-comum a afirmação de que as Faculdades de Filosofia. Ciências e Letras falharam em seus mais caros propósitos, necessário se torna que deixemos bem claro os exatos limites dessa critica, referindo-a não ao plano original de sua concepção, que este afinal jamais foi executado, porém às evidentes distorçõts que se lhe impuseram pela força da rotina e ao sabor dos interesses em choque. $\mathrm{O}$ que falhou não foi o ideal, que com elas se identifica, de criar um núcleo central do complexo universitário e dotar o país de cientistas e professores à altura das suas crescentes necessidades. O que falhou foram as escolas e Universidades em si mesmas que não encarnaram esse ideal, a ponto de conferir-lhe expressão real nos dados imediatos dos seus esquemas didáticos».

4 Valnir Chagas, A Luta pela Universidade do Brasil, MEC/UFRGS, 1967, pág. 15 . 
Mas não é só isto. O projeto da lei que veio a ser aprovado pelo Congresso procurou retomar a ideia, contida no Decreto $\mathbf{n}^{\mathbf{0}} \mathbf{1 9 . 8 5 1}$, de apresentar a Faculdade de Filosofia, Ciências e Letras como condição indispensável para a constituição de uma Universidade. "As Universidades», dispunha o art. 79 do projeto aprovado pela Câmara e pelo Senado, «constituem-se pela reunião, sob administração comum, de cinco ou mais estabelecimentos de ensino superior, um dos quais deve ser uma Faculdade de Filosofia, Ciências e Letras». A parte final do artigo foi vetada, mas foi mantida a exigência de um mínimo de cinco estabelecimentos de ensino superior reunidos sob administração comum. As razões do veto se apoiaram em dois pontos fundamentais: $l^{\circ}$, a exigência de uma Faculdade de Filosofia é desnecessária, pois já havia, na rede nacional de ensino superior, número elevado de tais escolas, que, «salvo raras exceções», vinham exercendo «exclusivamente a função de formar professores de grau médio»; $2^{\circ}$, a função integradora desempenhada também poderia ser exercida «por outros órgãos, tais como os Institutos Centrais, que já vêm sendo estruturados em algumas Universidades». Assim, por força de um veto, o art. 79 abriu caminho para a criação dos Institutos Centrais, nos moldes estabelecidos pela Lei $\mathrm{n}^{\circ} 3.398$, de 15 de dezembro de 1961, que autorizou o Poder Executivo a instituir a Fundação da Universidade de Brasília. A Lei de Diretrizes e Bases não facilitou apenas a substituição do modelo universitário baseado nas Faculdades de Filosofia, Ciências e Letras por outro modelo, o dos Institutos Centrais, da Universidade de Brasília, herança indisfarçável dos planos da COSUPI; ${ }^{6}$ em verdade, ela comprometeu totalmente a possibilidade de uma estruturação adequada das Universidades, ao permitir a dispensa dos requisitos estabelecidos no seu art. 79 para a «criação de Universidades rurais e outras de objetivos especializados» $\left(\S 1^{\circ}\right.$ do art. 79$)$.

Mas é preciso reconhecer que, sob outros aspectos, a Lei de Diretrizes e Bases representou inegável progresso em relação à legislação

5 A razão do veto é a seguinte:

«A rede nacional do ensino superior conta já com mais de 70 Faculdades de Filosofia, que vêm exercendo, salvo raras exceções, exclusivamente, a função de formar professores de grau médio. Nessas circunstâncias, a exigência de que toda Universidade mantenha uma dessas Faculdades torna-se desnecessária.

Acresce que as funções de órgão integrado que se deseja atribuir a tais Faculdades também podem ser exercidas por outros órgãos, tais como os Institutos Centrais, que já vêm sendo estruturados em algumas Universidades Federais.»

f Trecho da Mensagem do Ministro Clóvis Salgado que encaminhou o anteprojeto de criação da Fundação da Universidade de Brasília: «Desse modo, o conjunto dos Institutos Centrais, formando uma espécie de Faculdade de Ciências, Letras e Artes, será um estágio intermediário distribuindo os estudantes para as profissões tradicionais e para as atividades novas da ciência e da tecnologia, de que o país tanto carece na fase histórica que atravessa». Comissão Supervisora do Plano dos Institutos, Gráfica da Universidade do Rio Grande do Sul. Exposição apresentada à reunião de Diretórios Acadêmicos realizada em Itajubá no dia 10-10-60, pelo Presidente da COSUPI, Prof. Ernesto Luís de Oliveira Júnior. 
anterior. A ampla definição do conceito de autonomia das Universidades (autonomia didática, administrativa, financeira e disciplinar) (artigo 80) e a forma de constituição de sua personalidade jurídica (regime autárquico ou de Fundação - para as Universidades oficiais; associações ou Fundações para as particulares) constituem exemplos eloquentes dos propósitos de conceder às Universidades um status jurídico compatível com a peculiar natureza de suas atividades de ensino e pesquisa.

Apesar dos numerosos e insistentes empenhos ocorrentes nos anos que se seguiram à aprovação da Lei de Diretrizes e Bases, nenhuma alteração mais relevante foi introduzida nas linhas básicas da organização universitária brasileira. Os Estatutos das Universidades, aprovados pelo Conselho Federal de Educação, de acordo com o art. 112, limitaram-se a reproduzir, com adjetivas modificações, o modelo instituído em 1931. Nem sequer os currículos, que tiveram de ajustar-se ao novo padrão mínimo estabelecido, sofreram alteração substancial. Basta lembrar que os novos currículos nenhuma novidade trouxeram ao tradicional sistema de cátedras.

Com o Decreto-lei n" 53, de 18 de novembro de 1966, que fixou princípios e normas de organização das Universidades Federais, inicia-se novo processo de reformulação do ensino superior brasileiro. A ideia de integração é a diretriz fundamental das normas nele instituídas: «As Universidades Federais organizar-se-ão com estrutura e métodos de funcionamento que preservem a unidade das suas [unções de ensino $\mathrm{e}$ pesquisa e assegurem a plena utilização dos seus recursos materiais e humanos, vedada a duplicação de meios para fins idênticos ou equivalentes» (art. $\left.1^{\circ}\right)$.

Aplicando este princípio, as unidades universitárias (Faculdade, Escola, Instituto) passaram a ser definidas como órgãos de íntima associação entre pesquisa e ensino (art. 2», item I) . Distingue o decreto pesquisa e ensino básicos e pesquisa e ensino aplicados, e estabelece, para os primeiros, a concentração «em unidades que formarão um sistema comum para toda a Universidade» (art. $2^{\circ}$, item I) . «O ensino de formação profissional e a pesquisa aplicada serão feitos em unidades próprias, sendo uma para cada área ou conjunto de áreas profissionais afins dentre as que se incluam no plano da Universidade» (art. $2^{\circ}$. item III). Transparece claramente nestas normas a preocupação de assegurar melhor a integração do trabalho universitário. Neste sentido. dispõe ainda o decreto que «o ensino e a pesquisa desenvolver-se-ão mediante a cooperação das unidades responsáveis pelos estudos envolvidos em cada curso ou projeto de pesquisa» e que as atividades inter-escolares serão supervisionadas por órgãos centrais constituídos de modo a que neles estejam representados os vários setores de estudos básicos e aplicados. Estes órgão terão atribuições deliberativas (art. $2^{\circ}$, parágrafo único) .

Os termos do Decreto-lei ${ }^{0} 53$ não foram suficientemente precisos para criar esquemas operacionais capazes de propiciar a reforma da Universidade nas linhas de sua completa integração. Por isso, suprindo la- 
nele existentes, um novo decreto estabeleceu normas que dispõesôbre a constituição de departamentos, sobre os critérios para a organização do sistema de unidades (previsto no art. $2^{\circ}$, item II, do Decreto $\mathrm{n}$ ? 59) e sobre os órgãos centrais a que se refere o art. $2^{\circ}$, item $\mathrm{V}$, do mesmo decreto.

O Decreto-lei $n^{\circ} 252$, de 28 de fevereiro de 1967, no seu art. $2^{\circ}$ define o departamento como uma subunidade e como «fração da estrutura. universitária para todos os efeitos de organização administrativa e didático-científica e de distribuição de pessoal» $\left(\S 1^{\circ}\right.$ do art. $\left.2^{\circ}\right)$. O departamento, formado pela reunião das disciplinas afins, «congregará professores e pesquisadores para objetivos comuns de ensino e pesquisa» $\left(\S 2^{\circ}-\right.$ do art. $\left.2^{\circ}\right)$. Compete-lhe a elaboração dos planos de trabalho e a atribuição de «encargos de ensino e pesquisa aos professores e pesquisadores, segundo as especializações» $\left(\S 3^{\circ}\right.$ do art. $\left.2^{\circ}\right)$.

$\mathrm{O}$ art. $3^{\circ}$ define o sistema de unidades referido no item II do art. 2» do Decreto-lei $\mathrm{n}^{\circ} 53$, relacionando-o às «áreas fundamentais dos conhecimentos humanos, estudados em si mesmos ou em vista de ulteriores aplicações». Mais explicitamente, o parágrafo único do mesmo artigo indicou as seguintes áreas: Ciências Matemáticas, Físicas, Químicas e Biológicas, Geociências, Ciências Humanas, Filosofia, Letras e Artes. $\mathrm{O}$ processo de reforma das Universidades brasileiras encontra-se atualmente em pleno andamento. O Decreto-lei $\mathrm{n}^{\circ} 252$, dá às Universidades um prazo de 180 dias para apresentarem seus planos de reestruturação ao Ministério da Educação e Cultura, que, ouvido o Conselho Federal de Educação, elaborará o projeto do respectivo decreto. Noventa dias após a publicação do decreto, deverá a Universidade encaminhar ao Conselho Federal de Educação o projeto de Estatuto, reformado, de acordo com as disposições do Decreto-lei $\mathrm{n}^{\mathbf{1 0}} 53$. Os regimentos das unidades serão encaminhados ao Conselho Federal de Educação noventa dias após a aprovação do Estatuto da Universidade. 


\section{A EXPANSÃO DO ENSINO SUPERIOR}

A análise da obra realizada pelas instituições de ensino superior no Brasil revela uma problemática extremamente complexa, que, para fins metodológicos, poderia ser reduzida a dois tópicos:

I - aumento da capacidade da rede escolar superior;

II - adaptação desta rede para o eficiente cumprimento das tarefas «exigidas pelo desenvolvimento cultural, moral e econômico da Nação.

\section{I - O INCREMENTO DA CAPACIDADE DA REDE DE ENSINO SUPERIOR}

Com relação a este tópico, cumpriria, em primeiro lugar, ressaltar a situação particularmente grave criada pela explosão demográfica que nestes últimos anos vem ocorrendo no Brasil.

Para os países de população estável, a questão que atualmente se põe é o alargamento da rede escolar para atender ao número crescente daqueles que aspiram acesso às instituições superiores de ensino. Para nós, contudo, não se trata apenas de atender a estas aspirações, mas o problema se agrava e tende a se agravar mais no futuro com o número cada vez maior dos componentes das gerações que batem às portas de nossas escolas e Universidades.

1. Cumpre, pois, que o Governo adote uma política educacional solidamente fundada no conhecimento de nossa realidade, com vistas a estabelecer um planejamento racional que nos leve a aplicar mais recursos, de maneira mais eficiente, para prevenir o futuro.

A fixação desta política pelo Governo exigiria a arregimentação de todas as forças, federais, estaduais e municipais, reclamando um urgente e eficaz entendimento entre o Conselho Federal de Educação e os Conselhos Estaduais de Educação, no sentido de assentarem as grandes linhas de ação, a serem seguidas. A falta desta política tem originado a criação desordenada de instituições de ensino superior no país, sem atender aos setores prioritários, gerando inconvenientes para as instituições já existentes, sem que o esforço e o sacrifício da criação de novas entidades tenha servido, como deveria, à educação nacional, concebida como um todo.

O estabelecimento de um planejamento rigoroso neste setor é imperativo. Nota-se que as populações de cidades que atingem certa importância têm a preocupação de criar entidades de ensino superior, quer 
como instrumento de afirmação de um novo status, quer como forma de exigir restituição dos impostos pagos pelos cidadãos.

$\mathrm{O}$ atendimento das justas aspirações destas populações poderia ser realizado, com muito maior vantagem e com menos ónus, com a criação de «Centros de Educação e Cultura», sob a forma de Fundações, também elas objeto das subvenções reclamadas, mas com finalidade outra que não a criação indiscriminada de escolas de nível superior, cujos inconvenientes já foram apontados. Tais Centros poderiam manter um sistema de bolsas para os candidatos ao ensino superior, encaminhando-os para escolas e Universidades existentes na região, e, por outro lado, poderiam beneficiar uma parte muito maior da população, através da organização' de seminários, cursos de extensão e conferências, mediante convênio com as instituições de ensino superior mais próximas.

2. Outro ponto de grande importância, no que concerne ao acesso ao ensino superior, decorre de uma distinção que não tem sido suficientemente usada. Uma coisa é o benefício que pode um cidadão auferir de seu contato com as instituições de ensino superior, e outra, muito diferente, é a sua inscrição regular como aluno de um curso de formação profissional.

Pode ser que nosso País por muito tempo ainda não esteja em condições de oferecer a todos os candidatos a oportunidade de ingressar nas Universidades para obter um diploma de habilitação profissional. Contudo, com um esforço bem programado, nossas instituições de ensino superior poderiam atingir desde logo um número muito maior de pessoas, se fossem abertas a um campo extremamente importante de sua possível atividade que é o da extensão universitária. Realmente não se esgota com a formação profissional da juventude, tarefa a que se vem consagrando tradicionalmente a potencialidade de nossas instituições de ensinosuperior. Têm elas o dever de abrir suas portas e propiciar os benefícios de seu trabalho a um número muito maior de pessoas, não só no que concerne à preparação de profissionais, como também no que diz respeito à difusão da cultura e dos conhecimentos acumulados pelos seus professores.

No campo da formação profissional, as Universidades e escolas isoladas de ensino superior têm a possibilidade de organizar cursos de especialização, de adaptação e de atualização, acolhendo em seu seio não só profissionais já formados, mas também pessoas sem nível universitário que estejam em condições de se aproveitarem da iniciativa, que lhes dará nova habilitação no exercício de atividades necessárias ou úteis ao desenvolvimento do País. Durante anos nossas escolas superiores só formaram certos tipos clássicos de profissionais. Surgiram, contudo, muitas profissões e ocupações novas, e mesmo as profissões tradicionais apresentam exigências de especialização e atualização constante. Este é, pois, um campo de atuação de nossas entidades de ensino superior, que lhes permitiria, com pouco esforço mais, alargar desde logo o número de beneficiários de suas atividades. 
Ainda neste setor, nossas entidades de ensino superior poderiam e deveriam com facilidade dar maior atendimento às aspirações culturais das nossas populações, através do oferecimento de seminários e cursos rápidos sobre problemas atuais do País, ou sobre matérias de formação artística, social, cientifica e moral.

3. Outra medida que poderia contribuir para o aumento da capacidade de nossa rede de ensino superior seria a da adoção de um sistema que permitisse maior integração dos organismos já existentes, sobretudo das escolas isoladas, com as Universidades da mesma região.

As Universidades oficiais, em virtude de disposições legais, e as Universidades particulares, por livre opção, estão adotando uma estrutura nova que trará como consequência certa uma organização do ensino fundada na distinção entre ciclo básico de estudos e ciclo de formação profissional.

Dentro desta nova sistemática, nossas escolas isoladas de ensino deveriam também ser levadas a adotar o mesmo regime, de forma que pudessem admitir no ciclo básico um número muito maior de alunos que, depois, iriam terminar sua formação profissional nas Universidades ou em outras escolas diferentes, onde houvesse possibilidade de seguirem os estudos de sua escolha. A adoção desta política implicaria o estabelecimento de um sistema semelhante ao que vigora nos Estados Unidos, nas relações entre os colleges e as Universidades.

4. Outro ponto, que merece estudo muito mais aprofundado é o estabelecimento de uma política clara por parte do Governo, é o que diz respeito aos exames vestibulares. Importaria aqui fixar uma diretriz única para toda a Nação, respeitada, é claro, a autonomia das Universidades. Isto porque deixaria de ter todo o efeito desejável a adoção de qualquer medida renovadora partida só de uma instituição, cujo esforço isolado perderia muito do seu sentido.

Neste setor, importaria em primeiro lugar fazer que fossem preenchidas todas as vagas oferecidas pelas escolas e Universidades. Nestes últimos anos tem sido grande o número de vagas não aproveitadas, isso em virtude de vários defeitos que deveriam ser sanados.

O primeiro deles é a distribuição desigual dos candidatos nas diversas regiões do País. Deveria ser prevista a possibilidade de aproveitamento, em outras instituições onde houvesse vagas, dos candidatos aprovados em escolas assoberbadas com excesso de candidato. $\mathrm{O}$ mesmo se diga da distribuição desigual de candidatos dentro das escolas de uma mesma Universidade. Aí também devia ser adotado igual sistema de aproveitamento.

Ainda um assunto que mereceria exame aprofundado é o da pouca procura para certas carreiras, que são, contudo, de extrema importância para a Nação: Enfermagem, Serviço Social, Educação Familiar, Agronomia, Veterinária. Seria necessário criar um sistema de bolsas que estimulasse o interesse por essas carreiras. A adoção de um sistema de exame por áreas poderia levar à solução parcial do problema. 
Cremos que não seria lesiva aos direitos dos jovens a adoção de uma medida limitadora do número de vezes que um candidato pudesse apresentar-se a exames vestibulares, dando-se-lhe finalmente oportunidade de entrar para uma carreira similar quando não pudesse obter classificação para a carreira por êle desejada.

5. No que concerne à admissão dos candidatos ao ensino superior, importa não somente que todas as vagas sejam preenchidas, mas que as mesmas oportunidades educacionais sejam oferecidas a todos os brasileiros, independentemente da posse de recursos. Por isso, é necessária a criação de um sistema de bolsas que possibilite a qualquer candidato a entrada na escola de sua preferência, desde que tenha a exigida habilitação académica. Deveria ser implantado um sistema que atendesse pelo menos a dois tipos de carência. Referimo-nos primeiro aos muitos candidatos que não só não estão em condições de pagar qualquer taxa pelos estudos que pretendem fazer, como também não têm sequer recursos para sua manutenção durante os estudos, já que não podem arcar com despesas de alimentação, vestuário, transporte e compra de livros e material escolar. E, em segundo lugar, aos que não estão em condições de entrar para uma escola paga, como é o caso das instituições particulares. Importa muito criar um sistema que permitisse dar a estes candidatos condições para estudar com tranquilidade e eficiência.

Parece-nos sumamente recomendável a criação de um Fundo Nacional de Educação, que tivesse, entre outros fins, a concessão de bolsas a alunos carentes de recursos. Tais bolsas não deveriam ser concedidas gratuitamente, não estando o País em condições de enfrentar as grandes despesas daí advindas. Pondo-se em prática o princípio previsto no art. 183 da Constituição, essas bolsas deveriam ser objeto de reembolso futuro, após a obtenção do diploma, previsto um prazo de carência, para que o beneficiário pudesse consolidar sua situação profissional antes de começar a restituir ao Governo, em favor de outros candidatos, as vantagens de que gozou no passado.

Parecendo-nos de todo recomendável este sistema, decorre de sua admissibilidade outra medida que atende à carência de recursos nacionais para a Educação, qual seja a implantação do mesmo sistema de reembolso para os alunos das escolas oficiais, devendo as mesmas cobrar taxas que se aproximassem do custo real para cada aluno.

6. Muitos benefícios se podem esperar, para ampliação da capacidade de nossa rede de ensino superior, do estabelecimento futuro, em nossas Universidades, da distinção entre ciclo básico e ciclo de formação profissional.

$\mathrm{Na}$ realidade, parte considerável de nossos estudantes, sobretudo do sexo feminino, entra para a Universidade sem ideia clara quanto à futura profissão. Por outro lado, o exame vestibular não é um processo que permita a aferição da real capacidade dos candidatos para os estudos que pretendem fazer. 
As Universidades e escolas poderão admitir no ciclo básico um número de alunos maior do que o de vagas para o ciclo de formação profissional de modo que se processe, durante o ciclo inicial, uma nova seleção e o encaminhamento de candidatos para os cursos que mais lhes convierem.

O Conselho Federal de Educação elaborou, a este respeito, um parecer em que são aventadas estas hipóteses, bem como a da integração da rede escolar, a que nos referimos anteriormente $\left(n^{\circ} 3\right)$.

\section{II__ DA ADAPTAÇÃO CONDUCENTE A MAIOR EFICIÊNCIA DE NOSSA REDE DE ENSINO SUPERIOR}

Impõe-se uma observação inicial sobre o nosso sistema de ensino superior. Pelas condições históricas de seu desenvolvimento, nosso ensino superior está totalmente condicionado à ideia da formação profissional. Antes da seriação das Universidades, existiam no Brasil escolas de formação profissional. Quase todas as Universidades surgiram da reunião de escolas preexistentes, e as outras que se formaram pautaram por este modelo.

$\mathrm{O}$ ensino ministrado nessas escolas e Universidades obedeceu sempre ao sistema seriado, em que os alunos, desde o início, são submetidos a currículos de formação profissional idênticos para todos os da mesma série.

1. A estrutura de nossas Universidades, formadas de escolas profissionais superiores, não tem favorecido a realização de tarefas essenciais à Universidade, como a pesquisa e o serviço à comunidade. Por outro lado, duplicam-se esforços dentro da mesma Universidade, com multiplicação de organismos relativos a um mesmo setor do conhecimento, o que tem muitas vezes impedido o trabalho em campos sumamente úteis para a cultura e o desenvolvimento do país.

A reforma que se está operando nas Universidades brasileiras visa corrigir exatamente tais defeitos, e urge que, na implantação desta reforma, sejam tomadas medidas corajosas que, lutando contra interesses arraigados, se consiga realmente implantar uma estrutura nova, isenta das falhas por todos reconhecidas.

2. Quanto ao ensino a ser ministrado, a adoção de um sistema novo não será decorrência lógica da nova estrutura adotada. Cumpre, pois, uma análise corajosa da situação atual e a adoção de novos métodos que permitam a reformulação do sistema até agora vigente.

O abandono do sistema seriado de ensino e a adoção de outro correspondente ao chamado «sistema de créditos» está previsto, em germe, na Portaria Ministerial $\mathrm{n}^{\mathrm{o}}$ 159, de 14 de junho de 1958, baseada num $\mathrm{Pa}$ recer do Conselho Federal de Educação.

1 CAPES - Cursos, Currículos Mínimos, Duração e Estabelecimentos do Ensino Superior, julho de 1965, pág. 109, Documenta 38, de junho de 1965, C.F.E. 
É sumamente importante para o futuro do ensino no Brasil que as linhas contidas nestes documentos sejam adotadas e exploradas a fundo em nossas instituições de ensino superior.

3. A adoção do sistema semestral nos currículos, com a introdução de um período extraordinário durante as férias do fim do ano, seria também excelente medida, altamente conducente a maior eficácia de nosso sistema de ensino e abertura de maiores possibilidades aos nossos estudantes. Permitiria também este sistema facilidade maior na troca de professores entre as Universidades e estabelecimentos de ensino superior, podendo uma instituição, com maior facilidade, abrir mão de um professor seu durante período mais curto do que o de um ano. 


\section{O VESTIBULAR}

Em qualquer plano de reforma de ensino superior, o problema da admissão dos candidatos a esse nível de aprendizado deve merecer particular atenção. No Brasil, o chamado exame vestibular, que é a forma adotada para a seleção dos candidatos, assume importância capital, e poderíamos dizer que uma solução acertada desse problema já representaria enorme progresso.

O que determina a necessidade de algum exame de habilitação para o ingresso de estudantes na Universidade é, de um lado, a existência de número de vagas inferior ao número crescente de candidatos, e de outro lado, o fato de que nem todos quantos desejam cursar a Universidade estão realmente capacitados.

Quanto ao despreparo de muitos candidatos, despreparo real e muitas vezes de sabor até anedótico, o fato poderia levar os menos bem informados a uma reflexão que tentaremos resumir em poucas palavras. Todos quantos terminam o curso colegial, afirmam alguns, devem ser capazes, por definição, de ingressar na Universidade. Se não são capazes de ingressar na Universidade, não deveriam ter recebido o diploma de conclusão do curso médio. Haveria um único motivo lícito para o exame de habilitação, com suas rejeições inevitáveis: deficiência de vagas. Assim poderia ser, mais assim não é, nem na prática, nem sequer em teoria. Deixando de lado os estudantes relapsos, que receberam indevidamente o diploma de conclusão do curso médio, diremos que nem todos quantos o receberam legitimamente estão capacitados para cursar o ensino superior, altamente seletivo, por natureza. Assim o entendeu a Lei de Diretrizes e Bases que, em seu art. 69, não considera suficiente, para fins de graduação universitária, a simples conclusão do curso médio. Diz a lei:

«Art. 69. Nos estabelecimentos de ensino superior podem ser ministrados os seguintes cursos:

a) de graduação, abertos à matrícula de candidatos que hajam concluído o ciclo colegial ou equivalente, e obtido classificação em concurso de habilitação;

b) de pós-graduação, abertos à matrícula de candidatos que hajam concluído o curso de graduação e obtido classificação em concurso de habilitação;

c) de especialização, aperfeiçoamento e extensão, ou quaisquer outros, a juízo do respectivo instituto de ensino, 
abertos a candidatos com preparo e os requisitos que vierem a ser exigidos.»

Até para aqueles que cursaram um colégio universitário se exige con-

D de habilitação antes do ingresso na Universidade, conforme diz a mesma lei, no $\S 3^{\circ}$ do art. 79 .

«A Universidade pode instituir colégios universitários destinados a ministrar o ensino da terceira série do ciclo colegial. Do mesmo modo, pode instituir colégios técnicos universitários, quando nela exista curso superior em que sejam desenvolvidos os mesmos estudos. Nos concursos de habilitação não se fará qualquer distinção entre candidatos que tenham cursado esses colégios e os que provenham de outros estabelecimentos de ensino médio.»

A luta de todos os educadores é para não transformar o curso médio num simples curso de preparação para a Universidade.

Poderemos ainda, dentro da órbita do ensino médio, e sem prejuízo de suas finalidades básicas, formar técnicos de nível médio, dos quais o Brasil agudamente necessita. Mas há um limite. Não será possível tranformá-lo em curso propedêutico para a Universidade. A autonomia, ou melhor, a terminalidade do ensino médio é postulado defendido por todos os educadores brasileiros, que não aceitam vê-lo sobrecarregado de objetivos, por vezes até conflitantes.

O ideal seria que para a entrada na Universidade não figurasse sequer a exigência do curso médio, que deve ter uma finalidade em si mesmo, e não pode nem deve ser transformado em simples curso de passagem. Ou então que a lei oferecesse ao menos uma alternativa para o ingresso nas Universidades aos que não houvessem feito o curso médio, como seja um exame universitário de maturidade, com as exigências necessárias, diverso do exame de maturidade previsto no art. 99 da Lei de Diretrizes e Bases. Tal não aconteceu, lamentavelmente.

Nossa convicção é que há pessoas que poderiam com proveito real ingressar na Universidade sem ter diploma correspondente ao antigo «Bacharel em Ciências e Letras». Por outro lado, nem todos os que têm esse diploma estão necessariamente capacitados para ingressar e cursar com proveito a Universidade.

O Professor Valnir Chagas, ! em sua Indicação 48, aprovada pelo Conselho Federal de Educação em 15 de dezembro de 1967, citou dois trabalhos em favor desse ponto de vista, um publicado no Harvard Report, ${ }^{2}$ onde se estima entre 20 a 25 por cento o número relativo de

1 Valnir Chagas, Articulação da Escola Média com a Superior, Documenta 79, dezembro de 1967.

2 Harvard Committee - General Education in a Free Society - University Press, 1945, págs. 87-88, apud Valnir Chagas, ob. cit. 
pessoas capazes de um rendimento aceitável em nível superior, e outro da autoria de Conant, ${ }^{3}$ que fixou entre 15 e 20 por cento o número de estudantes academically tahnted entre a população escolar da high school. Recomendamos vivamente a leitura desse parecer do Professor Valnir Chagas, intitulado Articulação da Escola Média com a Superior.

Além daqueles, cujo despreparo resulta de mau aproveitamento no c urs o colegial. haveria ainda os que, embora estudiosos e aplicados, se mostram incapazes de corresponder às exigências do curso superior. Hoje, para dizer isso, é preciso coragem, pois a afirmativa fere certos conceitos correntes, inspirados em ideias até generosas. A partir da luta necessária contra os preconceitos raciais, que tanto mal têm causado ao mundo, e da luta contra os abusivos privilégios de classe, muitas pessoas passam a reagir contra qualquer consideração baseada em desigualdades individuais congénitas.

Prefere-se interpretar as evidentes diferenças intelectuais e vocacionais como resultantes apenas da educação anterior, do ambiente social, das vicissitudes da vida e da desigualdade de oportunidades. Confundese o bom princípio democrático da igualdade de oportunidade para todos com a noção clamorosamente falsa de serem todos os homens igualmente dotados. Ora, os homens são desigualmente dotados, quantitativa e qualitativamente. E nascem com propensões variadas.

No próprio nível primário, vamos encontrar não apenas os excepcionais positivos, muito acima da média, como os negativos, incapazes de acompanhar o curso com índice satisfatório de aproveitamento. Essa taxa de excepcionais no curso primário é mais ou menos a mesma em todos os países, e oscila de 3 a 5 por cento. Muitas dessas deficiências não são flagrantes. Mas são reais. Os negativos podem ter aptidões excepcionais para outros tipos de trabalho e não devem ser considerados débeis mentais, o que já formaria uma subcategoria à parte, a ser tratada fora da escola comunitária. Na Alemanha, esses negativos, após os dois primeiros anos do primário, são colocados em classes especiais, para cumprirem os anos de escolaridade obrigatória.

O tipo de ensino para quem foge da média, seja em sentido positivo, seja em sentido negativo, é mais oneroso, e acarreta uma série de problemas, fáceis de imaginar. $O$ que se procura é respeitar a natureza do educando e as diferenças individuais. O processo educativo deve ser essencialmente seletivo, sob todos os aspectos. As seleções não devem obedecer a critérios econômicos, raciais e sociais, mas devem basear-se em motivos exclusivamente pedagógicos. Isso o que se deseja, se busca e se procura aprimorar cada vez mais, inclusive no interesse da sociedade brasileira, que não deve continuar a perder a contribuição de muitos talentos que vêm sendo desperdiçados, em virtude da sua origem humilde.

3 Conant J. B., The American High School Today, Nova York, Mc Graw Hill Book Company, 1959, págs. 20 e 58. 
Nosso desejo ardente é que todos os que terminarem o curso primário façam também o curso ginasial e até, se possível, o colegial. Mas quando isso fôr realidade, esplêndida realidade, não poderemos desejar que todos os que alcançaram a conclusão do curso médio ingressem efetivamente na Universidade. Passaríamos a viver numa sociedade composta apenas de doutores, o que seria provavelmente desastroso. Entre outros motivos, porque seriam falsos doutores. De qualquer sorte, estamos longe dessa utopia.

E quaisquer que sejam os motivos, o que se observa em quase todos os países é que as vagas universitárias são em número menor que os postulantes.

O país que mais se aproxima desse ideal de oferecer tantas vagas quanto os postulantes são os Estados Unidos da América. Mesmo assim, apenas a metade aproximadamente dos que concluem o curso secundário continuam seus estudos num college ou numa university. Em 1964/65, concluíram o curso secundário 2.635.100 alunos (2.352.100 em escolas públicas e 273.000 em escolas particulares) . No outono de 1965, o número de ingressos no ensino superior foi de 1.441.822.

Nos Estados Unidos, a dificuldade principal para o aluno é matricular-se na instituição que êle prefere. Mas, se abrir mão desse desejo, êle encontrará outra instituição onde será recebido. Todavia, nem todos os que entram na Universidade nela permanecem. A evasão é apreciável, e maior nas instituições em que as exigências para admissão são menores. Os exames que propiciarão ou facilitarão o ingresso nas Universidades são feitos por agências nacionais particulares, e os estudantes procuram submeter-se a esses exames a fim de pleitearem, conforme seus desempenhos, admissão em tal ou qual escola superior. As Universidades estabelecem suas próprias exigências. Algumas dão preferência a certo tipo de teste (ACT), outras se inclinam por outro tipo (SAT), outras pedem ambos os testes. Algumas só aceitam candidatos que obtiverem grau muito favorável, como é o caso da Hatvard University. Mas há Universidades que aceitam candidatos com nota menos alta. Quase todas elas costumam pedir que o candidato traga um sumário autenticado de toda sua vida escolar, inclusive o julgamento emitido pelo diretor de sua high school. Há também a entrevista pessoal do candidato com a autoridade competente da Universidade. Mais adiante voltaremos a falar dos testes que foram mencionados.

Na União das Repúblicas Soviéticas Socialistas, para o ingresso na Universidade exige-se o curso secundário e pelo menos dois anos de trabalho em algum ramo da economia da Nação, após a graduação secundária. Certo grupo, que orça em 20 por cento dos estudantes, são aceitos sem exigência do trabalho prévio. Trata-se de alunos particularmente brilhantes. No exame de habilitação, correspondente ao nosso

Digest of Educational Statistics 1966 - U.S. Department of Health, Education and Welfare - O.S. Government Printing Office, 1966. 
vestibular (os graus são de 2 a 5), esses alunos se sobressaem em relação aos que ingressam após dois, três ou mais anos de trabalho, o que sempre acarreta certa perda de conhecimentos adquiridos no curso secundário. Mas, segundo informa o Professor V. A. Kitaitzev, ${ }^{5}$ essa desvantagem inicial é compensada pela maior seriedade e maturidade desses estudantes que interromperam seus estudos para trabalhar. São eles que obtêm durante o curso as melhores colocações.

A exigência do trabalho prévio não é universal. Além dos alunos a que nos referimos, que. mercê de seu desempenho excepcional no curso secundário, podem candidatar-se ao ingresso imediato na Univeridade, os demais podem tentar estudar e trabalhar simultaneamente, matriculandose em cursos superiores noturnos ou por correspondência. Nem todas as carreiras podem ser feitas nesses cursos noturnos, é óbvio. A Medicina, por exemplo, está fora da órbita do ensino noturno ou por correspendência.

Para a matrícula nos cursos diurnos, o limite de idade é de 35 anos. Para o ensino noturno ou por correspondência, não há limite de idade.

O exame de ingresso é severo, e os que obtêm apenas grau 2, que significa «insatisfatório», são recusados, não lhes sendo permitida a repetição do exame.

Os candidatos que deram baixa do serviço militar têm prioridade na admissão à Universidade e, em casos especiais (como foi o caso dos veteranos da Segunda Guerra Mundial), podem matricular-se sem exame de habilitação.

Basicamente, a URSS oferece vagas universitárias para 1/3 daqueles que concluem o ensino médio.

Em Israel, o jovem só chega à Universidade depois de servir três anos nas forças militares, o que é feito logo após o término dos estudos secundários. Os universitários israelenses são, por isso, em geral mais velhos que seus colegas de outros países.

$\mathrm{Na}$ França, não sabemos como virá a ser. Mas até recentemente a obtenção do baccalauréat dava direito à matrícula automática nas Universidades, mas não dava direito à matrícula nas chamadas grandes écoles, cuja tarefa é preparar pessoal para o exercício de certas funções, entre as quais a Administração Pública. Nestas se entra ou se entrava através de exames competitivos. Mas é engano supor que todos os que faziam o curso secundário obtinham o baccalauréat.

Para sua obtenção exige-se ou exigia-se um exame em duas etapas, a saber, no fim do $6^{\circ}$ ano e do $7^{\circ}$, respectivamente. $O$ índice de aprovações vinha-se mostrando muito constante, e era de 56 por cento de aprovações na primeira parte do exame e de 65 por cento na segunda

5 Access to Highec Educatkm, vol. II - National Studies, pág. 395. Union of Soviet Socialistic Republics by V. A. Kitaitzev — UNESCO, 1965. 
parte. Dos que obtinham o baccalauréat, apenas 80 por cento se dirigia à Universidade. Destarte, conforme se lê no estudo de Debeauvais, Filliozat, Lecerf e Garci, ${ }^{6}$ somente 30 por cento dos que faziam o curso secundário passavam a cursar a Universidade. É o que se patenteia deste cálculo que os autores citados oferecem:

$$
\frac{56 \times 65 \times 80}{100 \times 100 \times 100}=30 \text { por cento }
$$

No caso da Grã-Bretanha, o critério de ingresso no nível superior de ensino é variável, conforme o tipo de escola que se pretenda cursar. As Universidades fazem severas exigências na admissão, mas os admitidos quase todos chegam ao fim do curso. Em cursos técnicos de tempo parcial, são pouquíssimas as exigências, mas um número apreciável de estudantes abandona a escola durante o curso.

Variam também as exigências numa mesma Universidade, conforme a carreira preferida pelo candidato. De alguns se exige conhecimento real de latim, de outros não. Aliás, já no curso secundário as exigências são bastantes variáveis. Cerca de 4 a 5 anos após o ingresso no curso secundário, o aluno, em geral com 14 a 15 anos de idade, procura obter seu GCE (General Certificate of Education) do tipo «O» (=Ordinary). Mais tarde, com 18 anos, êle procurará ou não obter outro GCE de tipo «A» (= Advanced) . Há, finalmente, o GCE de tipo «S» (= Scholarship), com o qual se obtém certo tipo de bolsa de estudo.

Não vem ao caso expor em seus pormenores o sistema reinante. Bastará dizer, para nosso propósito, que o número de candidatos excede bastante o número de vagas naquelas Universidades de tempo integral.

Eis um quadro algo alarmante que vem no estudo do Professor J. A. Lauwerys:

\begin{tabular}{|c|c|c|c|}
\hline \multirow{2}{*}{ A NO } & \multicolumn{2}{|c|}{1959 PARA 1961} & \multirow{2}{*}{$\begin{array}{l}\text { NÚMERO MÉDIO } \\
\text { DE INSCRIÇÕES } \\
\text { PARA ADMISSÕES }\end{array}$} \\
\hline & INSCRIÇõES & ADMISSÕES & \\
\hline 1959 & \multirow{3}{*}{$\begin{array}{l}124.900 \\
139.100 \\
176.700\end{array}$} & \multirow{3}{*}{$\begin{array}{l}16.600 \\
18.400 \\
20.400\end{array}$} & 7,5 \\
\hline 1960. & & & 7,5 \\
\hline $1961 \ldots$ & & & 8,6 \\
\hline
\end{tabular}

FONTE: Commilee of $V$ ice-Chancellors and Principais, Report of an Hoc Commitiee on Pracedurt tf Sludents.

6 Access to Higher Education, vol. II - National, Studies, pág. 88: France. by Michel D. Debeauvais, Remy Filliozat, Didier Lecerf, and André Garci with an introduction by Jean Thomas, UNESCO, 1965. 
Na realidade, tal como ocorre no Brasil, o número de inscrições su-

o número real de candidatos. Conforme se verifica no Kelsall Committe Report, citado no trabalho de Lauwerys, ${ }^{7} 43$ por cento dos candidatos em 1955/56 não conseguiram matrícula em qualquer Universidade. Em 1961, a proporção de rejeições foi de 54 por cento.

Em conjunto, a impressão que se colhe é que o ensino superior na Grã-Bretanha continua a ser um dos mais exigentes, embora seja muito fácil a obtenção de bolsas de estudo (casa, alimentação, roupas, etc.) para os candidatos considerados realmente talentosos.

Em Portugal há o chamado exame do 7» ano, que representa um exame de conclusão do curso médio. Os alunos dos colégios secundários comparecem para prestar exames nos liceus oficiais, no $2^{\circ}$, no $5^{\circ} \mathrm{e}$ no $7^{\circ}$ ano. As notas são de 0 a 20 . Quem, neste último exame, o do 7 ano, obtiver 14 na média geral e 14 em duas matérias básicas de cada ramo tem sua matrícula assegurada na Universidade. Para os demais, exige-se um exame dito de aptidão. Difere, pois, do baccalauréat, no sentido de que não se aprova ou reprova simplesmente, mas no sentido de que se estabelece um privilégio, qual seja a dispensa do vestibular para os aprovados com nota 14 ou acima. Critério equivalente, conforme foi visto, observa-se na URSS.

Pelo visto, mais ou menos por toda parte o ingresso nas Universidades exige dos candidatos algum sacrifício, e prova de mérito superior à simples conclusão do curso médio. Na França, o baccalauréat, que é ou era até ontem título suficiente para ingresso na Universidade, deixou praticamente de ser uma prova de conclusão do curso secundário.

$\mathrm{Na}$ Argentina, durante certo tempo a Universidade aceitava todos os candidatos que apresentassem certificado de conclusão do curso médio. E esse certificado era simples, não correspondendo ao bacharelado francês. Acontecia, porém, que muito poucos eram os alunos que chegavam ao fim do curso universitário. A rejeição não se dava na entrada, mas durante o curso.

A experiência argentina não deu bons frutos e foi abandonada. Entre 1957 e 1963, o exame vestibular para o ingresso nas diferentes faculdades da Universidade de Buenos Aires foi-se generalizando progressivamente, acabando por ser adotado por todas, com exceção da Faculdade de Economia. Até 1956, quando a Universidade de Buenos Aires proporcionava ingresso livre, dois terços das novas matrículas ocorriam nessa Universidade e apenas um terço nas demais Universidades do país. Já em 1958, somente um terço das novas matrículas coube à Universidade de Buenos Aires. Uma comparação entre os anos de 1953, ao tempo da livre entrada, e 1962, já com o vestibular, é feita no quadro a seguir, que

Access lo Higher Education - vol. II, National Studies. pág. 491 United Kingdom (England and Wales) - Prepared under the direction of Prof. J. A. Lauwerys, UNESCO, 1965. 
devemos à gentileza da Professora Nádia Franco da Cunha, do Centro Brasileiro de Pesquisas Educacionais (CBPE), do MEC do Rio de Janeiro .

INGRESSO NA UNIVERSIDADE DE BUENOS AIRES EM 1953 E POR VOLTA DE 1962

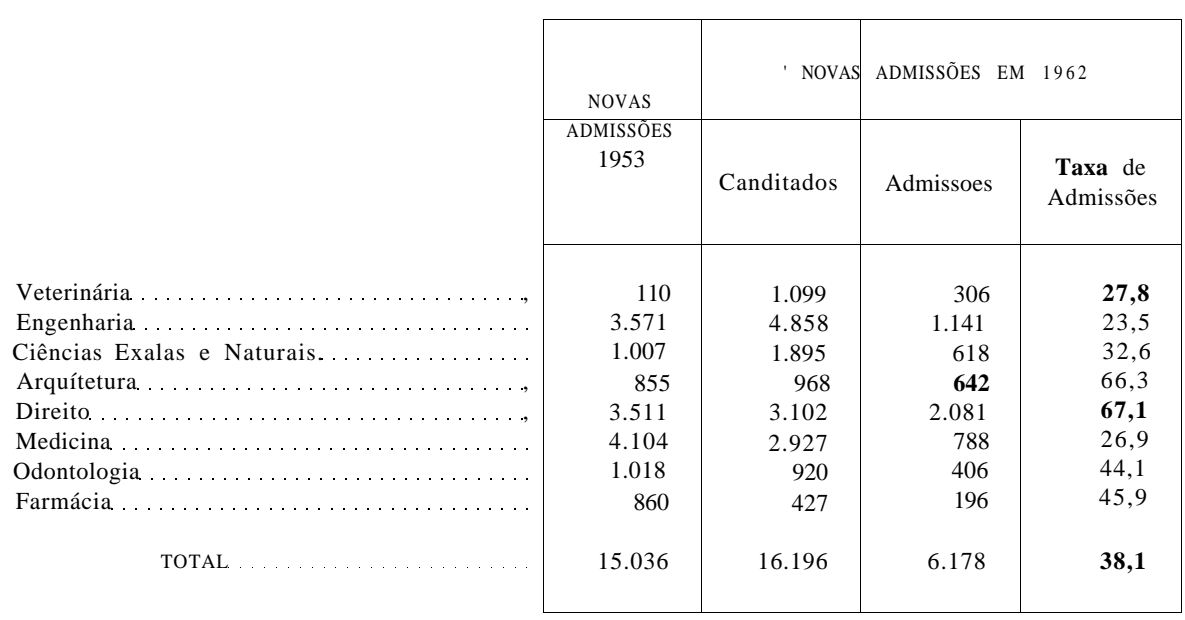

FONTE: Secretaria da Universidade. Os dadas da Faculdade de Filosofia e Letras estão incompletos e não constam desse quadro. Os dados de 1962 representam, em verdade, uma média dos anos de 1961,1962 e 1963

No Brasil, o número de pessoas que concluem o curso secundário é muito baixo, se o relacionarmos com a população do País. Infelizmente, grande parte de nossa população é composta de criaturas que não sabem ler nem escrever, e que ou vegetam à margem do processo econômico do País ou que, muitas vezes, oneram esse processo econômico. Assim. em 1965, apenas 111.307 pessoas concluíram o curso médio. O número de vagas nos vestibulares em 1966 foi de 60.137, e o número de novas matrículas foi de 46.617 .

No mesmo ano concluíram o curso médio nos Estados Unidos 2.635.100 pessoas, o que corresponde a 1,35 por cento de sua população, que era naquele ano de 194.592.000. A nossa cifra de conclusões do ensino médio em 1965 (111.307) foi, em termos relativos, 10 vezes menor, representando apenas 0,139 da população, estimada em 80.301 .000 para 1965.

O número de primeiranistas do curso superior em setembro de 1965 foi, nos Estados Unidos, de 1.441.822, o que representa uma percentagem de 0,74 em relação à população geral. No Brasil, no início de 1966, tínhamos 46.617 primeiranistas, o que dá uma percentagem de 0,059 em relação à população geral. O número de novas matrículas no curso superior foi de cerca de 13 vezes $(12,75)$ menor em termos relativos. Também a nossa renda per capita é cerca de 13 vezes menor que a renda per capifa norte-americana (USA, 3.210 dólares Brasil 232 dólares, em 1965). 
As cifras brasileiras de alfabetização, de matrícula nos níveis primário, secundário e superior são realmente tristes, mas a relação entre conclusão do curso secundário e novas matrículas no curso superior não é má. É certo que o número de vagas universitárias é muito inferior ao número de pessoas potencialmente capazes de seguir curso superior num país de 80 milhões de habitantes. Mas daí não se segue que o número de vagas universitárias seja inferior ao número de pessoas potencialmente capazes de seguir o curso superior, dentre aquelas que terminarem seu curso médio. Se o número de matrículas no curso secundário crescer, como é de desejar, e como a Nação precisa por todos os motivos, econômicos, sociais e políticos, então será necessário proceder-se a um aumento de vagas que assegure o ingresso na Universidade de pelo menos 50 por cento dos que deixam a escola secundária. Nossos esforços devem concentrar-se em melhorar os estrangulamentos que se observam antes do ingresso nas Universidades, sobretudo no último ano primário. E em combater as evasões que se iniciam na passagem da primeira para a segunda série do curso primário.

Mesmo dentro do mesquinho quadro existente, e conforme foi explicado, à base de exemplos de outros povos, não podemos oferecer vagas a todos quantos concluem o curso médio. Em 1965 houve 111.307 conclusões de curso, e houve 60.137 vagas universitárias em 1966. As vagas universitárias em 1967 passaram para 80.915. Observa-se nos últimos anos um aumento efetivo no número de vagas para o ensino superior. Infelizmente, nem todas as vagas são preenchidas, em parte devido ao sistema, que nos parece condenável, de reprovações. Ao término do vestibular, temos: 1) aprovados e aproveitados; 2) aprovados e não aproveitados por falta de vagas (= excedentes); 3) reprovados. Apesar de tudo, tem havido um incremento de matrículas no curso superior nestes últimos anos, conforme se vê no quadro abaixo:

\section{MATRÍCULA GERAL NO ENSINO SUPERIOR}

\begin{tabular}{|c|c|}
\hline Anos & Números \\
\hline 1964. & .142 .386 \\
\hline 1965 & 155.781 \\
\hline 1966. & .180 .109 \\
\hline 1967. & 213.741 \\
\hline
\end{tabular}

\section{FONTE: CAPES}

Os dados a seguir mostram a relação entre o ensino médio, as inscrições nos vestibulares e as novas matrículas. Convém lembrar que o número de pessoas inscritas é em média igual a apenas 75 por cento das inscrições.

Ensino médio - 2' ciclo - conclusões em 1964.

Vagas no vestibular em 1965

95.417 (SEEC)

Número de inscrições no vestibular

58.929 (CAPES)

Total de aprovados

125.408 (CAPES)

Total de matriculados na primeira série.

47.494 (CAPES)

45.774 (CAPES) 
Ensino médio - 2" ciclo — conclusões em 1965.

111.307 (SEEC)

Vagas no vestibular em 1966.

60.137 (CAPES)

Número de inscrições no vestibular.

123.319 (CAPES)

Total de aprovados.

51.223 (CAPES)

Total de matrículas na primeira série.

46.617 (CAPES)

Ensino médio - 2' ciclo — conclusões em 1966

129.917 (SEEC)

Vagas no vestibular em 1967.

80.915 (CAPES)

Número de inscrições no vestibular

183.150 (CAPES)

Total de aprovados.

70.337 (CAPES)

Total de matriculados na primeira série

66.001 (CAPES)

Dentro de limites modestos, estes dados refletem certo esforço em prol da educação no Brasil. O número de matriculados na primeira série do curso superior, cujo crescimento em 1966 fora de 1,84 por cento em relação ao ano anterior, passa em 1967 para 66.001, o que representa um crescimento de 41,58 por cento. Houve também de 1966 para 1967 um crescimento de 34,55 por cento no número de vagas. De 1964 para 1967 também aumentou o número de escolas superiores, conforme se vê abaixo:

ESCOLAS SUPERIORES NO BRASIL

EM 1964

EM 1967

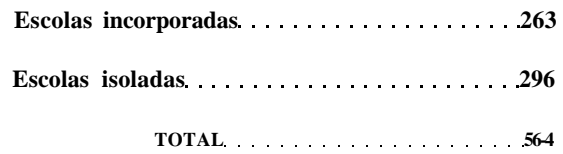

Escolas incorporadas. . . . . . . . . . 372

Escolas isoladas. . . . . . . . . . . . . . . 305

TOTAL.

677

\section{FONTE: CAPES}

O número de matrículas poderia ter crescido muito mais até, sem que o número de escolas necessariamente aumentasse. Seria mais econômico, e a qualidade do ensino a ser ministrado seria provavelmente melhor. De qualquer sorte, a abertura de uma nova escola em cidade onde existam outras, congéneres, tem aspectos positivos, sobretudo pela emulação que provoca. O que não acontece quando, em cidade pequena, se cria uma escola isolada. Aliás, como política geral, devemos desistimular a criação de Faculdades isoladas.

Para o ingresso nas escolas superiores adotou-se em nosso país um sistema de seleção chamado vestibular, vencido o qual o estudante tem praticamente a segurança de que obterá sua diplomação. 
Será bom esse sistema?

Conforme se verifica, analisando os sistemas de ingresso em diferentes países, chega-se à conclusão de que há sempre uma seleção a ser feita: a) ao nível do secundário; $b$ ) por ocasião do ingresso; c) durante o curso. A diferença entre os indivíduos, no que tange às aptidões e dedicação, há de manifestar-se em algum ponto, seja nos níveis apontados, seja no nível do pós-graduação ou então no nível do Prémio Nobel.

Uma seleção feita no secundário é o baccalauréat francês, que vem sendo recusado a um número muito grande de secundaristas. Entendemos que uma coisa é a conclusão do curso secundário, com o respectivo certificado dado a todos aqueles que foram aprovados, outra é o diploma mais específico para o ingresso na Universidade.

Vimos também que, sempre que se facilita o ingresso, crescem as rejeições durante o curso. Na Argentina foi assim durante certo período. $\mathrm{Na}$ Inglaterra, há pouquíssimas rejeições durante o curso nas escolas cuja severidade se mostra já na admissão, e muitas rejeições nas escolas e cursos cujas exigências são mínimas no que se refere à aceitação dos estudantes. O mesmo fenômeno se observa nos Estados Unidos.

O que será melhor: negar ab initio a oportunidade, ou dar a oportunidade e retirá-la a seguir? Evidentemente esta pergunta só teria sentido se o exame inicial fosse capaz de eliminar precisamente aqueles que depois viriam a ser eliminados. Isso, entretanto, não existe. Se existisse, a solução numerus clausus correspondente mais ou menos ao número dos que podem concluir o curso com razoável proveito seria a melhor. Não obstante, considerando os diferentes aspectos do problema, como sejam, escassez de recursos, impossibilidade e inconveniência de abrir as portas a todos os postulantes e o desejo de escolher os mais aptos pedagogicamente, parece que nossos esforços se devem voltar para corrigir os defeitos e aprimorar os processos do exame de habilitação para o ingresso nas escolas superiores. Eis um alvo ao alcance de nossas possibilidades. Embora sem atingir a perfeição, estamos convencidos que será possível melhorar bastante o sistema vigente.

Em nosso entender, no vestibular brasileiro se exige muito com critérios péssimos. Será uma prova válida para a seleção de certo tipo de personalidade com boa memória, resistência à fadiga e certo equilíbrio emocional. Mas, entre outros inconvenientes, não tem qualquer conotação vocacional.

Os alunos que vão ao vestibular sentem que estão diante de um mecanismo de rejeição e não de seleção. Há exames vestibulares em que figuram truques de má-fé, para cuja solução se exige esperteza e não inteligência. O betisier do vestibular é enorme e deveria ser levantado. Julgamos que os alunos que respondessem a certas perguntas que figuram em alguns exames deveriam até ser reprovados, pois no Brasil precisamos urgentemente desestimular a esperteza, tantas vezes tomada como sinal de inteligência. Não devemos estimular certa vivacidade de espírito in- 
terpretada como inteligência, e que apenas disfarça a pobreza de estruturas mentais. É preciso também não confundir inteligência com prontidão de resposta.

Para a preparação ao tipo de seleção representado pelo vestibular, criaram-se no Brasil os famosos «cursinhos» de pré-vestibular, que dão enorme lucro aos donos. Neles, a preparação é rigorosamente pragmática. Não há ensino, há adestramento. Isso cria em alguns um vício que poderá deformá-los para o resto da vida. Na Universidade eles irão procurar no professor universitário um tipo de explicador igual àqueles a que se habituaram nos «cursinhos».

É necessário declarar que nenhuma palavra de censura merecem esses cursos pré-vestibulares, nos quais há professores de alto gabarito. O que neles há de inconveniente é resultante da inadequação entre o curso médio e o ensino superior, e resultante do tipo de aferimetno que vem sendo usado. Esta ressalva é importante, pois afinal é neles que o aluno se prepara para enfrentar e vencer a mecânica do vestibular, tal como ela é. Pelo seu alto custo, eles representam verdadeiro crivo para o ingresso nas escolas superiores mais apetecidas, como Medicina e Engenharia. Quem não passar por esse gargalo, terá bem menores oportunidades de classificar-se no vestibular.

O mal maior em tudo isso vem da decadência do ensino médio, cuja função deveria ser proporcionar cultura geral e promover o desenvolvimento harmonioso das faculdades mentais do adolescente.

Convém esclarecer que por cultura geral, no ensino médio, entendemos cultura geral adequada às necessidades do mundo moderno, em que o elemento científico entra como necessidade indispensável do cidadão que vive nos dias de hoje. Não nos referimos apenas à cultura humanística, às letras clássicas. Para concretizar mais nosso pensamento, diremos que a Matemática deve ser ensinada em todas as séries do nível médio. Ela é indispensável tanto para a formação de tipo humanista quanto para a de tipo científico. O próprio aluno de Filosofia não se moverá bem no campo da Lógica sem razoável iniciação matemática. E muito menos se moverão em suas respectivas esferas o médico e o engenheiro.

Além de ministrar conhecimentos gerais, o ensino médio deveria visar, sobretudo, a desenvolver hábitos intelectuais. Mas parece que o professorado do ginasial e do colegial perdeu o élan. E seu nível caiu. $\mathrm{O}$ regime do salário-aula leva o professor a dar o maior número de aulas que lhe fôr fisicamente possível, a fim de alcançar uma remuneração condigna, que compense a queda diária do valor do dinheiro. Não lhe sobra tempo para acompanhar o aproveitamento de seus alunos, mesmo no Estado mais rico da Federação, que é São Paulo. Por um lado, o ensino ficou por demais facilitado, e chega-se até a tolerar em alguns lugares a instituição da cola. Por outro, continua a haver o afunilamento, que se inicia a partir da primeira série primária e que prossegue de série em série. 
O primeiro gargalo na vida do estudante é o chamado admissão, ou seja, a passagem do primário para o secundário. Suas vítimas não comovem a opinião pública, não realizam concentrações defronte do Palácio da Cultura e nem são objeto dessas reportagens sensacionais com que a imprensa procura distrair os seus leitores. Em 1957, concluíram o curso primário 535.712 alunos, mas somente 297.904 passaram a cursar o primeiro ano ginasial em 1958. Em 1958 concluíram o primário 589.925, mas apenas 318.623 ingressaram no secundário. E assim, todos os anos, apenas 55 por cento dos que lograram concluir o primário passam ao secundário. É uma situação equivalente mais ou menos à observada na passagem do colegial para a Universidade.

Temos, portanto, gargalos e afunilamentos. Consultando a Sinopse Estatística do Ensino Médio. ${ }^{8}$ vê-se que em 1950 havia na primeira série ginasial 318.623 alunos, dos quais somente 172.319 atingiram a quarta série. Esse afunilamento resulta sobretudo de abandono, devido às condições sócio-econômicas desfavoráveis do País. Reprova-se muito pouco. Nos colégios particulares, a tendência é aprovar sempre, o mais possível, porque só assim conseguem boa clientela. Não há fiscalização que consiga contrariar essa tendência.

Reza o art. 39 da Lei de Diretrizes e Bases:

«A apuração do rendimento escolar ficará a cargo dos estabelecimentos de ensino, aos quais caberá expedir ceitifiçados de conclusão de cursos.

$\S 1 \mathrm{Na}$ avaliação do aproveitamento do aluno preponderarão os resultados alcançados durante o ano letivo nas atividades escolares, asseguradas ao professor, nos exames e provas, liberdade de formulação de questões e autoridade de julgamento.

$\S 2^{\circ}$ Os exames serão prestados perante comissão examinadora formada de professores do próprio estabelecimento, e, se fôr particular, sob fiscalização da autoridade competente.»

Vê-se de pronto que nenhuma fiscalização realmente eficaz poderá incidir sobre a «apuração do rendimento escolar» ante a irrestrita liberdade do professor na formulação das questões e sua autoridade incontestável no julgamento das provas e dos exames.

Não se conclua do que está dito que sejamos adversários do ensino particular. Muito pelo contrário. Não participamos daquela aversão profunda e misteriosa que se observa em algumas pessoas contra as instituições privadas. Julgamos até que a salvação, neste domínio da Educação, como em tantos outros, está na liberdade, na livre empresa, na 
espontaneidade social que deve entretanto ser regulamentada pelo poder público. O que nos parece inconveniente é a apuração endógena do rendimento escolar. $\mathrm{O}$ assunto foge, entretanto, à nossa competência. E deixando de lado explicações e indagações, o fato é que há um descenso considerável do curso médio em relação à cultura geral e à preparação doa alunos para o curso superior.

A esta altura torna-se indispensável prestar um esclarecimento, a fim de que não se veja contradição em nossas palavras.

Se o ensino médio não se destina a preparar alunos para o curso superior, se o ensino médio deve ser um ensino com propósitos próprios, com sua terminalidade autónoma, conforme foi dito, nada impede que as Universidades elaborem seu sistema vestibular levando em consideração o tipo de ensino que foi ministrado no curso secundário e seu equivalente comercial, industrial e agrícola. Deve ser assim, é óbvio.

Mas sendo assim, o vestibular deveria ser sobretudo um exame de cultura geral, como foi dito e tal como êle foi definido, - sem as perguntas de algibeira, as perguntas capciosas ou muito especializadas, que tantas vezes o desfiguram. Então, realmente, se poderia fazer um exame vestibular único para cada Universidade, ou para as diferentes escolas e faculdades de uma mesma área geográfica. Voltaremos mais adiante a debater este ponto.

Antes, queremos frisar que nem o ensino médio vem sendo convenientemente ministrado, nem o tipo de aferimento para o ingresso nas escolas superiores vem sendo adequado. A prova clamorosa está na proliferação dos «cursinhos» de pré-vestibular, aos quais já nos referimos, «em falar nos próprios resultados desalentadores de alguns raros vestibulares bem elaborados.

Numa confissão da própria incapacidade, as escolas fazem convênio com os «cursinhos», convênios que foram proibidos, mas que, sob formas disfarçadas, continuam em vigor. À pág. 393 de seu livro, ${ }^{9}$ Nádia Franco da Cunha nos oferece um modelo de convênio.

A proliferação dos «cursinhos» representa um desmentido factual eloquente às intenções da Lei de Diretrizes e Bases. A Professora Nádia Franco da Cunha em página do seu livro lembra o art. 12 da mesma lei, que reza:

«Os sistemas de ensino atenderão à variedade dos cursos, à flexibilidade dos currículos e à articulação dos diversos graus e ramos.>

E a essa «idealização legal» contrapõe a «situação real» expressa nos dados referentes ao número de «cursinhos» na Guanabara:
em 1963
em 1964
55
em 1965
83
102

9 Nadia Franco da Cunha, Vestibular na Guanabara, MEC-INEP-CBPE, $196 \mathrm{~S}$. 
Imaginam alguns críticos que não se dilatam as possibilidades de sino nas escolas superiores, porque as classes dominantes não o querem . O caráter competitivo de nosso exame vestibular já foi apontado, até em documentos oficiais, ${ }^{, 0}$ como elaborados com a finalidade de impedir as transformações sociais que decorreriam da admissão, no ensino superior, de largo número de estudantes provindos de classes menos favorecidas. Segundo um artigo muito expressivo a esse respeito, ${ }^{u}$ as classes dominantes sabem que, se alargarem as entradas, haverá progresso, e com o progresso a eliminação dos privilégios existentes. Veja-se a astúcia, a malícia das classes dominantes! Não menos maliciosos nossos críticos percebem o golpe, e o denunciam:

Ocorrerá mesmo isso? A maldade humana será mesmo tão intensa? Serão os reitores agentes das classes dominantes? Enquanto pensarmos nesses termos, nada de construtivo será possível fazer. Se há carreiras universitárias em que a oferta de vagas é maior que a demanda, sirva de exemplo o caso da enfermagem, outras há em que a demanda é maior que a oferta, como é o caso da Medicina.

No nosso entender, o exame de admissão à Universidade deveria representar mais um teste de capacidade intelectual e de aptidão vocacional que de conhecimentos. Queremos basicamente saber se o aluno tem inteligência e se é capaz de usá-la. Secundariamente, se êle possui certos conhecimentos indispensáveis aos estudos que irá fazer.

Nosso desejo real é aumentar a matrícula de alunos nos cursos superiores, colocando esse número à altura das necessidades do mercado de trabalho, e até acima, se possível; mas não somos partidários da abolição de provas de seleção, quaisquer que sejam. Devemos modificar os critérios do exame vestibular, devemos estudar a possibilidade de substituí-lo por outro tipo mais correto de aferimento, mas algum aferimento deve ser feito. Dentro deste espírito, prosseguiremos em nossas considerações, estudando um caso particular, qual seja o exame vestibular para Medicina.

A carreira médica é, sem dúvida, aquela em que se observa o maior excesso de candidatos em relação ao número de vagas. $\mathrm{E}$ por isso mesmo vamo-nos deter neste tópico.

No quadro a seguir, retirado do Relatório da CAPES, de 1965, verse-á, no caso da Medicina, que em 1964 a relação entre o número de inscrições e o número de vagas foi de 7,6, seguida da Engenharia, onde a relação foi de 3,6. Em várias outras carreiras houve mais vagas que candidatos, como no caso da Enfermagem, em que a relação foi de 0,5. Em conjunto, houve mais vagas que candidatos aprovados.

10 -Access to Higher Education, vol. II. National Studies, pág. 14, Brazil, A Study by CAPES, with an introduetion by Anísio S. Teixeira, UNESCO, 1965.

'1 Visão, 15 de março de 1968. 


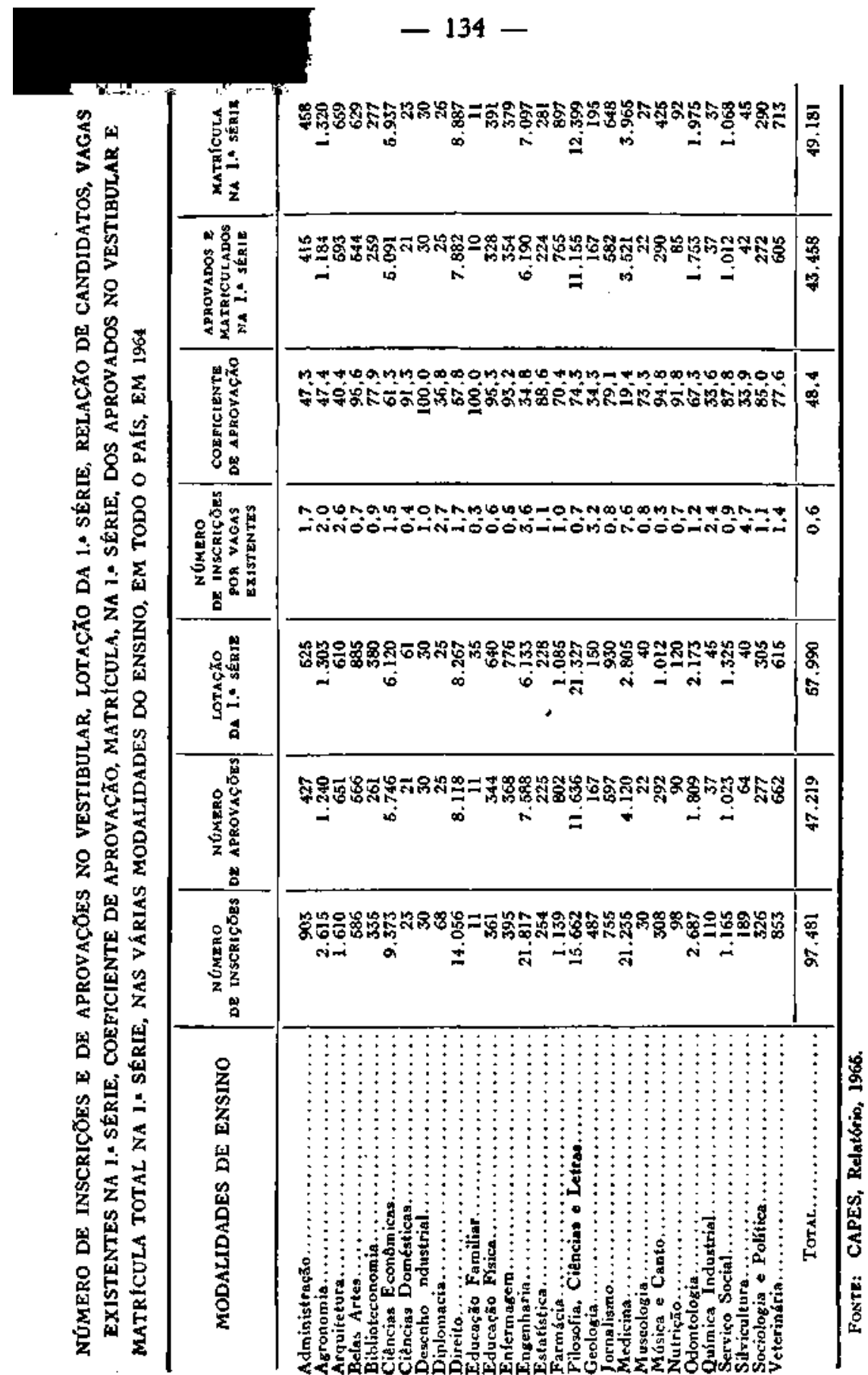


Fica evidente no quadro acima, que a Medicina constitui a profissão masi apetecida Em 1968, para 160 vagas em Belo Horizonte houve 1689 candidatos. E não foi desprezível o número de excedentes que, usando as facilidades do Acordo Cultural entre Portugal e Brasil, celebrado em Lisboa em 7 de setembro de 1966, se dirigiu para a outra banda do Atlântico, a fim de realizar na velha mãe-pátria o seu curso médico. Mas segundo informação publicada no Diário de Notícias, do Rio de Janeiro (19 de julho de 1968), a taxa de reprovações tem sido muito alta. $\mathrm{Na}$ Universidade de Coimbra, ao fim do primeiro ano do curso, em 100 estudantes brasileiros, apenas 6 foram aprovados.

A decidida preferência pela carreira médica pode ainda ser confirmada, quando se analisa o procedimento dos candidatos a ingresso na Universidade.

No ano de 1965, em São Paulo, entre os alunos que compareceram ao vestibular de Medicina, 42,94 por cento tentavam o ingresso na Universidade pela primeira vez, 13,72 por cento faziam segunda tentativa, e 40,93 por cento uma terceira tentativa. Apenas 1,54 por cento se dirigiam à Medicina após haverem procurado em vão ingressar em outra carreira uma vez, e somente 0,18 por cento compareciam ao vestibular de Medicina após haverem falhado mais de uma vez no ingresso em outras carreiras.

Essa relação, observada em São Paulo, corresponde ao que foi visto em Pernambuco e Rio Grande do Sul, conforme o quadro a seguir.

PARA MEDICINA, 1965

Vestibular inicial em Medicina

Exame anterior no mesmo ramo, uma vez......

Exames anteriores no mesmo ramo mais de uma vez..

Outro ramo, uma vez

Outro ramo, mais de uma vez.

Em diversos ramos.

FONTE: CAPES

\begin{tabular}{||c|r|r}
\hline PERNAMBUCO & SÃO PAULO & $\begin{array}{r}\text { RIO GRANDE } \\
\text { DO SUL }\end{array}$ \\
\hline 67,98 & $\mathbf{4 2 , 9 4}$ & 58,49 \\
$\mathbf{1 4 , 7 1}$ & $\mathbf{1 3 , 7 2}$ & $\mathbf{1 4 , 9 6}$ \\
16,34 & 40,93 & \\
0,82 & $\mathbf{1 , 5 4}$ & 25,62 \\
$\mathbf{0 , 1 5}$ & $\mathbf{0 , 1 8}$ & 0,76 \\
0,00 & 0,69 & $\mathbf{0 , 0 4}$ \\
& & $\mathbf{0 , 1 3}$ \\
\hline
\end{tabular}

Percebe-se a insistênica com que os candidatos tentaram o ingresso na carreira médica. Veja-se, agora, a atitude em relação à Veterinária:

PARA VETERINÁRIA, 1965

Vestibular inicial em Veterinária

E-xame anterior no mesmo ramo uma vez

$V$

Exame anterior no mesmo ramo, mais de uma vez

Outro ramo, uma ver.

Outro ramo, mais de uma vez.

Ern diversos ramos.

\begin{tabular}{||r|r}
\hline & \\
PERNAMBUCO & SÃo PAULO \\
& \\
\hline & \\
68,99 & $\mathbf{4 1 ~ 1 1}$ \\
5,43 & $\mathbf{0 , 3 9}$ \\
$\mathbf{3 , 8 8}$ & $\mathbf{0 , 7 9}$ \\
$\mathbf{1 3 , 1 8}$ & $\mathbf{1 1 ~ 8 6}$ \\
$\mathbf{4 , 6 5}$ & $\mathbf{3 8 , 3 4}$ \\
$\mathbf{3 , 8 7}$ & $\mathbf{7 , 5 1}$ \\
\hline
\end{tabular}

FONTE: CAPES. 
Muito poucos, sobretudo em São Paulo, os que insistiram no vestibular para Veterinária quando não aceitos na primeira tentativa. Mas foi significativo o número daqueles que, havendo falhado em tentativas de ingresso em outras carreiras, procuraram a Veterinária.

Também se observa firmeza entre aqueles que se dirigem à Engenharia, como se pode ver em alguns vestibulares de 1965:

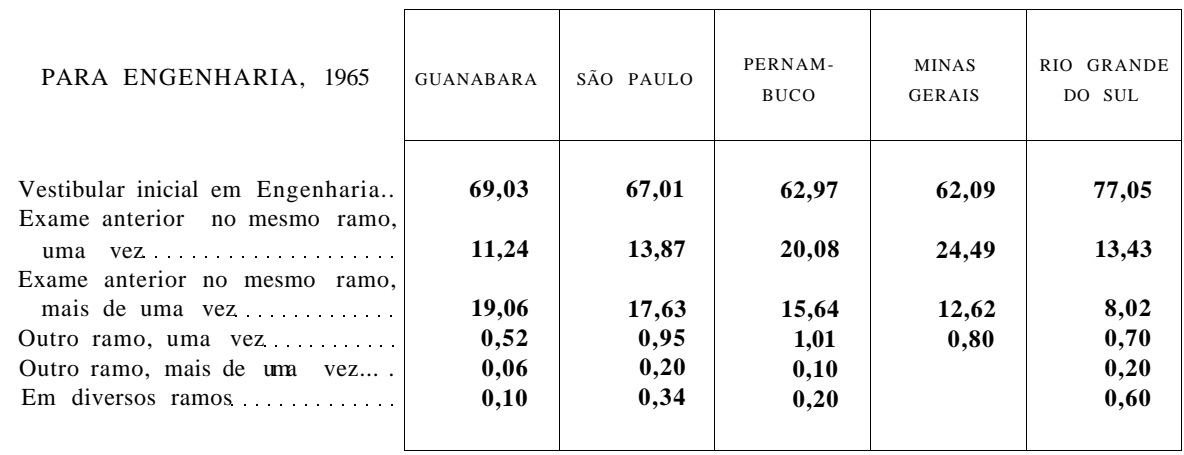

FONTE: CAPES. menor.

Em relação ao Direito, parece que a insistência na procura foi algo PARA DIREITO, 1965

Vestibular inicial $\mathrm{cm}$ Direito.

Exame anterior no mesmo ramo, uma vez.

Exame anterior no mesmo ramo, mais de uma vez

Outro ramo, uma vez.

Outro ramo, mais de uma vez

Em diversos ramos.

\begin{tabular}{|r|r|r|r|}
\hline GUANABARA & SÃo PAULO & PERNAMBUCO & MINAS GERAIS \\
\hline $\mathbf{8 9 , 5 9}$ & $\mathbf{7 2 , 7 7}$ & $\mathbf{7 8 , 8 2}$ & $\mathbf{8 1 , 1 1}$ \\
& & $\mathbf{1 0 , 5 9}$ & $\mathbf{1 0 , 9 3}$ \\
$\mathbf{6 , 0 0}$ & $\mathbf{1 5 , 6 2}$ & $\mathbf{2 , 3 5}$ & $\mathbf{4 , 0 5}$ \\
& & $\mathbf{1 , 7 7}$ & $\mathbf{2 , 9 7}$ \\
$\mathbf{1 , 2 3}$ & $\mathbf{7 , 5 4}$ & $\mathbf{1 , 1 8}$ & $\mathbf{0 , 4 0}$ \\
$\mathbf{0 , 5 3}$ & $\mathbf{0 , 6 9}$ & $\mathbf{5 , 2 9}$ & $\mathbf{0 , 5 4}$ \\
$\mathbf{0 , 5 3}$ & $\mathbf{0 , 5 4}$ & & \\
\hline
\end{tabular}

FONTE: CAPES

Estes dados, ainda inéditos, fazem parte de uma pesquisa muito mais ampla em andamento e à qual tivemos acesso graças à boa vontade do Dr. Francisco Montojos, Chefe da Divisão de Estudos e Planejamento da CAPES.

Eles justificam a necessidade de uma pesquisa específica sobre as preferências dos candidatos. Justificam também a instituição de um Serviço de Aconselhamento Vocacional, como está sendo proposto pela EAPES.

A insistência nas tentativas de ingresso na carreira hipocrática foi a mais expressiva. Apesar disso e do alto número de candidatos cada 
ano a matricula global nas Faculdades de Medicina se manteve estacionária sempre em torno de 10.000 alunos, de 1954 a 1962 . Entretanto, o número de Faculdades nesse período passou de 25 para 31 . A partir de 1963, aumentou tanto a disponibilidade de vagas, que, para 10.183 estudantes de Medicina matriculados em 1964, havia já 20.295 matriculados em 1967. Comparando as matrículas na primeira série em 1954, em número de 1.633 , quando havia apenas 25 Escolas de Medicina, com os matriculados em 1967, em número de 4.999, quando já havia 44 Escolas de Medicina, obteremos as seguintes proporções:

Incremento de escolas de 1954 para 1967.

$91 \%$

Incremento de matriculas na primeira série, de 1954 para 1967.

$206 \%$;

Em 1967, a situação em relação às Escolas de Medicina foi a seguinte:

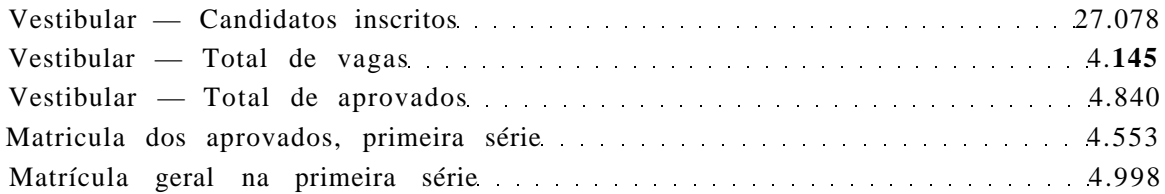

FONTE: CAPES.

Não se pode negar que o Governo Federal, que é o grande investidor em matéria de educação superior, se vem esforçando por atender menos mal à procura de vagas nas Faculdades de Medicina. Na Universidade Federal do Rio Grande do Sul, por exemplo, em 1965, o custo anual de um estudante na Faculdade de Medicina foi de NCr\$3.230,00, na Faculdade de Direito, de NCr\$670,00 e na Faculdade de Engenharia, de $\mathrm{NCr} \$ 830,00$.

Dir-se-ia, entretanto, ser ainda excessivo o número de candidatos não aceitos, num país que sofre ou sofria de carência aguda de médicos.

Haverá realmente essa carência de médicos? Nossa convicção é que temos menos médicos formados do que precisaríamos, mas temos mais médicos do que a sociedade pode pagar.

Nas profissões mais rendosas e mais consentâneas com o temperamento nacional, temos, frequentemente, profissionais em excesso, se não em relação às nossas necessidades teóricas, pelo menos em relação às necessidade reais do mercado.

Advogados, por exemplo, nós os temos em abundância, exercendo as mais variadas profissões: «bacharéis lavradores - escrevia A. Almeida Júnior em 1952 - bacharéis pecuaristas, bacharéis negociantes, bacharéis gerindo fábricas, bacharéis professores de ginásio, bacharéis banqueiros ou bancários, bacharéis corretores da praça, bacharéis escriturários de repartição, bacharéis postalistas, bacharéis no Exército ou na Força Pú-

12 Mário Rigatto. «Criação de novas Faculdades de Medicina e aumento do número de matriculas médicas no Rio Grande do Sul», Revista da AMRIGS, ano 10, $\mathrm{n}^{\circ 1} 2,1966$. 
blica, bacharéis na Aviação, bacharéis nas agências de publicidade, bacharéis no teatro, na rádio, no futebol...» $\mathrm{E}$ acrescentava mais tarde o mesmo autor, ${ }^{13}$ então membro do Conselho Federal de Educação: «De então para cá, graças aos informes colhidos em comemorações de formatura, novas posições ocupadas por bacharéis em Direito pudemos recensear: a de televisionista, a de inspetor de ensino, a de gerente de restaurante, a de balconista de botequim, a de Oficial de Justiça, a de palhaço de circo (dois pelo menos, aliás, excelentes!), a de caixeiro viajante, a de bibliotecário... Todas as profissões são dignas, desde que exercidas com honestidade: mas é antieconômico, e por vezes é também cruel preparar um jovem durante cinco anos para advocacia ou a magistratura e ao fim do curso dizer-lhe: - «Não há serviço para você! Enrole o seu diploma e vá cuidar de outra coisa.»

Mas voltemos ao caso dos médicos. O quadro a seguir servirá para mostrar a relação entre a distribuição de médicos e a renda per capita e também a relação entre distribuição de médicos e a extensão territorial.

MÉDicos, habitanTES POR MÉDicos, QUILÓMETROS QUADRADOS POR MÉDico,

E RENDA PER CAPITA, SEGUNDO AS REGIÕES E UNIDADES DA FEDERAÇÃO - 1964

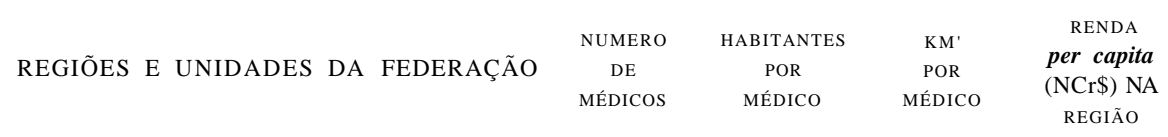

1. Rondônia, Acre, Amazonas, Roraima, Pará e Amapá

2. Maranhão e Piauí

3. Ceará, Rio Grande do Norte, Paraíba, Pernambuco. Alagoas e Sergipe.

4. Bahia

5. Minas Gerais e Espírito Santo

6. Rio de Janeiro.

7. Guanabara

8. São Paulo.

9. Paraná e Santa Catarina.

10. Rio Grande do Sul.

11. Mato Grosso, Goiás e Distrito Federa!....

\begin{tabular}{|r|r|r|r|}
\hline & & & \\
595 & 4.862 & $6.018,8$ & 98 \\
368 & 11.498 & $1.575,0$ & 60 \\
& & & \\
2.734 & 4.901 & 149,2 & 114 \\
1.700 & 3.757 & 330,0 & 105 \\
3.676 & 3.362 & 172,1 & 129 \\
1.782 & 2.177 & 24,1 & 182 \\
8.913 & 410 & 0,2 & 570 \\
8.659 & 1.681 & 28,6 & 343 \\
2.003 & 3.942 & 147,5 & 158 \\
2.756 & 2.152 & 102,4 & 242 \\
1.065 & 3.403 & $1.764,7$ & 169 \\
& & & \\
34.251 & 2.301 & 248,5 & 162 \\
& & & \\
\hline
\end{tabular}

FONTE: Serviço de Estatística da Saúde (número de médicos); Fundação IBGE- Instituto Brasileiro de Geografia (área) - Instituto Brasileiro de Estatística (estimativas de população).

Verifica-se a presença, na Guanbara, de 8.913 médicos, havendo, portanto, um médico para 410 habitantes. É o Estado em que se observa maior concentração de riqueza. O segundo lugar cabe a São Paulo em

A. Almeida Júnior. Sob $n s$ Arcada-, MEC-INEP. $1 \% 5$. 
médicos e renda per capita. Ocupam o último lugar Maranhão e Piauí, com o menor número de médicos, 368 para os dois Estados, e a relação de um médico para 11.498 habitantes. Em relação à extensão territorial, a situação mais grave é a da Amazónia com um médico para 6.018 quilómetros quadrados.

O quadro, a seguir, mostra a distribuição de médicos em relação à renda e à população.

RENDA INTERNA, POPULAÇão, RENDA PER CAPITA, MÉdicos, E HABITANTES POR MÉDICO, SEGUNDO AS REGIÕES DA FEDERAÇÃO - 1964

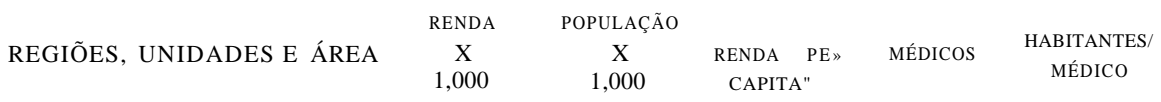
NORTE RO, AC, AM, RR, PA, AP, MA, PI $(4.129 .552 \mathrm{~km} 2)$ 534.767 $7.124,3$ 75,1 963 7.398 NORDESTE

CE, RN, AL, PB, PE, SE, BA (996.721 km2).

CENTRO-LESTE

MG, ES, RJ, GB. SP

(918.808 km2;

$$
9.375 .540
$$

SUL

PR. SC, RS

$(562.071 \mathrm{~km} 2)$

\section{CENTRO-OESTE}

GO, MT, DF

$(1.879 .356 \mathrm{~km} 2)$

FONTE: Fundação Getúlio Vargas — Instituto Brasileiro de Economia (estimativas da renda interna). Fundação IBGE - Instituto Brasileiro de Estatística (estimativas da população); Fundação IBGE — Instituto Brasileiro de Geografia (área); Serviço de Estatística da Saúde (número de médicos).

Em dois gráficos a seguir, vê-se ainda melhor como a distribuição de médicos no território nacional se faz de acordo com a renda. A correlação ordinal é perfeita entre renda per capita e habitantes por médico. Também se observa que, com a exceção do Norte, a correlação é linear. A distribuição não tem relação nem com a extensão territorial, nem com a densidade demográfica. 


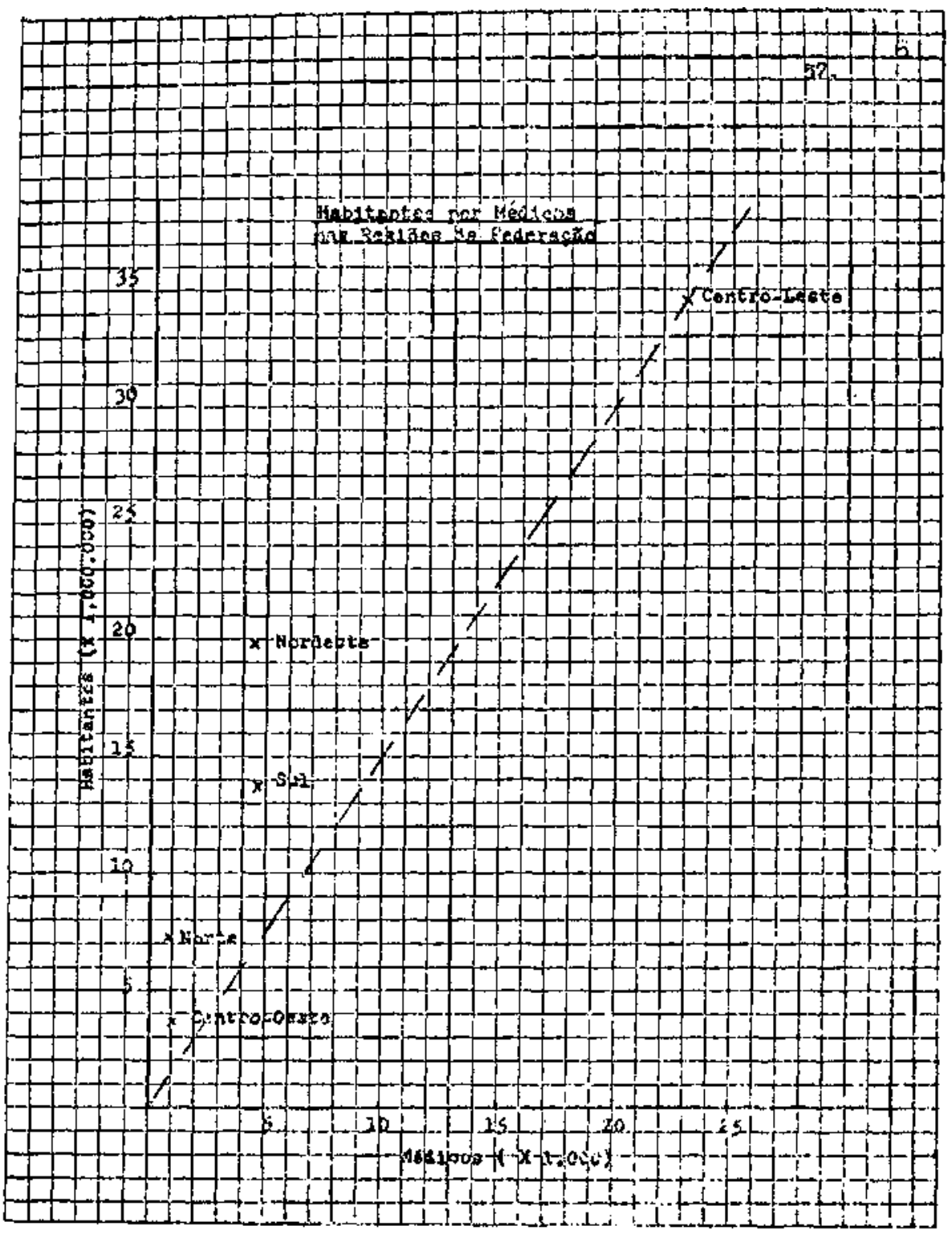




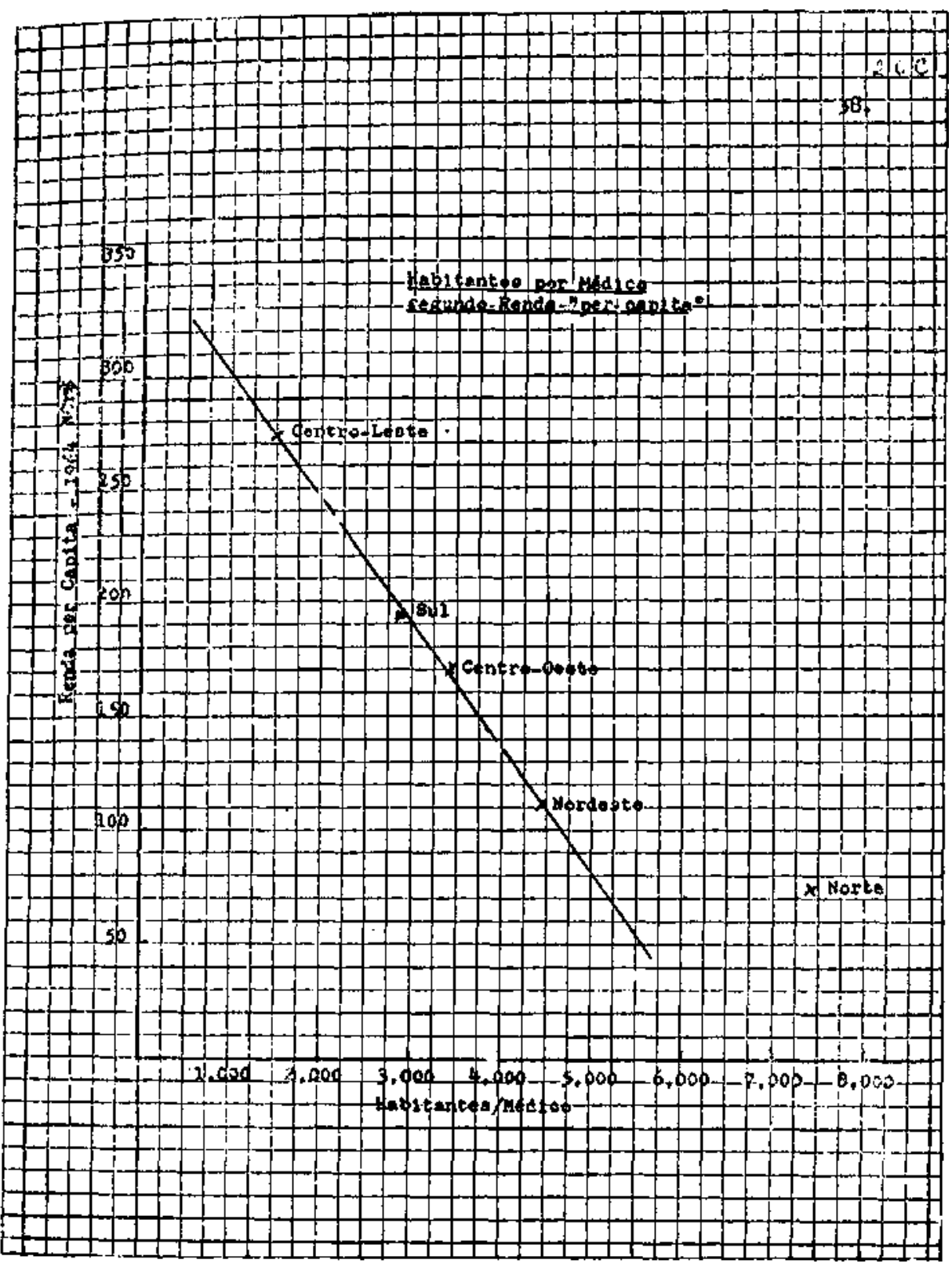


Parece que ninguém vai ser médico apenas pelo prestígio que o grau confere, mas sobretudo pela importância econômica da profissão. O mercado de trabalho deve ser considerado em todas as projeções a serem feitas acerca das necessidades futuras do Brasil. A simples perspectiva populacional não constitui bom critério de tratar o assunto.

É certo que na planificação do ensino secundário e superior, no Brasil não nos podemos guiar apenas pelo mercado de trabalho. Outros parâmetros devem ser levados em consideração, mas de maneira objetiva e critica. No caso em tela, logo se dirá que temos inúmeros municípios sem médicos, 38 no Amazonas, 60 no Pará, 102 no Maranhão, 97 no Piauí, 86 no Ceará, 125 no Rio Grande do Norte. Em Minas Gerais há 360 municípios sem médicos. Isso significa que só há médicos na metade dos 718 municípios em que se divide o Estado. Até em São Paulo há 160 municípios sem médico. Muitas vezes, não há médico domiciliado no município, mas a população é atendida por médicos do município vizinho, a 30 ou 40 minutos de distância. Em casos assim, há falta de médicos nas estatísticas, mas não na realidade. Tomemos, entretanto, o caso dos municípios em que realmente falta tudo, inclusive médicos e até advogado. Neles não há médicos, nem engenheiros, nem agrónomos, nem padres, nem produção de bens, nem consumo de bens. Há apenas uma economia de subsistência. Em tais casos, diz-se ser indispensável colocar médicos nesses locais, porque sem saúde não haverá desenvolvimento. É muito honroso para a classe imaginar que médico seja sinónimo de saúde e que a presença de médicos seja considerada não apenas índice de progresso, mas também causa de progresso. Em países ainda em desenvolvimento, mais que nos países ricos e prósperos, devemos aprofundar o sentido de muitas expressões correntes, usadas quase como slogans.

A incidência das doenças não tem relação com o número maior ou menor de médicos, embora tenha estreita relação com as descobertas da Medicina no campo da clínica, da microbiologia, da parasitologia e da farmacologia. Para combater as grandes doenças, e aqui nos referimos às doenças que matam muito ou que invalidam, não é necessário superabundância de médicos. Para combater as avitaminoses, e nesse terreno há os exemplos clássicos do escorbuto, do beribéri e da pelagra, não foi preciso mobilizar um exército de médicos. Bastaram medidas administrativas e governamentais relativamente simples, baseadas em descobertas realmente importantes, feitas por alguns médicos ilustres. Para combater o bócio, em termos de saúde pública, bastou iodar o sal. A luta contra a malária está hoje perfeitamente equacionada, pois consiste basicamente na aplicação domiciliar, duas vezes por ano, de inseticidas de ação residual (BHC ou derivados) . Na retaguarda dessa operação simples, há, no entanto, soma considerável de trabalho e de pesquisas médicas que não podem ser esquecidos. Contra a esquistossomose, a solução não está em colocar um médico ao lado de cada doente, mas sim na destruição de determinados caramujos que funcionam como hospedeiros intermediários. Nesse sentido, há várias pesquisas em andamento. O tratamento indi- 
vidual, com os medicamentos disponíveis até agora, é muito tóxico, só proporciona resultados inseguros, e ademais a reinfestação nos casos bem sucedidos é inevitável. Também o que se almeja na luta contra a doença de Chagas, cuja identificação, tanto da doença em si quanto do germe e do agente transmissor, é conquista médica brasileira, tornada possível graças à criação do Instituto Oswaldo Cruz, o que se almeja, dizíamos, é sobretudo a destruição do mosquito transmissor, por meio de inseticidas de ação retardada e graças à construção de casas com paredes lisas. Para combater a ancilostomose e necatorose, responsáveis pela opilação, baixa taxa de hemoglobina e consequente preguiça de milhões de brasileiros, não precisamos formar mais médicos ainda, mas apenas educar as populações, modificar certos hábitos e distribuir remédios. Para tanto, é mister haver médicos orientando tais campanhas, mas em número relativamente limitado. A vitória sobre a febre amarela é obra de médicos, mas a execução da luta foi feita sobretudo com mata-mosquitos.

O de que precisamos, realmente, é melhorar o padrão da cultura médica brasileira, e dar vida nova aos nossos institutos de pesquisas biológicas. Em Medicina há um padrão bom, abaixo do qual a queda é brutal. Medicina ou é excelente, ou nada vale. Um médico de segunda classe vale menos que um charlatão. E é mais perigoso. E o médico isolado, perdido na selva, sem laboratório e sem radiologia, para citar apenas duas deficiências, pouco poderá fazer.

Em virtude mesmo da evolução dos conhecimentos científicos, caminha-se hoje para a Medicina de grupo, até no terreno assistencial. Em países vanguardeiros, como os Estados Unidos, por exemplo, o paciente procura em suas aflições um serviço disponível em que possa confiar e a êle se entrega, como seja a Clínica Mayo, a Clínica Lahey, e assim por diante. Em países de Medicina socializada, como a Inglaterra, a tendência à formação de equipes médicas de alto padrão é ainda mais acentuada.

No terreno da assistência médica precisamos, isto sim, criar em vários pontos do território nacional centros convenientemente aparelhados aos quais possam dirigir-se os pacientes que o desejarem ou que apresentarem mais complexos problemas de saúde. A Previdência Social tem recursos para isso, e em colaboração com o Ministério da Saúde muito poderá fazer. Mas a primazia cabe, em nosso entender, às campanhas sanitárias, que deverão ser feitas em todo o país, inclusive nos municípios onde hoje não há médicos. Não devemos confundir Medicina pública com Medicina individual ou assistencial. Para esta, não temos ainda médicos em número suficiente, nem clientes que possam pagá-la, quer diretamente, quer através do Estado. Para aquela, temos médicos em número bastante. Precisamos, isto sim, elevar seu padrão e criar adequadas condições de trabalho.

Em resumo, o problema de saúde geral de uma nação é problema mais de ciência médica que de número de médicos.

Se, em virtude de algum programa nacional de saúde pública ou de socialização da Medicina, fôr preciso mobilizar um número de médicos 
maior do que os existentes, a Universidade deverá intensificar mais ainda os seus esforços, inclusive importando professores para formar mais médicos a toque de tambor. Como estão as coisas, o número de médicos existentes atende amplamente o mercado de trabalho, incluindo nesse mercado, é óbvio, o sistema previdenciário. E já se prevê, para os próximos anos um aumento considerável no índice de formaturas.

É realmente necessário realizar um estudo estatístico para todo o Brasil, na base do número de formaturas anuais de médicos, para o estabelecimento de projeções a curto e médio prazo, a fim de verificar qual a opção correia que devemos fazer: se aumentar a quantidade de médicos, incrementando e facilitando o ingresso nas Faculdades de Medicina, se melhorar a qualidade dos médicos em formação, à medida que são postos maiores recursos técnicos à disposição dos médicos já formados .

Em relação ao Rio Grande do Sul, há um estudo primoroso feito pelo Dr. Mário Rigato, ${ }^{14}$ que resumiremos em poucas palavras. De 1898 a 1953, durante 55 anos, portanto, o Rio Grande contou com uma única Escola de Medicina, a de Porto Alegre. Em 1966, já havia cinco. Depois disso, fundaram-se mais duas Faculdades de Medicina (Rio Grande e Caxias do Sul). O número total de admissões no primeiro ano do curso médico passou de 60 em 1951 para 420 em 1965. Houve, portanto, um aumento de 600 por cento. Nesse período, o aumento populacional foi de 48 por cento. O aumento de matrículas primárias foi de 126 por cento, o de matrículas secundárias de 79 por cento, o de leitos hospitalares de 94 por cento, e o aumento de Postos de Saúde foi de 66 por cento. Mesmo sem a criação de novas escolas (excluídas, portanto, as de Rio Grande e Caxias do Sul) e imaginando que as existentes até 1966 mantivessem o atual número de matrículas, a relação entre médicos e habitantes seria de 1 para 1.100 no ano de 1990, o que significa relação ótima, igual à da Suécia, onde a assistência médica preventiva e curativa é, sem contestação, a melhor do mundo. Tudo indica, portanto, que não há necessidade de aumento da produção de médicos no Rio Grande do Sul, durante os próximos 25 anos. Mas há, sem dúvida, necessidade de elevar o padrão de ensino nas escolas existentes.

Essa longa digressão sobre médicos e Medicina foi feita numa tentativa de ilustrar bem, sem apriorismos dogmáticos e sem idealizações românticas, a diferença entre uma necessidade real e uma «necessidade» ideal, entre uma necessidade cuja solução representará um avanço, um progresso, e uma «necessidade» mal pensada, cuja «solução» ou simulacro de solução representará um desperdício e somente servirá para agravar o círculo vicioso do subdesenvolvimento.

Voltando ao caso do exame vestibular, mas insistindo ainda no caso particular da Medicina, somos de parecer que, para a escolha de candi-

írio Rigalto, «O que falta ao Rio Grande do Sul em matéria de médicos" quantidade, qualidade ou distribuição geográfica», Revista da Associação Medica Brasileira, vol. 12, págs. 505-512, dezembro de 1966. 
datos às Faculdades de Medicina, o exame deveria constar apenas de três matérias: Português, Inglês e Matemática.

É indispensável, entretanto, que os examinadores saibam conduzir o exame.

No exame de Português o que importa é verificar se o candidato sabe exprimir-se, sabe dizer o que quer, embora cometendo alguns erros gramaticais .

Há erros de redação e de pontuação que não são erros de Português mas, como gostava de dizer o grande Sousa da Silveira, são erros de português, de inglês, de húngaro, de finlandês. Em suma, são erros de pensamento, a mostrar que o candidato não sabe articular as ideias, não sabe pensar, enfim.

Expressão confusa é sinal de ideias confusas.

É imprescindível, nos dias de hoje, uma prova desse tipo, tanto mais quando se verifica como se vem abusando do contexto nas comunicações e mensagens que nos são transmitidas.

Seguindo Albert Sechehaye, os especialistas em linguagem distinguem, na palavra falada, o texto e o contexto. Nos dias de hoje, o elemento de comunicação é contextual, a começar pelas histórias de quadrinhos, onde a situação é dada pelo desenho, e a continuar pela televisão, em que artistas abomináveis encantam a população lançando mão de uma mímica sempre excessiva, de gestos estapafúrdios, de músicas e de barulhos, a fim de suprir as deficiências do texto. É necessário verificar a possibilidade de comunicação de quem terá de cingir-se apenas a um texto escrito. Não se exigirá do candidato que seja um estilista, ou um gramático; apenas se pretende que êle saiba dizer o que quer e saiba articular suas ideias, sem mímica.

Entretanto, o sistema de testes objetivos de múltipla escolha, que permitem apuração mecânica, torna impraticável a análise, pela banca examinadora, da capacidade de redação dos alunos. Uma vez que o elevado número de candidatos impõe o uso de computadores, poder-se-á dividir a prova de português em duas partes, das quais uma seria apenas a prova de redação, a ser analisada pelos próprios examinadores. Ou então, dispensando-se a prova de redação, fornecer textos para leitura, com interpretação dos mesmos através de respostas de múltipla escolha. a fim de verificar se os candidatos entendem o que estão lendo. Assim, na Universidade Federal Fluminense, esse tipo de prova já foi realizado duas vezes pelos Professores Gladstone Chaves de Melo, Maximiano de Carvalho e Silva e Carlos Eduardo Falcão Uchoa, que todavia não a consideram a melhor solução.

O conhecimento do inglês (ou de língua de uso mais geral que o português ou o espanhol) é indispensável, sobretudo no que se refere à leitura. No vestibular de inglês não se deverá testar os conhecimentos gramaticais, e muito menos a pronúncia. Para o propósito específico em vista, todo peso da prova deve estar na capacidade de entender o que 
estiver escrito . O aluno deverá interpretar corretamente essa língua estrangeira. Deve-se acrescentar que isso não ocorre. A maioria absoluta dos universitários arranha o inglês muito mal e ignora totalmente o francês. Há muitas sociedades culturais ensinando inglês, mas nas $\mathrm{Fa}$ culdades de Medicina é surpreendentemente pequeno o número de alunos que realmente lê inglês. Daí, o consumo exagerado de traduções espanholas de livros ingleses e alemães.

Quanto à Matemática, trata-se de matéria hoje indispensável à formação do médico. Estamos longe do tempo em que iam estudar Medicina exatamente aqueles que «não tinham vocação para Matemática». Hoje deve ser precisamente o contrário, sob pena de agravar-se a distância que está havendo - e que as pessoas mais lúcidas já perceberam - entre a Medicina dos grandes centros e a nossa. De modo geral, o médico sabia apenas as quatro operações fundamentais e chegava à raiz quadrada já com dispneia de esforço. Modificar essa situação é tarefa urgentíssima, e do candidato à Medicina se deve exigir pelo menos tanta Matemática quanto se exige do candidato à Engenharia. Se nos exames para ingressar na Faculdade de Medicina e de Engenharia se viesse a exigir, em futuro próximo, a «mathématique élémentaire», que é matéria, na França, do último ano científico, já seria um notável progresso.

Se o estudante souber usar a sua língua, souber usar para leitura corrente uma segunda língua de trânsito bem mais universal que o português, e souber a Matemática elementar a que nos referimos, então poderemos ensinar-lhe com tranquilidade as matérias de que precisará para tornar-se médico. Êle estará habilitado a aprender, dentro da Universidade, a Física e a Química que forem necessárias.

O exame dessas três matérias permitirá classificar os candidatos. Para tanto, talvez bastassem duas matérias, como Português e Matemática.

Não acreditamos que um elenco maior de matérias que as três ou duas já citadas venha a proporcionar uma correlação prognóstica mais acertada relativamente ao futuro desempenho universitário do aluno. A esse respeito, parece-nos pertinente citar o estudo de Lins, Abell e Hutchins, ${ }^{13}$ que, analisando os diferentes testes de admissão usados nos Estados Unidos da América, verificaram que uma combinação maior de fatores ou matérias sobre as quais se baseiam esses testes tradicionais (SAT, ACT, CQT) não traz apreciável incremento do seu valor prognóstico. Nesses testes americanos, cuja elaboração vem sendo feita há 30 anos, ou mais, tenta-se medir mais a aptidão dos alunos que seus conhecimentos, sobretudo no Scholastic Aptitude Test (SAT). Já no College Qualification Test (CQT) procura-se mais aferir os conhecimentos. No American College Test (ACT) se combinam bastante bem itens que demandam raciocínio, com itens que demandam conhecimentos.

15 L. J. Lins, A. P. Abell and H. C. Hutchins. Relative usefulness in Predicting Academic Sucess o[ the ACT, the SAT, and some other variables - J. of Experimental Education, vol. 35, n. 2, Winter, 1966. 
O exame vestibular, na medida do possível, deve medir menos o arsenal de conhecimentos já adquiridos, e mais a capacidade intelectual dos candidatos. A nenhum candidato realmente capaz se deve recusar o acesso à Universidade.

É certo que um exame de conhecimentos é também, em larga medida um exame de aptidão, pois tanto mais se conhece quanto mais capaz se é. De nada serve uma potência que não se transforma em ato, ou uma aptidão que jamais se traduz em realização. Mas sabemos que há os late bloomers, ou seja, aqueles cujo aproveitamento nos estudos só se mostra algo tardiamente. Por outro lado, os early bloomers são algumas vezes pessoas de talento brilhante mas efémero. Todas essas coisas precisam ser lembradas e consideradas.

Dir-se-á que, se adotarmos o a ferimento baseado apenas em Português, Inglês (ou outra língua como francês, alemão ou russo) e Matemática, haverá repercussões inevitáveis e indesejáveis sobre o ensino médio, pois é de prever que os secundaristas passem a estudar apenas aquelas matérias que lhes permitirão o acesso ao ensino superior. $O$ argumento é ponderável, sem dúvida. Mas, se aumentarmos o número de matérias, estaremos fugindo ao intento de tornar indispensáveis, tanto quanto possível, os «cursinhos» de pré-vestibular. Reconhecemos que a tarefa não é fácil. Talvez se pudesse acrescentar ao exame vestibular provas singelas de Geografia e de História, sempre com a finalidade de colher mais subsídios, embora desnecessários, para um exame puramente classificatório. Mas pelo menos não contribuiríamos para que os secundaristas desprezassem o estudo da Geografia e da História, duas matérias que, por sua vez, dispensarão, parece, aprendizado em cursos especiais. Talvez devêssemos basear o vestibular naquelas matérias obrigatórias, indicadas pelo Conselho Federal de Educação, em número de cinco, e que são as mesmas para todo o País. Mas aí. novamente, estaríamos propiciando o florescimento dos «cursinhos». Como se vê, o problema apresenta muitas dificuldades.

Solução ideal seria a portuguesa, já citada, mas no Brasil ela nos parece impraticável, dada nossa extensão territorial e a previsível variedade de critérios, na atribuição de notas nos diferentes Estados da Federação, até na hipótese de serem os exames realizados apenas em colégios oficiais.

Não sendo praticável a solução portuguesa, nem desejável uma solução como a francesa, e não estando em nossa tradição o a ferimento da capacidade dos secundaristas, já no fim do curso médio, por meio de testes como ACT e a SAT, executados por agências nacionais particulares, tal como acontece nos Estados Unidos da América, será necessário realizar um esforço, de caráter administrativo e educativo, a fim de que se estabeleça uma distinção muito nítida entre a obtenção do certificado do curso médio, com suas exigências e seu valor próprio, e a realização do exame vestibular. É possível, entretanto, que se venha a criar algum dia um serviço oficial nacional para a execução de testes, libe- 
rando-se destarte as Universidades da tarefa ingrata do vestibular. Nesta hipótese, os testes poderiam ser feitos 1 a 6 meses antes da conclusão do curso médio, e estaria definitivamente afastada a necessidade do «cursinho» pré-vestibular. São problemas que merecem estudo acurado, e que poderão ser resolvidos em futuro próximo. Assim pelo menos desejamos e esperamos.

Em qualquer hipótese, o ensino secundário deve ter seus objetivos próprios, e deve saber defendê-los. A ninguém parecerá desejável que a eficiência maior do ensino secundário seja apenas função das exigências universitárias.

Mas, supondo que os secundaristas se dediquem com maior afinco ao Português, ao Inglês (ou outra língua viva aceitável como alternativa) e à Matemática, que mal haverá nisso?

No nosso entender, o número de matérias que se ensina tanto no primário quanto no secundário é excessivo. Procura-se ensinar tudo. porque se parte da ideia, duplamente falsa, de que tudo deve ser aprendido na escola, e de que tudo pode ser aprendido verbalmente, teoricamente, e depois memorizado. Acontece, na prática, que, havendo excesso de matérias, todas ficam mal aprendidas, e são depressa esquecidas. Assim, sempre foi precário o estudo de línguas estrangeiras no curso secundário. Basta ver o número dos universitários que para ler em inglês precisam matricular-se em sociedades como a Cultura Inglesa, o Instituto Brasil-Estados Unidos ou nos cursos Yázigi. Durante os anos em que o latim foi obrigatório, os alunos estudavam-no anos a fio a saíam do colégio sabendo apenas rudimentos, que rapidamente esqueciam.

A extensão que se dá à Física e à Química no curso secundário nos parece excessiva. Bastaria ministrar noções gerais, algo rudimentar e bastante objetivo dessas matérias, que depois deveriam ser ensinadas em profundidade no curso superior. Por outro lado, não se promove a habilitação dos alunos no manejo de determinadas técnicas e instrumentos de trabalho, como régua de cálculo, leitura rápida e dactilografia, que todo secundarista deveria obrigatoriamente aprender. O ensino secundário nos parece por demais intelectualizado, e ao mesmo tempo se deixam de ensinar algumas cousas que nos parecem indispensáveis. Assim, de maneira prática deverá o aluno ser preparado para a vida pública, visitando indústrias, repartições, fazendas, e recebendo instrução sobre moeda, sistema bancário, contabilidade elementar, enfim. preparando-se para o exercício da cidadania. Quando o ensino médio. gratuito e obrigatório, se tornar universal, nesse dia a carteira de eleitor deveria ser entregue ao aluno junto com o diploma de conclusão da escola secundária.

Repetimos: se o critério de simplificação do vestibular que aqui foi sugerido resultar numa dedicação maior ao ensino e aprendizado das poucas matérias escolhidas, tanto melhor. Já a lei vigente discrimina entre as inúmeras disciplinas do curso secundário. No caput do 
art. 35 da Lei de Diretrizes e Bases elas são classificadas em obrigatórias e optativas. No $\S 1^{\circ}$ desse art. 35 se diz que:

«Ao Conselho Federal de Educação compete indicar, para todos os sistemas de ensino médio, até cinco disciplinas obrigatórias, cabendo aos Conselhos Estaduais de Educação completar o seu número e relacionar as de caráter optativo que podem ser adotadas pelos estabelecimentos de ensino».

Como se vê, a lei não limita a cinco as matérias obrigatórias. Elas podem ser até oito.

$\mathrm{O}$ art. 40 da mesma lei manda dar relevo especial ao ensino de Português. $\mathrm{O}$ art. 45 estabelece que no ciclo ginasial haverá nove disciplinas, fixando-se entre cinco a sete o número das que podem ser dadas em cada série. $\mathrm{O}$ art. 46 estabelece oito disciplinas para o ciclo ginasial, das quais uma ou duas optativas. E no seu $\S 29$, o citado artigo estabelece:

«A terceira série do ciclo colegial será organizada com currículo diversificado, que vise ao preparo dos alunos para os cursos superiores e compreenderá, no mínimo, quatro e, no máximo, seis disciplinas, podendo ser ministradas em colégios universitários.»

A lei, como se vê, além de estabelecer matérias optativas e obrigatórias e de dar maior relevo ao ensino de Português, organiza a terceira série do curso colegial em função do preparo do aluno para os cursos superiores. Isso é absolutamente lamentável. Exatamente esta terceira série é feita muitas vezes, como vimos anteriormente, nos «cursinhos» de pré-vestibular, mediante convênios proibidos, mas vigorantes, pelo menos em alguns lugares.

Neste $\S 2^{\circ}$ do art. 46 da Lei de Diretrizes e Bases se favorece um tipo de excessivo entrosamento entre o ensino médio c o superior. Em alguns países, o entrosamento chegou a tal ponto, que já é possível, no próprio curso secundário, antecipar créditos para a Universidade. Não nos parece que seja esse o caminho acertado.

Entende-se que estivemos analisando o vestibular especificamente destinado ao ingresso em Faculdades de Medicina. Esta, entretanto, não é a hipótese melhor. No tipo de Universidade que temos em mente e do qual já se aproximam algumas Universidades brasileiras. o exame vestibular deverá ser o mesmo para todos os alunes, quaisquer que sejam suas aspirações profissionais futuras. Aí então, mais do que nunca, o exame de habilitação deve assumir esse caráter de exame simplificado. Porque só um a dois anos após o ingresso na Universidade é que o aluno escolherá em definitivo sua profissão. Hoje o estudante tem poucas opções, mas é de esperar, numa gradual reforma de ensino, 
que se proceda a uma reformulação das profissões e das atividades a serem oferecidas aos universitários.

Um serviço de aconselhamento vocacional, baseado inclusive e principalmente no desempenho dos alunos nas diferentes disciplinas de curso, poderá e deverá ser posto em funcionamento. Haverá então oportunidade para um estudo mais tranquilo das aptidões dos alunos e de sua real vocação.

$\mathrm{Na}$ ocasião mesma do ingresso não nos parece aconselhável, e achamos até inviável a realização de testes psicológicos paia a escolha profissional. Mas somos adeptos do exame psiquátrico como parte do exame médico de admissão. Em todas as nossas escolas superiores há sempre alguns psicopatas, cuja presença resulta numa perturbação para o ensino e para a convivência.

Em qualquer hipótese, seja para o ingresso na Universidade, seja para o ingresso numa determinada Faculdade, o exame vestibular, enquanto não fôr substituído por outro sistema, deverá ser rigorosamente classificatório.

Aliás, esse é c espírito da Lei de Diretrizes e Bases que, em seu art. 69, exige para o ingresso no curso superior, conforme vimos, conclusão do ciclo colegial ou equivalente e classificação em concurso de habilitarão. Ulteriormente, o Conselho Federal de Educação, em seu Parecer n' 58, ${ }^{16}$ reafirmou o caráter classificatório do concurso de habilitação.

Segundo julgamos, não deve haver aprovações nem reprovações, e todas as vagas existentes e previamente anunciadas deverão ser preenchidas, enquanto houver candidatos. Para Enfermagem, por exemplo, não só há mais vagas que aprovações, como há mais vagas que inscrições. Também em Jornalismo. Em 1964, para 930 vagas que houve no País, 755 inscrições apenas e 597 aprovações. A maioria dos formados em Jornalismo não encontra emprego, mas não haverá mal em que a oferta de profissional possa algumas vezes superar a demanda, desde que sejam devidamente informados os candidatos acerca do mercado de trabalho. A Universidade não é agência de empregos. Conforme foi dito, é bom levar em conta o mercado de trabalho no planejamento das atividades da Universidade, mas êste critério do mercado de trabalho de nenhum modo deve ser o único.

Sabemos que o preenchimento de todas as vagas disponíveis, enquanto houver candidatos, resultará algumas vezes na aceitação de candidatos muitos fracos. Mas esse inconveniente parece-nos menor do que a figura do chamado excedente, ou seja, do candidato aprovado, mas para o qual não há vaga. A exploração jornalística e política que se vem desenvolvendo em torno de tal figura torna urgente uma reafirmação do caráter, sobretudo classificatório, do exame vestibular.

'6 Documenta n" 4, 1962, pág. 58. 
O excedente, hoje; se julga um injustiçado, e de certa maneira ser excedente passou a ser título de glória.

Havendo vagas disponíveis e recursos ociosos, não haverá mal aceitação de alguns candidatos mais fracos do que seria desejável, pois eles poderão e deverão ser eliminados no decorrer do curso, caso se mostrem incapazes de corrigir suas deficiências e de corresponder às exigências do ensino em nível universitário.

É necessidade fundamental acabar com as aprovações quase automáticas que se fazem em certas escolas superiores, uma vez transposto o obstáculo vestibular. Aí está uma atitude a ser corrigida com urgência. Como também não se deverá tolerar a prática vergonhosa e aviltante da cola. Nem no secundário, nem, muito menos, no superior.

Uma aferição exigente do aproveitamento dos alunos, com as eventuais reprovações daí decorrentes, é uma necessidade, pois só assim poderão as Universidades abrir mais suas portas e alargar as matrículas, recebendo, inclusive, candidatos cujas perspectivas de aproveitamento não pareçam muito favoráveis. Por outro lado, alguns alunos realmente capazes, mas algo relapsos, ver-se-ão compelidos a realizar, enquanto joven?, um esforço que de outra maneira não fariam, mas cujos resultados abençoarão para o resto da vida. Devemos forçar cada aluno a oferecer o melhor desempenho de que seja capaz.

Com as cautelas apontadas e seguindo o tipo de aferição indicado, acreditamos que seja possível selecionar os estudantes mais capazes. Esse o nosso desejo real, pois nós nos consideraríamos monstros, monstros morais, se, a pretexto da preservação da boa qualidade do ensino, estivéssemos tentando preservar ilegítimos interesses de classe, de raça ou de religião. De nossa religião queremos defender apenas os interesses legítimos, não atentatórios ao bem comum. Mas também nos recusamos a ingressar no reino da utopia, pois conhecemos a tragédia social que ocorre sempre que se procura construir sobre areia. Os grandes utópicos já fizeram muito mal à Humanidade para que nos deixemos por eles guiar.

Estas declarações aqui feitas poderão parecer insólitas, mas elas se justificam quando se verifica o tipo de argumento talvez involuntariamente terrorista que se procura lançar contra quem se aventura a falar em qualidade e tenta defender a liceidade de um numerus clausus para as escolas superiores. Certamente não defendemos um numerus clausus fixo, invariável, imutável, mas defendemos a liceidade de oferecer cada ano um número claramente especificado antes dos exames, e contra o qual não se venha depois sofismar.

A limitação de vagas é uma imposição ditada por outras limitações como, no caso de Medicina, as que dizem respeito à falta de recursos, falta de professores competentes, número limitado de doentes, número limitado de cadáveres, e assim por diante. 
Na Faculdade de Medicina do Rio de Janeiro (antiga Faculdade de Medicina da Universidade do Brasil), no último concurso para professor de Anatomia Humana, os dois candidatos que se apresentaram foram reprovados. No concurso de Parasitologia da Faculdade de Medicina da Universidade da Guanabara não se inscreveu um único candidato.

Nem sempre o público está a par das dificuldades existentes para o preenchimento de certas cadeiras, sobretudo nos últimos tempos, em virtude de vários fatores, entre os quais citaremos falta de recursos financeiros para a pesquisa, baixos salários e campanhas de desprestígio contra os professores. Então, quando surgem vagas, ou não aparecem candidatos, ou os candidatos que aparecem não satisfazem certas exigências, sem as quais se deterioraria ainda mais o conceito do magistério superior no Brasil. 


\section{A REVISÃO dOS CURRÍCULOS}

A fixação dos currículos das escolas superiores brasileiras foi, até promulgação da Lei de Diretrizes e Bases, uma operação confiada a órgãos ou instituições do Governo central, dos quais emanavam as ordenações básicas ou es modelos e padrões a serem rigorosa e uniformemente seguidos $\mathrm{cm}$ todo o território nacional. $\mathrm{O}$ currículo das escolas da Universidade do Brasil estabeleceu o padrão que foi seguido pelas demais escolas brasileiras de nível universitário. Esses currículos vigoraram no ensino superior brasileiro até a promulgação da Lei de Diretrizes e Bases. Com esta lei, passou ao Conselho Federal de Educação a incumbência de estabelecer os currículos mínimos para os diferentes cursos da rede de escolas de ensino superior. Embora constituindo-se numa significativa mudança, com reflexos positivos na vida das escolas, esta medida se mostrou insuficiente, pois, como nas reformas anteriores, a nova sistemática da organização curricular só atendia exclusivamente aos interesses de escolas e cursos isoladamente, não permitindo o exame do problema e sua solução sob o ângulo propriamente universitário.

Desta maneira, a reforma que urge realizar no ensino superior do país deve implicar, necessariamente, reformulação dos curriculos. de acordo com uma visão universitária do problema, e procurando levar em conta os seguintes princípios:

$1^{\circ}$. Os currículos universitários devem ser suficientemente variáveis e flexíveis, de modo que atendam às inclinações e aptidões dos educandos. Isto significa que, embora possam dedicar-se a idêntico ramo de especialização intelectual ou profissional, os diversos estudantes poderão seguir diferentes rumos, em consonância com suas aspirações, anseios e preocupações pessoais.

$2^{\prime}$. Os currículos devem satisfazer às exigências da própria natureza dos conhecimentos, cabendo, através deles, preservar as conquistas fundamentais da cultura universal e nacional e incorporar incessantemente os novos avanços do conhecimento. Independentemente da maior ou menor procura, ou mesmo da eventual inexistência de alunos, cabe à Universidade manter o elenco de estudos que correspondam à amplitude do saber, bem como o seu trabalho, ao nível das mais altas exigências intelectuais. 
3'. Os currículos devem propiciar ampla variabilidade de tipos de formação universitária para completa adequação do ensino às carreiras profissionais de nível superior. É óbvio que, sendo imprevisíveis. dentro de certos limites, as oportunidades profissionais futuras, a atividade de ensino não se deve subordinar exclusivamente às flutuações aleatórias do mercado de trabalho.

$4^{9}$. Os currículos hão de ser suficientemente diferenciados e flexíveis, de modo que permitam a cursos diferentes equivalência pedagógica, para efeito de obtenção de graus acadêmicos, podendo haver assim vários currículos para a formação numa mesma área profissional ou de conhecimento. 


\section{A INSTITUIÇÃO DO SISTEMA DEPARTAMENTAL}

A reforma do ensino superior brasileiro, e particularmente de suas Universidades, está intimamente relacionada, nos dias atuais, ao problema do recrutamento e seleção do pessoal docente.

Parece-nos, portanto, indispensável examinar, em função dos dispositivos constitucionais e dos tópicos pertinentes ao assunto nas disposições legais, as questões inerentes à cátedra, à carreira do magistério e à constituição de departamentos.

Diz-se que as Universidades brasileiras, por serem recentes, não têm ainda tradição. Este asserto é apenas parcialmente verdadeiro. $\mathrm{Na}$ verdade, quando se organizaram as nossas primeiras Universidades, o legislador já contava com a experiência e a tradição de algumas escolas centenárias, em cujas raízes não será muito difícil identificar a influência do modelo de Coimbra, que, pelas origens, remonta às últimas décadas do século XIII.

Não iremos acompanhar, ao longo do desenvolvimento de nossas instituições de ensino superior, as transformações por que passou o modelo de Coimbra em sua adaptação ao meio nacional. Acreditamos, todavia, que a organização de escolas de nível universitário com o regime de cátedras seja um dos aspectos mais significativos da nossa herança educacional e de nossas vinculações à tradição universitária portuguesa.

O problema que passaremos a examinar - Cátedra, Carreira do Magistério e Departamentos - foi originariamente proposto, no ano de 1963, no Conselho Federal de Educação, a propósito da discussão do Regimento da Faculdade de Ciências Econômicas de São Leopoldo. O parecer, então aprovado, admitia a possibilidade de opção, podendo6e adotar ou não o regime de cátedra. O assunto deveria ser decidido,

«Para as lições das sobreditas Disciplinas, haverá seis Cadeiras regidas por tantos lentes, proprietários delas, A primeira será de Matemática Médica, a segunda de Anatomia, Operações Cirúrgicas; a terceira Instituições Médico-Cirúrgicas; a quarta de Aforismo; a quinta, a sexta, ambas de Prática, tanto de Cirurgia, como de Medicina». Estatuto da Universidade de Coimbra do Ano de MDCCLXX1I. Lisboa, na Régia Oficina Tipográfica, 1773, Cap. III, pág. 33. 
em última análise, de acordo com o art. 168 da Constituição de 1946, que expressamente estabelecia:

«A legislação do ensino adorará os seguintes princípios:

VI - para o provimento das cátedras, no ensino secundário oficial e no superior oficial ou livre, exigirse-á concurso de títulos e provas. Aos professores, admitidos por concurso de títulos e provas, será assegurada a vitaliciedade.

VII - é garantida a liberdade de cátedra».

Com a neva Constituição de 1967, o assunto, calorosamente discutido no Conselho de Educação, perdeu muito de sua razão de ser.

De fato, o ar'. 168, $\S 3^{\circ}$, inciso $\mathrm{V}$, suprimiu a palavra cátedra e extinguiu, por omissão, a exigência de concurso para o magistério do ensino livre e o privilégio da vitaliciedade assegurada aos professores admitidos por concurso de títulos e provas:

$« \mathrm{O}$ provimento dos cargos iniciais e finais das carreiras do magistério de grau médio e superior será feito, sempre, mediante prova de habilitação, consistindo em concurso de títulos e provas quando se tratar de ensino oficial».

Mas, sob outros aspectos, sobretudo como valor documental, o debate de 1963 no Conselho Federal de Educação é de indiscutível atualidade, diremos até que êle esclarece o sentido do dispositivo constitucional acima mencionado e a inegável conquista que êle pode representar para o processo de reforma por que passa o ensino superior brasileiro.

Este ensino organizou-se tendo as cátedras como unidade básica. A cátedra, de acordo com a Constituição de 1946, fazia parte de um sistema delineado nos seguintes pontos fundamentais: provimento por concurso de títulos e provas, liberdade de ensino (liberdade de cátedra) e vitaliciedade.

«O regime das cátedras vitalícias, afirma Miguel Reale, representa uma opção por um sistema institucional de ensino, fundado em exigência a que o legislador quis atender, como sejam: a) garantia da vitaliciedade aos membros do corpo docente $(\ldots)$, a fim de serem postos a cobro de perseguições políticas e ideologias, em salvaguarda da «liberdade de cátedra» que a Constituição proclama na alínea seguinte do mesmo artigo, o que 
muitas vezes se olvida; $b$ ) obrigatoriedade de concurso de títulos e provas como processo reputado mais adequado para a seleção dos professores, evitando-se as escolhas de mero favor ou simpatia; c) e mais, em se tratando de entidades mantidas pelos cofres públicos, reconhecendo-se a necessidade de uma forma de seleção que atenda ao princípio constitucional, segundo o qual «os cargos públicos são acessíveis a todos os brasileiros» (art. 184) .

Assim não o entendeu, entretanto, o Conselheiro Rocha e Silva, que preferiu interpretar o art. 168,

«cujo laconismo é de molde a pôr em dúvida a preocupação de estabelecer, como norma, a organização do nosso ensino superior no sistema exclusivo da cátedra»,

em função do veto total ao caput do art. 74 da Lei de Diretrizes e Bases que, se não fosse vetado, consagraria inteiramente o regime de cátedra. Afirmava convictamente o Conselheiro Rocha e Silva:

«A razão me parece óbvia: assim procedendo, vetando o art. 74 na sua totalidade, o Sr. Presidente da República quis deixar claro que a ideia da obrigatoriedade do sistema de cátedras não está implícita no art. 168 da Constituição Federal, o qual deverá ser interpretado à luz do próprio veto ao art. 74 da Lei de Diretrizes e Bases, como indicando pura e simplesmente que, no caso de haver cátedras, serão preenchidas por concurso de títulos e provas, e só aqueles que venceram tais maratonas receberão o título de professor catedrático vitalício. Essa é a interpretação dada pelo bom senso ao valor semântico das palavras utilizadas no art. 168 da Constituição Federal».

O Conselheiro Rocha e Silva pré-invoca, a propósito, a solução sugerida pela Universidade de Brasília:

$« \mathrm{O}$ sistema correto foi o proposto pela Universidade de Brasília, em que a unidade básica é o Departamento e o chefe é eleito dentre os seus membros. Cada Departamento terá certo número de professores, que se encarregarão dos diferentes cursos e trabalhos realizados no Departamento, mas todos em pé de igualdade, correspondendo a iguais deveres, iguais direitos, num sistema de integração que é o único aceitável num Departamento cuja função é realizar os grandes trabalhos de uma Universidade». 
Mas a instituição dos Departamentos é incompatível com a sobrevivência das cátedras. Cátedra e Departamento são realidades que mutuamente se excluem:

$« \mathrm{O}$ que disse, repito, e parece que o Conselheiro Almeida Júnior aos poucos vai admitindo, é a legitimidade e a superioridade do Departamento em relação ao sistema de cátedra. Digo mais; há quase uma impossibilidade de constituir Departamentos como agregados de cátedras.»

«Aqui não se trata apenas de uma interpretação da lei, que poderá ser retorcida de acordo com as conveniências dos interessados. Há aqui um conflito dialético, em que a existência de um torna impossível a criação do outro. A cátedra mata o Departamento, como talvez o contrário também seja verdadeiro: a ideia do Departamento exclui a cátedra.»

«... Quando duas ou mais cátedras se reúnem num Departamento, o que se está criando é uma supercátedra, e o problema que se apresenta é o de escolher quem vai ser, dentre os catedráticos preexistentes, o su.percatedrático que tomará conta da supercátedra que é o Departamento .»

Em sua contestação minuciosa e sistemática, apoiada em pareceres de grandes nomes do ensino jurídico em São Paulo, o Prof. Almeida Júnior procurou demonstrar que cátedra e concurso constituem imperativos constitucionais. E complementou sua intervenção invocando um argumento histórico:

«E é que o ensino superior brasileiro sempre se baseou na cátedra, com exclusão de qualquer outro tipo estrutural. A Lei de 14 de julho de 1831, que disciplinou a eleição da Regência Permanente e as respectivas atribuições, dizia, entre outras coisas, o seguinte, em seu art. 18: «O provimento das carreiras dos Cursos Jurídicos, Academias Médico-Cirúrgicas, Militar e da Marinha, continuará a ser feito como atualmente, precedendo sempre concurso».

E continuava:

«De lei em lei, e, nos últimos tempos, até em duas Constituições nacionais, só se fala em cátedra, sem a menor referência a outra solução para o caso do magistério. Sempre cátedra e unicamente cátedra. De sorte que, ao cuidar do assunto, o Constituinte de 1946 se manteve nas rotas batidas, abertas desde o século anterior. Aludia, pois, ao provimento «das cátedras», destas mesmas 
cátedras que continuariam a exercer no país, com exclusividade, o papel único e privilegiado que vinham desempenhando desde 1928».

Pareceres sobre o art. 168, argumentos históricos, apreciações pessoais sobre a qualidade do ensino superior brasileiro, tudo isto foi lembrado pelo Prof. Almeida Júnior para justificar a origem das cátedras e do concurso para todo o sistema de ensino superior brasileiro, tanto o oficial quanto o livre.

Embora aprovado pelo Conselho em 10 sessão, de 6 de junho de 1963, o Parecer $\mathrm{n}^{\circ}$ 3/63 ficou reduzido, no alcance de seus efeitos pela emenda do então Conselheiro Dom Cândido Padin, aprovado contra os votos dos Conselheiros Almeida Júnior, Francisco Maffet, J. Barreto Filho e Ajadil Lemos, vazada nos seguintes termos:

«Considerando que a Lei de Diretrizes e Bases, no art. 76, só prevê a necessidade e a instituição de professores catedráticos nos estabelecimentos oficiais federais de ensino superior;

Considerando que o texto do inciso VI do art. 168 da Constituição se limita a disciplinar o provimento das cátedras;

Considerando que já se manifestam no meio universitário brasileiro evidentes anseios no sentido de se empreenderem novas experiências em relação à carreira de professor universitário, algumas já autorizadas por este Conselho;

Somos de parecer que os estabelecimentos de ensino superior não oficiais poderão instituir, para a carreira do professor, modalidade própria julgada idónea por este Conselho ou pelo órgão competente para a aprovação de seu regimento».

Como se vê deste s:uscinto relato dos debates, as divergências giravam em torno do art. 168 da Constituição de 1946. Na realidade, o que alguns pretendiam - a este foi em última análise o sentido da emenda ao parecer Almeida Júnior - era introduzir nova forma de organização do ensino, com a criação do Departamento e com a plena consolidação da carreira docente. As objeções apresentadas e os desencontros de opinião decorreram sobretudo do fato de a cátedra ter sido encarada como elemento ou unidade administrativa incompatível, por sua natureza, com a estrutura departamental e com a carreira docente.

A legislação do ensino, anterior e posterior à Constituição de 1946, já dispunha sobre a existência de cargos e funções do magistério sem 
considerar o regime de cátedras. A Lei $\mathrm{n}^{\circ} 3.780$, de 12 de julho de 1960, ao classificar os cargos públicos federais, inclui na função do magistério, além do «professor catedrático» o «professor do ensino superior» o «assistente de ensino superior», o «instrutor de ensino superior» e o «professor de ensino agrícola». Anteriormente, entretanto, o Decreto-lei $\mathrm{n}^{\circ}$ 8.393, de 17 de dezembro de 1945, que instituiu as linhas gerais da reforma da Universidade do Brasil, estabeleceu que «a Universidade não poderá dispensar o concurso de titulos e provas para a admissão de professores efetivos (art. 24, letra D). Mas, completando esta orientação, o mesmo Decreto-lei acrescenta logo a seguir: (letra $h$ ) «as Faculdades e Escolas serão organizadas em departamentos, constituído o professorado em quadros de uma carreira de acesso gradual c sucessivo» (o grifo é nosso). Assim, o Estatuto da Universidade do Brasil, no seu art. 48, instituiu a carreira do magistério e o modelo por êle instituído foi reproduzido, algumas vezes com pequenas alterações, em todas as Universidades que posteriormente foram criadas e federalizadas. O quadro do magistério federal, depois da criação de diversas categorias docentes e da organização de carreiras nos próprios estatutos e regulamentos de cada unidade, ficou assim com estrutura dual: de um lado, os professores efetivos ou catedráticos, investidos nos cargos mediante concurso de títulos e provas; e, de outro lado, as demais categorias docentes, providas por indicação do próprio catedrático e aprovação das autoridades superiores. Precisamente esta dualidade estrutural, que não integra a cátedra na carreira e a carreira no Departamento, é que vem dificultando a reforma da Universidade brasileira. Os cargos do magistério não providos mediante concurso de títulos e provas permaneceram, a partir da Constituição de 1946, num regime sui generis, pois o que mais importava, de acordo com o preceito constitucional, era o provimento efetivo das cadeiras mediante concurso de títulos e provas e não a carreira do magistério, que, bem ou mal, se constituiu independentemente da existência de qualquer dispositivo constitucional.

A Constituição de 1967 alterou, entretanto, fundamentalmente a situação, ao revogar o privilégio da vitaliciedade e ao instituir o regime da carreira docente, mediante concurso de títulos e provas para os cargos iniciais e finais. Nesse novo contexto constitucional, a cátedra deve ser uma posição: o professor catedrático, titular ou pleno, como se the queira chamar, não deve ser o privilegiado beneficiário de uma estrutura até agora dual, mas elemento integrado na carreira docente, precisamente aquele que, pelos méritos e expriências comprovados em concurso de títulos e provas, alcançou o degrau mais alto, o último degrau dessa mesma carreira.

Não será outro, cremos, o entendimento do Parecer o» 281/67 do Conselheiro Valnir Chagas, aprovado na Câmara do Ensino Superior, em 5 de julho de 1967. Sem chegarmos ao extremo de dizer, como o ilustre relator, que a cátedra é «mero fantasma verbal» de uma 
«realidade morta». entendemos, entretanto, ter chegado a hora de uma redefinição da cátedra dentro de uma estruturação da carreira do magistério superior, pois, «a partir de quando se esboçaram novas categorias de pessoal docente, a cátedra periclitou como critério de organização; e no momento em que esse processo chega ao fim, com sua eclosão no dispositivo constitucional próprio e substituição, na lei ordinária e na prática, por uma carreira unificada em plano departamental, não seria a persistência de mero fantasma verbal que teria a força de exumar urna realidade morta» (Documenta 73, julho de 1967, pág. 63).

\section{3}

Nesta nova definição, a cátedra, despojada do privilégio da vitaliciedade de seus titulares, deixa de ser, na estrutura universitária, a unidade básica do ensino e da pesquisa, e em seu lugar deve emergir e consolidar-se o departamento, unidade colegiada de ensino e pesquisa, a qual se integram as diversas categorias da carreira docente, hierarquicamente estabelecidas. E isso de modo que, na medida do possível, a carreira não se afunile, convergindo no final para um único cargo: o de professor catedrático. Para que este objetivo venha a ser atingido, é preciso que todos os que ingressem na carreira docente tenham o direito de alcançar, pelos trabalhos realizados e pelos concursos vencidos, a posição mais alta. As categorias de assistente, adjunto e professor titular, pleno ou catedrático, devem fundar-se no mérito do docente ou pesquisador, devem ser muito mais uma «posição» na hierarquia da estrutura departamental do que um cargo a ser preenchido só quando vago. Somente assim, a «posição» de catedrático deixa de ser o privilégio de alguns e se transforma num estímulo para a completa integração departamental.

No Decreto-lei $n^{o}$ 53, de 18 de novembro de 1966, que fixou «princípios e normas de organização para as Universidades federais», e no Decreto-lei $\mathrm{n}^{\circ} 252$, de 28 de fevereiro de 1967, que estabeleceu normas complementares ao decreto de 18 de novembro, os departamentos são definidos como subunidades de cada Universidade Faculdade, Escola ou Instituto (Decreto-lei n' 53, art. $2^{\circ}$, inciso I, combinado com o art. 2", caput, do Decreto-lei $n^{9} 252$ ). No $\S 1^{\circ}$ do art. 2" do Decreto-lei n" 252, o departamento é definido como «a fração da estrutura universitária, para todos os efeitos de organização administrativa e didático-científica e de distribuição do pessoal». Parece-nos que esta orientação de todo para as partes, de unidade para a fração, de cima para baixo, poderá eventualmente comprometer o alcance da reforma universitária, porque mais desagrega serviços de pesquisa e ensino pela sua incorporação em novas unidades previstas do que os integra, numa estrutura universitária organizada.

$\mathrm{Na}$ reforma do ensino superior, o ponto de partida será, sem dúvida, a constituição dos departamentos como a unidade básica, a 
célula das estruturas administrativas mais complexas (institutos, faculdades, escolas, colégio superior), na qual se integram cadeiras $\mathrm{e}$ disciplinas idênticas e afins, perseguindo objetivos comuns, numa área determinada do ensino e da investigação, e com competência definida e orçamento próprio.

Parece-nos de capital importância o entendimento exato do que seja a organização departamental numa Universidade norte-americana, antes de adorarmos ou aconselharmos organização semelhante para $o$ Brasil, ou pelo menos para algumas Universidades brasileiras. Tentaremos, por isso mesmo, definir o departamento e dar uma ideia de sua posição nas Universidades norte-americanas. Mas aqui se impõem dois reparos de sua importância. O primeiro é que não há nos E.U.A. um sistema uniforme. Não existe um padrão universitário único a ser aplicado, nem para fins internos, nem para fins de exportação. Domina a heterogeneidade. Nas páginas que se seguem, tentaremos extrair desse mundo diverso e por vezes confuso, um padrão médio ideal. $O$ segundo reparo é que o termo «departamental» vem sendo tão mal usado em nosso país, que alguns educadores, naturalmente revoltados, resolveram abandoná-lo. Preferem falar em «unidades docentes». Professores ambiciosos chamam as próprias cátedras de departamento, sem a menor cerimónia. A tendência é majorar os títulos, promover as patentes, marechalizar as designações. O que nos Estados Unidos da América é apenas um departamento, é aqui rotulado, de pronto, como instituto (=college). Devemos admitir a razoabilidade de certa confusão entre departamento e instituto, dados os antecedentes da palavra «instituto» em nossas escolas superiores. Mas, desde que se passou a usar a palavra «departamento», com a qual «instituto» tinha alguma correspondência, torna-se necessário reajustar ambos os sentidos. Acreditamos que «instituto» deveria corresponder melhor ao que nos Estados Unidos se chama college. Nas Universidades norte-americanas não costuma haver institutos (=colleges) de Química, e sim, mais vezes, departamentos. Não há institutos (=colleges) de Matemática, apenas departamentos. $O$ estudo da Economia se faz em departamentos e não em institutos, escolas ou faculdades. O departamento de Economia estará integrado, é claro, em algum college, como seja no College of Business, da Universidade de Michigan, ou no College of Letters and Science, tanto na Universidade de Wisconsin, quanto na Universidade da Califórnia (Davis), ou, ainda, no College of Social Science, como ocorrerá em outras Universidades.

No Brasil temos Universidades com vários «departamentos» de Química Orgânica, cada qual pertencente a uma Faculdade. Reunidos e não integrados, formam o «conjunto das químicas». Enfim, a eterna dança de nomes que se observa em todas as reformas administrativas 
Departamento é uma unidade administrativa de ensino e de pesquisa, que reúne professores e técnicos de uma disciplina, ou de um conjunto de disciplinas de determinada área do conhecimento (disciplinary integrity), e em cujo âmbito o estudante pode conquistar os títulos de bacharel em ciências, letras ou artes e ainda títulos de pós-graduação correspondentes ao mestrado e ao doutorado. O Departamento oferece também cursos para estudantes não especializados em sua área, mas que desejam obter créditos para satisfazer requisitos gerais da Universidade e/ou de suas escolas profissionais. Também pode um estudante frequentar um departamento por puro interesse pessoal.

O ensino nas escolas ou faculdades profissionais é ensino de pós-graduação, dada a exigência, cada vez mais generalizada, de que o aluno possua um grau acadêmico (pelo menos B.A. ou B.S.) para nelas ingressar. Os departamentos das escolas profissionais de pósgraduação (Medicina, Direito, Saúde Pública, Jornalismo etc.) são organizados a fim de propiciarem em seu conjunto a instrução necessária à obtenção de um titulo profissional.

Como se vê, a Universidade confere graus acadêmicos (B.S. ou B.A., M.A., ou M.S., Ph.D. etc.) e graus profissionais (M.D., L.L.D., M.B.A. etc).

A palavra «departamento» tem significado um pouco diferente quando se trata de ensino propriamente acadêmico e de ensino de pósgraduação profissional. Até mesmo no ensino de pré-graduação (undergraduates), existem alguns «departamentos» que, por sua natureza, não conferem graus acadêmicos, tais como os de Inglês, Ciências Naturais. Ciências Sociais Humanidades. São apenas services departments, destinados a todos os alunos, tão logo ingressam na Universidade. Esses «departamentos» formam um basic college, têm um diretor (= dean) e representam, em seu conjunto, um esforço para dar aos que entram as seguintes habilitações, segundo se lê no Catálogo de 1967 de Michigan State University:

\section{Language Skills.}

2. Knowledge of our cultural herítage.

3. Understanding of the principies at work in the natural and social sciences.

•4. Recognition of humane válues and the dignity and responsibilities of the individual.

5. Familiarity with mans creatiue achievements.

6. Moral awareness.

Basic college não quer dizer que as matérias que o constituem, em geral quatro, sejam ensinadas antes de quaisquer outras. A colocação desse ensino básico pode ser horizontal ou vertical. Na Michigan State 
University, o estudante deve distribuir o aprendizado dessas matérias dentro dos trimestres dos dois primeiros anos.

Em resumo, além do verdadeiro departamento acadêmico, existem os purety service departaments, e os departamentos das escolas profissionais. Convém ter em mente essa distinção antes de se adotar no Brasil, sem maior exame, o termo departamento que, a nosso ver, só deverá ser usado para os casos correspondentes ao que chamaríamos de departamento verdadeiro.

Só deveriam merecer o nome de departamento aquelas unidades de ensino e de pesquisa nas quais haja integração, ou seja, nas quais se ministra ensino para estudantes de mais de uma escola profissional. Integração de finalidades ou de objetivos, como se vê, e não de assuntos. Haverá Departamento de Química quando, dentro de seu âmbito, estudarem alunos de várias Faculdades, como a de Medicina, Farmácia, Filosofia, e assim por diante. O Departamento é uma unidade teleológica.

Se, dentro de uma faculdade profissional, como a de Medicina, integrarmos a clínica obstétrica e a clínica ginecológica numa só unidade, não estaremos constituindo um departamento de ginecotocologia! A não ser que nessa unidade passem a estudar também enfermeiras obstétricas, parteiras e obstetrizes. Se juntarmos numa mesma unidade clínica médica e clínica cirúrgica, nem por isso tal unidade didática, a despeito de sua vastidão, merecerá o nome de departamento, por que só será frequentada por médicos e estudantes de Medicina. A clínica oftalmológica não pode constituir um departamento, porque somente frequentarão essa clínica estudantes de Medicina ou médicos já formados. Poderia ser considerada departamento, se através dela a Faculdade ou Universidade conferisse o diploma de ortopsia a profissionais não médicos. Na Universidade da Califórnia (Berkeley), o curso de opto metry se perfaz, entretanto, com quatro anos de estudos numa School of Optometry, durante os quais o aluno precisará obter os créditos necessários nas seguintes matérias ensinadas em seus respectivos departamentos: Inglês, Geometria Analítica, Química Geral, Química Orgânica, Física, Biologia e Psicologia. Após os quatro anos, recebem o título de «doutor em Ortopsia». Se amanhã, numa Faculdade de Direito, reunirmos os professores de Direito Constitucional, Direito Internacional Privado, e Direito Administrativo, nem assim a unidade resultante será um departamento, a não ser que essa unidade didática se destine a servir às necessidades de mais de uma faculdade profissional.

Mais um exemplo: falamos num Departamento de Economia, com muito acerto, porque neste departamento, além do ensino específico para economistas, se fornecerá o que fôr pedido de ensino de Economia para sociólogos, advogados, administradores públicos e de empresa, contabilistas e até para agrónomos.

Quem não quiser aceitar estas advertências e discriminações chame tudo de «departamento», vá lá, mas, pelo menos, procure entender a 
diferença entre o departamento autêntico, polivalente e o «departamento» univalente, no qual não existe a integração de finalidades, nem a serventia múltipla. Nosso prognóstico, aliás, é que a expressão «departamento» se há de generalizar, cobrindo tanto o departamento polivalente quanto o «departamento univalente, porque boa discriminação vocabular exige certo esforço de análise, ao qual se opõe o princípio da inércia, que pesa enormemente sobre o comportamento das pessoas.

Os graus acadêmicos são conferidos pela Universidade na base dos seus diferentes departamentos. O nome do grau indica uma área bem mais larga do que o campo de especialização que propiciou o grau. Assim B. S. (bacharel em ciências) pode referir-se tanto a alguém que se diplomou em Química, como a alguém que se diplomou em Geologia. Um economista escreverá assim: $B . S$. (economics). Nem todos os departamentos podem oferecer títulos de mestrado e de doutorado. Se um departamento quiser conquistar tal prerrogativa, deverá apresentar o respectivo pedido à Congregação, que delibera acerca dos programas de pós-graduação, habitualmente designada como a Graduate Faculty de determinada Universidade.

Convém esclarecer que expressões como graduate school e faculty não designam uma escola com prédio próprio ou um edifício determinado, mas correspondem a uma organização universitária com várias funções administrativas.

O conjunto de professores de um college é designado como faculty. Em português diríamos «Congregação». A expressão graduate school abrange os professores, administradores, estudantes e programas de todos os departamentos acadêmicos de uma Universidade, nos quais se podem obter os títulos acadêmicos de pós-graduação (M.A., M.S., e Ph.D.), tal como já foi dito. Mas esses departamentos são os mesmos onde se obtém os títulos de B.A. e B.S.

Cabe ainda um esclarecimento: nos E.U.A, não se fala em pós-graduação. Aquilo que chamaríamos ensino de pós-graduação é chamado lá de ensino para graduados, tendo em vista que tal ensino é ministrado a graduados, enquanto o ensino destinado a graduações é chamado de undergraduate studies, dado que seus alunos são undergraduates, ou seja, pré-graduados. No Departamento se fazem os undergraduate studies (graduação) e a graduation (pós-graduação). Enfim, o nome em português vem do alvo, da finalidade, em inglês vem da qualidade do estudante que fêz o curso.

A obtenção de determinados graus acadêmicos permite, por si só, o exercício de diferentes profissões, tais como a do engenheiro, nos seus diferentes ramos, para o que basta o B.S. em engenharia civil, ou engenharia aeronáutica, ou engenharia elétrica, ou engenharia mecânica ou metalúrgica, e assim por diante. O conjunto dos departamentos referentes à Engenharia é chamado de College of Engineering, como acontece, por exemplo, no campo Davis. da Universidade da Califórnia. 
Para atuar como verdadeiro profissional nos campos de Astronomia, Física, Economia, necessita-se de um Ph.D. na respectiva matéria, ou pelo menos de um M.S. A sistematização profissional não obedece, portanto, a um critério uniforme.

Para ser professor no ensino secundário, é necessário ter grau acadêmico em «Educação». O aluno que desejar ensinar Física no secundário poderá obter grau referente a «Educação, com especialização em «Física», e assim por diante. As possibilidades de arranjo combinatório são muitas.

Quanto às escolas profissionais, surge inevitavelmente alguma ambiguidade na caracterização. Algumas dessas escolas (que nós chamamos faculdades) se desenvolveram, no passado, longe e independentemente da Universidade, tais como as Escolas de Direito, de Medicina, de Teologia. Outras, como a escola profissional de business administration, de criação mais recente, surgiram dentro da Universidade. Assim, o ensino profissional específico pós-graduado que elas ministram é ministrado dentro dos departamentos da graduate school, o que não ocorre com a Medicina.

A obtenção do grau (profissional) de doutor em Medicina exige normalmente oito anos de estudos, assim distribuídos: quatro anos de estudos universitários básicos, e quatro anos de pós-graduação na Escola Profissional de Medicina, findos os quais o aluno recebe seu M. D. Para que êle possa atuar como médico, deverá, depois disso, submeter-se a exame perante o Estado no qual deseja clinicar. Há diplomas estaduais que são reconhecidos em outros Estados da Federação, na base de reciprocidade. Até o momento não há licenças federais.

Sirvam estes exemplos para dar uma ideia da variedade de aspectos da vida universitária norte-americana.

O sistema universitário departamental, nos moldes propostos, representa solução para inúmeros problemas. Dele decorre, naturalmente e imperiosamente, o estabelecimento do sistema de créditos, que leva o aluno a escolher êle próprio, entre vários caminhos, o que mais the convém. Um sistema de créditos pode ser adotado dentro de uma organização não-departamental de ensino, é certo e sabido, mas funciona muito melhor dentro da organização departamental. Isso é indiscutível. Uma vez na Universidade, o aluno que escolher determinada carreira poderá a tempo modificar sua escolha, fazendo uso dos créditos obtidos, sem muita perda de tempo. Embora não ficando obrigado ao regime rígido de seriação, deverá, entretanto, o aluno fazer em algum momento sua opção acadêmico-profissional, provavelmente ao término do segundo ano, como acontece nos E.U.A. Esta opção, a ser julgada pelas autoridades competentes, não é arbitrária, e dependerá do desempenho anterior, dos cursos feitos e dos créditos obtidos.

Os anos básicos para a obtenção do primeiro grau acadêmico (B.S. ou B.A., ou outro nome que lhe venha a ser dado no Brasil) 
são quatro nos Estados Unidos da América. No primeiro ano o aluno é freshman, no segundo sophomore, depois júnior e, finalmente, no quarto ano, sénior. A tendência é alargar a base humanista e cultural de todos os alunos, qualquer que seja a profissão escolhida, e isso significa progresso. A medida que se progride tecnologicamente, trabalha-se menos e se estuda mais. E procura-se evitar a formação de tecnicistas confinados, de estreita visão.

Após quatro anos, o aluno obtém o grau acadêmico, que tem, em muitos casos, valor profissional, conforme o currículo que houver sido feito. Isso permitirá, por exemplo, dentro do Colege of Engineering da Universidade, a diplomação completa em Engenharia mecânica ou elétrica, ou metalúrgica, ou agrícola, ou especial, e assim por diante. Se depois algum desses engenheiros desejar título profissional mais amplo, bastarlhe-á obter um grau acadêmico mais elevado, como seja o mestrado ou o doutorado. E esse grau acadêmico mais elevado terá ainda maior valor profissional.

Pode acontecer que, no Brasil, não se consiga de pronto inserir dentro do quadriénio acadêmico básico tudo quanto um engenheiro deve saber. Então ministrar-se-á um ensino pós-graduado de Engenharia. Se se vier a considerar que uma disciplina ou cadeira de Engenharia como a Química aplicada não poderá integrar-se no departamento de Química, essa disciplina virá a constituir uma cadeira não-departamental, ou um departamento univalente do ensino de pós-graduação.

No caso de Medicina, em que o grau acadêmico inicial é insuficiente para o exercício profissional, o aluno munido desse primeiro grau irá buscar numa Faculdade de Medicina, dentro ou fora de sua Universidade, o ensino profissional. Mas, dentro do Instituto Bio-Médico da Universidade, o grau acadêmico inicial, conforme o currículo feito, já será suficiente para conferir um título de biologista, bacterologista, farmacêutico, bromatologista industrial, e assim por diante. O farmacêutico que desejar um grau maior poderá tirar seu mestrado ou seu doutorado em algum dos assuntos básicos de seu currículo departamental. A legislação irá aos poucos dizendo quais os cargos para cujo desempenho se exigirá de um farmacêutico o mestrado ou o doutorado.

Os anos básicos da Universidade, em número de quatro, podem ser reduzidos a três e até a dois. Neste último caso. o número de matérias integradas será proporcionalmente menor, e a duração dos cursos nas faculdades profissionais necessariamente maior. Em vez de um quadriénio, poderemos ter um triénio. A nosso ver, devemos adotar o sistema de quatro anos, permitindo-se, todavia, aos alunos que o desejarem, a obtenção em três anos dos créditos correspondentes aos quatro anos normais. Programar-se-ia a obtenção dos diferentes títulos em tempo médio de quatro anos, mas tornando possível sua consecução em 
três anos, assim como se permitiria que as matérias do quadriénio fossem feitas em cinco ou seis anos para os que tivessem menos capacidade ou menos tempo disponível para o estudo. Deve haver limites a essas variações. Para obtenção de grau acadêmico, há que exigir certo número de créditos, dentro de um tempo estabelecido. Quem se mostrasse incapaz de corresponder a essa exigência, poderia frequentar a Universidade como um non-degree student.

A duração do ensino profissional específico pós-graduado (entendendo-se por graduação em título correspondente ao B.S. ou B.A. norte-americanos) será tanto maior quanto maior fôr o número de disciplina que não puderem ficar integradas nos departamentos do quadriénio acadêmico.

Todas as matérias passíveis de integração devem ser estudadas nos departamentos daquilo que poderíamos chamar de anos acadêmicos, os quais podem servir tanto para as exigências de graduação (= undergraduate studies) quanto para eventuais exigências de pós-graduação (= graduate studies) académica ou profissional. Além disso, haverá matérias, disciplinas ou cadeiras que são por natureza inintegráveis, como, no campo da Medicina, a clínica oftalmológica, a pediatria, a clínica médica, a clínica cirúrgica. A parasitologia é uma cadeira facilmente integrável, porque, tanto no que se refere ao ensino quanto no que tange à pesquisa, ela corresponde às necessidades de médicos, de sanitaristas, de farmacêuticos, de zoólogos e de veterinários.

São sobretudo essas cadeiras inintegráveis ou ainda não integradas que formam as escolas profissionais de pós-graduação.

A nosso ver, as disciplinas não integradas poderiam ser ensinadas em cátedras, mas essa designação desapareceu do dispositivo constitucional referente aos cargos do magistério. Falemos então em departamentos univalentes. Essa distinção, utilíssima de nomenclatura, entre o que chamaríamos «cátedra» e o departamento não existe no ensino norte-americano, onde tudo se chama departamento. Mas, repetimos, ela seria útil. O que nos fascina no departamento ê a integração plurivocacional, e sua distinção múltipla, e não o simples vocábulo. O departamento pode até, eventualmente, ter como objeto o estudo de uma única disciplina, mas com serventia múltipla. Assim, é admissível um departamento de Química Orgânica apenas, embora fosse melhor que a Química Orgânica, sem nada perder de sua individualidade, pertencesse ao departamento de Química.

Cabe aqui um último esclarecimento. Nos departamentos poderá haver, funcionando lado a lado, vários professores plenos, enquanto na cátedra, só haverá um catedrático em exercício. A carreira departamental, por sua natureza, não pode ser comparada a um cone. Será, quando muito, um tronco de cone, com propósitos múltiplos, aberto tanto para estudantes com vocações profissionais diversas quanto para a variedade de aspirações extraprofissionais de seus corpos docentes e discentes. E aberto ainda à promoção de cada professor, dependendo do mérito real de cada um, e não do número de vagas. 
No que diz respeito à expressão «professor pleno», correspondente a fali professor, haverá quem prefira outras, como a de «titular». Também poder-se-á dizer apenas «professor», sem qualquer adjetivo. Questão de gosto. Para o nosso, «professor pleno», é designação excelente.

Quanto à expressão «professor catedrático», ela seria boa. Mas é hoje designação obsoleta. Quaisquer que sejam os nomes, o que nos cumpre é colocar as coisas nos devidos lugares. O ensino das matérias não-integráveis é ensino de mestre para artífice, e exige em sua ministração comando mais pessoal. Mas falaremos apenas em «professor», dado que a expressão «catedrático» está destinada a desaparecer. Em nosso país a tendência é variar os rótulos, muito mais do que o conteúdo das coisas. Na Inglaterra, muda-se o conteúdo, conservando-se os velhos rótulos. Já na Alemanha, gosta-se de mudar o conteúdo e rótulo. Enfim, cada povo tem suas preferências.

Acreditamos que esses esclarecimentos propiciarão um melhor entendimento do plano universitário que, muito por alto, está sendo apresentado, e que corresponde, em boa medida, ao desejo já muitas vezes expresso por inúmeros educadores brasileiros. Em suas linhas gerais, êle já está sendo tentado em algumas de nossas Universidades.

Não pretendemos, por outro lado, que todo ensino superior seja organizado dentro do sistema departamental, tal como foi esboçado nesta exposição. Respeitadas as linhas fundamentais do Decreto-lei $\mathrm{n}^{\circ} 53$, de 18 de novembro de 1966, às Universidades se deve dar liberdade de escolha aos seus métodos de ensino e de pesquisa, conforme reza o art. 70 da L.D.B., que diz:

«O currículo mínimo e a duração dos cursos que habilitem à obtenção de diploma capaz de assegurar privilégios para o exercício da profissão liberal serão fixados pelo Conselho Federal de Educação».

Acreditamos até que, em relação às nossas Universidades mais antigas, será melhor não forçá-las demais à mudança de suas estruturas. Mas, em relação a Universidades que vierem a ser fundadas, deveria ser adotado, em toda a plenitude, o sistema departamental. É até bom que haja Universidades organizadas diferentemente. $E^{\prime}$ bom que haja escolas superiores isoladas. Aos poucos irá surgindo um sistema que refletirá melhor as necessidades brasileiras, e traduzirá nossos anseios de aperfeiçoamento e o desejo de cura dos males nacionais. O que importa é que pessoas e órgãos altamente colocados, como é o caso do Conselho Federal de Educação, não impeçam as transformações necessárias, e procurem estimular as soluções mais adequadas, freando ao mesmo tempo as soluções aviltantes para o ensino e para o progresso do Brasil. 


\section{A ORGANIZAÇÃO DOS CURSOS INTEGRADOS}

Um dos elementos fundamentais para conseguir-se a integração universitária serão os chamados cursos básicos, entendidos de forma mais ampla do que na sua conotação usual. Os cursos básicos, ou melhor, cursos de integração, a serem dados em nivel departamental, podem ser entendidos de duas maneiras complementares e coexistentes numa mesma Universidade: 1", cursos de caráter propedêutico, constituídos pelas matérias introdutórias aos cursos profissionais, que serão objeto das opções futuras dos estudantes; $2^{o}$, cursos de cultura geral, destinados a reforçar a formação básica dos estudantes e a permitir-lhes integrar os conhecimentos mais especializados dentro de uma visão abrangente da vida e da cultura. No primeiro caso, incluem-se disciplinas comuns a diversas opções intelectuais e profissionais posteriores, como é o caso dos conhecimentos de Química, Física, Matemática, Biologia Geral, etc, indispensáveis à escalada intelectual nos diversos ramos da formação científica mais especializada. As opções, neste caso, variarão naturalmente mais em função de uma tendência intelectual que começa a ser aferida desde os primeiros momentos da vida universitária, do que de uma opção definitiva e irretratável, como se costuma fazer hoje em dia. No segundo caso, trata-se de optar por matérias de formação geral, como a Filosofia, a História, as Letras etc. que se tornarão parte obrigatória do currículo individual, desde que livremente escolhidas. Essas disciplinas, colocadas desde início dos trabalhos escolares, além de ajudarem na própria definição dos destinos intelectuais de cada estudante, pela possibilidade de uma redefinição e onfronto crítico de valores intelectuais, eliminarão o perigo de isolamento e de uma visão distorcida e particularista a que pode levar a especialização profissional. Este sistema permitirá ao aluno a composição do seu programa de estudos, com a assistência de um serviço central de aconselhamento vocacional, em colaboração com os diversos departamentos. O programa de estudos, assim formulado, será obrigatoriamente cumprido, através da frequência às aulas teóricas e práticas, 'eituras, seminários, estudo dirigido e de verificação do aprendizado. É evidente que, no fim de cada período escolar, o estudante poderá redefinir o seu programa, desde que alcance uma média satisfatória de desempenho, alterando para o período seguinte algumas das opções anteriormente feitas. 
Esses cursos básicos, que preferimos denominar cursos integrados, poderão realizar-se horizontal ou verticalmente, isto é, poderão concentrar-se nos dois primeiros anos acadêmicos ou, como seria preferível, no caso das disciplinas de cultura geral, estender-se por todos os anos da vida universitária de um estudante, diminuindo, naturalmente, a sua importância e a carga horária e de trabalho correspondente, à medida que êle avance nos estudos. Desta maneira, os cursos básicos, ao invés de serem simplesmentente cursos de transição, isto é, o alicerce, ou melhor, o patamar ou vestíbulo da vida universitária propriamente dita, como têm sido habitualmente concebidos, passariam a ser a ossatura fundamental, o liame integrador dos estudos superiores. 


\section{CRIAÇÃO, NA ADMINISTRAÇÃO CENTRAL, DE SERVIÇOS DE ACONSELHAMENTO VOCACIONAL}

O sistema que propomos exigirá, para adequado funcionamento, a criação de um serviço técnico de aconselhamento vocacional, diretamente subordinado à administração da Universidade. A dimensão universitária dos serviços que prestará obriga a sua vinculação direta aos órgãos administrativos centrais da Universidade e não simplesmente a um Departamento especializado. Por outro lado, o caráter meramente auxiliar e consultivo desse órgão impedirá o seu crescimento desmesurado e mesmo a natural tendência para assumir papel preponderante nas decisões e na própria orientação vocacional, o qual deve caber fundamentalmente aos departamentos. O serviço de aconselhamento deverá ter um sentido estritamente técnico e acadêmico, sem nenhum caráter assistencial, clinico ou de orientação pessoal; deverá apenas fornecer subsídios, prestar informações e criar condições básicas para o esclarecimento individual e o autoconhecimento dos estudantes, e para a distribuição dos mesmos no seio dos diversos departamentos da Universidade.

As funções do serviço de aconselhamento vocacional, realizadas em estreito contato com os diversos departamentos, podem ser assim delineadas:

$1^{\circ}$, examinar candidatos ao ingresso na Universidade e, por solicitação, os próprios alunos da Universidade, sob os pontos de vista intelectual, de conhecimentos e de personalidade;

$2^{\circ}$, participar da coordenação dos exames vestibulares à Universidade, cooperando com os departamentos e demais órgãos incumbidos de sua realização;

$3^{\circ}$, organizar o cadastro dos alunos, catalogar as informações a respeito deles, mantendo-se atualizado, através de constante acompanhamento durante todo o curso. 


\section{A REDIFINIÇÃo dO PERÍODO LETIVO}

O art. 72 da Lei de Diretrizes e Bases, ao estabelecer que «será observado, em cada estabelecimento de ensino superior, na forma dos estatutos e regulamentos respectivos, o calendário escolar, aprovado pela Congregação, de modo que o período letivo tenha a duração mínima de 180 (cento e oitenta) dias de trabalho escolar efetivo, não incluindo

tempo reservado a provas e exames», identificou indevidamente o período letivo com o ano escolar. No novo regime que propomos, torna-se indispensável uma total reformulação das ideias e práticas vigentes relacionadas com o período letivo.

De início, cumpre deixar de lado definitivamente o ano letivo como ponto de referência, como unidade de medida do tempo escolar, pois cada vez mais êle se revela uma unidade inadequada, de dimensões muito amplas e de valor desigual, que deve ceder passo a unidades "ais compactas, de mais fácil manuseio e de valor relativamente constante.

Propomos, assim, com a renovação do mencionado artigo da Lei de Diretrizes e Bases, a substituição do atual período ou ano letivo por três ou quatro períodos letivos de duração variável, trimestrais ou, no máximo, quadrimestrais - mas de valor equivalente. A equivalência decorrerá fundamentalmente da carga horária semanal e, portanto, da carga útil de atividade académica, ao invés - como se dá presentemente - dos dias de duração do período. Desta forma, os cursos se dividirão em períodos letivos a serem densamente empregados na realização de determinado programa, com cargas semanais de aulas, seminários, sessões de estudo, aulas práticas, leituras obrigatórias, etc.

Se se fôr tomar por base do novo sistema o curso de três ou quatro meses - a que se poderia acrescentar o de dois meses, a realizar-se intensivamente, com sentido de recuperação, nas férias académicas torna-se necessário proceder a algumas alterações radicais em certos usos que tão profundamente marcam o sistema atual. Seria preciso, de início, abolir o sistema seriado, estabelecendo-se, para substituí-lo, um outro, de atendimento de exigências fundado na complementaridade de cursos, a ser definido nos regimentos departamentais ou escolares. 


\section{ESTABELECIMENTO DE UMA POLITICA DE INCENTIVO À PESQUiSA CIENTIFICA, COM O APOIO SOLIDÁRIO DO TRINOMIO ESTADO-UNIVERSIDADE-EMPRÊSA, ESTREITAMENTE LIGADA AOS PROGRAMAS DE PÓS- -GRADUAÇÃO UNIVERSITÁRIA}

O aperfeiçoamento do pessoal de nível superior assume hoje em nosso país, particularmente em razão do acelerado processo de desenvolvimento social e econômico brasileiro, importância de tal ordem, que êle se torna um dos capítulos obrigatórios de qualquer estudo sobre a reforma universitária nacional. Há que elaborar-se um programa de pós-graduação, voltado para a solução de alguns dos mais graves problemas que dificultam o progresso brasileiro: a carência de pessoal docente de nível superior, o imperativo da abertura de novas fronteiras no domínio da pesquisa científica e de formação de pesquisadores de alto nível, a exigência de manter a investigação científica do país em nível compatível com os padrões científicos internacionais e, finalmente, a necessidade de um trabalho de «reciclagem» para atualização de conhecimentos e técnicas dos profissionais graduados em escolas superiores. Urge assim promover uma política nacional de amplo incentivo à pesquisa científica nos diversos domínios do saber, a qual possa contar com o apoio solidário do trinômio Estado-Universidade-Emprêsa, de modo que atenda aos imperativos da segurança, da ciência e da produtividade.

A política que preconizamos deve orientar-se particularmente para a criação nos centros universitários mais bem dotados, de cursos de pós-graduação - de mestrado e de doutorado - com um sistema de bolsas e incentivos, que favoreça aos mais capazes e estimule a especialização nas áreas de maior importância para o país.

Esta política não pode esquecer os estabelecimentos isolados de ensino superior. $\mathrm{O}$ avultado número de tais instituições, cada uma com pouco, ou nenhum contato com as demais e com as próprias Universidades, e a gravidade dos problemas pedagógicos, técnicos e administrativos que elas enfrentam, fazem que se torne indispensável uma especial atenção para a sua reestruturação. Urge, pois, o estabelecer uma política eficaz de integração dos institutos isolados no sistema de ensino superior brasileiro, de modo que cada um deles, dentro de suas reais possibilidades, venha a desempenhar papel verdadeiramente positivo e 
criador, articulando-se inteligentemente uns com os outros e com as Universidades, redistribuindo-se geograficamente quando necessário, c mesmo redefinindo-se técnica e pedagogicamente, de molde a atender às necessidades das diversas regiões do País.

Recomendam-se, pois, as seguintes medidas:

1?, integração de escolas isoladas em Universidades, com o objetivo de evitar a duplicação de serviços e o baixo aproveitamento dos recursos disponíveis pela competição no oferecimento de vagas e a repetição ociosa do mesmo tipo de atividades;

$2^{9}$, integração regional de escolas, como ponto de partida para uma diferenciação de funções e futura integração em Universidades;

3? , criação ou transformação dos cursos das escolas existentes, com vistas ao estabelecimento de cursos de nível intermediário, nos moldes dos Júnior colleges norte-americanos;

$4^{\circ}$, reexame do problema da autorização para instalação e reconhecimento das escolas isoladas;

5, revisão da situação das escolas existentes, com vistas à redistribuição ou mesmo eliminação daquelas mal localizadas, ou que apresentem baixo rendimento;

$6^{\circ}$ reexame dos requisitos para o ingresso nas carreiras de nível universitário e redefinição do papel das escolas isoladas nesse particular. 


\section{A INSTITUIÇÃO DE CURSOS DE PÓS-GRADUAÇÃO}

! A política mencionada no item anterior terá, na instituição dos cursos de pós-graduação, um de seus elementos fundamentais. Os cursos de pós-graduação, a cargo dos diversos departamentos da organização universitária, deverão contar com a colaboração de todos os professores com qualificação diferenciada: doutores, livre-docentes, professores associados, catedráticos. Não se deve excluir, todavia, a cooperação de especialistas de notória competência, ainda que eles não possuam títulos acadêmicos específicos.

Os cursos de pós-graduação, que, em princípio, só devem ministrarse nas Universidades, deverão estruturar-se como cursos regulares, com aulas, seminários, conferências etc, e com obrigatória verificação do aproveitamento dos alunos. Sugerimos que a duração de tais cursos seja de seis trimestres para mestrado e de mais seis trimestres para o doutorado, podendo-se dispensar o primeiro, a juízo do professor orientador e com anuência do Departamento. Para a obtenção desses graus acadêmicos exigir-se-á defesa de tese fundamentada em pesquisa original, a qual será necessariamente apresentada no final do respectivo curso.

São inúmeras as vantagens que a instituição deste tipo de curso apresenta. Sabe-se, por exemplo, que a formação e o recrutamento do pessoal do magistério constitui hoje um dos pontos de estrangulamento da expansão do ensino superior. Atualmente não há nenhum sistema institucionalizado que cuide da preparação dos professores universitários. Os programas da CAPES e do Conselho Nacional de Pesquisas representam, sem dúvida, apreciável esforço para atenuar as graves falhas existentes. Mas há ainda muito por fazer. Os recursos existentes nas próprias Universidades têm de ser amplamente mobilizados, pela instituição de cursos de pós-graduação, ajudados pelos órgãos competentes das administrações federal e estaduais.

Não só a formação do magistério de nível superior, mas também a pesquisa científica será estimulada com os cursos de pós-graduação. Como os títulos de mestre e doutor estarão condicionados à apresentação de tese fundamentada em pesquisa original, a pós-graduação será poderoso instrumento para a abertura de novos campos ao trabalho da inteligência indagadora.

A pós-graduação, cumpre ainda assinalar, permitirá, por força do sentido eminentemente criador dos trabalhos que a caracterizam, o de- 
senvolvimento de pesquisas avançadas, indispensável, nos dias atuais, ao progresso científico, tecnológico e cultural do país. Dela dependerá, portanto, a eliminação do atraso em que nos encontramos. No setor da pesquisa, a pós-graduação funciona como fator multiplicador. O mestre utiliza melhor as suas potencialidades profissionais, reproduzindo-as criadoramente nos esforços dos alunos pós-graduados que orienta.

Impõem-se, todavia, alguns cuidados especiais. Urge. em primeiro lugar, estabelecer um programa em que se associem harmoniosamente o Conselho Nacional de Pesquisas, o Conselho Federal de Educação, a Diretoria do Ensino Superior e a Comissão de Aperfeiçoamento do Pessoal de Ensino Superior. Em segundo lugar, a pós-graduação, vinculada em princípio à Universidade como um todo, tem de ser realizada pelos Departamentos que disponham de recursos materiais e humanos capazes de ministrar cursos de alto nível. Sob este aspecto, a política governamental deve incentivar as Universidades, mas deve também ser extremamente rigorosa, e desestimuladora, quando verificar pobreza de condições imprescindíveis ao bom e sério funcionamento dos cursos no nível desejável .

Finalmente, importa sobretudo que essa política traduza o persistente empenho de aplicar, em escala ponderável, recursos financeiros. Dos níveis do ensino, a pós-graduação é, sem dúvida, a que assegura mais imediatos multiplicadores do capital investido. 


\section{UMA COMISSÃO PERMANENTE DE ASSESSORA- MENTO - A DESU}

Neste sentido, a atual EAPES há algum tempo enviou ao Sr. Ministro da Educação e Cultura o memorando abaixo:

«A Diretoria do Ensino Superior precisa de uma Comissão Permanente de Assessoramento (CPA), cuja necessidade vem sendo sentida em vários setores. Assim, ela foi prevista no Plano Decenal (Educação e Mão-de-Obra, vol. 1, pg. 83). Os seus membros deverão ter tempo fixo de mandato, e trabalhar em tempo integral, sendo recrutados pelo Diretor do Ensino Superior entre professores universitários, ou pessoas de alta qualificação, com aprovação ou não (assunto a ser discutido) do Conselho Federal de Educação para cada nome escolhido. A CPA virá substituir, com real vantagem, as comissões especializadas, que poderão, entretanto, ser formadas em caráter transitório, toda vez que fôr necessário, sempre com a participação de um membro da CPA. Enfim, as comissões ad hoc referentes a assuntos do Ensino Superior deverão ficar, necessariamente, vinculadas a essa Comissão Permanente.

Como se vê, não se pretende criar mais uma Comissão para sugerir medidas mais ou menos interessantes em matéria universitária. O que se pretende é evitar a proliferação de comissões para cada assunto e para cada emergência, graças à existência de uma comissão central de coordenação e de unificação.

Já se acreditou que algumas das atribuições da CPA deveriam caber antes ao Conselho de Reitores. Cabe esclarecer esse ponto, pois não desejamos entrar em conflito nem com o Conselho de Reitores nem, muito menos, com o Conselho Federal de Educação. Mas o certo é que a necessidade de uma tal Comissão, seja ela constituída pelo próprio Conselho de Reitores, seja ligada à Diretoria do Ensino Superior, vem sendo sentida. Conforme dito, ela foi prevista no Plano Decenal.

Parece-nos pertinente lembrar que, de acordo com o item 1 do Título 3 do Convênio de Assessoria ao Planejamento do Ensino Superior, assinado em 9 de maio de 1967, o grupo brasileiro, constituído de pelo menos quatro educadores de alto nível, é chamado de «Grupo Permanente de Planejamento» junto à Diretoria do Ensino Superior.

A necessidade da criação ou oficialização da Comissão que estamos propondo, foi, portanto, sentida pelos signatários brasileiros do Convênio de 9 de maio de 1967, a saber, o Sr. Ministro Tarso Dutra, o presidente em exercício do Conselho Federal de Educação, Prof. Al- 
ida Júnior, e o representante do Governo brasileiro para a Cooperação Técnica, Prof. Faria Góis.

A DESu deverá possuir, no futuro, pequeno staff, destinado a manter atualizados os dados referentes às necessidades de profissionais em todo o Brasil, a fim de serem corrigidas as disparidades entre procura e oferta no campo do ensino superior.

Não se pretende com isso que a DESu execute diretamente esse trabalho de pesquisa, pois já existem órgãos governamentais e instituições privadas que realizam a tarefa. A DESu deverá manter contato com tais órgãos e instituições e deverá divulgar anualmente os resultados dessa pesquisa, fornecendo inclusive conselhos às Universidades e aos alunos que nelas ingressam. Enfim, deverá haver, ligada a DESu, uma seção de estatística universitária que mantenha em dia dados referentes ao número de pessoas formadas que estejam realmente exercendo sua profissão. Deverá ainda o bureau ou seção de estatística universitária manter atualizados os dados referentes ao rendimento das bolsas de estudo fornecidas pela CAPES e por outros órgãos federais. A CP A orientará e fiscalizará a execução dessas e de similares atividades.

Órgão de luta contra as fraudes educacionais, órgão de coordenação. ao menos informativo, entre os currículos das Universidades numa mesma área geográfica, órgão de ligação da DESu com o Conselho Federal de Educação, com a CAPES, com o SEEC, com a CETRHU da FGV, com a FIBGE, com o Conselho de Reitores, etc, será essa comissão, por tudo isso, o órgão apropriado para o estudo dos problemas que digam respeito ao aprimoramento das Universidades brasileiras, sempre dentro do espírito da autonomia universitária e do reconhecimento das vantagens que decorrem da liberdade de experiência e de iniciativas, cerceando manifestações de megalomania. A CPA deverá elaborar, periodicamente, após as necessárias consultas a pessoas e instituições adequadas, listas básicas mínimas de livros que obrigatoriamente as bibliotecas das diferentes escolas deverão possuir, indicando-lhes ainda a melhor maneira de adquiri-los. Nesse terreno, caberá talvez à CPA orientar a COLTED no que se refere à compra e distribuição de livros do ensino superior. Sob a supervisão da CPA e em cooperação com o Conselho Federal de Educação e com os departamentos de Difusão Cultural das diferentes Universidades brasileiras, a DESu deverá publicar uma revista do Ensino Superior. Para tanto, a DESu deverá articular-se com o INEP e com o CBPE, a fim de evitar a duplicação e até a triplicação de funções, encargos ou atribuições já existentes. De qualquer sorte, em revista própria ou através de revista já existente, a CPA deverá promover a divulgação de seus trabalhos e pesquisas. Aí ficam exemplos de algumas funções da CPA.

O atual património da EAPES (resultante do acordo MEC/USAID) será oportunamente transferido para a CPA».

Convém ressaltar que, de modo algum, o memorando enviado significa ou significou sugestão para o aproveitamento, na futura comissão, 
de qualquer dos membros da atual.

O memorando traduzia unicamente nossa maneira de sentir.

Parece-nos que no encaminhamento da reforma, dois pontos preliminares devem ser rigorosamente respeitados: o princípio da autonomia universitária e a faculdade normativa do Conselho Federal de Educação nos assuntos de sua competência.

\section{I - AUTONOMIA E HETEROGENEIDADE EDUCACIONAL}

A autonomia didática, administrativa, financeira e disciplinar, mais o que um simples status jurídico, deve ser o resultado de uma conquista

a comunidade universitária como um todo. O progresso da Universidade brasileira está intimamente relacionado com as possibilidades de seu desenvolvimento autónomo, sem submissão a padrões uniformes impostos pelos artifícios da legislação. No fiel comprimento dos objetivos que lhe justificam a existência, a Universidade, sem perder os seus 'vinculos regionais e nacionais, alcançará assim, autonomamente, as condições que a individualizam como força criadora da ciência, da técnica e dos valores mais altos da cultura universal.

Como expressão do valor instrínseco das instituições universitárias na afirmação de sua individualidade, a heterogeneidade é desejável e caracteriza um sistema educacional altamente diferenciado. A heterogeneidade assim entendida é distinta da ingénua concepção de uma diferenciação institucional que resulte apenas dos fatores regionais de natureza geográfica, econômica, social e cultural. Ela visa assegurar a liberdade na busca permanente de soluções pedagógicas sempre mais aperfeiçoadas.

\section{II - AUMENTO DA CAPACIDADE DE MATRICULA NO ENSINO SUPERIOR}

Deve o Governo firmar uma política educacional solidamente fundada no conhecimento de nossa realidade, com vistas a estabelecer um planejamento racional, que nos leve a estar preparados a aplicar mais recursos, de maneira mais eficiente, para prevenir o futuro.

A fixação dessa política pelo Governo exigiria a arregimentação de tôdas as forças, federais, estaduais e municipais, reclamando, assim, um urgente entendimento entre o Conselho Federal de Educação e os Conselhos Estaduais de Educação, com vistas a assentar as grandes linhas de ação. A falta de tal política propiciou o surto desordenado de estabelecimentos de ensino superior no país, com a criação de escolas em setores não prioritários, o que prejudica as instituições já existentes, sem que o esforço e o sacrifício da fundação de novas entidades tenha servido, como deveria, à Educação nacional concebida como um todo.

É imperativo um planejamento rigoroso neste setor. Nota-se, nas populações de cidades que adquirem certa importância, o vivo interesse pela criação de entidades de ensino superior, quer como sinal de afirma- 
ção de um novo status, quer como forma de exigir restituição indireta dos impostos pagos pelos cidadãos.

Melhor se atenderiam, e com menos ónus, os justos anseios dessas populações criando-se «Centros de Educação e Cultura», que também poderiam ser objeto das subvenções reclamadas, mas com outra finalidade que não a criação de escolas de nível superior, cujos inconvenientes foram já apontados. Tais Centros poderiam manter um sistema de bolsas para os candidatos ao ensino superior, que seriam encaminhados para escolas e Universidades existentes na região; por outro lado, poderiam beneficiar parte muito maior da população, através de seminários, cursos de extensão e conferências, mediante convênio com as instituições de ensino superior mais próximas.

Recomendamos ainda, com o objetivo de atenuar os inconvenientes da situação atual, as seguintes medidas complementares:

1', instituição dos cursos integrados, nas Universidades:

$2^{\circ}$, incorporação de escolas isoladas em Universidades, com o objetivo de evitar a duplicação de serviços e o baixo aproveitamento dos recursos disponíveis, pela competição no oferecimento de vagas e a repetição ociosa do mesmo tipo de atividade;

$3^{\circ}$, integração regional de escolas, como ponto de partida para uma diferenciação de funções e futura incorporação em Universidade;

$4^{\circ}$, criação ou reforma das escolas existentes, com vistas ao estabelecimento de cursos de nível intermediário, nos moldes dos júnior colleges norte-americanos;

$5^{\circ}$, reexame do problema de autorização e reconhecimento das escolas isoladas;

$6^{\circ}$, revisão do problema dos exames vestibulares.

De qualquer forma, as medidas preconizadas visam ao aumento das matrículas nas Universidades e escolas existentes e não a criação de novos estabelecimentos de ensino superior.

\section{III - REVISÃO DO PROBLEMA DOS EXAMES VESTIBULARES}

Os exames vestibulares, como demonstramos nas considerações anteriores, devem relacionar-se com: $1^{\circ}$, a estrutura curricular do ensino médio; $2^{\circ}$, as exigências próprias do ensino superior; $3^{\circ}$, as expectativas dos candidatos e $4^{\circ}$, as projeções da demanda futura das carreiras profissionais. $\mathrm{O}$ desequilíbrio existente entre o número de candidatos e o número de vagas, acentuado em alguns cursos, como os de Medicina e Engenharia, poderá, a médio prazo, ser atenuado pela adoção de algumas providências urgentes:

$1^{\circ}$. Melhoria do ensino médio, com o objetivo de despertar nos alunos o interesse pelas carreiras não tradicionais. 
2". Generalização do regime vestibular de caráter classificatório, ajustado ao número de vagas, de modo que se apurem, mais do que conhecimentos, os níveis e tipos de inteligência, as inclinações e aptidões dos candidatos. A organização de serviços tecnicamente aparelhados para a elaboração e verificação de provas objetivas, nos termos propostos, corrigirá algumas graves falhas do sistema de seleção até agora adotado.

3. Aumento do número de vagas nas escolas e Universidades, condicionado ao fornecimento antecipado de recursos financeiros, de acordo com um programa especial de expansão das matrículas do ensino superior. A ampliação e total utilização das instalações existentes, o melhor aproveitamento do pessoal docente, com o estabelecimento de padrões salariais compensadores e com a extensão gradual do regime integral, constituem requisitos mínimos e indispensáveis à execução de qualquer programa que se destine a elevar o número de matrículas em nossas escolas superiores.

$4^{\circ}$. Instituição do vestibular único, com as seguintes modalidades: a) por tipo de escola; $b$ ) em todas as escolas da mesma região; c) para toda a Universidade. Estas três modalidades serão realizadas através de acordos livremente firmados entre as escolas e/ou Universidades. Haveria ainda a possibilidade de um vestibular único de extensão nacional, instituído por lei especial e com a criação de um serviço coordenado pelo Ministério da Educação e Cultura. Entretanto, não nos parece aconselhável esta modalidade.

Recomendamos, por fim, que se estude a viabilidade da implantação de um sistema de testes para aplicar, em escala nacional, ainda no decorrer do último ano do ciclo colegial.

De qualquer forma, urge estabelecer uma política clara, única para toda a Nação, respeitada a autonomia das Universidades. Torna-se necessária a fixação de tal política uniforme, de âmbito nacional, porque qualquer medida isolada de renovação não produziria o efeito desejável e teria alcance muito reduzido.

\section{IV - REVISÃO DOS CURRÍCULOS}

A reformulação dos currículos, de acordo com as novas exigências de uma estrutura universitária integrada, há de levar em conta os seguintes princípios:

$1^{\circ}$. Os currículos universitários devem ser suficientemente variáveis e flexíveis, de modo que atendam às inclinações e aptidões dos educandos. Isto significa que, embora se dediquem a idêntico ramo de 
especialização intelectual ou profissional, os estudantes poderão seguir diferentes rumos, em consonância com suas aspirações, anseios e preocupações pessoais.

$2^{\circ}$. Os currículos devem satisfazer às exigências da própria natureza dos conhecimentos, preservar as conquistas fundamentais da cultura universal e nacional e incorporar incessantemente os novos progressos da ciência. Independentemente da maior ou menor procura, cabe à Universidade manter o elenco de estudos que correspondam à amplitude do saber, bem como o seu trabalho ao nível das mais altas exigências culturais.

$3^{\circ}$. Os currículos devem propiciar ampla variedade de tipos de formação universitária, para assegurar completa adequação do ensino às carreiras profissionais de nível superior. É óbvio que, sendo imprevisíveis, dentro de certos limites, as oportunidades profissionais futuras, a atividade do ensino não se pode subordinar-se, exclusivamente, às flutuações aleatórias do mercado de trabalho.

4. Nas profissões em que o número de formados fôr superior às oportunidade reais oferecidas pelo mercado de trabalho, como é, por exemplo, o caso da advocacia, não se vê razão para reduzir a duração do curso embora haja motivos abundantes para reformular o currículo, tornando o ensino mais ajustado às necessidades sociais e às exigências culturais da profissão. Daí não se deduza que sejamos contrários às chamadas carreiras curtas, seja no campo das ciências bio-médicas, seja no campo da engenharia, seja no campo das ciências econômicas. É incontestável a vantagem de haver técnicos de nível intermediário, e nós a reconhecemos. Por vezes, nos currículos de graduação são ensinadas matérias de interesse muito restrito, que alongam desnecessariamente os cursos e que antes deveriam constituir objeto de nova especialização profissional, de duração menor. No entanto, não há porque reduzir o currículo das carreiras de alta especialização, para as quais existem atualmente mais candidatos que vagas e mais formaturas que empregos. Reduzindo-se-lhes o tempo, corre-se o risco de transformar depois os cursos de mestrado e de doutorado em simples cursos de complementação de um ensino superior deficiente, o que viria desvirtuar de todo a pós-graduação .

\section{V - ORGANIZAÇÃO DEPARTAMENTAL E CARREIRA DOCENTE}

O Departamento é a pedra angular da reforma universitária. Como unidade básica e célula das estruturas administrativas mais complexas. o Departamento deve integrar cadeiras e disciplinas idênticas e afins, que perseguem objetivos comuns numa determinada área do ensino e da investigação. A cátedra, despojada do privilégio da vitaliciedade e de sua denominação particular, deixa assim de ser, na estrutura universitária, a unidade básica do ensino e da pesquisa e em seu lugar deve emergir e consolidar-se o Departamento como unidade colegiada de en- 
sino e pesquisa, na qual se integram as diversas categorias da carreira docente, hierarquicamente estabelecida, e de tal modo que, na medida do possível, ela não se afunile, convergindo afinal para um único cargo. Para se alcançar este objetivo, é preciso que todos os que ingressem na carreira docente tenham direito de, pelos trabalhos realizados e pelos concursos vencidos, atingir a posição mais alta da carreira. As categorias de assistente, adjunto ou associado e professor titular, pleno ou catedrático, devem ser muito mais uma «posição» na hierarquia da estrutura departamental do que um cargo a só ser provido quando vago.

É indispensável, todavia, que os departamentos tenham competência deliberativa definida e que disponham de recursos orçamentários próprios. A elaboração dos programas de ensino e a articulação dos cursos devem constituir matéria de decisões departamental e interdepartamental, com vistas à plena integração dos planos de estudos.

Parece-nos que, na instituição do regime departamental, se deve manter distinção entre departamentos polivalentes e monovalentes, pois os primeiros exercem, nos cursos integrados, função relevante e inconfundível .

\section{VI - ORGANIZAÇÃO DOS CURSOS INTEGRADOS}

Os cursos básicos serão um dos principais elementos da integração do estudante na vida universitária.

Esses cursos básicos, que preferimos denominar cursos integrados, poderão realizar-se horizontal ou verticalmente, isto é, poderão concentrar-se nos dois primeiros anos acadêmicos ou, como seria preferível, no caso das desciplinas de cultura geral, estender-se por todos os anos da vida universitária do estudante, diminuindo-se, naturalmente, sua importância e carga horária à medida que o aluno avance nos estudos especializados. Desta maneira, os cursos básicos, ao invés de serem simplesmente cursos de transição, isto é, o alicerce, ou melhor, o patamar ou vestíbulo da vida universitária propriamente dita, como geralmente têm sido concebidos, passariam a ser a ossatura fundamental, o liame integrador dos estudos universitários.

\section{VII - CRIAÇÃO, NA ADMINISTRAÇÃO CENTRAL. DE SERVIÇOS DE ACONSELHAMENTO VOCACIONAL}

O serviço de aconselhamento, ligado à administração central e articulado com os departamentos, deverá ter sentido estritamente técnico e acadêmico, sem nenhum caráter assistencial, clínico ou de orientação ideológica: fornecerá subsídios, prestará informações e criará condições básicas para o esclarecimento individual e o autoconhecimento dos estudantes e para sua distribuição pelos diversos departamentos da Universidade. 
As funções do serviço de aconselhamento vocacional, exercidas em estreito contato com os diversos departamentos, podem ser assim delineadas:

I, examinar candidatos ao ingresso na Universidade e, por solicitação, os próprios alunos - sob os pontos de vista intelectual e de personalidade;

$2^{\circ}$, participar da coordenação dos exames vestibulares à Universidade, cooperando com os departamentos e demais órgãos incumbidos de sua realização;

$3^{\circ}$, organizar o cadastro do corpo discente com todas as informações úteis, tendo-se o cuidado de mantê-lo sempre atualizado ao longo do curso de cada aluno.

\section{VIII - REDEFINIÇÃO DO PERÍODO LETIVO}

Cumpre deixar de lado, definitivamente, o ano letivo como ponto de referência, como unidade de medida do tempo escolar, porque cada vez mais êle se revela inadequado, de dimensões muito amplas e de valor desigual, e por isso deve dar lugar a unidades mais densas, de mais fácil manejo e de valor relativamente constante.

Propomos assim a substituição do atual período ou ano letivo por três ou quatro períodos letivos de duração variável, trimestrais, ou máximo quadrimestrais - de valor equivalente. A equivalência decorrerá fundamentalmente da carga horária semanal e, portanto, da carga útil de atividade académica, ao invés - como se dá presentemente dos dias de duração do período. Desta forma, os cursos se dividirão em períodos letivos, maciçamente comprometidos na realização de determinado programa, com cargas semanais de aulas, seminários, sessões de estudo, aulas práticas, leituras obrigatórias, etc.

Dentro da reformulação ora proposta, o sistema de crédito, já consagrado em algumas Universidades brasileiras, será o instrumento indispensável para a avaliação do trabalho escolar.

\section{IX - INSTITUIÇÃO DE CURSOS DE PÓS-GRADUAÇÃO}

Os cursos de pós-graduação que, em princípio, somente poderão realizar-se nas Universidades, deverão estruturar-se em cursos regulares, com aulas, seminários, conferências, etc. e com verificação obrigatória do aproveitamento dos alunos. A duração desses cursos deverá ser de seis trimestres para mestrado e de mais seis trimestres para o doutorado, podendo-se dispensar o primeiro, a juízo do professororientador, com anuência do Departamento. Para a obtenção dos respectivos graus acadêmicos, exigir-se-á defesa de tese fundamentada em pesquisa original, a qual será necessariamente apresentada no final do curso.

Impõem-se, todavia, alguns cuidados especiais. Em primeiro lugar. o estabelecimento de um programa em que colaborem harmoniosamente 
o Conselho Federal de Pesquisa, o Conselho Federal de Educação, a Diretoria do Ensino Superior e a Comissão de Aperfeiçoamento do Pessoal de Ensino Superior. Em segundo lugar, a vinculação dos cursos, em princípio, ã Universidade como um todo, embora sejam eles realizados pelos Departamentos que disponham de recursos materiais e humanos perfeitamente adequados ao alto nível desejado e desejável. Sob este aspecto, o Governo deve incentivar as Universidades, mas também deve ser extremamente rigoroso e desestimulador de aventuras ou de obras de fachada, sobretudo no que diz ao corpo docente.

\section{$X$ - ESTABELECIMENTO DE NOVAS DIRETRIZES \\ A POLITICA DE SELEÇÃO E RECRUTAMENTO DO PESSOAL DO MAGISTÉRIO SUPERIOR}

O aperfeiçoamento do pessoal de nível superior assume hoje em nosso País, particularmente em razão do acelerado processo de desenvolvimento social e econômico, importância de tal ordem que a matéria se tornou capítulo obrigatório de qualquer estudo sobre a reforma universitária nacional. Faz-se mister a elaboração de um programa de pós-graduação, diretamente orientado para a solução de alguns dos mais graves problemas que dificultam o progresso brasileiro: a carência de pessoal docente de nível superior, o imperativo da abertura de novas fronteiras no domínio da pesquisa científica, a formação de pesquisadores de alto nível, em consonância com os padrões científicos internacionais e, finalmente, a necessidade de um trabalho de «reciclagem» para atualização de conhecimentos e técnicas dos profissionais graduados em escolas superiores.

A política que preconizamos deve orientar-se, antes de tudo, para a criação, nos centros universitários mais bem equipados, de cursos de pós-graduação - mestrado e doutorado - com um sistema de bolsas e incentivos que favoreça aos mais capazes e estimule a especialização nas áreas de maior importância para o País.

Esta política não pode também esquecer os problemas criados com os estabelecimentos isolados de ensino superior. $\mathrm{O}$ avultado número de tais instituições, alheias, ou quase, umas às outras e às próprias Universidades. e a gravidade dos problemas técnicos e pedagógicos que apresentam, exigem atenção especial para a questão do aperfeiçoamento do seu pessoal docente.

\section{XI - ESTABELECIMENTO DE UMA POLITICA DE INCENTIVO AO ENSINO E À PESQUISA CIENTIFICA COM O APOIO SOLIDÁRIO DO TRINÔMIO ESTADO-UNIVERSIDADE-EMPRESA}

$\mathrm{O}$ aperfeiçoamento do pessoal de nível superior e a instalação de cursos de graduação e pós-graduação constituem pontos básicos de uma política educacional intimamente associada aos programas de desenvolvimento do ensino em geral e da pesquisa científica. Política educa- 
cional e política científica representam, aliás, dois aspectos de um único problema: o da conservação, transmissão e renovação dos conhecimentos e valores da cultura. Urge assim estabelecer, vinculada à política educacional, uma política nacional de amplo incentivo à pesquisa científica nos diversos domínios do saber, a qual possa contar com o apoio solidário do trinômio Estado-Universidade-Emprêsa, para atender aos imperativos da segurança, da ciência e da produtividade. Em outras palavras, cumpre pôr fim à dissociação entre pesquisa e ensino.

O bom nível da pós-graduação é um dos pontos em que se faz sentir mais agudamente a necessidade da cooperação indicada.

\section{XII - INTENSIFICAÇÃO DOS PROGRAMAS DE EXTENSÃO UNIVERSITÁRIA E DE ATUALIZAÇÃO DE CONHECIMENTOS}

Há no problema do acesso ao ensino superior uma distinção que não tem sido suficientemente aproveitada. Uma coisa é o benefício que pode um cidadão auferir de seu contato com as instituições de ensino superior, e outra, muito diferente, é a sua inscrição regular como aluno de um curso de formação profissional.

Nosso país talvez por muito tempo não possa oferecer a todos os candidatos oportunidade de ingressar nas Universidades a fim de obterem, um diploma de formação profissional. Contudo, com esforço bem programado, nossas instituições de ensino superior atingiriam desde logo número muito maior de pessoas, se fossem abertas para um campo extremamente importante de sua possível atividade, que é o da extensão universitária. A atividade de nossas instituições de ensino superior não se esgota com a formação profissional da juventude, tarefa a que se vem consagrando tradicionalmente. Têm elas o dever de abrir suas portas e propiciar os benefícios de seu trabalho a um número muito maior de pessoas, não só no que concerne à preparação de profissionais, mas também no que diz respeito à difusão da cultura e dos conhecimentos acumulados pelos professores.

No campo da formação profissional, as Universidades e escolas isoladas de ensino superior têm possibilidade de organizar cursos de especialização, de adaptação e de atualização, acolhendo em seu seio não só profissionais já formados, mas também pessoas sem graduação universitária, que estejam em condições de se aproveitarem dessas iniciativas, que lhes dariam nova habilitação no exercício de atividades necessárias ao desenvolvimento do país. Durante anos, nossas escolas de ensino superior só formaram certos tipos clássicos de profissionais. Surgem, contudo, agora muitas profissões e ocupações novas, enquanto as profissões tradicionais entram a exigir especialização e atualização constante. Daí a necessidade de cursos de «reciclagem», que, em alguns casos, deveriam ser obrigatórios. Este é, pois, um campo de atuação de nossas entidades de ensino superior, que lhes permitirá, com 
-pouco esforço mais, aumentar desde logo o número de beneficiários de suas atividades.

Ainda neste setor, é de observar que nossas entidades de ensino superior poderiam e deveriam dar maior atendimento às aspirações culturais de nossas populações, através do oferecimento de seminários e cursos rápidos sobre problemas atuais do país, ou de formação profissional, artística, social, científica e moral.

\section{XIII - CRIAÇÃO DE UM SISTEMA DE ATENDIMENTO FINANCEIRO (FUNDO ESPECIAL, BANCO OU CARTEIRA)}

A criação de um Fundo Especial de Educação, de um Banco ou Carteira, que tivesse, entre outras finalidades, a concessão de bolsas a alunos carentes de recursos será medida útil e oportuna. Tais bolsas não deveriam ser concedidas gratuitamente, por não estar o país em condições de enfrentar as grandes despesas daí decorrentes. Pondo-se em prática uma norma constitucional (art. 183), conceder-se-iam tais bolsas contra reembolso futuro, após a diplomação e com um prazo de carência, para que o beneficiário pudesse consolidar sua situação profissional antes de começar a restituir ao país, em favor de outros, o que recebeu.

Parece-nos recomendável a extensão do sistema aos alunos das escolas oficiais.

Este Fundo, Banco ou Carteira poderia ainda conceder empréstimo .às Universidades e escolas isoladas, para construção de edifícios, aquisição de livros e equipamentos, e para contratação de pessoal docente, nos casos de comprovada necessidade.

\section{XIV - COMISSÃO PERMANENTE DE ASSESSORAMENTO}

A Diretoria do Ensino Superior precisa de uma Comissão Permanente de Assessoramento (CPA), cujos membros, recrutados pelo Diretor do Ensino Superior entre professores universitários ou pessoas de alta qualificação, terão mandato fixo e trabalharão em regime de tempo integral. A criação da CPA não impedirá a organização de novas comissões especialistas, de caráter transitório. Estas comissões ad hoc ficarão vinculadas à Comissão Permanente.

Como órgão de assistência técnica, a CPA estudará os problemas que digam respeito ao aprimoramento das Universidades, mas tendo sempre em vista a autonomia universitária e as vantagens da liberdade de experiência e de iniciativa. A CPA deverá organizar periodicamente, após as necessárias consultas a pessoas e instituições adequadas, listas mínimas de livros que as bibliotecas das diferentes escolas deverão obrigatoriamente possuir.

A DESu manterá atualizados os dados referentes às necessidades - de profissionais em todo o Brasil, a fim de atenuar o desajuste entre a procura e a oferta no campo de ensino superior. Para isto, manterá contato com os órgãos governamentais e com as instituições privadas 
que atuam no mesmo campo de pesquisa e análise. A DESu, diretamente ou através de órgãos especializados, manterá ainda um registro atualizado dos profissionais graduados no ensino superior existentes no país. A CPA orientará a execução dessas atividades e de outras similares .

\section{XV - GOVERNO DA UNIVERSIDADE}

A integração, nos moldes atrás propostos, implica o reexame da estrutura dos órgãos colegiados da administração universitária. A composição do Conselho Departamental e da Congregação deve ajustarse não mais à estrutura de cátedras, mas à de departamentos, com adequada redefinição de atribuições. O Conselho Universitário, até agora constituído por representação igualitária por escola (Decreto n" 19.851 . de 11 de abril de 1931), deve ser modificado, para organizar-se segundo critérios que correspondam aos encargos de trabalho das diversas faculdades da Universidade. Propomos assim que a composição do Conselho Universitário se faça à base de uma representação de caráter proporcional. que leve em conta, combinadamente, a carga horária semanal do trabalho docente da escola, o número de seus alunos, o número de seus professores e o seu orçamento médio no último quinquénio. No Conselho, assim reestruturado, ficará assegurada a representação dó corpo estudantil, dos ex-alunos e das diversas categorias da carreira docente.

\section{XVI - RECONHECIMENTO}

Para o reconhecimento dos estabelecimentos isolados de Ensino $\mathrm{Su}$ perior, o Conselho Federal de Educação exige o atendimento a uma série de requisitos bem conhecidos e bastante razoáveis. Entretanto. dever-se-ia permitir que qualquer entidade particular pudesse fundar escolas superiores, sem necessidade de pleno reconhecimento oficial, por um processo diverso do que atualmente vige. Satisfeitas exigências mínimas, a entidade poderia solicitar um tipo de reconhecimento, digamos parcial, à falta de melhor nome, permitisse aos alunos submeter-se anualmente a exame das diferentes disciplinas em faculdades oficiais especificamente designadas pelo Conselho Federal de Educação. Em vários pontos diferiria da autorização plena este reconhecimento parcial: a) não se permitirá o exame da própria escola enquanto ela não obtivesse pleno reconhecimento; b) o Conselho Federal de Educação determinaria as escolas onde os exames seriam prestados; c) o processo seria imediato, não se obedeceria ao prazo mínimo de dois anos do art. $9^{\circ}, \S 6^{\circ}$, da Lei de Diretrizes e Bases.

O reconhecimento parcial não impediria que a entidade solicitasse ulteriormente o reconhecimento pleno ao cabo de alguns anos, sobretudo se, através de exames prestados em outras escolas, ficasse comprovada sua capacidade docente. A escola superior, assim autorizada a funcionar ainda precariamente, esforçaria por adquirir boa fama, e teria tempo para providenciar o atendimento das exigências do pleno reconhecimento. 
Esta proposta vem conciliar muito bem o poder do Estado, através do reconhecimento das escolas pelo Conselho Federal de Educação, desde que preenchidas todas as exigências regulamentares vigentes ou novas a serem adotadas, com a liberdade dos particulares, aos quais se reconhece o direito de fundar escolas superiores, preenchidas exigências mínimas, desde que seus alunos se disponham a submeter-se a exame em faculdades federais especialmente designadas pelo Conselho Federal de Educação.

A alternativa é perfeitamente constitucional. O art. $168, \S 2^{\circ}$, da Constituição assim dispõe: «Respeitadas as disposições legais, o ensino é livre à iniciativa particular, a qual merecerá o amparo técnico e financeiro dos Poderes Públicos, inclusive bolsas de estudo». As exigências legais são, no caso, os preceitos constitucionais, particularmente os do Título IV: «Da Família, da Educação e da Cultura» (arts. 168 a 171). A Lei de Diretrizes e Bases não contraria as exigências da Constituição atual (art. 8", XVIII, q) . Falta-nos ainda o cumprimento de outra norma constitucional: realmente, de acordo com o art. $8^{\circ}$ XVIII, letra $r$, da Constituição de 1967, compete à União legislar sobre «condições de capacidade para o exercício das profissões liberais e técnico-científicas». O que há a respeito do assunto é uma legislação dispersa e tumultuaria. É verdade que o ensino é livre (art. 158, §2), mas é privilégio da União autorizar o exercício profissional (art. $8^{\circ}$ XVIII, r) . A competência da União nesta matéria exclui a dos Estados. Nessas condições, é lícito pensar que a União crie dispositivos ou designe estabelecimentos para aferir o valor do ensino livremente ministrado, antes de autorizar o exercício profissional. A elaboração de um anteprojeto de lei, de iniciativa do Executivo, viria consolidar e simplificar o que já existe, e ampliar a legislação para as novas carreiras que as impõem como consequência do desenvolvimento urbano e industrial.

Com esta proposta, não se pretende fomentar a proliferação de escolas mal aparelhadas. $\mathrm{O}$ que se visa é justamente o contrário: evitar a multidão de escolas superiores mal aparelhadas e, no entanto, plenamente reconhecidas. É de prever e esperar aferição exógena do rendimento escolar forçará mais as faculdades a apurar seu ensino do que no sistema atual de generalização aferição interna. Em outras palavras, as faculdades que preenchessem condições muito severas é que teriam o privilégio de aferição endógena.

Este sistema de reconhecimento parcial e de aferição fora da escola em que o estudante se preparou poderia dar azo à carga e fecunda expansão de ensino universitário.

Poder-se-ia, obtidas as necessárias autorizações, organizar programas referentes a determinadas matérias ou currículos, que os interessados pudessem estudar ou seguir onde e como quisessem (por exemplo, a de programador ou a de analista em computação), indo depois prestar os exames onde lhes fosse determinado. O título assim obtido teria reconhecimento oficial. É óbvio que este sistema só deveria ser usado em casos especiais, e na dependência das possibilidades do meio e das exigências do mercado. 


\section{XVII - - SERVIÇOS OFICIAIS DE RÁdIO E TELEVISÃO}

Deve o Estado contribuir para a Educação nacional como um todo, e acreditamos que para isso um dos elementos mais poderosos seria o estabelecimento de um sistema nacional de rádio e televisão, que oferecesse ao público programas de nível melhor do que os existentes. Não se trata de rádio e televisão com propósitos diretamente educativos, mas de uma rádio e TV oficiais funcionando ao lado de suas congéneres particulares. O rádio e TV oficiais absolutamente não fariam propaganda governamental. Sua finalidade precípua seria forçar as estações particulares, de maneira indireta, a melhorarem seus programas e policiarem o excesso de propaganda que lançam sobre o público.

No âmbito das escolas e Universidades, é aconselhável a utilização da TV em circuito fechado, sempre que o número de alunos o justifique.

As sugestões resumidas nestes 17 itens não representam a totalidade das que se contêm no presente relatório. Outras aí ficaram, amplamente justificadas, e dignas, a nosso ver, de atenção e seguimento. Por outro lado, a maioria das sugestões feitas serão plenamente aplicáveis dentro de um quadro econômico em expansão e dentro de uma consciência nacional muito nítida do problema da Educação, considerada como um todo praticamente indivisível. Em outras palavras, o presente relatório foi elaborado na convicção de que vivemos um momento de transição e de que existe uma vontade nacional efetiva de ordem e de progresso (para a qual se criaram até expressões como «segurança nacional» e «desenvolvimento»), que nos levará, nos próximos anos, à erradicação do analfabetismo e à obrigatoriedade do curso médio, pelo menos em sua fase ginasial, para todos os brasileiros. Uma tarefa educacional dessa amplitude não pode caber só ao Ministério da Educação e Cultura, por maiores que sejam suas verbas, mas há de representar um esforço conjunto dos Governos da União, dos Estados e dos Municípios, e sobretudo, da sociedade brasileira, que não se expressa apenas através de seus governos locais e central. Uma das funções do Ministério da Educação e Cultura será a de coordenar a expansão do ensino universitário, à medida que forem sendo corrigidos os afunilamentos desoladores várias vezes aqui assinalados, e que começam já na passagem do primeiro para o segundo ano primário.

A correção de muitos males do ensino oficial e do particular é sem dúvida função do desenvolvimento econômico, mas este é igualmente função de educação, conforme proclamaram economistas, como Adam Smith no século XVIII e Alfred Marschall no século passado. Importa, entretanto, que o ensino ministrado seja adequado, seja realmente eficaz, seja voltado, enfim, para a vida, tal como ela se nos apresenta, em sua multiplicidade de aspectos exteriores e em sua multiplicidade de aptidões vocacionais. Para tanto se espera das autoridades educacionais e daqueles que gostam de debater esses problemas uma visão objetiva e ampla da realidade, e não uma visão ideológica, isto é, restritiva da realidade . 


\section{RECOMENDAÇÕES E CONCLUSÕES}

Resulta do atento exame de alguns problemas de nosso ensino superior esta constatação simples: a Universidade Brasileira é ainda uma aspiração não-concretizada. As linhas básicas do modêlo instituído em 1931 não foram suficientes para criar em nosso meio uma estrutura universitária harmoniosa pelo equilíbrio das tendências divergentes, orgânica pela articulação de seus elementos constitutivos e integrada pela convergente utilização dos recursos necessários à realização de sua finalidade.

A reforma universitária que se impõe não depende apenas de uma nova ordenação jurídica ou da redistribuição de serviços existentes. É preciso afastar resolutamente a ideia de uma reforma a curto prazo, pois, sem um levantamento completo de todos os problemas com que hoje se defrontam as nossas Universidades e escolas superiores e sem um elenco bem definido de objetivos a alcançar, qualquer reforma será inútil. Parece-nos que na orientação geral da reforma dois principios devem ser rigorosamente respeitados: o da autonomia universitária e a faculdade normativa do Conselho Federal de Educação nos assuntos de sua competência. 


\section{APRECIAÇÃO SUMÁRIA DOS TRABALHOS DA EQUIPE AMERICANA}

- O problema do ensino superior em nosso país é, incontestavelmente, um dos mais graves destes dias conturbados que estamos vivendo.

Observe-se, aliás, que não nos é exclusiva a aflição. Em todo o mundo, ao menos em todo o mundo ocidental, a Universidade aparece como um dos problemas mais sérios de todo o processo de desenvolvimento cultural dos povos.

- Se o problema às vezes se apresenta com o caráter violento que nos pode levar à tentação de considerá-lo apenas como fonte de agitações e de conflitos, o certo é que êle transcende essa aparência. $E^{E}$ que, sob a forma subversiva que porventura assuma, há realmente nele alguma coisa de mais profundo, que precisa ser encarada com seriedade, com prudência, com a angústia própria das questões que afetam intrinsecamente a vida de uma nação.

- No Brasil, ao menos nos últimos dez anos, a questão do ensino universitário passou para o primeiro plano das preocupações nacionais.

E pareceu ao Governo que, para abordar problema de tão incontestável relevância, não seria desazado procurar a colaboração da longa experiência de outros povos.

- Daí a assinatura do Acordo ${ }^{\circ}$ 512-11-660-263, de 23 de junho de 1965 com a USAID, que visava a obter a vinda ao Brasil de um grupo de professores universitários dos Estados Unidos, para assessorar o trabalho dos técnicos brasileiros encarregados de estudar a matéria. Para tal, a USAID contratou, em $1^{\circ}$ de janeiro de 1967, os serviços do Midwest Universities Consortium (contrato número 1 a 380$)$.

A missão americana designada para esse trabalho de assessoramento era composta de figuras de primeira linha no mundo universitário americano.

- Eis os componentes do grupo americano:

5.1 - Chefe do grupo, o professor /. Martin Klotsche, Chancellor da Universidade de Wisconsin-Milwaukee, MA desde 1928 da Universidade de Nebraska, Ph. D. pela Universidade de 
Wisconsin em 1931, tendo exercido, entre outros, os cargos de:

5.1.1 - Diretor acadêmico do Wisconsin State College;

5.1.2 - Catedrático de História, da Universidade de Wisconsin;

5.1.3 - Diretor do Institute of World Affairs, de Paris;

5.1.4 - Diretor do Institute of World Affairs, de Genebra;

5.1.5 - Presidente da Wisconsin Academy of Sciences and Letters;

5.1.6 - Presidente da Wisconsin Association of Presidents and Deans.

O professor Klotsche é autor do livro The Urban University and the Future o[ our Cities, 1966.

5.2 - O professor John D. Ryder, Diretor da Escola de Engenharia da Michigan State University, MS pela Ohio State University, Ph. D. pela Iowa State University, tendo exercido, entre outros, os cargos de:

5.2.1 - Engenheiro da General Electric;

5.2.2 - Chefe de pesquisas sobre eletricidade na Bailey Meter Co. (Cleveland);

5.2.3 - Professor de Engenharia Eletrônica na Iowa State University e na Universidade de Illinois;

5.2.4 - Presidente da Conferência Nacional de Eletrônica, Chicago (1952);

5.2.5 - Diretor da Seção de Engenharia de Eletricidade da American Society for Engineering Education (Washington).

O professor Ryder é autor de vários livros sobre eletricidade (Networks, Lines and Fields, Engineering Electronic. traduzido também para o espanhol, e outros).

5.3 - O professor Henry W. Hoge, professor catedrático de Espanhol e Português na University of Wisconsin, MA e Ph. D., pela mesma Universidade, tendo exercido, entre outros, os seguintes cargos:

5.3.1 - Diretor da Seção de Linguística, Centro de Treinamento do Corpo da Paz., na Universidade de Wisconsin;

5.3.2 - Diretor do Laboratório Linguístico da mesma Universidade;

5.3.3 - Diretor do Centro Latino-Americano de Línguas e Cultura, da Universidade de Wisconsin.

O professor Hoge publicou, entre outros, os seguintes livros: Modem Portuguese (em colaboração) : A Selectiue Bibliography of Brazilian Literature. 
5.4___ O professor John M. Hunter, professor catedrático de Economia na Michigan State University, MS pela University of Illinois, Ph. D. pela Harward University, tendo exercido, entre outros, os seguintes cargos:

5.4.1 - Vice-Diretor e Diretor Interino do Departamento de Economia da Universidade de Michigan;

5.4.2 - Diretor do Centro de Estudos sobre Desenvolvimento Econômico da Universidade de Los Andes, Bogotá;

5.4.3 - Consultor da Fundação Ford.

O professor Hunter publicou, entre outros: Organización y Marcha de la Investigación, Racionalización Integral de la Universidad (em colaboração) .

6 - A equipe de assessores americanos não trabalhou completa durante todo o período.

A estada de cada professor no Brasil foi:

6.1 - professor Klotsche, 6 meses;

6.2 - professor Ryder, 12 meses;

6.3 - professor Hoge, 15 meses;

6.4 - professor Hunter, 17 meses.

7 - Como se vê, era a missão composta de técnicos de alto nível em seu país, e o tempo durante o qual aqui estiveram, para nos trazerem colaboração, foi bastante longo.

Usando, apenas para ilustração, uma unidade improvisada e falha, poderemos dizer que a cooperação americana correspondeu a 50 homens-mês

(o que equivale a 2 homens trabalhando 25 meses, ou a 10 homens trabalhando 5 meses).

Descrito assim o modo como foi planejada a colaboração, vejamos agora, em rápida síntese, o que resultou como solução ou início de solução.

\section{$O$ positiva e o negativo do Acordo}

8 - Desde logo, e sem querer antecipar qualquer juízo de valor, chamaremos a atenção para dois pontos contrastantes que, pela sua divergência, deixam ver toda a problemática da questão.

8.1 - O primeiro ponto é positivo e favorável: é de incontestável valor, para o estudo da Universidade no Brasil, conhecer como, sobre o assunto, se tem procedido nos Estados Unidos.

«A educação superior nos Estados Unidos, conforme se lê no Relatório Preliminar da Comissão Americana, fornece importantes dados de experiência para outros países, 
especialmente no que se refere aos tipos de problemas que teve de enfrentar, e à maneira como procurou resolvê-los.»

Há muitos elementos comuns nos esquemas educativos de todo mundo, e as soluções de uns países podem, mutatis mutandis, ser aproveitadas em outros.

No caso concreto, apesar das grandes diferenças, de formação histórica e de contexto cultural, é certo que tanto no Brasil como nos Estados Unidos encontramos um povo mais ou menos heterogéneo, que, numa terra nova e em grande parte hostil, procura soldar sua unidade e formar uma nítida consciência nacional.

Se a isso se acrescentar a base comum, que é a mesma natureza humana, teremos, sem dúvida, uma série de pontos de encontro e de coincidência no tratamento do problema educacional.

8.2 - O segundo ponto, este negativo, a considerar no exame do trabalho resultante do Acordo, são as sensíveis e por vezes profundas diferenças de temperamento e mentalidade, que necessariamente condicionam e forçam soluções diversas e eventualmente contraditórias.

É claro que um estudante brasileiro e um estudante americano não podem ser educados do mesmo modo. O que serve a um pode prejudicar a outro, o de que um necessita pode ser supérfluo a outro.

As divergências aí se observam de princípio no processo educativo: desde o adolescente que se tomou para educar (e que é tão diverso histórica, étnica e culturalmente nos dois países) até as metas a atingir na educação.

O Relatório Preliminar do grupo americano o reconhece, em outras palavras, quando diz:

«Todas as componentes da estrutura educacional brasileira têm como origem e consequência fatos sociais e históricos rigorosamente peculiares ao Brasil («uniqucly Brazilian social and historical circumstances»).

Ao examinar assim o que se pode tirar do Acordo e dos trabalhos que dele resultaram, parece-nos indispensável ter presentes estes dois aspectos discordantes e complementares.

Haverá vantagens, incontestáveis e grandes, em confrontar experiências culturais de dois povos que, embora diversos, têm uma subestrutura comum: a natureza humana.

Há, porém, que estar alerta para o perigo de aplicar, sem mais, soluções especificamente americanas a dificuldades peculiarmente brasileiras. 


\section{Trabalhos preparados pela equipe americana}

j0___ Além de visitas a umas poucas Universidades (talvez uma dúzia) e dos contatos com certo número de educadores brasileiros, os membros da equipe americana apresentaram um total de

17 trabalhos escritos,

abrangendo, na tradução,

258 páginas dactilografadas.

Destes 17 trabalhos,

6 são do professor J. D. Ryder,

8 do professor J. M. Hunter,

3 do professor H. W. Hoge.

Além disso, existem dois relatórios:

Relatório à USAID sobre as atividades que desenvolveram no Brasil. Uma cópia deste trabalho foi entregue à EAPES (9 páginas) .

Relatório à Comissão Brasileira, resumindo as atividades dos dezessete meses que passaram no Brasil (7 páginas) .

11 - É certo que nem todos esses trabalhos têm o mesmo valor, mas não é menos certo que entre eles alguns há de real e grande interesse.

Verifica-se nesses trabalhos, ao lado do pleno conhecimento dos problemas do ensino superior nos Estados Unidos, grande esforço para conhecer a situação brasileira. Esse esforço, louvável e evidente, não impediu que, em muitos casos, os ilustres técnicos da USAID se mostrassem incapazes de penetrar no mal definido problema universitário em nosso país.

Isto se deveu a vários fatores, que passamos a assinalar:

12.1 - A dificuldade de língua: se alguns deles tiveram tempo e vagar para aprender, na sua intimidade, o português, outros ficaram na periferia (o que é fácil de explicar, inclusive pela razão dada no item 12.2).

12.2 - A atmosfera de severa crítica com que o Acordo foi recebido em muitos meios (alguns deles isentos de qualquer errado sentimento de jacobinismo). No seu «Memorandum» final, de maio de 1968, dizem os professores Hoge e Hunter:

«pequena parte das reiteradas críticas (ao acordo MEC-USAID) foi justa, também houve críticas que decorreram de informações erróneas, mas a maior parte delas foram feitas de má-fé.»

12.3 - Um terceiro elemento que dificultou o trabalho dos professores americanos foi o relativo isolamento em que ficaram. Simples visitas a uma dúzia de Universidades 
e contatos mais ou menos seguidos com uma vintena de professores brasileiros não bastariam, evidentemente, para lhes permitir, apesar da sua competência e boa vontade, uma compreensão mais profunda do complexo e multiforme problema universitário brasileiro.

12.4 - Foi ainda causa das dificuldades encontradas pelos mestres dos Estados Unidos a deficiente bibliografia brasileira de que dispuseram. Exceto para um ou outro detalhe, tiveram de se contentar com uma parte relativamente muito pequena dos tão numerosos estudos (de valor desigual, é certo) publicados sobre a matéria no Brasil, nestes últimos decénios.

13 - Levando em conta todos esses obstáculos, é de elementar justiça reconhecer e concluir que foi realmente valiosa a contribuição trazida pelos professores americanos. Valeu, sobretudo, a nosso ver, porque traduziu

\section{uma visão externa}

dos nossos difíceis problemas educacionais.

Ao lado dos inegáveis prejuízos que essa «exterioridade» acarreta, deve-se assinalar que traz consigo algumas interessantes vantagens. Mesmo nos

\section{erros de apreciação}

que contenha, é de utilidade certa, porque nos leva a mais sincero, mais profundo, mais desapaixonado exame de consciência.

Estamos seguros de que os trabalhos apresentados constituem valiosa contribuição e atendem a esse

«vivo interesse pela educação superior» que, como assinala o Relatório final americano,

«existe (hoje) em todo o Brasil»,

mesmo quando se traduz,, para usar a maliciosa observação do mesmo Relatório,

«no entusiasmo em confeccionar cartazes e pintar paredes sobre o MEC-USAID».

\section{Apreciação geral dos estudos americanos}

14 - Os estudos preparados pelos assessores americanos podem ser distribuídos em três categorias.

É claro que seria possível classificá-los de maneira diversa; a classificação que adotamos parece-nos, contudo, a mais racional e lógica, do ponto de vista deste trabalho.

Dividiremos assim os trabalhos americanos:

$\mathrm{I}$ - O ensino superior no Brasil e 
II

A Universidade americana, com as seguintes subdivisões :

I - O ensino superior no Brasil

1.1 - Aspectos quantitativos

IA $A-O$ número de Universidades, pelo professor Ryder;

1.1.2 - O número de alunos, pelo professor Ryder;

1.1.3 - As instalações, pelo professor Ryder;

1.1.4 - O custo unitário da educação, pelo professor Ryder.

1.2 - Aspectos qualitativos

1.21 - Objetivos do ensino superior no Brasil, pelo professor Hunter.

1.2.2 - Processos de admissão às escolas, pelo professor Ryder;

1.2.3 - Pós-graduação, pelo professor Ryder;

1.2.4 - As Universidades como Fundação, pelo professor Hunter;

1.2.5 - O ensino de Economia no Brasil, pelo professor Hunter.

II - O ensino superior nos Estados Unidos

II. 1 - A estrutura visível da Universidade americana, pelo professor Hunter;

II.2 - A diversidade educacional nos Estados Unidos, pelo professor Hunter;

II-3 - O crédito do ensino superior americano, pelo professor Hunter;

II.4 - O Departamento nas Universidades dos Estados Unidos, pelo professor Hoge.

Além destes 13 trabalhos, concluídos, ainda houve quatro que não figuram entre os recebidos. São eles:

15.1 - O problema dos excedentes no Brasil, pelo professor Hunter;

15.2 - O corpo docente nos Estados Unidos, pelo professor Hoge;

15.3 - Reflexões sobre a Educação Superior no Brasil, pelo professor Hoge;

15.4 - A Economia dos Empréstimos no Exterior para Fins Educacionais em Geral, pelo professor Hunter. 
16 - Como se vê da enumeração, os trabalhos apresentados não constituem estudo sistemático e orgânico da situação do ensino superior no Brasil. Examinam-na sob diferentes aspectos, alguns deles de incontestável interesse, mas não formam um todo coordenado, que permita sucessivamente:

16.1 - um diagnóstico fundamentado e

16.2 - uma adequada terapêutica, capaz de corrigir os males que o diagnóstico porventura tenha identificado.

É possível que este caráter do trabalho realizado pela equipe americana seja consequência de uma exata compreensão de sua função de

assessoria

destinada, pela sua mesma natureza, mais a atender a necessidades específicas, do que a considerar o problema de maneira global.

Passaremos, no capítulo seguinte, a examinar sinteticamente, mas com a atenção que permita aproveitá-los melhor, os vários trabalhos entregues à EAPES.

\section{Aspectos quantitativos do ensino superior brasileiro}

17 - Os estudos apresentados pelos professores da USAID sobre os aspectos quantitativos do ensino universitário no Brasil revelam, com certeza, o cuidado com que procuraram documentar-se com o material estatístico existente no país.

É certo que, pelas razões já apresentadas, não lhes foi possível aproveitar senão uma limitada parte das fontes existentes, baseando-se quase que só nos dados preponderantemente e justificadamente de segunda mão, dos estudos, em tão boa hora e com tão bons resultados, feitos pelo Ministério do Planejamento sobre o assunto. A estes se acrescentaram os elementos obtidos nas Sinopses estatísticas oficiais.

Sendo estes dados os oficialmente disponíveis, parece que, por isso, podem ser aceitos como fundamento para o exame numérico dos fatos educacionais brasileiros.

18 - Há, porém, algumas falhas que não se pode deixar de considerar. 18.1 - Uma é aquela, já assinalada em estudo do professor Paulo Sá no CETRHU da Fundação Getúlio Vargas, e que consiste no seguinte:

as unidades consideradas não são iguais.

Isto sem dúvida tira certo valor aos resultados obtidos.

Com efeito, dizer, por exemplo, que o Brasil possui 40 Universidades significa pouco, porque as várias Universidades são muito diversas umas das outras, quer do ponto de vista quantitativo, quer do qualitativo. 
Quantitativamente, é claro, que são coisas muito diferentes a Universidade Federal do Rio de Janeiro, com 10.973 estudantes (em 1965), e a do Amazonas, 507 na mesma época (quer dizer, menos de $5 \%$ dos alunos da Universidade carioca) .

Qualitativamente, embora seja mais difícil demonstrá-lo, é indiscutível que não se pode esperar o mesmo valor educativo em duas Universidades situadas em locais distintos, tanto do ponto de vista cultural quanto do econômico.

18.2 - Outra causa de imprecisão é a incerteza dos dados estatísticos de que se dispõe.

Para citar um exemplo (apontado explicitamente no Inquérito sobre Universidade, do professor Ryder): o número das «faculdades isoladas». Serão 540? Ou 636? (pág. 2 do estudo University Survey).

Outra: Pelos dados fornecidos, não surgiu nenhuma Universidade nova nos anos de 1964 e 1965.

No entanto, a matrícula nas Universidades privadas teria sido de 54.721 em 1964 e de 66.795 em 1965. Como explicar esse aumento de mais de 12 mil alunos num ano?

Os exemplos valem para mostrar as dificuldades que os técnicos americanos encontraram no seu trabalho, e levam-nos a receber sempre com certa reserva as conclusões que se possam tirar.

Feitas estas considerações preliminares, passemos a examinar os principais estudos apresentados pela equipe de professores da USAID.

\section{Universidades no Brasil}

O primeiro deles será o

\section{Inquérito sobre as Universidades}

Trata-se, como dissemos, de um estudo que se restringe ao aspecto quantitativo do problema.

Isto, contudo, não the tira o valor, uma vez que é sobre essa base numérica que deve assentar o exame qualitativo do potencial universitário brasileiro.

Do inquérito feito resultaram as seguintes conclusões:

19.1 - foi recenseado no país um total de

40 Universidades,

Hoje, segundo os dados oficiais do C.F.E., são 43 (1968). 
sendo

24 federais (das quais 4 rurais),

3 estaduais,

e 13 particulares (das quais 10 católicas);

19.2 - além das Universidades, foram recenseadas

305 Faculdades isoladas

(num total que seria de 540 ou 686).

sendo

32 federais,

52 estaduais,

14 municipais,

207 particulares

(Parece-nos interessante assinalar a existência de

14 escolas superiores

de direção municipal);

19.3 - a matrícula total apurada nas Universidades e Faculdades incluídas no inquérito era em 1965 de

155.781 alunos,

sendo

61.181 das Universidades federais,

15.913 das Universidades estaduais, 20.808 das Universidades particulares

(ou seja, um total de 97.902 alunos universitários),

e mais

17.052 nas Faculdades oficiais

e 40.827 nas Faculdades particulares

(ou seja, 57.879 alunos de Faculdades).

19.4 - Parece interessante também citar os números que mostram a progressão quantitativa do ensino superior no Brasil:

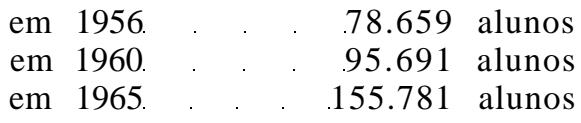

(praticamente dobrando o número no decénio).

\section{Matrículas}

O segundo trabalho nesta classe refere-se à «matrícula» (enro//menís).

O próprio trabalho cita as «causas possíveis» de erro. 
Entre outras, são:

20.1 - O ano escolar brasileiro coincide com o ano civil, ao passo que o americano começa no segundo semestre;

20.2 — há ambiguidade nos termos «matrícula geral» e «matrícula efetiva»;

20.3 - a matrícula total pode não incluir os alunos de pós-graduação;

20.4 - os totais muitas vezes se baseiam em amostras possivelmente não representativas;

20.5 - não se define (exatamente) o que seja um «estudante» (a student is not defined).

21 - Além destas, as causas gerais de erro e de imprecisão, sobretudo as que se referem às deficiências de muitas estatísticas educacionais no Brasil, tornam menos seguros os resultados apresentados.

Isto, aliás, não lhes tira todo o valor, porque se pode dizer que são aproximadamente certos.

Apenas, seria infundado querer tirar deles conclusões muito rigorosas: nem é esse o intento dos técnicos americanos.

22 - O primeiro dado que o trabalho americano apresenta - e que, aliás, não é novidade (nem é essa a sua preocupação) - é que se refere ao número de matrículas nos vários graus de ensino.

Tem-se, assim, em milhares de estudantes:

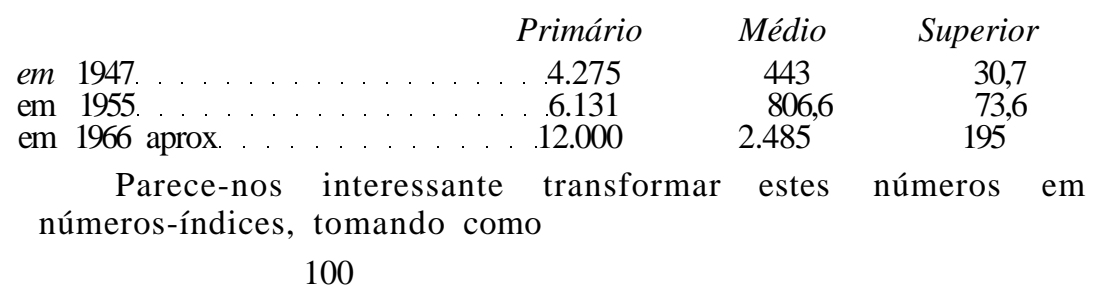

os valores correspondentes ao ano de 1947.

Teremos então:

\begin{tabular}{|c|c|c|c|}
\hline & Primário & Médio & Superior \\
\hline em 1947. & . . 100 & 100 & 100 \\
\hline em 1955. & .143 & 182 & 239 \\
\hline em 1965 & 281 & 561 & 653, \\
\hline
\end{tabular}

o que mostra que nesse período, enquanto as matrículas do primário não chegaram a triplicar, as do ensino médio quase sextuplicaram e as do superior mais do que sextuplicaram.

Observe-se ainda que nos primeiros oito anos o primário cresceu cerca de 50\%, o médio quase dobrou, o superior mais do que dobrou; e nos onze subsequentes anos, o aumento maior ocorreu na matrícula do ensino médio. 
23 __ Outra estatística interessante, reproduzida no trabalho, é a que se refere

à percentagem de população nas escolas nos vários grupos etários.

Tem-se assim, segundo os dados (relativos a 1960): (em milhares)

\section{Grumos etários}

\section{População}

$$
\begin{gathered}
\text { total } \\
9.400 \\
10.900 \\
\text { S. } 670
\end{gathered}
$$

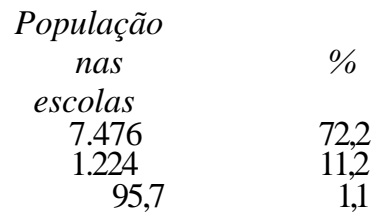

A estatística mostra o que já se tem afirmado: a extraordinária evasão nas escolas brasileiras. meros:

Pode ela ser expressa, aproximadamente, nos seguintes nú-

de 100 alunos do primário

10 vão ao médio

1 apenas vai ao superior

A conclusão seria desanimadora, se não fosse, antes e patriòticamente, estimulante de uma ação intensa, realística, contínua (muito diferente de simples declarações verbais, ou de atos protelatórios de comissões repetidas e ineficientes).

24 - Vale a pena também reproduzir uma estatística, aliás conhecida (já o dissemos: o Relatório americano, na parte brasileira, pouco terá de novo: sua vantagem está em juntar coisas já sabidas de alguns, mas desgarrada e parcialmente) .

Trata-se dos dados relativos aos candidatos inscritos nos exames de admissão às escolas superiores e ao número dos que passaram nesses exames.

Tem-se assim, no ano de 1966, para algumas carreiras (cita-

\begin{tabular}{|c|c|c|c|c|}
\hline Escolas & $\begin{array}{c}\text { Candidatos } \\
\grave{a} \\
\text { admissão }\end{array}$ & Aprovados & $\begin{array}{c}\% \\
\text { de } \\
\text { aprovação }\end{array}$ & Matrículas \\
\hline Medicina & 39.778 & 6.698 & 17 & 16.975 \\
\hline Engenharia & 32.239 & 7.017 & 22 & 23.514 \\
\hline Filosofia & 30.189 & 16.167 & 54 & 44.588 \\
\hline Direito. & 21.028 & 9.549 & 45 & 36.238 \\
\hline
\end{tabular}
mos as cinco cuja matrícula totaliza $88 \%$ da total em todas as escolas superiores do país - a amostra é, pois, quantitativamente representativa): 
24.2 - a parcentagem maior em outras escolas (Filosofia, Direito, Economia), onde a proporção de aprovados é de cerca de um em cada dois;

24.3 - subsidiariamente, a distribuição dos alunos pelos vários tipos de ensino: num total (que era de

174.604 estudantes),

cerca de um em quatro estudam Filosofia, cerca de um em quatro estudam Direito (as duas carreiras já absorvem a metade dos alunos), aproximadamente um em dez Medicina e um pouco mais um em dez Engenharia.

25 - Entre as estatísticas que o Relatório dos professores da USAID apresenta - ou reproduz — cremos ser também de interesse mencionar as que se referem à situação educacional do Brasil, comparada à de outros países.

Temos assim, como percentagem de mão-de-obra que, em cada país, teve educação escolar (college education) em 1960:

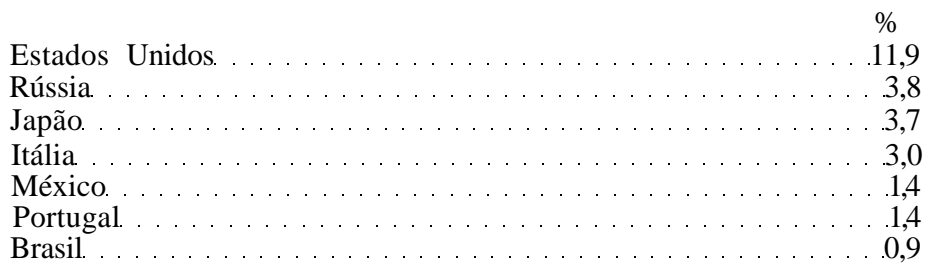

Vê-se no quadro a situação (que não hesitamos em classificar de triste) em que se encontra o nosso País: nem um trabalhador em 100 (no sentido exato do termo) tem preparo escolar, quer dizer, constitui, desse ponto de vista, simples e global

$$
\text { mão-de-obra qualificada. }
$$

26 - Vale a pena também, reproduzir a estatística que o Relatório americano cita e na qual se dá o número de formados (graduados) nas várias profissões existentes em nosso país em 1964.

Temos assim:

Médicos.

Dentistas

Engenheiros 24.000

Farmacêuticos. . . . . . . . . . . . . . . . . . . . . 12.700

Agrónomos . . . . . . . . . . . . . . . . . . . . . . . . . 5.000

Arquitetos . . . . . . . . . . . . . . . . . . . . . . . . . . . 300

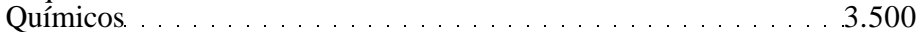

Veterinários . . . . . . . . . . . . . . . . . . . . . 2.300

Presentemente, após pesquisa promovida por Convênio entre o MEC e a FGV, os números de profissionais são outros. Vide Pesquisa sobre Pessoal de Nivel Superior. MEC-FGV — Setembro de 1969. 
É curioso observar:

26.1___ o relativamente grande número de médicos, lembrando a expressão de conhecido professor de Medicina:

«o Brasil é um vasto hospital»

(note-se que, apesar disso, temos 1.826 municípios sem um médico);

26.2 - o surpreendente número de dentistas e mesmo de farmacêuticos, sendo de notar que, em relação a estes, tem havido ultimamente uma campanha pela supressão da carreira (deixando apenas os que trabalham em laboratórios de drogas, uma vez que hoje pouco se usa o sistema antigo dos medicamentos «formulados» e preparados em farmácia);

26.3 - os poucos agrónomos, para um país que ainda se pode dizer, em grande parte «essencialmente agrícola».

27 - A apresentação de dados vai-se prolongando muito.

Pareceu-nos, porém, que deviam vir à baila.

- Aliás, constituiu um dos méritos mais incontestáveis do trabalho americano a reunião, num trabalho só, de estatísticas interessantes, muitas das quais só seriam acessíveis mediante a consulta, nem sempre fácil, da documentação esparsa.

Sabe-se como é difícil obter todos os documentos indispensáveis a qualquer estudo sistemático.

Embora já tenhamos aqui transcrito muitos dados estatísticos, cremos que não será demais apresentar ainda um quadro. É o que confronta o Brasil com outros países quanto ao número relativo de profissionais de nível superior. São dados referentes ao ano de 1964, sendo de ressaltar, como atrás ficou dito, que os quantitativos brasileiros são aproximados.

Vem assim:

NÚMERO DE PROFISSIONAIS POR MILHÃO DE HABITANTES — 1964

PROFISSÃO

Engenheiros

Agrónomos.

Químicos.

\begin{tabular}{|r|r|r|r|r|}
\hline & & P A I S & & \\
\cline { 2 - 5 } BRASIL & MÉXICO & PORTUGAL & CANADÁ & $\begin{array}{r}\text { ESTADOS } \\
\text { UNIDOS }\end{array}$ \\
& & & & \\
416 & 588 & 770 & 1.100 & 1.250 \\
303 & 700 & 526 & 2.500 & 4.100 \\
60 & 115 & 115 & 151 & 44 \\
43 & & 34 & 330 & 450 \\
\hline
\end{tabular}

Tem interesse acrescentar a este Quadro, simplesmente comparativo, outro que faz a comparação ao longo de quatro anos.

2 Estatísticas Médico-Sanitárias - Médicos — SES - Ministério da Saúde. 
PROFISSÕES

$\begin{array}{lcccc}\text { Anos } & \text { Engenheiros } & \text { Arquitetos } & \text { Agrónomos } & \text { Médicos } \\ & \mathbf{2 4 5} & \mathbf{2 0} & \mathbf{4 3} & \mathbf{4 2 5} \\ \ldots . & \mathbf{2 7 5} & \mathbf{3 1} & \mathbf{5 1} & 441 \\ \ldots . & \mathbf{2 7 6} & \mathbf{4 0} & \mathbf{5 5} & 430 \\ \ldots . & \mathbf{3 0 0} & \mathbf{4 5} & \mathbf{6 3} & \mathbf{4 1 9}\end{array}$

o que mostra:

27.1 - grande aumento do número de arquitetos;

27.2 - pequeno aumento do número de engenheiros;

27.3 - estagnação no número de médicos.

28 - Na parte relativa às matrículas, o Relatório americano apresenta ainda perspectivas dignas de atenção. Assim é que encontramos:

28.1 - Previsões

sobre números nos anos futuros.

$\mathrm{O}$ assunto afigura-se-nos muito controverso, e o tratamento que lhe dá o Relatório não nos parece satisfatório . tipos

O estudo comparativo que faz, de previsões de dois e parabólica,

carece de segurança, e por isso não é de molde a permitir prognósticos nesse ou naquele sentido.

Preferimos então não resumi-lo.

Em todo caso, quem tiver interesse em conhecer a matéria, procure-a no próprio Relatório, onde terá a mãos os elementos para possível reinterpretação, sempre difícil, discutível, incerta, aleatória.

28.2 - Os edifícios das Escolas

Outro estudo quantitativo incluído no Relatório americano é o que se refere aos edifícios

existentes nas escolas superiores brasileiras.

Nota-se aí a deficiência de dados fornecidos pelas nossas estatísticas.

$\mathrm{Na}$ verdade, o interessante seria apresentar todo o trabalho à base do número de metros quadrados por estudante

$o$ que daria impressão mais real do espaço disponível para o ensino.

Isto, porém, é muito difícil conseguir. 
Mesmo quando se têm os dados, eles são não raro contraditórios.

Basta lembrar que na estatística comparativa, que o Relatório apresenta, com Universidades estrangeiras, para cada uma das duas Universidades brasileiras referidas há dualidade de números.

Reduzidos por nós os valores a metros quadrados (em vez dos pés quadrados constantes do estudo), temos:

28.3 - para a PUC do Rio estes dois valores (aproximados):

- $18 \mathrm{~m}^{2}$ por aluno;

- $39 \mathrm{~m}^{2}$ por aluno.

A diferença terá sua explicação, mas é certamente perturbadora.

28.4 - Feita esta necessária observação preliminar, podemos referir em seguida o quadro que o Relatório fornece sobre as áreas disponíveis em Unidades estrangeiras (inglesas e americanas) e em Universidades brasileiras.

Reproduzimos também do Quadro o total de matrículas nas várias Universidades (o que permite fazer uma ideia da importância relativa das Universidades consideradas) .

Vem assim:

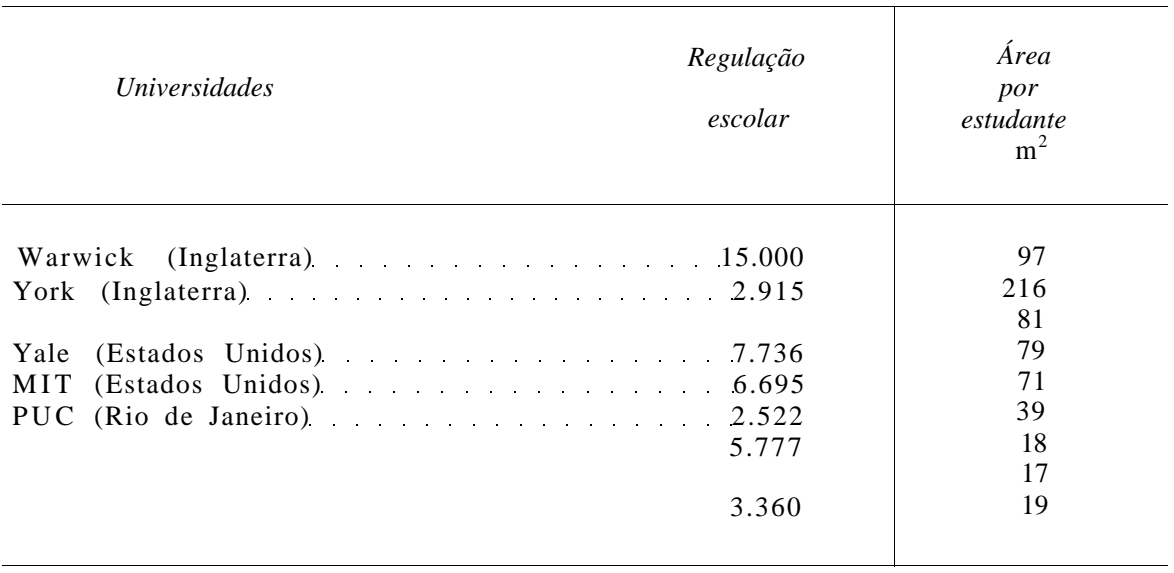

Vê-se como, nas Universidades brasileiras em pleno funcionamento, as áreas são relativamente pequenas.

Isso provavelmente se deverá menos a classes superlotadas do que à falta de todas as áreas suplementares que uma Universidade deve pôr à disposição do seu corpo discente: laboratórios, oficinas, salas de reunião, restaurantes etc. 
28.5 - A essa escassez de áreas nas Universidades em pleno funcionamento opõe o Relatório o que acontece com as projetadas mais recentemente:

«observou-se com razão, diz o Relatório, que o Brasil tende a ser otimista no planejamento das suas construções».

E cita dados correspondentes a duas Universidades. que provam a afirmação (designa-as, por letras, provavelmente como medida de discrição) .

\begin{tabular}{l|c|c}
\hline Universidade & $\begin{array}{c}\text { Número } \\
\text { de } \\
\text { estudantes }\end{array}$ & $\begin{array}{c}\text { Área } \\
\text { por } \\
\text { estudante }\end{array}$ \\
\hline A & 660 & $49,5 \mathrm{~m} 2$ \\
B & 950 & $43,5 \mathrm{~m} 2$ \\
\hline
\end{tabular}

28.6 - Mesmo com esse espaço restrito que as Universidades existentes oferecem, sua utilização ainda é pequena:

«o espaço de classes nas Universidades brasileiras, diz o Relatório, parece ser usado muito menos da metade do tempo total (very much less than one-half time).» pécie:

E acrescenta, o que já é falha grave, de outra es-

«professor médio ensina menos de três horas por semana.»

Com estes elementos, conclui o Relatório que seria possível aproveitar bem melhor o espaço restrito disponível .

Entra êle depois em estudos sobre os orçamentos de construções para ampliar as áreas existentes.

Neste ponto cremos que os dados fornecidos são pouco úteis, por causa da dificuldade das previsões. Sabe-se que a coisa varia de região para região e de ocasião para ocasião (os boletins de custo utilizados entre nós apresentam variações mensais).

28.7 - O custo do aluno-a.no nas Universidades

Um dos pontos mais importantes - e mais controversos - do estudo das Universidades em qualquer país é o relativo ao

custo do aluno-ano.

Com efeito, não há país, por mais rico, que não precise aproveitar bem os recursos financeiros de que dispõe. 
E sendo a Educação uma atividade justamente considerada de valor preponderante, corre-se às vezes o risco de desperdiçar os recursos a ela destinados, considerando, erradamente, que o que se gasta com seu custeio mesmo sendo além do necessário - é sempre e invariavelmente bem empregado.

28.8 - Se isto é um perigo para qualquer país, maior será, sem dúvida, para um país pobre como o Brasil.

Mas como entre nós, frequentemente - e ao contrário da tendência a que acabamos de nos referir - se encurtam as verbas para a Educação, é necessário que, fugindo ao fato e ao erro, se procure aproveitar da melhor maneira os recursos concedidos. diminuir

Daí a necessidade de um esforço sempre maior para

o custo unitário da Educação,

mesmo porque assim, benèficamente, se atingirá porção maior da população, já tão mal servida nessa matéria.

28.9 - Por outro lado, não é fácil, em assunto tão complexo, calcular exatamente esse custo unitário, definindo rigorosamente quais os gastos que realmente se devem fazer, e determinando com precisão o número de alunos beneficiários numa população escolar instável, descontínua e mal recenseada.

28.10 - O Relatório considera este assunto, e procura responder com a aproximação permitida pelos deficientes dados.

Acha assim para

custo do aluno-ano,

nas Universidades federais

$N C r \$$

maior custo - (Universidade Federal do

Rio Grande do Norte).

menor custo - (Universidade Federal

Fluminense)

sendo, em todas elas,

o cusro médio igual a NCr\$3.194,00.

Apresenta também, fora da comparação, o «exíremely high cost», na Universidade de Brasília, onde

o aluno-ano fica por mais de $\mathrm{NCr} \$ 21.000,00$

(feita a tradução do valor em dólares dado pelo Relatório, tomando o câmbio atual — julho/1968). 
28.11 - Passando-se às

faculdades isoladas:

nelas os números extremos encontrados (para o custo do aluno-ano) foram:

$\begin{array}{ccc}\text { máximo - Escola Paulista } & \text { NCr\$ } & \begin{array}{c}\text { Matrícula } \\ \text { total }\end{array} \\ \text { de Medicina. . . . . } & 7.540,00 & 568 \\ \text { mínimo - Direito, Piauí . . } & 961,00 & 180\end{array}$

28.12 A enorme variação observada,

de 1 para 4,2 nas Universidades

e de 1 para 7,9 nas faculdades isoladas, mostra como o assunto é mal controlado em nosso país.

Será justo e prudente acrescentar que talvez parte ao menos dessas extraordinárias diferenças se devam a variedade nos critérios e à deficiência dos dados.

Mesmo levando em conta essas possíveis causas de erro, os números apresentados denunciam uma situação séria, que exige particular cuidado dos responsáveis pela Educação.

28.13 - Devemos, aliás, chamar a atenção para um elemento que - parece-nos - não terá sido levado em conta nos valores reproduzidos no Relatório.

É o que se refere à

amortização

do enorme capital empregado nos edifícios e demais instalações das escolas e Universidades.

É claro que, num cálculo mais rigoroso (ou mesmo mais certo), deveria ser acrescentada uma parcela (e não pequena) para cobrir as importâncias correspondentes ao custo do terreno, das construções, do mobiliário, dos laboratórios, das instalações de todo género, indispensáveis à ministração do ensino a essa «entidade estatística» que é

o aluno-ano.

$O$ ensino pós-graduação

29 - O Relatório aborda, como não poderia deixar de ser, assunto relativamente novo no ensino superior brasileiro, mas cuja importância é grande e crescente.

Trata-se dos chamados

cursos de pós-graduação 
Sem procurar defini-los (o que seria menos fácil), diz que «o trabalho de pós-graduação parece ser constituído, em grande parte, de (simples) cursos ad hoc», fazendo, contudo, uma exceção (que não é justificada e não sabemos se será justificável) para Direito e Economia.

$\mathrm{Na}$ mesma linha crítica, observa o Relatório que «de acordo com a experiência americana, um programa intermitente de cursos ad hoc, no nível do mestrado, nada fornece de valioso (is not productive of quality).

291 - Com estas restrições todas, o Relatório cita uma estatística em que pretende resumir o que já se possui no género no Brasil.

Reproduzimo-la (notando que a fonte é o SEEC): $\begin{array}{llll}1963 & 1964 & 1965 & 1966\end{array}$

Cursos 58

56

56

44

Matrícula inicial

1.895

2.355

1.790

Matrícula no fim do ano

Conclusões ...

1.852

638

1.959

1.649

769 449

Universidades consideradas

\section{Os}

\section{4 cursos}

existentes em 1966 estavam distribuídos pelas seguintes carreiras (desde logo pode-se observar que há nelas, aparentemente, faltas incontestáveis):

Filosofia

Cursos

Saúde Pública . . . . . . . . . . . . . . . . . . . . . . 7

Direito . . . . . . . . . . . . . 7

Artes . . . . . . . . . . . . . . . . . . . . . . . 6 6

Arquítetura . . . . . . . . . . . . . . . . . 3

e outras, com apenas um ou dois cursos.

29.2 - A estatística, como dissemos, parece-nos muito falha (o que se pode talvez atribuir à imprecisão do termo pósgraduação) .

O certo é que nós mesmos conhecemos algumas dezenas de cursos 
que não se encontram no Relatório (e na estatística), mas que podem ser considerados, ao menos lato sensu, como de pós-graduação.

\section{O problema dos excedentes}

Entre as matérias classificadas como quantitativas, cogita ainda o Relatório do chamado problema dos excedentes.

É certo que na questão há um relevante aspecto numérico.

30.1 - Com efeito, como

excedentes

se consideram

ou os que simplesmente se candidatam a entrar nas escolas superiores, mas nelas não conseguem matrícula, ou os que, além de se candidatarem, [azem os exames de admissão requeridos, neles são aprovados, não encontram, porém, depois vagas onde possam ser aproveitados.

São, como se vê, dois casos bem distintos: no primeiro o excesso se exprime pela diferença

candidatos - matriculados,

no segundo, pela diferença aprovados - matriculados.

No primeiro caso, pode haver uma deficiência da parte dos candidatos;

no segundo, uma possível falha da parte das escolas.

30.2 - Devemos observar que o problema transcende o aspecto puramente quantitativo.

Para estudá-lo como convém, seria necessário ir mais fundo. Seria preciso verificar se o número de candidatos corresponde a uma exigência real da conjuntura nacional.

Seria conveniente apurar se os que se candidatam o fazem conscientemente, sabendo, de fato, o que é o curso e o que é a profissão a que aspiram.

Seria ainda de examinar se os processos de aferição nos vestibulares são os mais adequados a selecionar os mais aptos e os mais capazes.

Haverá ainda uma série de outros aspectos, mais qualitativos, sem os quais a consideração pura e simples de um deficit quantitativo pode levar - e a nosso ver tem levado - a conclusões imperfeitas, se não erradas.

30.3 - De qualquer modo, não há negar que existe na questão um fator quantitativo; é este que o Relatório procura 
estudar, sem deixar inteiramente de lado (embora não se detendo muito nele) o fator qualitativo.

Considerando apenas os números, apresenta o Relatório os dados globais existentes, relativos aos anos de 1964 e de 1965.

Segundo eles, os «excedentes» nesses dois anos aparecem assim:

\begin{tabular}{l|r|r|r|r}
\hline \multirow{2}{*}{ A N O S } & VAGAS & CANDIDATOS & APROVADOS & $\begin{array}{c}\% \text { DE VAGAS } \\
\text { PREENCHIDAS }\end{array}$ \\
\hline $1964 \ldots$ & 56.446 & 112.485 & 46.538 & 824 \\
$1965 \ldots$ & 58.929 & 125.406 & 47.494 & 80,5 \\
\hline
\end{tabular}

Parece-nos interessante juntar a estes dados um outro, calculando-se

a proporção de aprovações em relação ao número total de candidatos

Temos assim:

em 1964

$.41,5 \%$ de aprovados

em 1965 . $37,9 \%$ de aprovados

Quer dizer, aproximadamente:

de cada 10 estudantes

que pretendem entrar nas escolas superiores apenas quatro o conseguem.

30.4 - As estatísticas do Relatório mostram, por outro lado, e também aproximadamente, que

de cada 10 vagas existentes,

cerca de dois não são aproveitados.

A parte que o Relatório reservou para ligeira análise das provas de admissão parece-nos desnecessário resumi-la, porque, como dissemos, aí não se entra propriamente no âmago da questão.

Outros estudos

31 - Com o apanhado já feito, esgotamos, de certo modo, a parte do Relatório que se refere a valores quantitativos brasileiros. 
Passamos agora a examinar rapidamente os demais estudos nele incluídos.

Fá-lo-emos sem entrar em detalhes, porque a parte propriamente substantiva do trabalho já foi exposta. O que agora vamos focalizar serão antes questões opinativas, em que, se são realmente interessantes os pontos de vista americanos, não é menos certo que todos eles exigem uma discussão crítica, que excederia os limites deste resumo.

Vejamos, pois, sucessivamente, os capítulos do Relatório ainda não considerados por nós.

\section{Objetivos do Ensino Superior no Brasil}

Põe o Relatório em toco o difícil problema da definição dos objetivos ideais da Educação superior brasileira.

Depois de um exame perfunctório dos termos da questão:

«objetivos e valores»

«escassez de recursos»

e «inconsistência mútua»,

que levam a uma indispensável mas difícil opção; depois de ter posto como fundamento a ideia de que a educação deve preparar o homem para a comunidade em que viva, passa o Relatório a examinar algumas interrogações mais pertinentes.

Indaga, assim, sucessivamente:

«educação superior, (mas) para quem?»

«ensino, para fazer o quê?»

«que trabalho de pesquisa deve ser realizado?»

«quanto de homogeneidade se deve procurar na consideração dos diversos problemas?»

\section{O Valor da Diversidade Educacional}

Em outro capítulo o Relatório afirma a necessidade de diversificar o ensino superior, dando-se-lhe não uma estrutura rígida (que o vista como uma «camisa-de-fôrça», mas uma organização suficientemente flexível, para adaptá-lo às necessidades, variáveis no tempo e no espaço.

A favor dessa «elasticidade educacional», invoca então a experiência americana e as vantagens que dela derivam:

a) a diminuição dos custos, através «de melhor aproveitamento dos recursos»;

b) a tendência para aumentar o aproveitamento do aluno «de acordo com sua vocação» própria;

c) a possibilidade de maior progresso, pela «experimentação»e pela «competição interinstitucional». 
A Universidade-Fundação: uma Caixa de Pandora

34 - Ocupa parte importante do Relatório um estudo do sistema de Fundação

como remédio para sanar os males do nosso ensino superior.

Depois de mostrar as vantagens que podem resultar do sistema (sobretudo na escolha do pessoal docente, com maior flexibilidade e liberdade mais ampla, que permita melhor seleção), procura o Relatório salientar que o regime de Fundação não é uma panaceia, capaz de curar qualquer doença de qualquer doente.

Se resolve muitos problemas, traz consigo vários outros, e não é possível adotar a solução senão com boa dose de prudência e de cuidado.

\section{O Departamento na Universidade Americana}

35 - Outro estudo que o Relatório apresenta é o da divisão da Universidade em Departamentos.

Fá-lo, procurando, de certo modo, descrever o que seja «um departamento típico de uma Universidade norte-americana típica». Mostra como a estrutura departamental permite e estimula uma colaboração mais íntima dos professores de diversas disciplinas afins, com evidente e incontestável vantagem para o ensino.

O Departamento traz também - e obviamente - economia de despesas, uma vez que permite melhor aproveitamento dos professores .

Devemos, a propósito, observar que já temos no Brasil certa experiência desse sistema: a Escola Politécnica da PUC, por exemplo, o adotou há cerca de 15 anos, e ainda agora a nova $\mathrm{Fa}$ culdade de Tecnologia (Engenharia) da Universidade de Brasília entrou decididamente no regime departamental.

\section{Moeda Universitária: $\quad$ O Crédito}

36 - Explica o Relatório o regime chamado dos «créditos» para a promoção dos alunos.

Chama ao crédito, pitorescamente, moeda universitária.

Com isso quer dizer que o aluno, de certo modo, compra com conhecimentos

a sua formação, ou melhor, a sua formatura.

Define-se o crédito como

«o peso dado a cada disciplina oferecida pela Universidade».

Haverá assim, para a compra de determinado «título», disciplinas que valem mais e disciplinas que valem menos. 
Ao invés de fixar uma coleção fixa e rígida de moedas com que obrigatoriamente o título seja adquirido (regime do currículo invariável), prefere a Universidade dar

o preço global do título.

O aluno então, por conveniente escolha, mais adequada a seu tipo de preparo, procurará pagar esse preço com os «créditos» previamente fixados para as várias disciplinas.

É claro que a determinada disciplina corresponderá um «crédito» diferente, conforme o tipo do custo (conforme o «título») que se considere.

\section{A Estrutura da Universidade Americana}

Finalmente, o Relatório fornece uma

$$
\text { pisão panorâmica }
$$

do ensino superior nos Estados Unidos, juntando utilmente descrições que se encontram em trabalhos em que o assunto é encarado de diferentes pontos de vista.

Cremos ter dado ideia suficientemente clara e extensa do que é o Relatório da equipe de assessores americanos.

Resta-nos apenas reafirmar seu interesse e sua utilidade para quantos procuram, realmente, solução para o difícil problema universitário brasileiro. 


\title{
TOMO II
}

\section{INTEGRA DOS TRABALHOS DA EQUIPE AMERICANA}

\author{
I - Memorando ao Coordenador da EAPES \\ II - Apêndices ao Memorando
}

\section{RELAÇÃO DOS APÊNDICES}

Apêndice A - Cuniculum Vitae dos membros norte-americanos da EAPES

Apêndice B - Documentos do «Grupo de Trabalho sobre o Reconhecimento», preparados pelos Profs. Edson Nery da Fonseca e Rubens Borba de Morais:

B.1 - «Projeto de Inquérito sobre a Situação das Bibliotecas das Universidades Federais».

B.2 - «Obras de Referência: Bibliografia Mínima».

Apêndice $\mathrm{C}$ - Conjunto de trabalhos elaborados pelo Prof. John D. Ryder. Está dividido em:

$\mathrm{Cl}$ - «Study of Enrollments»

C.2 - «Utilization of Space and Faculty»

C.3 - «Unit Costs in Higher Education»

C. 4 - «Post-Graduate Education»

C.5 - «Admissions Policies and Practices»

C.6 - «University Survey».

Apêndice D - Conjunto de trabalhos escritos pelo Prof. John M. Hunter. Divide-se em:

D.1 - «A Universidade-Fundação: Uma Caixa de Pandora» («The Pandora's Box of the University Foundation») .

D.2 - «Moeda Universitária: O Crédito» («Academic Currency: The Credite).

D. 3 - «Notas sobre a Heterogeneidade» («A Note on Heterogeneity») .

D.4 - «Sobre o Ensino da Economia no Brasil» («On the Teaching of Economics in Brazil»).

D.5 - «Sobre os objetivos da Educação Superior no Brasil» ( «On the Objectives of Higher Education in Brazil»). 
D.6 - «Estrutura da Educação Superior nos Estados Unidos» («The Structure of Higher Education in the United States»).

D.7 - «Sobre o Problema dos Excedentes» («On the Problem of Excedentes»).

D. 8 - «A Economia dos Empréstimos no Exterior para Fins Educacionais em Geral» («The Economics of Borrowing Abroad for General Educational Purposes»).

Conjunto de trabalhos preparados pelo Prof. Henry W. Hoge. Está dividido em:

E.1 - «O Departamento na Universidade Norte-americana» («The University Department») .

E.2 - «Estrutura do Corpo Docente nos E.U.A.» («Faculty Structure»).

E.3 - «Reflexões sobre a Educação Superior no Brasil» («Reflections on Higher Education in Brazil») .

Relação dos trabalhos publicados na Imprensa brasileira. São os seguintes:

F.1 - «A Universidade-Fundação: Uma Caixa de Pandora», publicado na revista Estudos Universitários, $n^{o}$ 4, vol. VII, out./dez. 1967, págs. 23-42.

F.2 - «Notas sobre a Heterogeneidade», publicado no jornal $O$ Estado de São Paulo, em 16 de março de 1968, sob o título «O Valor da Diversidade Educacional», com introdução do Prof. Laert R. de Carvalho.

F.3 - «O Departamento da Universidade Norteamericana», publicado no jornal $O$ Estado de São Paulo, em quatro partes, nos dias 23, 24, 25 e 26 de maio de 1968, com introdução do Prof. Laert Ramos de Carvalho.

F.4 - «Moeda Universitária: O Crédito», publicado no jornal O Estado de São Paulo do dia 23 de junho de 1968, com introdução do Prof. Laert R. de Carvalho.

F.5 - «Sobre o Ensino de Economia no Brasil», a ser publicado na Revista Brasileira de Economia, número do mês de setembro de 1968.

III - Relatório da USEAPES (forma preliminar), dirigida à USAID, capítulo VII: «Recomendações» («USEAPES Report», Draft, Chapter VII - Recomendations). 
Obs.: Os trabalhos do Prof. J. D. Ryder não foram traduzidos por constituírem um levantamento e síntese crítica da literatura relativa à estatística educacional no Brasil.

Foram introduzidas pelo tradutor, de comum acordo com o autor, algumas modificações no texto em português de trabalhos dos Profs. J. M. Hunter (excetuando-se os dos apêndices D. 7 e D.8) e H. W. Hoge, bem como no «Relatório Preliminar da USEAPES» e no memorando dos professores mencionados ao Coordenador da EAPES.

Rio, 2 de maio de 1968

\section{MEMORANDUM}

De : Henry W. Hoge e John M. Hunter - EAPES

Para : Dr. Rubens Porto - Coordenador da EAPES

Conforme solicitação de V.Sa., vimos apresentar-lhe este documento relativo às atividades dos membros do grupo americano da EAPES a partir de $1^{\circ}$ de janeiro de 1967 . Este memorandum cobrirá sumariamente as atividades desenvolvidas, encontrando-se em anexo os documentos pertinentes e ilustrativos destas atividades.

\section{I - PRINCÍPIOS OPERACIONAIS BÁSICOS}

Acreditamos que o ensino - do qual a Educação superior é importante componente - é elemento crítico no desenvolvimento social, econômico e político de qualquer sociedade. Acreditamos que a Educação superior nos Estados Unidos constitui relevante experiência para outros países, especialmente quanto aos tipos de problemas por ela reconhecidos e quanto ao modo pelo qual estes foram tratados. Mas acreditamos ainda que o ensino é produto da sociedade e só pode sei entendido no contexto sócio-político-econômico desta sociedade. Assim. qualquer recomendação útil exige cuidadoso esforço para compreender o contexto social no qual a Educação superior desenvolve suas atividades, exigindo também completo conhecimento do funcionamento e desenvolvimento histórico das Universidades brasileiras.

Tendo em vista esta orientação básica, grande parte de nossas atividades consistiu em familiarizarmo-nos com a língua, com a sociedade e com as Universidades e suas estruturas. Esperávamos, corretamente, que pudéssemos oferecer pouca «assessoria» ou «auxílio» durante este ano inicial. Por outro lado, muito aprendemos sobre as instituições existentes, seus aspectos positivos e negativos; sabemos algo a respeito das forças que estão subjacentes à Reforma Universitária e algo acerca de seu provável rumo; identificamos as pessoas chave na Educação superior e travamos conhecimento com muitas delas. 
Resumindo, cremos que o ensino é importante, mas é necessariamente um produto da sociedade em que se insere e as transformações a serem nele efetivadas têm de ser relevantes e possíveis dentro de sua própria «realidade». Em virtude disto, procuramos aprender mais do que procuramos aconselhar; e sem dúvida alguma encontramos mestres excelentes e de boa vontade.

\section{II - FASE INICIAL}

Além do MEC e da USAID, a terceira parte contratante é o Midwest Consortium for International Activities, que inclui a Universidade de Illinois, a Universidade de Indiana, a Universidade de Wisconsin, e a Universidade do Estado de Michigan. Estas são quatro Universidades públicas de projeção e grande tamanho no MeioOeste dos Estados Unidos. O Chancellor J. Martin Klotsche (vide apêndice A para o curriculum vitae contendo material relevante) da Universidade de Wisconsin-Milwaukee e o Dean John D. Ryder, da Universidade do Estado de Michigan, chegaram ao Rio de Janeiro em princípios de janeiro de 1967. Em fevereiro chegou o prof. Hunter e em março o prof. Hoge. O Dr. Klotsche é o chefe da equipe americana, embora seus deveres para com sua própria Universidade lhe permitissem despender relativamente pouco tempo no Brasil. O Doutor Ryder desempenhou as funções de chefe de equipe em exercício até sua partida do Brasil em meados de fevereiro de 1968.

Os primeiros meses foram dedicados a cursos de língua portuguesa, a estudos intensivos e à familiarização com as fontes de dados, procurando travar conhecimento com vários líderes educacionais - o que foi gradativamente alcançado; e começamos a nos familiarizar com o processo político brasileiro à medida que testemunhávamos a mudança de governo e sucessivas substituições de Diretores do Ensino Superior. Estas atividades continuaram após o mês de julho, com crescente ênfase nas visitas a Universidades, na identificação dos seus problemas, posteriormente dedicando-nos à preparação de trabalhos escritos.

Nos últimos meses continuamos a visitar Universidades, a ler e estudar, e contamos com a presença de uma equipe de destacados brasileiros, com quem mantivemos troca de ideias e informações a qual teve caráter informal, porém importante. Nosso contato com os educadores brasileiros foi substancialmente aumentado através de excelentes seminários, organizados pelos nossos companheiros de equipe.

$$
\text { III - VISITAS }
$$

O programa de visitas a Universidades está longe de ser um programa completo, mas pelo menos algum de nós despendeu bastante tempo em cada uma das seguintes Universidades federais: Bahia, Ceará, 
Santa Catarina, Espírito Santo, Paraná, Goiânia, Pernambuco, Rio de Janeiro e Brasília. Além destas, visitamos também as seguintes Universidades particulares: Católica do Rio de Janeiro, Católica de Salvador, Mackenzie, Gama Filho. Os objetivos das visitas a estas instituições eram variados, mas de modo geral estávamos ansiosos para «sentir» o que era a comunidade universitária, para começar a compreender seus mecanismos. Além disso, era importante que conhecêssemos o trabalho de vários outros órgãos: Conselho de Reitores, IPEA, SEEC, Fundação Ford, Fundação Getúlio Vargas, Centro Brasileiro de Pesquisas Educacionais, INEP, etc. Estas visitas nos deram uma impressão geral das funções de cada instituição.

Queremos expressar aqui nossa gratidão por todos aqueles que nos receberam de modo tão hospitaleiro e que tanto nos auxiliaram. Em toda parte encontramos pessoas dispostas a se reunir conosco e a discutir o ensino superior brasileiro e seus problemas.

\section{IV - O GRUPO DE TRABALHO SOBRE RECONHECIMENTO}

$\mathrm{Na}$ ausência de uma equipe brasileira permanente durante os primeiros meses, mantivemos conversações e realizamos reuniões com vários grupos e pessoas. Obteve-se proveitosa associação com vários membros do Conselho Federal de Educação, especialmente com os Drs. Newton Sucupira, Rubens Maciel, Valnir Chagas e Roberto Santos. Após vários meses, este grupo e vários membros da atual equipe brasileira da EAPES criaram um grupo ad hoc e informal, destinado a estudar os problemas da «autorização» e do «reconhecimento». A USAID concedeu permissão para despender verba adicional com este estudo, a qual foi utilizada principalmente para adicionar ao grupo de trabalho, como consultores, dois eminentes bibliotecários brasileiros.

$\mathrm{Na}$ verdade este esforço só agora está começando. O grupo de trabalho deverá preparar um formulário e estabelecer padrões adequados para a solicitação de autorização e reconhecimento das novas Universidades e das novas faculdades isoladas. Algumas partes deste formulário já estão parcialmente elaboradas, enquanto que a preparação de outras ainda não foi sequer iniciada. A parte referente à biblioteca é a que se encontra mais avançada, e os dois consultores (Professores Edson Nery da Fonseca e Rubens Borba de Moraes) estão atualmente preparando um esquema de pesquisa para definir o trabalho que ainda é necessário realizar para que esta parte do formulário possa ser utilizada. A pesquisa a ser proposta será de imensa valia e deve ser levada a efeito pela sua própria relevância, independentemente de sua contribuição para o formulário geral.

Ao trabalharmos com os consultores brasileiros, procuramos sempre considerá-los como um pessoal de assessoria técnica para o grupo de trabalho, esperando demonstrar o valor de uma assessoria como esta 
- a necessidade de criar pessoal competente na sua área profissional, utilizando constante e regularmente este pessoal no planejamento e elaboração da política e das atividades educacionais.

Iniciou-se o trabalho nesta área porque era do interesse direto das pessoas com as quais, na época, mantínhamos um diálogo mais estreito. Julgamos que este é problema importante, para o qual podem e devem ser elaborados padrões concretos e detalhados, que servirão como dispositivos para orientar uma expansão ordeira do ensino brasileiro, sem sérios efeitos nocivos sobre sua qualidade (Atualmente só está disponível o esquema inicial da primeira parte deste trabalho, e mesmo assim numa forma bem primitiva. Vide Apêndice B. Este esquema posteriormente passou por consideráveis modificações e atualmente está sendo revisto mais uma vez).

\section{$\mathrm{V}$ - COMENTÁRIOS}

Durante o periodo inicial de nossos trabalhos, nos encontros que tivemos com várias pessoas da área educacional, realizamos um exame conjunto de várias ideias e problemas relativos à Educação. Alguns aspectos destas conversações levaram a «comentários» escritos, que são basicamente de três tipos. O Dean Ryder realizou levantamento abrangendo a literatura existente com relação à estatística educacional no Brasil. Sintetizou e resumiu dados extensos, fazendo uma revisão crítica dos resultados. Seu trabalho terá mais interesse para o leitor estrangeiro (Vide Apêndice C).

Como recebemos constantes perguntas e verificamos existir impressões inexatas sobre diversos aspectos da Educação superior nos E.U.A., animamo-nos a escrever vários trabalhos no sentido de explicar e esclarecer estas questões. São deste tipo trabalhos do prof. Hoge sobre o «Departamento» e sobre a «Estrutura do Corpo Docente nos E.U.A.» (Vide Apêndice E), bem como os do prof. Hunter sobre o «Sistema de Créditos» e sobre a «Estrutura da Educação Superior nos E.U.A.» (Vide Apêndice D) .

Outro conjunto de trabalho analisa problemas da Educação superior brasileira. O trabalho sobre os «objetivos» da política educacional analisa os tipos de perguntas que devem ser respondidas para a formulação de um conjunto concreto de objetivos. Outro trabalho sugere que a «Fundação» como estrutura para as Universidades resolverá alguns problemas; mas a flexibilidade em que implica a «Fundação» cria uma multidão de outros problemas. Outro trabalho sugere ainda que se deve dar cuidadosa atenção aos valores que derivam da heterogeneidade no sistema educacional. Outro examina o ensino de economia no Brasil e o problema dos excedentes. Estes trabalhos geralmente não ofecerem preceitos a serem seguidos fundamentalmente, porque não estamos em condições de oferecer soluções definitivas. Em primeiro lugar, foram preparados para nosso próprio benefício - a autodisci- 
plina que se precisa para descrever e definir problemas. Em segundo lugar, esperamos que algum observador de fora, tendo uma visão diferente dos problemas, possa trazer alguma luz nova, contribuindo para aumentar a compreensão e para se alcançar uma eventual solução (Vide Apêndices D e E).

\section{VI - RETORNOS À EDUCAÇÃO}

Um estudante de pós-graduação da Universidade do Estado de Michigan, Sr. A. J. Rogers III, está realizando significativa pesquisa sobre os retornos individuais e sociais da Educação superior do Brasil. Foi utilizada a amostra de $25 \%$ do Censo demográfico de 1960, que inclui os dados sobre ocupação e renda, e os resultados desta pesquisa foram recentemente obtidos e estão disponíveis. O estudo procura medir as diferenças entre os retornos econômicos aos vários tipos de despesas educacionais, particularmente aqueles que se referem às profissões. Os resultados devem ter importantes implicações para a elaboração de planejamentos.

\section{VII - CONCLUSÕES}

Esta lista de atividades dos últimos 16 meses talvez sugira um nível baixo de realização. Esta poderia ser uma conclusão exata. Mas não pensamos assim. Nossa intenção era desenvolver ampla base de compreensão e conhecimento, a partir da qual pudéssemos dar uma assessoria inteligente e na medida do nosso possível para o planejamento da Educação superior no Brasil. Julgamos que adquirimos muito deste conhecimento e compreensão básicos.

Estamos muito satisfeitos com trabalho ininterrupto dos nossos companheiros de equipe. Esperávamos ter obtido esta colaboração mais cedo do que foi possível, mas compreendemos e aceitamos as dificuldades encontradas para a organização da equipe. Aconteça o que acontecer, desejamos grande êxito à equipe e instamos para que use de toda sua considerável influência para assegurar sua própria continuidade, de uma forma ou outra, como equipe técnica profissional de alto nível e permanente junto ao Diretor do Ensino Superior.

Tendo sido o principal alvo da contínua publicidade negativa dada ao MEC-USAID, permitimo-nos uma ou duas palavras sobre o assunto: 1) Sentimo-nos muito lisonjeados pelo grau de influência que nos foi atribuído. Se tivéssemos tal poder, isto faria com que nos sentíssimos completamente inadequados para a tarefa e até mesmo atemorizados. 2) Uma parte das persistentes críticas foi justa, outra parte simplesmente derivada de informações erróneas, e uma boa parte destinada deliberadamente a dar informações falsas. Com respeito a estas maliciosas informações falsas, pouco se pode fazer, exceto ignorálas e continuar com o trabalho que se julga ser importante. 3) O 
entusiasmo em confeccionar cartazes e pintar paredes sobre o MECUSAID indica a existência em todo o Brasil de vivo interesse na Educação superior, e concordamos com esta avaliação da importância do ensino superior. Esperamos que, com a iminente extinção do MEC-USAID, já com data marcada, seja possível reunir todas as forças interessadas na causa comum que é o ensino superior no país, a fim de prosseguir com esta notável tarefa.

Traduzido em junho ,de 1968 - J. R. Velloso.

May 2, 1968

\section{MEMORANDUM}

To: Dr. Rubens Porto, Coordinator, EAPES

From: Henry W. Hoge, John M. Hunter, EAPES

In accordance with your request, we submit this statement of the activities of the U.S. members of EAPES from January 1, 1967. We will report briefly in this covering memorandum, appending related and supporting documents.

\section{I - BASIC OPERATING PRINCIPLES}

We believe that education, of which higher education is an impor tant component, is a criticai ingredient in the social, economic, and politicai development of any society. We believe that higher education in the United States provides relevant experience for other countries, especially with respect to the types of problems it has reccgnized and the manner in which it has dealt with them. But we further believe that education is the progeny of society, only to be understood in its socio-politico-economic context. Thus, any useful advice requires a careful effort to understand both the societal complex in which higher education operates as well as a thorough knowledge of the operation of Brazilian universities and their historical development.

With this basic orientation, much of our activity has centered on familiarizing ourselves with the language, with the society, and with the universities and their structures. $\mathrm{W}^{\wedge} \mathrm{e}$ correctly expected that little «advice» or «assistance» could be given during the initial year. On the other hand, we have learned a great deal about existing ínstitutions, their strengths and weaknesses; we know something of the forces behind university reform and something of its likely path; we have identified key persons in higher education and have become acquainted with many of them.

To summarize, we think that education is important but that it is necessarily a product of the society in which it is found and that changes in it must be relevant and possibte within its own «reality». 
Because of this, we have sought ío learn more than we have sought to advise; and, certainly we have found excellent and willing teachers.

\section{II - PERSONNEL INPUTS}

The third contracting party, with MEC and USAID, is the Midwest Universities Consortium for International Activities, including the University of Illinois, the University of Indiana, the University of Wisconsin, and Michigan State University. These are four large and distinguished public universities in the Midwest. Chancellor J. Martin Klotsche (see Appendix A for curriculum vitae containing relevant material) of the University of Wisconsin-Milwaukee and Dean John D. Ryder of Michigan State University arrived in Rio de Janeiro early in January, 1967. They were followed in February by Prof. Hunter and in March by Prof. Hoge. Dr. Klotsche is Chief-of-Party although his responsibilities to his own University have permitted him to spend relatively little time in Brazil. Dr. Ryder served as Deputy Chief-of-Party until he left Brazil in ruid-February, 1968 .

The early months were dedicated to language courses, intensive study, familiarization with source materiais, seeking out and becoming acquainted with various individuais; and we began to become familiar with the Brazilian politicai process as we witnessed the change of government and sucessive replacements of the Diretor do Ensino Superior. The months following July saw a continuation of these activities with increasing emphasie on university-visitation, the identification of problems, and later, more attention to writing. Recently, we have continued visiting universities, reading, studying, and we have had the presence of a team of distinguished Brazilian counterparts with whom there has been an informal but important exchange of information and ideas. Our exposure to Brazilian educators has substancially increased through a series of excellent seminars arranged by the counterpart team.

\section{III - VISITATION}

The university-visitation program is far from complete, but at least one of us has spent some considerable time in each of the following federal universities: Bahia, Ceará, Santa Catarina, Espírito Santo, Paraná, Pernambuco, Rio de Janeiro, and Brasília. In addition, we visited the following private universities: Católica do Rio de Janeiro, Católica de Salvador, Mackenzie, Gama Filho. The purpose of visiting these institutions varied somewhat, but generalíy we were anxious to get a «feel» for the university community, to begin to understand its mechanisms. In addition, of course, it was important that we get to know the work of many other agencies: Conselho de 
Reitores. IPEA, SEEC, Ford Foundation, Fundação Gelúlio Vargas, Centro Brasileiro de Pesquisas Educacionais, INEP, etc. These visits accorded a general impression of the function of each institution.

It is appropriate here to express our gratitude do ali who received us so hospitably and helpfully. We found everywhere a willingness to meet with us and great interest in discussing with us Braziiian higher education and its problems.

\section{IV - THE ACCREDITATION WORKSHOP}

In the absence of permanent Braziiian counterparts in the early months, meetings and conversations were held with many groups and individuais. A fruitful association developed with various members of the Conselho Federal de Educação, especially with Drs. Newton Sucupira, Rubens Maciel, Valnir Chagas, and Roberto Santos. After several months, this group and several members of the present Braziiian EAPES team established an informal, ad hoc group to study the problems of «authorization» and «recognition». USAID permitted the expenditure of additional funds for this purpose, which have been utilized primarily to add two eminent librarians as consultants to the workshop.

This effort is really just begun. The workshop should finally expect to produce a formulário and standards suitable for application in the authorization and recognition of new universities and isolated faculties. Some sections of such a formulário have been partially developed others and have not even been begun. The library portion is the furthest advanced, and the two consultants (Professors Edson Nery da Fonseca and Rubens Borba de Morais) presently are preparing a research design to outline the work still required to make this part of the formulário operable. The research to be proposed will be immensely valuable and should be undertaken for its own sake, independently of its contribution to the general formulário.

We have tried consistently to serve with the Braziiian consultants as a professional staff for the workshop, hoping to demonstrate the value of such a group - the necessity of developing professional competence and to have it available on a regular and continuous basis for the planning and developing of educational policy and activity.

Work has begun in this área because it was of immediate interest to the persons with whom our «dialogue» was at the active. We think it represents an important problem, one in which concrete and detailed standards can and should be developed as devices for governing the orderly expansion of Braziiian education without serious deleterious effects upon its quality (Only the first draft of a portion of this work is now available in even moderately suitable form. See Appendix B. This has subsequently undergone considerable mutation and is presently being re-revised). 


\section{V_COMMENTARIES}

In the familization process, there was a mutual exploration of ideas and problems with many people. Some aspects of these conversations led to written «commentaries». These are of basically three varieties. Dean Ryder thoroughly surveyed the existing literature with respect to educational statistics in Brazil. He synthesized and summarized the extent data, reviewing the results critically. His work will mostly be of interest to the foreign reader (See Appendix C).

Frequent questions or inaccurate impressions about various aspects of U.S. education encouraged the writing of several papers to expiam and clarify. Prof. Hoge's papers on the «Department» and «Faculty Structure in the U.S.» are of these types as are Prof. Hunter's on the «Credit System» and the «Structure of the U. S. University» (See Appendixes D and E).

Still another set of papers analyzes problems in Brazilian higher education. A paper on the «objectives» of educational policy analyzes the kinds of questions which must be answered to formulate a concrete set of goals. Another suggests that the «foundation» as a university-form will solve some problems and that the implied flexibility creates a host of others. Still another suggests that careful attention be paid to the values to be derived from heterogeneity in the educational system. Other papers examine the teaching of economics in Brazil and the «excedentes» problem. These papers generally do not offer prescriptions, primarily because «solutions» elude us. They were prepared first of ali for our own benefit - the necessary self-discipline of problem description and definition. Secondly, we hope that an occasional outsider's view of problem may cast some new light, contributing incrementally to understanding and eventual solution (See Appendixes $D$ and $E$ ).

\section{VI - RETURNS TO EDUCATION}

A graduate student from Michigan State University, Mr. A. J. Rogers III, is doing significant research on social and individual returns to education in Brazil. He uses the 25 per cent sample of occupations and income of the 1960 census, the results of which are just now available. The study seeks to measure the differences in economic returns to various kinds of educational expenditures, particularly those in the professions. The results should have important implications for planning purposes.

\section{VII - CONCLUSIONS}

This accounting of activities over the last sixteen-month period perhaps suggests a low levei of accomplishment. This may be a proper conclusion. But we think not. It was our purpose to develop a broad 
base of understanding and knowledge from which to assist wisely and as we could in the planning of nigher education in Brazil. Much of this basic knowledge and understanding we think we have acquired.

We are delighted at the continued development of our team of counterparts. We hoped to have had this collaboration much sooner than it proved possible, but we understand and appreciate the difficulty encountered in organizing it. $\mathrm{W}^{\wedge}$ hatever may happen, we wish it great success and urge that it use ali its considerable influence to assure its own continuity in some form or other as a high-level, professional, permanent staff for the Diretor do Ensino Superior.

As the principal recipients of the continuous negative publicity given MEC-USAID, we should be permitted a word or two on the subject: 1. We have been greatly flattered by the deqree of influence attributed to us. Had we had such power, it would have been to us thoroughly humbling, even frightening. 2. Some part of the persistent criticism has been just, some part of it simply misinformed, and a good portion of it deliberately misinforming. With respect to the malicious misinforming there is little one can do except to ignore it and continue with the work believed to be important. 3. The enthusiasm engendered in poster-making and wall-painting by MEC-USAID indicates a lively interest in higher education throughout Brazil, and we agree with this assessment of the importance of higher education. With the already scheduled impending demise of MEC-USAID, we hope that it will be possible to reunite ali the forces interested in the common cause of higher education in the country so as to get on with the very considerable task.

\section{EQUIPE NORTE-AMERICANA DA EAPES}

Os seguintes curricula vitae foram preparados para dar ao $\mathrm{Sr}$. leitor ligeira ideia do pessoal norte-americano vinculado à Equipe de Asscssoramento ao Planejamento do Ensino Superior: suas qualificações, sua experiência e seus interesses.

Baseia-se toda a seleção dos itens na tarefa da equipe aqui no Brasil

Rua Honório de Barros, 41 - apto. 802

$$
\begin{array}{cccc}
\text { Rio de Janeiro - Guanabara } \\
7 \text { de julho de } 1967
\end{array}
$$

\section{«CURRICULUM VITAE $>$}

NOME: J. MARTIN KLOTSCHE, Reitor, University of Wisconsin-Milwaukee LOCAL E DATA DE NASCIMENTO: 28 de novembro de 1907 (Scribner, Nebraska) ENDEREÇO: Rua Professor Saldanha, 147 - apto. 401 - Jardim Botânico. Telefone: $46-3277$

Permanente: University of Wisconsin-Milwaukee Chapman Hall

M lwaukce, Wisconsin 53211 


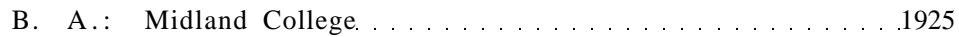

M. A.: University of Nebraska ................... 1928

Ph. D.: University of Wisconsin . . . . . . . . . . . . 1931

HONORÍFICOS: LL. D. Carthage College

D. Sc. Midland College

LL. D. University of Nebraska

ATUAÇÃO PROFISSIONAL:

Professor de História. Wisconsin State College . 1931-44

Diretor Acadêmico, Wisconsin State College . . . . . . . . 1944-46

Presidente, Wisconsin State College ....................... 1946-56

Reitor e Catedrático de História, University of WisconsinMilwaukee.

SOCIEDADES HONORÁRIAS: Phi Beta Kappa

Phi Kappa Phi

EXPERIÊNCIA NO ESTRANGEIRO:

Director of Institute of World Affairs, Paris, France- 1948

Director of Institute of World Affairs, Geneva, Switzerland 1949

U. S. Education Specialist in Germany. ............... 1953

Study of European Urban Universities under University grant, summer and fali

ATUAÇÃO PERTINENTE:

Presidente, Wisconsin Academy of Sciences and Letters

Presidente, Wisconsin Association of Presidents and Deans

Vice-Presidente, Association of Urban Universities

Diretor, Governor's Metropolitan Study Commission

Presidente, Goethe House

Governador Regional do Rotary International

PUBLICAÇÕES:

Book: «The Urban University and the Future of our Cities》 - 1966

(Mais de 40 artigos para publicações profissionais).

INTERESSES PROFISSIONAIS:

a) Administração universitária

b) Critérios para estabelecimento de ensino superior

c) Planejamento educacional a longo prazo

\section{«CURRICULUM VITAE $>$}

NOME: JOHN D. RYDER, Diretor da Escola de Engenharia e Professor Catedrático de Engenharia Elétrica da Michigan State University.

DATA E LOCAL DE NASCIMENTO: 8 de maio de 1907 (Ohio)

ENDEREÇO: Rua Joaquim Nabuco, 238 - apto. 702 - Ipanema

Permanente: School of Engineering Michigan State University

East Lansing, Michigan 48823

FORMAÇÃO:

B. S.: Ohio State University. . . . . . . . . . . . . . . . 1928

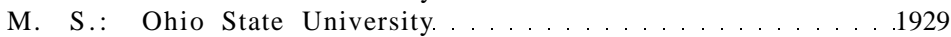

Ph. D.: Iowa State University, Ames, Iowa . . . . 1944

Doutor Honoris Causa em Engenharia - Tri-State College, Angola, Indiana 
ATUAÇÃO PROFISSIONAL:

1929-31 - Engenheiro da General Eletric Co., Schenectady, New York.

1931-41_Engenheiro e Chefe de Pesquisas elétricas, Bailey Meter Co., Cleveland. Ohio.

1941-49__ Professor de Engenharia Elétrica e Diretor Assistente do Departamento Experimental de Engenharia, Iowa State University.

1949_54 - Professor de Engenharia Elétrica e Chefe do Departamento de Engenharia Elétrica na Universidade de Illinois, Urbana, Illinois.

1954 - presente - Diretor da Escola de Engenharia e Professor de Engenharia Elétrica, Michigan State University, East Lansing, Michigan.

EXPERIÊNCIA NO ESTRANGEIRO:

Guatemala, Colômbia, Venezuela, Peru, Nigéria, índia, Japão, Okinawa, Austrália.

ATUAÇÃo PERTINENTE:

Membro da Diretoria, 1952-1964, e Presidente, 1955, Instituto de Engenheiros Elétricos e Eletrônicos (New York).

Presidente, Conferência Nacional de Eletrônica, Chicago, Illinois, 1952.

Diretor, Seção de Engenharia Elétrica, American Society for Engineering Education, Washington, D.C., 1952.

Editor, Instituto de Engenheiros Elétricos e Eletrônicos. New York, 1958-1959, 1963-1964.

Diretor, Seção de Engenharia, American Association of State Universities and Land-Grant Colleges, Washington, D.C., 1963.

PUBLICAÇÕES PERTINENTES:

Networks, Lines and Fields, Prentice Hall, Inc., 1957.

Electronic Engineering Principies, 2' edição, Prentice Hall. Inc., 1959.

Electronic Fundamentals and Applications, 3 edição, Prentice Hall, Inc., (em Espanhol, também), 1964.

Engineering Eletronics, 2» edição, McGraw-Hill Book Co., (em Espanhol também), 1967.

INTERESSES PROFISSIONAIS:

a) Educação em ciências e engenharia;

b) Critérios para estabelecimentos de ensino superior;

c) Planejamento para estabelecimentos novos.

\section{«CURRICULUM VITAE»}

NOME: HENRY WILliam HOGE, Professor Catedrático de Espanhol $e$ Português, da University of Wisconsin-Milwaukee

DATA E LOCAL DE NASCIMENTO: 15 de fevereiro de 1919 (Kentucky)

ENDEREÇO: Rua Figueiredo de Magalhães, 643 - apto. 401 - Copacabana

Permanente: Department of Spanish and Portuguese University of WisconsinMilwaukee

Milwaukee, Wisconsin 53211

FORMAÇÃO:

B. A.: University of Indiana

M. A.: University of Wisconsin

$\mathrm{Ph}$. D.: University of Wisconsin

1948

Pos-doutoral: Columbia University, N. Y 
ATUAÇÃO PROFISSIONAL:

Diretor, Departamento de Espanhol e Português, Universidade de Wisconsin-Milwaukee . . . . . . . . . . . . . . 1959-64

Diretor, Seção de Linguística, Centro de Treinamento do Corpo de Paz, Universidade de Wisconsin-Milwaukee . . 1962_64

Diretor, Laboratório Linguístico, Universidade de WisconsinMilwaukee.

EXPERIÊNCIA NO ESTRANGEIRO:

Visitas: Canadá, Inglaterra, França, Espanha, Portugal, América Latina, Cuba, Peru, Colômbia, Panamá, Brasil.

$.1961,1964,1967$

Residência: Cuba (1958), Colômbia (1959), Brasil (1964).

ATUAÇão PERTINENTE:

Diretor, Centro Latino-Americano de Línguas e Cultura,

Universidade de Wisconsin-Milwaukee
Professor visitante, Instituto Caro y Cuervo, Bogotá, Colômbia. .

PUBLICAÇÕES PERTINENTES:

Ora! Brazilian Portuguese (em colaboração):

Milwaukee, University of Wisconsin-Milwaukee, 1964.

$\mathrm{XII}+424 \mathrm{pp}$.

Modem Portuguese (em colaboração):

Austin, University of Texas, 1966. 2 vols.

III +346 and II + 326 pp.

A Selective BMiography of Luso-Brazilian Linguistics:

Milwaukee, Latin American Center, 1966. 70 pp.

A selective Bibliography of Contemporary Brazilian

Literature:

M1waukee, Latin American Center, 1967, 69 pp.

Aufo-Instructional Language and Área Training Material.

Brasil (in progress).

(Mais 20 artigos e livros sobre linguística aplicada).

INTERESSES PROFISSIONAIS:

D) Análise de currículo universitário;

b) Estrutura do professorado universitário;

c) Critérios regionais para a expansão do ensino superior;

d) Análise dos exames vestibulares.

\section{«CURRICULUM VITAE $>$}

NOME: JOHN M. HUNTER, Professor Catedrático de Economia, Michigan State University

DATA E LOCAL DE NASCIMENTO: 1 de dezembro de 1921 (Champaign, Illinois)

ENDEREÇO: Av. Vieira Souto, 526 - apto. 802 - Ipanema

Permanente: Department of Economics

Michigan State University

East Lansing, Michigan 48823

FORMAÇÃO:

B. S.: University of Illinois.

M. S.: University of Illinois

Ph. D.: Harvard University. 
ATUAÇÃO PROFISSIONAL:

Professor assistente, associado, e professor, Michigan State

University. . . . . . . . . . . . . . . . . . . . . " " . . . . . . . . . . . . . . . . . .

Vice-Diretor, Departamento de Economia . . . . . . . . . 1956_57

Diretor Interino. . . . . . . . . . . . . . . . . . . . . . . . . . . . . . . . . . . . . .

EXPERIÊNCIA NO ESTRANGEIRO:

Visitas: China - México - Equador - Brasil . . . . . . 1963-65

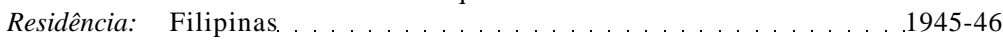

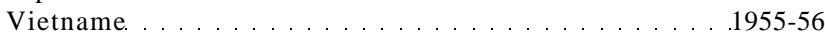

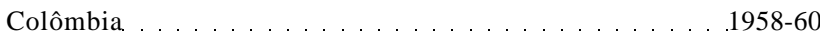

Argentina . . . . . . . . . . . . . . . . . . . . . . 1962-64

ATUAÇÃO PERTINENTE:

Economista, Michigan State University, Equipe de Assessoramento em Administração Pública. Vietname ....

$1955-56$

Diretor, Centro de Estudos sobre Desenvolvimento Econômico,

Universidad de Los Andes, Bogotá, Colômbia

$1958-60$

Assessor, Instituto de Economia y Finanzas, Universidad

Nacional de Córdoba, Córdoba, Argentina . . . . . . . . . . . . . . . . . . .

Consultor, A Fundação Ford . . . . . . . . . . . . . . . . . 1962

PUBLICAÇÕES PERTINENTES:

La Ensenanza de la Economia (com J. A. S. Ternent), CEDE, Bogotá, 1959.

Algunos Aspectos de la Organización y Operación de la Universidad de los Andes. Relatório ao Reitor da Universidad de los Andes, 1959.

Organización y Marcha de la Investigaciôn, Universidad Nacional de Córdoba, 1962.

Racionalización Integral de la Universidad (com Jo-ge Orgaz e W. T. Middlebrook), Universidad Nacional de Córdoba. 1964.

«Comentários de un Gringo sobre la Educación Universitária en Colômbia», Revista de la Universidad de los Andes, Março 1960.

«Qué es la Investigaciôn? II», Revista dei Banco de la República, Bogotá, Junho 1960.

«El Mejoramiento de la Ensefianza de la Economia en la República Argentina», Revista de Economia y Estadística, Afio IX, ns. 1, 2, 3, 4, 1965.

«Contadores. Contabilidad y Economia», Revista da Economia y Estadística, Ano VII, ns. 3, 4, 1963.

INTERESSES PROFISSIONAIS:

a) Exames vestibulares;

b) Critérios de reconhecimento das novas instituições;

c) Economia da Educação Superior (vários aspectos);

d) Metas educacionais do Brasil. 


\title{
PROJETO DE INQUÉRITO SOBRE A SITUAÇÃO DAS BIBLIOTECAS DAS UNIVERSIDADES FEDERAIS
}

\author{
1. INTRODUÇÃ O
}

Há poucos dias, o responsável por uma das mais novas indústrias de ensino superior em nosso País dirigiu-se, por escrito, à direção da Biblioteca Central da Universidade de Brasília, solicitando permissão para que os seus alunos (isto é, contribuintes) utilizem os serviços da referida Biblioteca. Dessas novas indústrias sabemos também que oferecem cursos em salas emprestadas, durante a noite - nas sombras da noite - por colégios secundários da nova Capital.

Se a escola superior - e aqui simplesmente parafraseamos a definição de Faculdade de Direito enunciada pelo Professor Haroldo Valadão - é ou deve ser, essencialmente: a) uma biblioteca cercada; b) de salas de aulas, competindo a mestres e alunos o debate em $b$ do que aprenderam em a - podemos concluir que as novas escolas superiores de Brasília conseguiram autorização para funcionar sem as condições essenciais.

E assim nascem quase todas as escolas superiores deste País. A própria Universidade de Brasília iniciou suas atividades docentes, em abril de 1962, sem biblioteca. E foi diante do clamor de professores contratados e intimados a dar um curso verdadeiramente superior que ela se sentiu compelida a organizar o que é hoje, com todas as suas deficiências, a melhor biblioteca universitária do Brasil.

O estabelecimento de padrões mais rigorosos para o reconhecimento de escolas superiores parece ser a solução adequada para o problema. Os padrões adotados em países mais desenvolvidos chegam a parecer utópicos, diante de uma realidade como a nossa. Esta realidade, portanto, deve ser cuidadosamente investigada, para que da investigação e da consideração dos padrões estrangeiros surjam padrões nacionais exequíveis.

Não é possível verificar o estado atual das bibliotecas universitárias brasileiras através de correspondência e de consulta aos repertórios estatísticos. No presente documento - solicitado pela EAPES a dois professores da Faculdade de Biblioteconomia e Informação Científica da Universidade de Brasília - propõe-se uma pesquisa in loco.

Essa pesquisa tem como finalidade, portanto, investigar a situação das bibliotecas das Universidades federais, nos seus variados aspectos. 
Sua realização obedecerá às seguintes etapas: a) questionário; $h$ ) Ifstas de livros básicos; c) seleção das Universidades e faculdades; d) investigadores, seleção e treinamento; e) prazos; /) tabulação e análise dos dados colhidos; $g$ ) orçamento: viagens, diárias e ajudas de custo.

\section{QUESTIONÁRIO}

O questionário elaborado abrange perguntas sobre pessoal, livros, periódicos, instalações e horários de funcionamento das bibliotecas.

Cada resposta é avaliada em algarismos (de 0 a 5), a fim de se ter um mesmo peso para a apreciação de todas as bibliotecas investigadas, de modo a não prejudicar a uniformidade dos critérios. A soma dos pontos obtidos será a nota final alcançada pela biblioteca. A nota média, calculada depois de concluído o inquérito, servirá como um dos elementos de base para o Conselho Federal de Educação determinar as condições necessárias para o reconhecimento oficial de uma faculdade ou Universidade, no que se refere à exigência de biblioteca.

No entanto, antes da conclusão do inquérito, deverá ser feito um estudo do significado dessa nota média, representantiva da situação real das bibliotecas estudadas. Esse estudo procurará estabelecer se a nota média resultante do inquérito é baixa ou alta, em comparação com os padrões internacionais, e qual a que seria válida para o caso do Brasil.

\section{LISTAS DE LIVROS BÁSICOS}

As listas de livros reputados indispensáveis para as diversas bibliotecas foram estabelecidas por professores da Universidade de Brasília. Como toda bibliografia desse género, está sujeita a criticas. Mas a sua aplicação para testar a coleção de livros de uma biblioteca tem a vantagem de proporcionar um critério uniforme, cujo peso é igual para todas as faculdades investigadas.

\section{SELEÇÃO DAS UNIVERSIDADES E FACULDADES}

Julgou-se que não seria necessário investigar todas as faculdades de uma Universidade. Escolheram-se somente as seguintes: Ciências Econômicas, Direito, Engenharia, Filosofia e Medicina. Pareceu-nos que essa amostra seria representativa do conjunto.

Quanto à seleção das Universidades federais, o critério adotado foi o de escolher 10 Universidades situadas em diferentes regiões do País. Esse critério pareceu ser suficiente para servir de indício da situação real da totalidade das Universidades federais. 
Belém, Pará

4.1.1. Faculdade de Ciências Econômicas, Contábeis e Atuariais Rua Governador José Malcher, 1.716

4.1.2. Faculdade de Direito Praça Barão do Rio Branco, 93

4.1.3. Escola de Engenharia Travessa Campos Sales, 295

4.1.4. Faculdade de Filosofia, Ciências e Letras Avenida Generalíssimo Deodoro, 413

4.1.5. Faculdade de Medicina Praça Dr. Camilo Salgado, 1

4.2. Fortaleza, Ceará

4.2.1. Faculdade de Ciências Econômicas Rua Luís de Miranda, 177

4.2.2. Faculdade de Direito Rua Clóvis Beviláqua, s.n.

4.2.3. Faculdade de Engenharia Avenida da Universidade, 2.762

4.2.4. Faculdade de Filosofia, Ciências e Letras Avenida da Universidade, 2.683

4.2.5. Faculdade de Medicina Rua Capitão Francisco Pedro, s.n.

4.3. Recife, Pernambuco

4.3.1. Faculdade de Ciências Econômicas Cidade Universitária - Engenho do Meio

4.3.2. Faculdade de Direito Praça Adolfo Cirne, s.n.

4.3.3. Escola de Engenharia Cidade Universitária - Engenho do Meio

4.3.4. Faculdade de Filosofia, Ciências e Letras Rua Nunes Machado, 42

4.3.5. Faculdade de Medicina Cidade Universitária - Engenho do Meio

4.4. Salvador, Bahia

4.4.1. Faculdade de Ciências Econômicas Praça 13 de Maio, 6

4.4.2. Faculdade de Direito Parque Universitário Edgard Santos

4.4.3. Escola Politécnica Rua Professor Aristides Novis, 2

4.4.4. Faculdade de Filosofia, Ciências e Letras Avenida Joana Angélica, 183 
4.4.5. Faculdade de Medicina

Rua Professor Aristides Novis, 62

\subsection{Belo Horizonte, Minas Gerais}

4.5.1. Faculdade de Ciências Econômicas

Rua Curitiba, 832

4.5.2. Faculdade de Direito

Avenida Álvares Cabral, 211

4.5.3. Escola de Engenharia

Rua do Espírito Santo, 35

4.5.4. Faculdade de Filosofia

Rua Carangola, 288

4.5.5. Faculdade de Medicina

Avenida Alfredo Balena, s.n.

4.6. Rio de Janeiro, Guanabara

4.6.1. Faculdade de Ciências Econômicas da UFRJ

Avenida Pasteur, 250

4.6.2. Faculdade de Direito da UFR)

Rua Moncorvo Filho, 8

4.6.3. Escola de Engenharia da UFRJ

Cidade Universitária, Ilha do Fundão

4.6.4. Faculdade de Filosofia da UFRJ

Avenida Presidente António Carlos, 40

4.6.5. Faculdade de Medicina da UFRJ

Avenida Pasteur, 458

4.7. São Paulo, São Paulo

4.7.1. Faculdade de Ciências Econômicas e Administrativas

Rua Dr. Vila Nova, 285

4.7.2. Faculdade de Direito Largo de São Francisco, 95

4.7.3. Escola Politécnica

Rua Coronel Fernando Prestes, 74

4.7.4. Faculdade de Filosofia, Ciências e Letras

Rua Maria Antónia, 294-310

4.7.5. Faculdade de Medicina

Rua Dr. Arnaldo, 425

4.8. Curitiba, Paraná

4.8.1. Faculdade de Ciências Econômicas

Rua Dr. Faivre

4.8.2. Faculdade de Direito

Praça Santos Andrade, s.n.

4.8.3. Escola de Engenharia

Centro Politécnico - Jardim das Américas 
4.8.4. Faculdade de Filosofia

Rua General Carneiro, 460

4.8.5. Faculdade de Medicina

Rua Lamenha Lins, 110

4.9. Florianópolis, Santa Catarina

4.9.1. Faculdade de Ciências Econômicas

Rua Almirante Alvim, 19

4.9.2. Faculdade de Direito

Rua Esteves Júnior, 11

4.9.3. Faculdade de Engenharia Industrial Bairro da Trindade

4.9.4. Faculdade de Filosofia, Ciências e Letras Cidade Universitária

4.9.5. Faculdade de Medicina Rua Ferreira Lima, 26

4.10. Porto Alegre, Rio Grande do Sul

4.10.1. Faculdade de Ciências Econômicas Avenida João Pessoa, 52

4.10.2. Faculdade de Direito Avenida João Pessoa, s.n.

4.10.3. Escola de Engenharia Praça Argentina, s.n.

4.10.4. Faculdade de Filosofia Avenida Paulo Gama, s.n.

4.10.5. Faculdade de Medicina Rua Sarmento Leite, s.n.

\section{INVESTIGADORES: SELEÇÃO E TREINAMENTO}

Por motivos óbvios, não seria conveniente que os questionários fossem prenchidos pelos funcionários encarregados das bibliotecas, mas sim por bibliotecários estranhos ao serviço e contratados especialmente para essa tarefa.

Esses bibliotecários deverão receber instruções precisas sobre o preenchimento do questionário, as finalidades do inquérito, etc. Antes do início de suas tarefas, serão treinados, coletiva e individualmente, tendo como objetivo familiarizá-los com as peculiaridades do inquérito e da região onde irão trabalhar. Terminada a coleta de dados nas faculdades e Universidades, será necessário realizar reuniões conjuntas de todos os investigadores, a fim de resolver problemas pendentes e acertar critérios uniformes para atribuição das notas finais.

Parece que seria mais eficaz e mais econômico escolher um número restrito de investigadores e distribuir entre eles diversas Universidades situadas numa mesma região. Cinco investigadores seriam suficientes. 


\section{ORÇAMENTO}

As despesas foram divididas em três parcelas: viagens, diárias e ajuda de custos.

$6.1 \quad$ Viagens

$1 \sim{ }^{\circ}$ grupo:

Brasília - Belém .

$\mathrm{NCr} \$$

Belém - Fortaleza

Fortaleza - Recife

Recife - Salvador .

Salvador - Brasília

$2^{\circ}$ grupo:

Brasília - Belo Horizonte

Belo Horizonte - Rio

Rio - São Paulo ...

São Paulo - Brasília

$3^{9}$ grupo:

Brasília - Curitiba

Curitiba - Florianópolis

Florianópolis - Porto Alegre

Porto Alegre - Brasília.

Como já se disse, para colher os dados serão necessários cinco investigadores, sendo 1 para o Norte (Belém, Fortaleza, Recife e Salvador), 3 para o Centro (Belo Horizonte, Rio de Janeiro e São Paulo) e 1 para o Sul (Curitiba, Florianópolis e Porto Alegre).

Calcula-se que o tempo a ser gasto em cada uma das cidades vizinhas seja de:

Belém - 3 dias.

Fortaleza - 4 dias.

Recife - 5 dias.

Salvador -6 dias.

Belo Horizonte - 5 dias.

Rio de Janeiro - 12 dias.

São Paulo - 12 dias.

Curitiba -5 dias.

Florianópolis - 3 dias.

Porto Alegre -8 dias.

A área do Norte demandará 18 dias de trabalho de 1 investigador. A do Centro demandará 3 investigadores, dedicando um deles 5 dias a 
Belo Horizonte, outro 12 dias ao Rio de Janeiro e outro 12 dias a São Paulo. A do Sul necessitará de 16 dias de trabalho de 1 investigador.

Assim sendo, os dias de trabalho serão:

18 para o Norte

29 para o Centro

16 para o Sul

63 dias no total.

É preciso, entretanto, calcular que os investigadores, principalmente os que visitarão a área Norte e a Sul, terão que viajar provavelmente mais e perderão alguns dias de trabalho por causa dos horários. Um dia de perda por cidade parece razoável. Assim sendo, teríamos:

Área Norte -4 dias

Área Centro - 3 dias

Área Sul -3 dias.

\section{PRAZO PARA A REALIZAÇÃO DO INQUÉRITO}

2 dias para treinamento dos investigadores.

29 dias para coleta e entrega dos dados.

2 dias para exame conjunto dos dados.

10 dias para tabulação e relatório final.

Considerando-se que muitas partes do inquérito serão feitas concomitantemente, acredita-se que o projeto possa estar concluído num prazo de 40 dias.

\section{DIÁRIAS}

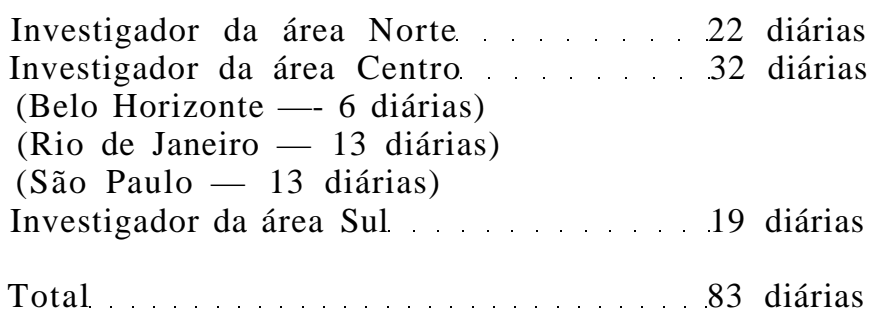

Uma diária de $\mathrm{NCr} \$ 50,00$ parece ser razoável. O custo total em diárias seria de $\mathrm{NCr} \$ 4.150,00$.

\section{AJUDAS DE CUSTO}

Parece que as ajudas de custo poderiam ser de $\mathrm{NCr} \$ 50,00$ por dia de trabalho. O total deste item seria de $\mathrm{NCr} \$ 4.150,00$. 


\section{TABULAÇÃO E ANÁlise DOS DADOS RECOLHIDOS}

Os dados recolhidos serão transportados para uma tabela com subtotais para cada Universidade e um total geral. A análise e os comentários serão feitos sucintamente, já que os dados numéricos falam por si. As médias obtidas serão comparadas com as dos padrões internacionais.

(Ver modelo da tabela em anexo.)

\section{ORÇAMENTO GERAL}

Passagens.

Investigadores:

Diárias.

Ajudas de custo.

$4.150,00$

Chefes do projeto

$1.000,00$

Secretário. 500,00

Total geral

$12.245,00$

\section{QUESTIONÁRIO}

\section{Identificação}

Universidade Federal . .

Nome da Faculdade ...

Endereço da Biblioteca

A biblioteca está subordinada administrativamente a

Data de fundação da biblioteca

\section{Pessoal}

Nome do chefe da biblioteca

Tem diploma de bacharel em Biblioteconomia

Nome da escola em que se formou

Há quanto tempo exerce a profissão

Avaliação

Bibliotecário formado ............. . . 5

Sem diploma, com alguns anos de prática $\ldots . \quad 2$ a 3

Sem preparo profissional ............. . . .

Dedicação exclusiva, tempo integral (40 horas por semana)

Tempo parcial (20 horas por semana) . . . 3

Menos de 20 horas por semana ......... 0 
$\begin{array}{lll}\text { Relação nominal de outros bibliotecários } & \begin{array}{c}\text { Tempo } \\ \text { integral }\end{array} & \begin{array}{c}\text { Tempo } \\ \text { parcial }\end{array}\end{array}$

(Se necessário, continuar a relação em folha à parte.)

Quantidade de pessoal que trabalha na biblioteca:

Em serviços bibliotecários

Em serviços auxiliares

Total.

O chefe da biblioteca participa nos órgãos da direção da Universidade (Faculdade)?

Sim.

Não.

\section{Livros}

Quantos volumes catalogados possui a biblioteca (exclusive periódicos)?

Atualmente.

Há 1 ano.

Há 2 anos

Há 3 anos

Quantos estudantes frequentam a Faculdade

Quantos livros a biblioteca possui por estudante

Avaliação

(Em branco.)

Qual o método adotado para arrumar os livros nas estantes?

Classificação Decimal Universal

Classificação Decimal de Dewey

Classificação da Library of Congress.

Outros sistemas de classificação

Por formato.

Por número de registro.

A biblioteca possui coleção de referência? Sim

Não

Avaliação

5 enciclopédias estrangeiras

4 enciclopédias estrangeiras

3 enciclopédias estrangeiras

2 enciclopédias estrangeiras 
1 enciclopédia estrangeira ............... . . .

Nenhuma enciclopédia estrangeira . . . . . . . 0

5 enciclopédias em língua portuguesa . . . . . 5

4 enciclopédias em língua portuguesa . . . . . 4

3 enciclopédias em língua portuguesa . . . . . 3

2 enciclopédias em língua portuguesa . . . . . 2

1 enciclopédia em língua portuguesa _. . 1

Nenhuma enciclopédia em língua portuguesa . . 0

Dicionários de línguas

Avaliação

Português

Francês

Inglês

Italiano

Espanhol

Alemão

Línguas clássicas.

Outras línguas.

Catálogo

Avaliação

Classificado ou sistemático. ............5 5

Catálogo dicionário .................. 4

Catálogo de autores somente ............. 1

Não tem catálogo ...................... 0

Coleção de livros (acervo)

Avaliação

Adequada ao ensino. . . . . . . . . . . . . . 5 5

Pouco adequada ........................ 3

Desatualizada . . . . . . . . . . . . . . 1

Insuficiente . . . . . . . . . . . . . . 0

Quanto foi gasto no último ano com a compra de livros e periódicos?

$\mathrm{NCr} \$$

Qual foi a quantia gasta por aluno no mesmo período?

Avaliação

(Em branco.)

A biblioteca empresta livros aos alunos para leitura a domicílio.

e aos professores. ... Qual o prazo de empréstimo? . . . dias.

Avaliação

Aos alunos e professores ................ 5

Aos professores somente. . . . . . . . . . . . 2 2

Não faz empréstimo. .................. . . . 
Qual foi a porcentagem de livros em circulação no último ano?

Avaliação

(Em branco.)

A biblioteca coopera com algum catálogo coletivo. . . . . 5

A biblioteca não coopera com nenhum catálogo coletivo ... 0

\section{Periódicos}

Quantos periódicos a biblioteca assina?

Quantos periódicos recebe por permuta ou doação?

Quantos em língua estrangeira?

Avaliação

Menos de 10

De 10 a 20 .

0

De 21 a 30

1

De 31 a 50 . 3

Mais de 50 .

Quanto se gastou exclusivamente em assinaturas de periódicos?

$\mathrm{NCr} \$$.

Quanto se gastou por estudante? NCr\$.

Avaliação

(Em branco.)

Qual o montante real das despesas feitas pela............ durante o último ano fiscal? (Não se consideram as dotações constantes do orçamento.)

$\mathrm{NCr} \$$

Avaliação

(Em branco.)

Qual o montante real das despesas feitas pela biblioteca (inclusive com salários e material)?

NCr\$.

Avaliação

(Em branco.)

Qual a relação percentual entre as despesas da biblioteca e o total das despesas da. ?

$\%$

Avaliação

(Em branco.) 
Tendo em vista o número de alunos nos 3 últimos anos, qual será o número de alunos nos próximos anos (5 anos)?

As coleçoes de periódicos estão completas para os últimos 5 anos? ....

\section{Instalações}

Possui edifício especialmente construído para biblioteca? . . 5

Possui edifício adaptado para uso exclusivo da biblioteca? . . . . . . 4

Está instalada em parte de edifício? . . . . . . . . . . . . . . . 3

Quantos metros quadrados tem a(s) sala(s) de leitura? .... $\mathrm{m}^{2}$

O espaço reservado para leitura comporta quantos lugares?

Avaliação

(Em branco.)

A biblioteca possui saletas para estudos individuais? .... Quantas? .... A biblioteca possui recursos para reprodução de documentos?

Equipamento para microfilmagem. Quantidade

Equipamento para leitura de microfilmes. Quantidade?

Copiadora Xerox. Quantidade.

Outros aparelhos. Quantidade

Laboratório fotográfico.

\section{Horário}

Quantas horas por semana a biblioteca fica aberta para os leitores durante o ano letivo?

Avaliação

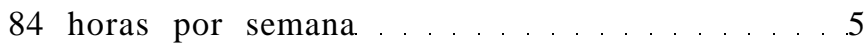

60-72 horas por semana ............. . . . .

48-59 horas por semana .................. 3

$36-47$ horas por semana. . . . . . . . . . . 2

Menos de 35 horas. ................ . . . .

(Anexar o horário de funcionamento da biblioteca e o horário de aulas.) Quem decide quanto à seleção de livros que devem ser adquiridos?

Seleção conjunta entre o bibliotecário, professores e alunos 5

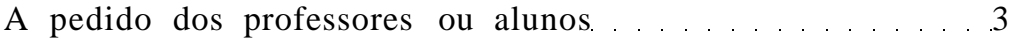

O bibliotecário segundo seu critério exclusivo.......... 2

Oferta de livreiros ....................... 0 


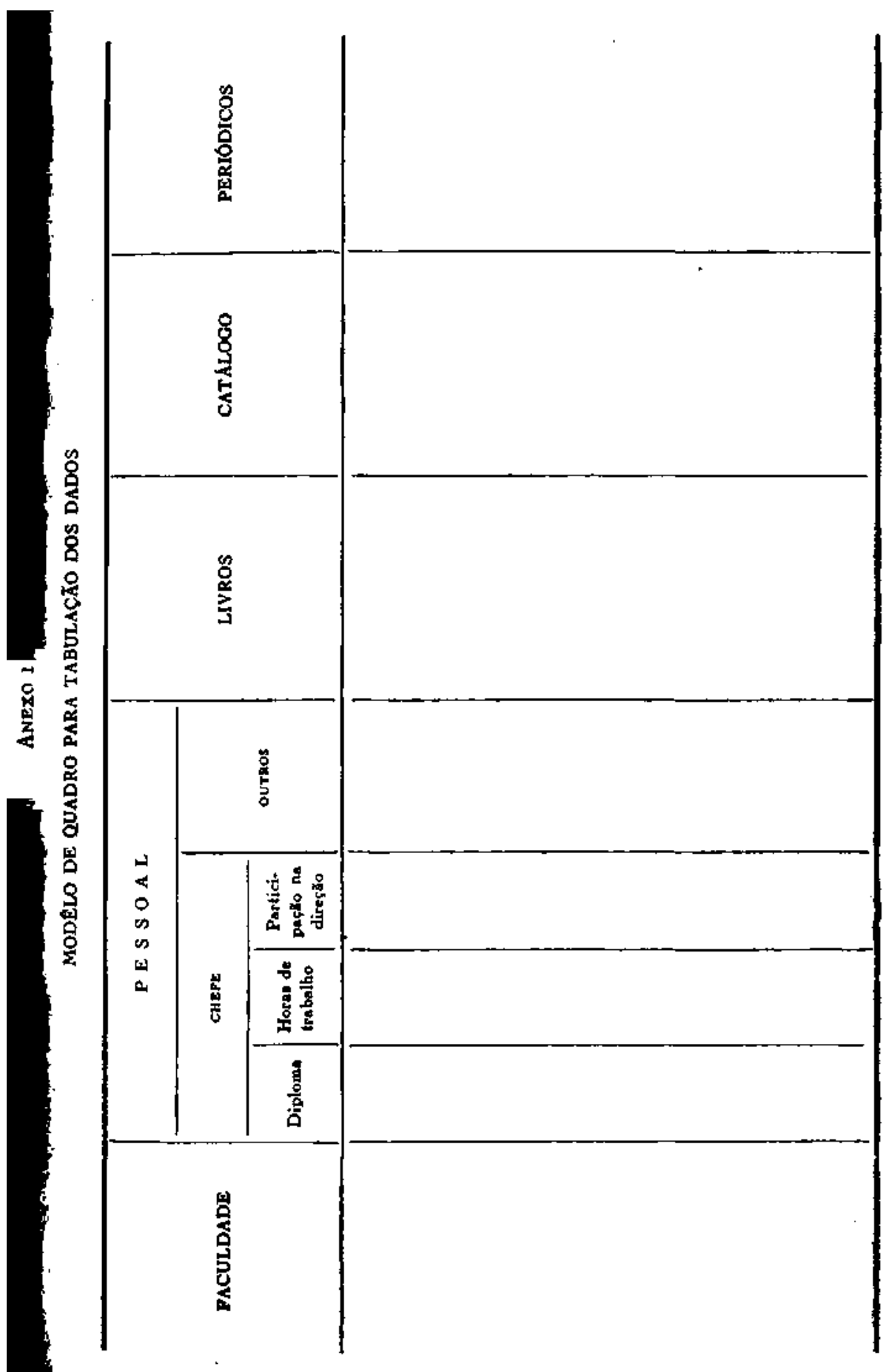




\section{OBRAS DE REFERÊNCIA: BIBLIOGRAFIA MÍNIMA}

Com o objetivo de oferecer ao Conselho Federal de Educação um instrumento prático para verificação das bibliotecas de escolas superiores que solicitam reconhecimento oficial, a Equipe de Assessoramento ao Planejamento do Ensino Superior (EAPES) está preparando, com a colaboração da Universidade de Brasília, uma série de bibliografias mínimas para cada uma das disciplinas oferecidas, no Brasil, em nível de graduação.

Nessas bibliografias serão indicadas, separadamente: a) as obras de referência; $b$ ) as monografias; c) os livros didáticos e $d$ ) as publicações periódicas rigorosamente indispensáveis na biblioteca de qualquer escola superior que ofereça as respectivas disciplinas.

Devendo ser indicadas, na primeira parte das bibliografias mínimas. as obras de referência especializadas, considerou-se também útil a compilação de uma bibliografia geral, que indique as obras de referência indispensáveis nas bibliotecas de qualquer escola brasileira de nível superior, seja qual fôr a sua especialização.

$\mathrm{Na}$ biblioteca de qualquer escola superior - como, de resto, em todos os tipos de biblioteca - o material bibliográfico está geralmente organizado em três grupos, correspondentes aos principais gêneros bibliográficos: a) obras de referência; b) obras de texto (didáticas ou não) e c) periódicos.

As obras de referência podem ser definidas como aquelas nas quais as informações estão ordenadas para consulta parcial e não para leitura integral. Embora não seja possível dizer qual dos três grupos é o mais importante, a coleção de referência destaca-se por ser aquela sem a qual a própria utilização das demais coleções ficaria irremediavelmente mais limitada.

Com efeito, é na coleção de referência que professores e alunos encontram soluções para os problemas suscitados rotineiramente pela consulta ou leitura de qualquer publicação, avulsa ou periódica: definição, etimologia ou emprego correto de uma palavra, localização de um acidente geográfico, data exata de um fato histórico, endereços de instituições, estatística de um produto, título e data da publicação de uma obra, preço da assinatura de uma revista, número e data de uma lei, etc.

As obras de referência - avulsas e periódicas - estão aqui indicadas na ordem alfabética das diferentes espécies em que formalmente se constituem, segundo o seguinte sumário:

Páginas

Anuários e almanaques. 3

Atlas e repertórios geográficos. 3

Bibliografias. 


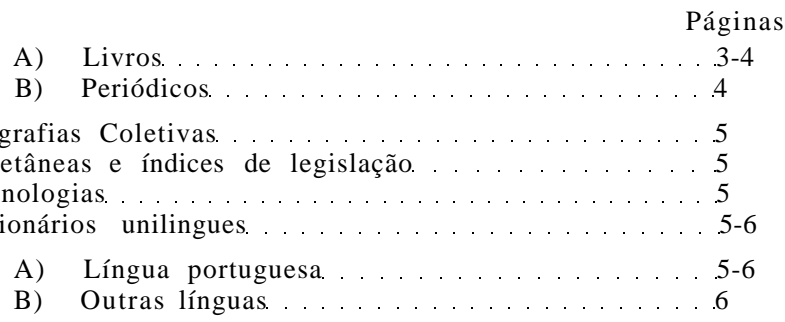

Dicionários bilingues. . . . . . . . . . . . . 6-7

Dicionários de particularidades lingiiistcas . .7-8

Dicionários especializados . . . . . . . . . . . . 8

Dicionários plurilingues. . . . . . . . . . . . . 8

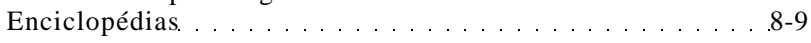

A) Era língua portuguesa $\ldots \ldots \ldots$

B) Era outras línguas...................... 9

Guias de Instituições Culturais .............. 9

\section{ANUÁRIOS E ALMANAQUES}

Anuário Católico do Brasil. III ed. 1965. Rio de Janeiro, CERIS (Centro de Estatística Religiosa e Investigações Sociais), 1966. 1.912 p.

Atualidadc Estatística do Brasil, v. 1. Rio de Janeiro, Fundação IBGE, 1968.

Anuário Estatístico do Brasil - 1967. Rio de Janeiro, Fundação

IBGE, Instituto Brasileiro de Estatística, 1967. 776 p.

Europa Yearbook. 1959. London, Europa Publications, 1959.

Statistical Yearbook. Annuairc Statistique. 1948. New York, United Nations, 1949.

\section{ATLAS E REPERTÓRIOS GEOGRÁFICOS}

Atlas Universal Aguilar. Madrid, Aguilar, 1966. $116+\mathrm{HO}$ p. Dicionário Geográfico Brasileiro. Porto Alegre, Globo, 1966. $559 \mathrm{p}$.

ENCICLOPAEDIA BRITANNICA, World Atlas, Chicago, 1961, 388 p.

FUNDAÇÃo IBGE. Conselho Nacional de Geografia. Atlas Nacional do Brasil. Rio de Janeiro, 1966. Não paginado.

- Carra cio Brasil ao milionésimo, Rio de Janeiro, 1960, 190 p.

- Instituto Brasileiro de Estatística. Divisão territorial do Brasil, Rio de Janeiro, 1961, 217 p.

- Enciclopédia dos municípios brasileiros. Rio de Janeiro, 1957-58, $37 \mathrm{v}$.

THE TIMES. Index-Gazetteer of the World. London, 1965, $959 \mathrm{p}$. 


\section{BIBLIOGRAFIAS}

\section{A) Livros}

CARPEAUX, Otto Maria. Pequena bibliografia crítica da literatura brasileira. 3» ed. rev. e aum. Rio de Janeiro, Letras e Artes, 1964. $335 \mathrm{p}$.

ou:

4. ed. Rio de Janeiro, Edições de Ouro, 1969. 335 p. (Biblioteca Mentor Cultural)

DICKINSON, Asa D. The world's best books, Homer to Hemingway. 3000 books of 3000 years, 1050 B.C. to 1950 A.D. selected on the basis of a consensus o/ expert opinion. New York, Wilson, 1953. $484 \mathrm{p}$.

MALCJ.ÊS, Louise-Noélle. Lcs sources $d u$ travail bibliographique. Genève, E. Droz. Lille, Giard, 1950-58. 4 v.

MORAES, Rubens Borba de $\tilde{o}$ Barrien, William, ed. Manual bibliográfico de estudos brasileiros. Rio de Janeiro, Gráfica Editora Souza, 1949. 849 p.

SABOR, Josefa Emília. Manual de fuentes de información. 2 ed., ampl., Buenos Aires, Kapelusz, 1967. 342 p.

SODRÉ, Nelson Werneck. O que se deve ler para conhecer o Brasil. 3. ed. Rio de Janeiro, Civilização Brasileira, 1967. 395 p. (Retratos do Brasil, v. 54).

UNIÃO PAN AMERICANA. Guide to Latin American scientific and technical periodicals, an annotated list. México. Centro de Documentación Científica y Técnica de México, 1962. 187 p.

- Index to Latin American pcriodical literature, 1929-1960. Boston, Hall, 1962. $8 \mathrm{v}$.

WALFORD, Albert J. Guide to reference material. London, Library Association, 1959. 543 p.

- Supplement. London, Library Association, 1963. 370 p.

WINCHELl, Constance M. Guide to reference books. 8 ed. Chicatjo, American Library Association, 1967. 741 p.

ZiMMERMAN, Irene. A guide to current Latin American periodicals. Humanities and Social Sciences. Gainesville, Fia., Kallman, 1961. 357 p.

\section{B) Periódicos}

Bibliografia Brasileira. 1964. Rio de Janeiro, Instituto Nacional do Livro, 1966.

Além dos volumes anuais, são indispensáveis os fascículos mensais. editados a partir de 1968: Bibliografia Brasileira Mensal. 
Ano I, $\mathrm{n}^{\circ} 1$ - novembro de 1967. Rio de Janeiro, Instituto Nacional do Livro, 1968.

Choice: Books for College Libraries. v. 1 - Middletown. Conn., Olin Library, Wesleyan University, 1964. Mensal (exceto o volume bimestral correspondente a julho/agôsto de cada ano) .

Fichero Bibliográfico Hispanoamericano: catálogo trimestral de toda clase de libros en espanhol publicados en las Américas, v. 1 1961 - New York, Bowker, 1964. Trimestral.

Handbook of Latin American Studies. v. 1, 1935. Gainesville, Fla., University of Florida Press, 1936. Anual.

Index Translationum; Répertoire International des Traductions; International Bibliography of Translations. v. 1. 1948. Paris, Unesco. 1949. Anual.

Ulrich's Periodicals Directory; a classified guide to a sclected list of current periodicals, foreign and domestic. 10 ed., New York. Bowker, 1963. 667 p. Trienal.

\section{BIOGRAFIAS COLETIVAS}

Coutinho, Afrânio, ed. Brasil e brasileiros de hoje. Rio de Janeiro, Ed. Sul Americana, 1961. 2 v.

The International Who's Who. 29 ed., 1965-66. London, Europa Publications, 1965. 1.272 p.

\section{COLETÂNEAS E ÍNDICES DE LEGISLAÇÃO}

Conselho Federal de Educação. Lei de Diretrizes e Bases da Educação Nacional (Lei ${ }^{\circ}$ 4.024, de 20 de dezembro de 1961) (Texto definitivo com índice remissivo e legislação respectiva), 3 ed., Rio de Janeiro, 1962. 202 p.

Coleção das Leis. 1939. Rio de Janeiro, Departamento de Imprensa Nacional, 1940. Trimestral (dois volumes por trimestre, contendo os ímpares, atos do Poder Legislativo e os pares, atos do Poder Executivo).

DIAS, José de Aguiar \& Dias, Floriano de Águia-, ed. Carteira da «Revista Forense». 2' ed., Rio de Janeiro Ed. Forense, 1961, $3.316 \mathrm{p}$.

- Suplemento $n^{\circ}$ 1. Rio de Janeiro, Ed. Forense, 1965. 1.138 p. ou:

PEREIRA, Osny Duarte, ed. Vade-mecum forense; coletânea de leis do Brasil. 5' ed. atualizada e ampl. Rio de Janeiro, J. Konfino, 1959.

- Apêndice de 1961. Rio de Janeiro, J. Konfino, 1962.

- Novo suplemento, 1961-1965. Rio de Janeiro, J. Konfino, 1965, $967 \mathrm{p}$. 
NÓBREGA, Vandick Londres da. Enciclopédia da legislação do ensino, Rio de Janeiro, Ed. do Autor, 1952-54. 2 v.

Referência Legislativa, v. 1, n 1 - setembro/dezembro 1965 - Brasília, Biblioteca da Câmara dos Deputados, 1966. Quadrimestral.

\section{CRONOLOGIAS}

Delorme, Jean. Chronologie des civilisations. Paris, Presses Universitaires de France, 1949. 437 p. (Clio: introduction aux études historiques) .

Rio BRANCO, José Maria da Silva Paranhos, Barão do. Efemérides brasileiras. Rio de Janeiro, Ministério das Relações Exteriores, 1946. 734 p. (Obras do Barão do Rio Branco, 6).

\section{DICIONÁRIOS UNILINGUES}

\section{A) Língua portuguesa}

Aui.ETE, Francisco Júlio Caldas. Dicionário contemporâneo da língua portuguesa. Edição brasileira atualizada, revista e aumentada por Hamilcar Garcia. Rio de Janeiro, Ed. Delta, 1964. 5 v.

FERreira, Aurélio Buarque de Holanda. Pequeno dicionário brasileiroda língua portuguesa. 11 ed. Rio de Janeiro, Civilização Brasileira. 1967. 1.301 p.

- ô PEREIRA, Manuel da Cunha. Novo vocabulário ortográfico da língua portuguesa. Rio de Janeiro, O Cruzeiro, 1961. 801 p.

MORAES SILVA, António de. Grande dicionário da língua portuguesa. 10 ed. rev., corrigida, muito aumentada e atualizada segundo as regras do Acordo Ortográfico Luso-Brasileiro de 10 de agosto de 1945, por Augusto Moreno, Cardoso Júnior e José Pedro Machado. Lisboa, Confluência, 1949-50. 12 v.

Das edições anteriores, as únicas recomendadas são a primeira (1789), a segunda (1813) e a nona (1922), que é faesimile da segunda. Todas, entretanto, estão esgotadas, motivo pelo qual se indica a décima.

NASCENTES, Antenor. Dicionário da língua portuguesa. Rio de Janeiro, Academia Brasileira de Letras, 1961-66. 4 v.

Novo dicionário brasileiro Melhoramentos ilustrado. 2 ed., São Paulo, Melhoramentos, 1964, 4 v.

\section{B) Outras línguas}

ACADEMIA ESPANOla. Diccionario de la lengua espanola. 18 ed., Madrid, Espasa-Calpe, 1956. 1.370 p.

Der Sprach Brockhaus. 6. verb. Aufl. Wiesbaden, Brockhaus, 1954. 799 p. 
LITTRÉ, Émile. Dictionnaire de la langue française. Ed. intégrale. Paris, J. J. Pauvert, 1956-58. 7 v. ou:

ACADÉMIE Française. Dictionnaire de l'Académie Francaise. 8 éd.. Paris, Hachette, 1931-35, 2 v.

MELzI, Gian Battista. // novíssimo Melzi: dizionavio enciclopédico italiano. $35 "$ ed. ampl. aggiornata. Milano, A. Vallardi, 1959. $2 \mathrm{v}$.

ou:

PALAZZI, Fernando. Novissimo dizionario delia lingua italiana. Milano. Ceschina, 1959. 1.404 p.

Webster's thivd new international dictionary of the English language, unabridged. Springfield. Mass., Merriam, 1961. 2.662, p. ou:

Webster's new international dictionary of the English language. 2" ed. unabridged. Springfield. Mass., Merriam. 1961. 3.194 p. ou:

STEIN, Jess, ed. The Randon House dictionary of the English language. New York. Randon House, 1966. 2.059 p.

\section{DICIONÁRIOS BILINGUES}

Azevedo, Domingos de. Grande dicionário francês-português. 4" ed., Lisboa, Bertrand, 1952. $1.487 \mathrm{p}$.

- Grande dicionário português-frances. 4' ed., Lisboa, Bertrand, 1953. $1.431 \mathrm{p}$.

HouAiss, António \& Avery, Catherine N. The new Appleton dictionary of the English and Portuguese languages. New York, Appleton, 1964. 2 v.

ou:

VAU.ANDRO, Leonel \& Vallandro, Lino. Dicionário inglês-português. 2» ed., Porto Alegre, Globo, 1966. 1.174 p.

Para ser usado em conjunto com:

TAYLOR, James L. A Portuguese-English dictionary. Stanford, University Press, 1958. $655 \mathrm{p}$. ou:

MICHAELIS, Henriette. Novo Michaelis: dicionário ilustrado. São Paulo, Melhoramentos, 1957-66. 2 v.

Langenscheidts Tashaschenwõrterbuch der portugiesischen und deutschen Sprache. II. Aufl. Berlin, Langenscheidt, 1967. 2 v. em 1. ou:

TOCHTROP, Leonardo \& Caro, Herbert. Dicionário alemão-português e português'àlemão. Porto Alegre, Globo, 1967. 1.124 p. 
martinez almoyna, Júlio. Dicionário de português-cspanhol- Porto, Porto Ed., s. d. 1.539 p.

Dicionário de espanhol-português, 2» ed., Porto, Porto Ed.: Riode Janeiro, Livraria Ofir; São Paulo, Luso-Brasil, s. d. 1.506 p

SPINElli, Vincenzo \& CASASAnTA, Mário. Dicionário completo italianoportuguês (brasileiro) e português (brasileiro)-italiano. Milão, U. Hoepli, 1957-62. 2 v. ou:

PARLAGRECO, Cario. Dizionario portoghese-italiano, italiano-portoghese ${ }^{\wedge}$ Milano, Vallardi, 1952. 528 p.

\section{DICIONÁRIOS DE PARTICULARIDADES LINGUÍSTICAS}

Costa, Altino. Dicionário de coletivos e correlatos- Rio de Janeiro, Ed. Spiker, s. d. 342 p.

FERNANDES, Francisco. Dicionário de regimes de substantivos e aditivos- 10» ed., Porto Alegre, Globo, 1967. 384 p.

- Dicionário de sinónimos e antónimos da língua portuguesa. 16 ed., Porto Alegre, Globo, 1967. 823 p.

- Dicionário de verbos e regimes. 20 ed., Porto Alegre, Globo, 1967. $606 \mathrm{p}$.

FROES, Heitor Praguer. Dicionário internacional de abreviaturas (siglas c abreviaturas comuns). 2» ed., Rio de Janeiro, Gráfica Muniz, 1961. $597 \mathrm{p}$.

NASCENTES, Antenor. Dicionário etimológico da língua portuguesa. Rio de Janeiro, F. Alves, 1932-52. 2 v. ou:

- Dicionário etimológico resumido. Rio de Janeiro, Instituto Nacional do Livro, 1966. 791 p. (Coleção dicionários especiais, 1).

RIBEIRO, João. Frases feitas; estudo conjetural de locuções, ditados e provérbios. 2 ed., Rio de Janeiro, F. Alves, 1960. 432 p.

NASCEnTES, Antenor. A gíria brasileira. Rio de Janeiro, Livraria Académica, 1953. $181 \mathrm{p}$.

ou:

Viotti, Manuel N. Novo dicionário da gíria brasileira. 3 ed. (refundida, corrigida e muito aumentada) em anexo: Vocabulário cigano e vocabulário quimbundo, de autoria do Prof. João Dornas Filho. Rio de Janeiro, Livraria Tupã, 1957. 276 p.

CÂMARA JÚNIOR, Joaquim Mattoso. Dicionário de fatos gramaticaisRio de Janeiro, Casa de Rui Barbosa, 1956. 225 p.

SPITZER, Carlos, S. I. Dicionário analógico da língua portuguesa. $3^{\mathrm{a}}$ ed., Porto Alegre, Globo, 1953. 389 p. 


\section{DICIONÁRIOS}

ESPECIALIZADOS

Coelho, Jacinto do Prado, ed. Diciário das literaturas portuguesa, brasileira e galega. Porto, Livraria Figueirinhas, 1960. 1.020 p.

Dicionário de sociologia. Porto Alegre, Globo, 1961. 377 p.

GOULD, Julius \& KOLB, William L., ed. A dictionary of the social sciences. London, Tavistock, 1964. 761 p.

LALANDE, André. Vocabulaire technique et critique de la philosophie. 8 éd. rev. et augm. Paris, Presses Universitaires de France, 1960. $1.323 \mathrm{p}$.

ou:

Ferrater mora, José. Diccionario de filosofia. 5 ? ed., Buenos Aires. Ed. Sudamericana, 1965. 2 v.

"AES, José Paulo ô MOISÉs, Massaud, ed. Pequeno dicionário de literatura brasileira. São Paulo, Cultrix, 1967. 276 p.

PIÉRON, Henri. Dicionário de psicologia. Trad. e notas de Dora de Barros Cullinan. Porto Alegre, Globo, 1966. 533 p.

\section{DICIONÁRIOS PLURILINGUES}

BUECKEN, Francisco. Vocabulário técnico português, inglês, francês, alemão. 4 ed. São Paulo, Melhoramentos, 19J61. 600 p.

Magalhães, Manuel de Faria e Sousa Calvet de. Dicionário trilingues português, francês e inglês. Lisboa, Confluência, 1966. 3 v.

\section{ENCICLOPÉDIAS}

\section{A) Em lingua portuguesa}

Ávila, Fernando Bastos de, S.I. Pequena enciclopédia de moral $e$ civismo. Rio de Janeiro, Ministério da Educação e Cultura, Departamento Nacional de Educação, 1967. 511 p.

Enciclopédia Barsa. Rio de Janeiro, Encyclopaedia Britannica, 1964. $16 \mathrm{v}$.

ou:

Enciclopédia brasileira Mérito. Rio de Janeiro, Editora Mérito, 1959-64. $20 \mathrm{v}$.

Enciclopédia Delta-Larousse. Rio de Janeiro, Ed. Delta, 1960. 15 v. MAGalÃes, Álvaro, ed. Dicionário enciclopédico brasileiro ilustrado. 6» ed., Porto Alegre, Globo, 1964. 4 v.

B) Em outras línguas

Enciclopédia universal ilustrada europeo-americana. Barcelona, Espasa, 1905-33. 81 v. 
- Suplemento anual. 1934 - Barcelona, Espasa-Calpe, 1935.

Encyclopaedia Britannka. Chicago, W. Benton, 1967. 23 v.

As últimas edições são sempre as mais recomendadas, mas admite-se que outras, quando completadas pelo Britannica Book of the Year (publicado a partir de 1938) são satisfatórias.

Encyclopédie françaisc. Paris, Comité de l'Encyclopédíe Française 1935-64. $20 \mathrm{v}$.

ou:

Grand Larousse encyclopédique. Paris, Librairie Larousse, 1960-64 $10 \mathrm{v}$.

Grande enciclopédia portuguesa e brasileira. Lisboa, Editorial Enciclopédia, 1935-60. $40 \mathrm{v}$.

\section{GUIAS DE INSTITUIÇÕES CULTURAIS}

CAPES. Estabelecimentos de ensino superior. Rio de Janeiro, 1960. $467 \mathrm{p}$.

- Instituições de pesquisa (básica e aplicada). Rio de Janeiro, 1957. $337 \mathrm{p}$.

INSTITUTO BRASILEIRO DE BIBLIOGRAFIA E DOCUMENTAÇÃO. Bibliotecas especializadas brasileiras: guias para intercâmbio bibliográfico. 2> ed., Rio de Janeiro, 1962. 375 p.

LIBRARY OF CONGRESS. International scientific organizations; a guide to their library, documentation, and information services. Washington, 1962. $794 \mathrm{p}$.

International handbook of universities and other institutions of higher education. $3^{\text {? }}$ ed., Paris, International Association of Universities, 1965. $1.034 \mathrm{p}$.

International library directory. 2 ed., London, A. P. Wales Organization, $1967 . \quad \mathbf{1 . 0 2 4} \mathbf{p}$.

União Pan Americana. Guia de bibliotecas de la America Latina. Ed. provisional. Washington, 1963. 165 p. (Série bibliográfica, 51). World of learning. 1947 - London, Europa Publications, 1947. Anual.

Seleção do Prof. EDSON NERY DA FONSECA, era consulta com os Professores ANTÓNIO AGENOR BRIQUET DE LEMOS, CORDÉLIA ROBALINHO CAVALCANTI e RUBENS BORBA DE MORAES.

Universidade de Brasília, junho de 1968. 
Apêndice C. 1

November 16, 1967

\section{STUDY OF ENROLLMENTS}

J. D. RYDER

This report is intended to consolidate for EAPES and USAID use, much information on Brazilian educational plans and performance as it has been found in various Brazilian papers and reports.

The collection of Brazilian statistics and performance data in the field of education is a relatively new practice, and consistency is not always found even in data attributed to the same source. Even when data appears superficially satisfactory its absolute accuracy may be questionable because of the lack of standards used in preparing reports and compilations therefrom by the educational institutions and government agencies involved. In this connection it seems appropriate to point out that in late 1967 there is being held the first of a series of conferences having to do with standardizing such things as the reporting of enrollments.

In addition there are pitfalls in language and calendar likely to be encountered by the North American attempting to use educational figures. A few of these are worth calling to the attention of the eader:

1. The academic and budget years are the calendar year. Final year enrollment and graduation figures will appear in the same calendar year.

2. Secondary school graduation, and entrance examinations occur under successive year dates (December and January).

3. «Matriculation» means total student enrollment, not the initial entrance to a higher education institution.

4. «Matrícula geral» means the student enrollment in the first semester of the academic year, and «matrícula efetiva» means the enrollment near or at the end of the academic year.

1 Largely, but not entirely, based upon

Diagnóstico Preliminar, I - EPEA - 1966

Diagnóstico Preliminar, II - EPEA - 1966

Sinopse Estatística do Ensino Superior, 1965 - MEC

Plano Decenal de Desenvolvimento Econômico e Social - VI Ministério do Planejamento, 1967

Ibidem, VII. 
5. Totais are frequently given from a sample of institutions. A warning is here given that such a sample is rarely scientifically selected but more often may represent only the institutions or persons that chose to reply to the questionnaire.

6. In some fields the number of institutions has changed so rapidly (29 new medicai schools in 17 years, for instance) that comparing data over a span of years may not mean the employment of the same institutional base.

7. There have been recent changes in organization which cause gaps in statistics. For instance, new schools or new departments add students, but not graduations, for 4 to 6 years. «Filosofia» has shifted from two programs «bacharelado», and «licenciatura», to one; Engineering occasionally lists «civil» and «especializado», and the specialized engineering fields are quite variable. Some engineering institutions now list ali the students in the first two years as in «fundamental engineering».

8. Total enrollment may, or may not, include post-graduate students where they exist.

9. Statistics on isolated faculties are often questionable - that these faculties enroll 27 per cent of the students gives a measure of the problem.

10. A «student» is not defined.

11. There can be a considerable difference between budget or promised, money received, and money spent in a calendar year (Three different figures).

12. Usually total enrollments are given, and it is difficult to find the size of an entering class or the number graduated in a given year.

13. There is a possible point of confusion in the distinction between «ensino médio» and «ensino secundário», the latter being non-specialized preparatory work for the university, within the overall «ensino médio» or secondary school in a U.S. sense. At one time entrance to a university was only possible from an «ensino secundário» course, and so earlier statistics often quote this; now the specialized fields are being reduced to elective series and entrance to a university is possible from ali.

For comparison purposes, «ensino secundário» enrollment represented about 75 per cent of total «ensino médio» enrollment, at least for the period 1947-64 (D-II-105) .

We here use «secondary education» in the U.S. sense. 


\section{General}

As might be expected, from these sources there is little indication of the development of a specific educacional policy for Brazil. One statement translated from Diagnóstico II is attached, but it is couched in broad platitudes which give little direction for the development of Brazilian higher education. Unfortunately, EAPES, in its own área of work, has also been unable to stimulate a Brazilian development of a detailed educational policy statement.

In the planning efforts reported herein, the general approach (oversimplified, perhaps) seems to be: higher education will continue along past paths, and its growth will be an extension of past patterns. Perhaps this is illustrated by the following translation from the first several pages of Chapter 1 of Diagnóstico I, which covers «Demand and Supply of Education in Brazil»:

«There is no general consensus on a definition for the demand for education. Adopting the definition of Hector Corrêa ${ }^{2}$ the demand for education is the request for authorization to attend a specific educational establishment, at a given levei and a certain type of teaching».

«This demand will be measured by the number of candidates that are matriculated in the diverse leveis and educational types».

«The current supply of education consists of the capacity of the school system to absorb, within the customary conditions of use of the available means, the flow of candidates that come to the system. This supply can be quantified by the number of existing vacancies in the different leveis and types of education».

Many Brazilian educators are aware of the problems of the educational system, and some thinking is also going on concerning the needs of a developing Brazil for more, better, and different types of education, but this thinking is not yet reflected in much planning for the future of education. There seems no awareness of the necessity to disturb the system if the recognized needs are to be met. There also seems no awareness of the inadequacy of the present system as a basis for a future system expected to meet the planned demands and the planned demands are quite possibly much below the actual demands of 1976.

\section{Enrollments}

The general rise in enrollments along with the population of the country $(3.5 \%$ per year) is recorded by the Serviço Estatística de Educação e Cultura (SEEC) as

2 Corrêa, Hector, The Economics of Human Resources, North Holland Publ. C», Amsterdam, 1963. 
D-I-35

Higher Educatpn

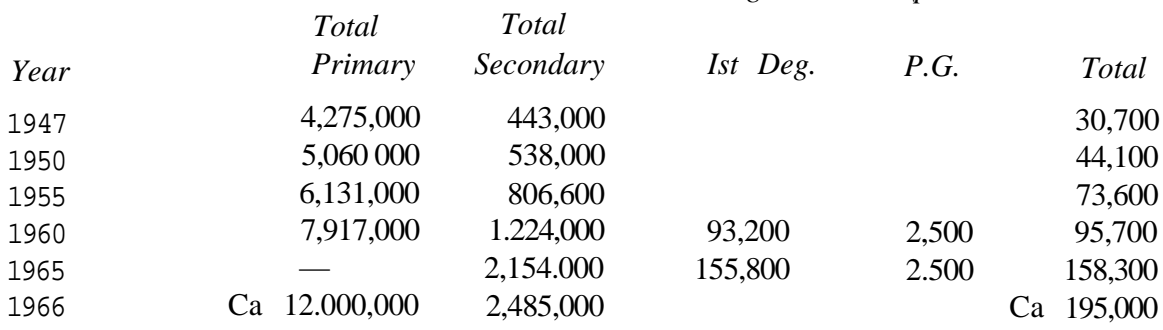

Contrast these figures with the school-age group population, estimated ${ }^{3}$ in 1960 as:

D-7-36,41

Population, 1960

In school, 1960

Per cent

$\begin{array}{cc}7-11 \text { years } & 12-18 \text { years } \\ 9,440,000 & 10,900,000 \\ 7,476,000 & 1,224,000 \\ 79.2 \% & 11.2 \%\end{array}$

19-24 years 8670,000 95,700 $1 \cdot 1 \%$

Examinations are required in Brazil for entrance to secondary school (50 per cent privately administered) and to higher education. An indication of the pressure on the system at these points is given by the following summaries.

At the secondary entrance levei, in 1965:

SECONDARY ENTRANCE 1965

$\begin{array}{cl}\text { Candidates } & \text { Approvals } \\ 929,000 & 477,000\end{array}$

It is possible to find data to expand the higher education picture in time. Note the break introduced between 1963 and 1964 due to the change in source of the information. The earlier data from CAPES represents the ten most important fields and are believed by the SEEC to be about 20 per cent low.

The years 1964 and following are SEEC data, believed to approximate the total:

31960 population data seera estimated by SEEC from a $1.27 \%$ sample of the 1960. National Census. As of November 1967, the complete 1960 census and analyses have not been published. 


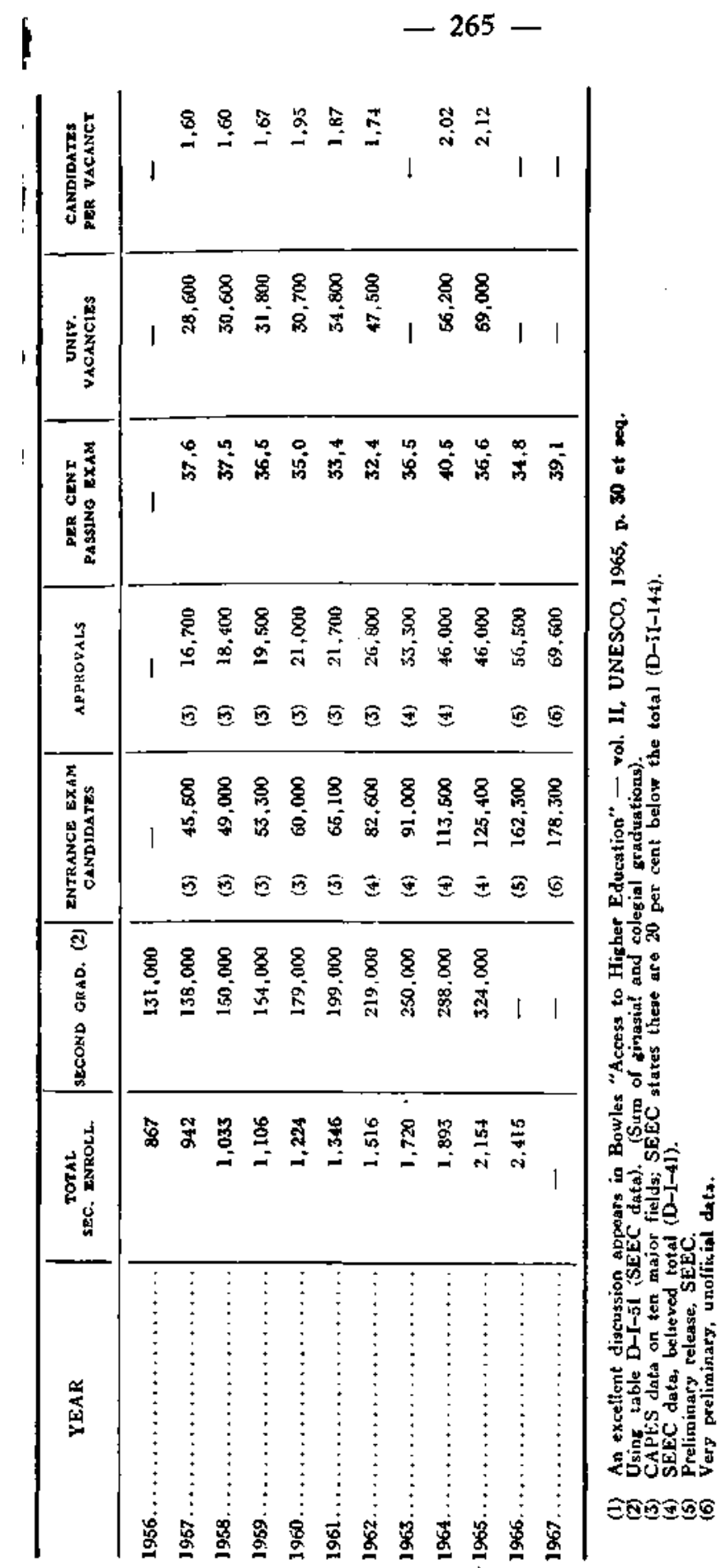




\section{THE SECONDARY-UNIVERSITY INTERFACE}

Over the years shown, and in fact since the record begins in 1947, the secondary graduations in a given year have been Constant at $15 \pm 1$ per cent of the total secondary enrollment. This may indicate that secondary education is not really increasing the penetration of its age group, but only continuing to reach the same percentage of its age group (and the same portion of the ability distribution).

The graduation percentage has also been maintained in spite of a stated decline in available teachers. There may have been a decline in abilities (it is stated that 75 to 85 per cent of these teachers do not have formal qualifications for their levei of teaching), but the change in student - teachers relations has not been great:

$$
\text { SECONDARY EDUCATION OVERALL }
$$

\begin{tabular}{|c|c|c|c|}
\hline Year & Teachers & Enrollment & Students/Teacher \\
\hline 1955 & 69,100 & 806,000 & 11.6 \\
\hline 1964 & 132,300 & $1,892,000$ & 14.3 \\
\hline ENSINO SECUNDÁRIO & - GENERAL & SUBJECTS, COLLEGES & ORIENTED \\
\hline Year & Teachers & Enrollment & Students/Teacher \\
\hline 1955 & 40,900 & 603,500 & 14.7 \\
\hline 1964 & 81,200 & $1,368,000$ & 16.8 \\
\hline
\end{tabular}

The higher student-teacher ratio in «ensino secundário», as compared to the overall picture in secondary education, probably indicates a failure on the part of the Schools of philosofy (education, largely) to prepare more people for teaching in science, mathematics, chemistry, physics. This illustrates a dedication to didatics, more than to subject matter - a point of view confirmed by Anísio Teixeira in conversation.

In view of the number of variables present, it seems remarkabie on first glance that the university approvals have stayed close to the 36 per cent levei over the years under observation. One of these variables is the use of a grade of 50 per cent as passing regardless of the examination used. Secondly, it has been pointed out by Bowles ${ }^{4}$ that in 1960 in Brazil outside the cities of Rio, Niterói, and São Paulo the passing percentage was 40.5 but in those three cities of high population density the percentage was only 27.4. It appears that the difficulty of the examination reflects the pressures for university entrance in those localities.

Another factor which confuses any discussion of percentage of candidates passing is that of the examination repeater. The study in Rio, Niterói, and São Paulo mentioned above also yielded data on the time of delay between secondary scholl graduation and the undertaking

4 Bcrwles, loc. cit., p. 32. 
of the examination, the degree of success achieved in the examination, and the number of repetitions. The following table results (figures are in per cent):

\begin{tabular}{cccccccc|c|c}
$\begin{array}{c}\text { Number of } \\
\text { times } \\
\text { examined }\end{array}$ & & Yeats & After & Secondary & \multicolumn{2}{c}{ Graduation } \\
\hline & 0 & 1 & 2 & 3 & 4 & 5 & or more & Total per cent \\
\hline 1 & 31 & 17 & 5 & 3 & 2 & 1 & 3 & 62 \\
2 & - & 15 & 6 & 2 & 1 & 1 & 1 & 22 \\
3 or more & - & - & 5 & 3 & 2 & 1 & 1 & 12 \\
\hline
\end{tabular}

That is, 62 per cent of the applicants were taking the examination $r$ the first time, but only half of these were taking it immediately after secondary graduation. Another group of 32 per cent were taking the examination one year after graduation but half of these were repeating the examination, and 12 per cent of the candidates were taking the examination for the third, or a larger number of times.

The degree of success of the candidates varied as

$\begin{array}{cc}\text { Number of } & \text { Per cent } \\ \text { exams taken } & \text { passing } \\ 1 & 25 \\ 2 & 23 \\ 3 \text { or more } & 17\end{array}$

It would appear that equally satisfactory results might have been achieved by relaxing the standards and passing more in the first instance.

A more recent study by the Centro Brasileiro de Pesquisas Educacionais (INEP) covering 18,000 students of law, economics, and social science, in ten major universities contributes similar data on the repetition of examinations.

As indicated above, it is fairly common practice to defer the entrance examination for one year after secondary graduation and take a private «cursinho» or «curso vestibular» — such a course being pointed at the learning of those facts believed needed for a particular examination. The extent of this practice - expensive in both tuition and lost time - is indicated by the growth of such private courses in the State of Guanabara:

$\begin{array}{rrr}\text { Year } & \text { Number- } & \text { D-II-138 } \\ 1963 & 55 & \\ 1964 & 83 & \\ 1965 & 102 & \end{array}$

The above-mentioned INEP survey showed that two-thirds of the students surveyed had taken «cursos vestibulares».

We have not been able to study the entrance examinations, which vary from university to university and from faculty to faculty. 
Cooperation between faculties is rare, although here in Rio three engineering faculties give a common examination. A few universities, under their reform plans, are working toward university-wide examinations by the early 70's.

So far, there seems no discussion as to what it is that the universities hope to accomplish by their entrance examinations, except possibly to reduce the entrant numbers to fit the number of student vacancies. The latter figures are arrived at in the various faculties as a consensus of teaching hours to be available, laboratory spaces, budgets expected, and social pressures.

\section{DISTRIBUTION AMONG CAREER FIELDS}

The mere passing of 36 per cent of the entrance examination candidates is not a reliable basis for interpretation, since it is a national average of a wide dispersion of passing percentages from the various educational fields. Of 162,000 candidates in 25 recognized career fields in 1966, the five fields of administration and economics, law, engineering, philosophy, and medicine were represented by 88 per cent or 142,000 candidates.

In order of descending numbers of candidates, SEEC preliminary data for 1966 are as follows:

$$
\text { ENTRANCE EXAMINATIONS AND TOTAL ENROLLMENTS -- } 1966
$$

Passing

Percent

\section{FfeJd}

Medicine

Engineering

Philosophy, Science \&

$$
\text { Law }
$$$$
\text { Letters }
$$

Adm. \& Econ.

Agriculture

Dentistry

Architecture

Pharmacy

Social Service

Vet. Med.

JournaMsm

Art

Phys. Educ.

Nursing

Library Science

Geology

Diplomacy

Statistics

Physiotherapy

Nutrition

Other (4)

\section{Candidates}

39,778

32,239

30,189

21,028

18,885

4,157

3,659

2,119

1,679

1,648

1,121

1,011

772

686

638

590

470

393

341

285

254

358
Approvals

6,698

7,017

16,167

9,549

7,730

1,296

1,846

561

787

1,071

503

499

644

536

484

335

120

27

113

151

123

217

\section{Enrollment}

16,975

23,514

44,588

36,238

22,76888 per cent

4,90712 per cent

6,579

3,139

2,111

3,199

1,991

1,359

1,772

1,135

1,111

978

528

45

485

255

400

527

174.604 
The number passing represents 34.7 per cent of the candidates; more properly it might be said to represent an average passing percentage among the five major fields which separately range from 17 to 54 per cent.

With the high selection (on an uncertain basis) that occurs in the process of graduating from secondary shool in Brazil, one can accept the fact that sufficient native intelligence may exist among the 88 per cent of the sample choosing the top five fields. But one can certainly ask if such a selection of fields is good for Brazil? Must not Brazil choose and emphasize its directions in education?

It will do little good to increase secondary graduations if the students' orientations (and more importantly, the orientation of the parents) are still predominantly toward only these five fields. Thus counseling, guidance, and career education become a very necessary adjunct to Brazilian secondary education. At present only a few small private services are available, nor do the entrance examinations provide much selection in aptitude for a field. For instance, a test for medicine may include the subjects of portuguese, english, mathematics, physics, chemistry, biology, and general information in history, logic and psychology. Engineering tests may differ by replacement of biology with another subject, sometimes French. We have been told that the examination in medicine gives little indication of capability and none of ultimate success. Yet once in, we are told, there is only a small percentage of Scholastic failure or dropout. The INEP research cited above states that first semester dropouts amount to only 11 per cent in economics, 9 per cent in law, and 7 per cent in social science.

That the examinations seem to fail in any objective except the reduction of numbers is indicated by two papers covering examinations in engineering and medicine. ${ }^{5}$ Variations in examination difficulty from year to year, variations in grade given to a particular answer by one student from perfect to 25 per cent when the paper is submitted to eight examiners, and lack of correlation with intelligence test results are ali shown.

With only about 210,000 university graduates in the country, the economic return to an individual is not yet a factor in choice of one career field over another. As shown by preliminary research results, ${ }^{6}$ the economic value lies in having a university education of any kind, or even a partial one.

The somewhat arbitrary actions of the various faculties in expanding or restricting the number of vacancies in the various fields are,

5 Leser, Walter, Revista Brasileira de Estados Pedagógicos, 37 jan.-março, 1962, p. 20; Ribeiro, Paulo, p. 55.

6 A. J. Rogers III, Study ol refurns to highec education in Brazil, EAPES. 
perhaps, making decisions for Brazil on narrow or improper bases. To these restrictions must be added the one imposed by the difficulty of the entrance examination for the field and the institution. Vacancies are apparently fixed by the faculty by decision based on spaces in a given classroom or laboratory, the desires of the teachers, the budget promised by the Ministry balanced against an estimate of what the institution might actually receive (there may be a significant difference) and the general pressures in the career field.

The total of vacancies in ali fields and ali institutions usually exceeds the number of approvals given by the arbitrary passing grade of 50 per cent. There are even a few fields in which the number of candidates is less than the number of vacancies, but the overall picture is one of vigorous restriction of capacity. For instance, in 1965, for ali of Brazil:

Vacancies

Candidates

Approvals
58,929

125,406 - 210 per cent vacancies

47,494 - 37 per cent candidates

As between public and private institutions:

\begin{tabular}{|c|c|c|}
\hline & Public & Private \\
\hline Vacancies & $.30,324$ & 28,605 \\
\hline Candidates & 77,867 & 47,539 \\
\hline Approvals & 23,572 & 23,922 \\
\hline
\end{tabular}

The lower rate of application at the private schools probably reflects the tuition element; the pressure of numbers on the higher educational system is coming from a rising middle classe with aspirations for their children but financially pressured by inflation and relatively fixed wages.

To carry the discussion of the five preferred fields still further, note for 1965:

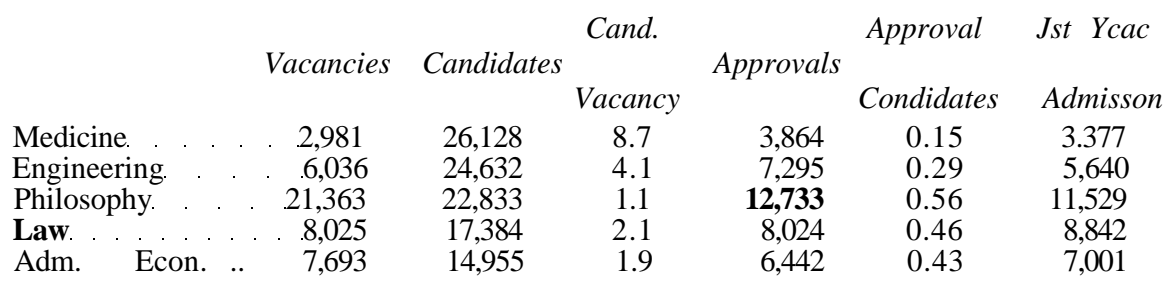

The excess of approvals over vacancies has lead to the problem of the «excedentes». These represent a group which has received «passing» grades over 50 per cent, but for which there is no place in the university. In the major cities, particularly Rio and São Paulo, this group has become a politicai force and in recent years has forced additional admissions in medicine and engineering in the local schools. That the problem is one of an artificial «passing» grade is fundamental, but it is 
also a problem duc to the enforced lack of mobility of the student due to the nature of the entrance examination. He may have been approved tor a given faculty in which no further vacancy exists because he was not examined for a neighboring faculty, he cannot be admitted there even if a vacancy does exist. This effect is evident in engineering, philosophy, and administration where the reported ${ }^{1}$ first year enrollment did not fill the vacancies announced, on a national basis. Some of this situation is also due to multiple applications, and the passing of several examinations by the same student. This practice is just beginning to grow, and is possible only where staggered scheduling of tests exists. If it becomes a significant factor, it will have a deleterious effect on admissions. Perhaps this will lead to improvements through the operation of the inherent law - - «before anything can get better, it must get worse».

Positive differences between admissions and approvals are usually stated as due to repeaters from the previous year. There is some feeling that admission irregularities also enter.

The increasing pressure of numbers in these several fields can be illustrated by a study over several years:

\begin{tabular}{|c|c|c|c|c|c|}
\hline$D-U-145$ & Year & Vacancies & Candidates & Approuals & $\begin{array}{l}\text { Ist Year } \\
\text { Enrollment }\end{array}$ \\
\hline Medic & $\begin{array}{l}1961 \\
1962 \\
1963 \\
1964 \\
1965 \\
1966\end{array}$ & $\begin{array}{l}3.036 \\
2,981\end{array}$ & $\begin{array}{l}15,006 \\
15,748 \\
21.342 \\
22,151 \\
26,128 \\
39,778\end{array}$ & $\begin{array}{l}2,090 \\
3,296 \\
3,457 \\
3,740 \\
3,864 \\
6,698\end{array}$ & $\begin{array}{l}3,895 \\
3.377\end{array}$ \\
\hline Engineering & $\begin{array}{l}1961 \\
1962 \\
1963 \\
1964 \\
1965 \\
1966\end{array}$ & $\begin{array}{l}3,035 \\
6.556 \\
6,036\end{array}$ & $\begin{array}{l}14,663 \\
15,892 \\
17,838 \\
24,719 \\
24,632 \\
32,239\end{array}$ & $\begin{array}{l}2,386 \\
4,143 \\
5,443 \\
7,715 \\
7,295 \\
7,017\end{array}$ & $\begin{array}{l}7,613 \\
5,640\end{array}$ \\
\hline Philosophy & $\begin{array}{l}1961 \\
1962 \\
1963 \\
1964 \\
1965 \\
1966\end{array}$ & 15,904 & $\begin{array}{r}10,616 \\
9,924 \\
12,419 \\
\\
22,833 \\
30,189\end{array}$ & $\begin{array}{r}6.064 \\
6,535 \\
8,884 \\
9,548 \\
12,733 \\
16,167\end{array}$ & 6,914 \\
\hline Law & $\begin{array}{l}1961 \\
1962 \\
1963 \\
1964 \\
1965 \\
1966\end{array}$ & $\begin{array}{l}7,620 \\
8,025\end{array}$ & $\begin{array}{l}10,829 \\
11,342 \\
13.211 \\
17,112 \\
17,384 \\
21,028\end{array}$ & $\begin{array}{l}5,165 \\
5,906 \\
6,974 \\
8,432 \\
8,024 \\
9,549\end{array}$ & $\begin{array}{l}8.782 \\
8,842\end{array}$ \\
\hline
\end{tabular}

1 Subject to inherent variability in reported figures. Bowles, loc. cit., p. 40.

D-II-145. 
It seems a general belief, at least in Rio, that many of these professionals want the degree only for social standing and do not intend to practice. If this is common, then much expensive education has not been put to its full purpose. Since the legislative bodies are largely drawn from groups educated under the prevailing system, it is unlikely that they will legislate to change the system, as for instance, the requiring of an internship in the interior for every doctor graduate prior to acceptance to practice.

It is very difficult to obtain useful figures on professionals in practice since a man may claim to be a doctor or lawyer long after he has undertaken other work under the Brazilian part-time practice. However, a preliminary figure from the 1960 census indicates only 62 per cent of engineering diplomas in São Paulo state practice the profession. Further data is hoped for on this point.

It is possible to get at the matter in another way for the professions of medicine and engineering. Making an assumption of an annual loss rate to medicine of 2 per cent per year, EPEA has correlated the annual registrations to practice by doctors with the number graduated over the same 15-year period.

$\begin{array}{cccc}\text { Year } & \begin{array}{c}\text { RegMered } \\ N \text { of doctors }\end{array} & \begin{array}{c}\text { Assumcd } \\ \text { Losses }\end{array} & \begin{array}{c}\text { Total } \\ \text { Graduations }\end{array} \\ 1950 & 22,114 & & \\ 1964 & 33,500 & & \\ \text { Net } & 11,386 & 8,316 & 21,715\end{array}$

The net increase should be $21,715-8,316=13,399$, whereas the increase in registrations is 11,386 . Considering the probable inaccuracy of the 2 per cent assumed annual loss, this seems a reasonable check. However, we note that a doctor may retain his registration as a right to practice long after he has transferred the major share of his time to another career.

\section{CHANGES IN CAREER CHOICE}

Some changes are occurring in the relations between the various career fields and these are indicated below. Unfortunately, these are occurring almost wholly through the actions of the various faculties in restricting or opening vacancies, and the action of the Federal Council in approving new faculties, and these are not coordinated efforts. Also, such actions tend to be very slow in response to social and technical needs. 


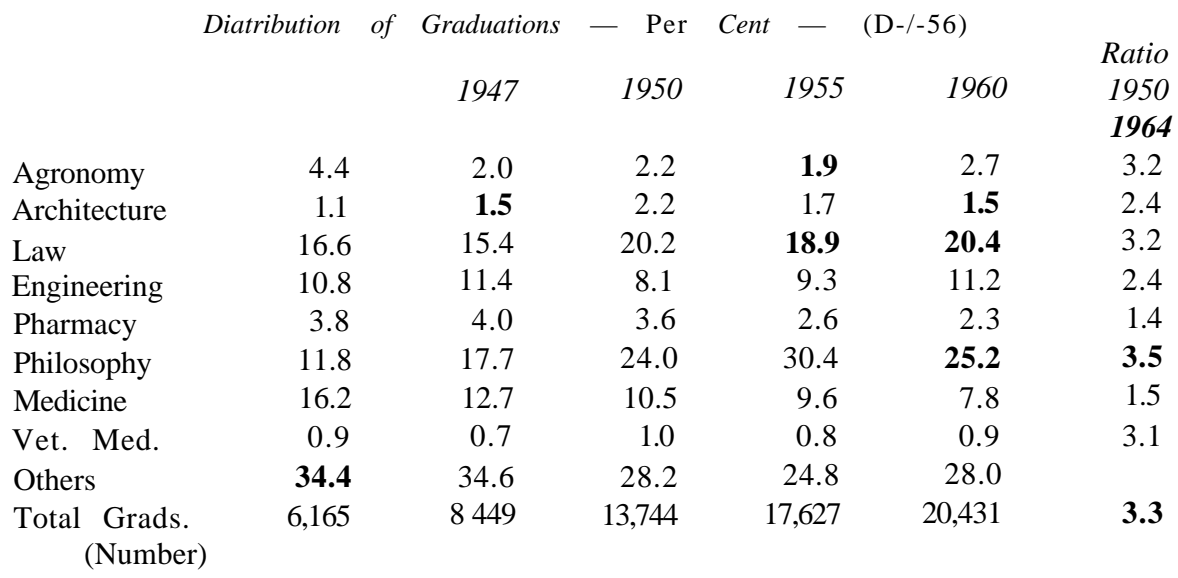

\section{AVAILABILITY OF HIGHER EDUCATION}

Brazil has an immense área, is sparsely settled, and a population which is not able to move very far for its education, as the higher education enrollment dips further into the emerging middle class. Therefore Brazil niust expect to pay high educational costs if it is going to provide an education in ali academic fields for ali regions. Yet under the present system of approval of new faculties there seems little concern that Brazil may be spreading its educational resources undesirably thin.

Considering the recognized educational fields, and the 21 states and one federal district, the distribution of faculties was as follows in 1965:

\begin{tabular}{lcc}
\multicolumn{1}{c}{ Field } & $N^{\prime}$ of & Total \\
States & having & Faculties \\
Philosophy & 22 & 92 \\
Law & 22 & 62 \\
Economics & 20 & 66 \\
Social Service & 20 & $\mathbf{3 5}$ \\
Dentisty & $\mathbf{1 9}$ & $\mathbf{3 9}$ \\
Medicine & $\mathbf{1 9}$ & 38 \\
Pharmacy & 17 & 23 \\
Engineering & 14 & 41 \\
Nursing & 14 & $\mathbf{4 1}$ \\
Administration & 12 & 20 \\
Agronomy & 11 & 16 \\
Music & $\mathbf{1 1}$ & 34 \\
Architecture & 10 & 11 \\
Fine Arts & 10 & 22
\end{tabular}

Includes arts, letters, natural science, education.

Territories not included. 
Field

Journalism

Library Science

Veterinary Medicine

Geology

Physical Education

Sociology

Domestic Science

Industrial Chemistry

Theatre

Nutrition

Statisfics

Diplomacy

Dance

Industrial Design

Muscum Science

Total (D-II-168-CAPES)
$N^{\prime} o[$

Srates having

\begin{tabular}{c}
10 \\
\hline 10 \\
\hline 10 \\
\hline 8 \\
\hline 7 \\
\hline 7 \\
\hline 5 \\
\hline 5 \\
\hline 4 \\
\hline 3 \\
\hline 2 \\
\hline 1 \\
\hline 1 \\
\hline 1 \\
\hline 1
\end{tabular}

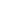

Total

Facuíties

17

13

13

9

0

8

5

5

4

4

2

1

1

1

1

632

\section{NORTHEAST}

Bahia,

Alagoas.

Peruambuco

Sergipe.

Rio Grande do Nort

Piaui.

Paraiba.

Ceara.

SOUTHERN

Espirito Santo

Minas Gerais.

São Paulo

Rio de Janeiro

Guanabara

Parana.

Santa Catarina

Rio Grande do Sul

NORTH \& WESI

Maranhão.

Paráa

Amazonas.

Goias

Diatrito Federal

Mato Grosso

\begin{tabular}{|c|c|c|c|c|}
\hline o/ $\begin{array}{l}\mathrm{A}^{\prime} .^{\circ} \\
\text { jacullm }\end{array}$ & $\begin{array}{c}\text { Stuients } \\
\text { per } 100.000 \text { hab. } \\
(1964)\end{array}$ & $\begin{array}{c}\text { Populalion } \\
\text { per q. km. } \\
(1960)\end{array}$ & $\begin{array}{l}\text { Unis. } \\
\text { EnroU. } \\
\text { (1965) }\end{array}$ & $\begin{array}{c}\text { EnroU. } \\
\text { per Facuíly }\end{array}$ \\
\hline 33 & 85 & 10.4 & 6.219 & 188 \\
\hline 7 & 74 & 44.7 & 1.063 & 152 \\
\hline 35 & 173 & 42.9 & 8.301 & 237 \\
\hline 6 & 45 & 34.2 & 421 & 70 \\
\hline 10 & 92 & 22.5 & 1.281 & 128 \\
\hline 3 & 32 & 5.2 & 410 & 103 \\
\hline 21 & 86 & 359 & 2.110 & 100 \\
\hline 18 & 115 & 23.0 & 4.533 & 252 \\
\hline 133 & & & & Average 154 \\
\hline 9 & 122 & 24.3 & 1.881 & 209 \\
\hline 66 & 133 & 15.1 & 16.804 & 255 \\
\hline 132 & 266 & 46.0 & 42.891 & 325 \\
\hline 23 & 163 & 65.8 & 6.579 & 286 \\
\hline 67 & 602 & $2,304.0$ & 24.513 & 365 \\
\hline 42 & 173 & 17.4 & 10,389 & 247 \\
\hline 8 & 64 & 21.4 & 2.097 & 262 \\
\hline 89 & 285 & 18.1 & 18.487 & 208 \\
\hline 436 & & & & Average 270 \\
\hline 8 & 24 & 5.98 & 807 & 101 \\
\hline 16 & 139 & 1.08 & 2.335 & 146 \\
\hline 5 & 64 & 0.39 & 600 & 120 \\
\hline 21 & 116 & 2.8 & 2.896 & 138 \\
\hline 13 & & & 764 & 59 \\
\hline 4 & 24 & 0.5 & 400 & 100 \\
\hline 67 & & & & Average 111 \\
\hline
\end{tabular}


! It does not seem possible to draw conclusions from data related to enrollments and population densities; enrollments in the 42 federal universities are more a function of the population of the city in which the university is located than they are related to the state's population density. It has been stated (INEP) that 60 per cent of an enrollment will be from the município (county) in which the university is located.

That the educational opportunities are somewhat in balance with the needs of the áreas is indicated by grouping the sta'es in the standard National Educational Plan áreas, and in the industrialized south the average enrollment per faculty is 270 , in the northeast it is 154 , and in the undeveloped north and west it is 111. Ali of these figures may be on the low side for desirable institutional operation, resulting in high per student cost. The indications are that too many faculties exist, and this seems a result of indiscriminate recognition of new schools in past years. The federal universities, being composites of existing faculties, often have duplicating faculties at different locations, again reducing efficiency and raising cost.

The figure of 111 students per faculty in the north and west probably should not be so criticized without a determination of where the faculties are, since the low figure and resultant high cost per student may be only the subsidy required to educate people in those remote áreas.

The low student ratio for Sergipe calls for study. By comparison with Piauí, it can be concluded that Sergipe simply has too many faculties. Its schools are ali in the capital, Aracaju, and consist of faculties of law, medicine, engineering, social service, philosophy, administration and economics. There is a Federal faculty, a state faculty, and at least one private faculty. Graduations in 1964 totalled 16 from the private faculty and 19 from the state and federal faculties. The faculties have 151 teachers. They are operating chemical engineering with an annual input of about 12 students, and 20 teachers, medicine with an input of 16-17 students and faculty of 28, social service with an input of 8 and faculty of 14. Law seems reasonable with an input of 30 but it has a faculty of 23 .

This is part of the penalty that must be paid if education is to be supplied in every state capital. Actually Aracaju is much closer to Salvador and its large university, than are many sections of the state of Bahia, expected to be served by Salvador. 
The growth in number of faculties can also be studied for some of the more popular fields (except engineering, for which the data is confused):

$\begin{array}{cccc}\text { Year } & N^{o} \text { of Schools } & \text { Enroll. } & \begin{array}{c}\text { Studentes } \\ \text { per School }\end{array} \\ & \text { MEDICINE } & & \\ 1947 & 12 & 7.550 & 629 \\ 1950 & 13 & 8.530 & 656 \\ 1955 & 23 & 9.900 & 430 \\ 1960 & 28 & 10.260 & 366 \\ 1964 & 41 & \mathbf{1 4 . 2 0 0} & 346 \\ & & & \\ 1947 & \text { PHARMACY } & \text { (D-II-189 et. seq) } . & \\ 1950 & 18 & 962 & 53 \\ 1955 & 20 & 1.300 & 65 \\ 1960 & 23 & 1.650 & 72 \\ 1964 & 22 & 1.700 & 93 \\ & 23 & 2.140 & \end{array}$

ACRONOMY

13

11

12

12

19

1.060

1.000

1.220

1.900

3.820

VET. MRD.

1947

1950

1955

1960

1964

1947
1950
1955
1960
1964

$\begin{array}{rrr}8 & 303 & 38 \\ 8 & 742 & 93 \\ 12 & 821 & 103 \\ & 1.516 & 126\end{array}$

LAW

$\begin{array}{lrl}23 & 7.758 & 337 \\ \mathbf{2 4} & 11.393 & 474 \\ 38 & 19.921 & 524 \\ 56 & 23.835 & 426 \\ 60 & 30.974 & 516\end{array}$

It might be hypothesized that:

1) If enrollments per school rise or stay levei with increase in number of faculties (schools), then new geographical regions are being reached, on enrollment pressures for the field are being met. This is demonstrated by the case of Agronomy.

2) If enrollments per school decline with increase in number of schools, new groups are not being so effectively reached, or the locations of the additional schools were poorly chosen, or there is insufficient need for the new schools. Medicine seems to illustrate this case; the excedentes problem in that field is of recent origin. 


\section{BRAZILIAN EDUCATIONAL NEEDS}

As of 1960, Brazil stood as follows in the percentage of the workforce having college education (D-I-166).

\begin{tabular}{|c|c|}
\hline Country & Per cent of ivor \\
\hline U.S.A. & $\ldots \ldots .11 .9$ \\
\hline USSR & 3.8 \\
\hline Japan. & $3-7$ \\
\hline Italy & 3.0 \\
\hline Greece & 2.3 \\
\hline Spain. & 1.7 \\
\hline México & 1.4 \\
\hline Portugal & 1.4 \\
\hline Brazil & 0.9 \\
\hline Pakistan & 0.4 \\
\hline Thailand & 0.3 \\
\hline
\end{tabular}

Numbers in the various major professions in Brazil, estimated from the 1950 census plus graduations and less estimated losses, are given for 1964 as:

\begin{tabular}{|c|c|}
\hline Doctors. & 33.500 \\
\hline Dentists. & 26.300 \\
\hline Engineers & 24.00 \\
\hline Pharmac:sts & .12 .700 \\
\hline Agronomists & 5.000 \\
\hline Architects & 3.600 \\
\hline Chemists. & 3.50 \\
\hline Vet. Med & 2.30 \\
\hline
\end{tabular}

(D-I-168)

No figures are given for lawyers, teachers, and other major segments of the educated population, but the total university educated population in 1960 was about 210,000 based on a 1.27 per sample of the 1960 census.

Worldwide statistics on professionally-trained manpower are sparse and of uncertain comparability. However, we have from OECD and IBGE, summarized D4-169, for 1964:

PROFESSKDNALS PER MILLION OF POPULATION - 1964

$$
\text { West }
$$

Agronomy

Engineering

Medicine

Pharmacy

Chemistry

Vet. Med.

$\begin{array}{rcrrrrr}\text { Brazil } & \text { México } & \text { Canada } & \text { Germany } & \text { Portugal } & \text { Norway } & \text { USA } \\ 60 & \mathbf{1 1 5} & \mathbf{1 5 1} & - & \mathbf{1 1 5} & 45 & 44 \\ 303 & 700 & 2.500 & 3.300 & 526 & 2.500 & 4.100 \\ 416 & 588 & 1.100 & 1.430 & 770 & 1.100 & 1.250 \\ 164 & 20 & 357 & 400 & 238 & 212 & 666 \\ 43 & - & 330 & - & 34 & \mathbf{1 1 6} & 450 \\ 29 & - & 83 & - & 76 & 130 & 84\end{array}$

«Agronomy» does not seem to imply uniform training or a firm body of knowledge in Brazil. Brazil is also including the new field of biochemistry with its pharmacy statistics. For the purposes of forecasting needs, this is a confusing move. 
None of the selected countries seem useful as an ideal target for Brazil in its present state of development. In preparation for the TenYear Plan, 1967, EPEA has made the following predictions of need. They are based on a 1966 population estimate of 85 millions, a 1976 population estimate of 110 millions.

\begin{tabular}{|c|c|c|c|c|c|c|}
\hline & $\begin{array}{c}\text { Available } \\
1966\end{array}$ & $\begin{array}{c}\text { Predic- } \\
\text { tion } \\
1967\end{array}$ & $\begin{array}{c}\text { Per } \\
\text { Million } \\
1966\end{array}$ & $\begin{array}{c}\text { Per } \\
\text { Million } \\
1967\end{array}$ & $\begin{array}{c}\text { Portugal } \\
1964\end{array}$ & $\begin{array}{c}\text { México } \\
1964\end{array}$ \\
\hline Agronomy & 6,500 & 13,800 & 76 & 126 & 115 & 115 \\
\hline Engineering & 27,000 & 60,000 & 320 & 545 & 526 & 700 \\
\hline Medicine & 37,400 & 60,000 & 440 & 545 & 770 & 588 \\
\hline Pharmacy & 6,000 & 14.700 & 71 & 134 & 238 & 20 \\
\hline Chemistry & 3.700 & 8,500 & 43 & 79 & 34 & - \\
\hline \multirow[t]{2}{*}{ Vet. Med. } & 2,620 & 7.000 & 31 & 63 & 76 & - \\
\hline & 83,220 & 164,000 & & & & \\
\hline
\end{tabular}

The number of engineers includes as «traditional engineers», those with training in civil, mining, metallurgy, electrical, electronics, and some in mechanical áreas. The number of engineers needed for 1976 v/as first placed at 670 per million of population $(73,000$ total $)$ from a comparison with other countries as indicated by the second preceding table. The figures are probably not based on the same type of engineering populations, but disregarding this, the assumed figure would place Brazil, in 1976, midway between the leveis achieved by Portuga] and México in 1964. However, another study indicated industrial needs for 25,000 engineers in 1976; the industrial sector presently uses one-half of the total of engineers, therefore a 1976 goal of 50,000 was indicated. The final figure of 60,000 was arrived at as an intermediate choice.

The classification of «chemist» was created by law in 1943, grouping together those with education in chemistry, industrial chemistry, and chemical engineering (Decreto-lei $\mathrm{n}^{9} 5.452-1943$ and Lei 2.800, 1956). Using a survey by the Instituto Universitário de Pesquisas do Rio de Janeiro, and a comparison with other countries as before

This fig ure of 6.000 for pharmacy in 1966, and 14.670 in 1976 requires comment. It must be compared with 12,670 given in Table 94, page 168 of Diagnostico I. The figures of 6,000 and 14,700 and the derived per million figures are special for Brazil, and are undoubtedly not to be compared with Portugal and México. Further comment follows.

Includes chemical engineers, as 45 per cent of the total. These engineers ar not duplicated in «Engineers», in Brazil, but probably are included as «Engineers» in Portugal and México. 
EPEA concluded there would be need in 1976 for 79 «chemists» per million population, for a total of 8.500. Forty-five per cent of these -would be chemical engineers. By reason of this legally introduced confusion. the future growth in chemists involves the efforts of several faculties in educational preparation.

The predictions for agronomists are related to pact growth rates (1950-1963) in cultivated lands, and the observation that in the past there has been a predictable exponential relation between área cultivated and the number of agronomists. Thus by use of agricultural forecasts on cultivated land to 1976, there was obtained the figure of 13,850 for agronomists in 1976.

The study reports that no similar relation is available between the number of veterinarians and the number of cattle. However, it is assumed that, without major educational investment, the number of veterinary doctors can be raised from 2,620 in 1966 to 7,000 in 1976. This is an increase of almost three times, but the number of cattle is expected to increase only 25 per cent.

The number of medicai doctors predicted for 1976 was largely based on the international rankings given in the previous tables, and was chosen as 60.000 or 545 doctors per million of population, being slightly less than the levei reached in México in 1964. No consideration was given to the geographical maldistribution of the present medicai corps, nor was it noted that the medicai schools have not been producing at a rate to maintain equality with population growth, as shown:

$\begin{array}{cccccc}\text { CHANGES IN } & \text { PROFESSIONALS PER } & \text { MILLION } & \text { POPULATION } & \text { BRAZIL } \\ \text { Year } & \text { Engineers } & \text { Architects } & \text { Agronomists } & \text { Med. Doctors } & \text { Pharmacists } \\ 1950 & 245 & 20 & 43 & 425 & 221 \\ 1955 & 275 & 31 & 51 & 441 & 205 \\ 1960 & 276 & 40 & 55 & 430 & 176 \\ 1964 & 300 & 45 & 63 & \mathbf{4 1 9} & 164\end{array}$

The data on pharmacist production is from D-I-168, which indicates a stock of 12,670 pharmacists in Brazil in 1964. This data is believed correct, and probably comparable to the international data of a previous table. The prediction for growth of the field made by EPEA and to be discussed, disregards the fact that pharmacist production has not kept pace with population, as also was indicated for medicine.

The Ten-Year Plan for Pharmacy goes much further than in other fields, in following out a plan of the Federal Council on Education (Parecer $\mathrm{n}^{\mathrm{v}} 268,1962$ ), to stimulate the production of high levei pharmacy-biochemistry graduates from the fouryear universities. In contrast the traditional pharmacist-manager for a pharmacy would be trained through yet-to-be-established work at the secondary levei.

Estimated by the Census, data received through SEEC. 
Thus the ten-year predictions for pharmacy are based on a 1966 levei of 6,000 in hospitais, the pharmaceutical industry, food industries, public-service laboratories and in teaching. Predictions of probable growth in these fields lead to the number of 14,700 pharmacist-biochemists in 1976. This restriction of the field of work probably makes the Brazilian forecasts in pharmacists per million inhabitants non • comparable with the rest of the world.

In passing, one is led to wonder at the ability of a traditional drug-trained faculty to change to a field which seems related to organic chemistry and a chemistry faculty.

The field of dentistry was also studied by comparison with other countries of the world:

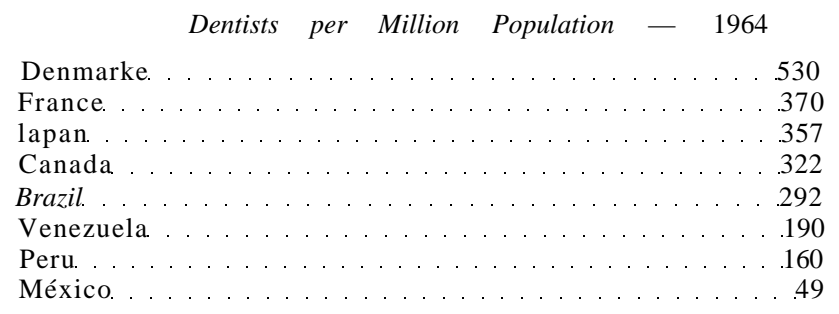

(1966)

A target of 370 dentists per million inhabitants was chosen, making Brazil equal to where France was in 1964, and calling for an increase from 24,000 to 40,000 dentists in the ten years to 1976 .

Compared to the rest of the world. Brasil is in good position in dentistry. Is this a fall-out from restricted enrollments in medicine? Do potential medicai students turn to dentistry when they see poor chances of medicai school entrance for themselves?

Nursing in 1966 has 6,700 practitioners. The Commission on Nursing Education of the Directorate of Higher Education of MEC estimated needs for 33,500 nurses and 229,000 auxiliaries in 1976. The basis for the estimate is not known - it would still be only about one-half nurse per docíor, but EPEA rejected it as impractical. The program of increase from 6,700 to 10,200 in ten years which was proposed, will call for an increase of 400 per cent in nursing enrollments and graduations.

Forecasts for the other major fields of administration, law, philosophy were not made for the Ten-Year Plan; it seems these are to grow at their natural rate. In particular no predictions were made for preparations of teachers for secondary schools.

\section{TOTAL UNIVERSITY ENROLLMENT - THE SUM OF THE PARTS}

The previous section shows the development of EPEA pianning into a structure of disconnected parts, without decisions on aree 
major stress, and without evident research on the needs of Brazil except as shown by decisions that Brazil should at least reach a levei equal to that of a target country. Also lacking is thought on the substructure of higher education - namely the fostering of growth and improvement at the secondary levei which seems generally accepted as the real bottleneck to Brazilian educational progress. Being 50 per cent in private hands this is a difficult sector to attack, and without acceleration at that levei perhaps the «let it grow» philosophy so evident in the reported planning is the easiest means for progress.

However, some measure of the total enrollment problem facing the universities in the next ten years must be obtained. One method is to approach the total enrollment os the sum of the predicted enrollments in the various fields of higher education; a second method is possible by extrapolation of past enrollments under the «let-it-grow» philosophy. A third method is that of extrapolation from secondary graduations over the expected period. This section of this report will arrive at an enrollment total from the several parts, subsequently to be compared with enrollment forecasts by the other two methods.

Past educational records are provided by the «Sinopse» of SEEC, but data is not entirely presented in the way in which predictions were made by EPEA. Chemistry figures are not available separately, but it is probable that «chemical engineering» is include in the figures for «Engineering». «Agronomy» is not so listed, but by comparability of figures, it appears to be shown in SEEC data as «Agricultura». Then:

UNIVERSITY ENROLLMENTS - BRAZIL - 1964 AND 1976

\begin{tabular}{|c|c|c|c|c|c|}
\hline & Actual * & Grad. & Predicted & Graduation & Enrollment \\
\hline & 1964 & 1964 & 1976 & 1976 & 1976/1964 \\
\hline Total . & 155.781 & 20.282 & $? ?$ & $? ?$ & \\
\hline Engineering & 21.986 & 2.298 & 33.855 & 5.744 & 1.54 \\
\hline Medjcine . & 15.574 & 1.596 & 35.810 & 4.962 & 1.61 \\
\hline Dentistry . & 6.044 & 1.214 & 22.244 & 4.559 & 3.68 \\
\hline Agronomy . & 4.397 & 548 & 7.066 & 1.392 & 1.61 \\
\hline Architecture & 2.601 & 300 & 9.286 & 1.540 & 3.57 \\
\hline Pharmacy - Bio Chemistry & 2.350 & 463 & 13.442 & 2.330 & 5.72 \\
\hline Vet. Med. ...... & 1.740 & 187 & 3.017 & 680 & 1.73 \\
\hline Jursing & 1.056 & 260 & 4.770 & 1.116 & 4.52 \\
\hline Sample total & 55.748 & 6.866 & 129.490 & 22.323 & 2.32 \\
\hline
\end{tabular}

There can be confusion in these figures. Sec original comment. 
As previously pointed out, there seems no evidence of planning for the future growth of the major fields of philosophy (secondary teacher training, and science), law, and administration and economics. An assumption, possibly a reasonable one under the apparent «let-it-grow» philosophy, is that these fields will grow in the same proportion as indicated for the average of the fields studied in detail. In 1964 these eight fields enrolled 36 per cent of the university students and contributed 34 per cent of the graduates. W can then arrive at a forecast for the total university enrollment in Brazil in 1976 as

$$
\begin{aligned}
& \text { Students in } 1976=\frac{155.781}{55.748} X \quad 129.490=362.000 \\
& \text { Guaduations in } 1976=\frac{20.282}{6.866} X \quad 22.323=65.900
\end{aligned}
$$

The figure for total students represents an increase to 230 per cent of the 1964 enrollment in 12 years. This is a growth rate of 7.2 per cent annually. This seems a practicable figure for the system to achieve.

Its reasonableness is further demonstrated if one looks at the previous ten year growth in 1956-1965. This was equal to $158.316-$ 78.659, an increase to 201 per cent of the 1956 figure. However, this too, is an annual growth rate of 7.2 per cent!

That is, the planning effort has predicted that, ío meet the needs of the country, the universities merely need to keep growing at the rate achieved in the ten years previsous to the study- Is there any doubt of the «let-it-grow» philosophy?

There seems no evidence of awareness at planning leveis, of the need for rapid acceleration in higher education if Brazil is to meet its objectives in overall development. This statement is supported by the low expansion rate assigned to engineering in the previous table, the failure to study needs in any science fields except chemistry and biochemistry (and "with an unrealistic result in the latter), the high expansion rates predicted by the last table for architecture and dentistry (already at a comparatively high levei in numbers) and the failure to point out the oversupply in law, the probable need for more business training and the failure to indicate needed growth in the secondary teacher field.

\section{TOTAL UNIVERSITY ENROLLMENT - PREDICTIONS FROM THE PAST}

EPEA undertakes a prediction of the 1976 enrollment in the universities by extension of the records of the past ten years, 1956-1965. They acknowledge that the method has limitations, hut suggest 
that the method is still useful to indicate the growth forces acting on the system of education.

We suggest that the underlying assumptions are too great to permit usefulness, including as they must the assumptions that only uniformly increasing forces are acting, that only the historical pattern of introducing new universities is followed, that there have been no sudden changes in birth rate or in infant mortality, and that the country intends to make no efforts to use education as an important base for its development. These assumptions that nothing is going to be done to disturb the system do not, or should not apply and so we discuss this EPEA method and its results only as an illustration of the manner of thought, and to support the previously made assertion concerning the lack of urgency in the visible planning for higher education.

In the years under study the university enrollments were as follows:

\begin{tabular}{|c|c|}
\hline 1956 & 79,000 \\
\hline 1957. & 80,000 \\
\hline 1958. & 84,000 \\
\hline 1959. & 90.000 \\
\hline 1960. & $.96,000$ \\
\hline 1961. & 102,000 \\
\hline 1962. & $.110,000$ \\
\hline 1963. & 126,000 \\
\hline 1964. & $.142,000$ \\
\hline 1965. & $.156,000$ \\
\hline
\end{tabular}

It is stated that (1 (1) - P73) the «historie enrollment sequence in higher education is suited to two types of curve: exponential and parabolic. The results are diverse and the exponential seems to represent the future desirable situation in a more adequate manner, while the parábola seems more perfect as an expression of trend, with less error in calculation».

These two equations are presented on p. 205-209 as

$$
\begin{aligned}
& \text { Exponential }=\mathrm{y}=104 \mathrm{X} 1.039 \\
& \text { Parabolic }=\mathrm{y} \text { ss } 0.24 \mathrm{t}^{2}+4.25 \mathrm{t}+98.58
\end{aligned}
$$

(Number of significant figures used as given by EPEA)

We suggest that the reasoning in the above is in error. An equation with three arbitrary constants, as $0.24,4.25$, and 98.58 in the "parabolic», can always be fitted to historical data better than can one with two constants, as 104 and 1.039 in the «exponential» equation.

The intent of the phrase describing the exponential as «representing the future desirable situation in a more adequate manner» is certainly unclear. We enter this discussion expecting an indication of future enrollments, and not to confirm a «desired» result.

The «exponential» equation does not give a curve which fits the historical data very well in the first place, and is an unfortunate choice. 
The historie curve of enrollment can be seen as one difficult to fit with only two constants, since the curve approaches that of two quasi-straight lines, the break occeurring in 1962 as can be shown:

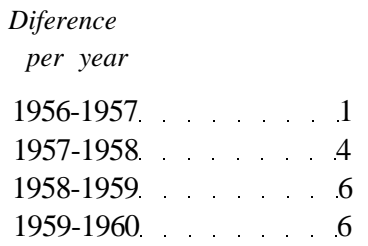

\begin{tabular}{|c|c|}
\hline \multicolumn{2}{|l|}{ Diference } \\
\hline 1960-1961. & \\
\hline 1961-1962. & \\
\hline 1962-1963. & \\
\hline 1963-1964 & \\
\hline 1964-1965. & \\
\hline
\end{tabular}

The EPEA choice of two points for determination of the two constants (at 1957 and 1963) largely overlooks this break in the rate of increase of enrollment.

A better fit to the historical data, 1956-1965, is given by the EPEA «parabolic» curve with three fitting constants at mid-1957, 1960, and mid-1963. However, it is possible to obtain a still better fit to the historie data if points at 1956, 1960 and 1965 are taken, resulting in a modified equation:

$$
y=0.87 t^{2}+0.77 t+79
$$

Comparative results and the predictions for enrollment growth to 1976 in the universities are as follows:

$\begin{array}{ccccc}\text { Actual } & \text { EPEA } & \text { EPEA } & \text { Ryder } & \text { Ten Year } \\ (\mathrm{SEEC}) & \text { «Eponential } & \text { «Parabolic» } & \text { 《Parabolic» } & \text { Plan } \\ (000) & & & & \text { Adopfed }\end{array}$

$\begin{array}{rrrrrr}1956 \ldots & 79 & 74 & 80 & 79 & \\ 1957 \ldots & 80 & 80 & 81 & 81 & \\ 1958 \ldots & 84 & 86 & 83 & 84 & \\ 1959 \ldots & 90 & 93 & 88 & 89 & \\ 1960 \ldots & 96 & 100 & 95 & 96 & \\ 1961 \ldots & 102 & 108 & 103 & 105 & \\ 1962 \ldots & 110 & 117 & 114 & 115 & \\ 1963 \ldots & 126 & 126 & 126 & 127 & \\ 1964 \ldots & 142 & 136 & 140 & 141 & \\ 1965 \ldots & 156 & 147 & 156 & 156 & 144 \\ 1966 \ldots & 175 & 158 & 174 & 164 & 156 \\ 1967 \ldots & 199 & 171 & 194 & 193 & 169 \\ 1968 . \ldots & & 185 & 216 & 215 & 183 \\ 1969 . \ldots & & 199 & 240 & 236 & 199 \\ 1970 \ldots & & 215 & 266 & 260 & 217 \\ 1971 \ldots & & 232 & 294 & 286 & 238 \\ 1972 \ldots & & 251 & 323 & 304 & 262 \\ 1973 \ldots & & 270 & 355 & 343 & 286 \\ 1974 \ldots & & 292 & 388 & 375 & 312 \\ 1975 \ldots & & 315 & 424 & 407 & 343 \\ 1976 \ldots & & 340 & 461 & 442 & 375\end{array}$


The only point in introducing a third form of equation was to show that such prediction methods are somewhat arbitrary. With a dif $\mathrm{f}$ erence as high as 100,000 to 120,000 predicted students due only to a variation in choice of mathematical method, it should certainly be apparent that cxtrapolation by such a method will not lead to an accurate target. The other variables, such as birth rates of 18-20 years ago, changes in secondary graduations, the control of admissions by control of number of vacancies, possible future variation in educational pattern, ali can introduce major changes in enrollments not predictable by extrapolation of history.

To further indicate the relatively weak foundation underlying predictions by this method, it can be seen that the enrollments finally used as the base of the Ten Year Plan follow neither EPEA curve, being intermediate to the two after 1969 and below either curve before that date. The value of 375,000 appears reasonable in terms of the 362,000 prediction of the previous section, based on EPEA studies of eight fields, and again indicates only about 7.4 per cent as the annual growth rate for the universities.

Is this enough to meet the country's needs and social pressures?

To indicate an answer to this question, and as a comment on the general inaccuracy of such extrapolations (in the USA as well as Brazil) it should be noted that the Brazilian university enrollment in 1966 was actually 175,000 and in 1967 was 199,000 . The latter figure is already 30,000 over the EPEA prediction for that year, and is actually at the levei predicted for 1969 .

\section{TOTAL UNIVERSITY ENROLLMENT - THE SECONDARY GRADUATION PRESSURE}

It seems that an absolutely essential element in prediction of university enrollments is a study of potential secondary school graduation since these are the input to the university system, and will reflect earlier-year birth rates and the Brazilian efforts to decrease drop-out losses in primary and secondary education.

The Ten Year Plan, and MEC-USAID sources, have given no useful information on this subject. There seems to have been neglect of this interface between secondary school and the university. Yet it is here, at the levei of the university entrance examination, at the point of decision on vacancies in the universities, that the «excedentes» or excess admissions problem and social disenchantment with the system of higher education are already appearing. This seems the present criticai point in Brazilian education - only after problem of admission to a university is solved will come general concern for the quality of teaching. going on there. 
This prediction of numbers seeking admission to higher education, and provision for such educational opportunity as will lead to personally satisfying and nationally useful careers for these numbers should be the concern of the educational planners of Brazil. As yet this has apparently not been true.

There is, of course, an earlier and serious interface problem between primary and secondary schools, with the examination and the financial barrier imposed by the large private secondary system. The time lag in coming through secondary school is so great, and data is so sparse because of the non-publication of the 1960 census, that this interface and the growing pressure from the primary enrollment cannot be considered here, except as a factor to make any predictions for the latter parte of the decade even more conservative.

The total enrollment in secondary education is increasing rapidly, due to increase of population, raising of the levei of the economy, and to opening of more secondary schools to reach additional segments of the population. In 1962 only 1,618 municípios (counties) of 3,144 total municípios in Brazil had secondary schools, so that new school construction will represent an important and continuing growth factor.

Secondary school in Brazil is composed of two cycles, «ginasial» of four years, followed by «colegial» of three years duration. SEEC states matriculation or enrollment in secondary school as the total of these seven years. However, even more confusing is the fact the graduations from the secondary levei are often stated as the total of the completions at the end of the ginasial course and at the end of the colegial course. Since only the colegial graduations are ready for university input, and they represent only about 30 per cent of the total, the danger of using total «ensino médio» graduations is seen, either as a measure of effective work by the secondary schools or for computing university entrance pressures.

Colegial or second cycle figures can be found, however, and appear in the following table: 


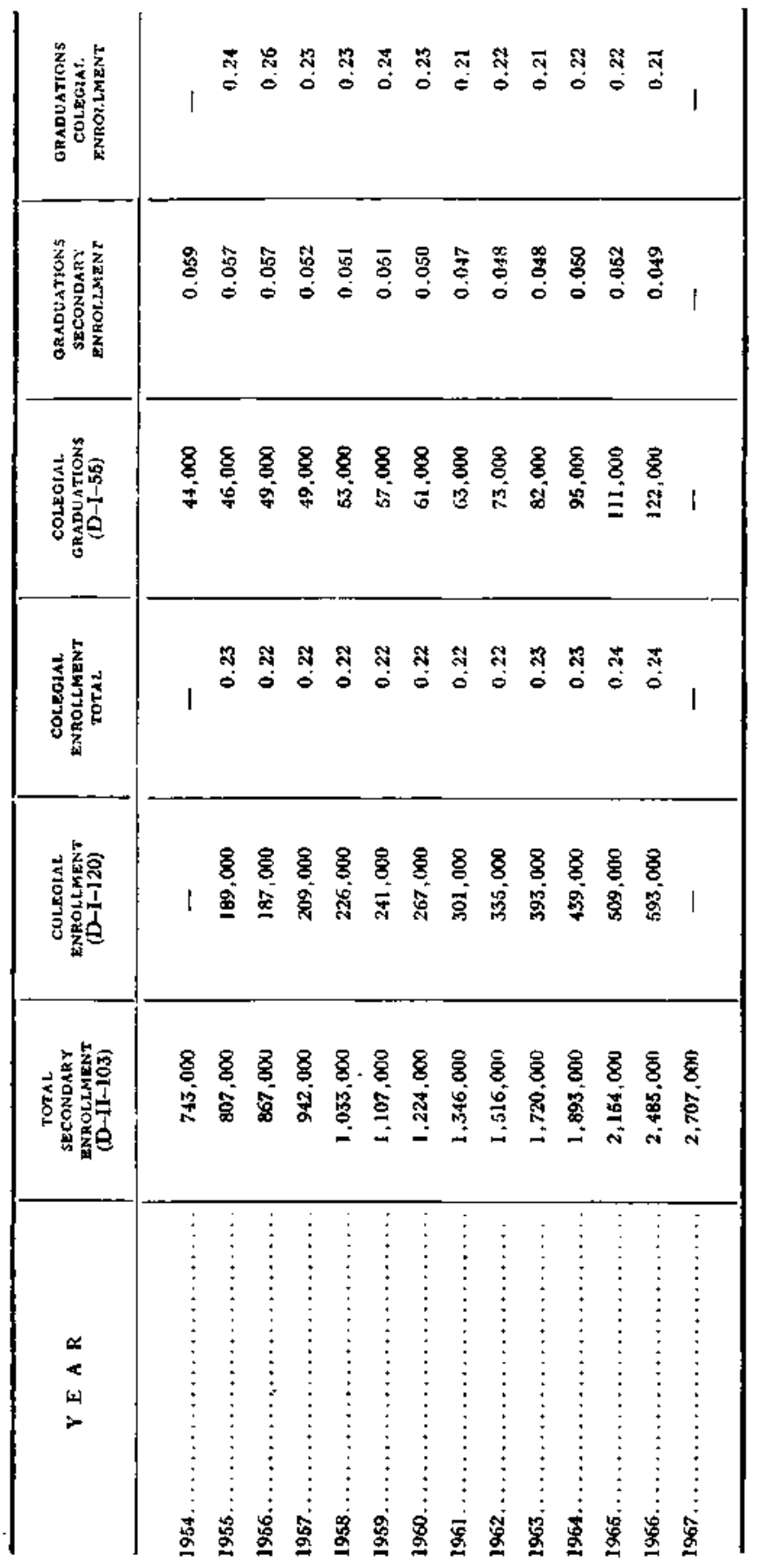


The relative stability in graduation percentage with increasing enrollment suggests need for further research. The lack of progress from efforts to increase «colegial» enrollment percentage should also be an área of great concern. It is probably connected with the fact that secondary education is largely private, and to foster more education is to foster more competition for students and tuition fees.

The secondary school-university interface also poses very great problems. With the Brazilian eductaional bottleneck persisting at the secondary levei, Brazil can ill afford further wastage above that levei if it is to its needs for educated manpower. Changes in the entrance examination are occurring slowly, and further progress could be achieved by a major study of the examination and its conduct. If these examinations were changed from a fact-hunting and restrictive means to a selective and guiding factor, and if the examination materiais recognized what was taught in the secondary schools, the system could be improved. Strong efforts are needed for rapid progress.

The second major limiting factor is that of vacancies available in the universities, since this is a subject in the hands of the individual faculties, and changes in that number are the results of budget manipulations, and social pressures on a field. Without major changes in administration viewpoints toward university responsabilities, classroom and laboratory usages, university financing and budgeting, the vacancy number seems not likely to increase by more than five to ten per cent per year in the more criticai fields (This would, however, meet the previously indicated targets!).

A further use of available figures shows that the entrance examination problem and the vacancy problem must be solved or Brazil will have much more serious «excedentes» incidents.

With an increasing secondary output and with certainly some improvement in secondary student quality, the percentage passing the entrance examination nationally has fluctuated as follows:

$\begin{array}{rrrrrrrrr}1956 & 1958 & 1960 & 1962 & 1963 & 1964 & 1965 & 1966 & 1967 \\ 0.357 & 0.376 & 0.344 & 0.406 & 0.432 & 0.416 & 0.380 & 0-349 & 0.396\end{array}$

Over the period from 1957 to 1965. while the number of quoted vacancies has increased 106 per cent and the secondary graduations have increased 100 per cent, yet the number of candidates has increased 200 per cent. A table and curve may illustrate the emerging problem more dramatically.

Walter Leser, «Considerações Gerais sobre a Seleção de Candidatos à Matrícula nas Escolas Médicas», Revista Brasileira de Estudos Pedagógicos, INEP, 37, janeiro/março de 1962 págs. 20/54.

Paulo Edmundo Costa Ribeiro «O Exame de Admissão às Escolas de Engenharia», Ibid., págs. 55/73. 
SECONDARY SCHOOL INTERFACE TO THE UNIVERSITY

\begin{tabular}{|c|c|c|c|c|c|}
\hline $\begin{array}{l}\text { «Colegial» } \\
\text { Graduations }\end{array}$ & Year & $\begin{array}{l}\text { Entrance } \\
\text { Candidates }\end{array}$ & $\begin{array}{c}\text { Univ. } \\
\text { Vacancies }\end{array}$ & Approvals & $\begin{array}{l}\text { University } \\
\text { First Year } \\
\text { Enrollment }\end{array}$ \\
\hline$($ Year-1) & Year & (D-II-145) 2 & Vacancies & (D-II-145) 2 & (V-I-71) \\
\hline $\begin{array}{l}44,000 \\
46,000\end{array}$ & $\begin{array}{l}1955 \\
1956\end{array}$ & $\begin{array}{l}43,000 \\
50,000\end{array}$ & & 18,000 & \\
\hline 49,000 & 1957 & 55,000 & 28,600 & 20,000 & \\
\hline 49,000 & 1958 & 59,000 & 30,600 & 22,000 & \\
\hline 53,000 & 1959 & 64,000 & 31,800 & 23,000 & \\
\hline 57,000 & 1960 & 72,000 & 30,700 & 25,000 & \\
\hline 61,000 & 1961 & 78,000 & 34,800 & 26,000 & \\
\hline 63,000 & 1962 & 79,000 & 47,500 & 32,000 & \\
\hline 73,000 & 1963 & 97,000 & & 42,000 & 40,000 \\
\hline 82,000 & 1964 & 113,0002 & 56,2002 & 47,0002 & 49.000 \\
\hline 95.000 & 1965 & 137,0002 & 59,0002 & 52,0002 & 48,000 \\
\hline 111,000 & 1966 & 162,0002 & & 56,5002 & 48,000 \\
\hline 122,0003 & 1967 & 113.000 & & 70.000 & \\
\hline 139,000 & 1968 & & & & \\
\hline 154,000 & 1969 & & & & \\
\hline 176,000 & 1970 & & & & \\
\hline 196,000 & 1971 & & & & \\
\hline 218,000 & 1972 & & & & \\
\hline 242,000 & 1973 & & & & \\
\hline 267,000 & 1974 & & & & \\
\hline 294,000 & 1975 & & & & \\
\hline
\end{tabular}

Some of the above data is also plotted on Figure 1. The problem which Brazil is now facing is illustrated thereon.

Prior to 1957 the number of candidates for the university entrance examination approximated the secondary school graduations. This is not to suggest that all secondary graduates took the examinations, because they did not. However, the curves indicate that the number of secondary graduates taking the examinations plus the number held over or repeating the entrance examination was in 1955 a little less than the total of secondary graduates. Over the years the number of repeaters has been increasing slowly, rising to an excess of candidates over graduates of 16,000 in 1962. But the near equality of numbers was such as to hide the trend; however the backlog of examination repeaters was growing, slowly.

In 1963 and succeeding years the size of the backlog of repeaters increased dramatically. Since not ali secondary school graduates expect to enter a university, the number desiring entrance examination approval

1 For 1963 and earlier the cited table is from CAPES, for certain major fields only. SEEC States these figures are about 20 per cent less than the total. The figures given in this table have been modified accordingly.

2 SEEC totais.

3 Predicted from curve for y $3.53 t^{2}+15.8 t+226$. 
is in excess of the difference between candidates and the secondary graduates of a given class. Therefore, the size of this group held back was in excess of:

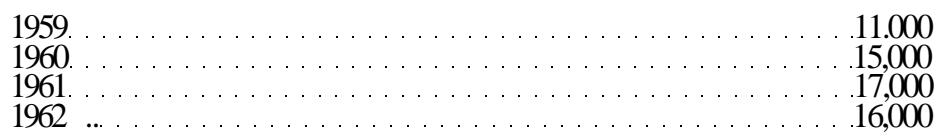

and relatively constant in those years, but has since grown to:

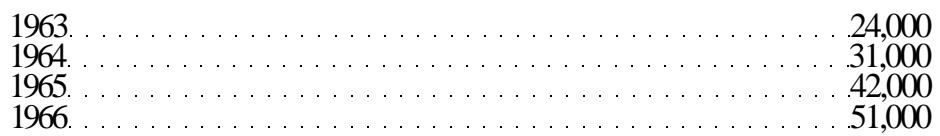

These figures indicate that in 1966 almost one-half of a year's secondary graduations thought they and university qualifications, but had been held back one or more years - and.this backlog of would-be students had tripled in four years. It should not be a surprise that the «excedentes» problem now exists. While that problem today is confined largely to medicine and engineering, it will spread to other fields if the backlog is allowed to continue its growth at the indicated rate.

The existence of this problem is confirmed by the earlier reported study on examination repeaters, showing that 40 per cent of the examinees in 1962 had been delayed one or more years, either by a previous failure, by the time needed to take a preparatory course, or for other reasons. Can Brazil afford this shortening of economic lifetime in this educated people?

However, if the excess of candidates over «colegial» graduations is overlooked, and if it is assumed that extrapolation of secondary school data might be useful in prediction, the secondary graduation curve can be extended as in Figure 1, indicating a graduation figure of 322,000 in 1975.

If this number is used as the candidates for the entrance examinations in 1976, and if only 36 per cent are accepted as has been the past history, then a first year class of 116,000 is indicated for the universities in that year. Traditionally the first year class has represented about 30 per cent of the university enrollment (29.7 per cent in 1965), and so a university enrollment of 386,000 might be anticipated for that year. This agrees with the total derived from the annual seven per cent growth rate which has been occurring.

\section{SUMMARY ON ENROLLMENT}

It would appear that if the system is not disturbed, there will be about 360,000 to 380,000 higher education students in Brazil in 1976. Of these, if the present $60 / 40$ ratio holds, there will be 220,000 in the 
«university» system and 150.000 in the «isolated faculties», not part of any university.

However, there are going to be disturbances - either from betterconceived MEC-USAID projects of the future, from social upheavals created by a middle-class population who see no higher educational opportunity for their children, or from an industry and business group who can find insufficient educated people for their needs.

Meanwhile, the problem of backlog in university admissions, with its rapidly increasing numbers, indicates further the incorrect nature of any prediction of Brazilian university growth using extrapolated demographic data. The problem of university admissions is no longer one of solutions by orderly demographic planning, if it ever was. Any real solution now will likely be impeded by politicai decisions taken in response to pressures. Final solutions await a Brazilian awareness of the necessity for orderly budgeting and financial responsability toward educational institutions, the resolution of a Brazilian purpose for education which reflects its desires for national development, and the inculcation of this philosophy into one of the world's most conservative organizations - a university faculty (congregação) .

The demographic projection of 360,000 to 380,000 Brazilian higher education students in 1976 may be correct, but with it there is the implication of a density of professionally educated people per million of population only approximating that reached by México in 1964. Progress to that levei requires only a continuation of past practices and the annual seven per cent rate of growth in higher education. But if Brazil is going to fulfill the hopes of those who see it as a leader in South America in 1976, then its educational system should be altered to prepare and receive at least 180,000 input students and to have an enrollment of 500.000 students in 1976. To do so its faculties must be revitalized, and given youth with its flexibility in thought and method. The Brazilian higher education system must be prepared to serve and help in the development of the country - to lead in the dissemination of knowledge wherever it is needed.

With an increase in administrative efficiency which must come in any case, the outlay of funds per student might not have to increase over the present levei. 


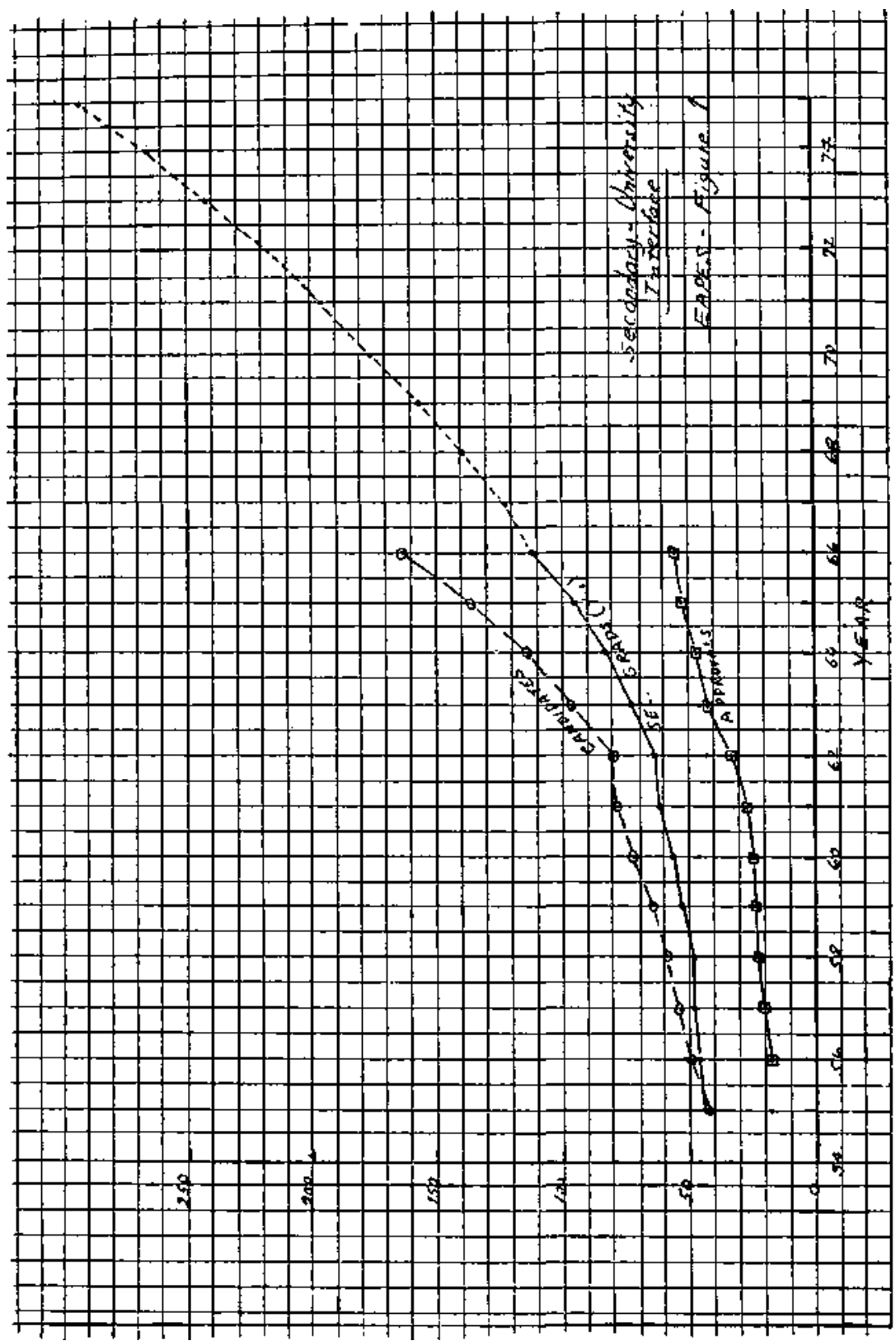


Apêndice C. 2

\section{UTILIZATION OF SPACE AND FACULTY}

J. D. RYDER

\section{ADVANCE PLANNING OF SPACE}

It is admitted in D-I-81 that the structure of the Brazilian university causes duplication of laboratories and general instructional space. This seems a result of past university history and present organization into almost autonomous faculties. Each faculty was formerly complete in most of its service fields, and continued so after its absorption into a university. Chairs of specialized mathematics and chemistry áreas in engineering faculties indicate this completeness and duplication. Usually each faculty had been geographically separated from the others and this condition also persists in most places. The Federal University of Rio de Janeiro operates at eleven sites, scattered completely across Rio, and the University of Guanabara exists at seven locations.

To compare Brazilian academic space needs with practices in other countries, as is done in D-I-83, is not conducive to meaningful results. Such comparison is even less meaningful when made on an área basis with only a definition of «área available». Brazil does not carry on much academic research. and most faculties have little or no graduate work.

To expande on the space problem in Brazil, we reproduce Table 36 from D-I-83:

\section{ÁREA AVAILABLE AT SOME UNIVERSITIES}

\begin{tabular}{|c|c|c|c|c|}
\hline University & Data & Enrollment & $\begin{array}{c}\text { Área } \\
\text { Available }\end{array}$ & Square $f t$. \\
\hline & Year & & Square ft. & Per Student \\
\hline Warwidk, England & 1970 & 15,000 & $16,205,000$ & 1.080 \\
\hline York, England . & 1970 & 2,915 & $6,990,000$ & 2,400 \\
\hline Harvard ..... & 1962 & 12,354 & $11,146,000$ & 900 \\
\hline Yale & 1962 & 7,736 & $6,800,000$ & 878 \\
\hline MIT . : & 1962 & 6,695 & $4,460,000$ & 667 \\
\hline PUC-Rio & 1965 & 5.777 & $11,152,000$ & $200(440)$ \\
\hline Univ. Ceará & 1965 & 3,858 & $11,152,000$ & $188(216)$ \\
\hline
\end{tabular}

IWarwidJc and Yoiik not yet in operation?

Enrollment at PUC in 1965 was 2,522, at Ceará it was 3,360 (Sinopse). 
There is no indication of the type of square foot usage, considered in the above table. Classrooms, laboratories, offices, dormitories, play fields, campus?

A clue can be obtained by analyzing several universities in which the situation is known.

Graduate work is a large component at the U.S. institutions cited; these do not seem good target institutions for Brazil, except on a prestige basis. They are also private institutions, whereas Brazil's institutions of concern are public in support. More practical targets for Brazil could have been chosen from the land-grant schools of the far midwest or the south of the U.S.

The Harvard figure is stated by one U.S. space expert to probably include academic facilities, the Yard área, residence halls, medicai facilities, athletic áreas and more. Personal knowledge indicates the figure for MIT must include government-sponsored research áreas to reach the indicated figure; the latter figure far exceeds the space given to the undergraduate program.

Overall building space assigned to the educational program at $\mathrm{Mi}$ chigan State University approximates 7,200,000 square feet (1967). Thus for 38,800 students on the campus there is 185 square feet of educationally-assigned building space per student. If campus land área (not farm), of about 1,000 acres is included, and 7,600,000 square feet of residential and non-educational building space is added, the total área at MSU reaches 58,300,000 square feet or about 1,500 square feet per student. This general agreement with the levei of figures in the table would seem to indicate that they are similar mixtures of building and land áreas.

A figure of 200 square feet of academic building space per student is considered normal in publicly-supported U.S. institutions.

Brazil seems to consistently build for large future enrollments - yet having the buildings, the faculties do not permit increase in entrance numbers. Some reasonable agreement should be sought in release of funds for construction as against assured future acceptance of students; it seems unrealistic to build for 5,000 to 10,000 future engineering students as has been done at Curitiba, when enrollment has advanced only from 600 to 1,000 in the last six years. Vacancies for the beginning class in 1968 number 240, yet they have buildings with over 600,000 square feet available.

Because of limited capital funds, it is usually not possible to overbuild for future growth in the U.S. More usually, new construction is used to raise a publicly-supported school up to the target levei from a more crowded situation. Thus the U.S. builds by repeated enlargement, rather than expecting one construction project to solve problems for the next 20 or 30 years. 
Brazilian building planning tends to great size, with large open foyers, reception halls, and student áreas. Appropriate location of site under urban conditions does not appear to be given much thought, although architecture includes the field of urban planning. The architects do not seem to feel pressure from budgets; there also seems a lack of planning for building function. Predilection to high rise academic building despite elevator shortcomings, inconvenient access between faculty office and classroom áreas, and a purely aesthetic layout of identical buildings, two for each department regardless of varying departmental sizes and needs, are examples of non-functional planning.

The architectural features predominate - we have been told that it is impossible to control an architect. If so, this may be part of the reason for the great size, and the lack of integration of the planned operations into the buildings. However, it seems that responsability must be shared by the part-time nature of faculty and administrative personnel, and lack of experience or example in educational planning. A few trips to institutions chosen for similarity to Brazilian needs, rather than to prestige institutions, might save much money.

The traveling groups should include architects as well as directors of schools and professors. They should be constantly shown how one builds under budget limitations. Budget limitations seem not so felt in Brazil with the money coming from a remote source - the federal government. In Brazil it seems easy to start a project, but too many projects stop before completion, either due to poor planning or lack of money, or both. Not ali such failures can be ascribed to inflation. Witness the unfinished hospitais at UFRJ, and UF Pernambuco, and the new wooden laboratories at the Polytechnic Institute of UF Paraná, next to an overbuilt library and a new examination building apparently to be used for entrance examinations one or two weeks per year.

\section{QUALITY OF CONSTRUCTION}

New academic construction in Brazil is of reinforced concrete, rather light by U.S. standards. The final result is adequate, well finished, and lighting is good. Maintenance tends to be slighted, partly by reason of lack of funds, partly because the matter does not seem important, and partly because of problems of a tropical climate. Paint, particularly the exterior cement paint available, does not stand up well. Maintenance labor, while low in cost, is not very productive.

Most space is hard surfaced and therefore noisy. Acoustic treatment materiais which will not be affected by the climate conditions are not generally available. In one school, excessive hallway noise was countered by a pérgola of wooden slats overhead. Elsewhere, the students and faculty suffer.

Air conditioning is practically non-existent. The summer vacation corresponds to the hottest months, and the temperature problem is not 
thought serious in the remainder of the year. Upkeep of laboratory 'equipment, storage of library books, then become serious maintenance ;problems under the frequently existing high humidity conditions.

\section{COSTS OF CONSTRUCTION}

It has just been stated that Brazil tends to be optimistic in its educational construction planning. Visits to three engineering schools, supported by other data, show the following:

\begin{tabular}{|c|c|c|c|c|}
\hline & ENGINEERING & $\begin{array}{c}\text { SCHOOLS } \\
\boldsymbol{A}\end{array}$ & $B$ & $C$ \\
\hline Students, undergraduate. & & 660 & 950 & 225 \\
\hline Classrooms. . . . & & 30 & 44 & 6 \\
\hline Laboratories & & 5 & 34 & 4 \\
\hline Average seats/classroom & & & & 46 \\
\hline Building área, sq. ft. & & 372,000 & 460,000 & 53,000 \\
\hline Building Area per student & & 560 & $483+$ & 235 \\
\hline
\end{tabular}

For school B which is entirely new, on a new site, the cost of building construction was given as $\mathrm{NCr} \$ 6,000,000$ and at the 1965 rate of conversion per dollar, this indicates a cost of about $\$ 10.00$ per square foot. Considering low labor cost, little reinforcing stcel and largely one and two floor design, this may be a possible Brazilian cost. The buildings are nicely built but in some ways poorly planned for their purpose. Certainly the 44 classrooms already provide more than enough seats to handle the entire present student body continuously. Since cnly 240 vacancies are announced for 1968, it is apparent that rapid filling of the facilities is not contemplated.

The new engineering building at the Federal University of Rio de Janeiro is reported to have over $1,500,000$ square feet of space, and engineering enrollment approximates 2,500, some of which is handled at another site. The engineering openings for 1968 have been announced as 300 . One school in the U.S. handles a similar enrollment, with entirely full-time students and graduate and faculty research, in 200,000 square feet. Its entering class is 900. However, Brazilian engineering schools usually teach ali their subjects and handle the students for five years, in contrast to the U.S. practice of teaching their own students for a little more than two undergraduate years. Thus some increase in space per student over U.S. practice is justified. In view of the part-time nature of the Brazilian student and faculty, and the lack of graduate work and research, it hardly seems possible to justify a standard of more than 300 square feet per student compared to the U.S. norm of 200 square feet.

Using the U.S. figure of 200 square feet of academic space per student and a building cost approximating $\$ 30$ per square foot, the

Rios reports - EAPES.

More space built since date of survey. 
U.S. builds with an investment of $\$ 6,000$ per student. Residence halls are also being built at about the same cost per student (two persons per room).

Additional supporting data appear in D-I-133, where it is shown that new African building and equipment costs, with building types similar to Brazilian needs, range from 1,630 per student at Dakar, 3,400 at University College, Ibadan, Nigéria, to 8,400 at an agricultural school in Tunis in 1961-67.

At school B reported above, the indicated direct building investment per student was $10 \times 483=\$ 4,830$. Additional Brazilian cost data are given by Corrêa (D-I-132) for scientific course áreas as U.S. \$ 6,160 per student in 1960; this includes equipment which the $\$ 4,830$ figure above does not. It is thus indicated that the dollar levei of investment per student approximates that of the U.S.A. However, without graduate study, with research space and equipment needed for very few faculties, with more part-time students, it seems that the Brazilian investment per student is as high or higher than in the U.S.A.

With its lower unit costs, Brazil could use its capital to improve more schools and more faculties if it coult depart from the concept of massive overbuilding. If each new project were entered into on the basis of providing facilities for 200 per cent of present enrollment, it would be possible to improve many more bad situations and would build for 1976, when overall enrollments will only have doubled the 1967 figure, if EPEA enrollment forecasts hold.

Lacking any national policy to direct more studants into engineering and science fields, it is certainly not realistic to build a Polytechnic Institute at Curitiba for a future enrollment of 5,000 to 10,000 such students, when present enrollment is 1,000; a similar comment seems appropriate for new buildings for engineering at UFRJ and UF Pernambuco which have been seen.

Incomplete figures prevent including a similar survey for the field of medicine. This also is not a concise field in terms of área employed because of use of hospital facilities for both teaching and patient care. A sampling of schools in the field of pharmacy indicates present usage of about 200 square feet per student, with little new construction having taken place.

\section{UTILIZATION OF SPACE}

Academic classroom space seems used very much less than onehalf time in Brazil. A classroom may be assigned to a given professor, and the average professor teaches less than three hours per

Corrêa, Arlindo Lopes, «Educaçã̃o e Desenvolvimento Econômico no Brasil». Consultec, Rio, 1963.

Reports of Rios study - EAPES. 
week (D-I-116) in a given school. It is also common for laboratories to be scheduled only in the afternoon .

The situation can be indicated by a sample study. and engineering is a limited field for which a large sample of classroom data is available. In 1966 there were 26 engineering faculties in the universities; data on classroom usage are available from 18 or 70 per cent of these schools, these 18 also enrolled 75 per cent of the engineering students of Brazil. The facilities reported are:

$$
\text { CLASSROOMS IN } 18 \text { ENGINEERING FACUI.TIES - } 1966
$$

\begin{tabular}{|c|c|c|c|}
\hline U.'F. Rio de Janeiro & 30 & 1,690 & 2.313 \\
\hline U.F. Minas Gerais. & 52 & 4,000 & 1,841 \\
\hline Mackenzie & 20 & 800 & 1.423 \\
\hline PUC - Rio de Janeiro & 30 & 1.000 & 1.062 \\
\hline U.F. Paraná ............ & 44 & 1,320 & 951 \\
\hline U.F. Pernambuco & 14 & 420 & 663 \\
\hline S.P. (São Carlos $) \ldots \ldots \ldots$ & 13 & 970 & 566 \\
\hline Est. Guanabara .......... & 17 & 680 & 537 \\
\hline U.F. Fluminense $\ldots \ldots \ldots$ & 5 & 200 & 516 \\
\hline U.F. Pará & 7 & 560 & 506 \\
\hline U.F. Ceará ........... & 8 & 320 & 355 \\
\hline U.F. Espirito Santo & 9 & 570 & 257 \\
\hline U.F. Santa Catarina & 6 & 280 & 226 \\
\hline Católica - Petrópolis & 5 & 420 & 225 \\
\hline U.F. Paraíba & 7 & 210 & 218 \\
\hline U.F. Alagoas & 11 & 660 & 128 \\
\hline U.F. Rio Grande do Norte & 5 & 105 & 116 \\
\hline U.F. Amazonas ......... & 1 & 38 & 38 \\
\hline & 284 & 14,243 & 11.941 \\
\hline
\end{tabular}

It wouid be possible to seat the entire student body continuously in ten of these schools and almost so in three more; in total there is an excess of 2,300 seats (entirely at Minas Gerais!) These are strange figures to a U.S. educator.

Of course, students are not in class continuously and rotative use of classrooms is the U.S. pattern. Omitting the unsually overbuilt Minas Gerais situation, there would be 10,243 seats for 10,100 students in 1966. In the remaining 232 classrooms there is an average of 44 seats each.

Assuming the indicated equality between students and seats, then an increased number of students could be handled as use in classroom 
hours per week goes up. Assuming a 40 hour week, and only a 70 per cent usage factor to allow for lost hours due to class scheduling problems, it would be possible to handle 86 per cent more students in the existing classrooms, not by increasing the number of students per class but by increasing the number of hours of classroom usage.

Again using a known U.S. example, an engineering school has 19 classrooms seating 28 , one seating 66 , and one seating 78 , and handles an undergraduate enrollment of 2,200. However, it teaches engineering courses largely to juniors and seniors, an effective enrollment of perhaps 800. On a 70 per cent usage basis, there are 18,928 seat hours per week available and a demand for 12,000 seat hours $\mathrm{cn}$ a basis of 15 class (not laboratory) hours per week per student. The excess classroom hours are assigned to classes from departments of mathematics. english, foreign languages, and education for an actual usage of over 70 per cent of the available hours (45 per week).

The classroom system in Brazil leads to inefficiency in classroom usage. This seems a supportable statement in ali áreas in visits to universities, one does not see classes meeting. However, while they might greatly improve the classroom usage within a faculty, they could not always schedule usage by other faculties because of the remote locations involved.

However, that classrooms are not presently a limit on Brazilian university enrollments seems a fully supportable statement. The importance of quickly improving the planning process and insuring planning which is realistic in terms of needs is indicated by the list of pending university projects in Brazil (D-I-181) (in U.S. dollars, since most are planned for externai financing as of 1965):

US\$

U.F. Rio de Janeiro, completion of Cidade Universitária, Fundão

Island.

130.000 .000

$4,000.000$

U.F. Ceará

$2,000,000$

U.F. Pernambuco, Cidade Universitária

16.000 .000

U.F. Santa Maria

$1,000.000$

Católica. Rio Grande do Sul

$3.300,000$

U. Est. Guanabara

$4,800,000$

Six other universities are also listed as having undefined projects.

With realistic planning this money could probably provide broader benefits.

\section{UT1LIZATION OF FACULTY}

It has been stated by Corrêa that the average teacher was in a classroom less than three hours per week in a given school in 1963 (D-I-116). There then being 126,000 university students, and assuming 
20 hours of instruction per week in classes of 30 students. there fchould be 84,000 class hours taught per week. With 29,803 professors and assistants listed as teaching, the average teaching load, need be only 2.8 hours per week.

It is possible to further study the subject of faculty utilization by use of the sample of engineering schools from the Rios study.

Other faculties could have been studied as well, but it is problable that the data would be repetitions. Data is available from 13 of the 26 faculties of engineering in the universities. These 13 faculties also enroll 50 per cent of the engineering students in the 26 universities .

It should be noted that the «faculty hours per week» entered in the following table is that figure computed from the faculty assignments supplied in the Rios reports. Since a faculty member is supposed to work 18 hours per week this was supplied in some cases; in other cases members of faculty working definite numbers of hours was supplied and used herein.

ENGINEERING FACULTY UTILIZATION - 1966

\begin{tabular}{ccc} 
Faculty & Total faculty & \\
& hours/week. & Enrollment \\
267 & 8,754 & 1,841 \\
133 & 677 & 663 \\
11 & 1,666 & 951 \\
109 & 343 & 566 \\
92 & 958 & 466 \\
81 & 577 & 537 \\
78 & 1,404 & 355 \\
71 & 1,278 & 257 \\
68 & 275 & 461 \\
58 & 277 & 227 \\
50 & 322 & 226 \\
32 & 185 & 225 \\
29 & 522 & 128 \\
\hline 1,187 & 17,238 & 6,903 \\
\hline
\end{tabular}

A first observation is that every student can have 2.5 hours per week of individual tutoring, if that were desired.

More realistically it may be noted that the engineering student teacher ratio is 5.8 to 1 , as against a national all-fields ratio of 4.6 to 1 in 1964 (D-II-163). Either of these figures is fantastically low when measured against U.S. faculty loadíngs.

Actual Brazilian university engineering student capacity, as limited by reasonable faculty utilization can be estimated. This does not 
include the isolated faculties on which no data has been presented. Allowing one hour of preparation for each hour of class or laboratory seems reasonable, since with part-time faculty there is little time given to committee work, little student consultation or advising, and little course planning. Therefore these 13 engineering faculties would have $17.238 / 2=8.619$ teaching hours available per week. Meeting with 44 student classes (average size of classrooms, see previous section) there are 379,200 classroom hours available. At 20 class and laboratory hours per week per student, the demand is for 138,060 classroom hours of teaching.

Therefore the ratio of hours available to demand is $379,200 / 138,060$ $=2.75$.

It appears that these engineering colleges could be considered 175 per cent overstaffed, by their own statements of faculty work hours, and by assumptions of student and class loads which are considered conservative in Brazil (Corrêa).

In another way it might be said that our sample indicates the Brazilian universities could handle engineering student increases, based on space and staff already available, amounting to

On a classroom-usage basis - 13.300 more studénts - $86 \%$

On a faculty-load basis - 27,000 more studénts - 175\%

Vacancies announced for 1968 are roughly unchanged from the number available in 1965 - there seems little intent to use this idle capacity.

It is not possible to measure capacity in terms of laboratory because of its variability. Visits to universities have not yet lead to observation of a single laboratory in session - it can be concluded that more intensive use of laboratory space and equipment is possible, but no measure can be given.

It is also realized that the stated available faculty hours of the Rios survey are not truly available hours, but they should be. The eighteen hours per faculty member stated by some institutions is a legal requirement, not met in practice. Some of the private schools that pay by the hour are more careful in their accounting. However, the point may still be made that there are sufficient faculty personnel if the hours of stated work were actually obtained.

The basic problem of vacancies and enrollments in Brazilian higher education is not involved with classrooms or faculty members, nor is it that of total financial resources applied. The problem is really a lack of an educational policy consistent with the ideas for development which the government holds, compounded by a lack of fiscal responsibility toward its educational institutions.

Rios reports - EAPES. 
Lacking an educational direction other than that dictated by traditions of the past, the resources are scattered and the results unverified. When university budgets are unfulfilled, it is natural that administrators be careful in announcing student openings for a follawing year. When faculty and administrative salaries are limited by law to an unrealistic levei the work done becomes commensurate with that levei.

Perhaps the following comments will illustrate the nature of the problems:

From the Dean of a small, new school with an enrollment of 130, in civil and electrical engineering: «Every year we make a budget request according to our needs, we asked essentially 1.7 billions of cruzeiros (\$770,000 US). "We asked 800 millions of cruzeiros (\$36,000 U.S.) for machines but we received 200 millions (\$ 9,000 U.S.)».

The requested budget of $\$ 770,000$ seems about three times the levei of operation of a U.S. school for the same number of students.

A Dean of Medicine of a large school: «The budget is always in deficit through lack of fulfillment of the promises of the government of the State. In 1961, in a meeting with the government, we agreed to raise the number of student openings with the aid of an increase in funds. The number of openings was raised, but up today the funds have not appeared».

From a Dean of Philosophy, Science and Letters (700 students): «Books are more essential than the buildings and furniture. To bring the library in order, it should have 2,000 books per curriculum. At the moment we have 300 fundamental books for each course. We cannot ask for more complete equipment because we would not have the surroundings. We bought the equipment for modern languages and psychotechnology. It is purchased but we have no classrooms».

The Federal Council on Education is aware of these problems, but it believes its role is deliberative, not administrative. The Council suffers from the common belief that to pass a resolution is to solve the problem. If the Council or the Ministry had an administrative career staff knowledgeable in education, the passing of a resolution would start administrative action. Lacking such staff there is no action.

The problems of Brazilian education can be foreseen - other countries have had and solved the same problems - but Brazilian education drifts in time, guided by the dead hand of tradition. 
Apêndice C. 3

\section{UNIT COSTS IN HIGHER EDUCÀTION}

\section{J. D. RYDER}

Studies of unit costs in Brazilian education are sparse and probably confused. What is covered by a budget is not defined and promised budgets are not fulfilled - in 1967 the Ministry failed to pay the last quarter to the federal universities. The universities have traditionally carried over funds to hedge against such occurrences, so that budget requests, funds granted. funds actually received, and funds expended may represent four diverse figures for a given year.

An attempt was made by SEEC in 1966 to develop unit costs by means of a questionnaire sent to federally-supported institutions. Ali of the federal universities answered but only a few of the federallysupported isolated faculties gave complete data. Here again we lack data on the isolated faculties, particularly information on the large private sector.

The data collected seem to represent an annual operating budget plus expenditures for «works»; uniformity from school to school is not to be expected. Enrollment figures as transcribed we,re not ccnsistent and these have been adjusted to the best available SEEC reports.

The survey indicates the following for overall annual costs: 19 Universities (Federal)

\begin{tabular}{cccc}
1965 & Annual cost & \multicolumn{2}{c}{ Annual cost } \\
Enrollment & por .student & per student \\
& NCr\% & US\$ & (1966)
\end{tabular}

Highcsi cost univcisity (Fed. Rio

G. do Norte).

.722

6.143

2.792

Averade costs.

3.194

1,451

Lowest cost university (Fed. Flu-

nense).

4,668

1,950

886

The extremely high cost situation at Brasília, \$6,600 per student per year, was not included in the above analysis.

12 Isolated Faculties (Federal)

$\begin{array}{cccc}\text { Highest cost unit (Esc. Paulista } & \text { Enrollment } & \begin{array}{c}\text { Annual cost } \\ \text { per student } \\ \text { NCr\% }\end{array} & \begin{array}{c}\text { Annual cost } \\ \text { per student } \\ \text { US\% (1966) }\end{array} \\ \begin{array}{c}\text { Le Medicina). } \\ \text { Lest cost unit (Piauí - (Law) }\end{array} & 568 & 7,540 & 3,427 \\ \text { SEEC - Serviço de Estatística da Educação e Cultura - MEC. }\end{array}$


These twelve federally-supported isolated faculties are better analyzed as five high-cost schools and seven low-cost schools. In both gioups the enrollment distributions are about the same, varying from 568 to 76 in the high-cost group and from 430 to 137 in the lowcost group. Represented in the two groups are:

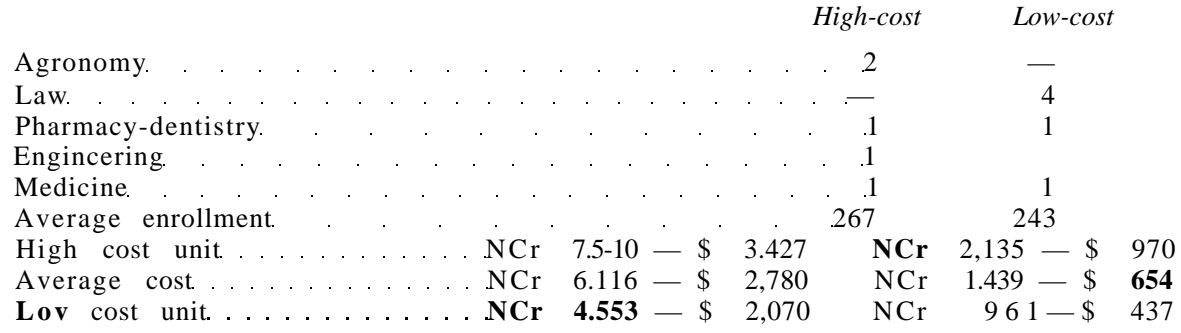

This pronounced difference, where the lowest cost in the upper group is more than twice the highest cost of the lower group, suggests a very considerable differential in quality of work. The high costs are well above the university cost and the quality at the low-cost units seems below the levei at the universities. Indications are, therefore. that an isolated federal faculty is not a bargain for Brazil at either end of the scale.

SEEC also made some studies of teaching costs in the various major curricula. These figures were averages of those submitted by the federal universities and the federal isolated faculties, and include only the costs of direct teaching personnel at ali teaching leveis. As might be expected, these teaching costs vary from $\$ 186$ per student-year in law, \$259 in economics and administration. \$383 in agronomy, up to $\$ 966$ in pharmacy, $\$ 1,173$ in veterinary medicine. $\$ 1,617$ in nursing, and $\$ 2,059$ in music (1966 U.S. dollars).

The average of the teaching personnel costs for ali faculties is $\$ 663$.

Assuming that these figures reasonably represent the situation (a major assumption, in view of accounting uncertainties), the costs as indicated are near or above the U.S. levei. It seems reasonable to accept class hours per student per week as 16, many curricula showing from six to eight courses per semester. Dividing the average cost of $\$ 663$ by 16 gives $\$ 41$ (U.S.) as the teaching cost per student class-hour per academic year.

Some figures are available from the U.S., indicating costs rangíng from $\$ 24$ in history to $\$ 100$ in engineering, but these costs include total departmental operations. Brazil is not receiving the same return in education. research, or extension service.

The Brazilian system suffers from built-in inefficiencies, as the civil-service problem for faculty, hidden student subsidies in food and 
housing. the problems of part-time faculty and administration, and politically-made budget decisions. The system lacks direction for the future - the job we were to help with here.

As an offset to that statement of problems, one must remembcr that more than half of the universities are in their first decade, and that university education is still burdened with the inefficiencies of the isolated-faculty system from which it has been derived. Thus help in planning for the future is needed even more. 
Apêndice C. 4

\section{POST-GRADUATE EDUCATION}

J. D. RYDER

Post-graduate education in Brazil is currently limited to work in 12 career fields and available in 1C states (1966). Only 14 of the universities are listed as offering such work in 1965. Because of the variations in institutions and fields reported from year to year, postgraduate work seems to be composed largely of ad hoc courses, except possibly in law and education. For instance, the field of engineering is represented by 28 «conclusions of course» in 1963 and 113 in 1964 - but ali 28 in 1963 and 107 of the 113 in 1964 were from a private isolated faculty in Bahia teaching petroleum engineering. An ongoing program for a master's degree in engineering (M.S.) at UFRJ claims 8 graduates in each of 1963, 1964, 1965 but these students were not reported to SEEC in those years by that institution.

It is not clear what degree, if any is given for «conclusion» of this post-graduate work and it is likely that much represents certificate work. It would appear that Brazil might spend its money more wisely by sending students abroad for graduate study, until it develops more trained faculty. If U.S. experience is any guide, an intermittent ad hoc program at master's levei is not productive of quality. A few doctorates can, perhaps, be handled in this fashion in connection with high quality research institutions where recognized staff are available.

\section{POST-GRADUATE DATA (SEEC)}

$\begin{array}{lrrrr} & 1963 & 1964 & 1695 & 1966 \\ \text { Courses reported . . . . . . } & 58 & 56 & 56 & 44 \\ \text { Initial Matric . . . . . . } & 2,191 & 1,895 & 2,355 & 1,790 \\ \text { «End of ryear» . . . . . . } & 1,852 & 1,959 & 1,649 & - \\ \text { «Conclusions» . . . . . . } & 638 & 769 & 449 & - \\ \text { Universities participating } & 14 & 17 & 14 & -\end{array}$


The ad hoc and part time nature of programs is hinted at by the variability of some of the following figures:

\section{STUDENTS BY FIELD (SEEC)}

\begin{tabular}{|c|c|c|c|c|}
\hline & jrses & Enrol & ment & Conclusion \\
\hline & 966 & 1965 & 1966 & 1965 \\
\hline Law & 7 & 884 & 868 & 78 \\
\hline Philosophy (Education orientation) & 0 & 486 & 228 & 116 \\
\hline Public Health & 7 & 131 & 135 & 96 \\
\hline Agriculture $\ldots \ldots \ldots \ldots \ldots \ldots$ & 1 & 63 & 136 & - \\
\hline Architecture $\ldots \ldots \ldots \ldots \ldots \ldots$ & 3 & 44 & 130 & 17 \\
\hline 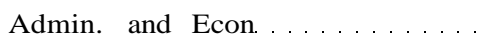 & 2 & 123 & 71 & 25 \\
\hline Nursing $\ldots \ldots \ldots \ldots \ldots \ldots \ldots \ldots$ & 2 & 41 & 62 & 62 \\
\hline Engineering & 2 & 89 & 57 & 15 \\
\hline Art & 6 & 90 & 44 & 7 \\
\hline Med. Science . . . . . . . . . . . & 1 & 22 & 14 & 19 \\
\hline Med. Educ. & 2 & 67 & 34 & 4 \\
\hline Pharmacy & 1 & 10 & 11 & 10 \\
\hline Total & 44 & 2,050 & 1,790 & 449 \\
\hline
\end{tabular}

UNIVERSITY POST-GRADUATE PROGRAMS — 1965

Courses Enrollmzni

\begin{tabular}{|c|c|c|}
\hline \multirow{4}{*}{$\begin{array}{l}\text { Pernambuco, Catolica } \\
\text { Alagoas, Federal .... } \\
\text { Bahia. }\end{array}$} & 1 & 60 \\
\hline & 1 & 6 \\
\hline & 1 & 32 \\
\hline & 1 & 43 \\
\hline Minas Gerais, Federal & 3 & 27 \\
\hline Minas Gerais, Rural. & 3 & 63 \\
\hline Fluminense, Federal & 2 & 103 \\
\hline Rio de Janeiro, Federal & 9 & 351 \\
\hline Guanabara, Federal & 1 & 103 \\
\hline PUC, Rio. & 3 & 23 \\
\hline U.S.P. & 9 & 978 \\
\hline Campinas, Catolica & 1 & 39 \\
\hline Parana, Federal & 1 & 80 \\
\hline R.G.S., Federal _.. & 5 & 69 \\
\hline
\end{tabular}
Law
Educ. orientation
Law
Law
Arch, Nuclear Eng., Public Health
Rural Econ., Vet. Med.
Law, Educ. orientation
Arch., Art, Law, Pharm., Phys. Educ.
Law
Adm., (M.S. and Doct.). Law
Law, Nursing, Education, Public Health
Educ. orientation
Educ. orientation
Arch., Music, Educ. orient.. Biology, 8 doctorates

\section{$41 \quad 1,977$}

Thus in 1965 the universities conducted 41 of the 56 reported programs and enrolled 1,977 of the 2,355 graduate students. One university enrolled nearly one-half of ali the graduate students. 
Except for public health and veterinary medicine the above fields seem not to need a high priority in a developing country. Brazil, once more, is allowing things to grow in their own way, and has failed to choose a direction for graduate study consistent with its ideas of technological development or with its resources.

Brazilian help for graduate study abroad is administered through CAPES and CNPq. In 1964 CAPES distributed 128 grants for «improvement» abroad. By field, these were:

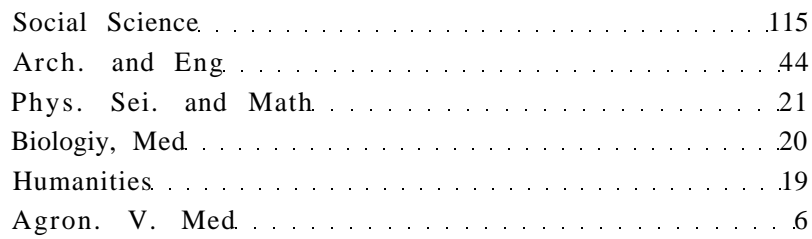

In choice of country, 56 students went to France, 23 to the U.S.A., 7 to England, with the remainder scattered.

The CNPq distributed 61 grants for foreign study, out of a total of 607 grants in 1964. These were for work in the advanced sciences. 
Apêndice C. 5

\section{ADMISSIONS POLICIES AND PRACTICES}

J. D. RYDER

\section{VACANCIES}

Numbers of vacancies or opening for entering students are set each year by the individual faculties, seemingly as a result of space thought to be available, faculty available, budgets expected, and whether a given career field is feeling a pressure for entrance or declining (with a response often in inverse proportion).

A survey of the available vacancies was published in O Jornal do Brasil of December 10, with little change indicated from last year. This illustrates the slowness of response of the educational system to the pressures against it. In view of the effective 25 per cent cut in educational budgets in 1967, it is of course not surprising that the universities have committed themselves for no real increases in student openings in 1968. Yet in 1968, the «backlog» pressures are shown by significant increases in predicted numbers of candidates, as:

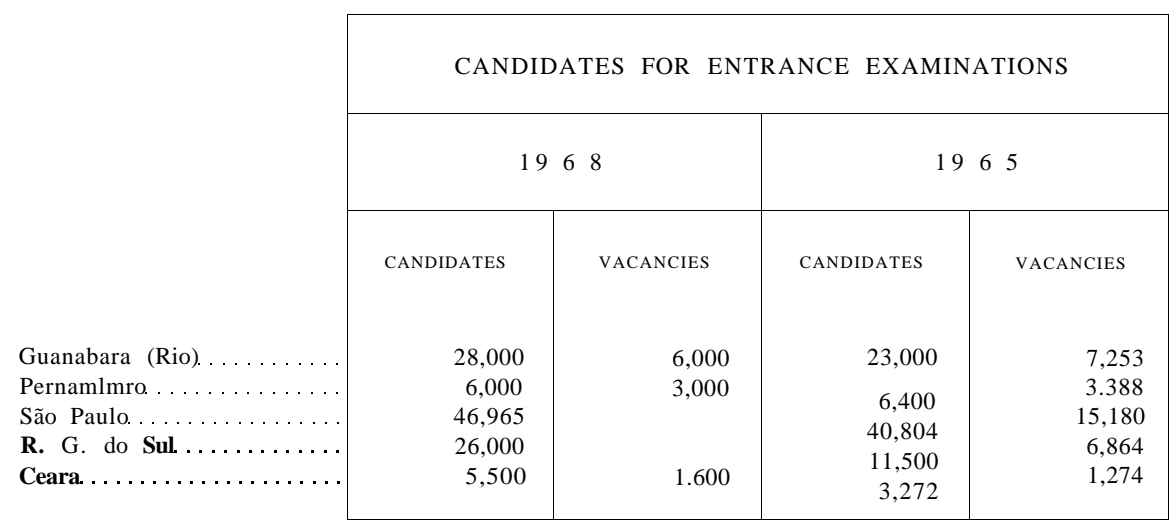


UNIV. OF CEARA

Engineering.

Medicine

Dentary.

Law.

Philosophy.

Nursing.

UNIV. OF SAO PAULO. .:

Engineering

Philosophy.

Social Service

FED. UNIV. RIO DE JANEIRO.

Engineering

Medicine

Pharmacy

Law.

Nursing

PUC - Rio

Engineering

Law.

U.F.PERNAMBUCO

U.F. PARANA

Engineering

Pharmacy.

Medicine.

Dentistry

Philosophy. . . :

Vet. Med

CAT. U. PARANA

Rio GRANDE DO SUL

\begin{tabular}{|c|c|c|}
\hline 1968 & 1965 & 1964 \\
\hline 1,600 & 1,274 & 715 \\
\hline 110 & 101 & 90 \\
\hline 160 & 130 & 90 \\
\hline 50 & 50 & 50 \\
\hline 200 & 150 & 150 \\
\hline 190 & 200 & 225 \\
\hline 20 & 30 & - \\
\hline & & 2,789 \\
\hline 420 & 420 & 464 \\
\hline 1,950 & 1,950 & 945 \\
\hline 50 & 50 & - \\
\hline & & 2,823 \\
\hline 300 & 300 & $\begin{array}{l}4 \quad 892 \\
\end{array}$ \\
\hline 200 & 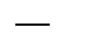 & 100 \\
\hline 80 & - & 50 \\
\hline 200 & - & 522 \\
\hline 90 & - & 25 \\
\hline 385 & - & 360 \\
\hline 300 & - & 180 \\
\hline 200 & - & 100 \\
\hline 1,820 & 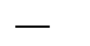 & 1,560 \\
\hline 2,320 & - & 3,605 \\
\hline 240 & - & 240 \\
\hline 60 & - & 40 \\
\hline 160 & 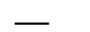 & 240 \\
\hline 80 & - & 80 \\
\hline 1,200 & 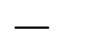 & 2,000 \\
\hline 80 & - & 50 \\
\hline 950 & $\longrightarrow$ & 660 \\
\hline 1,700 & - & 1,676 \\
\hline
\end{tabular}

From newspaper accounts, subject to errors by the papcrs in not understandinj academic tsrniinolosy.

What happen? 
What change could have been made in an engineering school that will raise the capacity from 90 to 110 students in four years, or nine students in one year? Why can a school of philosophy take only 190 students when four years ago they could handle 225? Why could two faculties of engineering, given very iarge new buildings in the four year period covered, increase places only from 340 to 540 ?

There are inconsistencies in totais, as at PUC, Rio, which can only be accounted for by changes in the statistical base used over the period. The data on vacancies seem not well pubblished; these might be considered politicai dynamite.

The last complete published survey is that of 1964, that of 1965 giving totais only by states. The survey of 1964 shows that for 37 universities, only 9 succeeded in approving enough students to fill their announced vacancies. As a group, the isolated faculties also failed to fill their announced openings. Totais for the two years are:

\begin{tabular}{|c|c|c|c|c|}
\hline Yeav & Vacancies & Candidates & Approvals & $\begin{array}{l}\text { Per cente } \\
\text { vacancies } \\
\text { filled }\end{array}$ \\
\hline 1964 & 56,446 & 112,485 & 46,538 & 0.824 \\
\hline 1965. & 58,929 & 125,406 & 47,494 & 0.805 \\
\hline
\end{tabular}

The problem of vacancies is partly one of maldistribution of available educational capacity and of the pressures for the major career fields. Places are left unfilled in the popular fields of Engineering and Uentistry in Pernambuco and the northern and southern states, while these fields overflow in the more populous central region. Brazilian students have little mobility -60 to 80 per cent of a university enrollment comes from its own city. There is reluetance to look for openings elsewhere and little to finance such transfer. The entrance examination locks a student inte one choice for a year.

Eight of 23 engineering faculties failed to fill their classes. Only two of 37 faculties succeeded in filling their places in Philosophy (largely teacher training in arts and natural sciences). These were UFRJ with 836 out of 1,545 candidates and Brasília with 40 places. Univ. of São Paulo was not able to fill 945 places from 3.022 candidates. In only ten of the 37 universities did Philosophy even attract candidates equal in number to the places available. Leaving out UFRJ and USP as special cases, there were 9,409 places and only 7,473 candidates at the 35 other universities. For ali of Philosophy:

Vacancies
Candidates

Approvals

First year enrollment
20,468

18,880

11,454
12,041 
The difference between vacancies and approvals is 9,014, almost equal to the national difference for ali fields shown as $56,446-46,538$ $=9,908$.

Is educaiton available in Brazil?

There seem some interesting statements of capacity as measured against demand. Choosing a few examples in Philosophy:

PHILOSOPHY

Vacancies

Pará

Maranhão

Paraíba

Pernambuco.

Católica, Pernambuco

Alagoas

Espírito Santo

Catól ca, Petrópolis . .

Paraná

Santa Catarina
200

150

140

400

500

200

245

120

2,000

300
Candidates

168

74

86

307

286

77

170

79

484

107

The most interesting examples of overátated demand are at Alagoas, 200 places and 77 candidates, Santa Catarina, 300 places and 107 candidates and Paraná with 2,000 places and only 484 candidates. Such study of announced openings seems to suggest evidence of developing «gamemanship» among the Rectors. Suppose you, as a Rector, had a promised budget not showing much of an increase, if any, and you had a fresh memory of not receiving ali that was promised. Yet the Ministry and the public are clamoring for more student places in the universities. What you do you?

Perhaps:

1. You consider the politicai adventages of a well-timed announcement of additional places in your school for next year.

2. The number of vacancies at your school last year was Y. You choose a not-too-round figure Z, larger than Y.

3. You calculate $\mathrm{Z}-\mathrm{Y}=\mathrm{X}$, assign $\mathrm{X}$ new vacancies to the faculty of Philosophy, and call for your director of publicity.

You have really ventured little — you are quite sure that the Philosophy candidates will not increase much — but the difficulty of the examination can be adjusted if the number of «inscritos» or applicants becomes large - and even if you receive an increase in Philosophy students, the subject is cheap to teach. But you have achieved 
a nice politicai and public relations victory in announcing a large number of new vacancies for next year!

A more detailed analysis of the vacancies existing in the five universities of the Rio área furnishes a fairly clear view of the problem. These schools are UFRJ, Fluminense, Guanabara, PUC-Rio, and Católica Petrópolis. Again using 1964 data since later data is not so detailed, these schools offered work in 37 faculties or fields. Each faculty announced its vacancies and conducted its entrance examinations and 22 faculties were unable to fill their announced quotas. Only one of five faculties of Philosophy was filled, there being 475 vacancies in the other four schools. The situation has tightened up in recent years, but the vacancies have not responded. At UFRJ, as an axample:

Vacancies

Law.

Philosophy

Engineering

Nursing

Economy

Pharmacy

Medicine
1964

1968

\begin{tabular}{r|r}
.- & 200 \\
656 & 100 \\
892 & 300 \\
35 & 90 \\
240 & 230 \\
50 & 80 \\
150 & 200
\end{tabular}

Can there be any doubt of the problems created by lack of secondary-university cooperation, lack of career guidance, and maladministration in placing scarcc resources in non-productive fields. The basic lack is in planning and establishment of priorities for the future.

\section{THE ENTRANCE EXAMINATION}

A student must apply for admission to the entrance examination for a particular university and a particular faculty within that university; the results of the examination are not transferable.

Requirements which must be completed before his examination card is issued are listed by Bowles, and include the following:

1. Certificate of completion of first and second cycles of the second-level (Colegial) course.

2. Record of credits for the seven years of study (Ginasial and Colegial) .

Undoubtedly included some fields announced separatel,y in 1968.

Bowles, F.P., «Access to Higher Education»-VII, UNESCO, p. 25. 
3. Identity document.

4. Certificate of good moral character.

5. Certificate of physical and mental health

6. Birth certificate.

7. Proof of fulfillment of military requirements.

8. Certificate of smallpox vaccination.

There is no contact with teaching personnel, there is no advisory or conseling service.

Subjects covered in the entrance examinations are largely prescribed by federal law; universities and faculties may include other subjects and Portuguese is frequently so added. Examination lasts two to four hours, and is largely comprised of multiple-choice questions, with a small amount of essay work. * Sample questions released to the newspapers seem often unclearly stated or calling for highly detailed knowledge. One examination subject is scheduled per day, with a spacing of one or two days, so that several weeks may be filled by this activity. Faculties are then called on to grade the thousands of papers in a day or two, on an overload or unpaid basis.

Required entrance examination for most of the major fields are indicated by the following table:

\section{REQUIRED ENTRANCE EXAMINATION SUBJECTS **}

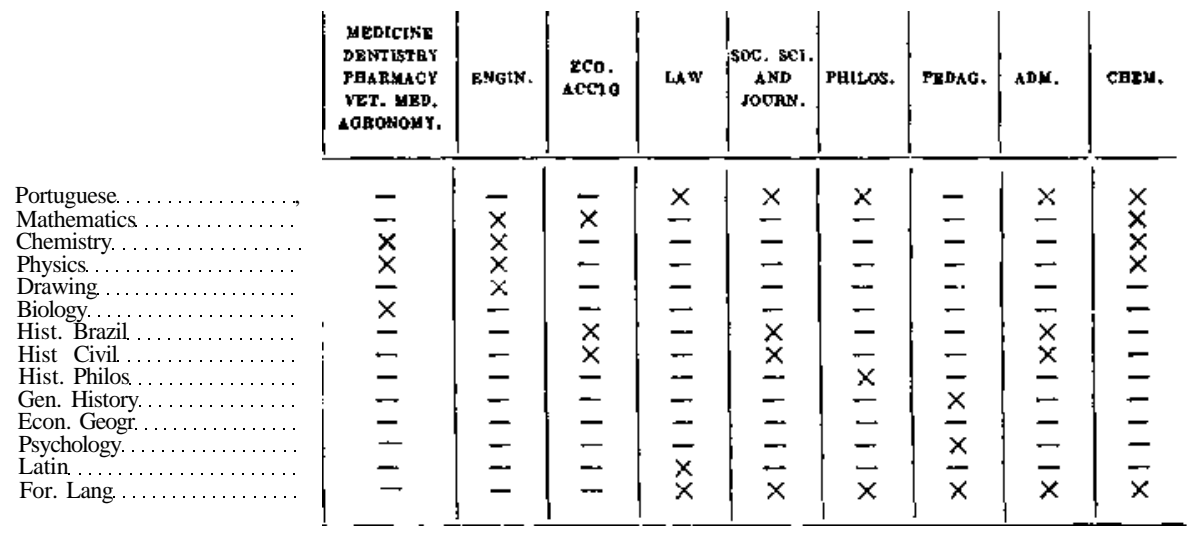

The foreign language usually permits a choice between French and English; German is sometimes included. Most medical schools add Portuguese; at the Federal University of Rio de Janeiro to the required medical subjects are added Portuguese, English and French. Schools of engineering and pharmacy adhere rather closely to the required list,

* O jornal do Brasil — December 31, 1967.

** Bowles, F.P., «Access to Higher Educations., VII — UNESCO, p. 26. 
although the University of Paraná adds Portuguese to ali fields. However, law shows a great diversity of reguirements.

EXAMINATIONS FOR LAW ENTRANCE (RIOS)

Portuguese..

Hist. Brazii.

Gen. History

Polit. Hist.

Hist. Civil..

Psychology. -

Latin . . .

English

French

Italian

For. Lang...

Sociolojy ..

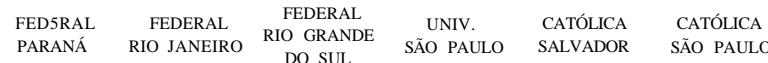

\begin{tabular}{|c|c|c|c|c|c|}
\hline$x$ & $x$ & $x$ & $x$ & $x$ & $x$ \\
\hline $\bar{v}$ & - & $x$ & - & - & $x$ \\
\hline$x$ & $\bar{x}$ & 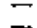 & $\bar{z}$ & $x$ & Z \\
\hline- & $\ddot{x}$ & $x$ & $x$ & $\leftarrow$ & $x$ \\
\hline- & - & - & $x$ & $\rightarrow$ & - \\
\hline- & - & - & - & $x$ & $\bar{z}$ \\
\hline$\leftarrow$ & 7 & - & - & $x$ & $x$ \\
\hline$\lambda$ & - & 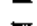 & $=$ & $x$ & $\underset{x}{x}$ \\
\hline$x$ & $x$ & $x$ & $x$ & $\dddot{-}$ & -2 \\
\hline- & $x$ & $\times$ & - & - & - \\
\hline
\end{tabular}

If these diverse requirements for law are ali justified, then the use of liberal arts preparation for the field of law in the U.S. seems even more justified. Does not the diversity of these requirements indicate that an examination in specifics subjects except possibly language, is not appropriate to the field of law?

The burden which the total requirements for ali fields places on the secondary system is evident. The inability of an already overtaxed and understaffed system to meet these requirements is demonstrated by the rapidly increasing use of «cursinhos» or preparatory school years between secondary (Colegial) graduation and the taking of university entrance examination. The cost and loss of time for this narrow preparation for a specific examination seems unjustified. A more realistic attitude should be taken by the universities, and efforts undertaken to insure better integration between university entrance and the programs and amount of educationpossible at the secondary levei.

There have been proposals to open up the examination fields somewhat, or to permit the last year of the secondary school to be more specifically oriented toward college entrance, or for the universities to reorganize their first years to recognize secondary deficiences. These have not yet led to useful experimentation, perhaps because of the monolithic characteristics of higher education in Brazii, and the lack of leadership from the Federal Council or the Ministry.

There have been several concrete suggestions (Ribeiro) for a preparatory year, as the third year of secondary school or as the first year of the university. to better treat the interface problem and ultimately to serve as a selection vehicle and replace the "entrance examination. Unfortunately, the predilection to let things drift is creating a plethora of unstructured, undirected «cursinhos» to perform this function in the more populous centers. The more these private money-making insti- 
tutions develop, the harder it will be to change to a logical and obviouslyneeded preparatory system.

Leadership in Brazilian education is not evident.

\section{CONDUCT OF ENTRANCE EXAMINATION}

Entrance examination employ various examination techniques, as in multiple-choice, topic comprehension, and some essay form. Examples of questions as published in the newspapers indicate poor question preparation, a point supported bk Ribeiro. One question cited in physics has no correct answer among the multiple choices, although an answer is apparent in a quick overview. The discerning student is often penalized by such superficiality.

Most examinations operate with a fixed cut off or passing grade, often 5 or 4 on a 10 total basis. Such a grade can have no validity whatever for an arbitrary and never previously given examination, but it does illustrate the apparent objective of the examination - to eliminate excess numbers. There is evidence that it does not eliminatc those ofpoorer qualifications; the emphasis seems on straight memory and not on reasoning ability.

To compound the problem, most examinations are «eliminatory»; that is, if a student receives less than the passing mark in the first or any following subject he is «out», or eliminated. In the UFRJ Medicai School tests of 1968, the first tests in cheministry and physics eliminated 1,800 of the 3,000 candidates for the 200 places. These examinations, of there hours duration, were held on the concrete seats of the Maracanã football stadium - it is somehow not considered possible to divide the students into groups suited to many smaller auditoriums and lecture rooms. Almost military security conditions are imposed. The papers are now machine graded and the results published the next day in the newspaperes. This does not preclude subsequent raising of low grades, a practice that is hinted at.

The effect of the «eliminatory» examination is shown by newspaper reports of January 14, 1968. For UFRJ, of 11 candidates for 30 places in Actuarial Science, ali were eliminated by the first two tests in Mathematics and Portuguese; in accounting 140 candidates for 70 places were reduced to 70 by the first examination. As has been shown a student may score 4 in ali four examinations and be approved; another student may score there 10's and one 3.5 and be eliminated!

Duplicate application to several universities or to several faculties is discouraged by simultaneous scheduling of examinations, and the only recourse to a student failing an exam in one área and wíshing to enter a second career field is to wait a year.

Ribeiro, Paulo Edrucnd, Revsita Brasileira de Estudos Pedagógicos, INEP, v. 37, Jan.-Março 1962, p. 55. 
No use is made of aptitude testing or of statistical methods, and this supports the statement that the testing objective is only to eliminate numbers. Ribeiro, in the cited paper, points out that in a capacity limited system, it is important that capacity be utilized by the best students. His paper of 1962 has apparently had no impact on the monolithic faculties in control of the situation.

\section{«EXCEDENTES»}

The word «excedentes», or literally «exceeders» has been much heard in recent years and the group represented a politicai force in Rio and São Paulo in 1967. With an accepted passing grade of 4 or 5, and a number of vacancies much less than the number of candidates, it may happen that the number passed or approved will exceed the number of openings. At UFRJ Medicai School in 1968, with 200 openings, it may be found that 388 receive 5 or higher in ali tests. The number 188 become «excedentes» - they are «approved» by the arbitrary passing grade but they exceed the capacity the school has set.

In 1967 some additional space was made for such students by pressure of the Ministry on local faculties. It is now a significant point in history that the promised funds for accepting these additional students have not been paid in ali cases. It is also of interest to record that after some group of students with grades down to the 5 levei were taken care of, another group of students with grades down to 4 became «excedentes» and banner-carrying demonstrators in 1967.

The cause of the problem is obviously the idea of a fixed «passing» grade for an arbitrary test, but the idea of a fixed passing grade seems almost a social institution in Brazil.

Minister Aragão suggested dropping the passing grade, but was unheard. Former Minister Lacerda suggested burning ali papers of students in excess of the vacancies, so that there would be no knowledge of grades among students not placed. There has not yet been the suggestion that the examination be made so difficult as to necessarily pas fewer than the stated vacancies; the Ministry could then make politicai «hay» by opening the gates to those ranking next, until ali places were filled, on a «justice» basis.

The problem of the excedentes will continue to grow and worsen until adequate steps are taken to provide better preparation in secondary school, realistic integration between secondary and higher leveis, and higher education is made responsive to the country's needs. 
Apêndice C. 5

\section{UNIVERSITY SURVEY - INTRODUCTION}

J. D. RYDER

The Brazilian complex of higher education includes six general types of institution, as classified by source of support, objective, or form of organization. The system includes universities and isolated and autonomous faculties, of which the universities are a very young element, over half having been established since 1959, as shown by the chart. The universities are not yet mature, and their role and structure is still uncertain. Experimentation and diversity of purpose is needed in this sector to fulfill the multiple needs of Brazil, but with the exception of the unfortunate Brasília attempt, establishment of new universities has followed the past pattern of agglomerating faculties. This does not increase the educational capabilities of the country in any marked manner.

The institutions of higher education may be groupd as:

Federal Universities. Twenty in number with at least one unit in 18 of the 22 States and the Federal District of Brasília. These institutions were grouped from five or more faculties or major disciplines, and are almost totally supported by federal monies received through allotments from the Ministry of Education and Culture, and are subject to federal civil service and other controls. Several of these institutions are organized as «fundações» (foundations) in an effort to avoid certain aspects of federal control, but support is still federal in nature, and for most of the purposes of this report no distinction will be made.

Federal Rural Universities- These are four in number smaller than the universities above, and with teaching confined to such subjects as forestry, agronomy or agriculture, agricultural engineering, veterinary medicine, and home economies. They were a responsibility of the Ministry of Agriculture but have been transferred (1967) to the control of the Ministry of Education; their support is federal.

State Universities. These include three institutions, the major university of the country in the University of São Paulo, one in the State of Guanabara (Rio), and one newly formed in Campinas, State of São Paulo. Except for their state support and freedom from federal restrictions on maximum salaries, these units are similar to the federal universities.

Catholic Universities. These number ten and are located in major population centers from Recife south. They receive church and some federal support, as well as having income from student tuition. 
Private Universities, the largest being Mackenzie university in São Paulo; the others in operation are the University of Goiás and the University of Maranhão. As this is written we have received an unconfirmed report that the latter institution has been federalized.

Isolated Faculties. These are schools teaching only one or several closely related disciplines, autonomous in action and control, subject only to general regulations on higher education established by the Federal Council on Education and administered, perhaps somewhat loosely, by the Ministry of Education and Culture. There are faculties with federal support, state support, municipal support, with the majority being private and operating on tuition income.

By 1965 there had been about 686 of these recognized, but the Serviço Estatística do Ensino e Cultura (SEEC) received reports only from about 300. In 1963 about the same number (and apparently the same faculties) reported, so it may be that something over 200 of these are very small or inactive. Because the Ministry failed to approve a request from the Brazilian side of this team for a survey of isolated faculties in early 1967, we have only sparse information on this segment of Brazilian higher education.

\section{Federal Universities}

$\begin{array}{cr}\begin{array}{c}\text { Date } \\ \text { Recognized }\end{array} & \begin{array}{r}\text { Enrollmeni } \\ (1965)\end{array} \\ .1920 & 10,973 \\ 1949 & 6,429 \\ 1950 & 6,189 \\ 1950 & 5,359 \\ 1960 & 4,668 \\ .1946 & 4,195 \\ 1946 & 4,056 \\ .1954 & 3,360 \\ \ldots .1957 & 2,124 \\ \ldots .1960 & 1,781 \\ \ldots .1960 & 1,723 \\ \ldots .1960 & 1,645 \\ \ldots .1960 & 1,471 \\ .1961 & 1,200 \\ .1960 & 1,028 \\ \ldots .1946 & 983 \\ . .1962 & 722 \\ . .1967 & 687 \\ & 507\end{array}$

Univ. Federal do Rio de Janeiro. 6,429

Univ. Federal de Minas Gerais.

Univ. Federal do Rio Grande do Sul

Univ. Federal do Paraná .

Univ. Federal de Pernat. .

Univ. Federal da Bahia.

Univ. Federal do Ceará .

Univ. Federal de Santa Catarina . . . . . . . . . . . . . . . 1960

Univ. Federal da Paraíba . . . . . . . . . . . . . . . . . . . . . . . . 1960

Univ. Federal do Espírito Santo . . . . . . . . . . . . . . . 1961

Univ. Federal de Goiás. . . . . . . . . . . . . . . . . . . . . . . . . . . 1960

Univ. Federal de Santa Maria . . . . . . . . . . . . . . . . . . . 1960

Univ. Federal de Juiz de Fora

Univ. Federal de Alagoas.

Univ. Federal do Rio Grande do Norte

Univ. Federal de Brasília

Univ. Federal do Amazonas.

Univ. Federal de Sergipe.

Federal Rural Universities

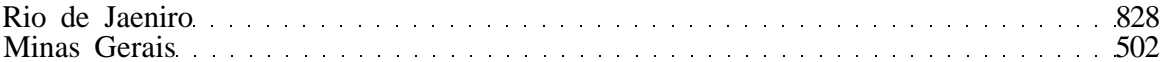

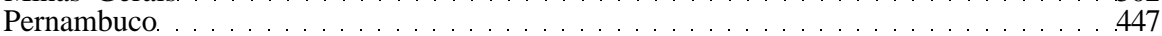

Rio Grande do Sul . . . . . . . . . . . . . . . . . . . . . . . . . . . . 
State Universities

São Paulo.

Guanabara

CaiUolic Universities

PUC - Rio Grande do Sul

pUC - Guanabara

Católica - Campinas, São Paulo.

PUC - São Paulo ...................

Católica - Pelotas, Rio Grande do Sul .

Católica - Paraná

Católica - Pernambuco

1952

Católica - Minas Gerais

1958

Católica - Petrópolis, Rio de Janeiro

Católica - Salvador, Bahia

Private Universities

Madkenzie

Goiás

Maranhão

Caxias do Sul

ISOLATED FACULTIES - BY STATES

Amazonas. .......

Pará. ..........

Maranhão. . . . . . .

Piau!. . . . . . . . .

Ceará. .........

R. G. do Norte

Paraíba.........

Pernambuco. ...

Alagoas. . . . . . . .

Sergipe . . . . . . .

Bahia.

Minas Gerais....

Espírito Santo...

Rio de Janeiro..

Guanabara...... .

São Paulo; . . . . . .

Paraná. .

Santa Catarina. .

R. G. do Sul...

Mato Grosso.....

Goiás.

Federal. . . . . . . .

TOTAL..

\begin{tabular}{|c|c|c|c|c|c|}
\hline FEDERAL & 5TATE & MUN: & $\begin{array}{c}\text { TOTAL } \\
\text { PUBLIC }\end{array}$ & $\begin{array}{c}\text { TOTAL } \\
\text { PRIVATE }\end{array}$ & $\begin{array}{c}\text { TOTAL } \\
\text { REPORTING }\end{array}$ \\
\hline & & & & 2 & 2 \\
\hline & 1 & & 2 & & 2 \\
\hline 2 & & - & 2 & 3 & 5 \\
\hline 1 & - & - & 1 & 2 & 3 \\
\hline - & 2 & - & 2 & 6 & 8 \\
\hline - & 1 & \} & 2 & 3 & 5 \\
\hline 1 & 1 & - & 2 & 5 & 7 \\
\hline .1 & 2 & - & 3 & 10 & 13 \\
\hline & & & & 1 & 1 \\
\hline 1 & 2 & & 3 & 3 & 6 \\
\hline 3 & 1 & - & 4 & 12 & 16 \\
\hline 8 & 3 & 2 & 13 & 22 & 35 \\
\hline - & 1 & 1 & 2 & 1 & 3 \\
\hline 1 & - & - & 1 & 4 & 5 \\
\hline 9 & 2 & - & 11 & 21 & 32 \\
\hline 2 & 17 & 6 & 25 & 71 & 96 \\
\hline- & 14 & - & 14 & 2 & 16 \\
\hline & 1 & - & 1 & 3 & 4 \\
\hline 1 & 1 & 4 & 6 & 31 & 37 \\
\hline 1 & 1 & - & 2 & 1 & 3 \\
\hline- & 2 & - & 2 & 4 & 6 \\
\hline & 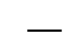 & - & 1 & 1 & - \\
\hline 32 & 52 & 14 & 98 & 207 & 305 \\
\hline
\end{tabular}


Federal university.:....

Federal Rural university

State university

Catholic university...

Private university.

TOTAL

Isolated faculty

Federal.

State

Municipal

Private

TOTAL
ENROLLMENT

20

4

3

10

59,100

2,081

15,913

15.595

5,213

40

32

52

14

207

17,052

40,827

155,781
PER CENT

ENROLLMENT

HISTORICAL CHANGES IN ENROLLMENT

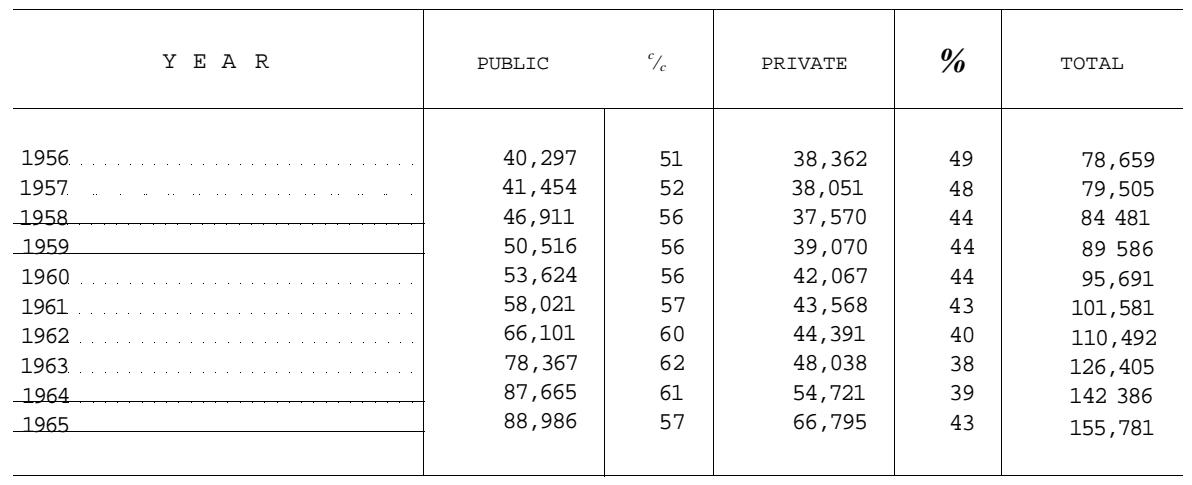

No post-graduaíe íncludej 
A few word further on the subject of isoleted faculties seem in order. These are usually restricted to coverage of one field, with the following fields including 70 per cent of ali faculties authorized, in 1965:

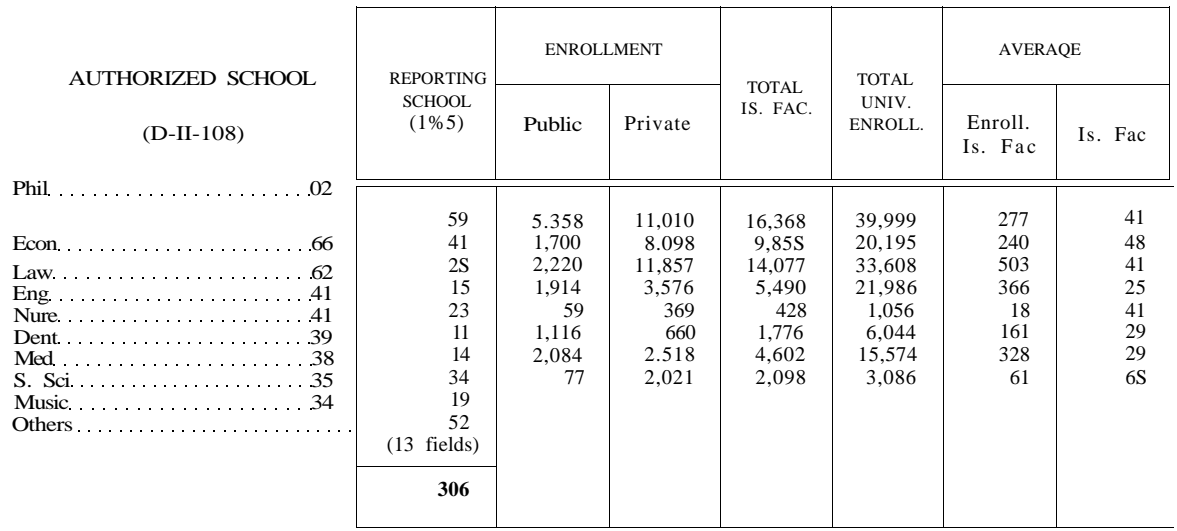

Since most of these schools are small on average, and since the expensive fields of engineering, dentistry, and medicine are on the above list, it would seem that unit costs must be high if quality education is to result. Since these faculties depend largely on tuition income, the quality of education must be questioned. There appears to be very little, if any, checking on quality of work by the Ministry, and there seems no assurance that a school, once approved, fulfills its promises or maintains its initial quality of program. If there were such checking why would SEEC fail to even get a report from 239 schools in 1965 ?

An isolated faculty is essentially self-sufficient, that is they do not depend on other institutions for service instruction, or a faculty of medicine teaches its own chemistry, for example. Because of the pressure of cost, an administration is not likely to broaden a program beyond the mere Federal Council minimum; this leads to a narrowness of treatment which will be found less and Iess desirable in Brazil. The federal universities have been put together in rather recent years as amalgamation of five or more such faculties, and so the federal universities continue as composed of self-sufficient faculties, isolated educationally and usually isolated in location as well. For instance, the federal University of Rio de Janeiro operates from eleven locations, separeted by distances as great as the width of the city.

The faculties not organized into universities represent about 37 per cent of the higher education capacity of Brazil. Unfortunately, these faculties do not greatly broaden the geographical coverage of the country. since a majority of the faculties are located in the same city as a federal university. They frequently duplicate in field of coverage as well. Do they represent overflow situation, resulting from lack of capacity in more organized education? Or are they a remnant organism from an earlier day? Against this. new institutions are still-being authorized. 


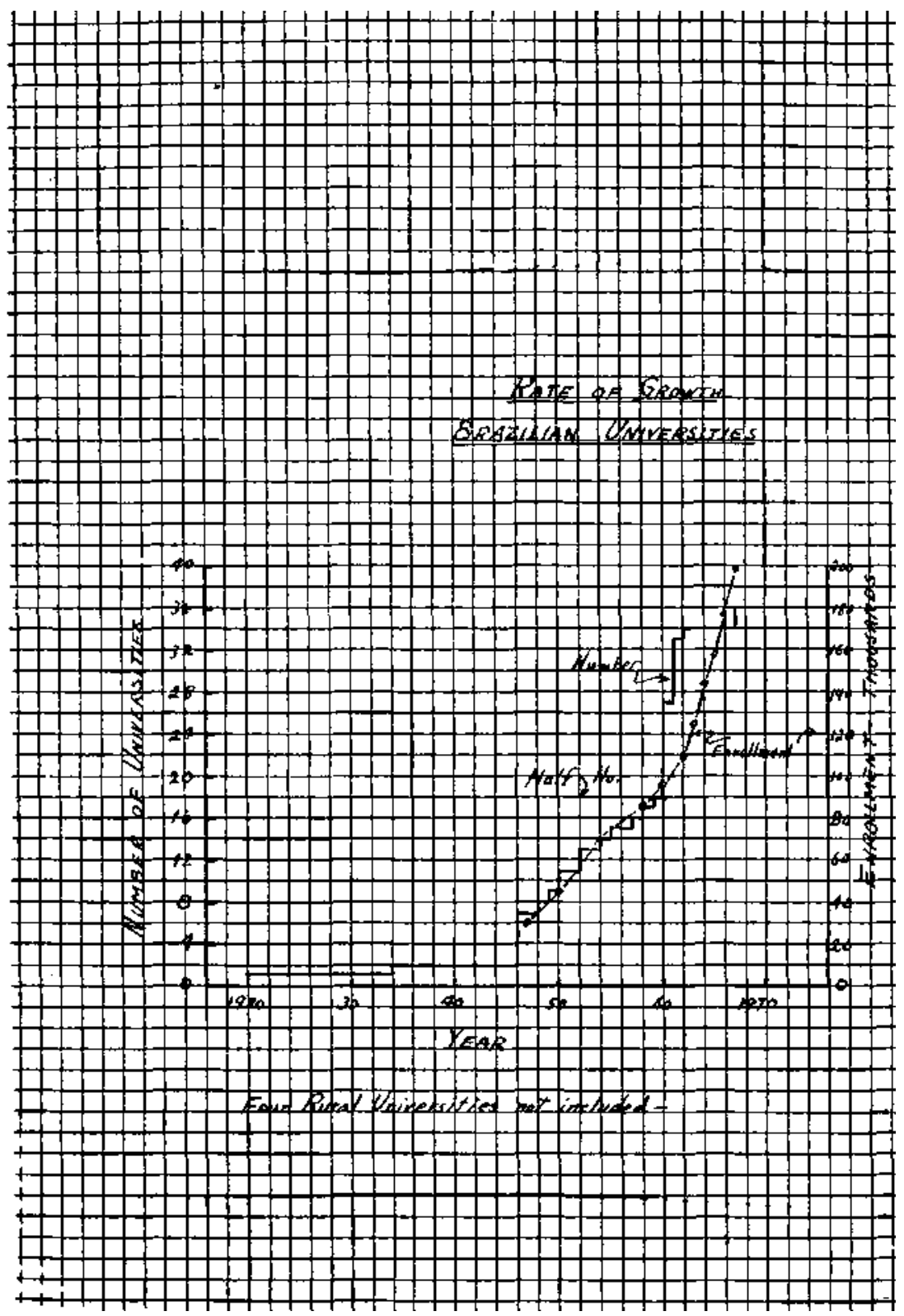


Apêndice D. 1

\section{A UNIVERSIDADE-FUNDAÇÀO: UMA CAIXA DE PANDORA}

Durante cerca de sete meses, examinando a situação da Educação superior brasileira, e piccurando compreendê-la, temos ouvido muito sobre a «Fundação» como sendo um expediente legal para «resolver» ou «atenuar» pelo menos boa parte dos problemas das Universidades. Uma das principais vantagens atribuídas à «Fundação» é a de «libertar» as Universidades de todas as normas, regulamentos e complexidades do DASP, particularmente no que toca ao pessoal docente. Encontram-se notáveis exemplos onde o esquema «Fundação» teve êxito, como sejam o IBGE, a Fundação Getúlio Vargas.

O objetivo deste trabalho não é argumentar contra ou a favor da Fundação como um expediente em si, mas sugerir que adotar a Fundação como forma de organização não resolve problemas. Pode facilitar sua resolução ou pode simplesmente converter um conjunto de problemas num conjunto diferente. Até certo ponto - e no mínimo -- o novo sistema libertará no organismo universitário toda uma série de novos problemas - a abertura da Caixa de Pandora - e são estes que vamos examinar aqui.

Problema do Pessoal Docente - Os problemas de pessoal relacionados ao pessoal profissional das Universidades, traduzidos nos seus termos mais simples, são: 1) Recrutamento - convite e contratação. 2) Fixação - - incluindo um sistema de recompensas e a elaboração de um conjunto de critérios para julgar o desempenho profissional. 3) Dispensa - talvez um aspecto especial da fixação. Porém, deve haver condições para a aposentadoria ou simplesmente para a «demissão» em virtude de falta de desempenho ou de algum tipo ae má conduta. 4) Proteção — um problema especial da «fixação» e da «dispense», que implica no reconhecimento da natureza muito especial do papel do magistério na sociedade.

Cada um destes aspectos será mais desenvolvido e melhor explicado posteriormente. Todos os sistemas se defrontam com estes mesmos problemas e, mal ou bem, os resolvem. Primeiro examinaremos o sistema atual e o tratamento nele dispensado àqueles aspectos do problema do pessoal; em seguida, analisaremos os nofos problemas que seriam levantados pela «libertação» do atual sistema. 


\section{O SISTEMA ATUAL}

Esta descrição será muito breve, quase caricatural, em parte para poupar a paciência do leitor e em parte devido a meu conhecimento incompleto do assunto. Além disso, meus comentários são mais pertinentes às instituições federais do que às estaduais, municipais particulares.

Recrutamento - Ne sistema atual, dá-se pouca atenção ao recrutamento de novo pessoal ou de. administradores universitários. Estes são eleitos, o que evita um programa de recrutamento segundo o sentido usual da expressão. Por outro lado, o recrutamento de professores não poderia constituir-se em intensa atividade, pois a maioria tem, no que se refere ao trabalho, «condicionamentos externos». Enquanto o pessoal docente trabalhar em regime de tempo parcial e o cargo docente não fôr c principal emprego, os atrativos deste serão provavelmente os fatores determinantes de sua localização geográfica, etc, permanecendo as condições do emprego universitário num plano nitidamente secundário. Além disso, os salários fixos e as condições de trabalho já determinadas permitem pouca flexibilidade para um intensivo programa de recrutamento. O concurso também é expediente muito mais adequado a situações de um excesso de pessoal qualificado procurando cargos altamente desejados do que a uma conjuntura de deficits de pessoal qualificado. $\mathrm{O}$ «condicionamento externo» limita seriamente a mobilidade e portanto restringe ainda mais o número de pessoas que podem ser candidatos efetivos a qualquer concurso.

Fixação - Desde que um professor seja admitido, suas expectativas de salário supõem correções monetárias automáticas, benefícios por tempo de serviço, e salário proporcional ao número de dependentes. Isto lhe é «devido», é um «direito» e não pode ser negado, nem reduzido nem aumentado pela Faculdade ou Universidade. Existem outros tipos de gratificações que pedem ser consideradas: 1) Diferenciação entre as tarefas destinadas a cada um, embora isto tenha significado limitado sob o sistema de cátedra. 2) Diferenciação na concessão de verbas para pesquisa e na designação de assistentes. 3) Diferenciação na concessão de bolsas, licenças, etc. Em tudo e por tudo, o sistema permite pouca flexibilidade nas negociações para induzir o pessoal a permanecer na Universidade e segundo minhas observações, suspeito que mesmo esta pequena flexibilidade é pouco utilizada.

Afastamento ou Dispensa - Com respeito à seleção de professores, o atual sistema funciona baseado em duas suposições: 1) Ou êle é infalível, ou 2) Admitindo um possível erro, a Universidade - e não o indivíduo - deve arcar com todos os ónus dos erros. A seleção pode ter sido mal feita, o professor pode vir a ser ineficiente; em qualquer dos casos, êle não pode ser dispensado. Aparentemente, 
mesmo que a disciplina de sua cátedra se torne obsoleta, êle também não pode ser dispensado. Assim, o sistema atual resolve o seu problema do «afastamento» só admitindo as possibilidades de morte, aposentadoria (incapacidade física prolongada?) ou renúncia voluntária ao cargo. Desconheço até que ponto as pessoas podem ser induzidas a renunciar ou a aposentar-se. Entretanto, de modo geral, existe pouca flexibilidade .

Proteção - Há muito que os professores mantêm uma posição favorecida, em virtude da natureza mesma de suas tarefas - buscar e ensinar a verdade, seja ela popular ou impopular, onde quer que ela possa ser encontrada. Esta tarefa não pode ser cumprida estando os políticos, sacerdotes, homens de negócios ou soldados supervisionando e revendo o trabalho des professores, ditando as áreas em que a verdade pode ser procurada ou ensinada. $O$ atual sistema reconhece claramente esta situação e dá o máximo de proteção aos professores.

Esta caracterização talvez seja exagerada e provavelmente existirão exceções ao perfil traçado, mas de modo geral são estas as impressões que um estrangeiro interessado pode obter num prazo de observação relativamente curto. Suponhamos agora que a Fundação como forma de organização permita que as Universidades estabeleçam sua própria política corn respeito aos professores. Como serão e como poderão ser tratados estes mesmos problemas?

\section{SOB O REGIME DA FUNDAÇÃO}

Recrutamento - Dada a liberdade e flexibilidade inerentes a esta nova organização, as únicas restrições óbvias ao recrutamento são as de ordem orçamentária. Uma dada Universidade - e seus variados componentes - tem apenas que decidir quais são as prioridades a serem concedidas e distribuir os recursos de acordo com estas prioridades. Entretanto, no processo de recrutamento, ela vai se defrontar com muitos e novos problemas, como: 1) Que percentagem do corpo docente deve trabalhar em regime de tempo integral? 2) Esta percentagem deve ser a mesma para todas as subunidades? 3) Uma Universidade teria algumas vantagens naturais que deveriam ser exploradas ou desvantagens que devessem ser superadas? 4) Podem ser descobertos, elaborados ou oferecidos alguns argumentos persuasivos tais como residência para professores, dotações especiais para pesquisas, etc? 5) Até que ponto poderia ser permitida uma competição

Pede-se ao leitor que desculpe as constantes referências aos Estados Unidos nos exemplos que se seguem. A razão é que estou mais familiarizado com o sistema deste país. 
inter-institucional, i.e.. uma instituição poderia «comprar» professores de outras instituições?

Das perguntas acima deprecnde-se claramente que a liberdade e a flexibilidade no recrutamento levantam muitos problemas que são evitados pelo sistema atual. Segue-se breve descrição de elementos que têm constituído, numa ou noutra circunstância, aspectos importantes do processo de recrutamento, e que demonstram as várias facetas novas da tarefa de contratação de um professor.

a) Salário - Certamente os salários e as expectativas de salários constituem aspectos importantes na contratação de professores. Isto levanta uma questão crítica, ou seja, a de que os salários devem ou não ser os mesmos para toda a Universidade e para professores mais ou menos equivalentes (assunto a ser discutido abaixo) .

b) Residência para o Corpo Docente - especialmente para os novos professores. Talvez isto seja menos importante no Brasil do que nos Estados Unidos, em virtude da mobilidade muito menor dos professores universitários brasileiros." Neste caso, possivelmente seria mais adequado adotar-se um sistema de residência permanente para os professores, seja êle subvencionado ou não. A Universidade Nacional de Tucumán na Argentina, por exemplo, fornece residência permanente para professores de outros Estados, reconhecendo a necessidade de encontrar algum meio de atrair pessoal de outras áreas. Isto substitui em parte as diferenças salariais que a Universidade não pode pagar legalmente.

c) Baixa Carga de Ensino - Este método é usado para o pessoal docente com alta prioridade para pesquisa. Pode ser utilizada para reduzir as cargas cada semestre ou ocasionalmente. Suponhamos, por exemplo, que a carga de ensino «normal» é de três disciplinas. Poder-se-ia dizer a um professor de prestígio que êle precisava dar somente duas disciplinas ou não precisava dar aula alguma cada terceiro ou quarto semestre. Esta política implica em custos e evidentemente não se pode oferecer cargas reduzidas a todos.

d) Dotações para Pesquisas, Tempo de Computadores - Todos os auxílios para pesquisa podem ser importantes expedientes

2 Como indicação da mobilidade existente, temos o fato de que a maioria das boas Universidades dos E. U. A. tem por norma não contratar os seus estudantes que nela concluíram cursos de pós-g-aduação (mestrado e doutorado). senão depois que hajam se afastado da instituição por alguns anos. Esta normn destina-se a evitar a formação de professores dentro do próprio corpo docente. Alem disso, os estudantes são aconselhados a que preferivelmente não façam seus cursos de graduação e de pós-graduação na instituição, a fim de travar conhecimento com diferentes abordagens do seu campo de estudo e de ter maior contato com. maior número de professores. 
recrutamento - - e podem até mesmo ser o item crítico. Um expoente pode ser atraído pela generosidade," e o pessoal júnior simplesmente pelas facilidades de pesquisa, tais como orçamento adequado para a biblioteca, suficiente ajuda de pessoal de secretaria, etc.

e) Política de «Licenças Especiais» $c$ outras Licenças - Um professor «produtivo» espera ter cada sétimo ano livre para pesquisa, estudo e viagens, recebendo pelo menos uma parcela substancial de seu salário.'

f) Viagem - A liberalidade no pagamento para participar de conferências, seminários, etc. - especialmente para as instituições isoladas - pode auxiliar a superar o isolamento detestado pela maioria dos professores.

g) Consultoria - A autorização para dar consultas particulares. com ou sem pagamento, pode também ser um atrativo, permitindo que o professor suplemente sua renda e mantenha contatos com o mundo real.

h) Finalmente, nenhum expediente para o recrutamento será mais útil do que possuir um grupo ativo, dinâmico e reconhecido dentro de uma Universidade respeitada."'

Um dos principais problemas tem sido e continua a ser o do salário. Discutiremos aqui um dos seus aspectos: o salário deve ou não deve ser o mesmo, em toda a Universidade, para o pessoal do tempo integral «igualmente qualificado»? Nos Estados Unidos, empregamos dois sistemas diferentes, e ambos sugerem negativas a esta pergunta, embora um sistema seja o contrário do outro. A essência do problema gira em torno do fato que engenheiros, economistas e químicos não têm maiores dificuldades em obter um emprego bem pago fora da Universidade. Os especialistas em História, Português. Musicologia têm poucas oportunidades fora do âmbito universitário. O resultado é que (quer concordemos ou não com isto) na nossa sociedade um engenheiro ou economista vale mais no mercado de que um historiador. Um grupo de Universidades nos Estados Unidos reconhece este fato e explicitamente paga salários distintos para os

3 Os «melhores» cargos de professor nos Estados Unidos atualmente pagam um salário adequado e, além disso, duas ou três vezes o valor deste salário com ,1 finalidade de financiar o trabalho pessoal de pesquisa do professor.

4 Frequentemente, êle tem um ano inteiro com melo salário ou meio ano com salário integral.

Estes «expedientes» só tèm realmente sentido para o corpo docente que é essencialmente de tempo integral, c para alguns casos específicos como os citados ern $y$, mas não têm absolutamente nenhum sentido para o co-po docente de 'empo parcial. Existe ainda toda uma série de outras possibilidades. A Universidade poderia criar uma escola modelo ou experimental, reservando, com anuidades reduzidas, vagas para os filhos dos professores de tempo integral. 
diferentes ramos profissionais, mas de modo geral procura aplicar os mesmos padrões de promoção para os vários níveis da carreira. Outro grupo de Universidades adotou o sistema de pagar o mesmo salário a todos os instrutores, todos os professores assistentes, etc. A experiência tem demonstrado que também este sistema responde ao mercado, e o progresso através dos diferentes níveis da carreira é mais rápido nas profissões de grande demanda do que nas outras.

Podemos condenar veementemente estes aspectos da realidade, mas será insensato ignorá-los. Pagar a todos os professores de acordo com o nível daquelas profissões melhor remuneradas pelo mercado seria extremamente dispendioso e reduziria seriamente o número dos professores que poderiam ser admitidos. A política de pagar a todos segundo o preço do mercado para as profissões menos procuradas seria ainda pior, pois resultaria na tendência do ensino universitário ser ministrado pelos piores engenheiros, piores advogados e piores médicos. ${ }^{\mathrm{G}}$

A mudança do atual sistema para o da Fundação certamente aumentaria o número e a variedade dos expedientes de recrutamento que a Universidade poderia utilizar. Dispondo de maior número de escolhas, deveria ser mais fácil, para a Universidade, resolver o problema do recrutamento, ou talvez encontrar melhor solução para este problema. Mas esta mudança de sistema certamente aumenta a necessidade de julgamento e de tomada de decisões e resultaria num aumento dos erros individuais, altamente prováveis, em lugar dos erros de sistema, também altamente prováveis. Se não se dispõe de escolhas, o processo é simples (embora os resultados possam ser ruins), mas com as possibilidades de escolha o processo torna-se complexo, e espera-se que os resultados sejam melhores.

Nada do que acima foi comentado está em termos de «recomendação»; simplesmente tentou-se examinar pelo menos as principais alternativas que existem, sem que se tivesse pretendido julgar sua validade, quer no contexto da educação brasileira, quer no dos Estados Unidos.

Fixação - Uma vez que o pessoal docente tenha sido recrutado. os problemas restantes referem-se a como manter aqueles que têm um desempenho adequado e como evitar conservar aqueles que não o têm. Nesta parte do texto discutiremos somente o problema da fixação, embora os dois estejam inextricavelmente interligados.

Existem, está claro, outros incentivos atém do salário para estimular os estudantes a se tornarem professores, mas o salário é. para muitos de nós, uma consideração importante. Muitos jovens deixam o magistério simplesmente porque não podem permanecer nele - da mesma forma que muitos brasileiros atualmente não tem recursos para ser professores universitários de tempo integral, mesmo reunindo dois cargos diferentes. 
A primeira decisão real a ser tomada é uma decisão das mais importantes: procurará o sistema distinguir entre aqueles que têm um desempenho adequado e aqueles que não o têm, e com que objetivos? Se fôr decidido que as nomeações são irrevogáveis e para toda vida, a questão está respondida quanto à fixação, mas poderá surgir de novo em outros assuntos.

Quando perguntamos «com que critérios os professores devem ser julgados?», estamos próximos do âmago do problema da Educação superior. O que é desejado, o que é esperado da Educação superior brasileira? Só poderá ser elaborado um conjunto de critérios para medir o desempenho dos professores quando já estiverem delineados os objetivos nacionais para a Educação superior. Os professores serão. em última análise, o principal veículo para a execução dos referidos objetivos.

Seja como fôr, e desde que minha intenção é muito mais levantar problemas do que resolvê-los, permitam-me sugerir alguns critérios que - dados os objetivos gerais - poderiam ser aplicáveis:

a) Uma das principais funções do sistema será certamente a de ensinar aos estudantes universitários, e portanto o desempenho de um professor (uma espécie de combinação da capacidade inata e do interesse) será importante item para julgá-lo. Infelizmente, não temos nenhuma medida conveniente que permitisse medir, digamos, numa «escala de Dewey», a boa ou má qualidade de um professor; e todo o pessoal universitário esclarecido logo reconhecerá a tarefa extremamente difícil que é julgar os desempenhos.

O professor de quem eu mais gostava, quando estudante, era um cavalheiro minucioso que escrevia no quadro negro o esquema da aula de cada dia; nós ouvíamos, copiávamos. memorizávamos, obtínhamos boas notas, mas hoje dificilmente conseguimos lembrar sobre o que era aquele curso. $\mathrm{O}$ professor mais irritante era aquele que nos deixava em dúvidas, confundia-nos em vez de esclarecer-nos, levantava mais problemas do que os resolvia. Nós, estudantes, enfrentando as provas, não gostávamos dele. Porém, agora, muitos anos mais tarde, não temos dúvida em ver que foi com êle que fomos estimulados intelectualmente, pois exigia que nós pensássemos, levava-.nos a procurar os fatos e os problemas importantes. Este exemplo sugere duas ideias: 1) Que os processos externos de ensino podem não ser perfeitamente adequados para um julgamento. 2) Que os atuais estudantes podem trazer uma contribuição positiva para a avaliação do desempenho de um professor, mas não se pode esperar que suas opiniões sejam totalmente dignas de confiança. O verdadeiro teste para o desempenho de um professor é a verifi- 
cação do resultado do aprendizado do aluno (tomada esta expressão em seu sentido mais amplo) vinte anos após deixar as salas de aula. O que êle ou qualquer outra pessoa pensa enquanto está nas salas de aula é somente um substituto imperfeito para o verdadeiro teste.

Existem ainda outros aspectos complexos: 1) O desempenho de um mesmo professor pode variar de uma matéria para outra. Alguém tem que ensinar as matérias menos interessantes e menos insinuantes. A boa vontade de executar esta tarefa é por si só uma parcela do desempenho do professor? 2) Uru indivíduo pode ensinar melhor a pequenos grupos de alunos as fronteiras do conhecimento porque se encontram neste campo as suas capacidades e interesses, enquanto que outro teria melhor atuação dando conferências a grandes turmas de alunos sobre as matérias mais elementares, e encarregando-se dos detalhes administrativos destas turmas. Como pode ser comparado o desempenho dos dois? 3) No mesmo curso. ou disciplina, uma pessoa pode ser mais eficiente usando. digamos, o método de «aula-conferência». enquanto que outra se baseia no método «socrático». Um destes métodos é preferível e é um deles mais meritório do que o outro?

O fato de levantarmos estas questões como imponderáveis não sugere que se deixe de fazer um julgamento acerca da qualidade do ensino. Se o ensino é importante, então parece ser duplamente certo que as Universidades têm que fazer julgamentos sobre o desempenho do professor, mesmo se a precisão não puder ser atingida e se forem prováveis os erros ocasionais nestes julgamentos. Recusar-se a cumprir este dever de responsabilidade é fazer funcionar um sistema que presume que todos os professores são: 1) igualmente bons mestres; 2) igualmente interessados nas suas tarefas de ensino. A experiência demonstra que ambas as proposições são falsas:

b) Além do ensino, o sistema universitário provavelmente irá (deve?) incluir a pesquisa nos seus objetivos. Se o fizer, há de esperar que o seu pessoal «profissional» (que pode ser ou não o mesmo que o pessoal de «ensino») realize trabalhos de pesquisa. E, mais uma vez, sendo a pesquisa um dos objetivos, a Universidade tem de estar preparada para avaliar este trabalho (ou para supor que todos são igualmente

7 Logicamente, as hipotéticas distribuições desiguas de 1) e 2) poderiam contrabalançar a ambos (i.e., o incapacitado seria altamente motivado e vice-versa). resultando num igual desempenho de todos nas tarefas de ensino. Por outro lado. nossa experiência sugere que as duas características têm mais probabilidades de serem auto-suficientes (i.e., o incapacitado seria pouco motivado e o capacitado. altamente motivado) . 
competentes, igualmente interessados, e trabalhando em problemas igualmente importantes).

Talvez a avaliação de um trabalho de pesquisa seja mais fácil do que a avaliação do ensino, particularmente porque existem algumas medidas externas. Se uma pessoa é repetidamente convidada a apresentar seus achados em congressos nacionais e internacionais, e/ou se estes achados aparecem com frequência em revistas profissionais reconhecidas nacional e internacionalmente, isto normalmente constitui clara evidência de um trabalho de pesquisa de alta qualidade. Mas não resolve, de modo algum, o problema de avaliação dos trabalhos de pesquisa. 1) Como se avaliaria a pesquisa magnum opus que leva anos para ser produzida? 2) Como se avaliaria a pesquisa sólida e honesta, de nível nacional. regional ou local e que pode nunca vir a atrair a atenção internacional? Num certo sentido, isto pode envolver a distinção geralmente estéril entre pesquisa «básica» e «aplicada». 3) Como seria comparado o «valor» do resultado de uma pesquisa em Biologia com o de uma em História?, como o de uma pesquisa em Economia? Nos Estados Unidos, geralmente funcionamos segundo o lema «pesquisa e ensino andam de mãos dadas, dando-se a isto significado bastante amplo. Sugere-se, portanto, que os pesquisadores devem ensinar $e$. os professores devem pesquisar, ponto de vista este que inclui certa dose de insensatez, e as Universidades brasileiras devem meditar com cuidado sobre este axioma.

Os bons professores, obviamente, têm que estar atualizados no campo de suas disciplinas, ${ }^{\mathrm{R}}$ mas isto não quer dizer que devam realizar um trabalho original de pesquisa. Esta suposição parece admitir que se eles estão trabalhando numa pesquisa, estão se atualizando, o que pode ser erróneo. E os estudantes certamente têm que ter contato com a pesquisa e com os melhores pesquisadores, mas esta necessidade não significa que todos os pesquisadores devam manter contato com os estudantes.

c) Podemos ainda levar em conta outras atividades ao fazermos o julgamento sobre o professor.

Dentre meus preconceitos, encontra-se o seguinte: parte substancial do sistema universitário (mas não necessariamente todas as Universidades) deve estar estreitamente relacionada com os problemas da sociedade que o criou. A Universidade

1 Mesmos campos de estudo «estáveis» como História, Línguas, Literatura, etc, constantemente passando por substanciais mudanças pedagógicas. 
é repositório de conhecimentos e de know-how que, até certo ponto, tem que ser colocado imediatamente à disposição da comunidade. Por exemplo: fui designado para ensinar «Fundamentos de Economia» a vários grupos de pessoas, tais como diretores de empresas, líderes sindicais, e todos os empregados de uma fábrica. O exemplo mais amplamente conhecido deste tipo de atividade da Educação nos E. U. A. é o dos cursos de extensão universitária sobre agricultura. levados diretamente ao fazendeiro, cursos que são, em grande parte, responsáveis pelo enorme aumento da produção agrícola neste século.

Este tipo de atividade não é um caminho com uma única direção a ser seguida. No meu caso pessoal, tive que me preparar para atingir uma audiência não obrigada a comparecer (e que compareceria ou não, dependendo de quanto eu pudesse tornar o assunto interessante). Isto fêz com que meus métodos e recursos de ensino melhorassem enormemente. pois exigia que eu elaborasse novas técnicas, fosse mais enfático, que «envolvesse» os alunos, e eliminasse as irrelevâncias e refinamentos do assunto. Professores de quase todas as disciplinas podem aprender bastante através de contato constante ou ocasional com o «público».

Não desejo prejulgar os objetivos brasileiros. Estes objetivos poderiam ser importantes, e se o forem, as Universidades teriam que encontrar algum meio de realizá-los - mais uma tarefa para os professores, cuja eficiência necessitaria de julgamento.

d) Finalmente, o professor tem de ocupar-se com muitas outras atividades intra-universitárias. que absorvem seu tempo e exigem seus conhecimentos: elaboração de currículos, constante atenção voltada para as mudanças curriculares, administração educacional, elaboração e edição de publicações universitárias. Estas e outras são atividades profissionais, são valiosas, e podem ser uma parcela dos objetivos da Universidade. Como podem ser avaliadas e comparadas a outras atividades desejáveis?

A discussão dos critérios para julgamento implica num julgamento global do mérito e sugere que o mérito é algo a ser recompensado de algum modo. Se o mérito deve ser recompensado e o desejo de livrar-se do automatismo do DASP sugere que deve - existe o problema do julgamento (que já foi discutido) e o problema de «recompensar com que»? Temos aí várias possibilidades. Frequentemente sugere-se aos observadores dos E. U. A. na América Latina que a remuneração para o mérito é o prestígio que se reflete na atividade não universitária de uma pessoa. $\mathrm{O}$ arquiteto que é também diretor 
de unia faculdade poderá receber honorários maiores do que aquele que fôr somente um professor, este poderá receber mais do que o arquiteto que não fôr professor, etc, etc. Isto pode muito bem ser verdade, e o fato de que o prestígio será altamente desejado e procurado no novo sistema tem que continuar também a ser uma verdade. Mas se o trabalho universitário em tempo integral torna-se um desidevatum, desaparece a possibilidade de- traduzir-se prestigio em termos de feijão. Provavelmente existem vários sistemas que relacionam o mérito à recompensa. Entretanto, desejo levantar questões somente acerca de dois deles: nível, e para dizê-lo cruamente, dinheiro.

Criar um sistema de níveis é um modo de distribuir prestígio. Nos Estados Unidos, temos quatro níveis principais: instrutor, professor assistente, professor associado, professor. Não existe nada de sagrado nestes nomes ou quanto às quantidades específicas existentes. Talvez devesse existir um maior ou menor número de níveis (se é que deve haver algum). A existência de níveis, é claro, implica em critérios para promover as pessoas de um nível para outro. Implica também, num mecanismo para tomada de decisões. Dois aspectos podem ser rapidamente abordados: 1) A promoção automática como função do tempo negaria a ideia do relacionamento entre nível e mérito. 2) O problema dos critérios e julgamentos sobre o assunto níveis não é exatamente o mesmo que o dos aumentos salariais em função do mérito. O primeiro diz respeito ao nível de realizações, enquanto que o segundo pode estar ligado ao aumento de realizações.

Com respeito ao dinheiro, seria bom se chegássemos à conclusão de que os professores não se preocupam com dinheiro, dedicando suas vidas à juventude e à busca do conhecimento. Outros poderiam preferir urgente mudança do sistema sócio-econômico, a fim de que que estas dedicadas almas não tivessem que se preocupar com objetivos materiais. Contudo, até chegarmos à utopia, o dinheiro desempenhará importante papel e. no nosso caso, em dois relevantes aspectos: 1) Se se pensa que é desejável um ensino e pesquisa em regime de tempo integral, então os .salários têm que ser suficientes para atrair jovens para o ensino universitário como uma carreira. Isto significa que o jovem que não tenha independência financeira deve poder olhar para o futuro e sentir, com alguma confiança, que pode sustentar razoavelmente a si e a sua família através do trabalho na Universidade. ${ }^{0}$ Se isto não puder ser feito, os únicos que podem ser atraídos para uma carreira universitária com trabalho em tempo integral são os que já possuem independência financeira, e não há muitos motivos para pensar que estes são os melhores. Pode-se talvez contar com o trabalho dos demais no máximo e unicamente em regime de tempo parcial. 2) O dinheiro, e especificamente os aumentos de salários. podem ser utilizados como parte de um sistema de recompensas. $\mathrm{Na}$

9 Tendo-se a noção de que os professores em potencial geralmente possuem «padrões de vida» razoavelmente elevados. 
instituição em que trabalho, ${ }^{10}$ revemos anualmente o desempenho de cada membro do corpo docente profissional - utilizando critérios bastantes semelhantes aos que discutimos anteriormente - com a finalidade de conceder aumentos salariais (de «zero» para cima). Estes são chamados de «aumentos por mérito». Isto nos dá o «prémio» e o «castigo», meios de recompensar o desempenho meritório e de corrigir o desempenho pernicioso. Sabemos que uma pessoa que «tendo estabilidade ${ }^{11}$ deixe de progredir, que não assuma sua parte das responsabilidades, que negligencie o ensino, não receberá aumentos de salários, enquanto que o desempenho «médio» trará modestos aumentos e o desempenho excepcional trará grandes aumentos salariais. Este ponto não deve ser super-enfatizado, pois faz com que os professores pareçam crianças de jardim de infância. Talvez cerca de $95 \%$ dos professores tivessem o mesmo comportamento se não existisse este sistema. Talvez o preguiçoso não seja afetado por este sistema, mas é ocasionalmente um instrumento útil e frequentemente uma catarse psicológica para saber que o colega negligente não será tratado da mesma forma que os outros. ${ }^{12}$

Desejo esclarecer mais uma vez que este sistema não é necessariamente uma recomendação, e que somente procurei mostrar os tipos de probieinas levantados pela flexibilidade.

Dispensa c proteção - Estes dois aspectos do problema do pessoal estão tão estreitamente relacionados que serão discutidos juntos. O problema essencial é que o corpo de professores deseja proteger-se das pressões externas no seu trabalho de ensino e pesquisa, e tem bons e justos motivos para tanto. Em última análise, proteger seus membros da eventualidade de uma demissão devida a razões injustas provenientes de qualquer fonte, ou por qualquer motivo derivado de forças de fora da Universidade. Esta é a essência da liberdade de cátedra e fora dos países totalitários poucas pessoas defenderiam posição contrária.

Tendo sido decidido que a <liberdade de cátedra» tem de existir. surge o problema da «liberdade para fazer o que?» ou da «liberdade para não fazer o que?». Não se admite que a «liberdade de cátedra» seja uma licença total, e o problema perene é o traçar as fronteiras entre o que é permitido e o que não. é. A «incompetência profissional» geralmente não é protegida (embora seja difícil de se provar), a

${ }^{10}$ Michigan State Unlversity, East Lansing, Michigan.

${ }^{11}$ A ser explicado abaixo, e bem separado dõste assunto.

${ }^{12}$ Supomos que os enganos nas nomeações ocorrerão mesmo quando as nomeações permanentes forem feitas somente após vários anos de observação, e de fato esta suposição é correta. É também fato que algumas instituições têm um automatismo muito maior nos seus sistemas de salários do que o aqui descrito. 
«baixeza moral» (qualquer que seja o significado dado a esta expressão) não é protegida, o continuado fracasso de um professor no cumprimento de suas tarefas provavelmente não será protegido. Existem muitas possibilidades que ainda estão um pouco obscuras: o que dizer do professor de matemática que usa sua sala de aula para defender a causa de Barry Goldwater? ou a posição de «parar com o bombardeio» ou os prncípios de determinado candidato político, durante a época das eleições? O que dizer dos poucos professores que, uma vez assegurada esta proteção, param suas atividades intelectuais? $O$ que dizer do professor que falta constantemente às suas aulas porque está dedicado a consultas fora da Universidade? Existe grande quantidade de possíveis «pecados» que podem ser acobertados pelo sistema que é destinado somente a proteger os direitos do professor trabalhar em suas pesquisas, como julgar mais conveniente e de ensinar a verdade como êle a vê.

Portanto, garantir a «liberdade de cátedra» envolve certo grau de proteção para o professor, isto é, certo grau de segurança em seu trabalho. Mas isto levanta questões importantes, como: 1) Que tipos de atividades devem ser protegidas? Num extremo, poderíamos sugerir «zero» atividades, ou absolutamente nenhuma liberdade de cátedra; no outro extremo, o professor poderia ser protegido contra os aborrecimentos do estacionamento proibido, contra as amolações dos cobradores de impostos etc. e entre estes extremos está toda uma série de atividades. Deve ser determinado um ponto em algum lugar desta série. 2) Quanto maior fôr a proteção dada, maiores serão as probabilidades do sistema vir a incorporar várias espécies de «indesejáveis»: o preguiçoso, o incompetente, o desmazelado, o desinteressado. Parece-nos evidente que existe uma positiva associação entre estes aspectos, ou seja, quanto maior fôr a liberdade de cátedra maior será a probabilidade de se protegerem atividades com características não imaginadas - ou por cerro não desejadas - nos objetivos iniciais. ${ }^{13}$ Se esta proposição fôr correta, então é importante que o pessoal seja selecionado com cuidado extremo e se encontre algum meio de reduzir ao mínimo os prejuízos potenciais dos «erros».

Suponho que exista uma gama infinita de sistemas possíveis. Mais uma vez, e sem nenhum caráter de recomendação, permitam-me descrever o sistema com o qual estou mais familiarizado.

O sistema americano é um «sistema de estabilidade» no qual certo número de professores é nomeado por períodos de tempo definidos (sem estabilidade), enquanto outros são nomeados por tempo inde-

Meditando sobre o assunto, e encarando os fatos com certa jovialidade, concluí que o sistema de estabilidade do serviço público ê ótimo para os países que não o possui, mas péssimo para aqueles países que o tem. 
finido - normalmente para toda a vida. Destes, digamos que têm «estabilidade». «Ter estabilidade» significa essencialmente que o professor não pode ser demitido do cargo senão em virtude de certos abusos da liberdade que goza, come baixeza moral, consistente falta de cumprimento dos regulamentos da Universidade etc.

Para os níveis iniciais da carreira, as nomeações são feitas sem implicar em estabilidade. Os instrutores são usualmente nomeados por um ou dois anos e podem ser reconduzidos. Os professores assistentes são usualmente nomeados por três anos e podem ser reconduzidos. Mas, via de regra, o período total em que uma pessoa pode ser contratada sem ganhar estabilidade é de seis ou sete anos. Por exemplo. um professor assistente é nomeado por três anos e depois readmitido por mais três anos. Qualquer recondução subsequente automaticamente inclui estabilidade. A promoção de professor assistente a professor associado inicialmente implica em estabilidade. Nomeações de professores (que não pertenciam anteriormente ao quadro da Universidade) implicam em estabilidade. ${ }^{14}$ As nomeações de professores associados são normalmente por dois ou três anos e qualquer recondução subsequente implica em estabilidade. Geralmente não há regras para evitar a concessão de estabilidade antes do? limites máximos sugeridos, e a promoção a professor associado frequentemente ocorre antes do período de experiência de seis/sete anos.

Este sistema provê um prazo de vários anos para uma tomada de decisão, durante o qual a Universidade presumivelmente poderá observar o indivíduo a fim de estar apta a fazer julgamentos válidos sobre seu interesse e capacidade de ensinar, sua capacidade de pesquisar, etc. Deve-se notar que a Universidade é obrigada a tomar uma decisão quanto à estabilidade: depois que um professor trabalhar durante o período "probatório», a Universidade tem que decidir se êle é ou não uma pessoa a ser contratada por toda a vida. Este aspecto do sistema é algumas vezes chamado de «promoção ou demissão». Tem por justificativa o fato de que seis ou sete anos constituem um prazo bastante longo para tomar-se uma decisão, e ninguém deve ser contratado além desse período sem a completa segurança garantida pela liberdade de cátedra. Além disso, a Universidade não deve, de modo algum, contratar uma pessoa por um período de tempo maior do que aquele, em bases «provisórias» e sujeita a uma não renovação de contrato não imporia por que motivo.

Nenhum sistema é tão perfeito a ponto de predizer as atividades profissionais de um homem por um prazo de trinta anos, ${ }^{15}$ mas existem meios marginais para suavizar os efeitos dos erros. O professor

H A razão fundamental é que neste nivel as nomeações são de pessoas de alto nível, que já são bastante conhecidas.

15 Supondo-se que $a$ estabilidade fosse concedida aos 35 anos de idade e que êle se aposentasse aos 65 . 
que se recusa a fazer pesquisa e a publicar trabalhos pode receber uma carga de ensino muito pesada (desde que, evidentemente, êle não seja um mau professor). Os maus professores, os velhos os cansados são designados para período;; de aula impopulares, onde seu contato com os estudantes é menor. Podem ainda ser designados para fazer trabalhos de «pesquisa em casa» ao invés de ensinar, simplesmente para reduzir ao mínimo os danos que podem causar. De certo modo, isto é semelhante às chamadas aulas «paralelas», algumas vezes organizadas em Universidades Latino-Americanas.

Existem processos complicador e elaborados para demitir uma pessoa com estabilidade. O processo é iniciado por alguma autoridade da administração da Universidade. Se o professor quiser entrar em litígio, uma comissão permanente de professores estuda o caso e faz uma recomendação. Se esta conclui contra o professor, não existe apelo para outra instância. Se conclui em seu favor, a administração pode ou não aceitar suas conclusões e arquivar o assunto, ou insistir na demissão simplesmente através da suspensão do pagamento de seu salário. ${ }^{16}$ No caso de flagrante abuso da liberdade de cátedra, a «American Associaton of University Professors» pode finalmente agir, censurando publicamente a Universidade, após cuidadosa investigação. Esta atuação não tem força de lei, mas é encarada seriamente por nosso mundo profissional. O recrutamento de bons profissionais é particularmente difícil para uma instituição «censurada».

\section{CONCLUSÃO}

Espero ter mostrado a grande quantidade de problemas que surgiriam unicamente na administração do pessoal docente, caso o atual sistema viesse a ser extinto. Foi descrito e discutido um grande número de alternativas para o atual sistema, mas sempre evitou-se tocar num aspecto: quem se encarregaria de todas as decisões a serem tomadas e de todos es julgamentos a serem feitos?

Esta questão deverá ser objeto de outro trabalho, e desejo somente comentar de modo geral alguns de seus aspectos.

Para melhoria do sistema Universitário, pode ser que seja desejável e necessário uma segura liderança de um ou mais indivíduos. durante considerável período de tempo. Não existe nenhuma garantia de que as instituições humanas medíocres venham a passar por rápida melhoria - se é que alguma melhoria — através da utilização do incómodo mecanismo da democracia pura. Não há nada de mágico no processo de somar os votos de pessoas medíocres, que podem muito bem ter velado interesse pela mediocridade. Um todo não é maior

18 Estes casos são extremamente raros. $\mathrm{Na}$ verdade, os casos raramente chegam até a comissão de professores. 
do que a soma de suas partes, e não contém qualquer «acréscimo» em termos de dinamismo, sabedoria ou qualidade.

Se a principal tarefa é a reforma estrutural e administrativa da Universidade (como a que vemos em andamento no Brasil), ela deve ser considerada como a renovação extensiva - senão a nova construção - de uma estrutura social importante e complexa, que requer tempo, paciência c liderança firme. Não seria razoável que pedíssemos a um arquiteto para iniciar uma obra importante e lhe disséssemos que dentro de dois meses êle estaria sujeito a um novo contrato, e ao fim de seis meses deveria desocupar o cargo. ${ }^{17} \mathrm{Nem}$ se constroem muitos edifícios quando o verdadeiro poder de decisão e a verdadeira autoridade estiverem nas mãos de uma comissão. Mesmo sem as «girafas», ${ }^{18}$ já existem problemas suficientes, na Educação superior.

Esta é uma posição «não democrática» se vista por determinados ângulos. A concessão de autoridade e a delegação de poderes para tomar e executar decisões representa um compromisso com $o$ que há de fundamental na democracia, na qual cada eleitor participa igualmente em cada decisão. O problema da delegação adequada de autoridade e da proteção contra a usurpação do poder e da autoridade é um problema gémeo da democracia. A exclusiva preocupação com este último levará à mediocridade inerte.

Uma pergunta final nesta série de perguntas. Suponhamos que a Organização $X$ é considerada deficiente, e que umas das razões para isso é que todos ou alguns de seus membros, tendo ou não tendo culpa, também são deficientes: incompetentes, sem base, não têm imaginação, são ociosos e muito ocupados com outros afazeres. Qual é o sentido de iniciar-se uma reforma que tem como principal fundamento não incomodar, de modo algum, todos os componentes atuais do sistema?

JOHN M. HUNTER

EAPES

Professor de Economia

Michigan State University

Tradução cie

JACQUES R. VELLOSO

Janeiro -1968

\footnotetext{
$1 \mathrm{~T}$ Neste exemplo os períodos de tempo são curtos, porque uma construção física é muito menos complexa e exige muito menos tempo do que construir toda uma Universidade.

18 Um sábio, ao ver pela primeira vez uma girafa, comentou: «Parece que foi feita por uma comissão».
} 
Apêndice D. 1

\section{THE PANDORAS BOX OF THE UNIVERSITY FOUNDATION}

In some seven months looking at the situation in and seeking to understand Brazilian higher education, we have heard a great deal about the «Fundação» as a legal device to «solve» or to «ease» at least many of the universities' problems. One of the principal advantages claimed for the «foundation» is that of «liberating» the universities of all the rules, regulations, and complexities of the DASP particularly with respect to the teaching staff. There are notable examples where the «foundation» scheme has been successful, the IBGE, the Fundação Getúlio Vargas.

The purpose here is not to argue for or against the foundation as a device but to suggest that adopting the foundation form of organization does not solve problems - it may make it easier to solve problems or it may simply convert one set of problems into a new set. To some extent, at least, a new system will let loose in the University system a whole new set of problems - the opening Pandora's box - and it is these that we examine here.

Teaching staff problems. In simplest terms, the personnel problems related to University professional staffs are: 1) Recruiting - attraction and hiring. 2) Retention - including a system of rewards and the development of a set of criteria for judging professional performance. 3) Release - perhaps a special case of «retention» but some provision may be made for retirement or simply «firing» for non-performance or some sorts of misconduct. 4) Protection - a special problem of «re tention» and of «release» which recognizes the very special nature of professorship in society.

Each of these will be expanded and explained more fully later. All systems face these same problems and well or badly resolve them. First, we examine the present system and its treatment of these aspects of the personnel problem and then we examine the new problems raised by «liberation» from the present system.

\section{THE PRESENT SYSTEM}

This description will be so brief as to be almost caricature partly to economize the reader's patience and partly because of my incomplete knowledge. Further, my comments pertain mostly to federal rather than state, municipal, or private institutions.

Recruitment. Under the present system, little attention is given to recruiting new staff or academic officers. The latter are elected which 
precludes a recruiting program in the usual sense of the word. Recruitment of professors cannot be vigorous either, since most are «externally conditioned» labor. As long as academic personnel is part-time and the academic appointment is not the principal employment, the attractiveness of the prime job is likely to be the determining factor with respect to location and so forth with the conditions of university employment remaining distinctly secondary. Fixed salaries and prescribed working conditions permit little flexibility for vigorous recruiting. The concurso, too, is a device much more appropriate to situations with a superfluity of qualified people seeking highly desired posts than to circumstances of shortages of qualified personnel. «External conditioning» severely limits mobility and thus restricts even further the numbers of people who can be effective candidates in any given concurso.

Retention. Once a professor has been employed his salary expectations are that he will be automatically granted inflation-corrections, seniority benefits, and a dependent's allowance. These are his «due», a «right» and can neither be withheld, reduced, or increased by the [acuidade or the university. Other emoluments are available and possible: 1) Differentiation of assigned duties but this is of limited significance under the cátedra system. 2) Dif ferentiation in research funds and assistants assigned. 3) Dif ferentiation in assignment of scholarships, leaves, etc. AU in ali, the system provides for very little flexibility for bargaining to induce personnel to remain. and from observation, I suspect that even that little flexibility is little employed.

Termination or reiease. The present system operates on one of two assumptions with respect to the selection of professors; 1) It is infallible, or 2) Permitting possible error, the university rather than the individual should bear all the costs of mistakes. However bad the selection may have been, however poor the professor may turn out to be, he cannot be removed. Apparently, even if the subject matter of his cátedra becomes obsolete, he cannot be removed. Thus the present system solves its «termination» problem by admitting only the possibilities of death, retirement (prolonged physical incapacity?), or voluntary resignation. The extent to which people can be induced to resign or to retire is unknown to me. But, in general, there is little flexibility.

Protection. Professors have long held a favored position because of the very nature of their tasks - to seek and to teach the truth, popular or unpopular, wherever it might be found. This simply could not be done with politicians businessmen, priests, or soldiers looking over their shoulders, dictating the áreas in which truth could either be sought or taught. The present system clearly recognizes this and maximizes protection for the professors.

These characterizations perhaps exaggerate and there are probably exceptions, but in general they are the impression an interested foreigner 
obtains in a relatively short period. Suppose now that the Fundação kind of organization permits the universities to establish their own policies with respect to professors. How will, and how can, these same problems be treated?

\section{UNDER THE «FUNDAÇÃO»}

Recrttitment. Given freedom and flexibility, the only obvious constraints on recruiting are budgetary. A particular university and its various components simply have to decide what the priorities are and allocate resources appropriately. But in the process, it faces many new questions, such as: 1) What percentage of the staff should be full-time? 2) Should this percentage be the same in all sub-units? 3) Does the University have any natural advantages which should be exploited or disadvantages which should be overcome? 4) Can special inducements be discovered, developed and offered — such as faculty housing, special research grants, etc? 5) To what extent is inter-institutional competition for professors to be permitted, i.e., will one institution be permitted to «buy» professors from other institutions?

It is clear from the questions that freedom and flexibility in recruiting raise many problems which the current system avoids. There follows a list of elements, briefly described, which have been important aspects of recruiting at one time or another. It demonstrates the many new facets of the task of hiring a professor.

a) Salary - Certainly salary and salary expectations are important aspects in hiring, which raises a criticai question of whether salaries ought be the same throughout the University for more or less equivalent professors (to be discussed below).

b) Faculty housing - especially for new faculty people. This is perhaps less important in Brazil than in the U.S. because of the much lower mobility of academic people here. ${ }^{2}$ Perhaps permanent housing for professors, subsidized or not, would be more appropriate here. The Universidad Nacional de Tucumán in Argentina, for example, provides some permanent housing for non-Tucumanos, recognizing the necessity of finding some means of attracting staff from other áreas. This substitutes in part for salary differentials which it cannot legally pay.

The reader is asked to pardon frequent reference to the U.S. in the examples which follow. This is the system with which I am most familiar.

2 As an indication of mobility, most good U.S. universities have a rule againft hiring their own graduate degree students until they has been away from the institutions for a number of years. This rule is to prevent staff inbreeding. Furlhermore, students are advised that it is preferable not to earn their graduate and underg-aduate degrees at the same institution in order to experience different approaches and become exposed to more professors. 
c) Low teaching toads - This is used for staff who put a high priority on research. It may be utilized to reduce loads every semester or occasionally. Suppose, for 'example, that the «normal" teaching load is three courses. A particulary sougth after person might be told he would be required to teach only two courses or not be required to teach at ali every third or fourth semester. There are costs to this policy, and reduced loads clearly cannot be offered to everyone.

d) Research funds, computer time - All aids to research may be important recruiting devices - and may even be the criticai items. A «star» may be attracted by magnanimity, ${ }^{3}$ and júnior people simply by a recognition of research needs such as an adequate library budget, sufficient secretarial assistance, etc.

e) Sabbatical and other leave policies - A «productive» professor expects to have every seventh year free for research, study, travei while receiving at least a substantial portion of his salary.

f) Travel - Especially for isolated institutions, liberality in paying for attendance at conferences, seminars, etc, may help overcome the isolation most scholars dread.

g) Consulting - Permission to do a limited amount of private consulting with or without pay may also be attractive, permitting the professor to supplement his income and to maintain contacts in the real world.

h) Finally no recruiting device will serve better than having an alert, dynamic, and recognized group within a respected university.

One of the principal problems was and is and will be salaries, and here we discuss one aspect. Should or should not salaries be the same throughout the University for full-time, «equally qualified» people? In the United States, we employ two different systems both of which suggest negative answers although one scheme is predicated on the reverse. The probleni essentially revolves around the fact that engineers, economists, chemists have no trouble in obtaining extra-university, wellpaying employment. Specialists in History, Portuguese, Musicology have few extra-university opportunities.

3 The «best» professorships in the U. S. now provide the professor with an adequate salary and in addition two or three times that salany to finance his personal research.

4 Frequently, he has a full-year at half-pay or a half-year at full pay.

5 These «devices» make the most sense for staffs that are essentially fulltime, and some such as $g$ ), make no sense at all for part-time staff. There are ali sorts of other possibilities. The University might establish a model, experimental shool and reserve places in it at reduced tuition for full-time professors' Shildren. 
The results is (whether one approves or not) that in our society an economist or engineer commands more in the market than the historian. One group of universities in the U.S. recognizes this and explicitly provides for different salaries for different career-specialists but tries generally to apply the same standards for promotion through the various ranks. Another group of universities adopted the plan that all instructors would be paid the same, all assistant professors the same, etc. Experience has demonstrated that this system, too, responded to the market, and progress through the ranks is much faster in the «active» or «hot» professions than it is in the others.

One may decry these facts of life but it is unwise to ignore them. To pay all professors in accord with those professions best recompensed by the market would be terribly expensive and seriously reduce the number of professors who could be employed. Even worse would be the policy of paying all professors at the market price of the least sought discipline which whould have the tendency of having university teaching done by the poorest engineers, the poorest lawyers, the poorest doctors.

Changing from the present system to the Fundaçao would certainly increase the number and variety of recruiting ploys which the universities could utilize. Having more choices should make it easier to solve the recruiting problem or, rather, it might make for a better solution to the recruiting problem. But it certainly increases the need for judgement and decision-making; and it suggests a transfer from highly probable system error to at least an increase in the probability of individual error. If one has no choice the process is simple (the results may be bad), but which choice, the process becomes complex - and hopefully the results better.

None of the above is «recommendation»; it simply attempts to examine at least the major alternatives that exist without attempting to judge them in the context of either Brazilian or U.S. higher education.

Retention - Once personnel has been recruited, the remaining problems concern how to keep those who perform adequately and how to avoid keeping those who do not. In this section, we discuss only the problem of retention but the two are inextricably intertwined.

The first real decision is the major one: will the system try to distinguish between those who perform adequately and those who do not and for what purposes? If it is decided that appointments are irrevocable

6 There are, of course, other incentives than salary for becoming a professor, but salary for many of us is an important consideration. Many young people leave the teaching profession simply because theiy cannot afford to stay in It just as many Brazilians cannot now afford to be full-time university professors even by combining two different posts. 
and for life, then this question is answered with respect to retention although it may still be of importance in other matters.

When we ask «Against what criteria are professors to be judged?», we are close to the heart of the problem of higher education. What is wanted, expected, from Brazilian higher education? Only when there is an adequate delineation of the national objectives for higher education can the set of criteria for measuring the performance of professors be developed. Professors will be, in the final analysis, the principal vehicle for carrying out the national objectives.

Be that as it may, and since my assigned task is to raise problems rather than to solve them, let me suggest some criteria which might be applicable given the over-all objectives:

a) Surely one major function of the system is that of teaching university students, and so a professor's teaching performance (some combination of native ability and interest) will figure largely in judging him. Unfortunately, we have no convenient meter to measure on a, say, «Dewey Scale» how good a teacher a man is; and all thinking university people will recognize at once the extremely difficult task of judging teaching performances .

The teacher I liked best as a student was an extremely conscientious gentleman who put an outline of each day's lecture on the blackboard. We listened, we copied, we memorized, we got good grades, but scarcely remember now what the course was about. The most aggravating professor was one who left us in doubt, who confused us rather than clarified everything, who raised more problems than he solved. As students facing examination, we disliked this man, but now, too many years later, it is no problem to see that it was from him that we got intellectual stimulation, that he required us to think, that he caused us to seek out the important problems and issues. This example suggests two ideas: 1) That the external trappings of a man's teaching may not be entirely adequate for judgement. 2) That current students may be helpful in evaluation of teaching performance but their opinions cannot be expected to be wholly reliable. The real test of teaching performance is how the student differs (from what he otherwise would have been) twenty years after he leaves the classroom; what he or any one else thinks while he is in the classroom is only an imperfect substitute for the real test.

There are other complications as well: 1) A single professor's performance may vary from subject to subject. Someome has to teach the less interesting and inspiring subjects. Is willingness to do this a part of teaching performance? 2) One man may best teach small groups of students at the 
frontiers of knowledge because this is where his interests and skills lie while another may be best lecturing to (and administering ) hordes of students in the most elementary courses. How do you compare the performance of the two? 3) In the same course, or subject, one person may be most effective using, say, the «lecture» method while another depends on the «socratic» method? Is there a preferred way - one more meritorious than the other? To raise these questions as imponderables does not suggest that no judgement should be made about teaching performance. If teaching is important, then it seems doubly certain that universities ought to make judgements about teaching performance even if precision is unattainable and occasional error likely. To refuse to exercise this responsability is to operate a system which assums that all professors are 1) equally good teachers and 2) equally interested in their teaching tasks. Experience demonstrates both propositions are false.

b) In addition to teaching it is probable that the university system would (should?) include research in its objectives. If it does, it must expect its «professional» staff (which may or may not be the same as its «teaching» staff) to do the research. And, again, if research be an objective, the university must be prepared to evaluate (or to assume all are equally competent, equally interested, and workind on equally important problems).

Perhaps evaluating research is easier than evaluating teaching, particularly since there are some external measures. If a person is repeatedly asked to present his findings at national and international congresses and/or if his findings frequently appear in nationally and internationally recognized professional journals, this is ordinarily clear-cut evidence of high quality research performance. But this by no means solves the problem of research evaluation: 1) How does one evaluate research on the magnum opus which takes years to produce? 2) How does one evaluate the honest and solid research of a national, regional, or local level which may never attract international attention. In a sense, this may involve the generally sterile distinction between «basic» and «applied" research. 3) How does one compare the «worth» of a research product in biology with one in history? with one in economics?

In the U.S., we operate generally under the dictum that «research and teaching go hand-in-hand» - whatever that may mean. It suggests that researchers must teach and teachers

7 Logically, the hypothes'zed unequal distributions of 1) and 2) could off-set each other (i.e. the unskilled being highly motivated and vice versa) so that all teaching performances would be equal. My experience suggests, on the other hand, that the two characteristics are more likely to be self-supporting (i.e. the unskilled being little motivated and the sk lled, highly motivated). 
must research, a view which includes a certain amount of nonsense, and Brazilian universities might take a careful look at this axiom. Good teachers clearly have to stay au courant in their fields, ${ }^{8}$ but this is not the same as saying they have to do original research. The presumption seems to be that if they are doing research they are staying up-to-date which may be erroneous. And students surely ought to be exposed to research - and to the best researchers, but again this need not mean that all researchers need be exposed to students.

c) Other activities may allso be considered in making judgements about the professor.

Among my prejudices is the following: A substantial part of the university system (but not necessarily all universities) should relate itself very closely to the problems of the society which created it. A university is a reservoir of knowledge and «know-how» which, to some extent, ought to be immediately available to the community. For example, I was assigned to teach «basic economics to various groups such as business executives, labor leaders, and all the employees of one entire factory. The most widely known example of this kind of activity in U.S. education is that of agricultural extension carried directly to the farmer and which is in larger measure responsible for the enormous increases in agricultural production in the last century.

This sort of activity is not a one-way street. In my own case, havind to prepare for a «non-captive» audience (which came or not depending on how interesting the subject could be made) improved my teaching tremendously as it required me to develop new techniques, to become more relevant, to «involve» the students, and to cull the material for irrelevancies and niceties.

The professor of almost any subject matter can learn by constant or occasional contact with the «public».

I do not wish to prejudge Brazilian objectives. These objectives could be important, and if they are. then the universities must find some way to accomplish the objectives another task for professors and about which their efficiency may need judgement.

d) Finally, there are the many intra-university activities which the professor must undertake, which absorb his time and require his knowledge. Curriculum development, constant attention to curricular changes, educational administration, the development and editing of university publications. These, and other activities are professional, are valuable, and may be part of

8 Even such «stable» fields as history, language, literature, etc., are under going constant substantive and pedagogical changes. 
university objectives. How are they evaluated and compared to other desirable activities?

$$
\text { * * * }
$$

The discussion of criteria for judgement implies an overall judgement of merit and suggests that merit is somehow to be rewardet. If merit is to be rewarded - - and the desire to get away from the automaticity of the DASP suggests that it is - there is the problem of judgement (which has already been discussed) and the problem of «rewarded with what?» There are various possibilities. It is frequently suggested to Yankee observers in Latin America that the «pay-off» for merit is prestige which carries over into one's non-university activity. The architect who is also a dean can collect fees greater than one who is only a professor who can collect more than the architect who is not a professor, etc., etc. This may very well be true, and it ought continue to be true that prestige would be highly desired and sought after under a new system. But if full-time university work becomes a desideratum, the possibility of translating prestige into beans disappears. There are probably a variety of systems which relate merit and reward, but I will raise questions about only two - rank and, to put it brutally, money.

Devising a system of rank is one way of distributing prestige. In the U.S., we have four principal ranks: instructor, assistant professor, associate professor, professor. There is nothing holy about these names or about the specific numbers. Perhaps there ought to be more ranks (if any at all) or less. The existence of ranks, of course, implies criteria for promoting persons from one rank to another. And it implies, as well, some mechanism for decision-making. There are two points to view in passing: 1) Automatic promotion as a function of time would negate the idea of rank and merit being related. 2) The problem of criteria and judgement on the matter of rank is not quite the same problem as occurs in the case of salary adjustments for merit. The former is a matter of level of accomplishment while the latter may be a matter of the increment of accomplishment.

With respect to money, it would be nice to feel that professors are not concerned about money - that they dedicate their lives to youth and to the pursuit of knowledge. Others might urge a change in the economic-social system so that such dedicated souls would not have to be concerned with material objectives. Until the millennium, houwever, money plays a role and in two very important respects: 1) If full-time teaching and research is thought desirable, then salaries have to be sufficient to attract young people into university teaching as a career. This means that the young person -without independent means must be able to look into the future and with some confidence feel that he can make a decent living for himself and his family in the university. ${ }^{8}$ If

9 With some awareness that professors and potential professors often have fairly high «standards of decency*. 
this cannot be done, the only people who can be attracted full-time to university careers are the independently wealthy, and there is little reason to think these are the best appointments. The services of others can be expected, at best, only on part-time bases. 2) Money, and specifically salary increments, can be utilized as part of a system of rewards. In my particular institution, ${ }^{10}$ we review each year the performance of each professional staff member using criteria pretty much as discussed above for purposes of making salary adjustments (from «zero» upwards) - - which we call «merit increases. This gives us both a «carrot» and a «stick» for rewarding meritious and chastising niggardly performance. We know that a person "with tenure»" who ceases to grow, who does not carry his share of the burden, who neglects his teaching will receive no salary increases while «average» performance will bring modest increases and exceptional performance large increases. This point should not be over-emphasized since it makes professors sound like kindergarden children. Maybe 95 per cent would behave no differently without this feature. Perhaps even the laggard is not affected by it, but it is occasionally a useful tool and more frequently a psychological catharsis to know that the colleague who slacks will not be equally treated. ${ }^{12}$

This scheme is not necessarily recommended; I repeat, I am only showing the kinds of problems that flexibility raises.

Release and protection - These two aspects of the personnel problem are so closely related that they will be discussed together. Essentially the problem is that the corps of professors desires to protect itself - for good and just reason - from outside pressure on its research and teaching and ultimately to protect its members from dismissal for unreasonable, cause from any source or for reason from the outside. This is the essence of academic freedom and few outside totalitarian states would argue that it should be otherwise.

Having decided that «academic freedom» ought to exist the problem arises as to «freedom to do what? or «freedom to not do what?» It is not arguable that academic freedom is total license - and the problem of drawing boundaries as to what is permitted and what is not permitted is the perennial problem. «Professional incompetence is generally not protected (but very difficult to prove), «moral turpitude (whatever that may mean) is not countenanced, persistent failure to perform one's assigned tasks probably also would not be protected. And there are many possibilities which are less clear: What about the

10 Michigan State University, East Lansing, Michigan.

11 To be explained below quite apart from this.

$12 \mathrm{We}$ assume, that mistakes in appointments will be made even when permanent appointments are made only after several years of observation; and, in fact, the assumption is correct. It is also the case that some institutions have a great deal more automaticity in their salary systems than described here. 
mathematics professor who uses his classroom to espouse the cause of Barry Goldwater? of «stop the bombing»? of a particular political candidate at election time? How about the occasional professor who, once he secures this protection, stops his intellectual activity? How about the professor who persistently misses his classes because of outside consulting? There are a great many possible «sins» which can be protected under the system which sets out only to protect the professor's right to research as he pleases and to teach the truth as it appears to him.

Providing «academic freedom*, then, involves some degree of protection for the professor - some degree of security in his job. But this raises important issues: 1) What sorts of activities are to be protected? At one extreme, we might suggest «zero» activities - or no academic freedom at all and at the other extreme the professor might be protected against harassment for illegal parking, against harassment by tax collectors, etc., and in between lies a continuum of activities. Somewhere on this continuum a point must be designated. 2) The greater the protection granted, the more likely it is that the system will incorporate various sorts of «undesirables» - the lazy, the incompetent, the slovenly, the disinterested. It seems clear that these are positively associated, that is, the greater the academic freedom the higher is the probability of protecting activities with characteristics not envisaged - or certainly not desired - in the original objectives. ${ }^{13}$ 3) If this proposition is correct, then, it is important to select personnel with extreme care and then to find some way to minimize the potential damage of the «mistakes».

There is, I suppose, an infinite range of possible systems. Again, without any recommendation, permit me to describe that system with which I am most familiar.

The U.S. system is the «tenure system» in which certain teaching personnel have appointments for definite periods of time (without tenure) while others have appointments of indefinite duration - essentially for life. These, we say, have «tenure». ${ }^{14}$ Essentially, «to have tenure* means that the professor may not be discharged except for certain abuses of the freedom, such as moral turpitude, consistent failure to abide by university regulations, etc.

The lower ranks are appointed without tenure. Instructors are generally appointed for one or two years and may be reappointed. Assistant professors are usually appointed for three years and may be reappointed. But generally the total period which a person may be employed without giving him tenure is six or seven years. For example,

13 I have thought for a long time, somewhat facetiously, that civil service arrangements are great for those countries that are without them but very bad for those countries that have them.

14 This is a corruption of the use of the term which properly is used in this context to describe an appointment of indefinite tenure. 
an assistant professor is appointed for three years and then reappointed for three years. Any subsequent reappointment automatically includes tenure. Promotion from assistant professor to associate professor usually includes tenure. New appointments of full professors (i.e., from outside the university) include tenure,,$^{13}$ new appointments of associate professors are usually for two to three years with any subsequent appointment to include tenure. There is generally nothing to prevent granting tenure sooner than the time limits suggested, and promotion to associate professor frequently occurs before the six-seven year trial period is over.

This system provides a decision-making period of several years during which time the university can presumably observe the individual in order to be able to make valid judgements about his teaching interests and abilities, about his research capacities, etc. But note, too, that the university is required to make a tenure decision: after a professor serves the «probationary» period, the university must decide whether or not he is a person employable for life. This aspect of the system is sometimes referred to as «up or out» and is justified on the grounds that six to seven years is long enough to make a decision and no one ought to be employed beyond that period without the ful security affored by academic freedom and that the University ought not to carry a person longer than that on a «tentative» basis subject to contract non-renewal for whatever reason.

No system is perfect that has to predict the professional activities of a man over a thirty-year period, ${ }^{10}$ but there are marginal ways of alleviating the effects of errors. The professor who refuses to do research and to publish may be assigned an extra heavy teaching load (provided of course that he is not a poor teacher). The poor, tired, old teachers are assigned unpopular class periods where their exposure to students is least and they may be assigned «house research instead of teaching simply to minimize the damage they can do. In a way, this is similar to the «parallel» classes sometimes organized in Latin American universities.

Elaborate procedures exist for dismissing a person with tenure. Some administrative officer initiates the proceedings. If the professor in question wants to dispute the action, a permanent committee of professors studies the case and makes a recommendation. If it finds against the professor, there is no further appeal. If it finds in his favor, the administration may either accept the findings and drop the matter or insist on the dismissal - by simply stopping salary payments. ${ }^{17}$ In the case of flagrant abuse of academic freedom, the American Associa-

15 The rationale is that at this level appointments are of senior people about whom a great deal is already known.

16 Assuming tenure is granted at age 35 and that he retires at 65 .

17 These cases are extremely rare. In fact, cases scarcely ever come before the faculty committee. 
tion of University Professors might finally act and publically censure the university after careful investigation. This carries no legal weight but is viewed seriously by our academic world. It is particularly difficult for a «censured» institution to recruit good professors.

\section{CONCLUSION}

Hopefully, I have demonstrated the vast array of problems that would arise in the management of professorial personnel alone if the present system were to disappear. And I have discussed and described a great many alternatives to the present system, but one aspect has been asiduously avoided: with all the decisions and judgements to be made, who is to undertake these activities?

This question in itself should be the subject of another paper, and I only want to comment in general on one or two aspects:

To improve the university, strong leadership on the part of one or a few individuals may be desirable and necessary - and over a considerable period of time. There is no guarantee that mediocre human institutions improve quickly or at all by utilizing the cumbersome mechanism of unfettered democracy. There is nothing magic in the process of adding the votes of mediocre people who may very well have a vested interest in the mediocrity — - the sum of the whole is no greater than its parts with no «plus» for dynamism and wisdom and quality.

If a principal task is the structural and administrative reform of the university (as we now see going on in Brazil), this should be regarded as the extensive renovation, if not the new construction, of a complex and important social structure. It is a long and complicated task and one which requires time, patience, and consistent leadership. One would not very likely start an architect out on an important construction task and say to him that in theree months he is to submit to re-election and at the end of six months he must vacate his office. ${ }^{18}$ Nor does one build many buildings with the real power of decision and the real authority vested in a commission and especially one elected from the parent group. There are enough problems in higher education without building «giraffes». ${ }^{19}$

In some senses this view is «undemocratic». The granting of authority and the delegation of the power to make and execute decisions always represent a compromise with the ultimate of democracy in which every constituent participates equally in every decision. These are twin problems of democracy: 1) the proper delegation authority and

18 These are short time periods because physical construction is much less complex and requires less time than building a university.

19 A savant on first seeing the animal commented, «It looks as if it had been designed by a committee. 
2) protection against the usurping of power and authority. Exclusive concentration on the second of these is apt to be condemnation to torpid mediocrity.

One final question in this recital of questions. Suppose that Organization $\mathrm{X}$ is deemed defective and that one of the reasons is that all or some of its members, regardless of fault, are defective - incompetent, poorly trained, unimaginative, lazy, too busy elsewhere. What sense does it make to start the reformation with the cardinal principal being that all present components must not be disturbed?

JOHN M. HUNTER

EAPES

Professor of Economics Michigan State University 
Apêndice D. 2

\section{MOEDA UNIVERSITÁRIA：O "CRÉDITO"}

Os planos de reforma universitária causaram bastante agitação intelectual no Brasil, quando foram amplamente discutidas as várias propostas, contra-propostas, técnicas, ideais, etc, nos Corpos Docentes, nos Conselhos Universitários, nos grupos de estudantes, no Congresso e nos jornais. Alguns querem seguir o sistema educacional dos Estados Unidos; outros condenam, a princípio, qualquer aspecto da Educação nos E.U.A. - e ambos o fazem sem qualquer exame ou compreensão da realidade educacional daquele país. Existem outras implicações sócio-políticas ao se procurar copiar as Universidades deste país, e não tenho a intenção de discuti-las neste trabalho. Nem proporei qualquer método ou sistema para ser adotado pelos brasileiros. Na verdade, minha intenção é explicar o uso do «crédito» universitário, sobre o qual existe considerável confusão no Brasil, e sobre o qual várias pessoas têm me perguntado.

O crédito é tão apolítico como o dólar, o rublo ou a piastra. Pode-òe atacar os E.U.A., a Rússia ou o Vietnam e seus sistemas econômicos, políticos, religiosos e/ou sociais, mas é pouco provável que isto seja feito atacando-se a unidade de cálculo, o meio de troca, a moeda. E o crédito é simplesmente, nem mais nem menos, a unidade de cálculo que é largamente utilizada na educação universitária dos E.U.A. E me proponho a explicá-lo como tal: uma unidade cálculo. que tem provado sua utilidade, num sistema onde ela é necessária. $\mathrm{O}$ Brasil não precisa utilizá-la, pois seu sistema universitário não possui as características que a exigiriam. Eu poderia estar ou não a favor de mudanças no sistema que exigiriam um sistema de cálculo semelhante, mas isto é outro assunto, que não será tratado aqui.

As três características que nos levaram a exigir um sistema de contabilidade universitária são as seguintes: 1) Existe grande mobilidade de estudantes entre as instituições e as disciplinas. Nós utilizamos os «créditos» para avaliar o que o estudante pode transferir de uma instituição para outra, de um curso de graduação ou pós-graduação para outro. 2) Os cursos têm, via de regra, grande flexibilidade e incluem a possibilidade de selecionar várias cadeiras optativas. É muito pouco provável que dois estudantes quaisquer venham a cursar exatamente o mesmo conjunto de disciplinas, e portanto é necessário algum dispositivo para estabelecer-se uma equivalência entre eles. 3) Mesmo seguindo um único curso, um estudante normalmente tem aulas em 
vários departamentos, além daqueles pertencentes ao seu principal campo de estudo. Sempre que isto ocorre, é necessário algum tipo de avaliação do que está sendo oferecido. Estas são as características que deram origem ao sistema de «créditos» ou qualquer sistema semelhante, algo de indispensável, mas parte completamente auxiliar dentro do sistema universitário.

Os «créditos» são simplesmente «pesos» dados a cada disciplina oferecida pela Universidade. A norma para determinar o número de créditos de uma disciplina é geralmente o seu número de horas de aula por semana. Porém, esta «norma» é modificada de acordo com o conteúdo da matéria. Assim, uma cadeira de Matemática com cinco horas de aula por semana (e exigindo uma média de duas horas de estudo além da aula por cada hora de aula) ' teria «cinco créditos». enquanto que uma cadeira de Inglês com três horas de aula por semana teria «três créditos». Ao interpretar-se este fato, pode-se dizer que êle significa que a cadeira de Matemática «vale» 1,67 vezes a cadeira de Inglês. Algumas disciplnas têm horas de trabalho em laboratório. substitutos para o estudo fora da aula, e portanto a norma de hora-de-aula exige uma modificação. Uma cadeira de Física com duas horas de aula e seis de laboratório pode ser avaliada como uma disciplina de 5 créditos. Outras, tais como Educação Física, que exigem pouco tempo de estudo fora das aulas, podem ter duas horas de aula por semana, mas valer somente 1 crédito ou mesmo $1 / 2$ crédito. Assim, cada matéria oferecida pela Universidade tem o seu valor em termos de «crédito» o seu peso. ${ }^{2}$

As Universidades geralmente descrevem suas exigências para graduação em termos de um mínimo de créditos ${ }^{3}$ e de um mínimo de grade points. deixando a cada departamento a descrição de suas exigências especificas. Pode-se supor que um estudante normal vai despender cerca de 48 horas por semana com seus estudos. Deste modo, se cada período letivo normal é de três quartos ${ }^{5}$ de dez semanas, teríamos uma carga «normal» de 16 «créditos» por período letivo (16 horas de aula e 32 horas de estudo além da aula). Três períodos letivos

1 Esta é uma parte essencial da definição, embora muito ambígua.

2 Existem também disciplinas que não contam créditos, que podem ser cursadas para fins de suplementação (por exemplo: estudar uma matéria que deveria já ter sido cursada antes) ou simplesmente para fins profissionais ou culturais sem relacionar-se aos estudos para graduação.

3 Os currículos podem não ser todos semelhantes entre si. Contudo, a maioria dos cursos de graduação têm quatro anos, o que permite um mesmo número de créditos exigidos para graduação em todos os cursos. Existem somente exceções ocasionais.

4 A ser explicado posteriormente.

5 Muitas instituições funcionam na base de cada semestre com 16 semanas, ao invés de três quartos de 10 semanas (ambos os períodos excluem o tempo dedicado a matrículas e exames). Em princípio, estas diferenças não são relevantes. 
por ano dariam então 48 créditos a serem obtidos por ano. Multiplicando-se este valor pelo número de anos dos cursos (quatro), teríamos um total de 192 créditos. Este total é pois a base, para toda uma Universidade, das exigências para graduação. Com respeito unicamente a estas exigências, o objetivo do estudante é cursar, com aprovação, disciplinas cujo valor total em créditos seja igual ou maior do que 192.

Outra parte das exigências da Universidade para a graduação é um mínimo de grade points. Isto requer uma explicação. Essencialmente, é a tentativa de medir, através de um só índice, o desempenho de um estudante, tendo por base o valor explícito das disciplinas em si (i.e.. os créditos) e a qualidade do trabalho do estudante. Geralmente atribui-se ao estudante, ao concluir os estudos de uma disciplina num período letivo, notas em termos de letras: A, B, C, D e F. Atualmente já se fixam valores numéricos para estas letras, conforme relação abaixo:

$$
\begin{aligned}
& \mathbf{A}=\mathbf{4} \\
& \mathbf{B}=\mathbf{3} \\
& \mathbf{C}=\mathbf{2} \\
& \mathbf{D}=\mathbf{1} \\
& \mathbf{F}=\mathbf{0} \text { e reprovação }
\end{aligned}
$$

\begin{tabular}{|c|c|c|c|c|c|}
\hline $\begin{array}{l}\text { DISCIPLINAS } \\
\text { (NAS QUAIS O ALUNO } \\
\text { SE MATRICULOU) }\end{array}$ & $\begin{array}{l}\text { (b) } \\
\text { NÚMERO DE } \\
\text { CRÉDITOS }\end{array}$ & NOTA & $\begin{array}{l}\quad(d) \\
\text { CRÉDITOS } \\
\text { OBTIDOS }\end{array}$ & PONTOS & $\begin{array}{c}\text { (f) } \\
\text { "GRADE } \\
\text { POINTS" }\end{array}$ \\
\hline & 5 & \multirow{6}{*}{$\begin{array}{l}\mathbf{C} \\
\mathbf{B} \\
\mathbf{A} \\
\mathbf{F} \\
\mathbf{C}\end{array}$} & 5 & \multirow{2}{*}{$\begin{array}{l}2 \\
3\end{array}$} & 10 \\
\hline$\ldots 201$ & 3 & & 3 & & 9 \\
\hline Filosofia & 3 & & 3 & 4 & 12 \\
\hline Alemão. & 3 & & $\mathbf{0}$ & $\mathbf{0}$ & $\mathbf{0}$ \\
\hline \multirow[t]{2}{*}{ Contabilidade. } & 4 & & 4 & \multirow[t]{2}{*}{2} & 8 \\
\hline & 18 & & 15 & & 39 \\
\hline
\end{tabular}

Temos, no exemplo que se segue, o cálculo de grade points para um estudante que teria seguido determinado curso durante certo período letivo.

A coluna a contém o nome das disciplinas, identificadas por números, por uma questão de conveniência da instituição. Os valores em créditos das disciplinas que o estudante cursou estão representados na coluna $b$. A coluna c indica a nota que êle recebeu em cada disciplina. Uma vez que êle foi reprovado em Alemão, o total de créditos obtidos (col. d) foi menor do que o valor total de créditos das disciplinas nas quais se matriculou. A coluna e simplesmente inclui o valor numérico equivalente às notas obtidas, e a coluna $\mathrm{f}$ contém o número de grade points para cada disciplina; é o produto das colunas $b$ e e. Deve-se 
notar que na cadeira de Matemática, que vale cinco créditos no exemplo acima, êle obteve nota $\mathrm{C}$, o que lhe deu mais pontos do que a cadeira de Contabilidade, que vale quatro créditos, onde êle também obteve nota C. Nosso estudante obteve assim 15 créditos a serem computados para sua graduação, tendo uma média de grade points igual a 2.17 para aquele período letivo (o total de grade points obtidos dividido pelo valor total em créditos das disciplinas, e não pelos créditos obtidos).

Se voltarmos um pouco atrás no seu histórico escolar, verificaremos que este é o quarto período letivo do nosso estudante e que êle obteve anteriormente as seguintes médias:

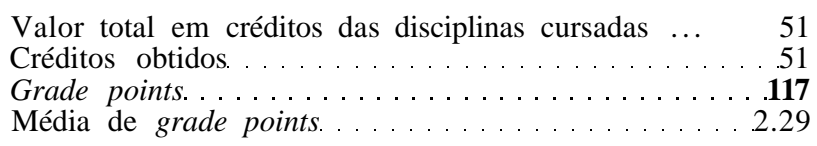

Os valores acima são facilmente atualizados, incluindo-se o período letivo que examinamos há pouco:

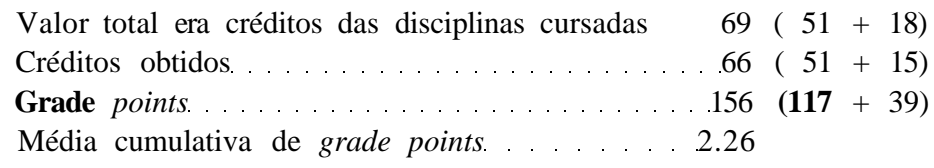

A partir desta explicação razoavelmente detalhada, ${ }^{6}$ deve ficar bem claro qual é uma das principais utilidades do sistema de créditos: é possível obter-se, através de cálculos com as notas em termos de números, um resumo numérico do desempenho do estudante. Este resumo de médias de grade points é muito importante para nós. Dentre outras, tem as seguintes finalidades:

a) Os requisitos para graduação numa Universidade são descritos em termos de um mínimo de créditos e de um mínimo de grade points. Por exemplo: pode ser exigida uma média cumulativa de grade paints no mínimo igual a 2 .

b) Exige-se que os estudantes mantenham uma média de grade points predeterminada, a fim de poder permanecer na Universidade. Se sua média fôr inferior a 2.0. por exemplo, o aluno pode passar a uma situação experimental (probation), durante um período letivo, no qual será exigido que êle obtenha um mínimo de 2.0 ou então deixe a Universidade.

c) Um departamento pode não permitir que um estudante obtenha um diploma na sua especialidade sem que êle tenha um desem-

6 Este não é um enunciado definitivo, e alguns detalhes foram deixados de: lado. Dependendo do motivo, podem ser dadas diferentes notas ao estudante que não consegue terminar uma disciplina. Pode ser dado um tratamento diferente às notas obtidas quando uma disciplina é repetida (o que conta são somente as notas obtidas nas disciplinas nas quais finalmente passou?). 
penho satisfatório mínimo nas disciplinas daquele departamento, como, por exemplo, ter obtido uma média igual a $2.0 \mathrm{em}$ todas as cadeiras de Física para que êle possa graduar-se em Física.

d) Existem algumas finalidades para as quais é importante podermos definir um estudante como primeiranista, segundanista, terceiranista. ${ }^{7}$ Esta definição é obtida simplesmente através do número de créditos que êle obteve. Os estudantes que têm menos de 45 créditos poderiam ser chamados de primeiranistas, os que têm de 45 a 89 créditos de segundanistas, etc.

e) As cargas máximas das disciplinas são descritas em termos de créditos. Alguns estudantes têm permissão para cursar um maior número de créditos do que o máximo normal, caso tenham um grade points suficientemente elevado. Os estudantes que tivessem uma média de grade points igual a 3.5 poderiam ter permissão para cursar um número de disciplinas que totalizaria até 20 créditos por período letivo, enquanto aqueles que tivessem uma média de grade points menor do que 2.2 poderiam ter o seu número de créditos limitado a 15 .

f)' Para algumas finalidades (tais como pagamento de taxas), é necessário classificar o estudante como de «tempo integral» ou de «tempo parcial». O primeiro pode ser definido como o que se matriculou para «13 ou mais créditos», e as taxas seriam pagas «por crédito» para aqueles matriculados com menor número de créditos.

g) Até certo ponto, os programas da Universidade são divididos em subprogramas: divisão inferior (ciclo básico) e divisão superior ou especializada (ciclo profissional). Para promover um estudante da divisão inferior para a superior, geralmente se exige uma determinada média de grade points - quer numa base global, quer em algumas disciplinas específicas.

h) Além disso, nós o usamos no setor administrativo. Um determinado departamento pode ter 500 alunos frequentando suas aulas, outro cerca de 600. Mas isto pode ser uma medida má em função do tamanho da carga dos departamentos. Se o primeiro tem todas suas disciplinas de 4 créditos e o segundo de 3 , o primeiro tem uma carga de ensino igual a 2.000 créditos e o outro só de 1.500. É útil conhecer estas diferenças para a distribuição de recursos entre as várias unidades.

O «crédito» como dispositivo de cálculo e de descrição tem ainda outra importante utilidade na elaboração de currículos específicos. Em

7 Como, por exemplo, na distribuição de entradas, tendo por base a «antiguidade» para, digamos, uma partida de futebol. É necessário um alto grau de não ambiguidade! 
Economia, por exemplo, exigimos que os estudantes cursem as seguintes disciplinas:

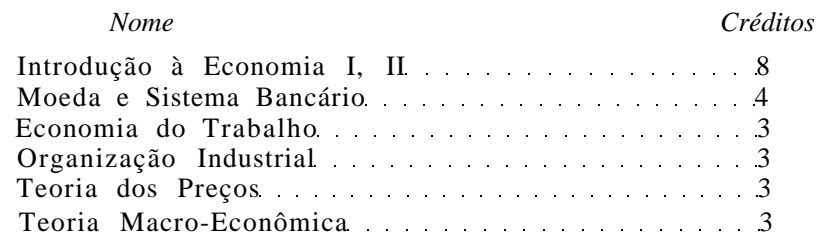

Além destas, outras disciplinas do Departamento de Economia devem ser cursadas, a fim de totalizar 45 créditos (cerca de $1 / 4$ dos requisitos para a graduação). Exigimos que eles cursem matérias chamadas de «instrumentais» num total de 18 créditos, 12 dos quais devem ser escolhidos de uma única disciplina «instrumental». Temos um curso destinado a tratar de temas atuais para os estudantes de modo geral, mas não para o especialista, e assim, na descrição das cadeiras, acrescenta-se que aquela «não conta créditos para o estudante de Economia especializado» (major). ${ }^{8}$ O Departamento de Matemática ministra aulas sobre uma disciplina específica em diferentes níveis de intensidade. e portanto caracteriza uma de suas disciplinas como a que «não vale créditos para estudantes com créditos em Matemática 208».

Deve-se mencionar uma utilidade final para o sistema de créditos. Quando o estudante se transfere de uma instituição para outra, seu trabalho na primeira é avaliado em termos das disciplinas que êle cursou, do seu desempenho nestas disciplinas, e finalmente o que êle pode transferir para a nova instituição. Isto é afinal convertido em «créditos de transferência».

Procuramos descrever aqui este animal peculiar, a unidade de cálculo das Universidades dos E.U.A.: o «crédito». Deve ser lembrado que êle é simplesmente isto: um dispositivo de cálculo, uma unidade de cálculo. Teve sua origem num sistema de considerável mobilidade e flexibilidade e na necessidade de lidar com grandes quantidades de estudantes.

É, como afirmam seus críticos, mecanista, mecânico e dá considerável ênfase às notas. Mas, em última análise, o sistema de créditos procura unicamente pesar os cursos, uns em relação aos outros. Neste

\footnotetext{
8 Major é o estudante que já escolheu definitivamente seu campo de especialização. Um major em economia c um estudante do Departamento de Economia que seguiu os requisitos do currículo, a quem o Departamento provê aconselhamento $\mathrm{cm}$ particular, e que será normalmente indicado para a obtenção de um diploma em Economia pelo Departamento.
} 
aspecto deve ser mecânico e não ambíguo. Juntamente com as notas (tentativas para «objetivar» um assunto especialmente subjetivo), os créditos podem ser utilizados num procedimento lógico para obter-se um resumo ponderado do desempenho individual. É isto o que pedimos seja feito pelo sistema; se seus resultados são ou não tratados, adequadamente, é outro assunto muito diferente.

JOHN M. HUNTER

EAPES

Michigan State University

Tradução de

Jacques R. Velloso

! , . ?

Janeiro - 1968. 
Apendice D. 2

\section{ACADEMIA CURRENCY: THE "CREDIT"}

University reform plans have caused a good deal of intellectual turmoil in Brazil as various proposals, counter - proposals, techniques, ideals, and so forth have been widely discussed in the Faculties, University Councils, in students groups, in Congress, and in the newspapers. Some want to follow the U.S.; some are ready to condemn any aspect of U.S. education - both without examination or understanding. There are certain politico-socio implications in emulating U.S. universities, and I have no intention of discussing those here. Nor will I propose anything here for Brazilian adoption. Rather, my propose is to explain the use of the academic «credit» about which there is considerable confusion in Brazil and about which a number of people have asked me.

The «credit» is as a-political as the dollar, the ruble, or the piastre. One might attack the U.S., Russia, or the Vietnamese and their economic, political, religious, and/or social systems but one hardly does this by attacking the unit of account, the medium of exchange, the currency. And the «credit» is simply no more - or less - than the unit of account which is widely used in U.S. university education. And I propose to explain it as such - a unit of account. It has proved useful to us in a system where we needed it. Brazil does not now need it since the university system does not have the characteristics which would require it. I might or might not favor changes in the system which would require some similar system, but this is another matter nor to be here discussed.

The three characteristics which have led us to require an academic accounting sistem are tho following: 1) There is great student mobility between institutions and courses. We utilize «credits» to evaluate what he is permitted to carry over from one institution to another, from one degree program to the others. 2) Academic programs in general have great flexibility and include possibilities for many electives. No two programs may be exactly the same in terms of classes taken and some device for establishing equivalence is needed. 3) Even in following a single course, a student ordinarily takes classes in many departments other than that of his major field of study. When he does this, some sort of evaluation of the offerings is necessary. These 
are the characteristics which have made the «credit» system or something similar to it an indispensable but entirelly ancillary part of the university community.

«Credits» are simply «weights» given to each course offered by the university. The standard for assigning credits to a course generally is the number of hours which it meets per week. Modification are made from this «norm». Thus, a mathematics course meeting five times per week (and requiring on the average two hours of outside study for each hour in class ${ }^{x}$ ) would carry «five credits while an English class meeting three hours per week would be a «3-credit» course. This can be interpreted to mean the mathematics course is «worth» 1.67 times the English course. Some courses may have laboratory periods which substitute for outside study, so that the hours-in-class standard requires modification. A physics class with two hours of lectures and six of laboratories might be evaluated as a 5-credit course. Others, such as physical education, which require little outside preparation might meet two hours per week but only be designated as 1 -credit or even $1 / 2$-credit courses. Thus, each course offered by the university has its «credit» evaluation - its weight.

Universities generally describe their graduation requirements in terms of minimum credits ${ }^{3}$ minimum grade points, ${ }^{4}$ leaving to each department the description of its own specific requirements. Thus, if the normal academic year is three quarters ${ }^{5}$ of ten weeks each, and the normal student can be expected to spend about 48 hours per week at his education, we woul have a «normal» load of 16 credits per term (16 hours in class and 32 hours in outside preparation). Three terms per year then whould give 48 credits to be earned per year times a four-year normal program giving a total of 192 credits. This, then, is the basis for a universitywide graduation requirement. With respect to this requirement alone, then, the student's objective is to take successfully courses whose total «credits» will equal or surpass 192.

Another part of the university's graduation requirement will be a minimum «grade-point». This requires explanation. Essentially, this

This is a critical put very ambiguous part of the definition.

2 «Non-credit» courses exist, too, which may be taken for remedial purposes (e.g. to study some subject which sould have been mastered earlier) or simply for cultural or profissional purpose not related to seeking a degree.

Not all curricula may be the same. Most undergraduate degree programs are four-year programs, however, which permits an equal credit requirement for all degrees. There are only occasional exceptions.

4 To be explained later.

5 Many institutions operate on a 16-week semester basis instead of 10-week quarters (both periods exclude term devoted to examination and registration). This makes no difference in principle. 
attempts to measure in one index student performance based on the explicit value of the courses themselves (i.e. credits) and the quality of student's work. We generally mark students A, B, C, D, F at the end of each course and have now assigned numerical scores to these as follows:

$$
\begin{aligned}
& A=4 \\
& B=3 \\
& C=2 \\
& D=1 \\
& F=0 \text { and failure }
\end{aligned}
$$

(a)

COURSE

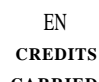

CARRIED

to
GRADE

d)
CREDITS
EARNED to POINTS GRADE POINTS b $\mathrm{x}$ e

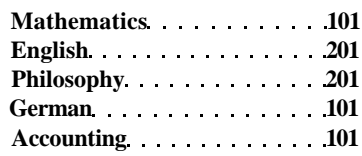

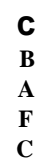

10

9

12

0

8

15

Column a represents the course names, identified by number for convenience. Column $b$ represents the credits for each course the student carried. Column $\mathrm{c}$ indicates the grade he received in each course. Since he failed German, he earned (Column $d$ ) fewer credits than he carried. Column e simply include the numerical equivalent to the latter grade, and Column $l$ records the grade points for each course and is the product of Columns $b$ and e. Note, for example, that the 5 -credit mathematics course with the $\mathrm{C}$ grade gave our student more points than the 4-credit, C-grade accounting course. Our student earned 15 credits toward graduation and had a 2.17 grade-point average for the term (total grade-points earned divided by «credits carried, not «credits earned).

If we look a little deeper, we discover that this is the fourth term for our student and that previously he had:

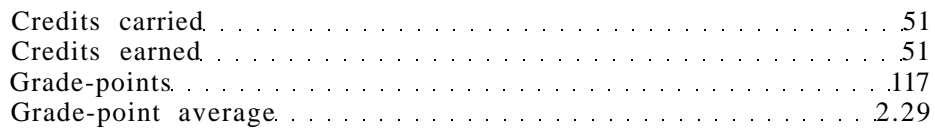

This is easily brought up to date to include the term we just looked at:

Credits carried.

$.69(51+18)$

Credits earned

$66(51+15)$

Grade-points

$156(117+39)$

Cumulative grade-point average

2.26 
From this rather uetailed explanation, ${ }^{6}$ one of the principal uses of the credit system should be clear: in conjunction which numerical grades, a numerical summary of student performance is possible. This gradepoint-average summary is very important to us. Among others, it has the following uses:

a) University graduation requirements are described in terms of minimum credits and minimum grade points, i.e., a cumulative «2-point» might be required.

b) Students are required to maintain a stated grade point average in order to remain in school. If they fall below a 2.0, for example, they might be placed on academic probation for one term in which they would be required to bring their performance back up to a 2.0 or to leave school.

c) A department may not permit a student to graduate with a degree in its speciality without the student's having some minimum performance in the courses of that department - e.g. having a 2.0 average in all physics courses to receive a degree in physics.

d) For some purposes, it is important for us to describe a student as a first-year, second-year, third-year student. ${ }^{7}$ We do this simply by defining these in terms of credits earned. Students having less than 45 credits might be called first-year students 45 to 89 , second-year students, etc.

e) Maximum course loads are described in terms of credits. Some students are permitted to carry additional credits if they have a sufficiently high «grade-point».

Students with a 3.5 grade point average might be permitted to «over-load» to 20 credits per term while those with less than 2.2 might be restricted to 15 .

/) For some purposes (such as fee collection), it is necessary to classify students as «full-time» or «part-time» students. The former might be defined as one enrolled for « 13 or more credits» and fees collected on a «per credit» basis for students enrolling for fewer credits.

g) To some extent university programs are divided into lower division (ciclo basico) and upper division or specialized (ciclo profissional) sub-programs. Passing from the lower to the

6 This is not a definitive statement and some details are left out. Different grades may be given the student who fails to complete a course depending on whose fault it is, etc. Different treatment may be given to grades received when a course is repeated (does the last grade only count?) .

7 As for example in distributing tickets on a seniority basis to some function. A high degree of non-ambiguity is required! 
upper generally requires a certain grade point average - either on an over-all basis or in certain specific courses.

The «credit» as an accounting and descriptive device has another important use in the development of specific curricula. In economics. for example, we require students to take the following courses:

Name

Credits

Introduction I, II 8

Money and Banking ....................... 4

Labor Economics. . . . . . . . . . . . . . . . . . . . . . . . . . . 3

Industrial Organization ........................ 3

Price Theory. . . . . . . . . . . . . . . . . . . . . . . . 3

Macro Theory ............................. 3

and in addition other economics courses to total 45 credits (about onefourth of the graduation requirement). We require him to take eighteen credits of «tool» subjects, twelve of which must be chosen from a single discipline. We have one course designed to treat of current topics for the general student but not for the specialist so we add to the description of that course «not for credit to economics majors». ${ }^{8}$ The mathematics department teaches a particular subject at different levels of intensity so it distinguishes one of its courses «not for credit to students with credit in Math 208».

Our final use of credits should be mentioned. When a student transfers from one institution to another, his work at the first is evaluated in terms of the courses be took, how well he did, and finally, what is allowed to carry over into the new institution. This is finally converted into «transfer credits.

We have attempted herein to describe this peculiar animal, the U.S. university's accounting «credit». It must be remembered that is is just that: an accounting device, a unit of account. It grew out of a system with considerable mobility and flexibility and the necessity of handling large numbers of students.

It is, as its critics claim, mechanistic, mechanical and puts a good deal of emphasis on grades. But in the final analysis, the credit system

8 A «major» is a student who has definitely selected his field of specialization. An «economics major» is a student of the Department of Economics, follows its curricular requirements, is officially advised by the Department, and will eventually be certified for a degree in economics by the Department, 
seeks only to weigh courses in relation to each other. It is supposed to be mechanical and unambigous $\mathrm{n}$ this respect. Coupled with grades (attempts to «objectivize» an essentially subjective matter) credits can be used in a logical procedure to give a weighted summary of individual performance. This is what we ask the system to do; whether we treat the results properly is another matter.

JOHN M. HUNTER

EAPES

Michigan State University

January, 1968- 
Apêndice D.3

\section{NOTAS SOBRE A HETEROGENEIDADE}

Há na Educação superior brasileira forte tendência para que exista identidade entre todos os elementos do sistema, para a tentativa de fazer de cada instituição educacional a imagem das demais. Encontra-se esta tendência nos regulamentos federais e no reconhecimento das profissões, nos vários dispositivos da Lei de Diretrizes e Bases, nos poderes e atividades centralizados do Conselho Federal de Educação. Sugere-se neste trabalho que a heterogeneidade entre as instituições é de considerável valia - é uma característica que merece, por si só, ser buscada. Este tópico será desenvolvido em duas partes: na primeira encontraremos breve caracterização ou descrição da Educação superior nos Estados Unidos, no que toca a este tema. Escolhi os Estados Unidos, porque é esta área geográfica com a qual estou mais familiarizado, porque ilustra convenientemente a segunda parte deste trabalho, e porque, através da pouca experiência que possuo, verifiquei que os brasileiros estão bastante mal informados sobre a natureza da Educação nos Estados Unidos. Na segunda parte veremos algumas das vantagens encontradas na heterogeneidade. Mas antes de tratarmos destes pontos principais, existem alguns aspectos suplementares a serem considerados:

1) A heterogeneidade ocorrerá, até certo ponto, mesmo que não tenha sido planejada ou desejada, ou mesmo que contra ela existam leis. Instituições tais como as Universidades são instituições sociais e suas características são provenientes da legislação básica existente, dos seres humanos que a elas estão ligados, das características nacionais e regionais, dos recursos disponíveis e das capacidades para utilizar estes recursos, etc. Mesmo que existisse uma lei descrevendo minuciosamente as Universidades, e mesmo que esta lei determinasse que todas deveriam ser iguais nos mínimos detalhes, isto simplesmente não ocorreria. Contudo, não é nesta heterogeneidade acidental e marginal que estou interessado.

2) Ainda não está definido até que ponto a heterogeneidade pode ser «planejada». Parece um tanto duvidoso que vários graus de heterogeneidade possam ser criados ou exigidos por meio de leis ou ordens administrativas. Mas se ela não pode ser especificamente planejada. certamente pode-se «criar condições» para que ela ocorra, tendo-se o cuidado de - ao planejar-se a Educação - dar à legislação básica uma natureza geral, que permita experiências, e tendo-se realmente em vista a expectativa de que instituições e circunstâncias não previstas possam desenvolver-se. 
3) A heterogeneidade no sistema de Educação superior implica considerável grau de mobilidade entre os estudantes. Assim, se país tiver três escolas para especialização em Economia (não confundir com administração de empresas ou contabilidade), isto implica em que os estudantes interessados nesta matéria devem poder e querer ir para as localidades onde se encontram estas escolas. Estou perfeitamente ciente de que esta mobilidade não é, hoje em dia, comum entre os brasileiros, mas desejo frisar que não existe alternativa prática para encontrar meios de desenvolver este tipo de mobilidade. Este assunto será discutido posteriormente, mas permitam-me ilustrá-la rapidamente, com um simples exemplo. Suponhamos que seja bastante desejável que o Brasil tenha um aumento anual de 40 psicólogos altamente treinados. Eles poderiam estudar em duas ou três escolas que graduariam 15-20 estudantes por ano, ou nas Universidades federais que diplomariam dois estudantes anualmente, cada uma. O custo da última alternativa será muito maior e a qualidade dos resultados muito menor. Sugiro também que não devemos supor uma falta total de mobilidade: há evidências, desde os dias de Brás Cubas, que os brasileiros estão dispostos a migrar em busca da Educação quando esta migração parece ser compensadora. Embora no passado esta disposição tenha sido amplamente demonstrada pela migração internacional, isto não exclui necessariamente a mobilidade dentro do País em busca da Educação.

Espero mostrar nos próximos parágrafos alguma coisa sobre a heterogeneidade da Educação nos Estados Unidos. Não porque penso que este seja um padrão que deva (ou que não deva) ser aplicado ao Brasil, mas porque é um padrão de heterogeneidade que auxiliará a esclarecer o que nós, naturais dos Estados Unidos, temos em mente quando falamos da Educação superior deste País.

A Escola «Superior». Um tipo de Universidade é aquela instituição pequena, de artes liberais, ' de nível superior e de cursos para graduação, tais como o Swartmore College, e os de Oberlin, Reed, Pamona, etc. São de nível «superior» no sentido de que aceitam para matrícula somente a elite intelectual. Não possuem cursos de pós-graduação e concentram-se num ensino excelente para os seus estudantes de primeira categoria. O número de alunos por professor é geralmente baixo, mas èspera-se que os alunos realizem boa parcela de seu estudo por eles próprios. Em Swarthmore, por exemplo, os estudantes, «honors» do terceiro e quarto anos não frequentam aulas - no sentido usual de expressão - e realizam a maior parte do seu a«prendizado» através de trabalho independente de pesquisa. Grande parte de graduados destas

1 A função das Faculdades de Artes Liberais se assemelha àquela das Faculdades de Filosofia no Brasil. 
instituições frequentam escolas de pós-graduação para fazerem seus estudos de pós-graduados em Medicina, Administração, Educação, etc.

A «Liga da Hera». ${ }^{2}$ Outro grupo de instituições, que poderíamos chamar de «Liga da Hera», é certamente mais conhecidos dos brasileiros: Harvard, Yale, Princeton, Columbia, Massachusetts Institute of Technology, John Hopkins. entre outras. Foram, há algum tempo, a elite das instituições para cursos de graduação nos Estados Unidos, mas atualmente têm importância muito maior como as mais notáveis instituições para estudos de pós-graduação. Sua função mais importante é, evidentemente, a de proporcionar nível de estudos o mais elevado possível para o preparo do futuros pesquisadores e professores de todo o país. Todas possuem cursos de graduação e selecionam rigorosamente aqueles que são admitidos, e seus diplomas de graduação são muito procurados. Mas o conjunto de excelentes professores, magníficas bibliotecas, os milhões de dólares destinados a pesquisas (que auxiliam a financiar os estudantes de pós-graduação) são fundamentalmente destinados a manter o setor de pós-graduação.

As instituições «land grant». Outro grupo de instituições extremamente importantes são as Universidades estaduais, tais como a Universidade da Califórnia, a Universidade de Minnesota, a Universidade de Wisconsin, a Universidade do Estado de Michigan, a Universidade de Illinois, a Universidade de Pennsylvania, dentre as mais conhecidas. Estas podem ser consideradas como o principal sustentáculo do sistema. Historicamente tiveram a função de levar a efeito, ao nivel de ensino superior, a filosofia característica da Educação nos E.U.A., ou seja, a de que todos os cidadãos capazes têm de ter uma oportunidade de estudar. As principais instituições estaduais são instituições land grant, cuja existência se tornou possível graças à Lei Morrill, de 1865, que determinava a doação de terras federais a cada Estado, para que a renda destas terras fosse destinada ao estabelecimento de instituições de ensino superior. Estas deveriam dedicar-se, dentre outras coisas, a ensinar «artes agrícolas e mecânicas» aos filhos e filhas dos fazendeiros e trabalhadores. Nenhuma destas instituições atualmente se considera dentro de limites tão restritos, mas a concepção de uma Universidade em cada Estado, dedicada ao desenvolvimento e ao ensino na área de assuntos tão mundanos como agricultura e artes mecânicas (a precursora da Engenharia) foi algo de revolucionário nos dias em que a maioria do conteúdo da Educação era de natureza clássica ou teológica.

Assim chamada porque as Universidades são antigas, têm prédios de tijolos cobertos de 'hera. Isto teve uma conotação de riqueza e de elevado nível social, que agora está desaparecendo.

3 Os brasileiros que frequentam uma destas instituições como estudantes em nível de pós-graduação aprendem muito pouco sobre as Universidades e sobre a Educação nos E. U. A. 
Assim as instituições land grant começaram com uma orientação para a educação vocacional — e para as profissões que se tornaram então da maior importância para o desenvolvimento do País. Estas instituições não eram destinadas a ser unicamente instituições de ensino, jnas também de pesquisa, particularmente dedicadas à aplicação dos conhecimentos básicos das ciências para uso prático pelas populações a quem as Universidades, ao serem fundadas, eram destinadas a servir. Não c decorrente de razões acidentais o fato de que a agricultura dos E.U.A, se tornou a mais produtiva do mundo: a base de recursos naturais foi evidentemente importante, mas não a única. As instituições land grant que concentraram recursos na pesquisa agrícola e que desenvolveram o mecanismo para a transmissão dos resultados destas pesquisas às fazendas e fazendeiros (uma outra forma de ensinar) são em grande parte responsáveis por esta revolução agrícola sem precedentes.

Mas este grupo de instituições tem sido uma mola mestra de imensa importância também em outras fases da Educação. Até recentemente, haviam absorvido, mais por omissão do que por planejamento, o crescente número de jovens que procuram educação universitária. As instituições particulares limitam sua matrícula e assim as instituições públicas tinham de decidir se se expandiam ou não. E com a firme convicção de que a Educação era um «direito da pessoa humana», as instituições estaduais foram compelidas a crescer. Esta pressão decorreu de uma série de fatores: 1) o crescimento da população e, especialmente, a partir da II Guerra Mundial, a existência de crescente número de jovens na idade universitária; 2) o crescimento da renda per capita, o que permite que maior percentagem da população possa arcar com as despesas educacionais; 4 3) as maiores demandas da economia que exige e paga uma mão-de-obra crescentemente especializada e assim uma percentagem cada vez maior dos graduados de nível secundário percebe que deve, a todo custo, obter uma educação superior. Deste modo, estas instituições tiveram a responsabilidade de fornecer educação superior a crescente número de jovens, tentando fazê-lo a um custo mínimo, a fim de que os recursos econômicos limitados fossem uma barreira mínima para obter uma Educação universitária. ${ }^{5}$ Inicialmente, a orientação era em grande parte vocacional, mas atualmente o é menos, pois as Universidades compreenderam que também é sua responsabilidade a de preparar futuros cidadãos e líderes, além de formar profissionais.

As Universidades estaduais, land grant, além da orientação para a agricultura e engenharia (serviços diretos e imediatos, prestados às sociedades que as mantinham) e dos ensinamentos ministrados a cres-

4 Espera-se que as despesas de uma família com a Educação cresçam como um percentual à medida que aumenta a renda.

5 E' bem possível que anuidades mais modestas ao lado de uma alta renda per capita não sejam mais - ou menos - pesadas quando comparadas no orçamento de famílias de localidades pobres. 
cente número de estudantes ao nível de graduação, desempenharam importante papel no ensino pós-graduado. As instituições para pósgraduação como Harvard, Yale, etc. não podiam atender às necessidades de formação de professores de nível médio e superior e de pesquisadores exigidos pelo Governo, pelo sistema educacional, pela indústria, e assim estas instituições dedicaram parte substancial de suas energias aos estudantes de pós-graduação.

Portanto, em resumo, este grupo de instituições tem como suas multifunções (e daí o termo «multiversidade», atualmente em voga) :

1) Educação de grande número de estudantes a um custo relativamente baixo para os próprios estudantes e ao menor custo possível para a população contribuinte.

2) Educação de estudantes pós-graduados para a maioria de cargos de ensino, de pesquisa e do governo que exigem pessoal com nível de pós-graduação.

3) Pesquisa, tanto básica como aplicada (se esta distinção fôr significativa) .

4) Contínua atenção voltada para as necessidades imediatas da sociedade nos seus vários aspectos e para satisfazer a estas necessidades, como é próprio da Universidade. Como resultado disto, foram criados programas de real projeção no setor da educação de adultos.

As escolas normais estaduais. Com o desenvolvimento de escolas normais separadamente das Universidades, a maioria dos Estados criou um segundo sistema estadual de Educação superior com a finalidade de preparar professores primários e secundários. Estas geralmente tendiam a ser menores, fisicamente separadas, sem cursos de pós-graduação e eram reconhecidamente de qualidade inferior. Entretanto, a partir da II Grande Guerra, como muitas destas instituições se expandiram rapidamente para que pudessem satisfazer às crescentes matrículas, aumentaram também o número de cursos oferecidos, deixando de ser especializadas unicamente em Educação, e algumas começaram também a oferecer cursos de pós-graduação. O que conhecíamos, há alguns anos atrás, como pacatas faculdades para a formação de professores, são hoje Universidades com 10-15-20 mil estudantes. Em muitos casos, as diferenças entre estas e as Universidades estaduais, descritas na parte anterior deste trabalho, são muito menores do que eram há duas décadas atrás.

Apêndices do sistema universitário estadual. Vários esquemas foram utilizados na «guerra dos números». As instituições simplesmente cresceram; algumas se dividiram como amebas (a Universidade da Califórnia, com cerca de 100.000 alunos, tem atualmente 10 campus); em outros casos, as instituições de nível inferior anteriormente existentes subiram de nível, como é o caso das escolas normais; mas a ocorrência mais importante talvez tenha sido a crescente importância da faculdade júnior (júnior college) ou escola da comunidade (community college). 
Para todas as especializações (ou para a maioria delas), os primeiros dois anos de estudos na faculdade são comuns, de disciplinas básicas: ciências naturais básicas, história e pensamento político dos E.U.A., inglês, matemática, etc. Estas disciplinas geralmente exigem menos em termos de equipamento de laboratório e em termos de professores que podem ser menos especializados, que não precisam ter formação tão completa. Assim, a experiência que está sendo levada a efeito é a de criar cursos de dois anos nas grandes e médias cidades (que ainda não possuam suas próprias instituições de ensino superior) para que: 1) os estudantes possam viver em suas casas durante os primeiros dois anos de estudos, o que representa economia de despesas; 2) as Universidades que atualmente já enfrentam dificuldades com grande número de alunos possam concentrar seus recursos nas áreas mais necessitadas - nos estudantes de terceiro e quarto anos, já em desenvolvimento e parcialmente formados, bem como nos trabalhos de pós-graduação. Existem problemas com este sistema e êle é relativamente novo, mas há muito para recomendá-lo. Poderia ter consideráveis atrativos para os brasileiros, pois reduz em muito as exigências de mobilidade do estudante.

Instituições menores, predominantemente particulares. $\mathrm{O}$ quadro é completado por centenas de instituições menores, via de regra particulares - na sua maioria escolas de graduação, com cursos de quatro anos. Algumas destas são — ou foram - relacionadas à Igreja. Existem algumas faculdades municipais que também cabem nesta categoria, e existem algumas escolas mantidas pelos Estados.

Estas instituições prestam serviço muito útil. $\mathrm{O}$ grande número de jovens que aí está matriculado pode não desejar, por uma ou outra razão frequentar uma das instituições gigantes. ${ }^{6}$ Alguns pais e estudantes podem gostar das bases morais e religiosas das escolas ligadas à Igreja e mesmo da instrução religiosa que aí é ministrada. E até certo ponto a existência destas instituições possibilitou a alguns estudantes a frequência a uma faculdade por causa da proximidade de suas residências, o que talvez não ocorresse, caso ela não existisse. Entretanto, esta última consideração provavelmente não é de grande importância.

As grandes omissões. Nenhum resumo ligeiro como este poderia incluir todas as instituições, e mesmo algumas categorias gerais se encontram excluídas. O principal tipo de instituição que estou ciente de haver excluído é o dos institutos tecnológicos (Illinois «Tech», Michigan School of Mines, Colorado School of Mines, etc.). Estes preenchem função definida, mas mesmo assim minha impressão é que estão tendendo a se tornarem cada vez mais semelhantes às Universidades, dando atenção à «cultura geral», além da educação técnica. As principais

6 Embora as instituições possam ser menores, isto não significa necessariamente que o número de alunos por professor seja menor, resultando presumivelmente numa maior disponibilidade de tempo do professor por cada aluno. 
faculdades mantidas por cidades, como o New York City College e algumas das grandes instituições particulares, também não foram incluídas, tais como a University of Southern Califórnia, Notre Dame Northwestern University. Contudo, minha intenção não era a de ser completo, mas a de pintar, em largas pinceladas, o quadro geral.

Uma palavra sôbrc a qualidade. Deve ser lembrado que num sistema tão vasto como este - se é que podemos chamá-lo de «sistema» - grande variedade de instituições está incluída. Esta é, talvez, sua principal característica - a diversidade - e isto torna muito difíceis os julgamentos a seu respeito. Um brasileiro disse-me recentemente que êle não tinha boa impressão acerca da qualidade da Educação nos E.U.A. Um filho de um amigo seu, que não pôde ingressar numa Universidade aqui (em nenhuma?), ingressou numa Universidade americana e suas notas lá obtidas foram todas «A». Perguntei que instituição este jovem havia frequentado e rapidamente compreendi que de um brasileiro com inteligência suficiente para concluir seu curso secundário aqui (situando-se nos $10 \%$ superiores de sua turma), temos que esperar bom desempenho naquela instituição que frequentou.

Para fazermos julgamentos com respeito à qualidade, confiamos no método formalista do «reconhecimento» - um tipo de «reconhecimento diplomático», dado por associações profissionais, indicando que a instituição alcançou determinados padrões mínimos. Além disso. sabemos, a partir de nossa experiência, que os melhores engenheiros provêm de dez instituições, e que se selecionarmos os segundos melhores estudantes de certas instituições, estes serão melhores do que os melhores de outras, etc. O mercado, pode-se dizer, aprendeu a selecionar dentre os produtos diferenciados. Certamente nossos julgamentos não são perfeitos e são perpetradas injustiças, mas, pesados os prós e os contras, o sistema funciona bem razoavelmente. Após cerca de um ano de trabalho, o progresso do graduado na indústria, educação ou no governo depende muito mais do seu desempenho do que da instituição que lhe concedeu o diploma.

Ademais, a qualidade varia dentro das próprias instituições. Uma Universidade é conhecida por ser da mais alta qualidade em, digamos, História, mas é muito fraca em Arte, ou boa em Biologia, mas fraca em Física.

Para dar a estes comentários com respeito à qualidade um aspecto prático, tomemos o caso dos latino-americanos, que ao estudarem nos E.U.A., na sua maioria gravitam em torno das escolas da «Liga da Hera», quer para estudos de graduação, quer de pós-graduação. No tocante ao primeiro caso, não há certeza de que estas sejam as melhores instituições ou que sejam as mais adequadas para os latino-americanos. Além disso, não são sempre as melhores em termos de estudos de

7 Naturalmente, os estudantes das melhores escolas devem ter melhor desempenho. 
pós-graduados, especialmente tendo-se em mente a grande variação com respeito aos campos de estudo. As melhores das Universidades estaduais têm tanto quanto ou mais ainda a oferecer em áreas específicas.

Como modelo, eu pessoalmente estou mais interessado em que os latino-americanos se tornem familiarizados com as instituições land grant do que com Harvard ou Yale. Estas últimas não são realmente importantes para o atual meio latino-americano, nem correspondem à Educação nos E.U.A, como um todo, pois constituem parcela pequena e atípica. As instituições land grant, grandes, mantitdas pelo Governo e de anuidades mínimas, «representam» muito mais verdadeiramente a média da Educação nos E.U.A.

A heterogeneidade da Educação tem demonstrado, na experiência educacional dos E.U.A., três grandes vantagens: 1) a diminuição dos custos através do aproveitamento das vantagens oferecidas pelas economias de escala; 2) uma tendência de elevar ao máximo os benefícios para o estudante através da especialização institucional não em disciplinas, mas de acordo com a vocação dos próprios estudantes; 3) o progresso, a experimentação e a disciplina através da competição interinstitucional. Examinaremos individualmente estas vantagens e também sugeriremos alguns dos problemas a elas relativos.

Porém, antes de continuarmos, deve ficar claro que não se sugere que o Brasil adote ou mesmo adapte o sistema ou padrão acima descrito. Mas é conveniente sugerir que as vantagens da heterogeneidade são de uma variedade técnica que é aplicável através de fronteiras internacionais .

Deve-se ter em mente um aspecto da vida nacional dos E.U.A. Aceitamos como um valor nacional (e como tal êle é singularmente nosso e incontestável) a noção de que a Educação não é somente um direito do indivíduo, mas para a população até certa idade é uma exigência imposta socialmente. O significado disto é que todos aqueles que completam o nível médio devem ter oportunidade para ter assegurada a sua educação universitária, caso realmente a desejem. De fato, alguns Estados exigem que as Universidades por eles mantidas aceitem rocios os graduados de nível médio daquele Estado que queiram frequentar uma Universidade, mas reconhece-se geralmente que nem todos os graduados de nível médio podem ou devem freqúntar uma faculdade.

8 Para dar uma dimensão estatística a este fato, temos: as matrículas nas Universidades em 1965 eram de 5.526.000 alunos, ou cerca de 2,9\% da população total e cerca de $40 \%$ da população na faixa de 20-24 anos. Em 1960. segundo dados do recenseamento, do todas as pessoas de 25 anos e mais, cerca de $8 \%$ haviam frequentado uma Universidade por quatro ou mais anos. FONTE: Statistical Abstract o[ the United Stntcs, 1966. 
As economias de escala. Ninguém consideraria seriamente a afirmativa de que todas as instituições de ensino superior têm de oferecer os mesmos cursos. Existem importantes diferenças regionais que explicam porque o City College of New York tem cursos sobre as técnicas de comércio e finanças internacionais e não tem nenhum sobre agricultura, porque a University of Illinois é boa em agricultura, mas só tem cursos teóricos sobre a economia do comércio internacional, porque o curso de engenharia de minas é um curso importante no Colorado e não na Flórida. Mas estas diferenças regionais não são suficientes para explicar as diferenças entre as instituições. As economias de escala são uma importante consideração neste aspecto. Por exemplo: o Estado de Michigan tem cerca de 70 instituições de ensino superior públicas e particulares, mas somente duas ou três destas oferecem cursos que levam à obtenção de um diploma em Medicina e somente uma oferece curso em Medicina Veterinária. Uma das razões é que os custos fixos mínimos do ensino médio são elevados (hospitais, laboratórios, professores muito bem pagos, bibliotecas, etc.) e portanto procuramos dividi-los por grande número de estudantes, a fim de reduzir o custo por aluno. O mesmo pode ser dito da Engenharia, Física, Agricultura, etc, em que os laboratórios, o equipamento e a terra desempenham importante papel.

Se uma instituição produz anualmente 20 estudantes de administração de empresas, é antieconômico (ou seja, é desperdicio) permitirIhes muita escolha de disciplinas, e certamente não se pode pensar em subespecialização. Mas se são 200 ou 500 alunos, então, após uma base de estudos comum a todos, pode-se permitir uma considerável escolha de disciplinas, ${ }^{10}$ podendo-se permitir também alguma especialização, dentro do amplo campo da administração de empresas, digamos em marketing ou contabilidade. ${ }^{\mathrm{n}}$

9 Outro aspecto que os brasileiros devem ter em mente e que utilizamos grande número de professores em tempo integral, dos quais exigimos que realizem trabalhos de pesquisa. Assim, se uma instituição quer construir e manter um departamento de Física, ela deve contar com a necessidade de fornecer laboratórios e equipamentos não somente para os estudantes em nível de graduação - com instalações relativamente elementares - mas também para os estudantes de pós-graduação e para os membros do corpo docente, o que requer um equipamento completo e requintado.

10 Uma das grandes vantagens do sistema de «departamentos», e que não existe no sistema de «faculdades», é que no primeiro todas as disciplinas da Universidade estão disponíveis para todos seus alunos, tornando possível uma variedade muito maior de disciplinas, o que de outro modo não seria possível. Se um estudante em cada 25 cursos, por exemplo, desejasse cursar uma disciplina sobre Crítica Musical, seria possível, para o Departamento de Música, fornecê-la, enquanto que, em outras circunstâncias, não se poderia reun!r número suficiente de alunos para permitir a existência de tal disciplina. Portanto, todas as disciplinas não somente se tornam disponíveis para cada aluno, mas muitas outras se tornam factíveis.

11 Temos sido justamente criticados pela excessiva especialização e pela demasiada subdivisão das disciplinas ministradas. Mas o que não é usualmente reconhecido 
Em resumo, portanto, para muitas especialidades universitárias, tem-se constatado que a alta qualidade da Educação requer custos fixos elevados e que o número de estudantes a serem preparados não garantem que cada instituição possa arcar com estas despesas. Consequentemente, as instituições tendem a especializar-se, procurando, sem dúvida alguma, aperfeiçoar a qualidade da Educação, obter custos muito mais baixos e uma maior variedade. Estes são lucros que não são facilmente perdidos.

Ajustando os estudantes $e$ as instituições. Talvez a maior vantagem da heterogeneidade seja a grande variedade oferecida ao estudante em perspectiva. Até certo ponto este é um serviço prestado ao consumidor, um «balangandã» que talvez não possa ser oferecido pelos países pobres, mas que de qualquer modo tem seu relevante mérito social.

A maior vantagem provém do reconhecimento de que nem todos os estudantes universitários em potencial são iguais. Eles não somente diferem quanto às preferências intelectuais, mas também são pessoas diferentes quanto a outras características: alguns são brilhantes, enquanto que outros são obtusos, alguns aprendem bem de modo independente, enquanto outros exigem supervisão, alguns são maduros, enquanto outros são infantis, alguns se sentem à vontade e aprendem no meio da multidão da educação de massas, outros aprendem melhor num ambiente mais calmo e com um menor número de pessoas. Talvez seja de bom alvitre selecionar os intelectualmente brilhantes (nas escolas superiores) onde possam realizar o aprendizado de acordo com seu próprio ritmo, sem serem atrasados pelo estudante médio. Talvez também o estudante médio se sinta mais à vontade e aprenda melhor sem a dura competição de seus colegas que tiveram a fortuna de ser mais bem dotados. Supondo que é desejável para a sociedade, até certos limites, desenvolver cada indivíduo até um máximo possível, então esta heterogeneidade contribui para este objetivo. ${ }^{12}$

Analogias são constantemente perigosas e algumas vezes úteis. Podemos ilustrar esta afirmativa sugerindo que os estudantes são algo

por tais críticos é que, via de regra, esta superespecialização é construída sobre base muito ampla. Por exemplo: nos estudos de um aluno de Administração de empresas que obteve seu diploma em «vendas a varejo» (uma subdivisão de marketing, que é por sua vez uma subdivisão de «Administração de empresas»), provavelmente $25 \%$ das disciplinas cursadas terão sido de matérias tais como Matemática, Economia, Estatística, outros 25-35\% de suas disciplinas terão sido em Administração de empresas, e os $15-25 \%$ restantes em matérias sobre «vendas a varejo».

12 O economista pode descrever teoricamente estes 1 mites: é vantajoso continuar a investir num indivíduo enquanto cada aumento no investimento custar menos que o atual valor descontado do futuro fluxo de benefícios, decorrentes destes investimentos. Contudo, as possibilidades práticas de descrever estes limites são muito, muito menores, devido a problemas de mensuração. 
parecidos com a terra. Alguns solos produzem milho, arroz, centeio, etc, etc, melhor do que outros. Alguns exigem grandes quantidades de investimento e fertilizantes, mas tornam-se então produtivos, enquanto outros produzem prodigiosamente com pequena aplicação de adubos. A elevação de uma produção ao seu máximo (com recursos finitos) exige cuidadoso discernimento na administração da terra. A heterogeneidade das instituições tem-nos permitido, embora de modo imperfeito, ajustar os estudantes às instituições, a fim de nos aproximarmos do máximo de produtividade do sistema educacional.

Os efeitos da competição. Educação, conhecimento, ensino, aprendizado, são todos aspectos dinâmicos do mundo moderno. Há tanto a ser ensinado, tanto a ser aprendido, e sabemos tão pouco quer sobre o aprendizado, quer sobre o ensino. As instituições educacionais trabalham nas fronteiras do conhecimento e preocupam-se - ou deveriam preocupar-se - acerca do que fazer com seus achados. No meio cultural dos E.U.A, a competição interinstitucional - nunca formal mas sempre presente — tem levado à experimentação; à inovação; a testar, rejeitar e aceitar novos dispositivos, novas técnicas, novas filosofias. O efeito total tem sido o de um sistema educacional vibrante. dinâmico, tendendo a liderar ao invés de seguir, a antecipar-se ao invés de atrasar-se. Parece provável que este tipo de atmosfera competitiva (com todos seus problemas) de alguma forma é mais capaz de levar ao desenvolvimento de instituições desejáveis do que um sistema cujo controle e leis partem de um poder centralizado, resultando em que grande parte das energias das instituições sejam gastas na luta para alcançar e manter a identidade externamente imposta - que talvez seja pouco desejada e imperfeitamente compreendida.

\author{
JOHN M. HUNTER \\ EAPES \\ Michigan State University
}

Tradução de

Jacques R. Velloso

Janeiro - 1968

'3 Uma das principais imperfeições do processo de ajustamento está no fato de que a renda dos pais não é distribuída de acordo com as necessidades dos futuros estudantes. Diante da crescente confirmação deste fato, principalmente no que toca às dispendiosas escolas «superiores», o desenvolvimento de extensivos programas de bolsas de estudo, tanto públicos como particulares, tem reduzido a importância da situação financeira dos pais, como determinante de escolha das instituições. 
Apendice D.3

\section{A NOTE ON HETEROGENEITY}

There is a strong tendency in Brazilian higher education towards conformity, towards seeking to make each educational institution in the image of all the rest. This comes about through federal regulations and recognition of the profession, through various provisions of the Lei de Diretrizes e Bases, through the centralized powers and activities of the Conselho Federal de Educacao, It is suggested in this paper that there is a considerable value in heterogeneity among educational institutions - that this is a characteristic worth pursuing in and of itself. This will be done in two parts: First, there will be a brief characterization or description of higher education in the U.S. as it relates to this theme. I select the U.S. because it is the geographic area with which I am most familiar, because it very well illustrates the second portion of the paper, and because, from very little experience, I have found Brazilians have considerable misinformation about the nature of U.S. university education. Second, we will examine some of the advantages found in heterogeneity. But before beginning these main points, there are three supplemental points to consider:

1. To some extent heterogeneity will occur even though it is unplanned, undesired, and legislated against. Institutions such as universities are social institutions and take their characteristics from basic legislation, the human beings associated with them, national and regional characteristics, resources available and the abilities to use those resources, etc. Even if there were $A$ law which minutely described universities and even if it prescribed that all were to be same in every detail, this simply would not occur. It is not this accidental, marginal heterogeneity with which I am concerned.

2. It is not clear to what extent heterogeneity can be «planned». It seems rather doubtful that various degrees of heterogeneity can be produced or required by legislation or by administrative fiat. But if it cannot be specificaliy planned it certainly can be «provided for» in education planning by keeping basic legislation general in nature, permissive of experimentation, clearly with the expectation that unforeseen institutions and circumstances are apt to develop.

3. Heterogeneity in the higher educational system implies a considerable degree of mobility among its clients. That is, if the country is to have three schools with specialization in economics (not 
to be confused with accounting or business administration), this implies that students interested in this discipline will be able and willing to go to those sites to study. I am very much aware that this mobility is not now common among Brazilians, but I urge that there is really no practical alternative to finding ways to develop this sort of mobility. This point will be discussed later, but let me illustrate here in passing by a simple example. Suppose that it is considered desirable that Brazil have an increase of 40 highly trained psychologists per year. These may be trained in two or three schools with 15-20 graduates from each or two graduates each from the federal universities. The cost of the latter alternative will be much greater and the quality of output mисh lower. I suggest, as well, that we ought not to assume too much about the lack mobility: there is evidence from the days of Braz Cubas that Brazilians were willing to migrate in pursuit of education when and if it seems to be worth it. Perhaps in the past, this willingness has been largely demonstrated in international migration but this does not necessarily preclude intranational mobility pursuit of education.

I hope in the next several paragraphs to indicate something of the heterogeneity of U.S. higher education not because I think that it is a pattern which ought (or ought not) to be applied to Brazil but because it is a pattern of heterogeneity which will help make clear what we Yankees have in mind when we speak of U.S. higher education.

The «superior» college - One kind of institution is the small. liberal arts, superior, undergraduate institution such as Swarthmore College, Oberlin, Reed, Pamona, etc. These are «superior» in the sense that they accept for admission only the intellectual elite. They have no graduate training and concentrate on excellent teaching for their first-rate students. Faculty-student ratios are generally low, but a great deal of independent work is expected of the student. At Swarthmore, for example, honors students of the third and fourth year attend no formal classes and do most of their «learning» through independent research. A high proportion of graduates from such institutions attend graduate schools for post-graduate training in medicine, business, education, etc.

The «/yy League» - Another group of institutions, which we might call the «Ivy League», is certainly much better known to Brazilians: Harvard, Yale, Princeton, Columbia, Massachusetts Institute of Technology, Johns Hopkins, among others. There were once the elite of undergraduate institutions in the U.S. but are now much more important as the foremost institutions for graduate training. Clearly, their most important function is to provide the highest possible level of training for the future researchers and professors for the 
whole country. All do have undergraduate programs and rigorously select those they admit and their undergraduate degrees are much sought, but the collections of superior professors, the superb libraries, the millions of dollars of research support (which helps finance graduate students) are primarily in support of the graduate training function.

The «-land grant» institutions - Another group of extremely important institutions are the state universities such as the University of California, the University of Minnesota, the University of Wisconsin, Michigan State University, the University of Illinois, the University of Pennsylvania - among the better known. These we might call the «work-horses» of the system. Historically, they have had the function of carrying out, through the level of higher education, the philosophy characteristic of U.S. education that all capable citizens ought to have an opportunity for education. The major state institutions are «land grant» institutions made possible by the Morril Act of 1865 which provided grants of federal lands to each state the proceeds from which were for the establishment of institutions of higher learning. These were to be dedicated, among other things. to the teaching of «agricultural and mechanic arts» to the sons and daughters of farmers and laborers. None of these institutions now views itself so narrowly restricted, but the conception of a university in each state dedicated to developing and teaching in the area of such mundane subjects as agriculture and mechanic arts (the precursor of engineering) was revolutionary in the days when most education was of a classical or theological nature.

So the land grant institutions started with an orientation toward vocational education - and in the vocations which were then becoming most important in the developing country. Not only were these institutions to be teaching institutions but also research institutions, particularly dedicated to the application of fundamental knowledge of the sciences to the practical applications of the peoples the universities were founded to serve. It is no accident that U.S. agriculture became the most productive in the world: the natural resource base was, of course, important but it was not unique and the land grant institutions which focused resources on agricultural research and which developed the mechanism for transmitting this information to the farms and farmers (another form of teaching) are largely responsible for the unprecedented agricultural revolution.

But this group of institutions has been an immensely important «work-horse» also in other phases of education. Until recently, they have, more by default than by planning, absorbed the increasing numbers of young people seeking a university education. The private

1 Brazilians who attend one of these institutions as graduate students learn very little about U.S. Universities and education. 
institutions restrict their enrollment, so the public institutions have had to decide whether to expand or not. And with the strong feeling that education was «human right», the state institutions were constrained to grow. This pressure has come from a number of factors: 1) increasing population and especially, since World War II, an increasing number of youngsters of college age; 2) increasing per capita income which makes educational expenditure possible for a greater percentage of the population; 23 ) the greater technical demands of the economy requiring, and paying for, increasingly specialized labor so that a greater and greater percentage of high school graduates feels it must, if at all possible, acquire a college education. So these institutions have had the responsibility to provide undergraduate education to increasing numbers of young people, and they attempt to do this at little cost to the student so that limited economic means would be minimum barriers to getting a university education. ${ }^{3}$ Initially, the orientation was largely vocational but it is less so now since the universities have come to see their responsibility as one of training future citizens and leaders as well as training professionals.

In addition to the orientation toward agriculture and engineering (direct and immediate service to the societies which supported them) and intruction of increasing numbers of undergraduate students, the land grant, state universities have filled an important role in graduate education. The superior graduate institutions, Harvard, Yale, etc., could not begin to fill the needs for training teachers, professors, researchers required by the government, the educational system, industry, so these institutions dedicate a substantial part of their energies to graduate student training.

In summary, then, this group of institutions has as its multifunctions (and thus the currently popular term, «multiversity»):

1. Education of large numbers at relatively little cost to the student and with as little as possible to the taxpayer.

2. Training of graduate students for the majority of teaching, research, and government jobs which require post-graduate personnel.

3. Research, both basic and applied (if that distinction is meaningful).

4. Continual attention to the immediate needs of the society in its various aspects and the servicing of those needs as befits a university. Really outstanding program in adult education have been established as a result.

Family expenditure on education is expected to increase as a percent as income increases.

It is quite possible that modest tuition fees with high per capita incomes are no more - or even less — burdensome than zero tuition elsewhere. 
The state normal schools - Most states established a second state system of higher education by developing normal schools separately from the universities for the purpose of training secondary and primary teachers. These generally tended to be smaller, physically separate, without graduate programs and were generally conceded to have been of poorer quality. Since World War II, however, many of these institutions have expanded rapidly to accommodate increasing enrollment, they have expanded their offerings to degrees other than these in education, and some have begun offering graduate work. What we thought of a few years ago as sleepy little teachers colleges are now universities wich 10-15-20 thousand students. In many cases, the distinctions between these and the state universities described in the preceding section are much less great than they were two decades ago.

Appendages to the state university system - A number of schemes have been utilized in the «battle of numbers. Institutions have simply grown; some have, amoeba-like, divided (the University of California with some 100,000 students presently has ten campuses); in other cases previously existing inferior organizations have been up-graded as were the normal schools; but perhaps the most important development is the increasing importance of the «junior college or «community college. For all (or most) specializations the first two years of collegiate work are common, basic courses: basic natural science, U.S. history and political thought, English, mathematics, etc. These courses generally require less in the way of laboratory equipment and less highly trained and specialized professors. Thus, the experiment is underway to develop two-year courses in major and sub-major metropolitan centers (not already having their own institutions of higher learning) so that 1) students can live at home during their first two years which would prove economical to them; 2) the already hard-pressed universities can concentrate their resources on the most needful areas - maturing and partially trained third and fourth year students and on graduate work. There are problems with this system, and it is relatively new, but it has much to recommend it. It might have considerable Brazilian appeal since it reduce considerably the requirement for student mobility.

Smaller, predominantly private institutions - The picture is largely completed by hundreds of smaller, generally private institutions mostly four-year, undergraduate colleges. Some of these are - or were - church related. There are some municipal colleges which also fit this category, and there are some state supported schools.

These institutions provide a very useful service. A great many youngsters are accommodated who may not desire, for some reason or other, to attend one of the mammoth institutions. ${ }^{A}$ Some parents

4 Although the institutions may be smaller, this does not necessarily mean that the number of students per professor will be smaller, giving presumably more professorial time per students. 
and students may be pleased wich the religious and moral bases of church related schools and even the religious instruction provided therein. And to some extent, the existence of such institutions has made it possible for some students to attend college closer to home than would otherwise have been the case, but this consideration is probably not of great importance.

The major omissions - No hasty summary of this nature will include all institutions, and even some general categories are excluded. The principal type of institution that I am aware of having excluded is that of the technological institutes (Illinois «Tech», Michigan School of Mines, Colorado School of Mines, etc.). These fultil a definite function, but even then it is my impression that they have tended to become more and more like the universities in their attention to a liberal education in addition to technical education. The major city colleges, such as New York City College and some of the large private institutions do not fit either, such as The University of Southern California, Notre Dame, Northwestern University. But the purpose has not been however, to be complete but to paint in broad strokes the general picture.

A word on quality - It must be remembered that in such a vast system as this - if «system» we can call it - a great range of institutions is covered. This is, perhaps, its principal characteristic diversity - and this makes judgements concerning it very difficult. A Brazilian recently told me that he did not think highly of the quality of U.S. education. The son of a friend of his, who could not get into university here (not any?) went to a U.S. university and get all « $\mathrm{A}$ ' $\mathrm{S}$ ». I inquired as to what institution this fellow had attended and then know at once that a Brazilian with enough intelligence to get through secondary education here (in the upper 10 per cent) ought to have been expected to have done well at that institution.

To make judgements with respect to quality, we rely on the formalistic method of «accreditation» - a sort of «diplomatic recognition» accorded by professional associations indicating the attainment of certain minimum standards. Beyond this, we know from experience that the best engineers come from ten institutions, that if we take the second-best student from some institutions, these will likely be better than the best from others, etc. The market, if you will, has learned to discriminate amongst the differentiated product. Certainly our judgements are not perfect and injustices are perpetrates; but on balance it works reasonably well. This is particularly the case since it makes little difference where the student get his degree after he takes the first job. After the first year or so, his progress whether in industry, education or government depends much more on his performance than the institution which awarded his degree. ${ }^{5}$ 
Furthermore, quality varies within institutions. One university is known to be of highest quality, say, in «history» but to be very poor in «art» or strong in biology but weak in physics.

To make practical these comments with respect to quality, most Latin Americans gravitate when they can towards the Ivy League schools either for undergraduate or graduate training. As far as the former is concerned, it is by no means certain that these are the best institutions or that they are the best for Latin Americans. They are not always the best, either in terms of graduate training, especially keeping in mind the great variation with respect to fields. The better of the state universities frequently have as much or more to offer in particular areas.

For purposes of emmulation, I personally am more interested in Latin Americans being familiar with the land grant institutions than with the Harvards and Yales. The latter are not really relevant for the present Latin American environment, and neither are they U.S. education. They are a small, atypical part. The large, publically supported, minimum tuition, land grant institution much more clearly «represents» the average of U.S. education.

\section{II}

Educational heterogeneity has demonstrated, in the experience of the United States, three great advantages: 1) the lowering of cost through taking advantage of the economics of scale; 2) a tendency to maximize benefits to the student through institutional specialization not in subject matter but in the nature of the students themselves: $3)$ progress, experimentation, and discipline though interinstitutional competition. We will look at these individually and also suggest some of the problems.

Before continuing, however, it is not suggested that Brazil adopt or even adapt the system or pattern described above. But it is appropriate to suggest that advantages of heterogeneity are of the technical variety which are applicable across international boundaries.

One aspect of U.S. national life ought to be kept in mind. We have accepted as a national value (and, as such, it is uniquely ours and indisputable) the notion that education is not only a right of the individual but up to a certain age a socially imposed requirement. This is understood to mean that those who finish high school ought to have a chance to secure a college education if they want it badly enough. Some states, in fact, require that their state supported universities accept alt high school graduates of the state who want to attend, but it is generally recognized that not all who graduate from high school can or should attempt a college course. ${ }^{8}$

6 Tog ve statistical d'mension, university enrollments in 1965 were 5.526 .000 or about 2.9 percent of the total population and about -40 percent of the population 
The economies of scale - No one would seriously consider the preposition that all institutions of higher education ought to offer the same programs. There are important regional differences which explain why the City College of New York has programs in the techniques of international trade and finance and none in agriculture, why the University of Illinois is strong in agriculture but has only theoretical courses in the economics of foreign trade, why mining engineering is an important offering in Colorado but not in Florida. But these regional differences are not sufficient to explain the differences between institutions. The economies of scale are an important consideration in this respect. For example, the State of Michigan has some 70 institutions of higher education, public and private, but only two or three of these offer work leading to a degree in human medicine and only one in veterinary medicine. One reason is that the minimum fixed costs of medical education are so great (hospitals, laboratories, high-cost professors, libraries, etc.), that we try to spread these over a large group of students in order to reduce the average (per student) cost. The same can be said for engineering, physics, agriculture, etc., in which laboratories, equipment, land, etc., play an important role.

If an institution produces 20 students per year in business administration, it is anti-economic (e.g. wasteful) to permit them much choice of courses, and certainly no sub-specialization can be contemplated. But if the number is 200 or 500 , then, on a common base, students may very well be permitted considerable choice of courses, ${ }^{8}$ and be also permitted a mild specialization in, say, marketing or accounting within the broader area of business administration.

aged 20-24. In 1960, the census reports that of all persons 25 years old and over, about 8 percent had attended universities for four or more years. Source: Statistical Abstract of the United States, 1966.

7 An additional aspect which Brazilians must keep in mind is that of our utilizing large elements of full-time professors of whom we require research. Thus, if an institution wants to build and maintain a good physics department, for example, it must expect to provide the laboratories and equipment not only for the relatively elementary undergraduate student but the complex, sophisticated equipment for graduate students and for faculty members.

8 One of the great advantages of the «department» system as opposed to the «faculdade» system is that in the former all courses of the university are available to all its students, making possible a much greater variety of courses than could exist otherwise. If one student of each of 25 programs, for example, were to desire a course in music appreciation, it might be possible for the music department to offer it while in other circumstances enough students could not be brought together to permit such a course. Thus, not only all existing courses become available to every student but many more become feasible.

9 We have justly been critibed for over-specialization or over-sub-division of the academic disciplines. But what is not commonly recognized by such crities is that generally the super-specialization is built on a very broad base. For example, a business administration student a degree in «retailing» (a sub-division of «marketing» 
In summary, then, for many academic specialities, it has been found that high quality education requires large fixed costs and that the numbers of students to be trained do not warrant every institution making these outlays. Consequently, institutions have tended to specialize with, no doubt, improvement in quality of education, lower costs and greater variety. These are gains not easily dismissed,

Matching students and institutions - Perhaps the greater advantage from the heterogeneity is the great variety offered the prospective student. To some extent, this is consumer's service, a «frill» perhaps unwarrant in poor countries, but it has important social merit, as well.

The great advantage comes from the recognition that not all potential university students are the same. They not only have different academic interests but they are different people in other characteristics as well: some are brilliant while others are dull some learn well independently while others require supervision, some are mature while others, are child-like, some relax and learn in the crowds of mass education, others do better in smaller environments. Perhaps it is well to segregate the intelectually brilliant (in the «superior» school) where they can learn at their own pace without being hold down by ${ }^{\mathrm{f}}$ he aveiage» student. Perhaps, too, the average student is more comfortable and learns better without the overpowering competition of his more fortunately endowed follows. Assuming that to some linr'ts it is desirable for the society to develop each individual to the maximum extent possible, then this heterogeneity contribules to that objective.

Analogies are frequently dangerous and sometimes useful. We may illustrate, the point here by suggesting that students are something like soils. Some soils produce one crop best and others another. Some require large amounts of investment and fertilizers but are then very productive while others produce prodigiously with little application of external assistance. The maximization of production (with finite resources) requires careful discrimination in land management. So it is with education. Heterogeneity in institution has permitted us,

which is in turn a sub-division of «business administration "which is in turn a sub-division of «administration») is likely to have had 25 percent of his courses such as mathematics, economics, statistics, still another 25-35 percent of his course in general business administration with only the remaining 15-25 percent in the «retailing» courses.

10 The economist can theoretically describe these limits: it is worthwile to continue investing in the individual so long as each increment of investment costs less than the presently discounted value of the future flow of benefits arising from the investments. The practical possibilities of describing these limits are much, much less, however, due to great problems of measurement. 
imperfectly to be sure, to match students and institutions so as to approach maximization of productivity of the educational system.

The effects of competition - Education, knowledge, teaching, learning are all dynamic aspects of the modern world. There is so much to be taught, so much to be learned, we know so little about either learning or teaching. Educational institutions work at the frontiers of knowledge and worry, or should worry, about what to do about their findings. In the cultural environment of the U.S. institutional competition - never formal but always present - has led to experimentation; to innovation; to testing, rejecting, accepting new devices, new techniques, new philosophies. The total effect has been a vibrant, dynamic, educational system tending, hoperfully, to lead rather than to follow, to anticipate rather than to lag. Somehow, it seems likely that this sort of competitive atmosphere (with all its problems) is more apt to lead to the development of desirable institutions than is a system centrally controlled and legislated for so that much of the institutions' energies must be spent in struggling to achieve and maintain externally imposed conformity - perhaps little desired and imperfectly understood.

\author{
JOHN M. HUNTER \\ EAPES \\ Michigan State University
}

\footnotetext{
11 One of the chief imperfections of the matching process is the different incomes possessed by students' parents which have little to do with students' needs (in the sense suggested above) in the selection of an educational institution. But incomes, on the other hand, have a great deal to do with the selection. Increasing awareness of this by expensive, superior schools and extensive scholarship programs, both public and private, have reduced the importance of parental affluence as a determinant of institutional selection.
} 
Apêndice D. 4

\section{SOBRE O ENSINO DE ECONOMIA NO BRASIL}

Os debates sobre o ensino de economia no Brasil ' têm sido de grande interesse para mim, um economista estrangeiro em visita a este país. Tive a oportunidade de visitar, como parte integrante das tarefas a serem desenvolvidas no Brasil, várias Faculdades de Ciências Econômicas. Estas experiências, juntamente com outras nos E.U.A, e noutros lugares, levaram-me a comentar o panorama brasileiro. Estes comentários não decorrem de algum conhecimento especial ou de quaisquer soluções novas, mas simplesmente porque o mesmo conjunto de problemas, quando vistos por prismas diferentes algumas vezes, revelam perspectivas interessantes, que ocasionalmente são valiosas.

\section{I}

Os economistas brasileiros já estão perfeitamente cônscios do que considero o primeiro e principal problema: não existe nenhuma definição ou compreensão clara do que é a economia, do que os economistas fazem, ou de como a economia se distingue das áreas afins. ${ }^{2} \mathrm{O}$ fato de nos referirmos às Faculdades de Ciências Econômicas sempre no plural sugere pelo menos um reconhecimento de uma dualidade ou multiplicidade de «ciências». Esta multiplicidade (e a confusão que a envolve) está no âmago do problema do ensino de «economia». 3 A conclusão mais óbvia a tirar-se desta multiplicidade de ciências é que nenhum conjunto único de cursos, como o que parece demandar a tradição brasileira, poderá satisfazer plenamente às necessidades de formação de todos os componentes.

Esta mesclagem de «ciências econômicas» parece estar estreitamente relacionada com as tradições universitárias francesa e espanhola (e italiana). Talvez as perspectivas e os backgrounds de Hume, Locke e Adam Smith tenham dado à economia «inglesa» seu impulso inicial

Particularmente na Revista Brasileira de Economia, ano XX, $\mathrm{n}^{\circ}$ 4, dezembro de 1966 (ã qual, doravante, nos referiremos como Revista), que relata os resultados de um seminário sobre este assunto, realizado em Itaipava, em março de 1966; também na Análise do Ensino de Economia no Brasil, ERGO, Rio de Janeiro, EPEA, 1966 (à qual doravante nos referiremos como Análise).

2 Ver, por exemplo, Mário Henrique Simonsen, «O Ensino de Economia $\mathrm{cm}$ Nível de Pós-Graduação no Brasil», Revista, págs. 19-29.

3 No sentido estrito da palavra, a ser definido abaixo. 
de «separação», pois desde então não foi confundida com direito, administração de empresas e/ou contabilidade. Na França, ao contrário, a disciplina desenvolveu-se como um ramo das Escolas de Direito e, juntamente com a contabilidade, como uma subespecialidade do direito, o que lhe deu historicamente papel substancialmente diferente no meio universitário e social. ${ }^{4}$

O presente reexame dos currículos provém da compreensão de que um programa de estudos destinado a preencher certos requisitos, e que talvez tenham sido definidos estreitamente, não pode absolutamente preencher outros requisitos. E tudo isto tem sido confundido com uma área de estudo que está surgindo, a chamada «administração de empresas» e que não é absolutamente uma «ciência», mas sim uma combinação de disciplinas técnicas com ciências do comportamento, convergindo para a administração de homens, materiais e finanças, e dirigida para fins específicos.

Qualquer avaliação séria do ensino de Economia deve, portanto, começar com algum tipo de definição que permita limitar o assunto e descrever seus objetivos. Como todos os economistas sabem, é difícil definir-se esta ciência. Se seguirmos o caminho de Jacob Viner, que disse que «a economia são todas aquelas coisas que os economistas estudam», seremos exatos, mas não chegaremos a lugar algum. Procurando uma definição próxima da melhor (second best), diremos que a economia é a ciência social que trata da produção e consumo coletivo de bens e serviços, juntamente com os vários dispositivos legais e financeiros que influenciam aquela produção e consumo. Isto não é substancialmente diferente da velha definição dos livros-texto que dizem que «a economia é o estudo do processo pelo qual o homem ganha sua vida», exceto num importante aspecto que é crucial na discussão deste assunto: a economia é uma ciência social. Percebe-se a importância desta distinção quando comparamos os objetivos últimos desta ciência. $\mathrm{O}$ contador e o administrador de empresas convergem seus interesses para o balanço ou para a demonstração de lucros e perdas da firma à qual estão ligados. O economista, por outro lado, preocupa-se com o balanço ou com a demonstração de lucros e perdas da sociedade. Seu instrumental analítico é todo destinado a compreender e a modificar a situação da sociedade, visualizada, pode-se dizer, através dos cálculos da renda nacional. Quando isto é perfeitamente compreendido, torna-se patentemente absurdo para um estudante o desejo de especializar-se em micro-economia (que procura explicar a distribuição de recursos e o tamanho e a composição da produção total através do impacto de vários

$\mathrm{Na}$ Argentina, por exemp!o, a Faculdadde Ciências Económicas teve sua origem na competência privativa, regulada por lei, dos contadores públicos, tal como a de exarar pareceres sobre finanças e de trabalhar como oficiais de justiça em certos processos legais. É em virtude desta última atividade que todos os graduados das faculdades, até bem pouco tempo, tinham que cursar pelo menos um ano de uma disciplina sobre «falências». 
fatores sobre a firma individual), porque êle quer ingressar no mundo dos negócios! Ainda assim, a muitos se diz para fazerem exatamente isto. ${ }^{5}$

Não posso insistir em demasia sobre este ponto: a economia e todos os cursos relacionados à administração de empresas são simplesmente duas áreas de ensino enormemente diferentes. A conclusão que se segue quanto à política a ser adotada é de importância primordial para o ensino de economia. Ensinar disciplinas que são próprias para um administrador embrionário de empresas não produzirá economistas adequadamente formados. O inverso talvez seja igualmente verdade. As disciplinas têm de diferir na sua filosofia básica e no seu conteúdo. As de administração de empresas são e devem ser destinadas a acentuar as capacidades de obtenção de lucros dos organismos subsocietários, sejam eles fazendas individuais, empresas dirigidas pelo proprietário, ou corporações gigantes. ${ }^{6} \mathrm{O}$ conteúdo técnico destas disciplinas trata da manipulação direta de variáveis limitadas, dirigidas para a finalidade ou finalidades específicas do organismo. O economista, por outro lado, preocupa-se com o bem-estar da sociedade como um todo. Preocupa-se com um mecanismo muito mais complicado, e os limitados recursos disponíveis para a manipulação das variáveis mais numerosas por sua vez envolvem estudos e pesquisas com métodos indiretos.

Isto não deve ser interpretado no sentido de que a economia é «melhor» do que a administração de empresas ou que ela é mais «valiosa», ou que deve ter alguma prioridade. Não acredito em nenhuma destas afirmativas. A economia é simplesmente diferente e não pode ser tratada como se fosse uma parte da administração de empresas ou - pela mesma razão - vice-versa. ${ }^{7}$

Isto também não deve ser interpretado como um indicador de falta de relacionamento entre as disciplinas orientadas para a administração e para a economia, pois estes campos partilham do mesmo instrumental básico: lógica, matemática, contabilidade e estatística. A administração atua no contexto econômico e social, e o bom administrador de empresas deveria compreender o meio no qual êle atua. Muito do seu sucesso dependerá de sua capacidade de interpretar e prever o comportamento do meio no qual êle age. Muito do interesse do economista também se dirige para as empresas - sua produtividade, sua eficiência, seu progresso e obstáculos. E assim o economista precisará saber acerca das empresas, mas suas necessidades relativas a este conhecimento

5 Por exemplo, vide Análise, pág. 3.

6 Sempre supondo-se que a economia tivesse um setor privado substancial. No caso do socialismo, a tarefa do administrador não mudaria muito, mas, como se sabe, é difícil encontrar-se boa medida de sua eficiência como administrador.

7 Pode ser de interesse para o leitor brasileiro saber que os Departamentos de Economia das Universidades dos Estados Unidos não são, frequentemente, formalmente relacionados às Escolas de Administração. São algumas vezes encontrados nas Faculdades de Letras e Artes, outras vezes nas Escolas de Ciências Sociais. 
comum são completamente diferentes e são as características distintivas destas duas amplas áreas de atividade.

Talvez esta definição de economia pareça mais simples do que ela é, e alguns comentários devem reestabelecer sua complexidade. A referida definição não diferencia total e singularmente a economia, como demonstram os exemplos que se seguem: 1) $\mathrm{Na}$ área do marketing, os problemas referentes à melhor maneira de expor os cereais usados no café da manhã pertencem obviamente à área da administração de empresas. Poderia ser dito o mesmo da demanda global por trigo? da demanda global pelos géneros alimentícios usados no café da manhã? da demanda nacional por uma marca específica destes géneros? 2) Nos casos em que somente poucas firmas produzem um dado produto, «firma» e «indústria» tornam-se quase sinónimos e a firma se torna o principal produtor, na sociedade, de um dado produto. Assim, embora nossa definição sugira que o economista tem pouco interesse no comportamento de uma firma em particular, isto realmente implica numa firma pequena, e aquele ponto de vista muda de acordo com o tamanho da firma. 3) A política de antimonopólio e antitruste pertence, em alguns aspectos, ao domínio dos advogados, pois a estes cabe finalmente o julgamento de casos particulares. Mas a análise de situações levando ao monopólio, o comportamento do monopólio, e os efeitos de um caso específico dependem do economista.

Portanto, a definição não é tão clara quanto parecia ser, e será resumida simplesmente no seguinte: o economista está interessado em fenómenos de um ponto de vista geral, global e societário, enquanto que o administrador de empresas está orientado para um campo muito mais restrito.

A primeira parte do trabalho procurou definir significativamente a economia e diferenciá-la de todo o conjunto de áreas afins, englobadas no título «administração de empresas». É conveniente, nesta parte do trabalho, declarar meus preconceitos acerca da administração de empresas e tratar particularmente dos objetivos que creio devam ser os objetivos das Faculdades de Ciências Econômicas.

Estou convencido de que as Faculdades de Ciências Econômicas fundamentalmente têm de preparar jovens na arte e na ciência da administração de empresas, excluindo o ensino em outras áreas. Existem várias razões que forçosamente levam a isto: 1) Uma boa administração de empresas (incluindo a administração de fazendas) é talvez o fator mais importante para o desenvolvimento. Os administradores são os que dirigem e utilizam os recursos nacionais de modo proveitoso ou ruinoso. São as pessoas que aceitam as mudanças da técnica, que as adotam os as rejeitam. São as pessoas que na luta competitiva pelo cruzeiro novo do consumidor presumivelmente estão reduzindo os custos (isto é, 
poupando recursos), aumentando o emprego, expandindo o mercado, etc. Não deifiquemos estas pessoas: elas não agem especificamente com a finalidade de beneficiar a sociedade, e frequentemente agem de modo contrário ao interesse social. Mas ainda assim, a verdade é que em economia, possuindo um substancial setor privado, o controle imediato de grande parte dos recursos da Nação está nas mãos dos seus administradores de empresas - para poupá-los ou desperdiçá-los. E um educador pensaria que eles terão melhor desempenho se tiverem preparo prévio do que se não o tiverem. 2) A partir de minhas experiências em várias instituições dos E.U.A., de cuidadosa observação da América Latina, e do que tenho lido no Brasil, não resta a menor dúvida de que a maioria dos estudantes, ao ingressarem nestes cursos, desejam e esperam seguir a carreira de administradores. Algumas pesquisas confirmam que isto é, de fato, aquilo que fazem após a graduação. ${ }^{8}$ Deste modo, se a grande maioria está inclinada a ingressar no mundo dos negócios — e de fato o fará - segue-se que devem receber boa formação nesta área, ao invés de se prepararem para uma profissão desvinculada da realidade e artificial. $^{9}$ 3) Por outro lado, é também verdade que o mercado para os graduados em administração de empresas é e será sempre maior do que para os economistas, no sentido estrito da palavra. A quantidade de firmas particulares ou autarquias a serem administradas ou gerenciadas é enorme. Cada uma delas tem de ser dirigida, e currículos bem elaborados para administradores de empresas devem tentar satisfazer a demanda por estes profissionais .

Não há lugar para discorrer longamente sobre a natureza da administração de empresas, mas um breve comentário talvez explique bem melhor qual é meu pensamento sobre o assunto. Ocorreu verdadeira revolução no ensino de administração nas duas últimas décadas. Não é mais um conjunto de disciplinas sobre «Vendas a Varejo - I, II, III», a serem cursadas umas após as outras, diferenciadas unicamente em função do tamanho da loja em perspectiva. Em vez dessa simples seriação, o aluno trabalha com o instrumental necessário (matemática, estatística, contabilidade) e desenvolve seus conhecimentos sobre a comunidade na qual êle trabalhará (economia, história, ciência política). Tudo isto é então inter-relacionado através das ciências do comportamento em função dos problemas específicos de gerência de pessoal, gerência de produção, gerência de finanças e «marketing-». Não há motivo que

Vide, por exemplo, Análise, págs. 151-153.

Os legisladores obviamente tiveram dificuldades ao estruturarem a lei (Decreto $\mathrm{n}$ « 31.794 , de 17 de novembro de 1952, art. 3') : «A atividade profissional privativa do economista exercita-se.. . por estudos, pesquisas, arbitragem, laudos, esquemas ou certificados sobre os assuntos compreendidos no seu campo profissional... ou por quaisquer outros meios que objetivam, técnica ou cientificamente, o aumento ou a conservação do rendimento econômico». 
impeça a elaboração de programas verdadeiramente universitários dentro desta linha. ${ }^{10}$

Estou ciente das bases legais da profissão de economista ${ }^{n}$ e talvez de algumas das complicações a ela vinculadas. É óbvio que a longo prazo até as leis e constituições não são imutáveis. A curto prazo, as faculdades devem decidir sobre o tipo de ensino que pretendem ministrar. Devem também decidir se realizarão uma mudança radical no programa de estudos e se vão levar a efeito uma intensiva orientação aos alunos e aos empregadores em potencial sobre o conteúdo do currículo. O currículo mínimo exigido pelo Conselho Federal de Educação não é, de modo algum, ótimo para o ensino de administração ou para o ensino de economia, embora não seja totalmente inútil para ambos.

Resumindo, minha opinião é que as faculdades devem se concentrar nesta função principal: formar estudantes para ingressar na administração. O diagrama abaixo sugere, muito superficialmente, como estas áreas poderiam situar-se face à Nação como um todo.

\footnotetext{
Esquema para $o$ funcionamento das Faculdade $A M$

Ciências Econômicas do B rasil
}

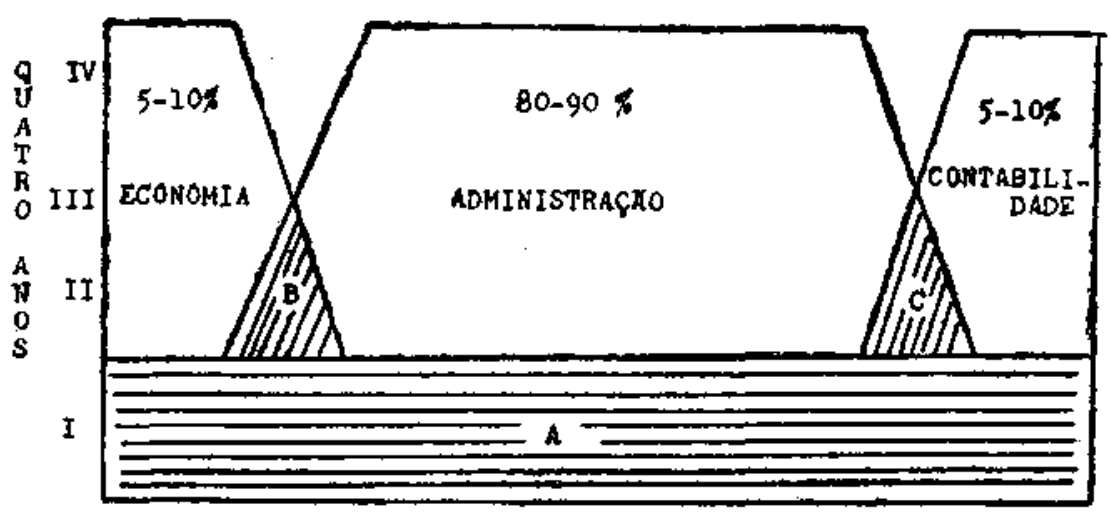

A distância vertical representa o período de quatro anos e a distância horizontal a distribuição dos estudantes pelas três especialidades: economia, administração e contabilidade. No primeiro ano (área A) as matérias

10 Na verdade, o Brasil tem instituição pionera na América Latina neste campo, qual seja a Escola de Administração de Empresas de São Paulo.

1' Vide Regulamentação da Profissão de Economista, Rio de Janeiro, Conselho Regional de Economistas Profissionais, Publicação $n^{\circ}$ 8, 1964, para documentação referente à matéria; e $\mathrm{S}$ monsen, ob. cit., pág. 29, para algumas implicações relativas ao assunto. 
poderiam ser comuns a todas três especialidades: estatística, matemática, economia elementar, história econômica, português, etc. Nos anos seguintes, os alunos de administração poderiam cursar disciplinas junto com a economia (área B), tais como «organização industrial» e marketing, c outras com a contabilidade (área C), tais como «auditoria elementar» e «contabilidade de custos». Este diagrama pretende ser somente uma sugestão e certamente não representa qualquer firme convicção de que os cursos comuns devem ser distribuídos segundo os anos ou as proporções deste diagrama.

Os contadores a serem preparados pelo sistema são analistas contadores de alto nível, pessoas tão capazes na sua especialidade que deles esperar-se-ia que analisassem as empresas (e as organizações governamentais) e idealizassem sistemas de contabilidade para elas. Existe grande necessidade de um pequeno grupo de contadores qualificados e altamente treinados para servir tanto às firmas como à sociedade; e embora a quantidade não precise ser grande, eles têm de ser algo diferente dos «sofisticados guarda-livros», que provavelmente hoje são formados.

$\mathrm{Se}$ eu estiver certo com respeito às adequadas proporções dos futuros graduados e se, dentro de limites razoáveis, a Educação é uma indústria de custos médios decrescentes, a conclusão é que as Faculdades de Ciências Econômicas (cerca de 70) não devem todas tentar preparar economistas (contadores). A maioria deve procurar dar o melhor de si ensinando administração de empresas e deixando para alguns poucos centros o trabalho de elaborar currículos em economia e contabilidade. $^{12}$

\section{III}

Numa nítida mudança de tópicos, esta parte apresentará meu ponto de vista sobre a economia como um dispositivo para estudar e compreender alguns aspectos do meio ambiente. Voltando à definição anterior, em primeiro lugar a Economia é uma ciência social. Como tal, procura explicar e prever alguns aspectos do comportamento do homem. Deste modo, relaciona-se necessariamente e justapõe-se a outras ciências sociais que procuram explicar e prever outros aspectos da conduta do homem, que são necessariamente relacionados entre si mesmos. Talvez a conclusão disto seja a de que o economista bem preparado deve estar razoavelmente familiarizado com as ciências sociais «irmãs» da economia.

Mas, acima de todas, a mais importante consequência da Economia ser uma ciência social é seu necessário relacionamento com um meio

12 Esta não é uma sugestão original. Vide Análise, pág. 204. e António Delfim Netto, «As Oportunidades, os Problemas e a Estratégia para Melhorar no Brasil o Treinamento Universitário em Economia», in Revista. Varas estimativas colocam a necessidade de economistas entre 125 a 500 por ano (Vide Análise, pág. 10). Isto sugere que um máximo de cinco escolas deve formar economistas. 
ambiente que poderá ser internacional, nacional ou regional. E esta disciplina só tem sentido em função do meio. O diagrama abaixo esclarece este ponto.

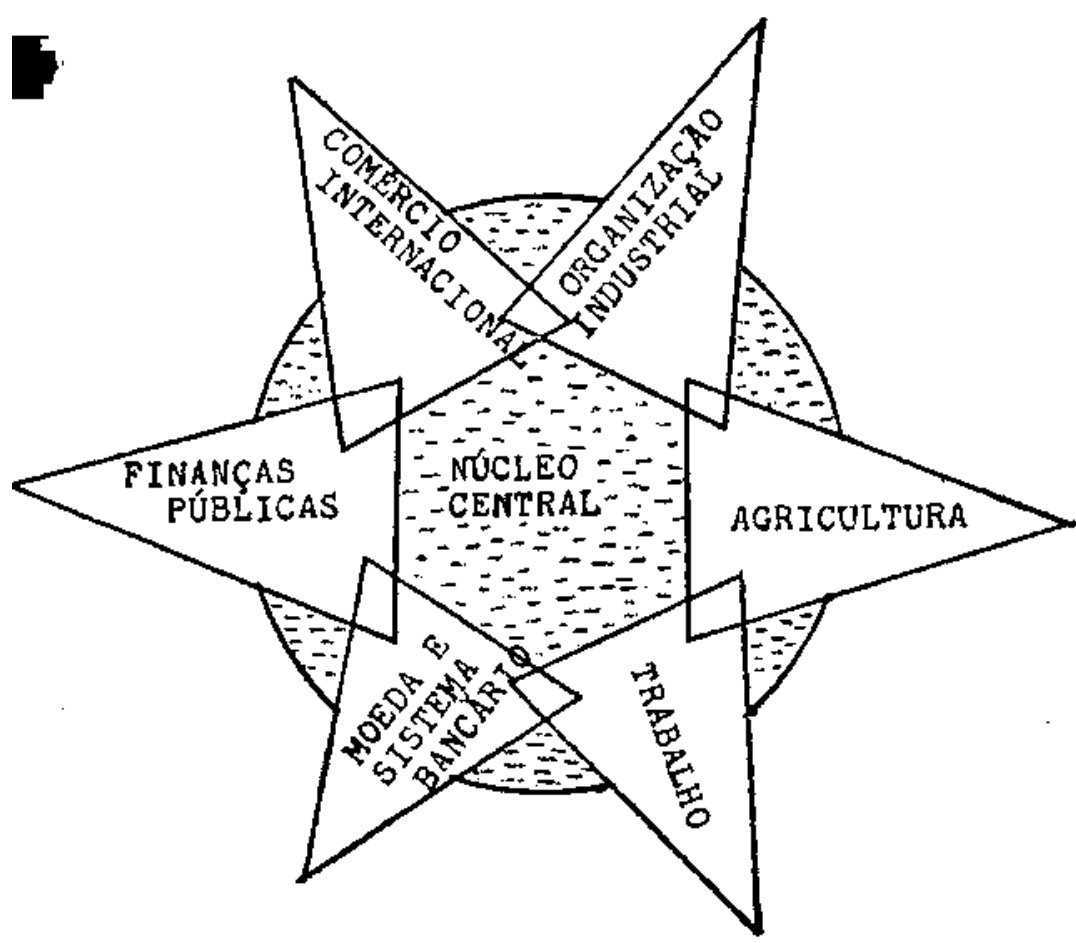

A parte circular e sombreada representa o núcleo central da Economia: a teoria, micro-e-macro, clara e límpida em suas hipóteses, pouco tumultuada pelas instituições a sua volta e geral na sua aplicação. $O$ núcleo engloba os principais instrumentos do economista - estatística, econometria, matemática e história. Mas isto não é tudo que existe em Economia. As saliências representam as áreas de disciplinas específicas da Economia, uma parte situada fora do núcleo central e uma parcela substancial situada dentro deste núcleo. Consideremos, por exemplo, o caso da economia do trabalho.

Pode-se fazer uma série de afirmativas sobre a determinação dos salários e do emprego utilizando o instrumental e as hipóteses da análise econômica moderna. Pelo menos ela fornece um quadro de referências adequado para as perguntas a serem feitas e para a natureza das respostas a serem procuradas. Entretanto, ainda há muito que não pode ser inteiramente manipulado pelo instrumental e teoria gerais: o trabalho tem um componente de bem-estar que o trigo não tem; o trabalho não vendido hoje está perdido para sempre mas o trigo pode ser guardado até amanhã; o trabalho é um ser político, o trigo não o é; as disputas 
trabalhistas são baseadas na lei, tradição história, poder, e todos variam de nação a nação, de uma época para outra. Estas características são as que determinam a representação (v. gráfico) daquela parcela fora no núcleo central. Estas áreas de interesse específico desenvolveram-se, porque havia algo acerca do produto ou da atividade destas áreas que demandava especial atenção - geralmente em virtude do modo pelo qual os fatores institucionais as influenciavam.

É útil comparar a Economia como é ensinado no Brasil com a dos E.U.A. O núcleo central pode ser, de modo geral, semelhante, enquanto que as instituições, as tradições, as leis e o meio social são imensamente diferentes, e o que é relevante e aplicável aos E.U.A. pode ser irrelevante e erróneo para o Brasil. «Economia do trabalho», «finanças públicas», «moeda e sistema bancário» são ou devem ser consideravelmente diferentes no seu conteúdo enquanto disciplinas ensinadas nestes dois países. Isto tem algumas implicações importantes:

a) Embora o «Samuelson» possa ser muito bom como texto de economia elementar para os estudantes dos E.U.A., não serve para os estudantes brasileiros. O mesmo se dá com a maioria dos textos em muitos outros campos do conhecimento, aplicado a áreas determinadas. A Análise Matemática para Economistas, de R.G.D. Allen, pode ser traduzida e servir admiravelmente como texto de estudo, mas um livro dos E.U.A, sobre economia agrícola teria interesse somente secundário.

b) Quando os latino-americanos estudam no estrangeiro, tendem a evitar as áreas de conhecimento aplicado, relacionadas às instituições, em virtude de sua aparente irrelevância, desfazendo-se de todo o componente institucional do que aprenderam. Quando retornam a seus países, ensinam o que lhes parece relevante ou menos irrelevante: a teoria pura, os modelos, a econometria - deixando de lado a tarefa de relacioná-los ao meio cultural e social, embora aquela teoria só tenha sentido se relacionada com o meio. O resultado é que o ensino de Economia tende a tornar-se mais estéril, estreito, e muito menos interessante do que é nos E.U.A. Por outro lado. o tradicional regime de tempo parcial dos professores é, na minha opinião, em grande parte responsável, pois aqueles que voltam do estrangeiro têm de trabalhar em vários empregos e nunca conseguem oportunidade de inicialmente «digerir» aquilo que aprenderam, a fim de que possam, mais tarde, «explorá-lo».

O diagrama não pretende ser uma representação gráfica de caráter definitivo: algumas pessoas acrescentariam a economia de transportes, a teoria de localização e a economia regional como áreas específicas, enquanto outras talvez argumentassem que a moeda e sistema bancário estão incluídos na teoria dos preços e na macro-economia. A representação também é dinâmica, pois há algumas décadas atrás a disciplina 
«ciclos econômicos» era importante subdivisão da Economia, mas hoje esta subdivisão praticamente desapareceu como consequência da revolução Keynesiana. O desenvolvimento econômico, atualmente muito em voga, não se enquadra absolutamente no diagrama, pois engloba como a história econômica - toda a Economia. O diagrama não pretende retratar a Economia com todas suas fronteiras, imitando exatamente seu campo, mas sim enfatizar a importância das áreas de conhecimento «aplicado» como parte integrante da Economia e salientar o relacionamento desta disciplina com a «realidade» - seja dos E.U.A., do Brasil, ou de Uganda.

A falta de interesse dos economistas latino-americanos pelos mercados de trabalho de seus próprios países é deprimente. Estes são os mercados mais importantes em qualquer país, tanto em virtude do volume total das vendas como do número de participantes do mercado. Quando alguém pergunta sobre a falta de interesse, há uma variedade de respostas dadas. "A lei é tão importante». "No final das contas, é tudo política». «A lei é cumprida muito desigualmente». «Nós não pagamos salários, pagamos as mais variadas quantias à Previdência Social, damos assistência médica gratuita, etc.» «Os dados disponíveis são muito ruins». «Muitas pessoas recebem salário em espécie e não em dinheiro». «A educação e o analfabetismo são muito importantes». "O que determina o emprego é a posição e prestígio dos parentes», etc, etc. Isto é bem verdade, mas seu conjunto demonstra exatamente que existem fatores institucionais que são unicamente chilenos, mexicanos ou brasileiros e que devem ser estudados e descritos caso a afirmativa de que «os salários são iguais ao produto da renda marginal» deva ser mais do que uma expressão estéril.

Resumindo, se a Economia deve ser significativa para o Brasil, tem de ter um substancial conteúdo brasileiro - alguma coisa que aparentemente está faltando. ${ }^{13}$

\section{IV}

Finalmente, esta parte trata do nível em que a Economia será ensinada, ou melhor, do nível de maturidade do futuro estudante.

O Brasil tem bem menos recursos para o ensino de Economia do que os E.U.A.: professores de tempo integral, livros-texto, bibliotecas, e mesmo alunos de tempo integral. Ainda assim, as Faculdades de Ciências Econômicas se propuseram a uma tarefa muito mais ambiciosa do que aquela a que aspiramos. Por motivos de ordem prática, não pensamos que podemos, em quatro anos de Universidade, preparar uma pessoa para ser um economista profissional.

13 Lendo a critica sobre as disciplinas na Análise, págs. 111-131, 13 vezes aparece a frase «deficiente nos aspectos brasileiros» ou outras de igual sentido. 
O estudante dos E.U.A, que ingressa numa Universidade geralmente estudou um total de doze anos no nível primário e secundário. Os cursos de graduação mais tradicionais exigem quatro anos de estudo, c os cursos profissionais e de pós-graduação seguem-se a estes quatros anos - direito, medicina, medicina veterinária, odontologia, seminário, etc. Os cursos de graduação, além do primeiro diploma universitário, são o curso de Mestrado, que é de um ou dois anos adicionais e o curso de Doutorado, que exige 2 a 4 anos adicionais. ${ }^{15}$

Os Departamentos de Economia não pretendem formar economistas ${ }^{16}$ ao nível graduação, embora no ano letivo 1964-65 um total de 10.875 pessoas tivessem recebido diploma de graduação nesta disciplina. O diploma de Mestre foi concedido a 1.268 pessoas, e 410 obtiveram o Doutorado. ${ }^{17} \mathrm{E}^{\prime}$ mais ou menos verdade que sérias intenções de exercer a profissão exigem um doutorado. Assim, os dados sugerem que menos de 4 por cento das pessoas que receberam diploma de graduação tornaram-se realmente economistas. O número de diplomas de Mestre é alto, mas engana como indicador do ingresso na profissão, pois muitos destes diplomas são quase que automaticamente concedidos aos estudantes durante o processo de obtenção do doutorado, enquanto outros são concedidos como uma espécie de «prémio de consolação» aos que tentaram, mas não conseguiram obter o Doutorado (isto é, lhes foi dito. essencialmente, que não deveriam esperar tornarem-se economistas). O diploma de doutorado, até certo ponto, não se constitui num selo de aprovação eterna para a pessoa que o obteve (especialmente no mundo universitário), mas este é assunto muito extenso e complicado para ser discutido aqui. Esta aproximação levanta pelo menos três questões: 1) Que tipo de preparo damos aos estudantes de Economia ao nível de graduação? 2) Por que seguem o curso de Economia ao nível de graduação, se não pretendem tornar-se economistas? ou, colocando a questão em outros termos, o que fazem quando se graduam? 3) Por que são aquelas pessoas deste nível excluídas do papel de economista profissional?

Uma das razões que leva bons e medíocres estudantes a serem atraídos pela Economia é que é sabido que este é um curso para a concessão de diploma não profissional e que, portanto, permite ao estudante considerável flexibilidade. Uma vez que não nos sentimos constrangidos a produzir economistas neste nível de estudos, não é

14 Geralmente isto é dividido em 6-2-4 anos de escola primária, curso secundário e curso colegial, respectivamente. A divisão 6-3-3 também ocorre, embora seja menos frequente. Portanto, os estudantes do Brasil e dos Estados Unidos que ingressam numa Universidade tiveram um número de anos de escolaridade formal aproximadamente idêntico.

15 Tanto esta afirmação como a precedente são muitíssimo simplificadas.

16 Não fazemos nenhum esforço para «definir» e regulamentar a profissão como se faz no Brasil.

17 Department of Health, Education and Welfare, Digest of Educational Statistcs, 1966, Washington, Government Printing Office, p. 81 . 
necessário tentarmos ensinar ao aluno tudo que é conhecido com relação a técnicas, metodologia ou informações sobre Economia. Êle raramente chega a aproximar-se dos limites onde o trabalho novo, de criação, está sendo realizado. Não possui o comando do instrumental adequado nem a perspectiva histórica da disciplina para julgar e avaliar este tipo de trabalho. Embora exista grande variação de uma Universidade para outra, sugere-se abaixo um curso tipico:

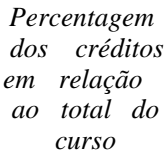

Matérias Gerais - um ano cora ciências naturais, humanidades, inglês, ciências sociais (todos ou quase todos os estudantes cursam estas disciplinas, não importando qual seja o seu principal campo de estudo)

Matérias de Economia - exigidas: introdução, teoria intermediária (após a elementar), moeda e sistema bancário. trabalho, organização industrial e ma s $1 / 3$ a $1 / 2$ dos créditos de livre escolha

Matérias Instrumentais- estatística, matemática, lógica. línguas estrangeiras, concentrando-se em algumas destas matérias.

Ciências Sociais Cognitivas - a serem escolhidas dentre grande variedade como sociologia, ciência politica, história, psicologia, planejamento urbano, geografia, antropologia, estudos sobre outros países, etc.

Livre escolha com a concordância do aconselhador . . . . . . . . 15

A principal característica de um curso como este é a sua flexibilidade. Seriam elaborados cursos muito diferentes para o estudante A, que pretende ingressar na Escola de Direito, para o estudante B que vai trabalhar na empresa de sua família, para o estudante $\mathrm{C}$ que ainda não sabe qual profissão vai abraçar, e para o estudante $\mathrm{D}$ que planeja ingressar na escola pós-graduada de Economia. Embora sob alguns pontos de vista esta flexibilidade seja altamente desejada, não existe sem alguns custos: 1) Grande parte do tempo dos professores deve ser dedicado a elaborar um programa que seja ótimo para cada aluno. 2) Com algum esforço podem ser elaboradas diferenças consideráveis quanto à dificuldade e rigor dos programas a serem seguidos pelos alunos. Isto significa que todos os diplomas não representam o mesmo esforço ou o mesmo nível de realizações.

Tal programa de estudos não prepara o aluno para uma carreira específica. A maioria dos estudantes com diplomas de graduação se dirige para carreiras nas empresas. A maioria estudou um pouco de contabilidade e cursou algumas disciplinas relativas à administração de empresas. Esperamos que eles tenham amplo conhecimento do mundo econômico, social e politico em que vão trabalhar. Presumivelmente, 
desenvolveram métodos analíticos de abordagem para os problemas que enfrentarão e aprenderam sobre o raciocínio e pensamento lógico. Não é um background de todo ruim para um novato no mundo dos negócios. ${ }^{18}$ Alguns poucos realizarão estudos pós-graduados em Economia. Um número considerável fará estudos de pós-graduação em outras áreas: direito, administração de empresas, e outras ciências sociais. Poucos torna-se-ão professores de ciências sociais em cursos colegiais.

Os principais empregadores organizados de economistas nos E.U.A. são os órgãos governamentais e as Universidades. ${ }^{19}$

Nos últimos anos, as Universidades tornaram-se cada vez mais inflexíveis quanto à necessidade de possuir um Doutorado (Ph. D. nosso título máximo) antes de dar um emprego normal (o oposto de «temporário») a um professor. Os governos federais e estaduais também impõem mais ou menos as mesmas exigências para contratar econômicas, embora existam muitos outros cargos para os quais o diploma de graduação em Economia é uma qualificação valiosa, mesmo que o cargo não seja o de economista. Ele pode desenvolver suas capacidades e conhecimento e tornar-se um economista pelo que faz e escreve, mas isto é mais uma exceção do que a regra.

A experiência dos Estados Unidos no campo da preparação de economistas profissionais pode ter considerável importância. Sendo ou não relevante, deve-se notar que os atuais objetivos parecem ser muito mais ambiciosos no Brasil do que nos Estados Unidos - e com recursos consideravelmente menores.

Tendo discutido uma série de assuntos correlatos, e já tendo revelado meus preconceitos, volto a enunciar, com outras palavras, as duas conclusões principais que decorrem de três premissas:

Premissa 1 A administração de empresas ${ }^{20}$ não é o mesmo que economia, e ambas são importantes para o Brasil.

Premissa 2. A formação de um economista profissional é mais uma tarefa longa e árdua que quase certamente exigirá mais do que os quatro anos que atualmente lhe são dedicados.

18 Particularmente antes do «novo ensino de administração de empresas» (ver página anterior), muitos homens de empresas preferiam graduados que tivessem amplos conhecimentos gerais, insistindo que assim poderiam melhor ensinar os métodos utilizados nos negócios de suas firmas.

19 O leitor deve lembrar-se que sob o sistema departamental as responsabilidades de ensino de um departamento podem transcender o ensino a seus próprios estudantes. O Departamento de Economia é essencialmente um departamento para «servir», ensinando economia a muitos estudantes de outros departamentos. Segundo minhas estimativas, no departamento em que sou professor, o número de estudantes matriculados que não estão se especializando em economia é cerca de sete vezes maior do que aqueles que estão.

20 Amplamente def;nida, incluindo todas as especialidades relativas ã administração de empresas, exceto a maioria das engenharias industriais. 
Premissa 3. A formação do estudante em administração de empresas e em Economia é, pelo menos inicialmente, uma indústria de «custos médios decrescentes».

Conclusão I. Devem ser reconhecidas as diferenças entre a Economia e as carreiras relacionadas à administração de empresas e deve ser logo iniciada uma separação entre ambas. ${ }^{21} \tilde{A}$ tentativa de combinar os estudos de ambas carreiras numa única matriz é um desperdício com o tempo dos alunos e com os recursos do sistema educacional.

Conclusão II. Em virtude do fato de que um número elevado e cada vez maior de alunos quer estudar as especialidades relativas à administração de empresas, a maioria das instituições deve concentrar-se nesta tarefa, simplesmente porque trará como resultado as vantagens das economias de escala. Poucas pessoas desejarão tornar-se economistas e o mercado absorverá menos ainda. Isto sugere que tanto do ponto de vista da qualidade da Educação como do ponto de vista das economias de escala, somente pequeno número de instituições deve dedicar seus recursos à formação de economistas. ${ }^{n}$

\section{JOHN M. HUNTER \\ EAPES}

Michigan State University

Tradução de:

Jacques R. Velloso.

Fevereiro - 1968.

\section{BIBLIOGRAFIA DE ESPECIAL INTERESSE}

R. A. GORDON and JAMES E. HOWELL, Highec Education for Business, New York, Columbia University Press, 1959.

HORACE TAYLOR (ed.), Teaching of Undergraduate Economics, American Economic Rev:ew Supplements, vol. XL, 5 de nov. $2^{5}$ Parte, dezembro de 1950.

2' Tenho ciência de que já está se realizando algum movimento nesta direção.

22 Existem muitas perguntas que foram propositadamente deixadas sem resposta: as poupanças decorrentes da especialização poderiam ser utilizadas para manter os estudantes nos poucos centros de ensino de economia? Qual seria o programa ótimo - dois anos juntamente com os estudantes de administração, mais dois de especialização com um diploma semifinal, seguindo-se então dois anos de intensiva profissionalização? Seria possível a concessão de diplomas conjuntos, a fim de permitir que o aluno iniciasse seus estudos numa instituição (digamos dois anos de matérias de caráter geral) e terminasse (especialização em economia) noutra. 


\section{Apendice D.4}

\section{ON THE TEACHING OF ECONOMICS IN BRAZIL}

The discussions of the teaching of economics in Brazil have been of considerable interest to me, a visiting foreign economist. As a part of my assignment in Brazil, I have also had the opportunity to visit a number of Faculties of Economic Sciences. This, with other experience in the United States and elsewhere, leads me to comment on the Brazilian scene not because of any special knowledge or of any new solutions but simply because the same set of problems seen through different eyes sometimes reveals interesting, and occasionally, valuable, insights.

The first and principal problem is one of which Brazilian economists are very much aware: there is no clear definition or understanding of what economics is, what economists do, or how economics is distinguished from related fields. ${ }^{2}$ The fact that we speak of Faculdades de Ciencias Economicas always in the plural suggests at least a recognition of dual or multiple «sciences». This multiplicity and the confusion surrouding it is at the heart of the problem of teaching «economics». ${ }^{3}$ The most obvious conclusion from the multiplicity of sciences is that no single set of courses, as Brazilian tradition seems yet to demand, will perfectly satisfy the training needs of all the components.

This admixture of «economic sciences seems to be closely related to French and Spanish (and Italian) academic traditions. Perhaps the outlook and backgrounds of Hume, Locke, and Adam Smith gave «English economics its initial «separation» impetus but it has not since been confounded with law, business administration, and/or accounting. On the contrary, the discipline developed in France as an off-shoot of law schools and developed, with accounting, as a sub-specialty of law

Particularly in Revista Brasilcira de Economia, ano XX, n' 4, dezembro de 1966 (hereinafter referred to as Revista which reports the resuts of a seminar in this subject held at Itaipava in March, 1966 and ERGO, Analise do Ensino de Economia. Rio de Janeiro, EPEA, 1966 (hereinafter referred to as Analise).

2 See, for example, Mario Henrique Simonsen, «0 Ensino de Economia em Nivel de Pos-Graduacao no Brasil», Revista, pp. 19-20.

3 In the very narrow sense to be defined below. 
which has historically given it a substantially different academic and social role. ${ }^{4}$

The present reexamination of curricula stems from the realization that a program of study designed to serve certain needs, perhaps narrowly defined, does not approach fulfilling others. And all this has been further confounded by the emerging area of study called «business administration which is not a «science» at all but rather a combination of technical subjects with the behavioral sciences focused on the management of men, materials, and finance toward particular ends.

Any serious assessment of the teaching of economics, must then start with some sort of a definition which permits bounding the subject matter and the description of objectives. As all economists know, this matter of definition is difficult. Following the lead of Jacob Viner who said that «economics is all those things which economists study» is accurate but gets us nowhere. Settling for «second-best, economics is a social science which is concerned with the collective production and consumption of goods and services in conjunction with the various legal and financial arrangements which impinge on that production and consumption. This is not substantially different than the old text-book definition that «economics is the study of the way man makes his living except in one important regard which is critical in the present discussion: economics is a social science. The import of this distinction is seen when we compare ultimate interests. The accountant and business administrator focus on the balance sheet or profit and loss statement of the firm with whom they are associated. The economist, on the other hand, is concerned with society's balance sheet or with its profit and loss statement. His analytic tools are all designed to understand and to modify the position of the society, visualized, if you will, through the national income accounts. When this is clearly understood it becomes patently absurd for a student to want to specialize in micro-economics (which attempts to explain the allocation of resources and the size and composition of total production through the impact of various factors on the individual firm) because he wants to go into business! Yet, we are told many do just that. ${ }^{5}$

I cannot insist upon this point too much: economics and all business related courses are simply two vastly differing academic areas. The policy conclusion which follows is of prime importance to the teaching of economics. Teaching courses appropriate for embryonic business administrators will not produce adequately trained economists. The converse is perhaps equally true. The courses must differ-in basic

4 In Argentina, for example, the Facultadde Ciencias Economicas had its origin, in the legal reservation of certain tasks for contadores publicos such as attesting to financial statements and serving as court officers in certain proceedings. It is by virtue of this last activity that all graduates of the faculties had, until very recently, to take at least a oneyear course in «bankruptcies».

5 For example, see Analise, p. 3. 
philosophy and in content. Business administrations courses are, and should be, designed to enhance the profit-making capacities of subsocietal organisms whether they be individual farms, owver-operated enterprises, or giant corporations. The technical content concerns the direct manipulation of limited variables to the end or ends of the specific organism. The economist, on the other hand, is concerned with the wellbeing on the society as a whole. $\mathrm{He}$ is concerned with a much more complicated mechanism, and the limited resources available for the manipulation of the more numerous variables involve a great deal more indirection.

This should not be construed to mean that economics is «better» than business administration or that it is more «valuable»; or that it should have some priority. I believe none of these. Economics is simply different and cannot be treated as if it were part of business administration or - for that matter - - vice-versa. ${ }^{6}$

Nor should this be construed to indicate a lack of relationship between business oriented courses and economics. They share basic tools: logic, mathematics and statistics. Business operates in the social and economic context, and the good business administrator should understand the environment in which be operates. Much of his sucess will depend on his ability to interpret and to forecast the behavior of the environment in which be operates. Much of the economist's interest, too, is business - its productivity, its efficiencies, its progress and barriers. And so the economist will need to know about business, but his needs for this common knowledge are quite different and are the distinguishing features of the two very broad areas of activity.

Perhaps this definition of economics appears more simple than it is, and a few comments should re-establish its complexity. The definition does not wholly and uniquely distinguish economics as the following examples demonstrate: 1) In the field of marketing, questions of how best to display breakfast food for better sales is clearly business administration, but what of studies concerning the over-all demand for wheat? for breakfast food in general? the national demand for a particular brand of breakfast food? 2) In the cases when only a very few firms produce a given product, the «firm» and the «industry» become near synonymous and the firm becomes society's principal producer of a given product. So while our definition suggests that the economists has little interest in the behavior of a particular firm this really implies an «atomistic firm» and the viewpoint changes with the stature of the firm. 3) Anti-monopoly or anti-trust policy belongs, in some respects, in the realm of the lawyers since they finally are involved in the adjudication of particular cases. But the analysis of situations leading to

It may be of interest to the Brazilian reader to know that Departments of Economics in U.S. universities are very frequently formally unrelated to the Colleges of Business. Sometimes they are found in the College of Arts and Letters; sometimes in College of Social Science. 
monopoly, the behavior of monopoly, and the effects of a particular practice depends on the economist.

So the definition is not all that clear and we simply leave it at that: the economist is interested in phenomena from a general, global, societal point of view while the business administrator is much more narrowly oriented.

The first section seeks to define economics meaningfully and to distinguish it from all the coterie of subjects glibly lumped under «business administration. It is appropriate in this section to air my prejudices about business administration and in particular focus upon the preferred objectives of present Faculdades de Ciencias Economicas.

I am convinced that the Faculdades de Ciencias Economicas ought primarily to train young people in the art and science of business administration to the exclusion of training in other areas. There are several compelling reasons for this: 1) Good business administration (including that of farm management) is perhaps the single most important factor in development. Administrators direct the wasteful or beneficial utilization of the nation's resources. They are the people who accept technical change, reject it, or adopt it. They are the people who presumably in the competitive struggle for the consumer's new cruzeiro are cutting costs \{i.e. saving resources), increasing employment, expanding the market, etc. Let us not deify these people: they do not act particularly to benefit society, and they frequently act contrary to the social interest. But the fact remains that in economies with a substantial private sector, the immediate control of much of the nation's resources is in the hands of its business administrators - to husband or to waste. And an educator would like to think they will perform better trained than not trained. (2) From my own experiences in various U.S. institutions, from careful observation in Latin America, and from what I have read in Brazil, there is not the slightest doubt but that monst of the sudents who enter these programs want and expect to enter business careers. Some research confirms that this is, in fact, what they do upon graduation. ${ }^{7}$ If the vast majority is so inclined and will enter business, it follows that it ought to be well trained in that area rather than for some synthetic, largely artificial and mythical profession. ${ }^{8}$ It is equally certain that the market for business administration graduates is and will be for greater than it ever will be for economists, narrowly

7 See, for example, Analise, pp. 151-153.

8 The framers of the law had obvious difficulties (Decreto n' 31.794, Nov. 17, 1952, Art. 3): «The professional activities -which are reserved to economists are exercised... by studies, researches, arbitration, opinions or findings, projects or certify cates on subjects of their professional field... the technical or scientific object of which is the increase or the preservation of economic returns. 
defined. The number of private or mixed firms to be administered or managed is enormous. Each must have management, and well developed curricula in business administration ought to be fulfilling the demand for these talents.

This is no place to dwell on the nature of business administration but a comment or two will perhaps explain a bit more fully what it is I have in mind. A veritable revolution in education for business has occurred in the last two decades. No longer is it a matter of one course after another in «Retailing I, II, III» distinguished only by the size of the prospective store. Rather the student develops a set of tools (mathematics, statistics, accounting) and develops an understanding of the community in which he will operate (economics, history, political science). All of this is then brought to bear through the behavioral sciences on the specific problems of personnel administration, production administration, financial administration, and marketing. There is no reason why completely respectable academic programs cannot be developed along these lines.

I am very much aware of the legal basis for the profession of economist ${ }^{10}$ and perhaps something of the complications. In the longrun, of course, even laws and constitutions are not immutable. In the short-run, faculties should decide what they want to do and undertake intensive education of student clients and the employer market. The minimum curriculum required by the Conselho Federal de Educacao is by no means optimal to business education or to economics education, but it would not be totally wasteful to either.

To summarize, it is my judgement that faculties should concentrate on this principal function: training students to enter business. The following diagram suggests very roughly how training in these areas might look for the nation on a whole.

SCHEMA FOR PERFORMANCE OF BRAZIL'S FACULTIES OF ECONOMIC SCIENCES

\section{(See diagram in the Portuguese translation)}

Vertical distance represents four years of time and horizontal distance the distribution of students betwen three specialities: economics, administration, and accounting. In the first year (area A), courses might be common to all three specialities: statistics, mathematics, elementary economic, economic history, Portuguese, etc. In the following years, administration might have courses with economics (area B) such as «public control and «marketing» and others with accounting

9 Indeed, Brazil has one of the pioneer and eading Latin American institutions in this field in the Escola de Administracao de Empresas de Sao Paulo.

10 See F(egulamenta<;ao da Profissao de Economista, Rio de Janeiro, Conselho Regional de Economistas Profissionais, Publicacao n" 8. 1964, for the documentation and Simonsen, op. ci'r., p. 29, for some implications. 
(area $\mathrm{C}$ ) such as «elementary auditing and «cost accounting. This diagram is intended only to be suggestive and certainly represents no firm conviction that common courses should be distributed temporally or proportionally as indicated.

The accountants which are envisaged as products of the system are high-level analytic accountants, persons so adept at their speciality that they would be expected to analyze businesses (and government organizations) and design accounting systems for them. There is great need for a small corps of highly trained, skilled accountants to serve both the firms and society, but the number need not be large and they must be something different from the «glorified bookkeepers probably produced today.

If I am correct with respect to the appropriate proportions of educational output and if, within reasonable limits, education is a decreasing average cost industry, it certainly follows that the 70 or so Faculdades de Ciencias Economicas should not all try to produce economists (accountants). Most should do the best possible with business administration and let a few centers develop curricula in economics and accounting.

\section{III}

In a distinct switch of topics, this section presents my view of economics as a device for studying and understanding some aspects of the environment. To return to the earlier definition, first and foremost. economics is a social science. As such, it attempts to explain and to predict some aspects of man's behavior. And as such it necessarily relates to and overlaps other social sciences which are seeking to explain and predict other aspects of his behavior - aspects which are necessarily related. Perhaps it follows from this that the well-trained economist should be modestly acquainted with his «sister» social sciences.

But by far the most important effect of economics being a social science is its necessary relationship with an environment which may be international, national, or regional. The discipline can only have meaning with respect to the environment. The following diagram clarifies this point.

\section{(See diagram in the Portuguese translation)}

The shaded, circular part represents the hard central core of economics: the theory, micro-and-macro, clean and neat in its assumptions,

11 This is not an original suggestion. See. Analise. p. 204 and Antonio Delfim Netto, «As Oportunidades, os Problemas e a Estrategia para Melhorar no Brasil o Treinamento Universitario em Economia» in Revista. Various estimates place the need. for economists at between 125 per year to 500 per year (See Analise, p. 10). This suggests that at a maximum of five schools should be producing economists. 
little cluttered by institutional surroundings and general in its application. This central core incorporates the principal tools of the economist statistics, econometrics, mathematics, and history. But this is not all here is to economics. The projections represent specific subject matter areas of economics a part of which lie outside the hard, central core, but a substantial portion of which lie within it too. Consider the case of labor economics, for example.

Much can be said about the determination of wages and employment using the tools and assumptions of modern economic analysis. At least this provides a proper frame of reference for the questions to be asked and the nature of the answers to be sought. But there is much, too, that cannot be handled entirely by general tools and theory: labor has a welfare component that wheat does not; labor not sold today is lost forever, but wheat can be held over until tomorrow; labor is immediately a political animal, wheat is not; labor bargaining is based in law, tradition, history, power and all these vary from nation to nation and from to time. These characteristics account for that part of the representation outside the central core. The other special interest areas developed because there was something about the product or about the activity that demanded special attention - generally because of the way institutional factors impinge upon it.

It is useful to compare the economics of Brazil with that of the United States. The central core may be generally similar, the institutional, traditional, legal, social environment is vastly different and what is relevant and applicable in the United States may be irrelevant and erroneous for Brazil. «Labor economics, «public finance, «money and banking are or should be considerably different in the courses taught in the two countries. This has some important implications:

a) However good «Samuelson» may be as an elementary text for U.S. students, it is unsuitable for Brazilian students. The same is true of most texts in any of the applied areas. R.G.D. Allen's Mathematical Analysis for Economists can be translated to serve admirably as a text, but a U.S. text on agricultural economics would be of only marginal interest.

b) When Latin Americans study abroad they to avoid institutioally related, applied fields because of their apparent irrelevance. They discard the institutional material they do learn. When they return, they teach that which appears relevant or least irrelevant: the pure theory, the models, the econometricsputting to one side the task of relating all this to the cultural and social environment only in which it has meaning. As a consequence, economic education tends to become more sterile, narrower, and much less exciting than it is in the U.S. And, in my view, it becomes less useful. The traditional part-time professorship is, also in my opinion, largely to blame since 
returnees are required to undertake several jobs and never really have an opportunity to «digest», first, and to «exploit», later, their education.

The diagram is not intended to be a definitive representation: some would add transportation economics, location theory, regional economics as special fields and others would argue perhaps that money and banking is incorporated in price theory and macro economics. The representation is dynamic, too, since a few decades back a major sub-field was «business cycles but this has practically disappeared as a result the Keynesian revolution. Economic development, the current fashion, fits not at all in the diagram since it encompasses - like economic history and the history of economic thought — the whole of economics. The diagram does not try to portray the discipline of economics with all its exact and limiting boundaries but emphasizes the importance of the «applied» fields as a part of it and to underscore the relationship of the discipline to «reality» - U.S., Brazilian, or Ugandan.

Latin American economists' lack of interest in their own labor markets is depressing. These are the most important markets in any country both by virtue of the total sales and numbers of participants. There is a variety of response when one inquires about the lack of interest. «The law is so important. «It's all politics, anyway». «The law is so unevenly enforced. "We don't pay wages, we pay vague fringe benefits. «Data are so poor. «So many people receive wages in kind not in money. «Education and literacy are so important. «What one's relatives are determines employment, etc. etc. This is true enough but their sum just demonstrates the point: these are the institutional factors which are uniquely Chilean, Mexican, or Brazilian and which have to be studied and described if "wages are equal to marginal revenue product is to be more than sterile shibboleth.

In summary, if economics is to be meaningful for Brazil, it must have a substantial Brazilian content - something which it apparently lacks. ${ }^{12}$

\section{V}

Finally, this section deals with the level of economics to be taught, or rather the maturity-level of the prospective student.

Brazil has considerably fewer resources than the United States for the teaching of economics: full-time professors, text books, libraries, and even full-time students. Yet the task which Brazilian Faculdades de Ciencias Economicas have undertaken is much more ambitious than that to which we aspire. For all practical purposes we do not think we can, in four university years, train a person to be a professional economist.

In reading the critique of courses in Analise. pp. 111-131, the phrase «deficiente nos aspectos brasileiros» or something similar occurs 13 times. 
The entering university student in the U.S. has generally had twelve years of primary and secondary education. ${ }^{3}$ The usual undergraduate program traditionally requires four years and graduate programs and professional programs follow those four years - law, medicine, veterinary medicine, dentistry, the ministry, etc. Degree programs beyond the first university degrees are the Master's degree which takes one or two additional years and the $\mathrm{Ph}$. D. which requires an additional 2-4 years. ${ }^{14}$

Departments of Economics do not pretend to produce economists ${ }^{15}$ at the undergraduate level although in the academic year 1964-65, 10,875 persons received undergraduate degrees in the discipline. Another 1,268 received the Marter's degree, and 410 received the doctorate. ${ }^{16}$ It is approximately true that serious intentions to exercise the profession require a doctorate. Thus the data suggest that fewer than 4 per cent of the persons receiving undergraduate degrees really become economists. The number of masters' degrees is deceivingly large as an indication of entrance into the profession since many are awarded almost automatically to students in the process of earning their doctorates and since others are awarded as sort of «consolation» prizes to students who have sought but failed to earn the $\mathrm{Ph}$. D. (i.e. they have essentially been told that they should not expect to become economists). To some extent, the $\mathrm{Ph}$. D. degree does not really put an eternal stamp of approval in the person who earns it (especially in the academic world) but this is too long and complicated a story to embark upon here. This impressionistic average sketch raises at least three questions: 1) What kind of training do we give undergraduate students of economics? 2) Why do they take economics as undergraduates when they do not intend to become economists? or, put another way, what do they do when they graduate? 3) Why are person at this level excluded from the role of professional economist?

One reason both good and mediocre students are attracted to economics is because it is known to have a non-professional degree program which can therefore permit the student considerable flexibility. Since we do not feel constrained at this level to produce economists, it is not necessary to try to teach the student all that is known respect to techniques, methodology, or information in economics. He seldom even approaches the frontiers where imaginative, new work is being done.

Generally, this is broken down into 6-2-4 years of primary school, middle school, and high school. Less frequently it is 6-3-3. Thus, Brazilian and U.S. entering university students have about the same number of years of formal schooling.

\footnotetext{
14 This and the preceding one are greatly oversimplified statements.

Brazil. We make no effort to «define» and regulate the profession as is done in
}

16 Department of Health, Education, and Welfare, D:gest of Educational Statistics, 1966, Washington, Government Printing Office p. 81. 
He has not the command of the appropriate tools nor the historical perspective of the discipline to appreciate and to evaluate this work. Although there is great variation from university, a typical program is suggested as follows:

Percentage of total program

General Education - one year each of natural science, humanities, English, social science (all or most students regardless of major subject interest take these courses).

Economics courses - required: introduction, intermediate theory, money and bankind, labor, industrial organization $-1 / 3-1 / 2$ free choice

Tool courses — statistics, mathematics, logic, language .- with some concentration

Cognate social science - to be chosen from a wide selection of sociology, political science, history, psychology, urban planning, geography, anthropology, foreign area studies, etc.

Free choice with agreement of advisor.

The principal characteristic of such a program is its flexibility. Greatly different programs would be developed for Student A who intends to enter law school, Student B who will enter his family's business, Student C who has no idea of what he will do, and Student D who plans to enter graduate school in economics. Although this flexibility is highly desirable from some points of view, it is not without cost: 1) A great deal of professorial time must be devoted to developing a study program which is optimal for each individual student. 2) With some effort, considerable differences in student programs can be developed with respect to difficulty and rigor. This means that all degrees do not represent the same effort or the same level of accomplishment.

Such a program does not prepare the student for any one career. Most students with undergraduate degrees enter business careers. Most have had some accounting and other business courses. We hope they have a through knowledge of the economy, society, and political world in which they will work. Presumably they have developed analytic approaches to problems and learned something of logical thought and reasoning. This is not at all bad background for a novice in the business world. ' Some few go on to do graduate work in economics. A considerable number do graduate work in other fields: law, business, and other social sciences. A few become teachers of social sciences in high schools.

17 Particularly before the «new business education (see p. above), many business men preferred to hire graduates with very broad backgrounds, insisting that they could better teach the business methods related to their firms. 
The principal organized employers of economists in the United States are governmental agencies and the universities. ${ }^{1 S}$ In recent years. the universities have become increasingly adamant about the necessity of having the $\mathrm{Ph}$. D. (our titulo maximo) before regular (as opposed to «provisional») employment. State and federal governments, too, impose more or less the same requirements in hiring economists although there are many other positions for which the undergraduate degree in economics is a valuable qualification even though the position may not be that of economists. He may develop his skills and knowledge and become an economist by what he does and what he writes, but this is the exception rather than the rule.

U.S. experience in the matter of training professional economists may have considerable relevance. In any case, it is noteworthy that present objectives appear to be much more ambitious in Brazil than in the United States - with considerably fewer resources.

Having covered considerable territory and having already disclosed my prejudices, I state again in different form the two principal conclusions which stem from three premises:

Premise 1. Business administration ${ }^{9}$ is not the same as economics and both are important to Brazil.

Premise 2. Training professional economists is a long, arduous task - almost certainly requiring more than the four years now devoted to it.

Premise 3. Training for business and in economics is at least initially a «decreasing average cost» industry.

Conclusion I. The differences between business related careers and economics should be recognized and an early divorcement initiated. Attempting to combine the training of both in a single mold is wasteful of the students' time and the educational system's resources.

Conclusion 11. Because vastly greater numbers need to be and want to be trained in the business administration specialities, most institutions should concentrate on this task simply because this take advantage of the economics of scale. Fewer people will want to become economists and

18 The-reader is reminded that under a departmental system the teaching responsabilites of a department may transcend teaching its ow students. The Economics Department is typically a «service» department teaching economics to many students from other departments. I estimate that the Department from which I come probably has about seven times the enrollments of students who are not specializing in economics as it does of those who are.

19 Broadly defined to include all business related specialties except most of industrial engineering.

${ }^{20}$ I am aware that some movement in this direction is already taking place. 
the market will take fewer. This suggests, both from the point of view of the quality of education and the economics of scale, that a mere handful of institutions should devote their resources to the training of economists. 21

JOHN M. HUNTER

EAPES

January, 1968

Michigan State University

\section{PARTICULARY RELEVANT BIBLIOGRAPHY}

R. A. GORDON and JAMES E. HOWELL, Higher Education for Business, New York, Columbia University Press, 1959.

HORACE TAYLOR (ed.) Teaching of Undergraduate Econom'cs, American Economic Review Supplements, vol. XL, Nov. 5, Part 2, December, 1950.

21 There are many questions purposely left unanswered: Could some of the savings from specialization be used to support students in the few centers? What would be the optimal program - two years jointly with business students, then two of specialization with a semi-terminal degree, then two more years of intensive professionalization? Would joint degrees be possible which could permit the student to begin this studies at one institution (say two years of general courses) and finish (specializing in economics) at another? 
Apêndice D.5

\section{SOBRE OS OBJETIVOS DA EDUCAÇÃO SUPERIOR NO BRASIL}

Um conjunto de objetivos razoavelmente bem delineados é pré-requisito para qualquer planejamento. Devem existir metas, desiderata. objetivos que possam ser descritos; de outra forma, o próprio conceito de «planejamento» não faz sentido. Um clube de automóveis ou uma agência de turismo podem ser solicitados a planejar uma viagem, mas as finalidades da viagem têm de ser conhecidas. Pretende-se chegar a destinos específicos ou, menos concretamente, pode-se dizer que «se deseja um máximo de descanso» ou «que queremos conhecer a Europa».

O planejamento econômico geral é usualmente expresso em termos de uma taxa de crescimento específico. A Aliança para o Progresso, por exemplo, estabeleceu $2,5 \%$ per capita por ano como a taxa de crescimento mínimo e aceitável. Dado este objetivo, pode-se analisar os vários setores de economia e determinar os vários subobjetivos, consistentes com o principal objetivo e que para êle contribuam. Dados os fins ou objetivos, pode-sc elaborar o planejamento de cada setor e sub-setor. Num nível mais elementar, a firma individual pode elaborar seu planejamento tendo por base algumas previsões do futuro mercado. De posse destes dados, os engenheiros, financistas e economistas podem determinar os melhores meios de atender às futuras exigências do mercado.

Neste sentido, o planejamento em Educação não é diferente de qualquer outro planejamento: só pode ser feito a partir de objetivos claramente definidos. Por outro lado, a Educação é bem mais complexa do que a maioria das outras «indústrias», e esta complexidade torna mais difícil sua racionalização em termos sociais. Os objetivos da Educação superior estão interligados com os da Educação secundária e primária. O material humano que ingressa no sistema educacional (insumo) é difícil ser conceituado e quantificado, e aquele que é produzido pelo sistema o é ainda mais.

Este trabalho procura explorar alguns aspectos dos fins ou objetivos que pertenceriam à Educação superior no Brasil. Alguns dos meus preconceitos e convicções tornar-se-ão evidentes, embora nenhuma solução seja sugerida. A Educação superior brasileira é, acima de tudo, «brasileira»; e seus objetivos podem e devem também ser brasileiros. 


\section{COMENTÁRIOS PRELIMINARES}

Devem ser esclarecidos três aspectos gerais do problema antes de entrarmos na discussão principal.

Objetivos e valores. Os objetivos de uma política ou de um sistema refletem valores. O «plano» consiste em meios para atingir os objetivos, mas os próprios objetivos dependem de valores fundamentais. Os objetivos que eu escolhesse para a Educação superior brasileira refletiriam meus valores que poderiam, por exemplo, incluir a preservação do capitalismo, a aniquilação do imperialismo colonialista, a distribuição mais equitativa da renda nacional. A determinação dos valores de um indivíduo é uma tarefa extremamente complicada, e certamente será difícil descrevê-los em termos quantitativos. Teoricamente, a tarefa de conhecer e quantificar um conjunto de valores da sociedade é muito mais complexa, pois tem-se de começar perguntando se os valores individuais podem ou não ser somados e, caso possam, como seriam somados. Todavia, a apuração e agregação daqueles valores nos dá uma ideia do que constitui o conjunto de valores do público, o que pode ser utilizado para estabelecer pelo menos algumas prioridades provisórias.

Esta é uma incómoda questão filosófica. Os atuais objetivos da Educação superior brasileira, ou os que vierem a ser determinados para esta Educação - quaisquer que sejam - são baseados em algum conjunto de valores, o agregado dos valores brasileiros. Como os valores do indivíduo são expressos, resumidos e então traduzidos em objetivos, é uma questão de estruturas políticas e sociais e de mecanismos de comunicação. Quanto a este último, tudo depende muito de quais são as mensagens que o sistema recebe, de quem, e do peso que a elas é dado. Desde que seja determinado quem está ouvindo e com que intensidade, o modo pelo qual as políticas são executadas para alcançar os objetivos ${ }^{1}$ depende dos recursos disponíveis e das capacidades dos instrumentos da Administração Pública e privada.

Não há meios de isolar os meus próprios valores de uma discussão dos objetivos; o leitor deve constantemente lembrar-se disto. Espera-se também que êle constantemente pergunte a si mesmo como meus comentários se ajustam aos seus valores, aos valores brasileiros, ou quais devem ser os valores brasileiros.

A Escassez de Recursos- Em virtude dos recursos serem limitados, os sistemas de valores estão ligados às intensidades dos desejos e às prioridades.

O fato de que não possuímos quantidades ilimitadas de todas as «coisas boas» exige escolha e distribuição. No seu estágio mais elementar, as verbas para a Educação estão envolvidas numa competição de recursos que apresenta três caminhos: consumo privado, investimento privado, e Governo, ' sendo que o recolhimento dos impostos consiste

1 Tudo isto é expresso em termo de despesa pública com a Educação. A análise para a Educação particular é semelhante. 
numa transferência do controle de recursos do setor privado para o setor governamental. Os recursos utilizados pelo Governo simplesmente não estão disponíveis para o investimento privado ou para fins de consumo. Presume-se que os recursos sejam distribuídos entre estes fins competitivos e de acordo com os valores da sociedade. Quando é determinada a parcela destinada ao Governo, as necessidades da Educação competem com as militares, com as de transporte, agrícolas e de saúde pública, etc. . Mesmo após a determinação do orçamento educacional, a Educação superior se vê numa competição com a Educação primária e secundária. A cada nível existe o problema da escolha e da distribuição de recursos escassos.

Assim, de fato, toda a gama de valores da sociedade participa desta competição: a demanda por um maior e melhor serviço hospitalar (consumo privado), uma maior frota pesqueira (investimento privado), e os caças a jato Mirage estão relacionados ao desejo da sociedade obter Educação.

É conveniente pensar em termos de cruzeiros, mas isto obscurece pelo menos um aspecto importante dos recursos educacionais. Num período relativamente curto, as «verbas» não são o problema e não poderiam resolver as dificuldades que enfrenta a Educação. Poder-se-ia, por exemplo, decidir possuir uma escola de pós-graduação de engenharia elétrica em cada cidade com mais de 500.000 habitantes. Os cruzeiros destinados a este fim não garantiriam que surgissem imediatamente os necessários professores, bibliotecas e equipamentos de laboratórios. É mais fácil pensar e planejar em termos de cruzeiros, mas a questão fundamental consiste nos recursos reais. ${ }^{2}$

Inconsistência mútua. A escassez de recursos leva a uma possível inconsistência mútua de objetivos. Este não é um problema novo: toda família gostaria de elevar ao máximo sua renda e seu lazer; desejaria elevar ao máximo suas poupanças e seus gastos com diversões. Portanto, na Educação superior, uma nação gostaria de ter todos estudando todas as disciplinas pelo menos em nível de graduação. Mas é evidente que não é possível elevar ao máximo os desempenhos em todos os objetivos, dentro de recursos razoáveis (ou mesmo finitos). Deve-se equilibrar um objetivo com o outro, procurando um máximo em termos de resultado total. Este é um problema antigo, mas que merece, vez por outra, ser mencionado.

Uma suposição básica. Suponho que a Educação e particularmente e Educação pública seja um ser da sociedade, da sociedade total, e deste modo deve se dedicar a atender às necessidades daquela sociedade na

2 O planejamento educacional é problema de dinâmica, pois alguns recursos reais são «dados» a curto prazo. Contudo, a longo prazo, os equipamentos, o número de professores, a qualidade dos professores e o tamanho e a qualidade das bibliotecas não são «fixos» ou «dados», sendo, de fato, as principais matérias a que se dedica o esforço de planejamento. 
medida que estas se encontrem ao alcance de suas capacidades. A Universidade, por exemplo, bem poderia estar envolvida no ensino do uso de fertilizantes a camponeses analfabetos, no ensino dos princípios da ciência da colheita a milhares de jovens de ambos os sexos, e simultaneamente estar preparando uma meia dúzia de jovens universitários brilhantes como técnicos em edafologia. Poderia a um só tempo e ao mesmo tempo ensinar a líderes sindicais, dentro e fora da sala de aula tradicional, matérias como administração de empresas, técnicas de acordo entre empregado e empregadores, direito do trabalho, e administração de sindicatos.

A suposição de que a Universidade tem uma responsabilidade para com a sociedade como um todo, é necessária para entendermos o que se segue. Outras suposições relativas às suas funções também são possíveis. Se, por exemplo, o papel da Universidade é preparar e manter uma elite instruída e intelectual, às custas de toda a sociedade, então muito do que se segue terá pouca relevância.

\section{OS PRINCIPAIS PROBLEMAS}

Educação Superior para Quem? A principal parcela da tarefa da Educação superior presumivelmente será a de ensinar ao tradicional grupo de idade universitária, isto é, dos 18 aos 25 anos, tratando a Educação universitária como uma extensão lógica e cronológica da escola secundária. Não há uma razão óbvia que obrigue a restringir a Educação universitária a este grupo. As instituições de ensino superior deveriam pelo menos sentir-se responsáveis pela tarefa de manter um contínuo diálogo com seus próprios ex-alunos, sempre procurando mantê-los atualizados quanto às novas técnicas e pesquisas de seus campos profissionais. Com a «explosão do conhecimento», a Universidade é e deve ser uma contínua fonte de informações e de know-how para todas as profissões. Mas também não existe qualquer motivo específico que limite aos universitários o diálogo com a Universidade. Se a Universidade tem algo interessante para dizer ao fazendeiro, porque não dizê-lo tanto em função dos interesses do país como dos próprios fazendeiros? Ou se as donas de casas querem cursar algumas disciplinas em ciência doméstica, sem que isto implique em qualquer diploma, não seria esta uma legítima função da Universidade?

Mas a principal função provavelmente continuará a ser aquela tradicional, a de educar a juventude. Mas «qual juventude»? «Ensino universitário para quem?» Existem várias possibilidades: 1) Num extremo poder-se-ia procurar dar preparo universitário a todos aqueles que completassem com aprovação os cursos secundários. ${ }^{3} 2$ 2) Noutro extremo, poder-se-ia procurar dar formação universitária somente à nata da elite, já identificada, tendo por base a inteligência, riqueza ou ascendência. 3) Entre estes extremos, poder-se-ia procurar ministrar ensino

3 A «filosofia» da sociedade com respeito à Educação secundária seria então um ponto crítico. 
universitário aqueles intelectualmente mais capazes, de acordo com o planejamento das exigências de mão-de-obra em áreas técnicas específicas. ${ }^{4}$

Existem alguns esforços no sentido de quantificar a proporção de graduados das escolas secundárias que são aceitáveis para ingressar na Universidade. O Prof. Valnir Chagas, em parecer do Conselho Federal de Educação, ${ }^{5}$ cita um Harvard Report que estima entre 20 e 25 por cento a parcela importante do grupo etário que poderia realizar estudos universitários aceitáveis. Conant, também citado, estima que 15 a 20 por cento seriam «capazes para a Universidade». Chagas adota uma estimativa de 20 por cento.

Esta abordagem merece alguns breves comentários:

1. É útil como instrumento global para a descrição dos limites do problema. Usando de alguma liberdade estatística, estimo que 1,7 por cento da população de 22 anos de idade ingressou na Universidade em 1960. ${ }^{6}$ No mesmo ano as graduações corresponderam a 1,6 por cento da população com 27 anos de idade. ${ }^{7}$ A matrícula geral nas Universidades girou em torno de 95.000 alunos e teria que ter chegado a 1.150 .000 para que fosse alcançado o objetivo de $20 \%$.

2. Os «capazes para a Universidade» e para «estudos universitários aceitáveis» não são «absolutos», e são determinados pelos valores da sociedade à qual são aplicados. Em uma sociedade que dá elevado valor à Educação em si mesma ou dá este valor por motivos relacionados a uma filosofia política, os padrões de desempenho mínimo admissíveis provavelmente serão menores do que naquela sociedade que encara a Educação de modo diferente. Pode-se postular a aplicabilidade da lei de Engel tanto às nações quanto às famílias, e que a Educação é um daqueles itens com os quais são gastos maiores percentagens da renda à medida que esta aumenta. Se isto fôr verdade, também sugere uma relatividade na adoção dos níveis mínimos de desempenho.

Estas hipóteses não esgotam as possibilidades.

6 Articulação da Escola Média com a Superior, dezembro de 1967, versão mimeografada, pág. 2. Posteriormente publicada como Indicação $\mathrm{n}^{\circ} 4 / 67$, separata da Documenta 79, dezembro de 1967, onde Chagas é o relator da matéria.

6 Tomando-se o valor médio para uma classe de 5 anos, segundo o Recenseamento de 1960, e relacionando-a às aprovações. A fonte de dados é o EPEA, Educação II - Diagnóstico Preliminar, Rio de Janeiro, Ministério do Planejamento e Coordenação Econômica, 1960, pág. 145. Os dados sobre a população pertencem à mesma fonte - - Demografia, pág. 50. A escolha da idade 22 anos tem alguma razão de ser. Vide «Caracterização Sócio-Econômica do Estudante Universitário», Centro Brasileiro de Pesquisas Educacionais, 1966, que dá como média para a idade de ingresso, numa grande amostra, 22,11 anos (= 4.68). 
3. Os padrões aplicados aos E.U.A, podem ser de pouca importância para o Brasil. Exemplo específico deste caso é o da grande proporção de jovens nos E.U.A, que terminam o curso médio. De cada 1.000 alunos cursando a $5^{\text {a }}$ série primária em 1957-58, 710 completaram o curso médio em 1965. ${ }^{8}$ Os dados para o Brasil - e que permitem uma comparação aproximada quanto à correspondência dos níveis de escolaridade - sugerem que de cada 1.000 alunos da primeira série do curso ginasial em 1958, somente 140 terminaram o ciclo colegial em 1964. Alguns destes abandonaram o currículo tradicional e ingressaram no ensino comercial. No mesmo período, em virtude deste fato, de cada 1.000 que ingressaram no ensino comercial em 1958, 790 terminaram o curso em 1964. Contudo, este magnífico resultado é devido a uma descontinuidade estatística ao final da quarta série. Estes problemas são eliminados ao juntarmos ambos os dados. Combinando o ensino secundário e o ensino comercial, verificamos que dos 267.958 alunos que iniciavam ambos os cursos em 1958, 61.583 ou 220 por 1.000 terminaram estes cursos em 1964. ${ }^{9}$ Esta perda realmente substancial ocorre após uma perda que comparativamente é ainda maior nos primeiros anos da escola, e adquire um significado ainda maior se considerarmos o fato de que para cada 1.600 crianças brasileiras somente 1.000 chegam a começar o primeiro ano da escola primária. ${ }^{10}$ Os dados apresentados por Chagas também mostram que somente $1,5 \%$ dos que ingressam na escola primária terminam a escola secundária (ou $0,9 \%$ daqueles que poderiam ter ingressado), nem sequer aproximando-se dos possíveis» («ótimos»?) 46,5\% determinados teoricamente.

O problema da aplicabilidade daqueles $20 \%$ para o Brasil apresenta dois aspectos. Em primeiro lugar, não faz sentido falar de $20 \%$ como sendo o «potencial universitário» quando tão poucos estudantes terminam a escola secundária. Se a inteligência inata e a motivação estivessem distribuídas aleatoriamente pela faixa etária de - digamos - 18 anos, então somente 20 por cento dos que terminaram a escola secundária constituiriam material universitário adequado. Mas não há motivo para acreditar que esta distribuição seja aleatória, e há boas razões para

7 EPEA, Educação (I), pág. 68.

8 Department of Health, Education, and Welfare, Digest of Educational Statistics, 1966, Washington, Government Printing Office, 1966.

9 EPEA, Educação (II), Diagnóstico Preliminar, Rio de Janeiro, Ministério do Planejamento e Coordenação Econômica, 1966, págs. 112, 117. Os dados já disponíveis para outro componente principal, o ensino normal, não são comparáveis e não podem ser tratados do mesmo modo. Ibid., pág. 131.

10 Chagas, ob. cit., págs. 6-7. 
crer que já ocorreu, nos primeiros anos de escola, alguma seleção natural feita na base da inteligência e motivação. Todavia, outros fatores (não existência de escolas, pobreza, etc.) têm nitidamente demonstrado sua grande importância como fatores de seleção. Nos E.U.A, é bastante razoável supor-se que a maioria dos estudantes com «aptidão para a Universidade» podem completar e completam o curso médio, mas no Brasil não se pode, absolutamente, levantar esta suposição. Das 1.666 crianças de sete anos citadas por Chagas (das quais 1.000 ingressam na escola e o restante não), presumivelmente cerca de 133 são «aptas para a Universidade» e que nunca sequer chegaram a ingressar na escola primária.

Há toda uma variação de argumentos defendendo a expansão da Educação superior, mesmo com bastante sacrifício de outros objetivos privados e sociais:

1. Um eleitorado bem informado é pré-requisito de uma democracia efetiva, se a consideramos um sistema de tomada de decisões, no qual o grau de controle sobre os negócios particulares e da comunidade é para todos os indivíduos mais ou menos igual. As manifestações de democracia (tais como partidos políticos e eleições) podem existir sem uma população instruída, mas qualquer participação realmente positiva de um grande segmento da população exige que este possua instrução e seja bem informado. Se os valores da sociedade incluem a extensão de uma efetiva democracia a todas as camadas da população, as despesas com a Educação devem ter alta prioridade em detrimento de outros benefícios.

2. A Educação é um dos principais fatores que contribuem para aumento da mobilidade social e que, portanto, favorecem o desenvolvimento de uma sociedade relativamente aberta. Do ponto de vista econômico, uma crescente mobilidade é desejável, porque permite que os indivíduos procurem e encontrem os empregos onde eles são mais produtivos. A menos que a Educação esteja de modo geral disponível, a própria sociedade, consequentemente, negará os serviços potenciais de cirurgiões altamente preparados, de engenheiros, etc. Pessoas que poderiam tornar-se grandes escritores, médicos, músicos, podem nunca chegar a deixar seu trabalho na lavoura, porque o ensino primário não existe nas áreas rurais. A maior capacidade de satisfazer às frustrações que tem uma sociedade aberta, comparada à que tem uma sociedade fechada, é outra característica que merece ser considerada.

3. As pessoas que realmente tomam decisões numa sociedade cada vez mais complexa têm de surgir dentre as que possuem preparo apri-

11 A distribuição aleatória neste grupo é suposição muito mais realista do que no grupo de 18 anos de idade, no qual alguns completaram o curso secundário e outros não.

$1^{2}$ Por outro lado, pouca Educação pode aumentar, ao invés de diminuir as frustrações, se ela alargar o «horizonte dos desejos» mais rapidamente do que expandir as oportunidades oferecidas. 
morado, não importa qual seja a base filosófica do Governo. Quanto maior fôr a base educacional da sociedade, mais competentes, mais representativos, mais eficientes podem ser aqueles encarregados de tomar decisões. Esta suposição refere-se ao setor industrial, comercial e agrícola, bem como ao setor público.

4. Em termos puramente econômicos, há crescente evidência sugerindo que os recursos destinados à Educação (investimento em capital humano) são mais produtivos do que os outros investimentos alternativos. ${ }^{\text {I3 }}$ A maioria das autoridades concorda que a extensão do ensino a parcelas cada vez maiores da população é condição necessária para o «desenvolvimento econômico», qualquer que seja a definição desta expressão. ${ }^{14}$

Estas ponderações de ordem econômica e social sugerem uma prioridade altíssima para o ensino em geral (e para a Educação superior em particular), o que depende, em última instância, dos próprios valores da sociedade. Mas todas estas ponderações não nos levam muito adiante no tocante ao problema da quantificação. O maior insumo possível de estudantes é presumivelmente o total de estudantes que completam os cursos secundários. Se todos estes viessem a ser aceitos pelas Universidades, então a solução do problema quantitativo dependeria inteiramente da política relativa ao ensino médio, no que toca tanto à quantidade, quanto à qualidade (o que por sua vez dependeria da política relativa ao ensino primário). A escolha de uma proporção específica de graduados de nível secundário como meta máxima para a admissão à Universidade tem de ser muito arbitrária, mas pode-se introduzir alguma lógica nesta escolha, conforme demonstrado no exemplo abaixo:

Inteligência

$$
\begin{gathered}
\text { Proporção } \\
\text { de } \\
\text { Graduados }
\end{gathered}
$$

Insuficientemente dotados para esperar-se que o estudante se gradue

Graduação improvável

Graduação possível, até mesmo provável

Graduação altamente provável

Graduação praticamente certa

$$
\begin{gathered}
10 \text { por cento } \\
20 \text { por cento } \\
\text { - } 40 \text { por cento } \\
20 \text { por cento } \\
\text { - } 10 \text { por cento }
\end{gathered}
$$

Motivação

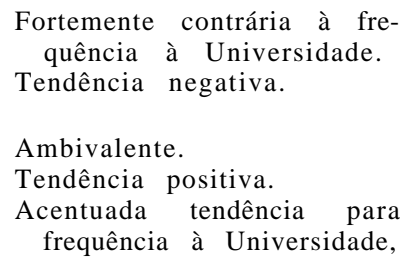

13 Como exemplo de várias referências, há uma crescente literatura sobre o assunto, vide $M$ - Blaug, «Selected Annotated Bibliography in the Economics of Education», Education Libtaries Bulletin, Suplemento n' 8, Londres, Universidade de Londres, Instituto de Educação, 1964.

H Ver, especialmente, Frederick Harbison and Charles A. Myers, Education, Manpower and Economic Growth, New York, MacGraw-Hill Book Company, 1964. 
Pode-se especular sobre o corte transversal da distribuição destas carcterísticas do seguinte modo:

\begin{tabular}{|c|c|c|c|c|c|}
\hline \multirow[b]{2}{*}{ INTELIGÊNCIA } & & \multicolumn{2}{|c|}{ M O T I V A Ç Ã O } & \multirow[b]{2}{*}{$\begin{array}{c}\text { TENDÊNCIA } \\
\text { POSITIVA } \\
20 \%\end{array}$} & \multirow[b]{2}{*}{$\begin{array}{c}\text { FORTE } \\
\text { TENDÊNCIA } \\
\text { POSITIVA } \\
10 \%\end{array}$} \\
\hline & $\begin{array}{l}\text { CONTRARIA } \\
10 \%\end{array}$ & $\begin{array}{c}\text { TENDÊNCIA } \\
\text { NEGATIVA } \\
20 \%\end{array}$ & $\begin{array}{l}\text { ANBIVAMENTE } \\
40 \%\end{array}$ & & \\
\hline Insuficientemente dotado $10 \% \ldots \ldots \ldots$ & 8 & 1 & 1 & 0 & 0 \\
\hline Graduação improvável $20 \%, \ldots \ldots \ldots \ldots$ & 1 & 6 & 10 & 3 & \\
\hline $\begin{array}{r}\text { Graduação possível até mesmo provável } \\
40 \%\end{array}$ & 1 & 10 & 18 & 10 & 1 \\
\hline Graduação altamente provável $20 \%$. & 0 & 3 & 10 & 6 & 1 \\
\hline Graduação certa $10 \%$. & 0 & 0 & 1 & 1 & \\
\hline
\end{tabular}

A designação de números para cada espaço entre as linhas e colunas envolve uma suposição que, em última análise, determina o resultado, mas que possui alguma base lógica. Examinando a primeira coluna, o número 8 - relativamente elevado - na linha superior sugere que os estudantes relativamente não inteligentes seriam numerosos dentre aqueles contrários à continuação de sua instrução - se não fôr por outra razão, além de terem sido quase reprovados ao completarem o curso colegial. Os números muito baixos no final da coluna sugerem que a inteligência e o desempenho estão correlacionados com a motivação. Verificamos que esta correlação se refletirá em cada coluna e em cada linha. De posse desta informação, as Universidades talvez devessem admitir todos os que têm pelo menos uma posição «ambivamente» face a frequência à Universidade e que têm uma inteligência média. Somando os 9 espaços do meio para baixo e para a direita (que atendam às exigências esboçadas acima), teríamos uma «meta» de admissão igual a 56 por cento.

$\mathrm{O}$ aspecto mais importante da análise não é o resultado em termos da percentagem, mas, sim, as perguntas que devem ser feitas e as necessárias suposições a serem levantadas. Tudo que deriva desta análise é consequência das suposições anteriormente feitas, e além disso bastante incerteza pode existir em torno do assunto. Entretanto, as Universidades coletivamente aceitam certa percentagem de graduados das escolas secundárias e é claro que deveria existir algum relacionamento planejado entre os dois agregados. 
Após haver feito esta análise teórica, o relacionamento empírico do real possui um interesse especial:

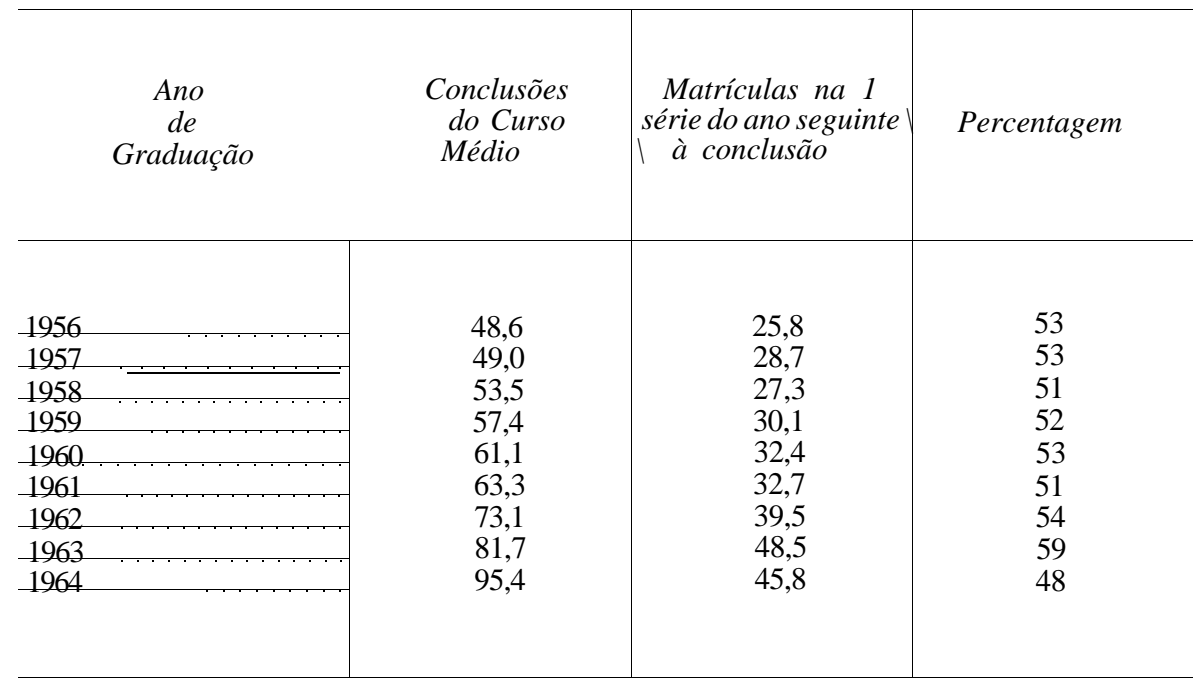

Francamente, surpreende-mc que as percentagens calculadas sejam tão elevadas, em parte por causa da publicidade dada ao problema dos excedentes, em parte porque minha impressão era a de que poucos graduados dos cursos normal e comercial se tornavam universitários. A análise e os dados sugerem o seguinte:

1) O problema do excedente é em parte mais um problema de localização e de especialização do que um problema geral de admissões, com dimensão nacional. Isto é, o problema do excedente surge mais do desejo dos estudantes ingressarem na Escola de Medicina da Guanabara do que do seu desejo de ingressarem nas Universidades do Brasil.

2) A suposição de que há uma distribuição normal da motivação pode estar errada, sendo o sistema primário e secundário muito seletivo por sua própria natureza. Se modificarmos aquela suposição, a fim de que a motivação seja positiva no sentido da frequência à Universidade

FONTE: EPEA, Educação (I), Diagnóstico Preliminar, Rio de Janeiro, Ministério do Planejamento e Coordenação Econômica, 1966, pág. 55. Este total, talvez impropriamente, é a soma de todas as conclusões no ensino médio colegial, do qual o secundário, o comercial e o normal são os principais elementos.

FONTE: Para a maioria dos anos citados, Ministério do Planejamento e Coordenação Econômica, Plano Decenal de Desenvolvimento Econômico $c$ Social tomo VI, Desenvolvimento Social-Educação e Mão-de-Obra, vol. 1 (1), Rio de Janeiro, 1966, A-17. Para 1964: SEEC, Sinopse Estatística do Ensino Superior, 1964, Rio de Janeiro, Ministério da Educação e Cultura, 1965, pág. 11 . Deve-se notar que estes números não correspondem, como seria preferível, às «admissões», mas incluem uma quantidade substancial de estudantes que foram anteriormente admitidos e que estão repetindo a $1^{\mathrm{a}}$ série. 
(tabela abaixo), os nove espaços abaixo e à direita corresponderão a um total igual a $69 \%$ de estudantes suscetíveis de admissão à Universidade.

\begin{tabular}{|c|c|c|c|c|c|}
\hline \multirow[b]{2}{*}{ INTELIGÊNCIA } & \multicolumn{5}{|c|}{ M O T I V A Ç Ã O } \\
\hline & $\begin{array}{c}\text { CONTRÁRIA } \\
2 \%\end{array}$ & $\begin{array}{c}\text { TENDÊNCIA } \\
\text { NEGATIVA } \\
8 \%\end{array}$ & $\begin{array}{c}\text { AMBIVAMENTE } \\
20 \%\end{array}$ & $\begin{array}{l}\text { TENDÊNCIA } \\
\text { POSITIVA } \\
40 \%\end{array}$ & $\begin{array}{c}\text { FORTE } \\
\text { TENDÊNCIA } \\
\text { POSITIVA } \\
30 \%\end{array}$ \\
\hline Insuficientemente dotado $10 \%$ & 2 & 5 & 2 & 1 & 0 \\
\hline Graduação improvável $20 \% . . . . . . . . .$. & 0 & 2 & 6 & 10 & 2 \\
\hline $\begin{array}{l}\text { Graduação possível até mesmo provável } \\
\qquad \underline{40 \%} \ldots \ldots \ldots \ldots \ldots \ldots \ldots \ldots \ldots \ldots \ldots \ldots \ldots \ldots\end{array}$ & 0 & 1 & 8 & 18 & 13 \\
\hline Graduação altamente provável $20 \%$. & 0 & 0 & 4 & 10 & 6 \\
\hline Graduação certa $10 \%$. & 0 & 0 & 0 & 1 & 9 \\
\hline
\end{tabular}

3) Estes números são, em qualquer caso, de pouca valia para os administradores e planejadores universitários, pois uma das grandes mudanças na Educação brasileira do futuro deve ser a rápida extensão da Educação primária e secundária a um número de jovens cada vez maior. O verdadeiro problema que surgirá não será o das Universidades escolherem, para admissão, ou 25 ou 75 por cento do pequeno número de graduados do ensino médio, mas sim o que acontecerá quando o total de conclusões do ensino médio fôr 3,5 ou mesmo 10 vezes maior do que é hoje.

Ensino para fazer o que? Como a sociedade vai arcar com uma parcela substancial da carga educacional, a pergunta a ser feita não é somente «quem deve ingressar no sistema escolar?», mas também «ensino para fazer o que?» Isto leva a uma grande variedade de problemas interessantes. A que ocupações ou profissões devemos dar preferência? A Educação deve ser ampla ou restrita? Deve ser, por natureza, fundamentalmente vocacional? Nesta parte do trabalho examinaremos algumas facetas destas questões.

A sociedade toma a seu cargo a tarefa de subsidiar a Educação, presumivelmente porque espera algum benefício social. Segue-se, presumivelmente, que os recursos da sociedade devem concentrar-se naquelas áreas onde são maiores os benefícios sociais decorrentes da Educação. ${ }^{15}$ Os instrumentos que possuímos para medir e dar valores a estes benefícios são muito rudimentares, e as decisões finais serão algo arbitrárias e certamente sujeitas a discussão. Supondo que o desenvolvimento econômico

15 Foi sugerido anteriormente que o investimento em Educação provavelmente traz benefícios mais elevados do que os investimentos na maioria das outras áreas. Aqui sugerimos que os vários campos dentro da própria Educação resultam em benefícios sociais distintos. 
- definido em termos de aumento de renda per capita - é objetivo de alta prioridade para a sociedade, as seguintes áreas devem ocupar posição destacada para uma concentração de esforços e distribuição de recursos :

a) Agricultura e todas suas ramificações. No processo de industrialização e modernização, uma percentagem cada vez menor da população deve estar capacitada a fornecer alimentos e vestuário para toda a população. Isto significa que a produtividade por trabalhador na lavoura tem de aumentar enormemente.

b) Engenharia. Isto é de crucial importância quanto à indústria - que é um aspecto limitado da economia e quanto a outros aspectos muito mais amplos, relacionados à crescente integração da economia.

c) Administração pública e de empresas. Os «executivos» e os administradores de empresas industriais, de casas comerciais, de estabelecimentos agrícolas e de todas as atividades governamentais são os gerentes dos recursos da Nação. Se coletivamente eles administram bem, os recursos são combinados eficientemente e o fluxo de renda em termos de bens e serviços é grande; se não, os recursos são utilizados de modo ineficiente e a renda é baixa.

d) Administração da Saúde, incluindo medicina, odontologia, enfermagem, saúde pública e administração de hospitais. A boa saúde de uma população está associada à elevada produtividade, exatamente como a doença está associada a frequentes ausências ao trabalho e ã "baixa produtividade. A boa saúde, é claro, é também um dos principais componentes do bem-estar da maioria dos indivíduos.

e) Formação de Professores. O desenvolvimento econômico efetivado através da crescente industrialização e integração demanda níveis de educação sempre crescentes à medida que os processos se tornam mais artificiais, mais complexos, e que as comunicações se tornam mais indiretas. Isto se aplica a todos os setores: agricultura, Governo, comércio, indústria, finanças.

Sem dúvida alguma, cada leitor terá sua própria lista e terá motivos para ser fortemente contrário a esta apresentada. Ela merece ser melhor caracterizada. Em primeiro lugar, tudo que sugeri foi uma «concentração» nestas áreas e não a exclusão de todas as demais. Não foi sugerido que devêssemos acabar com o estudo do direito, da literatura, das artes, das ciências sociais. Porém, com recursos limitados, deve-se escolher entre comprar um dinamômetro e um violoncelo, entre contratar um novo professor de estatística e um de grego, entre distribuir bolsas de estudo aos estudantes de agricultura, e aos estudantes de ballet. Estas decisões têm de ser feitas e o importante é o critério e a base lógica utilizada para tomar estas decisões. 
A segunda característica é mais complexa e relaciona-se ao tipo de educação imaginado para este programa com orientação essencialmente vocacional. De início, quero frisar que deve ser dada atenção à educação ampla e global ao invés da educação restrita e vocacional. Existem muitos motivos relevantes para que isto seja feito.

1. É inevitável que os graduados universitários de hoje venham a tornar-se a elite governante ou a que tomará as decisões daqui a 10, 20 anos. Esta afirmativa não é necessariamente insidiosa, mas estas pessoas possuirão a renda, o lazer, o interesse e as capacidades para o exercício da liderança. Por vários motivos esta responsabilidade de tomar decisões transcenderá os estreitos limites da formação profissional. As Universidades devem, pois, assegurar a todos estes graduados ao menos um mínimo de conhecimentos - suficientes para poder trabalhar - acerca da natureza do meio ambiente nacional, incluindo sua estrutura econômica e social e herança cultural, um mínimo de capacidade na complexa arte das comunicações interpessoais, e algum conhecimento mínimo das ciências básicas.

2. Estreitamente relacionada ao que foi dito acima está a noção de que um dos motivos para a sociedade tomar a seu cargo a formação de um indivíduo é o de fazer dele um melhor líder e um cidadão mais competente. Quanto mais vigorosos forem os valores democráticos da sociedade, tanto mais isto ocorrerá. Se este fôr um objetivo importante, segue-se que os currículos devem incluir componentes que contribuam diretamente para este fim.

3. Até certo ponto, a Educação superior tem de escolher entre formar técnicos competentes que possam manipular perfeitamente os assuntos de rotina e preparar indivíduos de mente criadora, de imaginação e independentes. A receita educacional não é a mesma para ambos os casos. O último tem de ser «levado» («ensinado» não é o termo correio) a pensar, a analisar, e sintetizar, a fazer pesquisa, a ler, a procurar e reconhecer a autoridade - uma tarefa que não é pequena e que quase certamente envolve uma educação em bases mais amplas do que o treinamento de técnicos competentes. Em determinada área, a escolha é entre preparar o contador que pode ingressar numa firma imediatamente após sua graduação, adaptando-se ao sistema de contabilidade da firma, e preparar o contador que pode examinar uma nova firma e criar para êle um sistema de contabilidade. Para dizê-lo em outras palavras, a escolha é entre preparar técnicos de amanhã e preparar aqueles que serão as principais pessoas do país encarregadas de tomar as decisões daqui a 15 ou 20 anos.

Façamos com que não paire dúvida sobre quais são as minhas preferências com relação a este último problema. A meta deve ser produzir pessoas criadoras e de imaginação. Até certo ponto, elas poderão cuidar do trabalho técnico de rotina, e, além disso, se a meta não fôr alcançada, o esforço despendido resultará na produção de «pés-de-boi» em quanti- 
dade suficiente. A probabilidade de formar tanto pessoas criadoras como administradores para a rotina é muito maior se o sistema educacional estiver estruturado para a formação daqueles, do que se estiver estruturado para a formação destes. Porque a intenção é preparar estudantes que continuarão a se desenvolver muito tempo após haverem deixado as Universidades, amplitude, pesquisa e concentração nas perguntas não respondidas é algo bem mais adequado do que concentração no aprendizado de soluções definitivas para um dado conjunto de problemas.

Onde ensinar? A distribuição geográfica do ensino superior é um dos grandes problemas da Educação brasileira. É aqui que ingressamos em manifestações de regionalismo e, mais especificamente, na proliferação de Universidades e de faculdades isoladas, a qual parece não ter fim. Enquanto que nisto se encontra o elevado propósito de trazer a Educação superior até as portas da casa de cada estudante em perspectiva, na melhor das hipóteses o resultado é um desperdício de recursos escassos e, na pior, uma deterioração do nível de ensino. Existem dois aspectos relacionados a este fato a serem examinados.

Em primeiro lugar, o recurso mais escasso na Educação superior é o professor dedicado e entusiasmado, que deseja devotar-se a ensinar à juventude. A qualquer tempo e sob um dado sistema salarial, existe um número fixo destes professores e a criação de novas faculdades e/ou Universidades qualquer que seja a sua quantidade, não fará com que este número aumente. A mudança da política salarial aumentará, especialmente se transcorridos períodos de tempo bastante longos, a quantidade de bons professores. ${ }^{16}$ Expandir as instalações educacionais sem fornecer condições para um aumento do pessoal docente de igual qualidade, provavelmente resultará mais na tendência de produzir diplomas do que na de produzir ensino - o que, está claro, não é absolutamente a mesma coisa. A menos que a qualidade da nova instituição adicionada ao sistema seja melhor do que a média existente, a adição levará à uma deterioração da qualidade. ${ }^{17}$ E isto é um fato aritmético intimador para os que têm responsabilidades de criar e/ou reconhecer novas instituições.

Em segundo lugar, a qualidade da Educação - até certo ponto envolve custos médios decrescentes, isto é, existem algumas economias de

16 Isto é em parte uma questão de inverter o processo do êxodo de inteligências (brain-drain), que ocorre em parte por questões de salário, mas que nos países da América Latina ocorre principalmente em virtude das incertezas e dificuldades para a realização de um trabalho sério, como uma carreira universitária para toda a vida profissional.

17 Isto sugere uma primeira norma para o reconhecimento de novas instituições: uma demonstração da sua capacidade para alcançar pelo menos a qualidade média (supondo-se que a qualidade seja algo a ser considerado). 
escala. Os padrões certamente variam de disciplina para disciplina. Este aspecto pode ser ilustrado pelo diagrama abaixo.

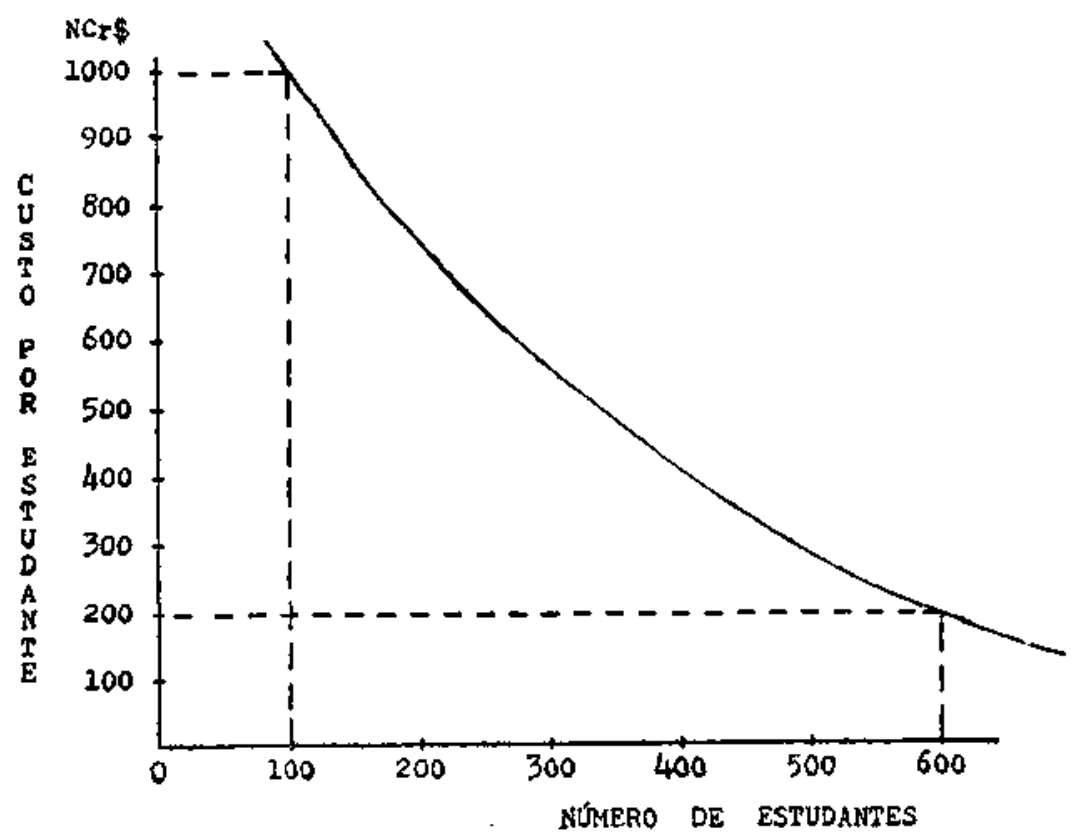

Mesmo se só existirem poucos estudantes, tem-se que contratar alguns professores, um determinado número de publicações tem de ser adquirido pela biblioteca, laboratórios têm de ser fornecidos. Estes custos são essencialmente fixos (para fornecer educação de uma dada qualidade) e portanto o custo por estudante diminui à medida que cresce a matrícula. Neste exemplo hipotético, o custo para preparar 600 estudantes numa única-instituição é de $\mathrm{NCr} \$ 120.000,00$ (600 X X NCr\$ 200,00) . Entretanto, se fosse desejável ter seis instituições separadas (por motivo de prestígio da comunidade, regionalismo, etc), então o custo de formação dos 600 estudantes seria de $\mathrm{NCr} \$ 1.000,00 \mathrm{X}$ X 100 alunos X 6 instituições, ou NCr\$ 600.000,00.

$\mathrm{Na}$ realidade, suspeito que os custos médios não se comportam deste modo e que nas pequenas instituições os custos unitários são mantidos baixos pela não existência de bibliotecas, pela existência de laboratórios ruins e de poucos professores para todo o currículo, etc. Em outras palavras, os custos unitários podem ser reduzidos através de redução na qualidade da Educação.

Os custos aqui comentados são os custos sociais, pouco relacionados aos custos para os estudantes individualmente. Nossa análise, até certo ponto, é a favor da centralização do ensino, o que significa que os estudantes poderiam ser obrigados a deixar a casa paterna a fim de fre- 
quentar as Universidades. Estes são custos (alguns explícitos e talvez alguns psicológicos) relacionados a este fato e que tendem a perturbar e tornar menos decrescentes os custos anteriormente referidos. Entretanto, este efeito é geralmente exagerado pela comparação dos custos explícitos da vida do estudante longe de casa com a vida em casa que teria um custo fictício igual a «zero».

Não há neste trabalho nenhuma recomendação, exceto a de que a situação deve ser estudada com muito cuidado ao considerar-se a futura estrutura ou padrão da Educação brasileira. É evidente a urgente necessidade de obter-se estimativas de custos relacionados ao tamanho da instituição para conseguir uma qualidade mínima no ensino.

Outro fator a ser considerado neste assunto é a demanda relativa de graduados. Se cada ano o mercado pode absorver 1.000 novos agrónomos e a faculdade de tamanho mínimo deve ter 500 alunos, dos quais $20 \%$ se graduam anualmente, então o mínimo adequado de $\mathrm{Fa}$ culdades de Agronomia não pode ser maior do que dez. Na administração de empresas, o tamanho mínimo para uma faculdade pode ser menor, digamos, 400 alunos (com 20\% de graduações anuais) e o mercado absorveria 6.000 por ano. Isto sugere um máximo de setenta e cinco destas faculdades, permitindo dispersão geográfica bem maior.

Que trabalhos de pesquisa devem ser realizados? Num sistema de Educação superior digno de crédito, a pesquisa tem que ser uma das principais funções dentre as várias do sistema, e isto implica em que seus principais componentes têm de realizar trabalhos de pesquisa. Cada professor em cada campo não precisa estar realizando pesquisa, mas se os professores pretendem preparar estudantes de mentalidade criadora, eles não só têm de estar atualizados em seus campos, como têm de antecipar o futuro desenvolvimento da pesquisa na sua área. Além disso, se vão preparar estudantes intelectualmente curiosos e capazes de resolver problemas, têm de fornecer alguma experiência de pesquisa para os alunos. Em terceiro lugar, contrato da Universidade com a sociedade deve incluir, no mínimo, um componente de destaque para a pesquisa aplicada: a Universidade deve manter-se atualizada com as descobertas em outras partes do mundo e deve testar, descrever e propagar sua aplicabilidade aos problemas brasileiros.

É difícil imaginar como até mesmo um sistema de Educação superior com objetivos mínimos pode deixar de ter a pesquisa como um componente principal.

Quanto de homogeneidade? São vários os fatores que na Educação superior brasileira constituem a razão do sistema tender para uma identidade dos seus componentes. Os problemas talvez devam ser levan-

18 Isto implicaria em mais do que um simples estudo das relações existentes de custo-tamanho da instituição. Também devem ser consideradas as alternativas de vários modelos para despesas. 
tados tendo em vista os benefícios provenientes desta situação e os seus: custos. Existem várias razões para recomendar, com urgência, o estabelecimento de um elevado grau de heterogeneidade.

Mais importante ainda - a Educação superior deve estar essencialmente viva, vibrante, antecipando as tendências do futuro. Deve permanecer nas fronteiras do conhecimento, e não deve ser necessário mover montanhas de seções, de diretorias, de comissões e de conselhos para que possam ser introduzidos cursos de programação de computadores, astrofísica e similares. Além disso, é errado supor que métodos de ensino eficazes, currículos desejáveis e estudantes são iguais em toda a parte.

Com a finalidade de ilustrar o assunto, poderíamos imaginar grandes instituições, mantidas pelo Governo, com turmas de primeiranistas da ordem de milhares de alunos, talvez aceitando todos os estudantes incluídos na metade de melhor aproveitamento das turmas de graduados secundários. As escolas co-existentes seriam de preferência pequenas, públicas ou particulares, que aceitariam somente a elite intelectual. Ambos os tipos, bem como outros, poderiam estar se esforçando para atingir o mesmo fim, o preparo de profissionais e cidadãos competentes, pensantes, criadores e independentes. Contudo, existem poucos motivos para esperar que sigam, de modo ótimo, os mesmos caminhos pedagógicos e curriculares. Não há motivo até mesmo para supor que seus cursos exigirão o mesmo número de anos de estudo.

A heterogeneidade pode ser de grande auxílio ao se tentar alcançar o objetivo de obter o maior retorno para uma dada aplicação. Por exemplo, poderia ser possível elaborar um sistema onde os dois primeiros anos da Educação superior seriam oferecidos ao nível local - em faculdades municipais ou da comunidade. Estes anos são os de menores exigências em termos de biblioteca, instalações, equipamento especializado e dispendioso, e professores especializados. O sistema poderia incluir 90 instituições de dois anos, amplamente espalhadas pelo País. Os diplomas tradicionais poderiam ser obtidos pela frequência, durante dois a quatro anos adicionais, à uma das 15 ou 20 principais instituições que concederiam os diplomas. Talvez uma ou duas destas principais instituições devessem elaborar programas de pós-graduação em cada uma das disciplinas universitárias de maior importância. Isto demonstra os tipos de lucros que poderiam ser obtidos pela existência de uma variedade de instituições educacionais. Não há especial importância quanto às quantidades específicas referidas.

Mas a heterogeneidade pode também levar a uma dispendiosa proliferação de programas e de instalações com uma consequente deterioração dos padrões até o ponto em que o ensino oferecido se torna quase uma fraude. Podem ser encontrados exemplos deste fato em toda parte.

19 Assunto discutido com maiores detalhes em meu trabalho Notas sobre a Heterogeneidade. 
Existe uma difícil linha a ser traçada para permitir a heterogeneidade: ela oferece grandes vantagens, mas em contrapartida existem custos e perigos. Isto sugere que deve ser dada cuidadosa atenção aos meios de que dispõe a sociedade para exercer o controle sobre suas próprias instituições educacionais.

\section{COMENTÁRIO FINAL}

Este ensaio presumivelmente se preocupa mais com os «objetivos» do que com os «meios». Mas desejo concluir tecendo breve comentário sobre este último. A maioria dos objetivos discutidos deve apoiar-se na contratação de pessoal das instituições de ensino superior e de suas principais subdivisões, pessoal este que deve substancialmente consistir em professores cuja principal atividade de sua vida seja o trabalho na Universidade. A Universidade é uma organização social importante, tão difícil de ser administrada como qualquer outra. Não esperamos que uma divisão do Exército possa funcionar com pessoal predominantemente de tempo parcial, o mesmo se dando com uma indústria, com um importante órgão governamental. A Universidade não é menos complexa nem mais estática.

Isto não quer dizer que não há lugar para os professores de tempo parcial ou que os professores de tempo integral devam retirar-se do mundo «real». Eu simplesmente não acredito que possa ser alcançado grande progresso na melhoria da qualidade da Educação até que exista um corpo ou quadro de pessoal de tempo integral em cada Universidade principal.

Este corpo ou quadro de pessoal será um importante determinante final da qualidade da Educação. Os estudantes podem ser defensores ardentes e entusiasmados de uma qualidade melhorada, mas não se pode contar com eles para a liderança, pois seu entusiasmo iguala sua ignorância e inexperiência. ${ }^{20}$ Professores de tempo parcial não têm nem tempo nem motivação para a constante vigilância, estudo e preocupação com os assuntos universitários. Minha experiência pessoal sugere que eles são frequentemente o grupo de orientação mais tradicional, já que qualquer mudança representa uma ameaça a seus cargos ou demanda um curso pessoal de adaptação.

JONH M. HUNTER

EAPES

Tradução de:

Michigan State University

Jacques R. Velloso

Março - 1968.

20 Isto não significa menosprezo por ê!es. Os estudantes são inexperientes e ignorantes acerca dos sistemas e problemas educacionais, porquanto ainda não passaram por uma escola de ensino superior. 
Apendice D. 5

\section{ON THE OBJECTIVES OF HYGHER EDUCATION IN BRAZIL}

A reasonably well delineated set of objectives is a prerequisite for planning. There must be targets, desiderata, goals which can be described; otherwise the concept itself of «planning» makes no sense. An automobile clube or a tourist agency can be asked to plan a trip, but the purposes of the trip must be given. Either arrival at a specific destination is sought or, less concretely, «maximum relaxation is desired», or "we want to 'know' Europe may be suggested.

General economic planning is usually couched in terms of a specific growth rate. The Alliance for Progress, for example, settled upon a minimum acceptable rate of $2-1 / 2$ per cent per capita annually. With this objective given, the various sectors of the economy may be analyzed and various sub-objectives assigned, consistent with and contributing to the principal objective. Planning in each sector and sub-sector may then be carried out, given the goals or objectives. On a more elementary level, the individual firm can do its planning based upon some prediction of the future market. Given this, the engineers, financiers, and economists can determine how best to meet future market requirements.

Planning education, in this sense, is no different than planning anything else: it can only be done with clearly defined objectives. On the other hand, education is considerably more complex than most other «industries», and this complexity makes more difficult its social rationalization. The objectives of higher education are inter-twined with those of secondary and primary education. The educational «inputs» are difficult to conceptualize and quantify, and the «outputs» are even more, so.

This paper seeks to explore some of the aspects of goals or objectives for higher education in Brazil. Some of my beliefs and prejudices will become evident, but no solution is suggested. Brazilian higher education is, above all, «Brazilian»; and its objectives can and must be «Brazilian», too.

\section{PREPARATORY COMMENTS}

Before turning to the main discussion, three general aspects of the subject merit clarification.

Objectives and values. The objectives of a policy or of a system reflect values. The «plan» is the means of reaching objetives, but the objectives themselves depend upon fundamental values. The objectives 
I might select for Brazilian higher education would reflect my values which could, for example, include the preservation of capitalism, the furtherance of colonialist imperialism, the more equal distribution of income. The determination of an individual's values is an immensely complicated task, and they are certainly difficult to describe in quantifiable terms. Theoretically, the task of searching out and quantifying a set of values of the society is much more complex since one has to start with the question as to whether or not individual values are additive and, if so, on what basis. Polling and aggregating gives some notion, however, of the constituent public's set of values and may be used to establish at least some tentative priorities.

This is an bothersome philosophical question. Whatever the objectives of Brazilian higher education are or may be determined to be, they are based on some collectivity of values, the aggregation of Brazilian values. How the values of the individual are expressed, aggregated, summarized and then translated into objectives is a matter of political and social structure and the communications mechanism. With respect to the latter, this is largely a matter of what messages the system receives, from whom, and what weight is given them. Once it is determined who will be listened to and with what intensity, how the policies for attaining the objectives are executed depends upon the resources available and the skills and instruments of public and private administration.

There is no way to separate my own values from a discussion of objectives; the reader ought to be constantly aware of this. Hopefully, too, he will constantly be asking himself how each of my comments fits with his values and with Brazilian values, or what Brazilian value ought to be.

The scarcity of resources. Because resources are limited, value systems are concerned with intensities of desires and priorities.

The fact that we cannot have unlimited amounts of all «good things» requires choice and allocation. At the most elementary stage, funds for education are involved in the three-way competition for resources: private consumption, private investment, and government, ' the collection of taxes being a transfer of the command over resources from the private sector to the governmental sector. Resources utilized by the government are simply not available for private investment or consumption purposes. Presumably, resources are allocated among these competing ends according to the values of the society. When the government's share is determined, educational needs compete with the military, transportation, agriculture, public health, etc. Even after the educational budget has been determined, higher education finds itself

This is cast in terms of public expenditure for education. The analysis :s similar for private education. 
in competition with primary and secondary education. At each level there is the problem of choice and of allocating scarce resources.

Thus, in a very real sense, the whole gamut of society's values are involved: demands for more hospital care (private consumption), a greater fishing fleet (private investment), and Mirage fighters are related to the society's desire for education (and how well and intensively expressed it is).

It is convenient to think in terms of cruzeiros, but this obscures at least one important aspect of educational resources. In the relatively short period, «funds are not the problem and could not solve, the educational difficulty, One might, for example, decide to have a graduate school of electrical engineering in each city over 500.000 population. Cruzeiros budgetted for this purpose would not assure the immediate appearance of the necessary professors, libraries and laboratory equipment. It is easier to think and plan in terms of cruzeiros, but fundamentally, the concern is real resources. ${ }^{2}$

Mutual inconsistency. The scarcity of resources leads to the possible mutual inconsistency of objectives. This is no new problem: every family would like to maximize its income and its leisure; it would like to maximize its savings and its recreational expenditure. So, in higher education, a nation would like to educate everyone in all disciplines at least through the graduate level. But it is evident that it is not possible to maximize performance in all objectives within reasonable (or even finite) resource limits. One must balance one objective against another in seeking a maximum total solution. This is an ancient problem, but one worthly of occasional repetition.

A basic assumption. I assume that education, particularly public education, is a creature of the society, the total society, and as such it ought to be dedicated to serving the needs of that society as they fall within its competence. The University, for example, might well be involved in teaching the use of fertilizer to illiterate peasants, teaching the principles of crop science to thousands of young men and women, and simultaneously developing a half-dozen brilliant young scholars in edaphology. It could at one and the same time be teaching business administration in and out of the traditional classroom and bargaining techniques, labor law, and union administration to labor leaders.

This assumption of the University's responsibility to the whole of society is necessary for what follows. Other assumptions of function are possible. If, for example, the role of the University is to equip and maintain an educated and intellectual elite at the expense of the whole society, then much of what follows has little relevance.

Planning education is a problem in dynamics, some real resources are «given» in the short-run. In the long-run, however, facilities, the number of professors, the quality of professors, and the size and qualities of librares are not «fixed» or «givens》 and are in fact the principal subjects of planning efforts. 


\section{THE MAJOR QUESTIONS}

Higher Education for Whom? Presumably the major part of higher education's task will be the instruction of the traditional university age-group, i.e. 18-25 years, treating university education as a logical, chronological extension of secondary school. But there is no compelling, obvious reason to restrict the University to educating that age-group. Institutions of higher learning should at least feel the responsibility to maintain a continuing dialogue with their own alumni, seeking always to keep them up to date on new professional techniques and research. "With the «knowledge explosion, the University is and should be a continuing source of information and «know-how» for all the professions. But there is no particular reason either to limit the University dialogue to universitarios. If the University has something of interest to say to the farmer, why should it no say it both in the interests of the country and of the farmers themselves? Or if housewives want a few courses, not leading to any degree, in domestic science, why is this not a legitimate function of the University?

But the major function will likely continue to be the traditional one of educating the youth. But «What youth?» «Education for whom?» There are a variety of possibilities: 1) At one extreme, one might seek to educate all those who successfully complete secondary schools. ${ }^{3}$

2) At another extreme, one might seek to educate only the off-spring of the elite already identified on the basis of intellect, wealth, or heritage. 3) Somewhere in between, one might seek to educate the intellectually most able in accordance with planned manpower requirements in specific teachical areas. ${ }^{4}$

There are some efforts to quantify the proportion of secondary school graduates who are acceptable university «inputs». Professor Valnir Chagas, in parecer of the Conselho Federal de Educacao, ${ }^{5}$ cites a Harvard Report which estimated between 20 per cent and 25 per cent of the relevant age-group could do acceptable university work. Conant, also cited, estimated that 15 to 20 per cent were «academically talented». Chagas adopts a 20 per cent «estimator» for his own purposes.

This approach deserves some comment in passing:

1. It is useful as a gross tool for describing the boundaries of the problem. Taking considerable statistical licence. it is estimated that 1.7 per cent of the population 22 years old

\footnotetext{
3 The «philosophy» of the society with respect to secondary education would then be critical.

4 These by no means exhaust the possibilities.

5 Articulação da escola media com a superior, December 1967. mimeograph version, p. 2 (Subsequently published as Indicação $\mathrm{n}^{\circ}$ 48/67. Separata da Documenta 79. Dez. 1967, Chagas listed as relator).
} 
entered the University in $1960 .{ }^{6}$ In the same year, graduations were 1.6 per cent of the population wich was 27 years old. University enrollments were about 95.000 and would have had to have been $1,150.000$ to have reached the 20 per cent objective.

2. Academically talented» and «acceptable university work» are not «absolutes» and are determined by the values of the societies in wich they are applied. A society wich values education highly per se or for reasons related to political philosophy will probably tolerate lower standards of minimum performance than one which views education differently. One may postulate as well that Engel's law may be applied to nations as well as to families and that education is one of those items on wich greater percentages of incomes are spent as income increases. If this is true, this also suggests relativity in the adoption of minimum performance levels.

3. Standards applied to the U.S. may have little relevance in Brazil. This is particulary the case since a large proportion of U.S. youngsters finish high school. Of 1.000 in the fifth grade in 1957-58, 710 graduated from high school in 1965. ${ }^{8}$ Roughly comparable figures suggest that of 1.000 beginning the first sen'e of the ciclo ginasial (ensino secundario) in 1958 only 140 graduated from the ciclo colegial in 1964. Some of these left the traditional curriculum and entered ensino comercial. In the same period, because of this, of 1.000 beginning ensino comercial in 1958, 790 graduated in 1964, but this imposing result is due to the statistical disconnuity at the end of the fourth side. These problems are eliminated by treating the two together. Combining both ensino secundario and ensino comercial, we find that of the 267.958 beginning both careers in $1958,61.583$ or 220 per 1.000 finished in 1964.9 This very substantial loss occurs

6 Taking the average value for the 5-year class from the 1960 census and relating it to aprovacoes. The data source is EPEA, Educacao (II), Diagnostico Preliminar, Rio de Janeiro, Ministerio de Planejamento e Coordenação Economica, 1966, p. 145. Population data are from the same source, Demografia, p. 50. The choice of 22 years of age has some basis. See «Caracterizaçao Socio-economico do estudante universitario», Centro Brasileiro de Pesquisas Economicas, 1966, which reports the average entering age for a large sample as being $22.11(8=4.68)$ years.

7 EPEA, Educacao (I), p. 68.

8 Department of Health, Education, and Welfare, Digest of Educational Statistics, 1966, Washington, Government Printing Office, 1966.

9 EPEA, Educacao (II) Diagnostico Preliminar, Rio de Janeiro, Ministerio do Planejamento e Coordenaçao Economica, 1966, p. 112, 117. Readily available data for the other major component, ensino normal, are not comparable and cannot be similarly treated. Ibid., p. 131. 
after an even comparatively greater loss in the early school years and the fact that only 1.000 of 1.600 Brazilian children even star the first year of primary school. ${ }^{10}$ Chagas, data also suggest that only 1,5 per cent of those who start primary school finish secondary school (or 0,9 per cent of those who could have begun) as compared to a «possible» («optimal?») 46,5 per cent determined theoretically.

The concern about the applicability of a 20 per cent figure for Brazil is two-fold. In the first place, it makes no sense to talk about 20 per cent as being the «university potential when so few graduate from secondary school. If native intelligence and motivation were distributed randomly among, say, 18 years olds, then only 20 per cent of secondary school graduates would be appropriate university material. But there is no reason to believe that the distribution is random, and there is good reason to believe that some natural selection on the basis of intelligence and motivation has already taken place in the earlier years. But other factors (non-availability of schools, poverty, etc., etc.), have clearly been of great importance, too, as selection factors. In the U.S. it is a reasonably good assumption that most «academically talented students can and do graduate from high school, but in Brazil this assumption cannot be made at all. Of Chagas' 1.666 seven-year olds (1.000 begin school and the remainder do not), presumably close to 133 are «academically talented who never even star primary school. ${ }^{n}$

There is a wide range of arguments for expanding higher education at considerable sacrifice of other private and social objectives:

1. An informed electorate is a prerequisite of effective democracy if we mean by that a system of decision-making and execution in which each individual has roughly equally effective control over his own and the community's affairs. The manifestations of democracy (such as parties and elections) may exist without general education, but any really effective participation of a large segment of the population requires that it be educated and informed. If the values of the society include extending effective democracy, expenditure on education should have a high priority regardless of other benefits.

2. Education is a major contributor to increased social mobility and thus to the benefits of a relatively open society.

10 Chagas, op. cit., p. 6-7.

11 Randon distribution in this group is a much better assumption than amongst the 18 years olds some of whom have graduated from secondary schools and some of whom have not. 
From an economic point of view, increased mobility is desirable since it permits individuals to seek and find those positions in wich they are most productive. Unless education is generally available, society consistently denies itself the potencial services of highly trained surgeons, engineers, etc. People who might have become great writers, doctors, musicians may never get out of the cotton fields because primary education is not available in rural areas. The greater frustration - relieving capacity of an open-society as compared to a closed one is another characteristic worth consideration. ${ }^{12}$

3. The immediate decision-makers for the aver more complex society must increasingly come from among the highly educated, regardless of the-philosophic basis of government. The wider the educational base, the more competent, the more representative, and the more efficient can be the decision-mark ers. This supposition pertains to the industrial, commercial, and agricultural sectors as well as to the public sector.

4. In purely economic terms, increasing evidence suggests that resources devoted to education (investment in human capital) are more productive than alternative investments. ${ }^{13}$ Most authorities concur that expanded education is a necessary condition for «economic development, however that may be defined. ${ }^{14}$

These economic and social considerations suggest a very high priority for education in general (and higher education in particular depending ultimately on the society's own values. But they do not carry us far in quantifying the problem. The maximum possible student input presumably is the number graduating from secondary education programs. If all such graduates were to be accepted by the universities, then resolution of the quantity question would depend entirely on policy regarding ensino medio with respect both to numbers and quality (which would depend in turn on policy regarding primary education). The selection of specific proportion of secondary graduates as a maximum target for university admission must be largely arbitrary, but some logic can be inserted into the choice as is demonstrated in the following example.

12 On the other hand, a litle education may increase rather than decrease frustration if it, widens the «want-horizon» more quicky than it expands opportunities.

13 For example, see M. Blaug, «A Selected Annotated Bibliography in the Economics of Education. Education Libraries Bulletin, Supplement Eight, London, University of London, Institute of Education, 1964, for many references to the expanding literature.

14 See especially, Frederick Harbison and Charles A. Myers, Education. anpower and Economic Growth, New York, McGraw-Hill Book Company, 1964. 
We begin the analysis by considering the characteristics of secondary school graduates. Perhaps «intelligence» and «motivation» are the two most relevant, and we also assume that these are distributed more or less normally, as follows:

Inteligence

Insufficiently endowed to expect to graduate.

Graduation improbable.

Graduation possibe, even probable.

Graduation highly probable Graduation practically certain
Motivation

- 10 per cent - Strongly opposed to university attendance

-20 per cent - Negatively inclined

- 40 per cent - Ambivalent

- 20 per cent - Positively inclined

- 10 per cent - Insist on attendance

We may then speculate that the cross-distribution of these characteristics is as follows:

\begin{tabular}{|c|c|c|c|c|c|}
\hline \multirow[b]{2}{*}{ INTELLIGENCE } & & \multicolumn{3}{|c|}{ M O T I V A T I O N } & \multirow[b]{2}{*}{$\begin{array}{c}\text { INSISTENT } \\
10 \%\end{array}$} \\
\hline & $\begin{array}{c}\text { OPPOSED } \\
10 \%\end{array}$ & $\begin{array}{l}\text { NEGATIVELY } \\
\text { INCLINED } \\
20 \%\end{array}$ & $\begin{array}{c}\text { AMBIVALENT } \\
40 \%\end{array}$ & $\begin{array}{c}\text { POSITIVELY } \\
\text { INCLINED } \\
20 \%\end{array}$ & \\
\hline Insufficiently endowed $10 \%$ & 8 & 1 & 1 & 0 & 0 \\
\hline Graduation improbable $20 \%$. & 1 & 6 & 10 & 3 & 0 \\
\hline Graduation possible, even probable $40 \%$ & 1 & 10 & 18 & 10 & 1 \\
\hline Graduation highly probable $20 \%$. & 0 & 3 & 10 & 6 & 1 \\
\hline Graduation certain $10 \%$ & 0 & 0 & 1 & 1 & 8 \\
\hline
\end{tabular}

Assignment of numbers to the cells involve an assumption which ultimately determines the results but which has some logical base. Examining the first column, the relatively large number «8» in the top row suggests that the. relatively unintelligent would be numerous among those opposed to continuing their education - if for no other reason than that they were near-failures in finishing secondary school. The very low figures at the end of the column suggest that intelligence and achievement are correlated with motivation. This correlation will be found reflected in each and row. Given this information then universities perhaps should admit all those who are at least «ambivalent» in their attitude toward university attendance and with average intelligence. Summing the 9 «south east» cells (which fit the requirements outlined above), we have an admission «target» of 56 per cent.

The most important aspect of the analysis is not the percentage conclusion but rather the questions one must ask and the necessary assumption. Nothing comes from this analysis that was not put there 
by the assumptions and a good deal of uncertainty may surround them, but universities, collectively, do accept some percentage of secondary school graduates and there clearly should be some planned relationship between the two aggregates.

Having done this theoretical analysis, the empirical relationship of the real world command special interest:

Year of

Graduation
Graduations

1956 .

1957 .

1958 .

1959 .

1960 .

1961 .

1962 .

1963 .

1964 .
Enrollment, 1 st serie

gear following Per cent

graduation

$\begin{array}{lll}48,6 & 25,8 & 53 \\ 49,0 & 28,7 & 58 \\ 53,5 & 27,3 & 51 \\ 57,4 & 30,1 & 52 \\ 61,1 & 32,4 & 53 \\ 63,3 & 32,7 & 51 \\ 73,1 & 39,5 & 54 \\ 81,7 & 48,5 & 59 \\ 95,4 & 45,8 & 48\end{array}$

I find it surprising, frankly, that the percentages computed were so high partly because of the great publicity given to the problems of excedentes, partly because it was my impression that few graduates of normal and comercial programs subsequently became universitarios. The analysis and data suggest the following:

1) The excedente problem is in part a problem of location and specialization rather than a general, nation-wide problem of admissions. That is, the excedente problem arises more out of students wanting to enter medical faculties in Guanabara than out of their wanting to enter universities in Brazil.

2) The assumption of normal distribution of motivation may be in error with a primary and secondary system so selective in nature. If we modify that assumptions as in the following table so that rao-

SOURCE: EPEA, Educacao (I) . Diagnostico Preliminar, Rio de Janeiro, Ministerio do Planejamento e Coordenaçao Economica, 1966, p. 55. This, perhaps inappropriately, is the sum of all graduations, ensino medio, colegial of which secundario, comercial, and normal are the principal elements.

SOURCE: For most years, Ministerio do Planejamento e Coordenaçao Economica, Piano Decenal de Desenvolvimento Economico e Social, tomo VI, Desenvolvimento Social, Educacao e Mao-de-Obra, vol. 1, Rio de Janeiro. 1966, A-17. For 1964, SEEC, Sinopse Estatistica do Ensino Superior, 1964, Rio de Janeiro, Ministerio da Educacao e Cultura, 1965, p. 11. Note that these figures are not «admissions» as one would prefer but include substantial numbres of students previously admitted who are repeating the 1 st serie. 
tivation is skewed toward university attendance, the nine «southeast» cells yield a sum of 69 per cent susceptible of university admission.

\begin{tabular}{|c|c|c|c|c|c|}
\hline \multirow[b]{2}{*}{ INTELLIGENCE } & \multicolumn{5}{|c|}{ M O T I V A T I O N } \\
\hline & $\begin{array}{c}\text { OPPOSED } \\
\mathbf{2 \%}\end{array}$ & $\begin{array}{c}\text { NEGATIVELY } \\
\text { INCLINED } \\
\mathbf{8 \%}\end{array}$ & $\begin{array}{c}\text { AMBIVALENT } \\
\mathbf{2 0 \%}\end{array}$ & $\begin{array}{c}\text { POSITIVELY } \\
\text { INCLINED } \\
\mathbf{4 0 \%}\end{array}$ & $\begin{array}{c}\text { INSISTENT } \\
\mathbf{3 0 \%}\end{array}$ \\
\hline Insufficiently endowed $10 \% \ldots \ldots \ldots$ & 2 & 5 & 2 & 1 & $\mathbf{0}$ \\
\hline Graduation improbable $20 \%$. & $\mathbf{0}$ & 2 & 6 & 10 & 2 \\
\hline Graduatíon possible, even probable $40 \%$ & $\mathbf{0}$ & & & 18 & 13 \\
\hline Graduation highly probable $20 \%$. . & $\mathbf{0}$ & & & 10 & 6 \\
\hline Graduatíon certain $10 \%$. & $\mathbf{0}$ & & & 1 & 9 \\
\hline
\end{tabular}

3) There is little succor in these figures in any case to university administrators and planners since one of the great changes in Brazilian education in the future must come in a rapid extension of education to more and more youngsters at the primary and secondary levels. The real problem will arise not from whether the University ought to admit 25 per cent or 75 per cent of the small numbers of ensino medio graduates but what will happen when ensino medio graduates multiply in number by 3, 5, or even 10 .

Education to Do What? As society undertakes a substantial part of the education burden, it should ask not only the question "who to educate?» but «education to do what?» This leads to a great variety of interesting problems: What occupations or professions should be given preference? Should the education be broad or narrow? Should it be primarily vocational in nature? In this section, we examine some of the facets of these questions.

A society presumably undertakes subsidizing education because it expects some social return. It follows, presumably, that society's resources should be concentrated in those areas where the social returns are the greatest. ${ }^{15}$ The tools we have for measuring and placing values on these returns are very poor, and decisions ultimately will be somewhat arbitrary and certainly subject to great debate. Assuming that economic development - defined in terms of increasing per capita income - is a high priority goal of the society, the following areas should rank highly for concentrated efforts and resource allocations:

a) Agriculture in all its ramifications. In the process of industrialization and modernization, a smaller and smaller percentage of the labor force must be able to provide food and clothing for the total po-

15 It was suggested earlier that investment in education probably yields high returns compared to investments in most other areas. Here we suggest that there are different returns among the various fields within education. 
pulation. This means productivity per farm worker must increase tremendously.

b) Engineering. This is of critical importance in the narrow aspects of industry and in the much broader aspects related to increased integration of the economy.

c) Business and public administration. The executives and administrators of industrial firms, commercial houses, agricultural establishments and all government activities are the manage of the nation's resources. If they collectively manage well, resources are combined efficiently and the income flow of goods and services is large; if not, resources are used inefficiently and income is lower.

d) Health management, including medicine, dentistry, nursing, public health and hospital administration. Good health is associated with high productivity just as sickness is associated with absenteeism and low productivity. Good health, of course, is also a major component of most individual's welfare.

e) Teacher training. Economic development through increasing industrialization and integration demands ever increasing levels of education as processes become more sophisticated, more complex, and as communications become more indirect. This applies to all sectors: agriculture, government, commerce, industry, finance.

Each reader will no doubt have his own list and have reason to be violently opposed to this one. It merits some qualification. In the first place, all I have suggested is «concentration» on these, not to the exclusion of all else. It is not suggested that the study of law, literature, the arts, the social sciences be given up. With limited resources, though, one must choose between buying one dynamometer or a cello, hiring one new professor of statistics or one of Greek, distributing scholarship to students of agriculture as opposed to students of ballet. These decisions must be made and what is relevant is the criteria and rationale used for making them.

The second qualification is more complex and relates to the sort of education envisaged for this essentially vocationally oriented program. At the outset, I urge consideration for a broad, comprehensive education rather than a narrow, vocational one. There are many important reasons for this:

1. Inevitably the university graduates of today will become the governing or decision-making elite of ten-twenty years from now. This is not necessarily insidious, but these people will have the income, the leisure, the interest, the capabilities for the exercise of leaderhip. This decision making responsibility will, for many, far transcend the narrow limits of professional training. The unversities, then, ought to assure that all these graduates have at least a minimum working knowledge of the nature of the national environment including its social and economic 
structure and cultural heritage, a minimal skill in the sophisticated art of interpersonal communications, and some minimum knowledge of the basic sciences.

2. Closely related to the above is the notion that society undertakes the training of an individual partly to make him a better leader and a more competent citizen. The stronger the democratic values of the society, the more should this be the case. If this is an important objective, it follows that curricula should include components directly contributing to it.

3. To some extent, higher education has to choose between training competent technicians who can excellently handle routine matters and producing creative, imaginative, independent people. The educational recipe is not the same for each. The latter must be «lead» («taught» is not the right word) to think, to analyze, to synthesize, to do research, to read, to seek and recognize authority - no small task and almost certainly involving education on a much broader basis than the training of competent technicians. In one field, the choice is between training the accoutant who can enter a firm immediately after graduation and adapt himself to the firm's accounting system and the accountant who can examine a new firm and devise an accounting system for it. To put this still another way, the choice is between training tomorrow's technicians as opposed to training the nation's principal decision-makers of ten-fifteen years from now.

Let there be no doubt about where my own predilections lie on the latter issue. The target should be that of producing creative, imaginative people. To some extent, they can handle the routine technical work, and furthermore, falling short of the target will result in the production of sufficient «hacks». The probability of producing both creative people and the routine operatiors is much greater if the educational system is geared to the former rather than if it is geared to the latter. Since the purpose is to produce students who will continue to grow intellectually long after they leave the universities, breadth. research, concentration on the unanswered questions is a great deal more appropriate than concentration on learning the definitive solutions to a given set of problems.

Education where? The geographic distribution of higher education is one of the great problems of Brazilian education. It is here we run into manifestations of regionalism but more particularly the apparently endless proliferation of universities and of independent faculties. While this has the very noble objective of bringing higher education to the doorstep of each prospective student, at best it wastes scarce resources and at worst it results in a deteriorization of the level of education. There are two related aspects of this to be examined.

In the first place, the most scarce resource in higher education is the dedicated, inspiring teacher who is willing to devote himself to the teaching of youth. At any one time and under a given salary system, 
there are a fixed number of such professors and no amount of creating new faculties and/or universities will increase this number. Changing the salary policy will, especially over considerable periods of time, increase the numbers of good professors. ${ }^{16}$ Expanding educational facilties without providing for an increased teaching staff o fequal quality likely will tend more to the production of diplomas than to the production of education which, of course, are not the same things at all. For those charged with the responsabilities of creating and/or recognizing new institutions, it is an appalling bit of arithmetic that unless the quality of a newly added institution is better than the existing average, the addition will lead to a deterioration of quality.

Secondly, quality education to some extent involves decreasing average costs, that is, there are some economics of scale. The patterns surely vary from discipline to discipline. The point can be illustrated in the following diagram.

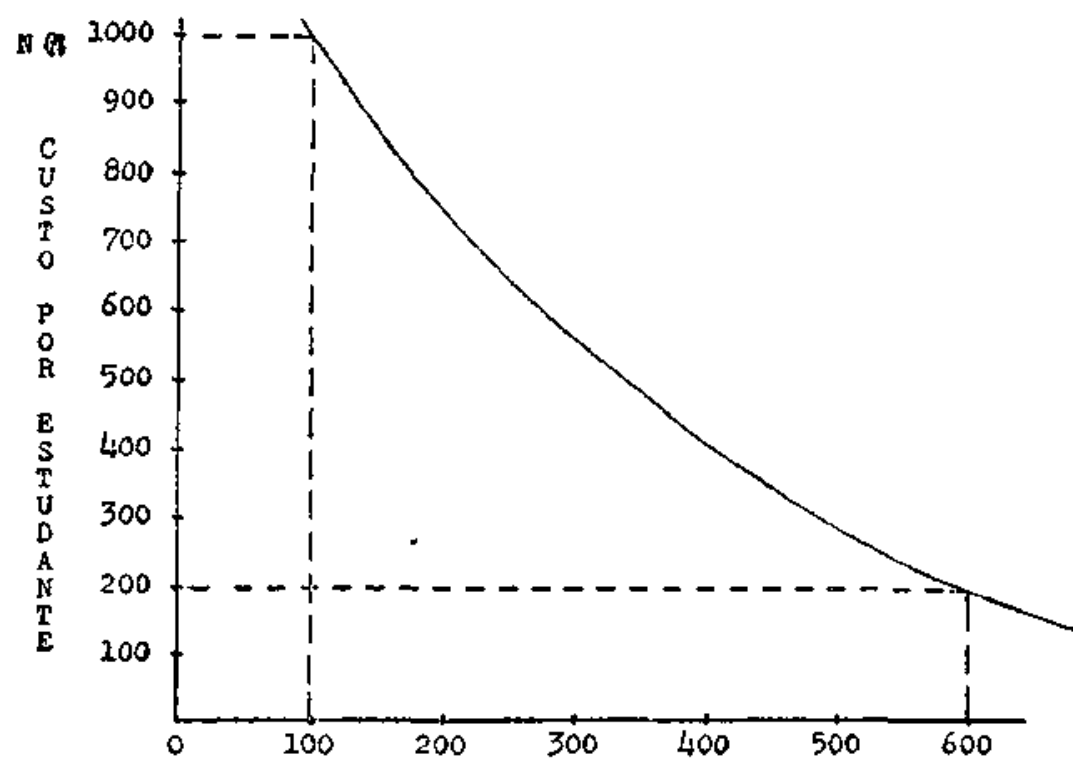

10 This is partly a matter of revesing the «brain drain which occurs partly for matters of salary, but in large measure in Latin American countries because of the uncertainties and difficulties in serious work, as a life-time career, in the universities .

1T This suggests a first rule-of-thumb in the accreditation of new institutions: a demonstration of their ability to reach at least average quality (assuming that quality is of concern). 
Even if thereare only a few students, a certain minimum number of professors must be hired, certain minimum library acquisitions must be purchased, laboratories, etc., must be provided. These costs are essentially fixed (to provide education of a given quality) and so the cost per student falls as enrollment expands. In this hipothetical example, it costs NCr\$ 120,00 (600 X NCr\$ 200) to train 600 students in a single institution. If, however, it were desired to have six separate institutions (for purposes of community prestige, regionalism, etc.), then the costs of training 600 students are NCr\$ $1.000,00 \mathrm{X} 100$ students X $\mathrm{X} 6$ institutions of $\mathrm{NCr} \$ 600,00$.

In reality, I suspect average costs do not behave this way and that unit costs are kept down in the small institutions by not having libraries, by providing poor laboratories, by covering the curriculum with fewer professors, etc. In other words, unit costs may be reduced by reducing the quality of education.

The costs discussed are those social costs little related to the costs to the individual student. To some extent our analysis argues in favor of centralization of education wich means students might have to leave their paternal homes in order to attend universities. There are costs (some explicit and peharps some psychological) related to this which tend to offset and to make less steep the decreasing costs previously noted. This effect, however, is generally exagerated by comparing the explicit costs of the student's living away from home with a ficticious «zero» cost of living at home.

There is no recommendation herein except that the situation ought to be studied with great care in considering the future structure or pattern of Brazilian education. Careful estimates of costs related to size for minimum quality education are clearly needed.

An additional factor in considering these matters is the relative demand for graduates. If 1.000 new agromomists can be absorbed by the market each year and the minimum - size faculty is 500 of which 20 per cent graduate each year, then no more than ten faculties of agronomy is appropriate. In business administration, the minimum - size faculty might be smaller, say 400 (with 20 per cent graduating) and the market 6.000 per year. This suggest a maximum of seventy-five of such faculties, permitting considerably more geographic dispersion.

What Role Research? A creditable system of higher education must have research as a major part of its function, and this implies that its major components must participate. Every professor in every field need not be doing research, but if professors are going to develop creative students, they have not only to be up in their fields but they must be anticipating future developments. Furthermore, if they are to develop intellectually curious and problem solving students, they must pro-

18 This would involve more than a study of existing cost-size relationships. It ought also to consider alternative spending patterns. 
vide some research experience for the students. Thirdly, the universities' contract with the society ought to include minimally a major component of applied research: keeping up with developments in other parts of the world and testing, describing, and disseminating their applicability to Brazilian problems.

It is difficult to see how an even minimum - target higher education system can fail to have a major research component.

How much homogeneity? Various factors in Brazilian higher education cause the system to tend to conformity. Questions perhaps should be raised regarding the benefits of this and the costs. There are a number of reasons for urging an important degree of heterogeneity.

Most important, higher education should be vitally alive, vibrant, anticipating the trends of the future. It ought to remain on the frontiers of knowledge, and it ought not to have to move mountains of bureaus, directories, commissions, and councils in order to introduce courses in computer programming, astrophysics and the like. Furthermore, it is erroneous to assume that effective teaching methods desirable curricula, and students, are everywhere the same.

For purposes of illustration, it is possible to envisage large, governmentally supported institutions with entering classes numbering in the thousands, perhaps accepting all students in the upper 50 per cent of secondary school graduates. Co-existent might be rather small schools, public or private, which would accept only the intellectual elite. Both types, and others, might be striving toward the same end of producing competent, thinking, creative, independent professionals and citizens, but there is little reason to expect that they will optimally proceed along the same pedagogical and curricular paths. There is no reason, even to assume that their programs would necessarily require the same number of years of study.

Heterogeneity can be of great assistance in seeking the objective of getting the most return from a given input. For example, it might be possible to work out a system whereby the first two years of higher education would be offered at the local level - in municipal or community colleges. These years are generally the least demanding in terms of libraries, facilities, specialized and expensive equipment, and specialized professors. The system might include 90 two-year institutions widely scattered geographically. Traditional university degrees might be earned by attending one of 15-20 major degree-grating institutions for an additional 2-4 years. Perhaps one or two of these major institutions would develop graduate work in each of the most important academic disciplines. This points out the sorts of gains which may be realized by allowing for a variety of educational institutions; no special importance attaches to the specific numbers.

Discussed in greater detail in my paper «A Note on Heterogeneity; 
But, the heterogeneity can also lead to expensive proliferation of programs and facilities with a consequent deteriorization of standards to the point where offerings become nearly fradulent. Examples of this can be found everywhere.

There is a difficult line to draw in permitting heterogeneity: it offers great benefits, but there are costs and dangers. This suggests that careful thought be given to society's means for exercising control over its own educational institutions.

\section{A FINAL COMMENT}

This essay presumably concerns «objectives» rather than «means». But I conclude with a brief comment on the latter. Most of the objectives discussed, most ideas for university reform should be supported by staffing institutions of higher education and their major subdivisions in substantial measure by professors whose principal life-work is in the university. The university is an important social organization, as difficult to manage and as complex as any other. We do not expect an Army division to operate with predominantly parti-time personnel, nor a major industry, nor a major governmental agency. The university is no less complex and no more static.

This is not to say that there is no place for part-time professors or that full-time professors should withdraw from the «real» world. I simply do not believe great progress will be made in improving the quality of education until there is a corps or cadre of full-time people in each major unit.

This corps or cadre will be an important final determinant of the quality of education. Studants may be fiery and enthusiastic supporters of improved quality but they cannot be counted on for leadership as their enthusiasm is matched by their inexperience and ignorance. Part-time professors have neither the time or motivation for constant vigilance, study, and concern in university affairs. My experience suggest that they are frequently the most tradtion-oriented group since any change poses either a threat to their positions or demands a personal cost of adaptation.

JOHN M. HUNTER

EAPES

Michigan State University

20 This is not meant disparaginply. Students are inexperienced and ignorant of educational systems and problems having as yet failed to pass through even one system. 
Apêndice D. 6

\section{A ESTRUTURA DA EDUCAÇÃO SUPERIOR NOS ESTADOS UNIDOS}

Quando se defrontam duas ou mais línguas, existem problemas de comunicação, porque as mesmas palavras ou palavras semelhantes em dois idiomas transmitem ideias que são substancialmente diferentes para duas ou mais culturas. $\mathrm{O}$ uso da palavra faculty pelos estadunidenses, significando não uma organização ou unidade da Universidade, mas tendo um sentido amplo, o de um grupo de professores, deve provocar confusão para os latino-americanos; esta palavra também é frequentemente usada como um adjetivo. «A Congregação votou não pela proposta». (The faculty voted «no» on the proposal). Temos faculty clubs (isto é, para professores), e faculty wives. A intenção deste ensaio é descrever a organização das Universidades dos Estados Unidos, talvez aclarando algumas ambiguidades.

A unidade básica no ensino superior é a «Universidade». Falamos de modo genérico sobre a educação universitária, embora nem todas as instituições de educação superior sejam Universidades. Essencialmente, «Universidade» significa para nós um conjunto de departamentos de ensino, provavelmente organizado em várias grandes unidades, contendo diversos departamentos cada uma. A principal característica que a identifica é a oferta de cursos que levam à obtenção de vários diplomas, como os de «Bacharel em Ciências» - «Engenharia», «Bacharel em Artes» Música», «Bacharel em Ciências - Agricultura», etc. Não é preciso que uma «Universidade» ofereça cursos de pós-graduação e algumas não o fazem. É certo que nem todos os cursos de bacharelado são estendidos ao nível de pós-graduação. Deve-se notar - e este é fato curioso - que uma instituição deixa de ser o que era antes (vide abaixo) e começa a ser uma Universidade quando adquire objetivos múltiplos — se é que isto pode realmente ser diferenciado de modo significativo.

Além da Universidade, há no nível da Educação superior duas outras instituições; ou melhor, empregamos ainda dois outros termos. Um é o college e outro é instituto (institute).

Dentre as melhores instituições de ensino de graduação que possuímos estão o Oberlin College, o Reed College e o Swarthmore College. E o Harvard College é o componente de ensino ao nível de graduação da Harvard University. As instituições interessadas fundamentalmente no ensino ao nível de graduação frequentemente são chamads de colleges, embora nem sempre seja assim. Oberlin, por exemplo, tem alguns 
cursos de pós-graduação. Certamente não se pode julgar a qualidade de uma instituição pelo nome que ela própria se dá: embora o termo «Universidade» implique em algum prestígio a mais para a instituição, isto não determina a qualidade do ensino ao nível de graduação ou em outros níveis.

O Massachusetts Institute of Technology talvez seja o mais famoso dos «Institutos», seguido do Carnegie Institute of Technology, e do Califórnia Institute of Technology. Estes tiveram sua origem no ensino de Engenharia e gradualmente expandiram-se para outras áreas. O M.I.T., por exemplo, possui um dos melhores departamentos de economia dos Estados Unidos; e também é bastante conhecido por seus estudos sobre técnicas de ajuda ao exterior. Oferece excelentes cursos de graduação e pós-graduação numa grande variedade de áreas. Existem muitos outros «Institutos» e algumas «escolas» (schools) especializadas, tais como a Colorado School of Mines, que tiveram sua origem em áreas de estudo bastante restritas. Algumas permaneceram dentro de seus limites iniciais, outras não.

Resumindo, então, usamos indiscriminadamente as palavras college e university: «Quero que meus filhos cursem uma Faculdade» (I want my kids to go to colleges) . «Todos têm direito ao ensino universitário» (Everybody has a right to a college education). "Êle possui um diploma universitário» (He is a university graduate - diríamos talvez college graduate, mas nunca institute graduate). Talvez a única verdadeira diferença que ainda permanece é quando um college é a segunda instituição mais importante de um Estado e uma «Universidade» é a sua principal rival. Mas as diferenças históricas entre as instituições com várias denominações distintas desapareceram em grande parte, e assim muito pouco pode ser inferido unicamente a partir da denominação.

Clark Kerr criou o termo «multiversidade» para descrever a instituição de ensino superior que ampliou suas funções para além dos vários cursos que concedem diplomas. Estas instituições tendem a ser muito grandes; ministram cursos de graduação e dedicam grande esforço a seus cursos de pós-graduação; insistem em que seu corpo docente realize pesquisas; e podem ter intensa participação em programas internacionais e em contratos de pesquisa. Portanto, possuem múltiplos objetivos e qualquer um destes pode ser negligenciado ou aparentemente negligenciado. Os estudantes de graduação têm sido, recentemente, particularmente categóricos ao expressar sua insatisfação com a falta de prioridade dada ao ensino de graduação pela multiversidade. Este é somente um termo descritivo e nenhuma instituição incorporou-o ao seu nome!

Assim, usarei indiscriminadamente o termo «Universidade» para referir-me a uma «instituição de ensino superior», ficando entendido que isto inclui os colleges e os institutes.

A primeira e principal subdivisão de uma Universidade são suas sucursais (branches) ou campuses. A maioria das Universidades não 
adota esta divisão, embora seja adotada por algumas muito importantes. A University of Califórnia, por exemplo, segundo os últimos dados de que disponho, possuía cerca de 100.000 alunos distribuídos em dez branches: Berkeley, Los Angeles, Davis, Santa Barbara, Riverside, etc. Referimo-nos erroneamente a estas sucursais como campuses. Diremos assim que «êle trabalha no campus Davis», enquanto que realmente queremos dizer «no componente de Davis». A palavra campus usada adequadamente refere-se de fato à localização e ao espaço físico em torno das instalações da instituição. «O campus de Cornell é muito bonito». «O campus de Medicina é longe do restante da Universidade». Referir-se ao Davis campus da University of Califórnia constitui na verdade uma corruptela da palavra, embora seu sentido seja para nós perfeitamente claro. A maior autoridade em todo o complexo é usualmente o Presidente (President), havendo também uma autoridade máxima em cada um dos branches (normalmente o Chancellor) . Pode haver (e há) grande variação nos laços que interligam estes tipos de instituições - essencialmente todas aquelas possibilidades existentes entre um forte centralismo e um frágil federalismo. Em alguns casos, pede existir uma igualdade entre os branches, em outros a situação é mais semelhante a de um órgão central com várias seções subsidiárias.

Estes conglomerados existem e, sem dúvida, criam confusão. Contudo, este tipo de divisão não é essencialmente uma divisão na área do ensino. Existem vários campuses numa única instituição, porque o Estado tem de prover uma grande quantidade de ensino, e econômica e politicamente faz sentido distribuir esta quantidade por vários lugares, ao invés de concentrá-la num só. Para o governador e para a Assembleia Legislativa será certamente mais fácil lidarem com um «sistema universitário» integrado, do que tentarem lidar com duas ou quatro instituições principais e uma dúzia ou mais de instituições menores, todas competindo pela mesma receita de impostos.

Antes de deixarmos a discussão deste tema, devo ainda referir-me a outra instituição importante, o júnior college e/ou o community college. Estes termos são frequentemente sinónimos, embora nem sempre o sejam. O desenvolvimento dos júnior colleges deveu-se principalmente a motivos de ordem econômica. Os primeiros dois anos da Educação superior são (para nós) geralmente pouco especializados, exigindo equipamentos simples, exigindo menos em termos de bibliotecas, e talvez exigindo professores menos especializados. Porque a Educação é um serviço que tem de ser pessoalmente prestado àquele que o recebe, existe sempre o problema da centralização geográfica: até que ponto os alunos devem se concentrar em torno do professor e até que ponto o professor deve ser levado aos alunos. A razão de ser do júnior college está ligada à noção de que nos primeiros dois anos pode existir uma distribuição geográfica mais ampla dos professores e das escolas neste nível do que nos níveis mais avançados de estudo. 
Deste modo, desenvolveu-se nos E.U.A, um sistema de colleges satélites com dois anos de curso, preparando os estudantes para terminarem sua educação em alguns poucos locais centrais. Isto permite que os alunos vivam em seus próprios lares (os jovens dos E.U.A. ingressam no college com uma idade média de 18-19 anos, que é bastante menor do que a média de idade dos primeiranistas brasileiros), o que pode ser do agrado de alguns pais e certamente reduz os custos da Educação para o estudante como indivíduo e para a família. Este sistema também pode dar ao estudante a possibilidade de trabalhar num centro urbano durante os primeiros dois anos do curso, pois algumas das grandes Universidades estão propositalmente situadas em locais calmos e campestres, onde não existem muitos empregos para um estudante trabalhar em regime de meio expediente. Uma vez que o termo júnior tem uma conotação pejorativa, o termo community college o está substituindo progressivamente. Isto dificulta em vez de facilitar a compreensão do assunto. São consideradas júnior colleges as instituições com cursos de dois anos que não concedem diploma e cuja principal função é substituir os primeiros dois anos que normalmente são encontrados nas instituições com cursos de quatro anos. O communitLi college não possui esta conotação. Sugere unicamente que a instituição foi fundada por uma cidade ou por cidades vizinhas; muitos deles evoluíram para instituições com cursos de quatro anos, concedendo diplomas. De passagem, podemos lembrar que em virtude desta evolução institucional, atualmente muitos destes colleges se dão a si próprios o título de «Universidade».

Mas estas divisões são essencialmente administrativas e não de ensino. Para ser mais preciso, desejo esclarecer que quando empregar o termo «Universidade» estarei me referindo à unidade de ensino aquela parcela central da instituição que tem uma localização ${ }^{x}$ definida e consiste em várias partes interrelacionadas.

A primeira subdivisão da Universidade em termos de ensino é o college, ${ }^{2}$ algumas vezes chamada de school. $^{3}$ O tipo de faculdade

Podem existir algumas exceções. As partes especializadas da instituição podem estar situadas longe do campus central.

2 Os termos college ou school, empregados neste sentido, de unidade correspondente a uma subdivisão da Universidade, no Brasil não correspondem aos termos faculdade e escola e o autor prefere que se use o termo em inglês na tradução (N. do Tradutor).

Desconheço qualquer diferença substancial entre os dois, a não ser o fato de que não se pode ter uma subdivisão de um college com nome de colleges. Há alguns anos atrás, o Michigan State College (apesar dos violentos protestos da University of Michigan) mudou seu nome para Michigan State University. A School de Administração e a de Engenharia imediatamente transformaram-se nos Colleges de Administração e de Engenharia sem quaisquer mudanças aparentes. 
mais freqente justapõe e relaciona as disciplinas de ensino, os estudantes, os departamentos e os programas num todo integrado, e sob uma única liderança. O College de Engenharia inclui, sob a orientação e supervisão do seu Diretor (Dean), os departamentos de engenharia elétrica, engenharia civil, engenharia mecânica, etc. O College de Ciências Naturais incluiria química, física, matemática, geologia, etc. O college existe em parte por motivos administrativos: alguma organização intermediária tem de intervir entre a principal autoridade de ensino na Universidade e talvez dúzias de departamento. ${ }^{4}$ Para obter-se uma administração factível (para não dizer «eficiente», é preciso que a quantidade de organizações diretamente subordinadas ao Provost seja algo menor do que o número total de departamentos. Entretanto, o mais importante é justapor e relacionar os estudantes, professores e currículos. Os estudantes dos vários ramos da Engenharia têm em comum grandes parcelas do currículo, e faz sentido que os seus currículos e as suas disciplinas sejam conjuntamente elaborados, orientados e ministrados.

Aqueles que estão familiarizados com o panorama da Educação dos E.U.A, questionarão a clareza desta descrição. Êle não é assim tão simples, tão definido, tão exato. As Universidades são instituições sociais e como tal são produtos da evolução histórica, sendo algumas vezes dirigidas mais segundo a tradição do que segundo critérios racionais. Durante muitos anos, as «Artes» e as «Ciências» eram encontradas juntas no mesmo college, e hoje, em algumas instituições, ainda o são (é difícil definirmos o termo «Artes» no sentido empregado). Encontram-se constantemente cursos peculiares que não se enquadram perfeitamente em quaisquer categorias de cursos usuais, mas que por motivos de ordem administrativa têm de ser inseridos em algum college. Em algumas instituições, por exemplo, o departamento de Economia está localizado no College de Administração; em outras, no College de Artes Liberais (ou de Ciências Sociais). Existe alguma lógica na distribuição dos departamentos pelos vários colleges, mas também existe alguma irracionalidade.

Podemos distinguir quatro tipos distintos de colleges, o que aumenta incomensuràvelmente a confusão existente. Encontramos no Diagrama 1 o tipo I (pág. 459), que é o mais elementar e se parece com o que está sendo chamado de «institutos básicos» no Brasil. A razão de sua

A principal autoridade executiva de uma Universidade é geralmente chamada de Presidente (President). Os Chancellors podem dirigir as várias sucursais da Universidade, subordinadas ao Presidente. À medida que crescem as atribuições do Presidente, uma das primeiras nomeações que êle fará sua equipe de assessores é a do Provost, que terá a seu cargo os assuntos relativos ao ensino na Universidade. $\hat{E}$ frequente o Presidente também contar com um Comptroller ou VicePresidente para Finanças. Outra importante autoridade dirige os assuntos estudantis. 
existência não depende do relacionamento disciplinar usual, mas do grau de identidade do nível de ensino. Normalmente, durante os dois primeiros anos da Universidade, o estudante dos E.U.A, segue um currículo muito amplo. Cerca da metade do seu tempo será despendido em disciplinas de natureza geral, no campo das ciências naturais, das ciências sociais, e da técnica de comunicação - entendendo que isto varia de instituição para instituição. Em virtude da existência de problemas comuns de ensino neste nível e porque os estudantes deste nível têm problemas e características semelhantes, nas últimas três décadas verificou-se o desenvolvimento deste tipo de organização. Foram elaboradas novas disciplinas de natureza geral, foram exploradas novas técnicas de ensino para lidar com grandes quantidades de alunos nas disciplinas obrigatórias, desenvolveram-se novas técnicas de administração. Estes colleges não concedem diplomas, não ministram disciplinas em nível avançado; sua tarefa é proporcionar a formação básica e comum que todos os estudantes devem receber, e orientar o aluno até que êle esteja qualificado para ingressar num college ou school de nível mais avançado.

Quando um estudante ingressa na Universidade, matricula-se como aluno de .Basic College, ou University College, ou General College qualquer que seja sua denominação. Se já sabe que curso deseja definitivamente seguir, então matricula-se no Basic College com uma preferência, digamos, por Matemática ou Engenharia. Se ainda não está certo quanto à escolha de sua carreira, matricula-se como um aluno «sem preferências» (non-pre/erence). Os que já declararam suas preferências são aconselhados quanto ao currículo determinado para a profissão escolhida, enquanto que os chamados «sem preferências» cursam disciplinas em várias áreas de ensino, procurando, através da experiência, encontrar sua principal área de estudos, de acordo com seus interesses. Ambos são alunos do Basic College, ambos cursam suas disciplinas. $\mathrm{O}$ estudante «sem preferências» tem de escolher uma disciplina major antes de deixar o Basic College, e ambos precisam completar cerca de dois anos de estudos satisfatórios antes de serem admitidos na escola adiantada de sua escolha. ${ }^{5}$

6 Nem tudo se ajusta e funciona perfeitamente neste tipo de organização. Assemelha-se um pouco ao serviço público: uma grande lacuna para os países que não dispõem deste, mas um desastre para os que o tem. Concordo sinceramente com o princípio de que todos os estudantes devem ter conhecimentos sobre o mundo social, natural e cultural em que irão viver e agir como cidadãos; devem todos cursar aquelas matérias especiais. Mas a prática não é tão simples como a teoria. O futuro engenheiro não encontra na arte, na poesia ou na sociologia o menor interesse para sua carreira; pode ver estas matérias como um desperdício de tempo e tratá-las como tal. Os professores destas disciplinas repetem sempre as mesmas aulas para os alunos do primeiro e do segundo ano, o que não é uma experiência muito estimulante (Déve-se lembrar que via de regra poucos 
DIAGA A A I

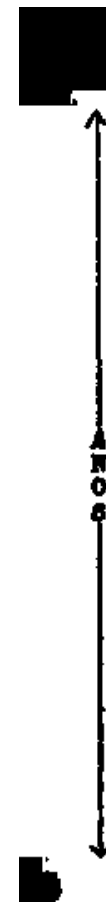

OS COLLEGS
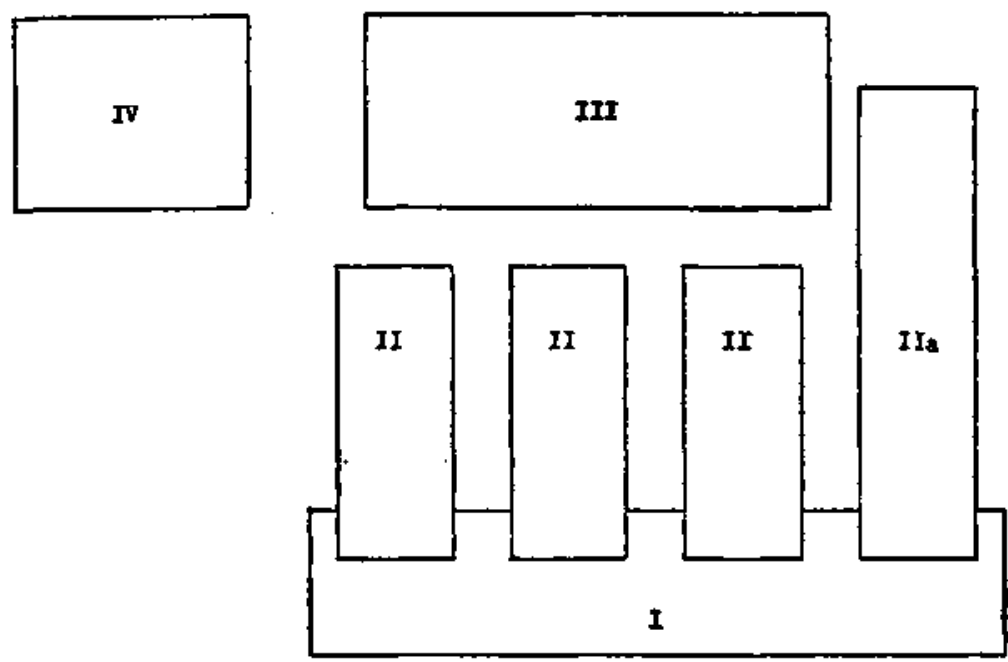

DISCIPLINAS

Os colleges do tipo II são os tradicionais colleges «acadêmicos»: «Letras e Artes», «Educação», «Ciências», «Engenharia», «Agricultura», «Administração», etc. Como mencionamos anteriormente, eles tomam nomes diferentes e formas diferentes em diferentes campuses, mas a ideia é essencialmente a justa posição de disciplinas interrelacionadas, de alunos com interesse semelhantes quanto a área de estudo, e de currículos com necessidades e objetivos comuns. Estas são as escolas onde o aluno realmente se especializa: são frequentemente chamadas de escolas da «divisão superior»; os seus cursos de graduação levam à obtenção de um diploma de «Bacharel em Ciências» ou de «Bacharel em Artes». No diagrama, seus limites se confundem com os do Basic College, porque os estudantes cursam disciplinas em ambas

são os professores nos E.U.A, que lecionam uma única matéria). O fato de que muitos professores ministram parcelas de uma mesma disciplina, todas orientadas para um exame comum, cria alguns problemas pedagógicos que nâo cabem ser descritos em detalhes neste trabalho. Em tudo e por tudo, o esquema funciona razoavelmente bem, embora esteja longe de dar uma solução ao problema de proporcionar aos estudantes universitários uma educação geral ou «ampla», educação esta que os estudantes podem desejar ou não. 
e ao mesmo tempo. O currículo do Basic College mais o dos colleges tipo II são normalmente elaborados para exigir quatro anos de estudos no conjunto." O tipo $\mathrm{Ha}$. é pequena variação do anterior. Ocorre quando o college é uma escola profissional, exigindo estudos que demandam um período de tempo bem maior para a obtenção de um diploma profissional, do que o tempo exigido pelos outros colleges. Medicina veterinária é exemplo deste tipo; para a obtenção de um diploma profissional, normalmente são necessários quatro anos, além do Basic College.

O tipo III é o College de Pós-Graduação (Graduate College) que usualmente engloba todos os colleges profissionais e tem a responsabilidade específica de elaborar e supervisionar a formação pósgraduada. «Formação pós-graduada» (postgraduate training) refere-se especificamente a estudos que levam à obtenção de diplomas posteriores aos de Bacharel acima citados. Geralmente logo acima do nível de Bacharel temos o diploma de Mestre em Artes (Master of Arts) ou de Mestre em Ciências (Master of Science) (aqui existem algumas variações, como, por exemplo, o M.B.A. ou Mestre em Administração de Empresas - Master of Business Administration), seguindo-se o nível mais avançado, o doutorado ou diploma de Doutor em Filosofia (Docíor of Philosophy - Ph. D.) . Também existem diversas pequenas variações do doutorado fora da área da Medicina. O College de Pós-Graduação não tem professores próprios e não ministra suas disciplinas. Sua principal tarefa é auxiliar o departamento na elaboração dos seus currículos de pós-graduação, e em particular assegurar a manutenção da qualidade dos programas pós-graduados em toda a Universidade. Sendo os cursos de pós-graduação fator de prestígio para a unidade de ensino que os possuem, e como a maioria dos professores prefere lecionar disciplinas de pós-graduação, e a maioria dos departamentos aspira a renome e orçamentos cada vez maiores, há elevada propensão para diluir a qualidade do ensino, caso os cursos de pós-graduação sejam deixados unicamente a cargo dos departamentos. O Diretor do College de Pós-Graduação geralmente é e deve ser uma espécie de pináculo em termos de conhecimento e de qualidade académica no campus.

Encontra-se na maioria das instituições algo chamado de «Corpo Docente de Pós-Graduação" (Graduate Facultg). Suas funções, poderes e influências variam de lugar para lugar e, presumivelmente, de uma época para outra. Este corpo docente provém da divisão do pessoal de ensino em dois grupos: os que são julgados competentes para

Recentemente, algumas instituições vêm realizando experiências o ano letivo, a fim de melhor utilizar os recursos de capital, bem como o tempo do aluno. No lugar de dois semestres com um extenso período de férias, estão tentando implantar o regime de três semestres de igual extensão e com férias muito curtas. Este regime cria problemas, mas também possui vantagens suficientes para merecer bastante atenção. 
lecionar a estudantes de nível pós-graduado e aqueles que não o são. A base do julgamento pode consistir em diplomas obtidos, pesquisas realizadas, experiência, etc. Este corpo docente é geralmente a maior autoridade no College de Pós-Graduação. embora o verdadeiro poder possa estar em grande parte nas mãos do Diretor ou de um grupo selecionado dentre os membros do corpo docente, usualmente chamado de Conselho de Pós-Graduação.

A partir da limitada observação que pude fazer, sou levado a crer que a importância do papel desempenhado pelo College de Pós-Graduação vem diminuindo gradativamente. Tinha considerável importância o seu papel disciplinador, mas processos externos de reconhecimento o estão substituindo. Entretanto, mais importante ainda é a mensuração da qualidade que é proporcionada através da interrelação das disciplinas. O melhor meio de julgar-se o departamento de Economia da Universidade X não é julgar o seu Corpo Docente de Pós-Graduação ou o Diretor do seu College de Pós-Graduação, mas compará-lo com outros departamentos de Economia. Este julgamento é feito com regularidade e seus resultados soam alto e claramente. Se um dado departamento consegue atrair unicamente maus alunos das redondezas e se seus produtos não conseguem encontrar empregos ou só encontram maus empregos, não há dúvidas sobre a avaliação do preparo profissional que é dado por aquele departamento em particular.

Os colleges do tipo IV são aqueles tipicamente de pós-graduação, orientados profissionalmente, e sem cursos de graduação. As Escolas Médicas e as Escolas de Direito são os exemplos melhores e mais comuns, embora a Escola de Pós-Graduação em Administração de Harvard também se enquadre nestas características. O aluno de um curso de graduação que deseja seguir a profissão de médico ou de advogado ingressa em um curso «prê-médico» (pre-med) ou de «pré-advocacia» (pre-law). Ao graduar-se requer admissão numa Escola de Medicina ou numa Escola de Direito. ${ }^{7}$ As vagas são escassas e êle será ou não admitido, dependendo de suas notas e de seu desempenho anterior, dos testes vocacionais, etc. Estes colleges são altamente especializados e encarregam-se do seu próprio ensino, isto é, as disciplinas integrantes do seu currículo normalmente não são cursadas por seus alunos em outros colleges. Os estudantes de Medicina, porém, terão cursado suas disciplinas básicas (Biologia. Química, Física e similares), enquanto eram estudantes do pré-médico em algum College de Ciências e Letras. ${ }^{8}$

\footnotetext{
No meu entender, esta separação tradicional e completa tende a desintegrar-se. Hoje alguns estudantes de Medicina ingressam nas escolas médicas após três anos de estudos ao nível de graduação e sem haverem obtido anteriormente um diploma de Bacharel.

8 Há ainda outro tipo de college que começa a surgir no panorama educacional dos E.U.A., procurando copiar o pequeno college residencial e semi-independente, encontrado na Universidade britânica tradicional.
} 
Mudando de assunto, devo dizer que o Diretor (Dean) é necessariamente um indivíduo importante. A êle cabe tomar as decisões orçamentárias cruciais que permitem a um departamento expandir-se e ganhar renome nacional, enquanto que outro pode ter determinada sua extinção gradual. É neste nível que são tomadas as difíceis decisões relativas a promoções do pessoal, salários e nível de contratação do pessoal. O nível em que se situa o departamento faz com que êle esteja muito próximo das pessoas que o integram e assim o departamento terá a tendência de desejar aumentar os salários de todos, promover a todos, etc. O Diretor torna-se então um carrasco, porque está mais distante daquelas pessoas e porque sua nomeação é feita diretamente pela administração central. Os presidentes ou chefes de departamentos podem ser eleitos por seus colegas ou nomeados pelo Diretor, mas são como os comandantes das companhias de infantaria, servindo no campo de batalha junto com as tropas. Embora possam dever lealdade e submissão aos seus superiores, respondendo perante estes, são colegas de trabalho de todos os membros do departamento. Isto não acontece com o Diretor. Êle é nomeado pelo Reitor e permanecerá no cargo enquanto fôr da confiança do Reitor (embora também seja professor de alguma matéria). Não resta dúvida sobre sua subordinação direta ao gabinete do Reitor. Mesmo nas instituições dirigidas de modo bem democrático, o Diretor é uma figura chave, simplesmente porque os documentos mais importantes têm de passar sobre sua mesa e as decisões cruciais são tomadas nas suas reuniões.

Alguns colleges grandes e de difícil administração são subdivididos em «divisões». Quando isto ocorre, os motivos são em grande parte de ordem administrativa, pois a «divisão» como organismo de ensino ainda não se tornou importante como instituição. ${ }^{9}$

O departamento é a unidade básica de funcionamento da Universidade e foi admiravelmente descrito pelo Professor Hoge, ${ }^{10}$ e aqui unicamente resumiremos sua descrição. O departamento é a unidade básica sobre a qual os colleges e finalmente as Universidades são construídas. A característica que o identifica é ser o local de toda a atividade universitária relacionada a uma matéria ou disciplina específica. $^{11}$ Todos os professores de História, por exemplo, são membros do departamento de História. Nesse caso, é o departamento que determina quem pode e quem não pode ser professor de História. Ministra todas as disciplinas de História na Universidade, e decide quais devem ser as exigências para o bacharelado, para o mestrado e doutorado em História (dependendo de aprovação dos níveis superiores

\footnotetext{
9 Segundo informações recentes que obtive em algumas instituições, a «divisão» é um importante organismo dentro do college.

10 «O Departamento na Universidade Norte Americana», in O Estado de São Paulo, dias 23, 24, 25 e 26 de maio de 1968.

11 Algumas exceções estão comentadas adiante.
} 
e supondo que não sejam conflitantes com a política de ensino adotada pela Universidade). Decide que disciplinas são ensinadas, com que frequência, em que horários e por quem. Decide quais as novas matérias que devem ser adicionadas ao conjunto existente (mais uma vez dependendo de aprovação). Decide o que é considerado bom ou mau desempenho de seus membros e faz as recomendações iniciais para as promoções, aumentos por mérito, término de contrato (novamente tudo sujeito a aprovação) .

É neste nível que se encontra um dos aspectos menos agradáveis da vida universitária nos E.U.A.: a batalha jurisdicional que o Brasil evita tão habilmente. O sistema de faculdades independentes evita responder a perguntas como: a Matemática ensinada pelo departamento de Matemática é adequada para Engenharia? para estatísticos? para matemáticos? A Educação brasileira não responde a esta pergunta, pois cada faculdade se encarrega de seu próprio ensino em todas as matérias, e a Universidade e a sociedade pagam o preço elevado de uma grande duplicação de esforços e recursos. Procuramos evitar a duplicação através do sistema de interdependência departamental, e o custo deste sistema é uma luta para decidir quem deve ensinar quais disciplinas. Se existe um departamento de Estatística, deve êle ensinar teoria estatística? estatística biológica? estatística econômica? etc? Se êle possui uma orientação teórica muito acentuada, os departamentos de administração de empresas podem levantar objeções e talvez começar a dar sua estatística «clandestina». Os engenheiros podem fazer o mesmo. Idêntico problema repete-se mais uma, mais outra vez. A quem pertence a disciplina História da Arte; ao departamento de Arte? ou ao departamento de História? Este problema torna-se às vezes muito desagradável, especialmente para os departamentos que são em grande parte «departamentos de prestação de serviços», isto é, aqueles que possuem pequeno número de alunos seus, mas ensinam a elevado número de estudantes que pertencem a outros departamentos. Se cada ano temos mil estudantes de Administração, aos quais se exige que cursem Estatística, eles constituirão parcela substancial da carga de ensino do departamento de Estatística (e portanto do orçamento), e assim este tenderá a precaver-se zelosamente contra a usurpação do seu «território».

O número de variações nos métodos de dirigir um departamento $e ́$ quase tão grande quanto o número de departamentos existentes. A maior autoridade é um «presidente» ou «chefe», o primeiro sugerindo uma organização mais democrática do que o segundo.

O presidente pode ser eleito por seus colegas e ocupar o cargo por determinado período, sendo depois substituído por outro colega eleito. É mais provável que o «chefe» seja nomeado pelo Diretor e permaneça no cargo enquanto fôr da sua confiança. Isto varia muito de instituição para instituição e mesmo dentro de uma dada instituição. O modo pelo qual um departamento é dirigido depende: 1) do tipo 
de orientação que lhe imprime o Diretor, e do que êle espera da liderança e do departamento; 2) da personalidade do presidente ou chefe; 3) da docilidade (ou falta de docilidade) dos membros do departamento; e 4) da confiança que os membros depositam no presidente e da sua disposição de levar a efeito uma administração cooperativa no departamento.

O departamento deve dar atenção quase que constante a três áreas gerais: 1) currículo de graduação e pós-graduação - sendo ambos frequentemente revistos, dependendo dos novos achados em cada campo profissional, dos interesses dos professores e das mudanças de pessoal; 2) pessoal - incluindo especialmente a contratação de novos professores, as recomendações para promoção, e os julgamentos anuais do «mérito» de cada um, tendo em vista os aumentos salariais em cada caso específico; 3) ensino - ajustando em particular as necessidades de aprendizado do aluno ao pessoal disponível e suas preferências de ensino. Não é preciso muita imaginação para perceber a delicadeza de algumas das decisões a serem tomadas e o tempo consumido nas tentativas de se chegar a estas decisões através de processo razoavelmente democrático, especialmente quando se leva em conta a grande propensão que os professores têm para falar! Estas decisões podem ser concentradas nas mãos de um chefe ditatorial - e algumas vezes o são; outras vezes estão nas mãos de uma comissão departamental permanente.

Até aqui tive a oportunidade de resumir as principais divisões, quanto ao ensino das instituições educacionais: a Universidade e suas sucursais, os colleges e os departamentos. Entretanto, com rápida vista de olhos nos curriculum vitae, nos títulos dos professores e lendo-se os jornais, percebe-se logo que existem «institutos», «centros», «escritórios» e serviços anexos às várias Universidades ou como parte integrante delas. Estes organismos variam quanto a sua importância. mas se comparados aos principais elementos acima descritos só podem ser caracterizados como desempenhando papel secundário. Variam de tal maneira quanto à função, tamanho, atividade, vitalidade e importância, que está fora de cogitação qualquer tipo de exame mais detalhado, e as generalizações tenderão a iludir ao invés de esclarecer.

Estes institutos especializados ${ }^{12}$ foram criados, na sua maioria, para desempenhar funções especiais que não eram totalmente adequadas aos departamentos de ensino tradicionais. Em alguns casos, foram criados, porque a natureza interdisciplinar da matéria sugeria uma combinação de departamentos participantes. O «Centro de Segurança Rodoviária», por exemplo, poderia muito bem ter professores de Engenharia, Economia, Psicologia e Medicina. Não existe nenhuma razão lógica que nos obrigue a «situar» este centro em qualquer departamento

12 Não devem ser confundidos com os institutos equivalentes a Universidades, já mencionados anteriormente. 
determinado. A criação de uma entidade separada, com vida independente e responsabilidade própria é realmente mais atraente para pessoas e fundações doadoras de auxílio do que a organização departamental, mais comumente encontrada. É mais fácil, também do ponto de vista da Universidade, administrar em separado estas verbas, sem confundir funções, verbas e administradores dos assuntos departamentais. Algumas vezes estas organizações «dependem» diretamente do Reitor ou do Provost, mas na maioria das vezes são seres que pertencem a um college e estão sob as ordens diretas do Diretor. Sua característica singular talvez seja a de que não possuem uma vida universitária própria e independente. Seus integrantes «normais» são professores de nível e cargo nos departamentos tradicionais. Podem ser nomeados em regime de meio expediente para o instituto e também meio expediente para o departamento - ou com qualquer outra combinação de horários, dentre uma variedade de possíveis. Além destes professores, o pessoal profissional contratado que não se enquadra nos níveis e cargos do quadro docente, e que não ensina, só será considerado como empregado temporário da Universidade, files complicam a estrutura organizacional das Universidades dos E.U.A., mas preenchem uma finalidade dentro de um esquema geral.

Existem ainda dois grandes apêndices da Universidade dos E.U.A. encontrados principalmente nas grandes instituições públicas. O primeiro é um órgão destinado a lidar com os programas internacionais da Universidade e que não deve ser confundido com uma possível «escola de estudos internacionais». Muitas Universidades se tornaram profundamente envolvidas em vários programas no estrangeiro: programas de intercâmbio de estudante e de bolsas de estudos, de assistência técnica, de ensino e de pesquisa. Estes programas frequentemente exigem grandes conhecimentos técnicos em administração, em desenvolvimento, em negociações e seleção de pessoal. Os programas também são constantemente de natureza interdisciplinar. Dependendo dos interesses que a instituição tenha nos programas internacionais, o tamanho deste órgão varia consideravelmente. Pode estar a seu cargo a supervisão de despesas que montam a centenas de milhares de dólares cada ano. A principal autoridade, um Dean, Vice President ou Director, está diretamente subordinada ao President, sendo de sua responsabilidade o desenvolvimento dos programas internacionais, a coordenação e assistência aos programas dos departamentos de ensino usuais, cabendo-lhe ainda zelar para que a orientação dada aos programas mantenha sua legitimidade de ensino.

Outra organização existente é o chamado «Serviço de Extensão Universitário (University Extension Office) ou serviço de Continuação da Educação (Continuing Education Service), cuja direção cabe a um Dean, Director ou cargo semelhante. Sua função é levar a Educação (cursos universitários normais ou cursos especializados) à parcela adulta da população do Estado. A autoridade central da Universidade 

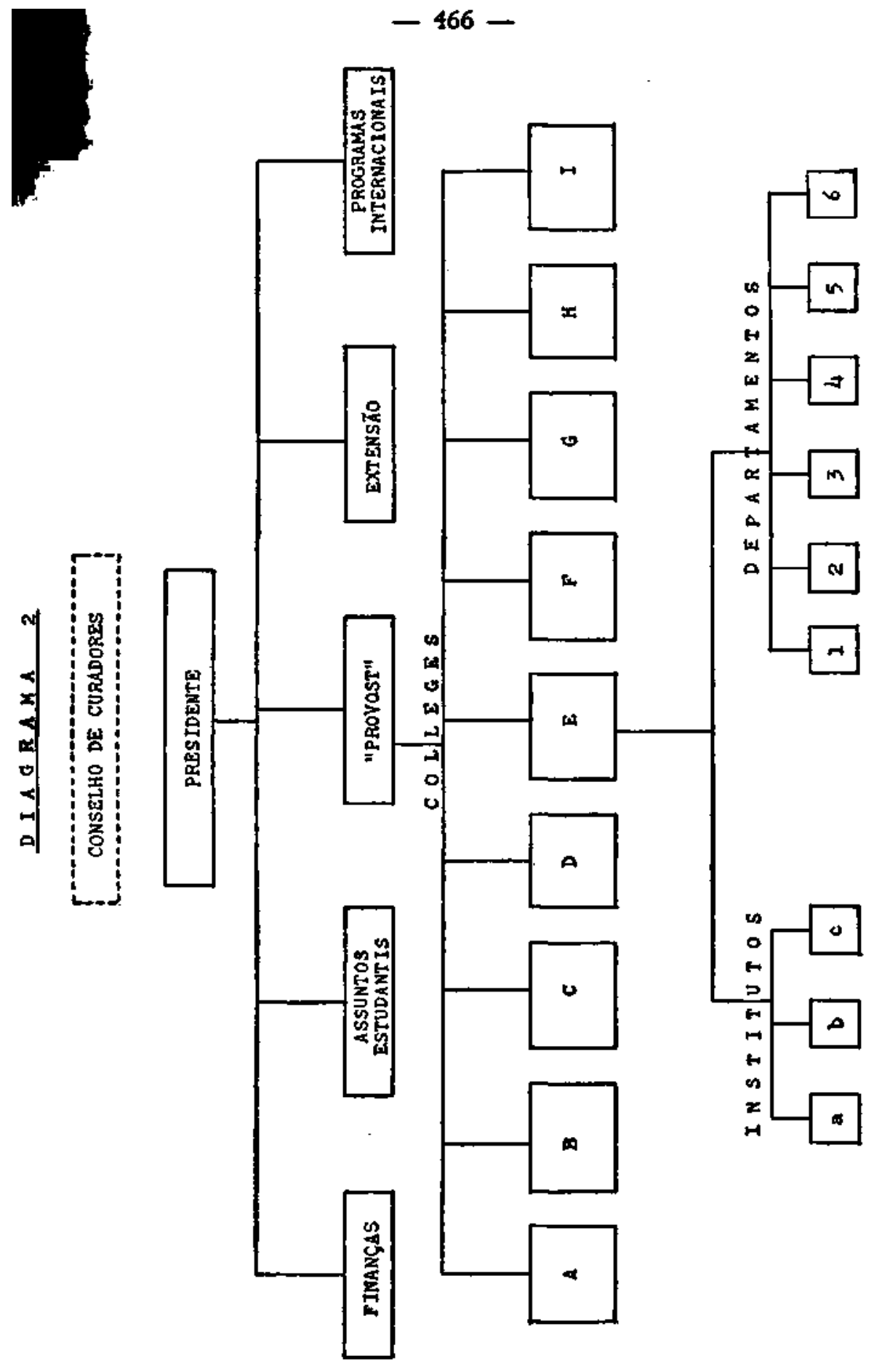
essencialmente um organizador e um administrador, reunindo e relacionando os recursos de ensino da Universidade às necessidades educacionais da comunidade. Segundo informações recentes de uma Universidade, mais de 60.000 pessoas por ano vêm a seu campus para seguir tais cursos e outros milhares de pessoas são alcançadas através dos cursos ministrados fora do campus, cursos estes que podem ou não valer créditos. Num ano foram ministrados mais de 700 destes cursos fora do campus a mais de 17.000 participantes.

O Diagrama 2 (pág. 466) procura resumir, de modo o mais simplificado possível, o que foi descrito acima. Entretanto, existe ainda um hiato que deve temporariamente (ou para sempre) esperar por uma descrição. Examinamos aqui a organização da Universidade, mas ao lado desta hã outra «organização» que ignorei completamente — a do «corpo docente». O pessoal docente normal da maioria das instituições mantém o controle - ou gosta de pensar que mantém controle — da política de ensino da instituição. Isto envolve um elaborado conjunto de mecanismos, tais como o Senado Acadêmico, o Conselho Acadêmico, uma Comissão Diretora, etc, tudo sugerindo ainda outro conjunto de problemas, a ser considerado em algum outro lugar.

JOHN M. HUNTER

EAPES

Março - 1968

Tradução de:

Jacques R. Velloso

Junho -1968

13 Michigan State University Publication, Catalog Issue, 1967, pág. 234. A participação de um professor nestes programas pode ser considerada como uma parcela dos seus deveres usuais, conquanto haja grande variedade de meios de participação. Êle pode receber um pagamento adicional por sua «sobrecarga», ou sua carga departamental normal pode ser reduzida como compensação por suas atividades na extensão universitária. 
Apendice D. 6

\section{THE STRUCTURE OF HIGHER EDUCATION IN THE UNITED STATES}

There are problems in communicating in bi-or multi-lingual situations because words, the same or similar in two languages, convey substantially different ideas in the two or more cultures. One confusion for Latin Americans must be the ianqui use of «faculty», not as an organization or unit of the university but, very loosely, as a group of professors and very often we use word as an adjective. «The faculty voted «no» on the proposal. We have «faculty clubes» (i.e., for professors), and «faculty wives». The purpose of this essay is to describe the organization of U.S. universities, perhaps clarifying the obscurities which naturally exist.

The basic unit in higher education is the «university». We talk about university education generically although not all institutions of higher learning are «universities». Essentially, we mean by «university» a collection of teaching departments, sometimes arranges into «schools» or «colleges» each composed of several departments. A major distinguishing characteristic is that it offers programs leading to several degress, perhaps a «Bachelor of Science in Engineering, a «Bachelor of Science in Agriculture, a «Bachelor of Arts in Music», etc. It is not necessary that a «university» offer graduate work and some do not. Certainly not all the bachelor degree programs will be extended into the graduate level. The point, curiously enough, is that an institution stops being whatever it was before (see below) and starts being a university when it acquires multiple objectives - if one can really make any meaningful distinction at all.

There are two institutions other than universities at the higher education level; rather, there are two other names we use. One is «college» and the other «institute». Oberlin College, Swarthmore College, Reed College are among the best undergraduate educational institutions that we have. And Harvard College is the undergraduate component of Harvard University. Institutions primarily interested in undergraduate education are frequently called «colleges» but this is not always the case. Oberlin, for example, has some graduate programs. One surely cannot judge quality on the basis of what an institution calls itself: while the term «university» is somewhat more prestigious /or the institution this does not determine the quality of the education at the undergraduate or other levels. 
The most famous, perhaps of the «institutes», is the Massachusetts Institute of Technology followed by such as Carnegie Institute of Technology, and California Institute of Technology. These had their origins in engineering education and have gradually expanded into other areas. M.I.T., for example, has one of the best economics departments in the United States and is well known, too, for its study of the techniques of foreign assistance. It offers excellent graduate and undergraduate programs in a wide variety of fields. There are many other institutes and some specialized «schools such as the Colorado School of Mines which had their origins in rather narrow technical areas. Some have remained within the initial bounds, some have not.

In summary, then, we use «college» and «university» indiscriminately. «I want my kids to go to college. «Everybody has a right to a college education. «He is a university (or college but never institute) graduate. Perhaps the only real difference remaining is when the second most important public institution in a state is a «col!ege» and its principal rival is a «university». But the historical differences between institutions variously called have largely disappeared, and very little can be inferrede simply by the name.

Clark Kerr coined the term «multiversity» to describe the institution of higher education which expanded its functions beyond the several degree programs. These institutions tend to be very large; they teach undergraduates and devote great energy to their graduate programs; they insist upon faculty research; and they may be heavily involved in international programs and in contract research. They have multiple objectives then, anyone of which may be neglected or apparently neglected. Undergraduates have recently been particularly vocal in expressing disgust with the priority given undergraduate teaching by the multiversity. This is just a descriptive term, and no institution has incorporated into its name!

So, I will use the term «university» indiscriminately to mean institution of higher learning with the understanding in particular that it includes the «college» and the «institutes».

The first major subdivision of a university is that of «branches» or «campuses». Most universities do not so divide themselves, but some very important ones do. The University of California, for example, had by my last count about 100,000 students distributed in ten branches: Berkeley, Los Angeles, Davis, Santa Barbara, Riverside, etc. We refer to these erroneously as «campuses». «He works at the Davis campus when we really mean «component». There is one principal officer (usually «President») for the whole complex with a principal officer (usually «Chancellor») at each of the branches. There can be (and is) great variation in the ties that bind these kinds of institutions together - essentially all those possibilities existing between strong centralism and weak federalism. In some cases, there may be a equality among the branches; in others, the situation is more nearly that of a central 
agency and various subsidiary branches. «Campus» properly used refers to the actual physical location and environment of the institution's facilities. «Cornell's campus is very beautiful. «The medical campus is far from the rest of the university. To speak of the «Davis campus of the University of California is really a corruption of the word although its meaning is quite clear to us.

These conglomerates exist and are no doubt confusing. This sort of division is not an essentially academic one, however. Various campuses of a single institution exist because the state must provide a great deal of education, and it makes good economic and political sense to provide it in a variety of locations instead of in just one. Certainly, it is much easier for the governor and legislature to deal with a consolidated «university system than to try to deal with two to four principal state institutions and a dozen or more lesser ones - all competing for the same tax dollars.

Perhaps before leaving this topic, I should touch upon one other major institution, the «junior college and/or the «community college. The terms are frequently, but not always, synonymous. The junior college developed principally for economic reasons. The first two years of higher education are generally (for us) little specialized, require only equipment, require less of the libraries, and perhaps require less specialized professors. Since education is a service that must be delivered in person to its recipients, there is always the problem about the extent the recipients must congregate in one central location, and to what extent the «dispensers» can be dispersed to the students. The junior college's raison d'etre involves the notion that in the first two years, the dispersion of the educatiors and the educational media can be greater than for more advanced study. So there has developed a satelitic system of two-year colleges preparing students to finish their university education at fewer central locations. This permits students to live at home (U.S. youngsters enter college at an average age of 18-19 wich is considerably less than the average entering age of Brazilians) wich may please some parents and which certainly reduces the cost of education for the individual student and/or his family. This system may also make it possible for the student to work in an urban center during the first two years since some of the major universities were purposely located in quiet, pastoral settings where employment for parttime student labor is not plentiful. Since the term «junior has some pejorative connotation, the term «community college is replacing «junior college. This confuses rather than clarifies understanding. Junior colleges are understood to be two-year institutions which grant no degrees and whose principal function is to substitute for the first two years normally found at four-year institutions. «Community college carries no such connotation. It suggests only that the institutions was founded by a city or neighboring cities; many of them have evolved into 
four-year, degree-granting institutions. As a matter of passing interest and a note on institutional evolution, many now call themselves «universities».

But these are essentially administrative, not academic, divisions. To be clear, when I speak below of a «university», I will mean the academic unit - that central part of the institution which has one location ${ }^{l}$ and consists of a number of interrelated parts.

The first academic subdivision of the university is the «college», sometimes referred to as «school». ${ }^{2}$ The most frequent type of college juxtaposes academically related disciplines, students, departments, and programs in one integrated whole and under single leadership. The college of Engineering under its Dean includes Departments of Electrical Engineering, Civil Engineering, Mechanical Engineering, etc. The College of Natural Sciences would include chemistry, physics, mathematics, geology, etc. The college exists partly for administrative reasons some intermediate organization must intervene betwen the perhaps dozens of departments and the university's principal academic officer. For administrative feasibility (not to say «efficiency»), the number of organizations directly responsible to the Provost has to be something less than the total number of departments. But more important is the juxtaposition of related students, professors, and programs. Students in the various branches of engineering have large portions of the curricula in common, and it takes sense that their programs be jointly conceived, led, and administered.

Those familiar with the U.S. scene will question the neatness of this description. It is not all that simple, that clearcut, or that correct. Universities are social institutions and as such are products of historical evolution and are sometimes more tradition - bound than rationally governed. For many years, «arts» and «sciences» were found together in the same college, and in some institutions they still are. («Art» in this sense is hard to define). Frequently, there are misfit programs which do not really fall neatly into any category but have to be put into some college for administrative purposes. Some disciplines may logically be located in more than one college. For example, in some

There may be some exceptions. Specialized parts of the institution may be located away from the central campus.

2 I know of no substantive difference between the two, except possibly that one cannot really have subdivisions of a «college» called «colleges». A few years ago, Michigan State College (in spite of violent objections of the University of Michigan) changed its name to Michigan State University. The «School» of $\mathrm{Bu}$ siness, and the «School» of Engineering immediately became «Colleges» of Business and of Engineering with no other apparent changes.

The principal executive officer of a university is usually called its «President». «Chancellors» may direct various branches of the university under its President. As the role of the president expands, one of the first staff appointments he is likely to make is that of «Provost» who is given the responsability for the academic affairs of the university. He frequently has a Comptroller or Vice President for Business and Finance as well. Another important officer directs all student affairs. 
institutions, the Department of Economics is in the College of Business; in others it is in the College of Liberal Arts (or Social Science). There is a certain amount of logic to the distribution of departments among the various colleges, but, there is a certain amount of irrationality, too.

We can distinguish four distinct types of colleges which adds immeasurably to the confusion. Referring to Diagram 1, Type I is the most elementary type and resembles what is coming to be called the «basic institutes in Brazil. Its rationale depends not on a common disciplinary relation but upon the commonality of the level of teaching. Typically, ianqui students take very broad programs their first two university years. About half of their time will be involved in comprehensive courses in humanities, in natural science, in social science, and in communications skills - it being understood that this varies from institution to institution. Because there are common problems in teaching at this level and because students at this level have similar characteristics and problems, this sort of organization has developed over the last three decades. New comprehensive courses were developed, new teaching techniques have been explored for handling large numbers of students in required courses, new administrative devices have been developed. These colleges grant no degrees, teach no advanced courses; their task is to provide the basic, common training that all students take and to administer the student until such time as he is elligible to enter an upper school or college.

When a student enters the university, he enrolls as a student in the Basic College, or University College, or General College - whatever it may called. If he already knows what course he ultimately wants to follow, then he enrolls in the Basic College with a preference, say, for mathematics of engineering. If he is not certain of his ultimate career choice he enrolls as a «non-preference» student. Those students with announced preferences are advised concerning the curricula prescribed for their particular preferences while those «non-pref», as we call them, shop around in various academic areas seeking through experience to find an acceptable major area of study. Both are students of the Basic College, both take its courses. The «non-pref» must select a «major» before he leaves the control of the Basic College, and both must complete approximately two years satisfactorily before being admitted to the upper school of their choices

Type II colleges are the traditional, «disciplinary colleges — «Arts and Letters, «Education», «Sciences», «Engineering, «Agriculture»,

All is by no means «peaches and cream» with this arrangement. It is a little like civil service: a great deficiency for those countries that do not have it but a disaster for those that do. I an heartily in acco'd with the principle that all students should be made aware of the social, natural, and cultural world in which they are going to live and act as citizens; they should all take these special courses. But the practice is not so neat as the theory. The embryonic engineer does not see Art. Poetry, or Sociology as being of the slightest interest to him; he may view these required courses as a waste of his time and treat them as such. The professors. 

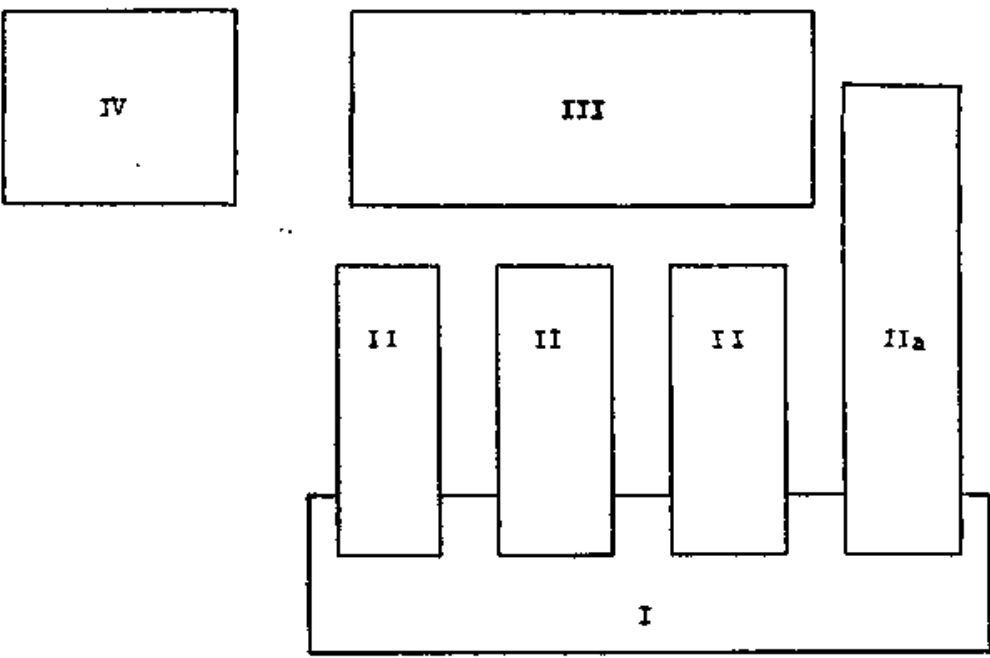

«Business», etc. As mentioned earlier, they have different names and different conformations on different campuses, but the idea is essentially the juxtaposition of related disciplines, students with similar academic interests, and programs with common needs and objectives. These are upper division schools; and study in them at the undergraduate level leads to a «bachelor of science or a «bachelor of arts» degree. On the diagram, they are intermixed with the Basic College because students do take courses in both at the same time. Ordinarily, the program of the Basic College plus the Type II colleges is designed to require four years of study. ${ }^{5}$ Type Ila is a minor deviation when the college is a

of these courses repeat the same course over and over to first and second year students - not a very stimulating experience (It will be recalled that few U.S. professors consistently teach a single course). The fact that many professors are teaching sections of the same course, all pointed to a common examination, creates some pedagogical problems which I cannot describe in detail here. All in all, the scheme works fairly well, but it is far from a perfect solution to the problem of providing a general or a «broad» education to university students who may or may not want it.

5 Relatively recently, some institutions have been experimenting with the academic year so as to make better use of capital facilities and also of the student's time. Instead of two semesters and a long vacation, they are trying three semesters of equal lenght with very short vacations. There are problems with this but enough advantages to merit considerable attention. 
professional school requiring considerably more time to earn the professional degree than is the case in the other colleges. Veterinary Medicine is an example of this; earning the professional degree ordinarily requires four years beyond the Basic College.

Type III is the Graduate College which ordinarily encompasses all the traditional Colleges and has the special responsibility of developing and supervising postgraduate training. «Postgraduate training means specifically work leading to degrees higher than the bachelor's degrees mentioned above. Generally these are, at the next level, the Master of Science or Master of Arts degree (there are some variations here, for example, the «M.B.A.» or «Master of Business Administration) followed by the more advanced «doctorate» or Doctor of Philosophy degree (Ph. D.). There are some minor variations of the doctorate, too, outside the medical field. The Graduate College has no professors of its own and teaches no courses. Its principal task is to assist the departments in the development of their graduate programs and in particular to assure the continued quality of the graduate programs throughout the university. Since prestige is acquired by having graduate programs, since most professors prefer to teach graduate courses, and since all departments aspire to greater glory and greater budgets, there is a high propensity for dilution of quality if the departments are left to themselves to develop graduate studies. The Dean of the Graduate School generally is and should be a sort of pinnacle of scholarship and academic quality on the campus.

In most institutions one finds something called the «Graduate Faculty. Its functions, powers, and influence vary from place to place and, presumably, from time to time. The Graduate Faculty stems from the division of the instructional staff into two groups: those adjudge competent to teach graduate students and those not. The basis for judgement may be degrees earned, research done, experience, etc The ultimate authority of the Graduate College usually rests in its Graduate Faculty although the actual power may rest largely in the hands of the Dean or in some select group of the Graduate Faculty, usually called the Graduate Council.

From limited observation, it is my view that the role of the Graduate College is declining. The disciplinary role had considerable importance, but external accreditation procedures have increased in substitute for it. Most important, though, is the measurement of quality supplied intradisciplinarily. The best judge of the department of economics at University $X$ is not its Graduate Faculty or the Dean of its Graduate School but rather other department of economics. This judgement is made regularly and rings loud and clear. If a given department can only attract poor students from outside the immediate locale and if its products can find no jobs or only poor ones, there is no doubt about the profession's evaluation of that particular department. 
Type IV colleges are those that are typically postgraduate colleges, professionally oriented, and without undergraduate programs. Medical schools and law schools are the best and most common examples although the Graduate School of Business at Harvard also fits these characteristics. The undergraduate student who wants to enter the medical or legal profession follows a «pre-med» or a «pre-law» program. When he graduates, he applies for admission to a medical school or law school. ${ }^{6}$ He will be admitted or not to the scarce number of openings depending upon his previous record, vocational testing, etc. These colleges are highly specialized and do all their own teaching; that is, their students do not ordinarily take courses in other colleges. The medical students will have had, however, all their basic courses (biology, chemistry, physics, and the like) as pre-med students in some College of Arts and Sciences.

The Dean, to turn to another matter, is necessarily an important individual. He makes critical budget decisions which permit one department to expand, to gain national recognition while another may be required to languish. At this level the very hard decisions are made on staff promotions, salaries, and contract status are made. The departmental level is too close to the persons and the department is apt to want to increase everyone's salary, promote everyone, etc. The Dean, then, becomes the hatchet man because he is further removed from the individuals involved and because he is more clearly the appointee of the central administration. Department chairmen or heads may be elected by their colleagues or appointed by the Dean, but they are like the in fantry company commander who serves in the field with the troops. Although they may owe loyalty, submission, and response upward, they are fellow teachers with, and colleagues of, all the members of the Department. This is not the case with the Dean. He is appointed by the President and serves in that capacity at the President's pleasure (although he will also be a professor of something). There is no doubt about where his responsabilities lie. Even in the most democratically run institutions, the Dean is a key figure simply because it is over his desk that critical papers must pass and it is at his meetings where critical decision are made. ${ }^{8}$

Sometimes large and unwieldy colleges are subdivided into «divisions». When this is the case, the reasons are largely administrative; the «division» has not become an important academic institution.

6 It is my understanding that this traditional, complete separation in tending to disintegrate and some medical students now enter medical schools after three years of undergraduate preparation and without earning a previous bachelor's degree.

7 There is still another college beginning to appear on the U.S. scene. It seeks to duplicate the residential, semi-independent small college found in thetraditional British university.

8 I am now informed that in some institutions the division is an important sub-college organization. 
The department is the primary operating unit of the university, and has been admirably described by Professor Hoge, ${ }^{\circ}$ and his description will only be summarized here. The department is the basic unit from which colleges and ultimately universities are built. Its distinguishing characteristics is its being the locus of all the activity in the university related to a specific academic subject or discipline. ${ }^{10}$ All the professors of history, for example, are members of the Department of History. In this respect it determines who can be a professor of history and who cannot. It administers all the courses in history in the university. It decides (subject to approval from above and assuming no conflict with university policy) what the requirements for B.A., M.A., and Ph. D. degrees in history shall be. It decides what courses will be taught, how often, at what hours, by whom. It decides what, new courses should be added (again subject to approval). It decides what it thinks is good performance and what is poor on the part of its members and makes the prime recommendations for promotion, merit increases, contract termination (again all subject to approval) .

It is at this level that one of the least lovely aspects of U.S. university life is found - the jurisdictional battle which Brazil so neatly avoids. The independent faculdade system avoids having to answer the question: Is the mathematics taught by the mathematics department suitable for engineers? for statisticians? for mathematicians? Brazilian education does not ask this question; for each faculty teaches its ow in every subject, and the university and society pay the high price of a great deal of duplication. We seek to avoid the duplication by the interdependent departmental system, and the cost is a struggle over who should teach which courses. If there is a statistics department, does it teach statistical theory? biological statistics? economic statistics? etc? If it is highly theoretically oriented, the business departments will object and perhaps start their own «bootleg» courses. The engineers may do the same. The same problem is repeated again and again. Where does a course in the History of Art belong; in the Art Department? or in the History Department? This problem at times gests very nasty especially for departments which are largely «service departments, i.e. those having few students of their own but teaching large numbers of students for other departments. A thousand business students a year required to take statistics will form a substantial proportion of the teaching load (and hence budget) of the statistics department, so it is apt to zealously guard against encroachment on its «territory».

There are nearly as many variations in the way departments are governed as there are departments. The principal officer is either a «chairman» or a «head», the former suggesting a more democratic

(See the Portuguese text).

Some exceptions are noted below. 
organization than the latter. The chairman may be elected by his fellows and serve on a rotating basis. The «head» is more likely to be appointed by the Dean and serve at his pleasure. This varies greatly from institution and even within a given institution. How a department is governed depends: 1) upon the sort of «tone» the Dean imparts and what he expects both of the leadership and the department; 2) upon the personality of the department head or chairman; 3) upon the docility (or lack of it) of the members of the department, and 4) upon the confidence of the members of the department in the chairman and their willingness to undertake a cooperative administration of the department.

Almost constant departmental attention must be given to three general areas: 1)graduate and undergraduate curricula - both constantly being revised depending on new knowledge, changes in professors, interests, and changes in staff; 2) personnel - including especially employment of new professors, recommendation for promotion, annual consideration of «merit» for purposes of discriminatory salary increases, and 3) teaching - in particular balancing the teaching needs of students against available staff and its teaching desires. Only a little imagination is required to envisage the «delicacy» of some of the decisions and the difficulties and time consumed in attempting to reach these decisions in a reasonably democratic manner especially given the high propensity of professors to talk! These decisions can, and some times are, concentrated in the hands of a dictatorial department head; sometimes they are concentrated in a fossilized «senior staff»; sometimes they are concentrated in standing departmental committees.

To this point, I have outlined major academic divisions: the university and its branches, the colleges and the departments. One quickly becomes aware, however, from glancing at curriculum vitae and at academic titles and in reading the newspapers that there are «institutes», «cenlers», «offices», «services» appended to, or a part of, our universities. These vary in importance, but compared to the major elements described above they can only be characterized as playing a secondary role. They vary in function, size, activity, vitality and importance so greatly that any sort of detailed examination is out of the question, and generalization is apt to be misleading.

For the most part, these specialized institutes " (to settle upon one name for them) have been organized to undertake special functions not entirely suitable for the traditional teaching departments. In some cases they are organized because the inter-disciplinary nature of the subject matter suggested a combination of participating departments. For example, a «Highway Safety Center might well include professors

11 Not to be confused with the university - equivalent institutes mentioned earlier. 
of engineering, economics, psychology, and medicine. There is no compelling logic to «locate» it in any particular department. The creation of a separate entity with an independent life and responsability of its own is frankly more attractive to people and foundations who give away money than is the more usual departmental organization. From the point of view of the university, too, the separate administration of these funds is easier without mixing up functions, funds, and administrators in departmental affairs. Sometimes these organizations «depend» directly from the President or Provost, but most generally they pre creatures of individual colleges and are responsible to the dean. Perhaps the most important other single fact to make clear about them is that they have no independent, academic life of their own. Their «regular» members are academic professors with rank and status in the traditional departments. Trey may be assigned «half-time» to the institute and half-time to the department - or one of a variety of other arrangements. To the extent that these institutes hire additional, professional people, they are without rank and status, do not teach, and can only be regarded as temporary employees of the university. They complicate the organizational structure of the U.S. university, but they serve a purpose in the general scheme of things.

There are two additional major appendages to the U.S. university, especially related to the larger, public institutions. The first is an office to deal with the university's international programs, not to be confused with a possible «school of international affairs». Many universities have become deeply immersed in various programs abroad: student programs, technical assistance undertakings, teaching and research programs. These frequently require great expertise in administration, in development and negotiation, and in staffing. Frequently, too, the programs are interdisciplinary in nature. Depending on the institutional interests in international programs, the size of this office varies considerably. It may supervise the spending of several hundreds of thousands of dollars each year. The principal officer, a «Dean», «Vice President, or «Director», is usually responsible directly to the President for developing the international programs, for coordinating and assisting the regular academic departments in their programs, and for ascertaining that the direction of the program maintains academic legitimacy.

Another organization is the «University Extension Office or «Continuing Education Service led by a «Dean», «Director» or some such. Its function is to carry education (regular university courses or specialized courses) to the adult constituency of the state. The central university officer is essentially an organizer and administrator, bringing together the academic resources of the university and the educational needs of the community. One university reports that over 60,000 people come to its campus annually under such programs and thousands more are reached through credit and non-credit courses offered away 


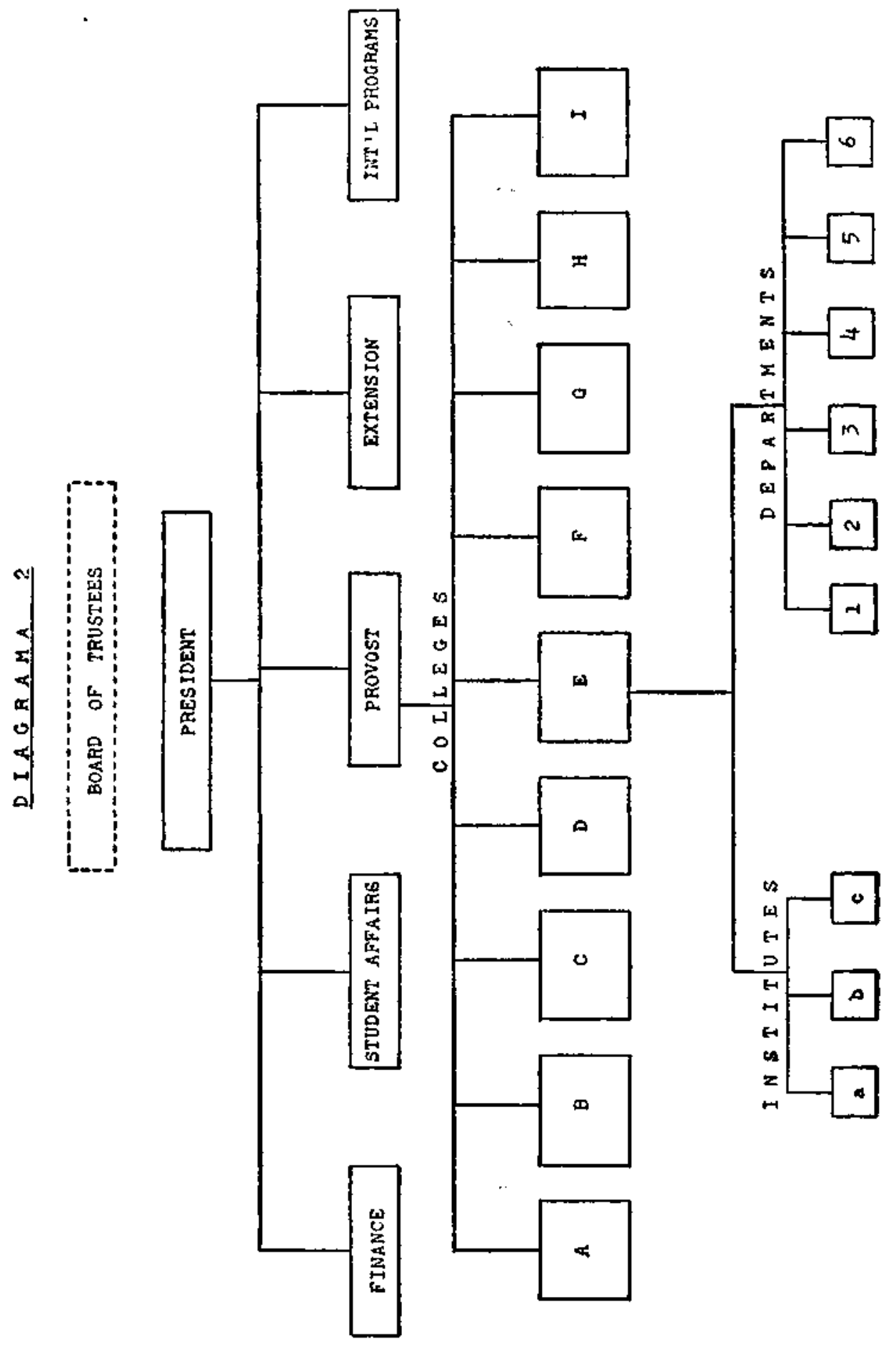


from the campus. In one year it taught over 700 such off-campus courses to more than 17.000 participants.

Diagram 2 seeks to summarize in most simplistic fashion that which has been described. There is a great gap, however, which must temporarily (or forever) await description. We have looked here at the organization of the university, but at the side of this is another «organization» which I have completely ignored - that of the «faculty». The regular teaching staff in most institutions maintains control - or likes to think it maintains control - of the academic politics of the institution. This involves an elaborate set of mechanisms such as an Academic Sentate, Academic Council, a Steering Committee, etc. - all of which suggest still another set of problems to be taken up elsewhere.

JOHN M. HUNTER EAPS

March 20, 1968

12 Michigan State University Publication, Catalog Issue, 1967, p. 2M. With variation for many factors, a professor's participation in these programs may be considered as a part of this normal duties, he may the paid an additional amount for the «overload», or his regular departmental load may be reduced in compensation for his university extension activities. 
Apêndice D. 7

\section{SOBRE O PROBLEMA DOS EXCEDENTES}

Os meses de janeiro e fevereiro no Brasil parecem ser marcados por dois eventos principais: o carnaval e os vestibulares; o primeiro libertando a comunidade de alguns problemas sociais, e o segundo contribuindo com alguns novos, particularmente com aqueles relativos aos excedentes. Este ensaio explorará alguns dos problemas da admissão às Universidades, o que está diretamente relacionado com o problema dos excedentes, esperando contribuir com algo no sentido de sua solução.

A natureza do problema. Em seu aspecto estrutural, os excedentes surgem porque o número de estudantes que procura ser admitido numa dada faculdade ou conjunto de faculdades é maior do que o número de vagas existentes. Um método de exame (o vestibular) é utilizado como dispositivo seletivo a fim de eliminar o «excesso» de candidatos ou. em outras palavras, para igualar o número de admissões ao número de vagas. Simbolicamente, podemos dizer que o número de candidatos (C) é igual ao número dos que foram admitidos $(\mathrm{A})^{1}$ mais aqueles que foram recusados (R) por falta de vagas. Assim, temos

$$
C=A+R
$$

Mas $\mathrm{R}$ é realmente divisível em 2 partes distintas: $\mathrm{R}^{\prime}$ representa os que foram recusados, mas obtiveram grau melhor do que um certo valor arbitrário (x) no complexo de exames chamado vestibular. É curioso notar que as pessoas do grupo $\mathrm{R}^{\prime}$ dizem haver «passado» no vestibular, embora se dê pouca atenção às futuras implicações deste particípio passado: aprovado para fazer o quê? Deste modo, temos

$$
\mathrm{C}=\mathrm{A}+\left(\mathrm{R}^{1}+\mathrm{R}^{\prime \prime}\right)
$$

onde $\mathrm{R}^{\prime}$ são aqueles que obtiveram grau acima de «X»e $\mathrm{R}^{\prime}$ aqueles cujo resultado de seus exames é inferior a "X». O grupo $R^{\prime}$ é conhecido como excedentes.

Naturalmente esta formulação não acrescenta ao problema nenhum elemento ou análise nova, mas coloca diante de nós, de modo claro, cada aspecto do método utilizado, possibilitando seu exame e discussão.

Igual ao número de vagas, qualquer que seja este. 
De início examinaremos o misterioso « $\mathrm{x}$ » que distingue tão nitidamente os excedentes do grupo R".

Algumas vezes o «X» tem um valor numérico igual a 4 e outras vezes igual a 5, o que sugere uma certa arbitrariedade. Suponho que $o$ valor «X» está vinculado à natureza eliminatória das diversas partes do vestibular. Se uma pessoa tem que obter nota 4 na 1 parte a fim de poder fazer a $2^{a}$ parte, e nesta obter grau 4 para que possa fazer a 3 parte, pode-se concluir que os graus 4 eram as notas mínimas exigidas e/ou que uma média 4 seria suficiente para «passar». Superficialmente esta suposição parece apresentar-se de modo muito mais lógico do que através de uma análise mais profunda. Pode-se também argumentar que um candidato a estudante de engenharia que obteve 4 em matemática (1 parte), teria de sair-se excepcionalmente bem em Física (2 parte), ou obter nota 6 ou mais para que pudesse ser um candidato convincente. Então a média mínima aceitável para os dois exames juntos seria 5, e para a $1^{\text {a }}$ parte não seria permitido grau menor do que 4. Assim, uma média das notas mínimas exigidas em cada um dos componentes não indicaria, necessariamente, a aprovação. Historicamente, o conceito parece ter-se desenvolvido neste sentido, mas não há motivos para que fosse necessariamente neste sentido específico. Questionar a base lógica destes fatos enfatiza a natureza arbitrária do «X» e natureza ambígua do «passar» no exame.

Os mesmos problemas são levantados de outro modo, principalmente quando se examina os vários objetivos dos vestibulares. Se eles se destinam a ser um dispositivo seletivo, então se forem manipulados perfeitamente, o grupo $\mathrm{R}^{\prime}$ tem de ser zero. Em outras palavras, os excedentes desapareceriam. «Passar» no vestibular seria equivalente a ser admitido e qualquer grupo $\mathrm{R}^{\prime}$ de tamanho apreciável não teria sentido senão o de indicar erros no sistema. Se o objetivo fosse este, restaria o problema de determinar a eficiência do vestibular, isto é, saber se realmente os «mais desejáveis» seriam encontrados no grupo A e os menos desejáveis no grupo $R^{\prime \prime}\left(R^{\prime}=O\right)$. A qualidade de «ser desejável» sugere a questão dos critérios que será desenvolvida adiante. Como alternativa, o vestibular pode ser exclusivamente um dispositivo para previsões, que presumivelmente procure prever o provável êxito dos indivíduos nos cursos de nível superior que seguiriam. Se fosse assim, o grupo A poderia ser menor ou igual a $C$, e R' e R" poderiam ter valores iguais a zero ou positivos. Neste caso, poder-se-ia interpretar que uma nota para «passar» significa que «esta pessoa tem as probabilidades mínimas exigidas para completar com êxito um dado curso universitário".

$\mathrm{O}$ atual sistema brasileiro aparece para o observador estrangeiro interessado como uma combinação inadequada de ambos os objetivos. $\mathrm{O}$ fato de que o grupo $\mathrm{R}^{\prime}$ é frequentemente grande, bem identificado, e está firmemente convencido que recebeu certificado de material universitário cujo aproveitamento implica em poucos riscos, sugere elementos 
substanciais da função de «previsão». Mas a natureza das decisões, da concessão das notas, da administração dos exames, e acima de tudo, do tipo de material usado para o exame sugere a supremacia da função seletiva, distribuitiva e eliminatória. Há bastante dúvida de que êle preencha bem até mesmo esta função.

Não há motivos para que a seleção e a previsão sejam mutuamente exclusivas. O ideal seria classificar os candidatos pelas notas e determinar um nível bem definido acima do qual as possibilidades de êxito seriam elevadas e abaixo do qual elas seriam inaceitàvelmente baixas. A ordenação permitiria que se admitissem estudantes tendo por base sua capacidade e dependendo do número de vagas. As atuais dificuldades decorrem de utilizar inadequadamente um sistema de previsões somente com o objetivo de realizar uma seleção. ${ }^{2}$

Todo o problema dos excedentes torna-se então, de certa forma, um problema falso. A nota «X» que divide o grupo R' do R", os excedentes das reprovações «comuns», representam tão pouco em termos de previsão que a nota que permite «passar» tem pouco significado real. No mínimo, deve ser reconhecido que qualquer mensuração isolada de características complicadas e mal definidas é arbitrária e de validade duvidosa.

O problema dos excedentes não é um problema geral cu, em outras palavras, a representação simbólica deve ser desagregada para representar verdadeiramente a situação. Esta desagregação pode ser feita tendo por base a região geográfica ou a disciplina. As Faculdades de Medicina, por exemplo, constantemente têm excedentes:

$$
\mathrm{CM}=\mathrm{AM}+\left(\mathrm{R}^{\prime} \mathrm{M}+\mathrm{R}^{\prime \prime} \mathrm{M}\right) \text { sendo } \mathrm{R}^{\prime} \mathrm{M}>\mathrm{O}
$$

Por outro lado, as escolas de enfermagem frequentemente se encontram numa situação onde $\mathrm{C}<\mathrm{A}$; a expressão $\mathrm{R}^{\prime}+\mathrm{R}$ " deve portanto ser negativa! As Facultades de Filosofia com frequência estão na situação onde R'F é negativo, embora R"F possa ser positivo. Este é o caso onde existem candidatos reprovados (de qualidade muito baixa, supõe-se) e vagas não preenchidas. Do mesmo modo, é sabido ser o problema muito mais sério na Guanabara do que no Amazonas, e poderíamos desagregar geograficamente a expressão.

2 As críticas aos vestibulares são muito frequentes e muito difundidas para que seja preciso apresentarmos extensa documentação. Tomando por base o que li e ouvi, aceito sem maiores discussões que a maioria dos vestibulares, do modo pelo qual são atualmente ministrados, constituem dispositivos de previsão muito ruins. Por exemplo vide: Nádia Franco da Cunha, Vestibular na Guanabara, Rio de Janeiro. Centro Brasileiro de Pesquisas Educacionais, 1967; Walter Leser, «Considerações gerais sôb-e a seleção de candidatos â matrícula nas escolas médicas». Revista Brasileira de Estudos Pedagógicos, Janeiro-Março, 1962; e Paulo Edmundo Costa Ribeiro e outros, «O exame de admissão às escolas de engenharia» no mesmo número desta revista. 
Há mais uma prova de que o problema dos excedentes não é de natureza geral. Os dados abaixo comparam o número de estudantes que concluíram o curso médio colegial ${ }^{3} \mathrm{em}$ vários anos com o número de pessoas matriculadas na 1 série do ensino superior no ano seguinte.

Os dados indicam que cerca da metade dos que concluíram o curso de nível colegial, em cada ano, estão matriculados, no ano seguinte, no ensino superior. Uma parcela substancial dos que concluíram o curso colegial provavelmente não estão altamente motivados para cursar a Universidade, não são intelectualmente capazes de ter êxito nos estudos universitários, e/ou não podem frequentar uma faculdade por razões de ordem econômica ou outras quaisquer. O curso comercial, o normal e os de outras escolas técnicas (isto é, outros que não o secundário)

\begin{tabular}{|c|c|c|c|}
\hline $\begin{array}{l}\text { ANO DE CONCLUSÃO } \\
\text { NO CURSO MÉDIO * }\end{array}$ & $\begin{array}{l}\text { CONCLUSÕES } \\
\quad \text { NO } \\
\text { CURSO MÉDIO } \\
\text { (EM MILHARES) }\end{array}$ & \begin{tabular}{|c|c|} 
MATRÍCULAS \\
NA $1 . »$ SÉRIE \\
DO ENSINO SUPERIOR \\
(EM MILHARES)
\end{tabular} & $\begin{array}{c}\text { MATRÍCULAS } \\
\text { COMO } \\
\text { PERCENTAGEM } \\
\text { DAS CONCLUSÕES }\end{array}$ \\
\hline 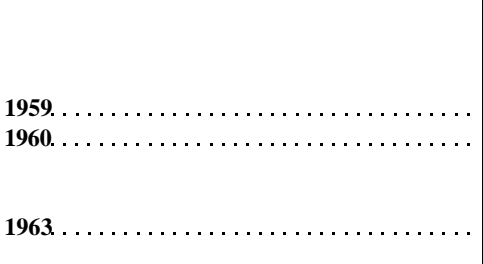 & $\begin{array}{l}\mathbf{4 8 . 6} \\
49.0 \\
\mathbf{6 3 . 5} \\
\mathbf{6 7 . 4} \\
\mathbf{6 1 . 1} \\
63.3 \\
73.1 \\
81.7 \\
\mathbf{9 5 . 4}\end{array}$ & $\begin{array}{l}25.8 \\
28.7 \\
27.3 \\
30.1 \\
32.4 \\
32.7 \\
39.5 \\
48.5 \\
45.8\end{array}$ & $\begin{array}{l}\mathbf{5 3} \\
58 \\
\mathbf{5 1} \\
52 \\
\mathbf{5 3} \\
\mathbf{5 1} \\
\mathbf{5 4} \\
59 \\
\mathbf{4 8}\end{array}$ \\
\hline
\end{tabular}

devem ser considerados como «finais» por muitos dos seus alunos, embora todos estes estejam incluidos nas «Conclusões» acima citadas. Isto sugere que os estudantes que concluíram o curso médio e querem realmente frequentar uma Universidade e possuem pelo menos uma capacidade intelectual modesta e meios econômicos suficientes, podem provavelmente fazê-lo em algum lugar e em alguma faculdade. Isto quer dizer que o problema dos excedentes não parece ser um problema geral. Torna-se um problema específico quando um grande número dos que concluíram o curso médio no Rio de Janeiro e áreas vizinhas querem estudar Medicina na UFRJ. Pouco adiantará explicar-lhes que podem ser admitidos, digamos, na Faculdade de Filosofia do Pará.

3 Do qual o secundário, comercial e normal são os elementos fundamentais.

Fontes: EPEA, Ministério do Planejamento e Coordenação Econômica, Edu cação (I) Diagnóstico Preliminar, 1966, pág. 55; Ministério do Planejamento e Coordenação Econômica, Plano Decenal de Desenvolvimento Econômico e Social, tomo VI (Desenvolvimento Social, Mão-de-Obra) vol 1 (1), 1966, A-17. A matrícula na primeira série inclui um número substancial de alunos que a estão repetindo. Assim, este valor não é exatamente igual às admissões. 
O fato do problema ser específico ao invés de ser geral não o faz menos sério nem sugere que êle não se tornará geral. Se o ensino de nível médio expandir-se rapidamente e melhorar sua qualidade, aumentará a demanda pela admissão à Universidade. A menos que a Universidade anteveja este fato, existirão cada vez mais estudantes batendo às portas fechadas da Universidade.

A Argentina trata de modo diferente o problema da admissão. Não há vestibular, e todos os graduados do nível médio estão qualificados para ingressar em qualquer faculdade de qualquer Universidade. ${ }^{5}$ $\mathrm{Na}$ representação simbólica isto significa que $\mathrm{C}-\mathrm{A}$, sendo $\left(\mathrm{R}^{\prime}+\mathrm{R}^{\prime \prime}=\mathrm{O}\right)$, onde o limite de $\mathrm{C}$ é a quantidade dos que concluíram o curso médio. Além disso, a matrícula é grátis. Os resultados são catastróficos. As Faculdades de Medicina (e outras) têm turmas de primeiro ano com milhares de alunos. A frequência às aulas não é obrigatória, e os exames são separados do ensino ou do trabalho na sala de aula. Assim, uma faculdade pode ter uma matrícula nominal de 20.000 alunos, embora o número de estudantes «ativos» esteja muito abaixo disto. O primeiro ano torna-se de fato um ano de eliminações gigantescas. Frequentemente, só 15 a $20 \%$ dos que começaram chegarão ao final; um processo de enorme desperdício. Há poucas provas e nenhum motivo a priori para suspeitar que o processo empregado na Argentina é uma mensuração mais delicada ou acurada do que a brasileira atual.

Voltemos à questão central. O problema dos excedentes surge porque em alguns casos específicos o número de vagas é menor do que o número de candidatos, e o vestibular é utilizado primeiro para determinar quais são os estudantes que serão admitidos (o grupo A) e os que não serão (o grupo R). É também usado para distinguir, neste segundo grupo, o que seriam admissíveis ( $\left.R^{\prime}\right)$ e os que não seriam ( $\left.R^{\prime \prime}\right)$. É sobre esta última distinção que farei alguns comentários, sugerindo que no momento atual ela é amplamente fictícia.

1. O vestibular, portanto, procura distinguir dois grupos de estudantes. Aqueles com elevada probabilidade de completar com êxito um curso universitário e aqueles com uma probabilidade tão pequena que não valem o investimento.

2. As características pessoais mais importantes que determinam o êxito num curso universitário são provavelmente as seguintes:
a) inteligência inata;
b) motivação básica;
c) escolha adequada da carreira
d) saúde;

Este sistema mudou substancialmente, por força de uma lei universitária básica mais ou menos recente. 
e) situação econômica;

f) nivel de preparo básico;

Esta lista não é definitiva e é provavelmente discutível, mas o fato importante é que existem numerosas carcteristicas que determinam o êxito mencionado e há poucas provas de que o vestibular procura medir qualquer uma destas características, exceto a última.

3. É discutível a validade de qualquer resultado aritmético absoluto de qualquer exame único realizado. Examinadores extremamente capazes podem estimar, dentro de limites, o desempenho num dado exame, mas hesitarão em fazê-lo, a menos que grande quantidade de pessoas faça o exame, e que os graus conferidos não estejam sujeitos a variações subjetivas nem a erros na determinação das próprias notas. A prática brasileira de vestibulares anuais únicos, de conferir notas de modo não objetivo, ${ }^{(i}$ e de pequenas unidades (faculdades individuais ou pequenos grupos de escolas) aumenta as dúvidas com relação a qualquer valor único determinado arbitrariamente para separar os «capazes de cursar uma Universidade» dos «incapazes».

4. Não há, de modo algum, qualquer padrão de absoluto e determinado para o êxito na Universidade, já que o número de pessoas a serem admitidas as Universidades é, em última análise, problema de valores e objetivos da sociedade. Uma nação pode decidir que $40 \%$ dos seus jovens deve ter formação universitária e criar as instituições para alcançar este objetivo. A Nação pode estar perfeitamente ciente de que os menos qualificados destes $40 \%$ não aproveitarão o curso universitário tanto quanto os mais qualificados. A «linha divisória» entre os «aceitáveis» e os «não aceitáveis» não depende de um padrão sacrossanto, inviolável, mas sim dos valores, recursos, e governo da sociedade. Além disso, estes padrões «imutáveis» podem mudar através do tempo numa dada sociedade e numa mesma Universidade.

Resumindo, todas as provas sugerem que o excedente é um ser artificial, cuja existência é de validade duvidosa. A comunidade académica certamente não agiu em seu benefício permitindo o desenvolvimento histórico do conceito e da atual posição do grupo, que este pensa ser justa.

Isto não pretende ser uma crítica insidiosa. A avaliação de trabalho dos estudantes produz uma variação considerável de julgamento entre diferentes leitores, e no mesmo leitor à medida que êle lê a primeira dúzia de trabalhos e prossegue até o 200", todos sobre a mesma matéria elementar. Prefiro estes tipos de questões tendo em vista alguns objetivos em outras circunstâncias, mas eles são indefensáveis como expediente para medir pequenas gradações- Por este motivo, grande parte da aparente exatidão de outras técnicas de exame também é falsa.

7 Isto não significa que os padrões de ensino seriam os mesmos em todos os locais. Algumas instituições poderiam se preparar para ensinar somente à faixa de $1 \%$ dos melhores alunos, outras poderiam se concentrar nos $30 \%$ melhores algumas poderiam lutar com os $10 \%$ que houvessem sido considerados como dentro do mínimo aceitável. 
Uma retratação rápida. A conclusão acima deve ser entendida somente no seguinte contexto: o problema dos excedentes obscurece ao invés de esclarecer os principais problemas da matrícula nas Universidades do Brasil. Voltando ao simbolismo anterior, temos

$$
\mathrm{C}=\mathrm{A}+\left(\mathrm{R}^{\prime}+\mathrm{R}^{\prime \prime}\right)
$$

Vemos que a questão dos excedentes concentra sua atenção essencialmente no grupo $\mathrm{R}^{\prime}$ e na diferença entre o grupo $\mathrm{R}^{\prime}$ e $\mathrm{R}^{\prime \prime}$. Isto põe em foco os problemas secundários e suas soluções ao invés de destacar os problemas fundamentais. $\mathrm{O}$ que foi dito acima também não pode, de modo algum, ser interpretado como uma afirmativa que favorece mais e não menos o ingresso limitado nas Universidades, ou como sendo, de qualquer forma, uma afirmativa contrária aos objetivos dos atuais excedentes .

Uma análise mais detalhada: $O$ « $\mathrm{A}$. $\mathrm{O}$ tamanho e a composição de «A», o número de vagas, deve ser nossa principal preocupação. As faculdades de maior relevo decidem por si mesmas quantos estudantes podem admitir. Aparentemente baseiam sua decisão numa mistura dos seguintes itens:

1. O passado histórico recente é considerado fato de grande importância. O número de estudantes aceitos no ano anterior e os recursos recebidos são naturalmente elementos de peso nas novas decisões. Entretanto, isto na verdade foge à lógica do problema, já que deixa sem explicação as decisões dos anos anteriores.

2. As faculdades e a DESu aparentemente realizam algum tipo de jogo. As Universidades procuram elevar ao máximo suas receitas provenientes da DESu, enquanto esta retém as verbas para serem aplicadas, no último momento, na criação de vagas extras.

3. Os padrões de procedimento existentes, o equipamento existente e a organização existente nas instituições são determinantes de grande importância. Estes tendem a tornar-se padrões imutáveis, segundo os quais se adota um dado procedimento, e a «eficiência» é medida em relação a estes padrões.

4. Algumas disposições financeiras existentes que parecem acarretar efeitos ruins no orçamento.

Cada um destes aspectos será analisado em separado.

É normal e natural que o passado recente seja fator fundamental na determinação das decisões atuais. Indivíduos e instituições ajustamse mais facilmente a mudanças marginais, e normalmente supõe-se que, na ausência de provas em contrário, «este ano será bem semelhante ao ano passado». Pressão política, otimismo modesto, e o fato de que os recursos raramente são determinantes do tamanho da turma (especialmente dos estudantes da primeira série) resultam na política de «aceitar mais alguns do que no último ano - de alguma forma nós acomoda- 
remos estes alunos». Assim, o «A» aumenta lentamente e não ocorrem outras modificações. A ser este o padrão, o único caminho para aumentar «A» de quantidade necessária e significativa é através da criação em massa de novas instituições, o que pode ser ou não uma solução factível e/ou inteligente. A característica predominante do desenvolvimento econômico é a mudança - - não a mudança marginal e gradual, mas a quebra abrupta e revolucionária dos padrões históricos. As instituições educacionais e o sistema educacional situam-se entre os mais importantes contribuintes do desenvolvimento econômico (e social) . Como tal, pode ser preciso que eles mudem radical e rapidamente a fim de contribuir de modo eficaz. O passado torna-se um não-padrão ou uma norma de como «não proceder», ao invés de um padrão em função do qual são tomadas as decisões atuais. Isto também se aplica ao nível das faculdades onde o número de vagas é decidido pela Congregação, bem como nos escalões mais elevados onde alguém decide qual é a parcela do orçamento que vai para Educação e não para os Ministérios das Forças Armadas, da Agricultura, dos Transportes ou das Relações Exteriores .

O processo orçamentário é na melhor das hipóteses um processo difícil. Nos seus termos mais simples, procura distribuir verbas escassas entre os muitos que as desejam, cada um procurando obter uma parcela ou aumentar sua parcela relativa. O problema é o de uma distribuição racional entre os vários usos a que se destina o dinheiro. Neste contexto, a racionalidade implica num conjunto bem nítido de objetivos e em estimar como se pode alcançar estes objetivos. Numa situação de desenvolvimento o passado é um mau guia para as necessidades presentes e futuras. Há um século atrás, uma parcela substancial dos recursos destinados ao ensino superior no Brasil talvez fosse adequadamente absorvido pelo ensino de Direito. Engenharia, Administração de empresas. Agricultura, Ciência pura tornaram-se relativamente mais importantes do que eram, e o Direito, pari pasu, menos importante. As necessidades de hoje e de amanhã devem ser mais importantes no processo orçamentário do que a prática de ontem - um argumento, se desejarem, para o planejamento educacional segundo estas linhas.

A priori, não há motivos para supor que se os recursos deste ano são iguais aos do ano passado, o número de vagas deve ser o mesmo. Isto envolve a suposição implícita de que o padrão de despesas é ótimo. $E^{\prime}$ possível que «A» possa ser aumentado sem perda de qualidade, mesmo com recursos fixos.

a) A presente reforma universitária está procurando evitar uma dispendiosa duplicação de esforços de ensino combinando alunos de várias faculdades em disciplinas comuns. A experiência provavelmente indicará que isto é menos nocivo do que o sistema atual, e pode ser levado mais adiante do que agora parece ao brasileiro, que só conhecia o sistema anterior. Redução de despesas como estas significa a possibilidade de mais vagas com a mesma despesa total. 
b) Agora que a cátedra é aparentemente algo do passado, novas e amplas perspectivas estão abertas para a programação dos cursos. Deve-se ter muita atenção ao estudar o tamanho ótimo das turmas, levando-se em conta os problemas específicos do ensino da disciplina. No sistema de catedráticos e de professores de tempo parcial, o número de vagas era teoricamente limitado ao maior número possível de alunos da menor cátedra. Como um exemplo, suponhamos que um curso tem somente três matérias, e que as seguintes quantidades de alunos podem realizar seu aprendizado em cada uma delas, sem séria perda de qualidade. ${ }^{8}$

Matérias

Introdução à Biologia

Introdução à Anatomia Humana

Cirurgia Elementar
Número

possivel

de alunos

200

100

25

Sob o rígido sistema de cátedras, com professores de tempo parcial, esta faculdade só poderia admitir 25 estudantes, porque o professor de Cirurgia Elementar não poderia ensinar a mais de 25 alunos numa única apresentação da matéria. Existiria considerável capacidade não utilizada nas outras duas matérias. Suponhamos também que cada professor receba $\mathrm{NCr} \$ 1.000,00$ por mês. Assim, o custo seria de .... NCr\$ 3.000,00 ou NCr\$ 120.00 por aluno (os outros custos não são considerados). Sob o novo sistema em desenvolvimento, temos as seguintes possibilidades:

Matérias

Introdução ã Biologia.

Introdução à Anatomia Humana

Cirurgia Elementar.

\section{Número \\ Possivel \\ de Alunos}

200

100

25

\begin{aligned} & \multicolumn{2}{c}{ Número } \\ & de Sessões \\ &$e$ Alunos \end{aligned}

$1 \times 200$

$2 \times 100$

$8 \times 25$
Número
de
Professores

1

2

8

A Biologia poderia ser o fator limitativo com uma única sessão possível. Dois professores de Anatomia ensinariam cada um a 100 alunos e também realizar-se-iam oito sessões de cirurgia de modo que 11 professores (NCr\$ 11.000,00) ensinariam a 200 estudantes, sendo de NCr\$ $55,00^{9}$ o custo por aluno.

c) Existem muitas práticas tradicionais que podem ser luxos dispendiosos. Uma vez visitei uma Faculdade de Ciências Econômicas na

\footnotetext{
8 As matérias receberam nomes somente para fins de ilustração, e o exemplo é puramente hipotético.

9 Este é um exemplo altamente simplificado, ignorando muitos aspectos. Entretanto, grande parte de nossas observações sugere que existe este tipo de situação. Salas de aula e laboratórios vazios durante grande parte do dia (e do ano) constituem uma possível prova disto. Obviamente, muitas outras providências ainda podem ser tomadas a partir do exame destes tipos de problemas.
} 
Colômbia que só tinha aulas à noite. Seu currículo previa que o aluno deveria frequentar a faculdade durante 30 horas por semana, o que exigia uma quantidade enorme do tempo dos professores. ${ }^{10}$ Foi elaborado um programa para reduzir as horas de aula. Uma parte da poupança foi utilizada para aperfeiçoar a biblioteca, e o saldo para aumentar os salários dos professores. Os estudantes deveriam então realizar mais estudos independentes (o que não era feito antes) na biblioteca. A qualidade da educação provavelmente melhorou e certamente não decaiu.

d) Em outra faculdade (não é no Brasil), concluí que um curso de 5 anos poderia ser condensado em 2,5 anos sem perda de qualidade e supondo que os alunos não despenderiam no estudo esforço maior do que aquele despendido pelos estudantes de graduação nos Estados Unidos. Isto poderia ser feito devido em grande parte ao tempo de ensino perdido durante o ano: semana do estudante, feriados, férias de verão muito longas e aumentadas não oficialmente pelos estudantes e professores, longos períodos de exames orais em todos os cursos. Estes são anos importantes na vida dos estudantes, e poupar o seu tempo beneficia em dobro a sociedade. Não tenho dúvidas de que estas possibilidades existem no Brasil: cada unidade educacional deve buscá-las com imaginação e ousadia.

Estas possibilidades são «infinitas», mas a questão é que provavelmente muito pode ser feito com os atuais recursos inadequados, se as práticas e métodos tradicionais forem verificados cuidadosamente e se supusermos, desde o início, que nada é «dado».

As presentes práticas orçamentárias no MEC e nas Universidades levam a algumas distorções da prática sensata. Prédios são iniciados, mas não são terminados, são construídos novos prédios de proporções monumentais, enquanto existem outros que são mal mantidos, grandes novas estruturas são edificadas, quando a principal escassez não parece ser de espaço, mas de professores competentes. Esta não é uma observação nova, nem este fenômeno é unicamente brasileiro. Deveria haver interesse para saber porque este fato ocorre constantemente. Suspeito que um dos motivos é o desejo de usar verbas para prestar homenagem a alguma pessoa ou instituição. ${ }^{13}$ As despesas usuais com pintura, serventes e mesmo com professores não atendem a esta finalidade, e isto pode ser uma parte da explanação em que não posso ir mais além. Há

E' bastante presunção por parte dos professores. Será que corpo docente teria realmente tanto para dizer cada semana e poderia dizê-lo de modo interessante a alunos sonolentos?

11 Eu preferiria reduzir o período para 4 anos ao invés da redução para 2.5, obtendo uma melhoria substancial no conteúdo e na qualidade.

12 As instituições supervisoras como o DESu e o Conselho Federal de Educação deveriam apoiar e estimular esta atitude, embora a tendência seja o oposto.

13 O que normalmente é um ato louvável, a menos que o homenageado seja também quem homenageia. 
muito tempo venho pensando que a «cadeira que recebe uma grande doação permanente» (cndowed chair), " bastante comum nos Estados Unidos e de origem europeia, deveria ter amplos atrativos na América Latina, talvez conduzindo a uma substituição dos edifícios monumentais pelas cadeiras ${ }^{15}$ «monumentais». Poderiam ser criadas cadeiras com dotações permanentes para o ensino e/ou a pesquisa, com o nome de companhias e criadas pelos amigos de sábios pobres, mas famosos, com o nome de cada Presidente da República ou cada Ministro da Educação, etc, etc. Os doadores destas cadeiras teriam seu nome a elas associado, e seriam então conhecidas como «Cadeira de Direito João Pessoa», e deste modo o nome de João Pessoa se torna imortal. Esta é, pelo menos, uma pequena ideia que poderia levar a uma investigação. É uma nova forma de monumentalismo que poderia ser desejável explorar.

Resumindo, nesta parte examinamos o componente «admissões» da equação, fundamentalmente do ponto de vista da possibilidade de aumentar as admissões com os recursos existentes, ou com «recursos dados», sugerindo alguns caminhos de exploração para aumentar a eficiência do sistema e da estrutura atual.

Uma análise mais detalhada: $O \ll \mathrm{C} »$. $\mathrm{O}$ aspecto mais alarmante da educação superior brasileira talvez seja encontrado ao meditarmos sobre a futura relação entre os estudantes que concluem o curso médio e os que ingressam nas Universidades. É bastante conhecido o fato de que a população do Brasil é jovem e que é objetivo do País incluir um número cada vez maior de jovens no sistema educacional, como certamente terá que ser feito para que o desenvolvimento econômico possa processar-se. Estima-se que somente $3 \%$ dos que ingressam na escola primária (cerca de $2 / 3$ das crianças brasileiras) concluem o curso médio, quando esta percentagem deveria ser de aproximadamente 50\%. ${ }^{15}$ Pode-se esperar que quaisquer metas para o ensino médio, sendo razoáveis, humanitárias e passíveis de amparo pela economia, inundarão literalmente as Universidades com candidatos à admissão. Face a isto, é importante lembrar que é mais difícil aumentar o «abastecimento» do ensino universitário do que o do ensino médio ou do ensino primário. Este aumento simplesmente não pode ser obtido a curto prazo porque a essência do ensino universitário é o contato com professores altamente treinados e especializados, o contato com o conhecimento acumulado pela humanidade conforme é encontrado nos livros, e contato com outras mentes jovens, inquiridoras e que levantam problemas. Somente este último é facilmente obtido. O dinheiro ajuda a constituir equipes de professores e a formar

11 Não deve ser confundida com a cadeira brasileira, bastante conhecida.

15 O termo usado em inglês é pro[essorship. Isto não significa o ensino de uma dada disciplina e não deve ser confundda, como já observou o autor, com a cátedra no Brasil. É neste sentido que o termo é empregado (N. do T.).

16 Conselho Federal de Educação, Articulação da Escola Média com a Superior. Separata n" 29, da Documenta 79, Dezembro, 1967, págs. 10-11. 
bibliotecas, mas de qualquer forma é preciso tempo e dinheiro para se obter um ou outro. A existência do problema dos excedentes e a agitação política que este parece produzir sugere que hoje já se dispõe de pouco tempo.

Aspectos de uma solução. Há três aspectos principais na solução do problema: 1) Determinação dos recursos totais a serem destinados à Educação. Esta é, em grande parte, uma questão de valores da sociedade e do modo pelo qual eles são expressos, uma área em que os comentários de um estrangeiro são particularmente inadequados. 2) O uso que terão os recursos destinados à Educação. Sugeri anteriormente que uma imaginação revolucionária devia dedicar-se a desenvolver alternativas para os atuais padrões de despesas. 3) Elevar ao máximo a racionalidade na seleção de candidatos para utilizar recursos educacionais presumivelmente escassos. É neste aspecto que desejo concentrar minha atenção.

Há grandes vantagens em considerar-se a possibilidade de usar um teste nacional de «aptidão para a Universidade», que doravante será denominado «EAU». Uma comissão nacional pode, no curso de alguns anos, elaborar um conjunto de testes a serem ministrados anualmente a todos os que aspiram a ingressar nas Universidades brasileiras. Os testes poderiam destinar-se a medir:

1) capacidade de raciocínio;

2) capacidade de manipular conceitos abstratos e analíticos;

3) capacidade de leitura e de compreensão;

4) nível de conhecimento em uma ou mais áreas de ensino, tal como matemática.

Supõe-se que estes testes seriam ministrados principalmente aos alunos do último ano do ensino médio, embora não sejam necessariamente restritos a este grupo. As Universidades e faculdades, ao menos inicialmente, teriam permissão para exigir outra prova de que o aluno tem condições para ingressar numa faculdade, tal como o atual exame vestibular. As instituições poderiam não acreditar no «EAU», ou este poderia não abranger matérias de especial interesse para faculdades específicas .

Os resultados seriam comunicados ao candidato e às instituições de sua escolha. Estes resultados poderiam indicar a colocação percentual do candidato em relação a todos que fizeram o exame. Assim, nosso estudante, João Domingo e as três Universidades em que êle desejaria se matricular receberiam a seguinte comunicação: «João Domingo realizou o EAU a 30 de novembro com outros 50.000 candidatos. Seus resultados estão discriminados para cada parte do exame, e cada número indica a percentagem de examinandos que se classificaram abaixo dele. Assim, um resultado igual a 80 significa que $80 \%$ tiveram desempenho 
pior ou que o examinado situou-se na faixa de $20 \%$ de melhores desempenhos .

Capacidade de raciocínio .......................74

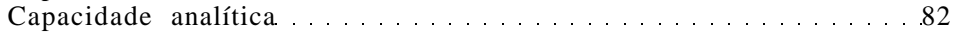

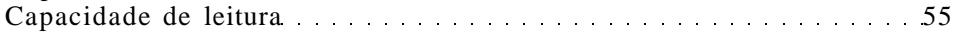

Matemática (nível de dificuldade II) . . . . . . . . . . . 90

média 75,2

Estes tipos de resultados poderiam ser de enorme utilidade para as autoridades encarregadas das admissões às Universidades, particularmente depois que elas houvessem adquirido experiência em lidar com eles: não são valores absolutos mas relativos, de modo que os exames em si não constituem um dado de grande importância para se fazerem comparações de ano a ano, a menos que sua natureza mude radicalmente. ${ }^{16}$ Todavia, diante do grande número de participantes, a posição relativa de um indivíduo teria significado. Eles serviriam também para dizer ao futuro estudante universitário bastante sobre suas capacidades.

Conforme foi sugerido anteriormente, as instituições teriam permissão para utilizar outros tipos de testes. Mas, através da experiência, a maioria das Universidades descobriria que este tipo de exame traria melhores resultados do que os exames preparados pelas Universidades e faculdades para nelas serem realizados.

Supondo que o EAU fosse o único critério utilizado para admissão (o que seria inauspicioso), as Universidades teriam uma lista de candidatos classificados pelo desempenho médio neste conjunto de exames. As Universidades (ou suas faculdades) ofereceriam admissão a tantos candidatos quantas fossem as vagas, segundo a classificação em ordem decrescente da lista. Se algumas destas ofertas fossem recusadas (em virtude de oferecimentos por parte das Universidades preferidas, p. ex.), seriam feitas ofertas aos classificados seguintes. Este processo continuaria até que não existissem mais vagas ou até que os resultados alcançassem um nível abaixo do qual as Universidades não mais desejassem aceitar os estudantes. Isto é, as Universidades poderiam desejar aceitar alunos com médias até 50 (ou seja, aproximadamente, a metade superior), mas prefeririam deixar vagas não preenchidas a aceitarem candidatos piores.

Tal método também ajudaria no desenvolvimento de um sistema universitário heterogéneo e diferenciado. Pode haver grande vantagem na tendência dos estudantes mais brilhantes se congregarem em certas

1T Não estou preparado para discutir a elaboração dos exames nem a forma exata que eles devem tomar, mas posso garantir que é possível preparar exames que dêem uma mensuração significativa das características relacionadas acima, e que tais resultados terão um valor muito maior do que os do vestibular isolado. A melhor fonte de informações que conheço sobre este assunto é A Description of the College Board Achievement Tests e A Description of the College Board Scholastic Aptitude Test, Box 592, Princeton, New-Jersey: College Entrance Examination Board, 1967. 
instituições. Também há certamente grande vantagem em evitar que os menos inteligentes, porém competentes, sintam-se frustrados ao estudarem em instituições muito além de suas capacidades. O tipo de classificação imaginado capacitaria então as instituições a melhor selecionarem os estudantes e também permitiria que os estudantes escolhessem melhor as instituições. Nos Estados Unidos, por exemplo, os conselheiros dos cursos colegiais, que orientam os alunos acerca das Universidades às quais pretendem se candidatar, dispõem de dados estatísticos sobre os resultados médios dos testes das turmas que ingressaram nos vários milhares de faculdades e Universidades. Este tipo de dados informa os estudantes e seus pais sobre as possibilidades de serem aceitos em qualquer instituição específica, quando o estudante conhece os resultados de seus testes.

A realização deste tipo de testes também permite estabelecer distinções dentro de uma mesma Universidade. Nosso estudante hipotético acima citado poderia ter sido julgado um bom candidato para uma Escola de Engenharia, porém ruim para o departamento de biblioteconomia de uma Faculdade de Filosofia. Embora o estudante possa preferir ignorar esta informação, obviamente será melhor para êle estar de posse destes dados do que nada saber a respeito.

Resumindo as vantagens deste sistema, encontramos o seguinte:

1. O fato mais importante talvez seja a melhoria dos exames ministrados. Destinar-se-iam a medir capacidade, inteligência etc, e não quantidades de material já dominado e memorizado. Seria muito melhor que algumas pessoas trabalhassem em tempo integral na preparação destes exames do que o atual sistema de várias pessoas não especializadas na elaboração de testes, preparando-os para pequenos grupos em todo o País.

2. O grande número de participantes e o esforço persistente para manter coerência dariam um caráter de confiança e de validade aos resultados. Naturalmente, ninguém discutiria se as mensurações são exatas ou se pequenas diferenças nos resultados representam diferenças apreciáveis entre os candidatos. Os testes não podem levar em consideração o estudante que estava num «dia ruim», nem o aluno «que não pôde fazer o exame».

3. As características de diferenciação constituem informações a partir das quais as universidades, os candidatos e seus pais podem tomar as devidas providências. Julgamos que é melhor ter mais informações do que menos.

4. A distribuição mais racional de alunos pelas oportunidades escassas deverá assegurar um maior retorno para a sociedade. Resultaria na formação de pessoas em maior quantidade e/ou de melhor preparo para cada cruzeiro investido no sistema educacional. Deve ocorrer melhoria em várias direções: os estudantes devem ingressar em instituições mais adequadas, tenderão a escolher as carreiras mais adequadas, deverá ocorrer menor evasão durante o curso. 
5. Poder-se-ia argumentar contra este sistema, afirmando que os estudantes menos bem dotados seriam impedidos de ingressar nas melhores instituições, talvez nas profissões de maior demanda (mais desejadas?), e/ou nos locais mais desejados. Isto é verdade, mas é exatamente o objetivo do sistema: fazer discriminações válidas entre as variadas capacidades intelectuais, exatamente por estes motivos. O estudante medíocre poderia querer estudar Medicina na escola de maior renome no país, mas talvez o máximo que a sociedade possa lhe oferecer seja uma vaga em alguma outra área de especialização, numa instituição de qualidade um pouco inferior. São decisões difíceis, mas têm que ser tomadas e o sistema de exames proposto deve melhorar a qualidade das decisões.

6. Desapareceriam muitas das deficiências do atual sistema: os estudantes não seriam aprovados nem reprovados, mas classificados. Em particular, desapareceria a categoria dos que «passaram, mas não foram aceitos».

7. Com o passar do tempo, seriam coletadas informações permitindo julgamentos acertados sobre as qualidades individuais de cada escola secundária. Isto deverá ser de grande valor para os pais, Secretários de Educação etc.

8. Espero que na maioria dos casos o cursinho pré-vestibular tenha sua importância diminuída e talvez desapareça. Os testes imaginados, conforme nossos comentários anteriores, teriam como objetivo primordial a avaliação da capacidade e da inteligência do candidato. O cursinho típico não seria de muito auxílio na preparação para estes testes.

Deve-se notar que a adoção deste sistema não aumentará o número de vagas, o que certamente precisa ser feito. Voltando pela última vez à representação simbólica, este sistema procura somente melhorar a qualidade das escolhas de «A», mas nada faz para aumentar sua quantidade.

JOHN M. HUNTER

EAPS
Michigan State University
Fevereiro de 1968

Tradução de JACQUES R. VELLOSO

Julho de 1968. 
Apendice D. 7

\section{ON THE PROBLEM OF "EXCEDENTES"}

Januaries and Februaries seem to be marked in Brazil by two principal events: carnaval and vestibulares, the former perhaps ridding the community of some social problems and the latter contributing new ones, particularly those of the excedentes This essay will explore some of the problems of university admissions which bear directly on the problem of the excedentes, hopefully contributing something toward a solution.

The nature of the problem. In skeletal form, excedentes arise because there are more students seeking admission to a given faculty or set of faculties than there are openings. An examination procedure (the vestibular) is used by the universities as a selection derive to eliminate the «excess» applicants or, in other words, to equate admissions and openings. Symbolically, the number of candidates (C) equals the numbers admitted (A) ${ }^{1}$ plus those who are refused admission (R) for want of openings. Thus, we have

$$
\mathrm{C}=\mathrm{A}+\mathrm{R}
$$

But this $\mathrm{R}$ actually is divisible into two distinguishable parts: $\mathrm{R}^{\prime}$ represents those who are refused admission but who scored better than some arbitrary number $(\mathrm{x})$ on the complex of examinations called the vestibular. Curiously, the $\mathrm{R}^{\prime}$ people are said to have "passed» the vestibular although little attention is given to the future implications of that part participle: passed for what? Aprovado para fazer o que? So we have

$$
\mathrm{C}=\mathrm{A}+\left(\mathrm{R}^{\prime}+\mathrm{R}^{\prime \prime}\right)
$$

where $\mathrm{R}^{\prime}$ are those with examination grades above « $\mathrm{x}$ » and those $\mathrm{R}$ " with examination grades below « $\mathrm{x} »$. The $\mathrm{R}^{\prime}$ group is known as excedentes.

This formulation, of course, adds no new element or analysis, but it does put each aspect of the procedure clearly before us for examination and discussion. We begin by examining the mysterious « $\mathrm{X}$ » which so clearly delineates the excedentes from the R" $\mathrm{s}$.

Sometimes the «X» has a numerical value of «4» and sometimes a value of «5» which suggests something its arbitrariness. I suppose the

Equal to the number of openings however determined. 
value of «X» is associated with the eliminatory nature of the various parts of the vestibular. If one must earn a «4» in Part $\mathrm{I}$ in order to take Part II and a «4» on that in order to take Part III, one might conclude that «4's» were minimally required grades and/or that a «4» average would be «passing». The logic of this supposition superficially appears much better than it does on close examination. One can also argue that a prospective student of engineering with a «4» in mathematics (Part I) would have to do exceptionally well in physics (Part II) and earn a «6» or better in order to be a convincing candidate. Then the minimum acceptable average for the two exams together would be «5» with Part I being permitted to be no less than « 4 ». Thus, an average of minimally required grades on each of the componnts does not necessarily indicate «passing». Historically, the concept seems to have developed this way, but it need not have. Questionning the logical base emphasizes the arbitrary nature of the «X» and the ambiguous nature of the «passing» of the exam.

The same questions are raised in another way, principally by examining the various purposes of the vestibulares If they are designed to be a selective device, then if managed perfectly the $\mathrm{R}^{\prime}$ group ought to be zero; in other words, the excedentes would disappear. «Passing» the vestibular would be equivalent to being admitted and any appreciable $\mathrm{R}^{\prime}$ group would make no sense, other than to indicate errors in the system. If this were the objective, then the remaining problem would be that of determining the efficiency of the vestibular, i.e. wheter it in fact the «more desirables would be found in Group A and the «less desirables in $\mathrm{R}^{\prime \prime}\left(\mathrm{R}^{\prime}=\mathrm{O}\right)$. «Desirability» suggests the issue of criteria of which more will be said below. Alternatively, the vestibular may be exclusively a predictive device, presumably attempting to predict the probable success of individuals in subsequent university programs. If this is what it is, the A group could be smaller than or equal to $\mathrm{C}$ and $R^{\prime}$ and $R^{\prime \prime}$ might have either zero or positive values. In this case a «passing» grade can be interpreted as «this person has the minimum required probabilities of successfully completing a given university course.

The present Brazilian system appears to the interested foreign observer as an injudicial combination of both objectives. The fact that the $\mathrm{R}^{\prime}$ group is frequently large, well-identified, and is firmly convinced that it has been certified as low-risk-university material suggests substantial elements of the «predictive» function. But the nature of making up, grading, administering, and above all, the kinds of material used for the examination suggests the supremacy of the selectivity, rationing, or elimination function. There is considerable doubt that it fills even this function very well.

There is no reason why selection and prediction need be mutually exclusive. Ideally, candidates would be ranked by grades with an 
absolute cut-off above which the probabilities of success would be high and below which they would be unacceptably low. The ordering would permit admitting students on the basis of ability depending upon the number of openings. The present difficulty comes from operating a predictive system badly only for purposes of selection.

The whole problem of exccdentcs then becomes something of a false issue. The grade «x» which divides the $\mathrm{R}$ ' 's from the $\mathrm{R}$ " 's, the excedentes from the «common» failures, has so little predictive capacity that the «passing» aspect of the grade has little real meaning. At the very least, it ought to be recognized that any single measure of complicated and poorly defined characteristics is arbitrary and of doubful validity.

The problem of excedentes is not a general problem or, in other words, the symbolic representation must be disaggregated to truly represent the situation. This disaggregation can be done either on the basis of region or on the basis of discipline. For example, faculties of medicine frequently have excedentes:

$$
\mathrm{CM}=\mathrm{AM}+\left(\mathrm{R}^{\prime} \mathrm{M}+\mathrm{R}^{\prime \prime} \mathrm{M}\right) \quad \text { with } \mathrm{R} \mathrm{M}>0
$$

Nursing schools on the other hand frequently find themselves in the situation when $\mathrm{C}<\mathrm{A}$; the expression $\mathrm{R}^{\prime}+\mathrm{R}^{\prime \prime}$ must therefore be negative! Faculties of philosophy frequently find themselves in the situation where R'F is negative although R"F may be positive. This is the circumstance where there are prospective students turned away (of presumably poor quality) and unfilled vacancies. Too, the problem is known to be much more severe in Guanabara than in Amazonas, and we could disaggregate the expression geographically.

There is additional evidence that the excedente problem is not a general one. The following data compare the numbers of students

2 Condemnation of vestibulares is too frequent and widespread to require extensive documentation. On the basis of what I have read and heard, I accept without further question that most vestibulares as now administered are very poor predictive devices. For example, see: Nadia Franco da Cunha, Vestibular na Guanabara, Rio de Janeiro: Centro Brasileiro de Pesquisas Educacionais, 1967; Walter Leser, «Consideiagoes gerais sobre a selecao de candidtos a matricula nas escolas medicas», Revista Brasileira de Estudos Pedagogicos, Janeiro-Marco, 1962; e Paulo Edmundo Costa Ribeiro e outros, «0 exame de admissao as escolas de engenharia» no mesmo numero dessa revista.

Of which secundario, comercial and normal are the primary elements. 
graduating from ensino medio, colegial "• in several years with the numbers of persons enrolled in higher education, first series the following year. The

\begin{tabular}{|c|c|c|c|}
\hline YEAR OF GRADUATION ${ }^{4}$ & $\begin{array}{c}1000 \\
\text { GRADUATIONS }\end{array}$ & $\begin{array}{c}1000 \\
\text { ENROLLMENTS } \\
\text { IST SERIE }\end{array}$ & $\begin{array}{l}\text { PER CENT } \\
\text { ENROLLMENTS } \\
\text { GRADUATIONS }\end{array}$ \\
\hline 1956 & 48.6 & 25.8 & 53 \\
\hline 1967. & 49.0 & 28.7 & 58 \\
\hline 1958 & 53.5 & 27.3 & 51 \\
\hline 1959 & 57.4 & 30.1 & 62 \\
\hline 1960 & 61.6 & 32.4 & 53 \\
\hline 1961 & 63.3 & 32.7 & 51 \\
\hline 1962 & 73.1 & 39.5 & 54 \\
\hline 1963 & 81.7 & 48.5 & 59 \\
\hline 1964 & 95.4 & 45.8 & 48 \\
\hline
\end{tabular}

data indicate that about half those graduating from ensino medio each year is enrolled the following year in higher education. Substantial numbers of the graduates probably are not highly motivated toward university attendance, are not intellectually capable of successful university work, and/or cannot attend for economic or other reasons. Programs of commercial, normal and other technical schools (i.e. other than secundario) must be regarded as «terminal» by many of their students, yet all these are included among the graduates in the data. This suggests that the ensino medio graduate who really wants to attend a university and has at least modest intellectual equipment and the economic means can probably do so in some place and in some discipline. This is to say that the problem of the excedente does not appear to be a general problem. It becomes a specific problem when larger numbers of the graduates of ensino medio in and around Rio de Janeiro want to study medicine in the U.F. R. J. It solves little to explain to them that they can be admitted, say, to the Philosophy Faculty in Para.

That the problem is specific rather than general makes it no less severe nor does it suggest that it will not become general.

If ensino medio, expands rapidly and improves in quality, the demand for university admission will increase. Unless the universities anticipate this, there will be more and more students beating at the closed university doors.

4 SOURCES: EPEA, Ministerio do Planejamento e Coordenacao Economics, Educacao (I) Diagnostico Preliminar, 1966, p. 55; Ministerio do Planejamento e Coordenacjio Economica, Piano Decenal de Desenvolvimento Econimico e Social, Tomo VI (Desenvolvimento Social, Mao-de-Obra) vol. 1 (1), 1966. A-17. First-year enrollments include a substantial number of students repeating it, so this not exactly equivalent to admissions. 
Argentina handles differently the admission problem. There is no vestibular, and all graduates from ensino medio are elligible to enter any faculty in any university. ${ }^{6}$ In the symbolic representation this means hat $\mathrm{C}=\mathrm{A}$ with $\left(\mathrm{R}^{\prime}+\mathrm{R}^{\prime \prime}=\mathrm{O}\right)$ where the limit on $\mathrm{C}$ is that number graduated from ensino medio. Furthermore, registration is without charge. The results are catastrophic. Medical faculties (and other) have entering classes in the thousands. Class attendance is not reauired, and the examination procedure is separated from the teaching or classroom work, so a faculty may have a nominal enrollment of 20,000 although the number of «active» students will be far below this. The first year becomes in fact a gigantic «eliminatory» year. Frequently as few as 10-15 per cent of those who begin ever finish, an enormously wasteful process. There is little evidence and no a priori reason to suspect that the Argentina procedure is a more delicate or accurate measure than the present Brazilian one.

We return to the central question. The excedente problem arises because of the number of openings being smaller in specific cases than the numbers of candidates, the vestibular is used first to determine those students to be admitted (the «A» group) and those not (the «R» group). It is further used in the latter group to distinguish between those otherwise admittable $\left(R^{\prime}\right)$ and those not $\left(R^{\prime \prime}\right)$. It is this latter distinction on which I now comment to suggest that at present the distinction is largely fictitious.

1. The vestibular attempts, thus, to distinguish two groups of students, those with a high probability of successfully completing a university course and those with so low a probability as to be not worth the investment.

2. Probably the most important personal characteristics which determine ultimate success in a university course are the following:

a) native intelligence

b) basic motivation

c) appropriate choice of course

d) health

e) economic situation

[) basic level of information

This list is not definitive and probably debatable, but the important point is that there are multiple characteristics which determine success and that there is little evidence that the vestibular attempts to measure any of them except possibly the last.

3. The validity of any absolute arithmetic score on any uniquelygiven examination is doubtful. Extremely skilled examiners can estimate, within limits, performance on a given examination but hesitate 
to do this unless the examination is given to very large numbers and its marking is not subject to subjective variations and marking error. The Brazilian practice of annualy unique vestibulares, non-objective ${ }^{6}$ grading, and small units (individual faculties or small groups of them) increases doubts concerning any arbitrarily determined single number to divide the «university capable from the «incapable».

4. There is no absolute and given standard for university success anyway since the numbers of persons to be permitted to pass through the universities is ultimately a problem of the values and objectives of the society. One nation may decide that 40 per cent of its young people ought to be university-educated and provide the institutions for this purpose. It could be fully aware that the least qualified of the 40 per cent would not get nearly as much benefit from the experience as the best qualified. The «dividing-line» betwen those «acceptable» and «not acceptable depends then not on some sacrosanct, inviolable standard but rather upon the values, resources, and government of the society. ${ }^{T}$ Furthermore, these «immutable» standards may change through time in a given society and in given universities.

In summary, all the evidence suggests that the excedente is an artificial being existence is of doubtful validity. Clearly the academic community has done itself no service in permitting the historical development of the concept and the present rather «righteous» position of the group.

A quick disclaimer. The above conclusion should be read only in the following context: the excedente problem obscures rather than clarifies the major issues of university enrollments in Brazil. Returning to the earlier symbolism,

$$
\mathrm{C}=\mathrm{A}+\left(\mathrm{R}+\mathrm{R}^{\prime \prime}\right)
$$

the excedente problem concentrates attention primarily on the $\mathrm{R}^{\prime}$ group an the difference between the $\mathrm{R}^{\prime}$ and $\mathrm{R}^{\prime \prime}$ group. This focuses on secondary issues and remedies rather than on the primary ones. Nor can the above in the least be construed as favoring more rather than less limited entry into the universities or as being in any way in opposition to the objectives of present excedentes.

6 Not intended as insidious criticism. Evaluating essays by students produce considerable variation among different readers and from the same reader as he proceeds through the first dozen to the 200th essay on the same elementary subject. I happen to prefer these types of questions for some purposes in other circumstances, but they are indefensible as accurate measuring devices of small gradatio'ns. Most of the apparent accuracy of other examination techniques is spurious, too, for that matter.

7 This does not mean that academic standards would everywhere be the same. Some institutions might be developed to train only the top I per cent, others might concentrate on the upper 30 per cent, some might then struggle with the lowest acceptable 10 per cent. 
A further examination: The «A». The size and composition of «A», the number of vagas, ought to be the first concern. The relevat faculties decide for themselves how many students to admit, apparently basing their decisions on some mixture of the following:

1. The immediate historical past is a major consideration. Thenumber of students accepted the preceding year and the resources received are naturally very large elements in new decisions. But, this really begs the question since it leaves unexplained, the preceding years decisions.

2. Some sort of game is apparently played between the faculties and DESu. The universities seek to maximize their receipts from $\mathrm{DESu}$, and it seeks to withhold funds to be applied at the last moment to create extra vagas.

3. Existing patterns of behavior, existing equipment, existing institutional arrangements are major determinants. These tend to become immutable standards in which behavior takes place and against which «efficiency» is measured.

4. Certain existing financial arrangements which seem to have some perverse budgetary effects.

Each of these is considered in turn.

It is normal and natural that the immediate past should be a prime factor in the determination of current decisions. Individuals and institutions adjust most easily to marginal changes, and one normally assumes in the absence of evidence to the contrary, that «this year will be pretty much like last year». Political pressure, modest optimism, and the fact that facilities are seldom absolute determinants of class size (especially for first year students) result in the policy of «accepting a few more than last year - we will be able to handle it some way Thus, «A» increases slowly, and no great changes occur anywhere. If this is to be the pattern, the only way to increase «A» significantly and discretely is by. the massive creation of new institutions which may not, be a feasible and/or wise solution. The predominant characteristic of economic development is that of change - not marginal, incremental change but abrupt revolutionary breaking with historical patterns. Educational institutions and the educational system are major contributors to economic (and social) development. As such, it may be necessary that they change radically and rapidly in order to contribute effectively. The past becomes a non-standard or a pattern of how «not to behave».rather than as the standard from which present decisions are made. This is equally as true at the faculty level where the number of vagas is decided by the Congregacao as it is at the top where someone decides how much of the budget goes to education as opposed to the military, agriculture, roads. the foreign ministry.

The bugetary process is at best a difficult one. In its simplest terms, it attempts to allocate scarce funds among many seekers, each one 
trying to get a share or to increase its relative share. The problem is one of rational allocation between various uses. Rationality in this context implies a clear set of objectives and estimates about how these oojecuves may be met. The past in a development situation en a poor guide to present and future needs. A century ago, a substantial amount of the resources devoted to higher education in Brazil was perhaps properly absorved by the teaching of law. Engineering, business administration, agriculture, pure science have become relatively more important than they were, and law, pari pasu, less important. Today's and tomorrow's needs ought to be more important in the budgetary process than yesterday's practice - a plea if you will, for educational planning along these lines.

There is no a priori reason to assume that if resources are the same this year as last that the number of openings should be the same. This involves the implicit assumption that the existing expenditure pattern is optimal; observation suggests that it may not be. This is to say that the «A» might be expandible even with fixed resources without loss of quality.

a) Current university reform is seeking to avoid expensive duplication of teaching efforts by combining students of various courses in common subjects. Experience will probably indicate that is less deleterious and can be carried further than it now appears to the Brazilian who knows only the former system. Reducing expenses such as these means the possibility of more openings for the same total expenditure.

b) Now that the catedra is apparently a thing of the past, great new vistas open in programming courses. Careful attention should be given to consideration of optimal size classe on the basis of cost per student taking into account the particular teaching problems of the subject matter. "With the catedratico system and part-time teacher, the number of openings was theoretically limited to the maximum number of students possible in the smallest catedra: As an example, suppose a course has only three materias and that students can be taught in the following numbers in each without serious loss of quality.

\section{Materia}

Possible

number of students

Introduction to Biology.

200

Introduction to Human Anatomy.

100

Elementary Surgery.

Under a rigid catedra system with part-time professors, this faculty could admit only 25 students since the professor of Elementary Surgery

The courses are given names only for illustration purposes, and the example is purely hypothetical. 
could handle no more than 25 students in his single presentation of the subject. There would be considerable unutilizable capacity in the other two materias. Suppose, too, that each professor is paid NCr\$ $1.000,00$ per time period. Then, the cost would be

$\mathrm{NCr} \$ 3.000,00$ or $\mathrm{NCr} \$ 120,00$ per student (other costs are ignored). Under the new, developing system we have the following possibilities:

$\begin{array}{cccc} & \text { Possible } & \text { Number of } & \text { Number } \\ \text { Materias } & \text { Student } & \text { Sections and } & \text { of } \\ & \text { Numbers } & \text { Students } & \text { Professors }\end{array}$

Introduction to Biology. .

200

100

Introduction to Human Anatomy.

Elementary Surgery.

25

$\begin{array}{llrl}1 & X & 200 & 1 \\ 2 & \times & 100 & 2 \\ 8 & \times & 25 & 8\end{array}$

Biology might be the limiting factor with only section possible. Two professors of Anatomy would each teach 100 students and eight sections of surgery would also be held so that 11 professors. (NCr\$ 11.000,00) would teach the 200 students at a per student cost of $\mathrm{NCr} \$ 55,00$.

c) There are many traditional practices which may be expensive luxuries. I once visited a Faculty of Economic Sciences in Colombia which only held classes at night. Its curriculum anticipated student attendance approximately 30 hours per week which required an enormous amount of professorial time. " A program was worked out to reduce the teaching hours. A part of the savings were used to improve the library, and the remainder was used to increase professor's salaries. Students were then to do more independent work (of which they did none before) in the library. The quality of education probably improved and certainly did not deteriorate.

d) In another faculty (not in Brazil), I concluded that the 5-year program could be condensed into $21 / 2$ years without loss of quality and assuming that students could be expected to work no harder than average undergraduates on the U.S. This could be done largely because of instruction time lost during the year: semana do estudante, holidays. very long summer vacations unofficially extended by students and professors, long periods for oral examinations in all courses. " These are important years in the students' lives, and saving their time doubly be-

This is a highly simplified example which overlooks many aspects, but much of what observation suggests that this sort of situation exists. Classroom, and laboratories empty much of the day (and year) are possible evidence. Clearly there is much that can he done in examining these kinds of questions.

10 And a good deal of professorial arrogance. The corpo docente really had that much to say number and could say it interestingly to sleepy students?

11 It was not my preference to reduce the period to $21 / 2$ years but rather to -1 with a substantial improvement in content and quality. 
nefits society. I have no doubt that such possibilities exist in Brazil: Each educational unit should seek them out with imagination and daring.

The «possibilities» are endless, but the point is that much can probably be done with present inadequate resources if a careful look is taken at traditional practices and methods and it nothing is assumed from the beginning to be «given».

Current budgetary practices in MEC and the universities lead to some perversions of wise practice. Buildings are started but not completed, new buildings are constructed in monumental proportions while eriting ones are poorly maintained, large new Structure are built when the principal scarcity seems not to be space but competent professors. This is not a new observation, nor is it a uniquely Brazilian phenomenon. There should be concern as to why this pattern consistently occurs. I suspect one reason is the desire to use funds in honor of some person or institution. !:! Ordinary expenditures for paint, janitors, and even professors cannot really serve this purpose, and this may be a part of the explanation into which I can venture no further. I have long thought that the "endowed chair». ${ }^{14}$ fairly common in the U.S. and of European origin, should have wide appeal in Latin America perhaps leading to the substition of «monumental» professorships for monumental edifices. Permanent endowments of teaching and/or research professorships could be established in the name of companies, by the friends of poor but honorific savants, in the name of each President of the Republic and each Minister of Education, etc, etc. The holders of these professorships would be known as the «João Pessoa Professor de Direito» and João Pessoa becomes immortalized in this way. This is. at small idea which could bear investigation. It is a new form of «monumentalism» which it may be desirable to exploit.

In summary, in this section we have examined the «admissions» component of the equation primarily from the point of view of the possibility of increasing admissions with existing resources, or with «given resources», suggesting a number of avenues of exploration to increase the efficiency of the present system and Structure.

A further examination: the $« \mathrm{C} »$. Perhaps the most frightening aspect in Brazilian higher education is contemplating the future relationship between students finishing ensino médio and those entering the universities. It is well known that Brazil's population is young and that its objectives are to include more and more young people in the educational system as indeed will have to be done if economic development is to occur. It is estimated that only 3 per cent of those who start

12 Supervising institutions such as DESu and the Conselho Federal de Educação should support and encourage this although the tendency will be the reverse.

13 Ordinarily a laudable act unless the honorer is also the honoree.

14 Not to be confused with the well-known Brazilian cadeira. 
school (only about twothirds of young Brazilians) finish escola media when about 50 per cent of them should finish. " Any reasonable. humaniatarian, economically supportable targets for ensino medio can be expected in the future literally to inundate the universities with candidates for admission. In the face of this, it is important to note that the «supply» of university education is more difficult to increase than that of ensino medio or ensino primario. It simply cannot be done in the short-run because the essence of a university education is exposure to highly trained and specialized professors, exposure to the accumulated knowledge of mankind as found in books, and exposure to other young. inquiring questionning minds. Only the latter comes easily. Money helps develop professorial staffs and it helps accumulate libraries, but it takes both time and money in any case to do either. The existence of the excedente problem and the political agitation which it seems to beget suggests that already the time is short.

Aspects of a solution. There are three principal aspects in a solution to the problem: 1) The determination of the total resources to be devoted to education. This is largely a matter of societal values and the manner of expressing them, an area in which a foreigner's comments are particularly inappropriate. 2) The use to which allocated resources are put. I have suggested earlier that revolutionary imagination be brought to bear in developing alternatives to current expenditure patterns. 3) Maximizing the rationality in the selection of candidates to utilize presumably scarce educational facilites. It is on this aspect that I want how to concentrate attention.

There is great merit in considering the possibility of a national «university aptitude» test, hereinafter referred to as the «EAU». In the course of a tew years, a national commission can develop a battery of tests to De given annually to all aspiring to enter Brazilian universities. The tests would be designed to measure:

1) ability to reason;

2) ability to handle analytic and abstract concepts;

3) reading skill and comprehension;

4) level of knowledge in one or more academic areas such as mathematics.

It would presumably be given mostly to students in the final year of ensino medio although it would not necessarily be restricted to them. At least initially, universities and faculties would be permitted to require other evidence of admissibility such as the present vestibular. They might not trust the EAU, or it might not cover subjects of special interest to particular faculties.

The results would be reported to the prospective student and to the institutions of his choice. They could indicate his percentile ranking

15 Conselho Federal de Educacao, Articulacao da Escola Media com a Superior, Separata N 29, da Documenta 79, Dezembro. 1967, pp. 10-11. 
with all who took the examination. Thus, our student, Joao Domingo and the three universities he would like to attend receive the following message: «Joao Domingo took the EAU on November 30 with 50.000 others. He scored as follows on each part of the examination with each number indicating the percentage of examinees who scored below him. Thus a score of 80 indicates that 80 per cent did loss well or that the examinee scored in the upper 20 per cent.

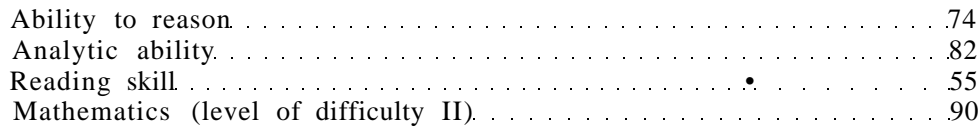

average $75.2^{\prime \prime}$

These kinds of results could be of enormous utility to university admissions officials particularly after they had acquired experience in dealing with them: 1) They are not absolute values but relative ones so that the examination itself is not critical in making comparisions from year to year unless the nature of it changes drastically. ${ }^{\text {CG }}$ Yet with the large numbers involved, the relative position of an individual would have significance. They would, too. tell the prospective university student a good deal about himself.

As suggested earlier, institutions would be permitted to use other testing devices, but with experience most universities would discover that this type of examination would yield results than feasible, locally prepared, examinations.

Assuming that the EAU would be the sole criterion used for admission (which would be unfortunate), universities would have a list of candidates ranked by the average performances on this battery of examination. They (or their individual faculties) would offer admission as far down the list as they had vacancies. If some of these offers were refused, (e.q., because of offers by preferred universities), ihose next in rank would be made offers. This would go on until such time as there were no more vacancies or until the scores reached a point below which the university was unwilling to accept the students. That is, the university might be willing to accept students "with averages down to 50 (i.e., the upper half approximately) but would rather have unfilled vacancies than to accept poorer prospective students.

Such a system would asssit, too, in the development of a heterogenious and discriminating university system. There may be great

16 I am not prepared to discuss the preparation of the examinations or the exact form "which they should take. I assert that it is possible to prepare examinations which make meaningful measurements of the characteristics listed above and that such results would be of much greater value than those procedud by the isolated vestibular. The best source of information available to me on this subject is A Description of the College Board Achievement Tests and A Description of the College Board Scholastic Aptitude Test, Box 592, Princeton, New Jersey: College Entrance Examination Board, 1967. 
merit in the brightest students tending to congregate in certain institutions, and there is certainly great merit in keeping the dull but competent from becoming frustratingly involved in educational institutions far beyond their capacities. The kinds of ranking envisaged would then enable institutions to select students better and also permit students to make better selections of institutions. In the U.S., for instance. high school counselors who advise prospective university students about institutions to which they might go have statistical information relating to the average test scores of incoming classes for the several thousand colleges and universities. This kind of information informs the students and their parents about the possibilities of being accepted at any given institution when the student knows his test scores.

Testing in this fashion also permits discrimination within universities. Our hypothetical student above might well be judged a very good candidate for an engineering school but a poor one for the library departments of a philosophy faculty. Although the student might choose to ignore such information, he is clearly better off to have it than not to have it.

Summarizing the advantages of such a system, we find the following.

1. Perhaps most important would be the improvement in the examination given. They would seek to measure ability, intelligence, etc. rather than the amounts of material already dominated and memorized. A few persons working full-time on the preporation of such examinations would be far preferrable to the present system of many people, not specially skilled in test preparation, doing it for small groups all over the - country.

2. The large numbers involved and the persistent effort to maintain consistency would give reliability and validity to the results. Of course, no one would argue that the measurements are precise or that small differences in scores represent appreciable differences between individuals. It cannot take into account the student with the «bad day» nor the student who «cannot take examinations.

3. The discriminatory features give the universities, prospective students, and their parents better information on which to act. More information is thought to be better than less.

4. The more rational distribution of students among scarce opportunities should guarantee a greater return to society. It would produce more and/or better trained persons for each cruzeiro invested in the educational system: Improvement should occur in several directions: students should get into appropriate careers, three should be fewer drop-outs.

5. One might argue that this scheme would mean that lesser -endowed students would be barred from the best institutions, perhaps 
from the more demanding (more desired?) professions, and/or from the most desired locations. This is true, but this is just what the system is intended to do - make valid discriminations between varying intellectual capacities for just these reasons. The mediocre student might very well want to study medicine in the nation's most distinguished medical school, but perhaps the most the society should offer him is a vacancy in some other area of specialization at a less good institution. These are hard decisions to make, but they must be made and the sort of examination system proposed should improve the decisions made.

6. Much of the weakness of the present system would disappear: students would not be passed or failed but ranked. In particular the distinctive category of «passed but not accepted would disappear.

7. Through time, information would be gathered permitting tentative judgements about the quality of individual secondary school. This should be of great value to parents, state secretaries of education, etc.

8. For the most part, I would expect the pre-vestibular cursinho to diminish in importance and perhaps to disappear. The tests envisaged would concentrate in ability and intelligence as indicated. The typical cursinho would not be very helpful in preparation for such tests.

It will be noted that adopting such a system would not increase the number of vacancies which surely needs to be done. To return one last time to the symbolic representation, such a scheme seeks only to the improve the quality of the "A» choices; it does nothing to increase their number.

JONH M. HUNTER

\section{EAPES}

Michigan State University

February, 1968. 
Apêndice D. 8

\section{A ECONOMIA DOS EMPRÉSTIMOS NO EXTERIOR PARA FINS EDUCACIONAIS EM GERAL}

A intenção desta nota é examinar os efeitos econômicos de empréstimos tomados no estrangeiro com o objetivo de financiar programas educacionais internos. Focalizaremos especialmente os efeitos dos empréstimos tomados pelo Governo, desde que este são mais prováveis no contexto brasileiro. Suporemos que o «empréstimo» é para fins educacionais em geral: talvez para a expansão e melhoria do ensino nos níveis primário, médio e/ou superior; e que o empréstimo cobre uma variedade de despesas: produção e distribuição de livros-textos, salários, construção de salas de aula, formação de professores, etc. Assim, analisaremos os efeitos econômicos de empréstimos tomados no estrangeiro pelo Governo para a expansão e melhoria de seus programas educacionais.

A discussão do assunto não tocará no problema da Educação ser ou não um «investimento» para o indivíduo ou para a sociedade. Estou convencido de que a Educação é um investimento para ambos e, no caso em pauta, o sujeito do empréstimo. Este leva a um aumento do fluxo de renda, aumento este que pode ser utilizado para amortizar o empréstimo, bem como pagar algum juro. Este ponto não será discutido aqui, mas deve ser lembrado que um empréstimo - mesmo um empréstimo «suave» - tem implicações de amortização e juros.

O problema a ser examinado é: que tipo de contribuição o empréstimo feito no estrangeiro pode trazer para a Educação brasileira no curso dos próximos anos? A hipótese geral a ser explorada é que a contribuição será muito pequena e que a maioria dos suportes ganhos advindos dos empréstimos já estão disponíveis através de outros expedientes .

A exposição do assunto é algo complexa, e precisa-se de um «modelo» simples, a fim de não se confundirem os vários aspectos dos efeitos do empréstimo. Na situação anterior ao empréstimo, «R», recursos nacionais, resultam na produção de «B», bens e serviços. Esta produção é distribuída pelos mercados que envolvem uma demanda agregada «D» e uma quantidade específica de cruzeiros «Cr». Cada um destes componentes exige alguma explicação.

$\mathrm{R}$ - representa o total dos recursos produtivos brasileiros empregados (ou empregáveis) na produção de bens e serviços. Inclui terra, 
trabalho, e bens de capital já existentes. Em qualquer momento dado$\mathrm{R}:=\mathrm{Re}+\mathrm{Ro}$, onde $\mathrm{Re}$ são os recursos empregados e Ro são os recursos desempregados. ${ }^{l}$

B - representa o produto total da economia. Em virtude da empréstimo estrangeiro envolver o setor internacional, os efeitos das importações e exportações devem ser levados em conta. Na situação anterior ao empréstimo, podemos supor que uma parte do produto B é de bens de exportação «X», que são trocados por um valor equivalente de bens de importação «M». Assim temos:

$\mathrm{B}=$ produção para uso doméstico $+\mathrm{X}$ (supondo-se inicialmente que $\mathrm{X}$ é igual a $\mathrm{M}$, para evitar uma complicação de balanço de pagamento) .

$\mathrm{Cr} \cdot-$ representa o total da oferta de dinheiro. Seu tamanho depende de muitos fatores incluindo a lei, a psicologia dos banqueiros, etc. Mas geralmente o volume de dinheiro pode ser mudado pela ação do Banco Central e isto pode estar vinculado ou não a algumas exigências do sistema de reservas (isto é, ouro, moedas estrangeiras fortes), pela ação do Governo juntamente com (ou independentemente do) o Banco Central, e através das práticas de empréstimo dos bancos comerciais. ${ }^{2}$ Não deve ser dada ênfase demais à quantidade de dinheiro, já que o seu padrão de Uso é igualmente importante na determinação de quaisquer efeitos finais.

D - representa a demanda total da sociedade. Num dado período de tempo, isto envolve o número de «Cr» e o número de vezes em que eles são gastos naquele período (velocidade). Para nossa análise. só precisamos nos lembrar que:

$$
\mathrm{D}=\mathrm{Dg}+\mathrm{Dp}+\mathrm{Dx}
$$

A demanda total constitui-se da demanda do Governo por bens e serviços e das demandas de setores não governamentais (privados). A demanda de exportação (Dx) será considerada constante e ignorada, porque nada na nossa análise deve afetar as demandas dos estrangeiros pelos produtos brasileiros. Se, por outro lado, as demandas brasileiras de importação fossem mudar, estas refletir-se-iam em mudanças de composição na $\mathrm{Dg}$ e Dp. Um aumento das demandas governamentais ou privadas por importações acarretariam um decréscimo correspondente nas demandas pela produção doméstica. ${ }^{3}$

1 Alguns acrescentariam Rd para representar recursos inadequadamente empregados - «desemprego disfarçado» - mas isto não aumenta em nada a nossa compreensão do problema em pauta.

2 Isto deve ser aceito em confiança, pois não pode ser explicado aqui.

3 Isto supõe que não há mudança nas poupanças (isto é, nos padrões de poupança, uma suposição feita para fins de simplificação) . 
Resumindo, bens e serviços B são produzidos com recurso R. Êles tornam parte do quadro econômico através de sua troca ou distribuição. Seus preços dependem de alguma forma da oferta de dinheiro «Cr» que é traduzida pela demanda total de bens e serviços, D .

O efeito direto de um empréstimo levantado no estrangeiro é dar ao Brasil o controle sobre recursos externos adicionais. Suponhamos que o Brasil tome emprestado 50 milhões de dólares. Estes dólares têm utilidade para comprar nos E.U.A, mas não no Brasil. Êste é o primeiro ponto principal. Um empréstimo estrangeiro (ou «doação») dá ao Brasil controle sobre recursos estrangeiros e não sobre recursos nacionais. Segue-se então que uma vantagem de um empréstimo tomado no exterior é este controle sobre recursos estrangeiros. Se o projeto de empréstimo fosse para uma usina hidrelétrica e fossem necessários geradores e outros equipamentos suíços, poder-se-ia providenciar um empréstimo em francos para o componente em moeda estrangeira, $o$ que permitiria a importação do equipamento necessário. As únicas outras alternativas seriam: 1) aumentar o valor das exportações; 2) realocar as receitas de câmbio destinadas a outros usos, e 3) diminuir as reservas existentes de dólares, libras esterlinas, francos, ou ouro.

Segue-se o segundo aspecto principal: Em geral, é muito pequeno o componente de moeda estrangeira da Educação. A maioria das despesas é com pessoal, e a importação de pessoas para servirem de professores em todo o sistema não é factível e nem provavelmente seria bem recebida. Uma das grandes necessidades para a expansão da Educação no Brasil é o aumento do número de salas de aula. Estas também, na sua maioria, exigem mais a utilização de recursos nacionais - terra. cimento, telha, tijolo, trabalho de construção — do que de recursos importados. Os livros-textos têm de ser impressos em português e a maioria não pode (ou não deve) ser importada in totó para uma simples tradução, sem a elaboração de algum conteúdo nacional. Entretanto, existem alguns elementos que podem e talvez devam ser adquiridos no estrangeiro, e que exigiriam despesas em divisas: 1) equipamento, usualmente para laboratórios e pesquisa das Universidades e faculdades; e 2) o treinamento especializado de algumas pessoas tais como professores e futuros professores, normalmente ao nível de doutorado e de pós-doutorado. Estes são os principais componentes em moeda estrangeira de um plano de expansão educacional.

Antes de voltarmos à análise de situações específicas, devo reafirmar que:

1) A principal vantagem de tomar um empréstimo no estrangeiro é obter o controle sobre recursos externos. 
2) A educação, na sua maioria, não precisa e de fato não pode usar quaisquer grandes proporções de recursos estrangeiros. ${ }^{\prime \prime}$

Examinaremos agora várias circunstâncias possíveis, a fim de analisarmos os efeitos de tomar um empréstimo no estrangeiro para fins educacionais em geral.

Caso 1. Suponhamos que todos os recursos brasileiros estão sendo completamente empregados, isto é, que há pleno emprego dos recursos, não há capacidade ociosa, e que não há "desemprego disfarçado». ${ }^{\mathrm{r}}$ Assim, temos o empréstimo em dólares. E sendo convertido em cruzeiros para construir salas de aula e para contratar professores, com a limitação de que os recursos utilizados devem ser retirados das atividades em que estão empregados.

$$
\mathrm{E}-\mathrm{Cr}-\mathrm{R}-\mathrm{B}
$$

Colocando à parte, no momento, o problema da conversão dos dólares, é evidente que a natureza do verdadeiro problema é o de realocar alguns recursos dos seus usos existentes para usos educacionais aumentados. Contadores, advogados, enfermeiras, banqueiros, donas de casa (?), ${ }^{6}$ etc. têm de ser induzidos a interromper o que estão atualmente fazendo, tornando-se professores. Por hipótese, não existe um conjunto de pessoas simplesmente esperando para assumir estes cargos, quando o financiamento fôr obtido. A construção de novas escolas, da mesma forma importará na redução de outra atividade talvez na construção de menos hospitais, de menos habitações de baixo custo, de menos apartamentos de luxo, ou talvez seja retirado trabalho da indústria de automóveis ou da produção de alimentos. O que realmente aconteceria depende da natureza do mercado, da sua capacidade de responder às mudanças, e de toda uma gama de políticas governamentais. Não devemos nos preocupar com estes fatos. O problema é que existem recursos finitos produzindo um determinado produto total. $\mathrm{O}$ aumento da produção de qualquer componente do produto total exige que seja reduzida a produção de algum outro componente.

4 Isto pode parecer estranho para aqueles que lutam sem cessar para obter um grani da Fundação Ford ou da USAID. Mesmo que estes pudessem ser usados para pagamento de salários (e geralmente não podem), a instituição que os recebesse presumivelmente venderia os dólares recebidos, a fim de pagar os salários em cruzeiros. Mesmo se professores estrangeiros fossem importados e pagos em dólares, eles venderiam muitos dos seus dólares para pagar aluguel, comprar alimentos, gasolina, entradas para teatros, etc, e estariam consumindo ou utilizando recursos brasileiros.

5 Isto não é uma projeção da realidade, mas um dispositivo analítico.

6 Dependendo da definição que se dê ao «pleno emprego».

7 Existe a possibilidade de uma «eficiência» maior na utilização dos recursos, isto é, o emprego mais eficiente de $\mathrm{R}$ terá como resultado maior produção de $\mathrm{B}$. Esta possibilidade não é considerada aqui, sendo eliminada da definição de pleno 
Se todos os compradores de bens e serviços da época anterior ao emprestimo permanecerem com as quantidades de cruzeiros de que dispunham na época (isto quer dizer que a demanda de bens e serviços daquela época não se modifica), então as novas demandas por bens e serviços educacionais significarão um aumento na demanda total, embora exista uma mesma quantidade de bens e serviços, o que simplesmente resultará num aumento de seus preços — inflação.

Esta possível conclusão exige o exame do complexo problema da conversão dos dólares do empréstimo em cruzeiro e na subsequente demanda por recursos nacionais. Infelizmente, existe uma série de possibilidades, todas com diferentes efeitos. Suponhamos, para simplificar o caso, que o montante em moeda estrangeira decorrente do empréstimo seja inicialmente depositado no Banco Central que, por sua vez, colocará à disposição do MEC o equivalente em cruzeiros, para que possa ser gasto. ${ }^{8}$ O Banco Central, tendo estas reservas de divisas no seu ativo, poderá:

1) «esterilizar» o aumento de divisas colocando à disposição do MEC os cruzeiros existentes. Isto será feito através da redução de alguma outra parte do ativo - possivelmente seus empréstimos a bancos comerciais — num valor correspondente ${ }^{9}$

2) neutralizar os efeitos, permitindo imediatamente um aumento nas compras de importação com as novas divisas recebidas;

3) «reforçar» as possibilidades inflacionárias retendo as novas divisas como reservas contra futuras emissões de papel moeda e/ou empréstimos a bancos comerciais.

A primeira destas alternativas, a «esterilização», seria neutra com respeito a inflação. A nova demanda do MEC no mercado seria compensada pela redução das demandas em outras áreas, de modo

emprego. Caso a possibilidade existisse, certamente não dependeria da existência do empréstimo. Ignorá-la não quer dizer que «o aumento da eficiência não é importante», mas ela é colocada de lado, por não fazer parte do problema em apreço.

8 Esta é uma suposição razoável e permite considerar todas as alternativas para qualquer caso.

Os mistérios do sistema de reserva fracionária bancária são complicados demais para serem explicados neste breve trabalho. As vezes estou sendo propositalmente inexato para evitar longas explicações e qualificações. Este trabalho também não pretende ser uma descrição precisa dos métodos institucionais bancários. Entretanto, os princípios são válidos para o Brasil. 
que $\mathrm{D}$ permaneceria o mesmo e $\mathrm{B}$ também não mudaria. ${ }^{10}$ Este procedimento, com bastante sorte, ${ }^{11}$ faria com que o nível dos preços permanecesse o mesmo e deixaria o Banco Central com reservas adicionais (mas «não utilizáveis»). Esta política essencialmente conservadora seria, portanto, neutra com relação aos preços.

A «neutralização» dos efeitos do empréstimo, através da permissão para importações adicionais (que não exigiriam exportações adicionais), seria realmente deflacionária. Todos os bens e serviços anteriormente produzidos continuariam disponíveis no mercado, aumentado pelas importações adicionais. Assim, se o dinheiro para o MEC é proveniente dos cruzeiros existentes (por meio da redução da demanda agregada) e se aos compradores de câmbio para as importações adicionais é çxigido que o façam com os cruzeiros existentes, existiriam mais bens e serviços $(B+M)$ e não haveria aumento no volume de cruzeiros existentes. Deveríamos esperar então que os preços caíssem. ${ }^{12} \mathrm{Se}$ fossem criados ou impressos novos cruzeiros para as novas importações ou para a transferência de dinheiro para o $\mathrm{MEC}$, os efeitos sobre os preços seriam inexistentes. Se os cruzeiros fossem criados para ambos os objetivos, o nível de preços deveria subir.

O aumento de divisas depositadas no Banco Central traria como provável consequência a sua utilização como «reservas» adicionais para expandir a oferta de dinheiro. Se o Banco Central mantém, por lei ou por costume, uma «reserva» de 5 a $10 \%$ em ouro ou em moeda forte contra suas emissões em cruzeiros, um aumento na reserva de 50 milhões de dólares permitiria um aumento de 1,0 bilhão ou 0,5 bilhão no total de cruzeiros em circulação, respectivamente. A situação é mais complicada e ainda mais explosiva se o Banco Central empresta aos bancos comerciais e estes, por sua vez, usam estes empréstimos como reservas contra seu passivo em depósito.

Resumindo, dada a hipótese de pleno emprego, tomar empréstimo no estrangeiro para fins educacionais em geral terá como resultado: 1) facilitar a aquisição do componente em moeda estrangeira para o aumento das despesas com a educação, mas não se espera que estas despesas sejam grande parte do total; 2) ser talvez levemente

\footnotetext{
10 Outra forma de se obter a esterilização, na ausência de um empréstimo. é lançar impostos sobre aquelas entidades cujas despesas devem ser reduzidas e carrear os recursos assim obtidos para o MEC.

11 Um aspecto traiçoeiro deste procedimento é a redução da demanda numa área pertinente. Se desejamos construir escolas, sugerir-se-ia uma redução nos empréstimos para outros tipos de construção. Embora como exemplo extremo, se as demandas dos consumidores de bebidas fossem reduzidas por meio de impostos elevados sobre as bebidas, o efeito poderia bem ser um aumento líquido na demanda acompanhado de um aumento de preços na indústria de construção e de desemprego na indústria de pinga.

12 Conforme foi discutido na nota 11, poderia oco;-rer o mesmo tipo de desequilíbrio.
} 
deflacionário se forem permitidas importações adicionais e as autoridades monetárias seguirem uma política não-expansionista; 3) que provavelmente serão desde «levemente inflacionários» até «seriamente inflacionários», novamente dependendo da política adotada pelas autoridades monetárias e da capacidade de resposta da economia. Excetuando-se o componente de moeda estrangeira, não parece que tomar empréstimos no exterior contribui diretamente com algo para a Educação. Pode trazer sérias consequências inflacionárias e, e, em última análise, implica em amortização, o que sugere a necessidade de um aumento nas exportações, sem aumento correspondente nas importações durante o período de amortização.

Caso 2. Suponhamos agora, de modo mais realista, que há alguma considerável capacidade ociosa na economia. Alguns recursos estão claramente desempregados e alguns estão disfarçadamente desempregados .

Como resultado do empréstimo, as mesmas políticas monetárias discutidas acima poderiam ser usadas, mas as políticas de esterilização e neutralização seriam menos atraentes. A política expancionista e «reforçadora» resultaria num aumento da quantidade de cruzeiros que levaria, espera-se, a um aumento de gastos, que levaria (novamente «espera-se») não a um aumento de preços, mas a um aumento do emprego dos recursos anteriormente subempregados. Isto, por sua vez, significaria um aumento de B. sem aumento de preços. No melhor de todas as hipóteses, o aumento de $\mathrm{B}$ poderia ser algum múltiplo do aumento dos gastos, pois os primeiros que recebessem o dinheiro também o gastariam, talvez aumentando o emprego, e os segundos que recebessem o dinheiro o gastariam, etc, etc.

Há bastante dúvidas de que na prática isto possa funcionar facilmente. Se o subemprego fôr na indústria de construções, então os gastos do MEC podem aumentar o emprego. Mas se o subemprego fôr na agricultura, o aumento dos gastos do MEC para construções e professores provavelmente não aumentará, a curto prazo, o emprego, mas simplesmente elevará os preços em alguns setores. ${ }^{13}$

Tomar empréstimos no exterior nestas circunstâncias parece ser muito mais atraente do que no caso de pleno emprego, mas isto também é principalmente ilusão. O problema básico ainda é obter prédios escolares brasileiros construídos no Brasil e brasileiros ensinando nas salas de aula. Não está claro que os dólares emprestados contribuem diretamente para estes objetivos. Os aparentes benefícios são provenientes, neste caso, das políticas monetárias expansionistas que poderiam

13 Esta é a essência do debate «monetarista-estruturalista», que vem desde alguns anos. Naturalmente não há nada de errado em aumentar os preços num setor, se eles induzem a um movimento de recursos neste setor. Os estruturalistas argumentam que devido à rigidez das instituições há pouca resposta às mudanças relativas dos preços. 
ter sido aplicadas em qualquer caso. O volume de cruzeiros a ser criado ou o volume de empréstimos bancários a serem concedidos certamente não deve depender da capacidade do Brasil tomar empréstimo no exterior para fins educacionais.

Portanto, em ambos os casos, do ponto de vista económico, só se pode esperar poucos benefícios para Educação brasileira ${ }^{, 4}$ provenientes de empréstimos no exterior. A maioria dos benefícios aparentes no caso em que a situação não é de pleno emprego depende de políticas monetárias expansionistas, uma solução disponível sem o empréstimo.

A análise anterior deve ser colocada na sua perspectiva correta. Não argumenta definitivamente contra o empréstimo para fins educacionais em geral. Afirma que os benefícios para a Educação, decorrentes do empréstimo, não são tão elevados como se poderia pensar, e que a maioria de quaisquer benefícios potenciais estariam disponíveis para o Brasil na ausência do empréstimo. E como alguém poderia concluir que tal empréstimo poderia ser inflacionário por natureza, isto também deve ser colocado dentro de uma perspectiva correta. O total dos empréstimos e/ou doações não será tão grande que possa, por si mesmo, fazer a economia «desenvolver ou falir». Duvido que os possíveis efeitos inflacionários possam impedir seriamente uma corajosa política anti-inflacionária ou que eles acrescentem muito aos efeitos de uma política menos corajosa.

Poder-se-ia afirmar corretamente que os empréstimos e doações do exterior têm importantes efeitos não-econômicos. As condições do empréstimo podem exigir que este seja «igualado» pelo MEC, resultando assim num aumento das despesas educacionais, além daquelas provenientes do empréstimo. Este pode exigir mudanças substanciais nos padrões de despesas existentes. Por exemplo: poderia ser exigido que as partes do empréstimo destinadas a despesas de pessoal fossem gastos somente com professores de tempo integral - ou com pesquisas na Universidade - ou com algum outro objetivo. Poder-se-ia obter maior eficácia insistindo em que o dinheiro fosse gasto somente nos Estados que preenchessem tais ou quais condições. Este tipo de dinheiro é algumas vezes chamado de «dinheiro-semente» — uma quantidade relativamente pequena, plantada numa ou mais inovações educacionais, esperando-se que resulte numa colheita nacional de mudanças educacionais revolucionárias.

Excetuando-se sempre o componente de moeda estrangeira. 
Neste sentido, não há como negar a utilidade potencial de empréstimos ou doações do exterior. A possibilidade de obter tais quantias pode trazer mudanças nos métodos educacionais ou na distribuição de recursos para a Educação, que de outro modo não ocorreriam. Este efeito poderia ser chamado de «efeito psicológico». Entretanto, análise econômica sugere que as mudanças decorrentes de um empréstimo no exterior, que ocorreriam devido ao «efeito psicológico», poderiam ocorrer sem o empréstimo.

JOHN M. HUNTER

EAPES

Michigan State University

Tradução de

JACQUES R. VELLOSO

Julho de 1968. 
Apendice D. 8

\section{THE ECONOMICS OF BORROWING ABROAD FOR GENERAL EDUCATIONAL PURPOSES}

The purpose of this note is to examine the economic effects of borrowing abroad for the purpose of financing internal educational programs. We focus specifically on the effects of the government's borrowing since this is most probable in the Brazilian context. The «loan» is assumed to be for general educational purposes - perhaps for the expansion and improvement of instruction at the primary, secondary, and/or higher levels - and to cover a variety of expenditures - text book production and distribution, salaries, schoolroom construction, teacher training, etc. Thus, we are to analyze the economic effects of the government's borrowing abroad for expansion and improvement of its educational programs.

The discussion will not touch upon the question of whether or not education is «investment either for individual or for the society. I am satisfied that education is investment for both and quite properly the subject of borrowing. It leads to an increased flow of income, the increments of which can be utilized to repay the principal of a loan as well as some interest. The point is not here in question, but it ought to be recalled that a loan - even a «soft» loan - has repayment and interest implications.

The question to be examined is: what kind of contribution can borrowing abroad make to Brazilian education in the course of the next few years? The general hypotheses to be explored is that the contribution will be very small and that most of the supposed gains from borrowing are already available through other devices.

The exposition is somewhat complex, and simple «model» is needed in order to keep straight various aspects of the loan's effects. In the pre-loan situation, $\langle\mathrm{R} »$ national resources work to produce $« \mathrm{G} »$ goods and services. This production is distributed through markets involving an aggregate demand («D») and involving a specific quantity of cruzeiros $(« \mathrm{Cr} »)$. Each of these components requires some explanation . 
$\mathrm{R}$ - represents the total of Brazilian productive resources engaged in (or engageable in) the production of goods and services. It includes land, labor, and capital goods already in existence. At any given moment, $\mathrm{R}=\mathrm{Re}+\mathrm{Ro}$ "when $\mathrm{Re}$ is employed resources and Ro is unemployed resources. ${ }^{1}$

$\mathrm{G}$ - represents the total product of the economy. Because the foreign loan involves the international sector, the effects of imports and exports must be accounted for. In the «pre-loan» situation, we can assume that some of the $G$ product is for export goods «X» which are exchanged for an equivalent amount of import goods «M». Thus,

$\mathrm{G}=$ production for domestic use $+\mathrm{X}$ (assumed initially equal to $M$ to avoid a balance of payments complication).

$\mathrm{Cr}$ - represents the total money supply. Its size depends upon many facts including the law, the psychology of bankers etc. But generally, the amount of money can be changed by action of the Central Bank with or without reference to some requirement for reserves (i.e., gold, key foreign currencies), by the government acting in conjunction with (or independently of) the Central Bank, and through the lending practices of commercial banks. ${ }^{2}$ Too much emphasis should not be placed on the quantity of money since its use pattern is equally important in determining any eventual effects.

D - represents are total demand of the society. In a given time period this involves the number of «Cr» and the number of times they are spent in that period (velocity). For our purposes, we need only recall that:

$$
\mathrm{D}=\mathrm{Dg}+\mathrm{Dc}+\mathrm{Dx}
$$

The total demand is made up of the government's demand for goods and services and the non-governmental sector's demands (civilian). The demand for exports (Dx) will be considered constant and ignored since nothing in our analysis should affect foreigners' demands for Brazilian products. If, on the other band, Brazilian demands for imports were to change, these would be reflected in compositional changes in Dg and Dc. An increase in either governmental or civilian demands for imports would entail a corresponding decrease in demands for domestic production. ${ }^{3}$

1 Some would add $\mathrm{Rd}$ to represent improperly empolyed resources «disguised unemployment, but this adds nothing to our understanding of this particular problem.

- This must be accepted on faith since it cannot be explained here.

8 This assumes that there is no change in savings (i.e., hoarding patterns, an assumption made for simplification purposes). 
To summarize, goods and services $G$ are produced by resources R. They become part of the economic picture by their being exchanged or marketed. Their prices depend somehow on the supply of money «Cr» which is translated into the total demand for goods and services, D.

The immediate effect of a loan from abroad is to give Brazil mand over additional foreign resources. Suppose Brazil borrows 50 million dollars. These are useful for buying in the U.S. but not in Brazil. This is the first major point: a foreign loan (or «gift») gives command over foreign resources, not national resources. If follows then that one advantage of a loan from abroad is this command over foreign resources. If the loan-project were hydro-eletric power and Swiss generators and other equipment were needed, a franc loan for the foreign currency component might be arranged which would provide for the importation of the necessary equipment. The only other alternatives would be: 1) increasing the value of exports, 2) reallocating existing exchange earnings from other uses, and 3) depleting existing reserves of dollars, pounds sterling, francs, or gold.

The second major point follows: In general, education has a very small foreign currency component. Most expenditures are for personnel, and the importation of persons to serve as teachers throughout the system is neither feasible nor would it be likely to be well received. In expanding Brazil's education, one of the great needs is increased numbers of classrooms. These, too, for the most part require the use of national resources - land, cement, tile, brick, construction labor rather than imported resources. Text books must be printed in Portuguese and most cannot (or should not) be imported in toto for simple translation without the development of some national content. There are, however, some elements which can and perhaps should be purchased abroad which would require the expenditure of foreign exchange 1) equipment, usually for laboratories and research in higher education and 2) the specialized training of some persons such as professors and professors-to-be, usually at the graduate or post-graduate levels. These are the main foreign currency components of an educational expansion plan.

Before turning to the analysis of specific situations, these two points are restated:

1) A principal advantage of borrowing abroad is the command obtained over foreign resources. 
2) Education, [or the most part, does not require and, in [act, cannot use any great proportion of foreign resources.

We now examine various possible circumstances in order to analyze the effects of borrowing abroad for general educational purposes.

Case 1. Let us suppose that all Brazilian resources are fully employed, i.e. that there is full employment, no excess capacity, that there is no «disguised unemployment. ${ }^{5}$ Thus, we have the dollar loan, E, being converted into cruzeiro to build classrooms and to hire professors with the constraint that resources utilized must be taken from their existing activities.

$$
\mathrm{E}-\mathrm{Cr}-\mathrm{R}-\mathrm{G}
$$

Leaving aside the dollar-conversion question for the moment, it is evident that the nature of the real problem is that of reallocating some resources from their existing uses to expanded educational uses. Accountants, lawyers, nurses, bankers, housewives (?), ${ }^{6}$ etc. must be induced to stop what they are now doing and to become, instead. teachers. By assumption, there is no pool of persons just waiting to enter these positions when financing is found. The construction of new schools likewise will involve the reduction of other activity perhaps the construction of fewer hospitals, less low-cost housing. fewer luxury apartments, or perhaps labor will be drawn from the automobile industry or from the production of food. What would actually happen in detail depends on the nature of the market, its responsiveness, and a whole host of governmental policies. This needs not concern us here. The point is that there are finite resources producing a given total product. To produce more of any component of that total product requires a reduction in the production of some other component. ${ }^{7}$

This will sound strange to those who struggle ceaselessly to get a Ford Foundation or a USAID grant. Even if such funds were available to pay salaries (as generally they are not), the institution - recipient would presumably sell granted dollars so as to pay in cruzeiros. Even if foreign professors were to be imported and paid in dollars, they would sell many of the dollars to pay rent. to buy food, gasoline, theatre tickets, etc. - consuming or utilizing Brazilian resources.

5 This is not a projection of reality but an analytic device.

6 Depending on how one defines «full employment.

7 There exists the possibility of greater «efficiency» in the use of resources, i.e. by employing $R$ more efficiently, greater $G$ would result. This possibility is not considered here, it being «disposed of» in the definition of full employment. Should the possibility exist, it certainly will not depend upon the existence of the loan. Ignoring it is not to say that increasing efficiency is not important. Rather it is left aside as no part of this particular problem. 
If all pre-loan purchasers of goods and services are left with their pre-loan quantities of cruzeiros (that is to say, the pre-loan demand for goods and services is not disturbed), then the new demands for educational goods and services will mean an increased total demand for the same amount of goods and services which will simply result in an increase in their prices - inflation.

This possible conclusion requires examining the complex question of the conversion of the dollar loan into cruzeiros and into the subsequent demand for national resources. Unfortunately, a variety of possibilities exist, all with differing effects. To simplify matters, let us suppose that the foreign currency proceeds of the loan are initially deposited in the Central Bank which will, in turn, make the equivalent cruzeiros available to the MEC for spending. ${ }^{8}$ The Central Bank, having these foreign exchange reserves among its assets, may:

1) «sterilize» the increase of foreign exchange by making existing cruzeiros available to the MEC. It would do this by reducing some other asset - possibly its loans to commercial banks in a corresponding amount. ${ }^{9}$

2) neutralize the effects by immediately permitting increased import purchases with the new foreign exchange.

3) «reinforce" the inflationary possibilities by holding the new foreign exchange as reserves against further emission of paper money and/or loans to commercial banks.

The first of these alternatives - «sterilization» - would be neutral with respect to inflation. The new demand of the MEC in the market would be compensated for by reduced demands elsewhere so that $\mathrm{D}$ would remain the same while $\mathrm{G}$ likewise would not change. ${ }^{10}$ This, with a good deal of luck ${ }^{11}$ would leave the price level unchanged

8 This is a reasonable assumption and permits considering all alternatives in any case.

8 The mysteries of fractional reserve banking are too complex to go into here. I am purposefully being inaccurate at times to avoid lengthy explanations and qualifications. Nor is this intended to be an accurate description of Brazilian institutional banking arrangements. The principles, however, are valid in Brazil.

10 In the absence of a loan, another way of accomplishing this is to tax those entities whose spending is to be reduced and to turn the proceeds over to the MEC.

A tricky aspect of this is that of reducing the demand in a relevant area. If school construction is desired, reducing loans for other kinds of construction is suggested. If, as an extreme example however, the demands of drinkers were reduced by a heavy tax on liquor, the effect might very well be a net increase $\mathrm{m}$ demand with rising prices in the construction industry and unemployment in the pinga industry. 
and the Central Bank with additional (but «non-working») reserves. This most conservative policy would be neutral, then, with respect to prices.

«Neutralization» of the effects of the loan by permitting additional imports (which would not require additional exports) would actually be deflationary. All the goods and services previously produced would continue to be available in the market augmented by the additional imports. So if the funds for the MEC come from existing cruzeiros (reducing aggregate demand) and if the purchasers of exchange for the additional imports are required to do so from existing cruzeiros there would be more goods and services (G -+- M) and no increase in cruzeiros. We should expect prices, then, to fall. ${ }^{12}$ If new cruzeiros were created or printed for either the new imports or for the transfer of funds to the MEC, the price effects should be nil. If cruzeiros were created for both purposes, the price level should rise.

A likely consequence of the increased foreign exchange holdings of the Central Bank would be their use as additional «reserves" to expand the money supply. If by law or by custom, the Central Bank maintains a 5 percent or 10 percent «reserve» of gold or hard currency against its cruzeiro emissions, an increase in reserve of 50 million dollars will permit an expansion of cruzeiros in circulation of 1,0 billion new cruzeiros or 0,5 billion respectively. The situation is more complicated and even more explosive if the Central Bank lends to commercial banks and they, in turn, use those loans as reserves against their deposit liabilities.

In summary, given the full employment assumption, the borrowing abroad for general educational purposes will: 1) facilitate the acquisition of the foreign currency component of increased expenditures for education but these are not expected to be a large portion of the total; 2) perhaps be mildly deflationary if additional imports are permitted and non-expansionary policies are followed by the monetary authorities; 3) more probaly be «midly inflationary to «seriously inflationary», again depending on the policies of the monetary authority and on the responsiveness of the economy. Except for the foreign exchange component, it does not appear that borrowing abroad contributes anything directly to education. It may have serious inflationary consequences, and it does have ultimate repayment implications which suggest the necessity for «unrequited» exports during the repayment period.

Case 2. Now let us suppose, more realistically, that there is some considerable slack in the economy. Some resources are clearly unemployed and some are disguisedly unemployed.

As a result of the loan, the same monetary policies discussed above are available but the sterilization and neutralization policies would

12 The same sort of sectoral imbalance might develop as discussed in note 11 . 
have even less appeal. The expansionist, «reinforcing» policy would result in an expanded amount of cruzeiros leading hopefuilly to expanded demand in spending leading (again «hopefully») not to increased prices but to increased employment of previously underemployed resources. This, in its turn, would mean an increase in $\mathrm{G}$ with no increase in prices. In the best of all circumstances, the increase in $G$ might be some multiple of the increase in expenditures as the first income recipients would also spend the monev. perhaps expanding employment, the second recipients would spend, etc., etc.

There is considerable doubt that this could work out smoothly in reality. If it is the construction industry which is under-employed, then the MEC expenditures may develop increased employment. But if agricultural resources are underemployed, MEC's increased expenditures for construction and professors is likely not to increase employment in the short run but simply to raise prices in some sectors. ${ }^{1}$

Borrowing abroad in these circumstances seems considerably more appealing than in the full-employment case, but this is mostly illusion, too. The basic problem is still to get Brazilian schoolrooms built in Brazil and Brazilians in the classrooms teaching. It is not clear that borrowed dollars contribute directly to these objectives. The apparent benefits come, in this case, from the expansionist monetary policies which could have been resorted to in any case. Surely the amount of cruzeiros to be issued or the amount of bank loans to be made ought not to depend upon Brazil's ability to borrow abroad for educational purposes.

In both cases, then, from the economic point of view, little benefit can be expected for Brazilian education"' from borrowing abroad. Most of the apparent benefits in the lessthan-full-employment case depend upon expansionist monetary policy, a remedy available without the loan.

The foregoing analysis ought to be put into its proper perspective. It does not argue definitively against borrowing for general education purposes. It argues that the gains to education from the loan are not as great as one might think and that most of any potential gains would be available to Brazil in the absence of the loan. And while one might conclude that such a loan is apt to be inflationary in

This is the gist of the «monetarist-structuralist» debate of a few years age. There is, of course, nothing -wrong with rising prices in one sector if they induce a movement of resources to that sector. Structuralists argued that because of institutional rigidities, there is little response to relative price changes.

14 Alway excepting the foreign currency component. 
nature, this, too, ought to be kept in perspective. The sum of loans and/or gifts for educational purposes is not apt to be so great that they will, by themselves, «make or break the economy. I doubt that the possible inflationary effects could seriously impair a courageous anti-inflationary policy or that they would greatly add to the effects of a less than courageous policy.

It may be properly argued that loans and gifts from abroad have important non-economic effects. The conditions of the loan may require that it be «matched» by the MEC and thus result in increased expenditures for education besides those from the loan. The loan may require substantial changes in existing expenditure patterns. For example, those parts of the loan destined to expenditures for personnel might be required to be spent on fulltime professors only - or on university research - or some other desideratum. More leverage mightbe obtained by insisting that funds be spent only in states performing in one way or another. These sorts of funds are sometimes called «seed money» - a relatively small amount judiciously planted in one or more educational innovations expected to result in a nation-wide crop of revolutionary educational change.

There is no denying the potential usefulness of foreign gifts or loans in this respect. The prospect of obtaining such funds may bring about changes in educational methods or in the allocation to education which would not otherwise occur. We might call this a «psychological effect». The economic analysis suggests, however, that the changes from a foreign loan which would occur through the «psychological effect could occur without the loan.

JOHN M. HUNTER EAPES 
Apêndice E. 1

\section{O DEPARTAMENTO NA UNIVERSIDADE NORTE- AMERICANA}

H. W. HOGE EAPES

Este trabalho é uma tentativa de descrever o funcionamento e a estrutura do Departamento na Universidade Norte-Americana. É importante ressaltar, de início, que não descrevemos um departamento «típico» de uma Universidade Norte-Americana «típica». Esta Universidade não existe. Não há uma estrutura única, preestabelecida ou padronizada, determinada pela legislação ou pela tradição para a Universidade Norte-Americana ou para seus componentes. Consequentemente, nota-se grande variação quanto às características estruturais e operacionais do Departamento, bem como das outras unidades componentes da Universidade nos Estados Unidos.

Apesar desta variação, parece existir certo grau de uniformidade operacional nas funções desempenhadas pelo departamento. No seu sentido mais amplo, o departamento pode ser descrito como a pedra fundamental da estrutura universitária: é ao mesmo tempo a unidade administrativa mais elementar e a unidade de ensino básico de maior relevância dentro daquela estrutura. Deve ser difícil, para um observador de fora, obter completo conhecimento dos processos de funcionamento interno do departamento; mesmo um professor visitante estrangeiro, após vários semestres de contato com uma instituição de ensino, pode muito bem não perceber como funcionam os princípios operacionais mais importantes, já que êle estaria quase que exclusivamente realizando ou/e orientando trabalhos de ensino e pesquisa numa determinada área do programa departamental (na seção de estudos de pós-graduação, por exemplo), e frequentemente evitar-se-ia que êle arcasse com os ónus dos compromissos de atuação nas comissões departamentais básicas.

Portanto, nossa descrição será a de um departamento fictício. Os dados sobre algumas variações estruturais aparecerão sob a forma de notas. A terminologia essencial não definida no próprio texto será encontrada num glossário em anexo, sendo tais termos marcados com um asterisco. Suporemos que as palavras «normal» e «usual» devem ser aplicadas a todas as descrições feitas neste trabalho. 


\section{I - Composição (Estrutura externa)}

O Departamento pode compreender um grupo de membros do corpo docente, organizado para realizar as tarefas de ensino, pesquisa, elaboração de programas e de atividades administrativas de uma única disciplina universitária (geográfica, física, química, francês, e tc); ou de uma disciplina mais ampla e menos específica (ciência política, geologia, oratória, linguística, etc); ou de um grupo de disciplinas relacionadas entre si (línguas modernas, línguas romanas, belas-artes, literatura comparativa).

O «lar» básico ou unidade de exercício das tarefas dos membros do corpo docente da Universidade Norte-Americana é o departamento. $\mathrm{O}$ membro do corpo docente considera-se diretamente ligado a esta unidade, e a citará como seu cargo atual: êle dirá que é professor no departamento de Economia (por exemplo) ao invés de dizer que é professor na Escola ( School) ou Faculdade ( College) à qual este departamento pertenceria. Esta identificação básica com o departamento decorre do papel que esta unidade desempenha nos processos de seleção e nomeação, no de promoções para níveis superiores da carreira e no de reajustes salariais para os membros do corpo docente.

O departamento como unidade consiste em todo o pessoal contratado, incluindo secretários e estudantes assistentes em regime de tempo parcial e por hora. Restringindo nossa descrição ao pessoal docente, poderíamos ter a seguinte ordem de níveis num departamento:

\section{Professores Titulares (ou simplesmente «professores») ${ }^{1}$ \\ Professores Associados \\ Professores Assistentes \\ Instrutores (tempo integral ou parcial) \\ Assistentes de Pós-Graduação (Graduate Assistents)}

Não existe nenhum quadro de pessoal prefixado, destinado a organizar um departamento. Em uma destas unidades de tamanho médio existem usualmente vários professores titulares. ${ }^{2}$ Não há uma proporção padronizada que seja aplicável aos diversos níveis: pode haver dois ou três professores titulares num departamento e somente

As outras categorias de docentes podem ser: a) o Conferencista (Lecture), ou Professor Visitante (pode ser-lhe concedido um nível especifico, como «Professor Associado Visitante»). O Professor Visitante pode gozar de todos os privilégios do departamento (voto, etc), mas não adquire estabilidade com o tempo de serviço; b) $\mathrm{O}$ Assistente de pós-graduação (graduate assistant), ou estudante-assistente de pós-graduação pode também ser chamado de «associado de ensino» ou «colega de ensino» (teaching fellow), ou ainda «associado de pesquisa» (research associate); e este último implica na contribuição de um número especifico de horas de trabalho num programa de pesquisa dirigido por um professor sénior.

A quantidade de pessoal nos diferentes niveis num departamento poderia ser determinada pelas atividades de recrutamento desenvolvidas pelo presidente (chairman); um professor titular de boa qualidade e que estivesse disponível poderia ser trazido para o departamento, sem que isso tivesse relação com a distribuição dos níveis existentes. 
um professor associado; ou pode haver vários professores associados e só um professor titular. Pode-se também mencionar o fato de que só excepcionalmente a nomeação de membros do corpo docente é fe ta dentre os que realizaram estudos de pós-graduação na própria instituição. O jovem que obteve seu doutorado ( $\mathrm{Ph}$. D.) não procurará nem esperará ser nomeado pelo departamento que lhe concedeu o diploma. Um departamento com dez membros do corpo docente em tempo integral teria professores com diploma de doutorado de pelo menos seis instituições diferentes. ${ }^{3}$

Os pré-requisitos e as condições para os níveis docentes estão resumidamente relacionados abaixo:

Professor. O mais alto nível dentro do departamento, gozando de todos os privilégios concedidos ao corpo docente. O administrador do departamento é frequentemente - embora nem sempre - escolhido ou nomeado dentre os elementos deste nível. Geralmente existem vários professores num dado departamento. A estes professores cabe a tareia de ministrar aulas de disciplinas em nível avançado, cada um dentro de sua própria especialidade; nos departamentos onde existam matérias introdutórias com grande número de matriculados, um profesor titular pode fazer conferências sobre o assunto (lecture sections) e supervisionar o trabalho da equipe de assistentes que se encarregará da;- sessões de debates e avaliação do aprendizado ( quiz \& recitation sections). As disciplinas e seminários em nível de pós-graduação, num departamento, são geralmente ministradas e orientadas por professores ou professores associados. Os estudantes de pós-graduação que rea'izam trabalhos para obter um doutorado têm conselheiros ou uma comissão de doutorado ( $P h$. D. Committee), selecionada dentre este grupo de conselheiros. A nomeação de um professor titular ou a promoção a este nível implica no reconhecimento de um trabalho universitário de significação numa dada área do conhecimento, e está usualmente ligada a uma reputação nacional e à publicação de vários livros e monografias. Raramente este nível é concedido unicamente em função de excelente desempenho nas salas de aula.

Professor Associado. O nível logo abaixo do mais elevado. Ao atingir este nível, geralmente concede-se estabilidade ao membro do corpo docente e êle é considerado qualificado para a nomeação ou

O principio universitário inerente a este fato é significativo, pois o resultado disto é a dispersão, propagação e fusão de técnicas de ensino e pesquisa através do sistema nacional. A prática de conservar os produtos locais é chamada de inbreedng. O mesmo princípio é aceito na composição do corpo discente, tanto em nivel de graduação como de pós-graduação. Considera-se desejável uma per" centagem bem elevada $(20$ a 30\%) de estudantes de outros Estados. Fatores da po!i'ica estadual ocasionalmente, exercem uma pressão inversa nesta área, já que o Estado subsidia essencialmente a educação de estudantes não-naturais do Estado (anuidades para alunos de fora do Estado, embora muito mais elevadas do que as taxas para os naturais do Estado, não cobrem os custos reais do ensino por estudante). 
inclusão no Corpo Docente de Pós-graduação ( Graduate Faculty). Se eleito ou nomeado, o professor associado pode também ocupar o cargo de administrador-chefe do departamento (embora vários professores titulares façam parte do pessoal do departamento). A promoção a professor associado ou a nomeação para este nível é assim um marco significativo na carreira universitária de um membro do corpo docente, indicando que aquele que o recebeu realizou pesquisas de importância na sua área de estudos e é dotado de um potencial que permitirá o futuro desenvolvimento de suas qualidades no mundo universitário.

Professor Assistente. O menor nível dentro da categoria de «professor». Este nível é mais ou menos automaticamente atingido era virtude da obtenção do diploma de doutorado. Esta é uma fase de «julgamento»: o professor assistente já demonstrou que recebeu o preparo e que tem o potencial para realizar um ensino e pesquisa de maior valor; espera-se então que êle demonstre, de fato, este potencial.

Instrutor- O nível inicial dentre o pessoal de tempo integral. Em algumas instituições não são concedidos ao instrutor certos privilégios do corpo docente. O instrutor frequentemente é uma pessoa que já preencheu todos os requisitos para obtenção do doutorado, exceto a dissertação ou tese. Portanto, êle tem liberdade para aceitar um emprego de lempo integral numa outra instituição, enquanto prepara ou completa sua dissertação na instituição em que realiza seus estudos.

Assistente de Pós-Graduação - Associado de Ensino. Este cargo não é considerado como pertencendo à Congregação, e compreende ensino em tempo parcial ou trabalho de assistente em pesquisas. $O$ assistente ou associado de ensino é um estudante de pós-graduação: completou os quatro anos básicos de formação universitária e obteve o devido diploma (B.A.-Bacharel em Letras e Artes; B.S.-Bacharel em Ciências). Portanto êle está cursando as matérias para obter seu Mestrado (M. A. Master of Arts) ou Doutorado (Ph. D. - Doctor $o$ [ Philosophy). Suas atividades de ensino em tempo parcial lhe dão uma modesta renda $;{ }^{4}$ frequentemente a Universidade fornece moradia com aluguéis razoáveis. Quando o assistente de pós-graduação tiver cursado todas as matérias exigidas para obter diploma de Doutor, poderá transferir-se para outra instituição como instrutor; após a obtenção do seu diploma, êle será, como de rotina, promovido a professor assistente.

\section{II - Carga de Ensino e Tabela de Salários.}

A carga de ensino do corpo docente é expressa em termos de horas ou créditos. ${ }^{5}$ Cada hora significa uma hora de aula ou de qualquer

Variando de U.S. $\$ 3,000$ a $\$ 3,500$ por ano letivo (nove meses).

O valor das matérias pode variar de 1 a 5 créditos. Uma disciplina valendo 2 créditos usualmente terá duas horas de aula por semana durante um semestre As aulas em laboratório (Química, Física, etc.) podem ter peso diferente 
outra atividade numa sala de aula. O professor recentemente nomeado é informado de que seus deveres não consistem somente em ensinar, mas também em desenvolver trabalhos de pesquisa e prestar serviços à comunidade. Portanto, as horas de ensino e o total de horas (incluindo a preparação das aulas) devotadas à profissão variam grandemente. ${ }^{0}$

As cargas de ensino variam de acordo com o nível da carreira: os professores de nivel mais elevado têm menos horas de ensino por semana, contudo, ministram aulas de nível mais adiantado. Em várias disciplinas ou conjunto de disciplinas, o professor ou professor associado não dará aulas nas seções elementares ou de introdução; em departamentos nos quais o programa de pós-graduação ocupa a maior parte da unidade, êle poderá até não dar aulas ao nível de graduação.

A carga de ensino em nosso departamento fictício poderia ser, por níveis, a seguinte:

Nivel

Professor

Professor Associado

Professor Assistente

Instrutor

Assistente de Ensino ${ }^{7}$

\section{Carga \\ $\mathrm{cm}$ \\ Créditos}

6 a 8 Um seminário (2) e duas disciplinas em nivel avançado (4 a 6).

8 a 10 Duas matérias em nível avançado (4 a 6) e uma ou duas de nível intermediário (4 a 6 ).

10 a 12

Duas matérias em nível intermediário (4 a 6) e uma ou duas em nível elementar (6 a 8 ).

12 a 15 Vánas matérias em nível de introdução $(8$ a 10$)$ e uma ou duas em nível intermediário (4 a 6).

4 a 6 Uma ou duas aulas em nível de introdução.

em termos de horas de aula versus crédito. As matérias de nível mais avançado frequentemente possuem menos horas de aula por semana (céditos) do que os cursos elementares e de introdução. Os cursos elementares tendem a va'er de 3 a 5 créditos; os de nível intermediário, 2 a 3 ; e os de nivel mais elevado ou de pós-graduação, 2.

6 Recente levantamento realizado na Universidade de Wisconsm mostrou que o número médio de horas de atividades profissionais por semana era de 541 . Deste total, cê-ca de $33 \%$ ou 18 horas por semana eram dedicadas à pesquisa; cerca de $6 \%$ ou 3 horas a se viços prestados à comunidade, e o saldo, 33 horas, era dedicado à leitura de publicações pertinentes às disciplinas e à preparação eadministração das aulas.

- O assistente de ensino pode dar duas disciplinas de nível introdutório num semestre e uma disciplina no semestre seguinte. O número de materiais que êle pessoalmente vai cursar, tendo em vista o preenchimento dos requisitos para obter seu diploma de pós-graduação pode ser controlado em função do volume de ensino. Durante o semestre em que êle ensinar duas disciplinas pode lhe ser permitido cursar somente uma matéria valendo créditos para seu diploma; durante o semestre seguinte, êle poderia cursar quatro disciplinas valendo créditos. 
Os salários do pessoal universitário nos E.U.A, aumentaram nitidamente nos últimos anos. O salário para o pessoal docente é calculado tendo como base o ano letivo, ou seja, nove meses de aulas; o professor pode também dar aulas nos cursos de verão (essencialmente a metade de um semestre) recebendo 20 a $25 \%$ a mais do seu salário básico. O cálculo para o pessoal docente com alguma responsabilidade administrativa (Diretor assistente ou Diretor associado de uma faculdade, Diretor de um programa de pesquisas, etc.) é geralmente feito na base de cnze meses. O salário pode ser assim aumentado de 20 a $25 \%$ para resultar num salário anual. ${ }^{8}$

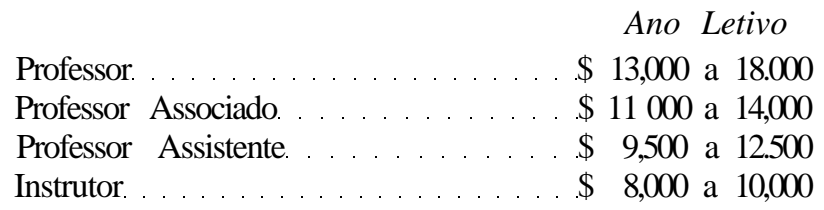

Esta não é uma tabela derivada de dados estatísticos. Os valores não são médias, medianas ou pontos extremos. É uma tentativa de descrever o atual quadro salarial de um departamento, por níveis, e numa Universidade moderadamente competitiva nos E.U.A. O salário médio por nível de todos os professores nos E.U.A, é quase sem significado; a variação indica somente a inexistência de uma escala salarial uniforme. A impressão do autor é que o «valor do mercado» para cada nível - o salário que deve ser oferecido para obter-se um professor bem qualificado - tem aumentado recentemente em torno de US\$ 1,000 por ano. Não dispomos de dados que mostrem o salário por nível em função dos anos de serviço; mas num mercado de constantes e rápidas mudanças, estes valores não seriam significativos. Os valores dos salários que se superpõem são muito significativos: no contexto atual, é bem possível que um professor associado recémnomeado receba um salário mais elevado do que um professor titular mais experiente e mais qualificado do mesmo departamento.

8 Os valores acima apresentam bastante variação se comparados com os dados oficiais. Em 1965, o Digest of Educational Statistics (National Center for Educational Statistics, U.S. Gov. Printing Office, 1966, p. 76) dava a seguinte informação:

\begin{tabular}{|c|c|c|c|}
\hline \multirow[b]{2}{*}{ Professor. } & \multirow{2}{*}{$\begin{array}{l}\text { Média } \\
12.200\end{array}$} & \multicolumn{2}{|c|}{ Variação } \\
\hline & & 9.200 & 17.000 \\
\hline Professor Associado. & 9.600 & $7.500 a$ & 11.600 \\
\hline Prof. Assistente. & .7 .400 & $6.400 \mathrm{a}$ & 9.400 \\
\hline Instrutor. . . . & 6.400 & $5.200 \mathrm{a}$ & 7.800 \\
\hline
\end{tabular}

Estes valores não nos fornecem um quadro realista da atual situação, tendo-se em vista o incrível aumento de salários do corpo docente nos últimos quatro anos; e uma vez que constituem a média de todas as instituições de ensino superior, não representam, mesmo em 1965, a verdadeira situação na Universidade progressista e de tamanho médio, tomada como base para este trabalho. 
Ocasionalmente, uma instituição estabelece salários mínimos para cada nível. Isto significa que nenhum novo professor será trazido para a instituição por menos do que o mínimo determinado para o seu nível. Estes salários mínimos poderiam ser: Professor US\$ 14,100; Professor Associado \$12,000; Professor Assistente \$9,500; Instrutor $\$ 8,00$. Para promoções dentro do departamento, é necessário elevar o salário do candidato ao mínimo determinado para o próximo nível em questão. Por exemplo: um professor assistente com 4 a 5 anos de serviço pode ter um salário atual de $\$ 10,000$. Se êle vai ser promovido, o departamento tem de conseguir verba do seu orçamento para dar ao candidato o salário mínimo determinado para um professor associado (\$12,500, digamos). A promoção dentro do departamento torna-se portanto uma pesada carga para o orçamento departamental. Isto cria uma situação peculiar (e infeliz): é mais fácil para o professor assistente pular de $\$ 10,500$ para $\$ 12,500$ transferindo-se para outra instituição; e uma vez que os salários para novas nomeações não precisam ser incluídos no orçamento departamental existente, é mais fácil, para o departamento, procurar contratar um novo professor associado com um salário de $\$ 12,500$ ou mais. Depois desta nomeação ser efetivada, o salário torna-se então parte integrante do orçamento departamental.

\section{III - Orçamento Departamental.}

Como foi mostrado acima, o departamento tem um orçamento em separado, uma identidade fiscal. $\mathrm{O}$ orçamento departamental constitui-se num elemento do orçamento total da faculdade ou escola onde se localiza aquela unidade. $\mathrm{O}$ orçamento consiste no total de salários de todo o pessoal contratado pelo departamento (pessoal docente e pessoal auxiliar de escritório, o que inclui estudantes), mais as verbas destinadas aos gastos com material, equipamento e serviços. O total de salários do pessoal docente normalmente fornece o valor base para o cálculo das verbas a serem destinadas aos aumentos salariais por mérito ou por promoção. No caso do crescimento do corpo docente para atender a uma crescente matricula ou para enriquecer a variedade de disciplinas oferecidas numa determinada área, o salário do pessoal adicional é somado ao orçamento departamental. O presidente do departamento, como porta-voz da comissão executiva, discute e resolve estes assuntos com o Diretor da Faculdade.

\section{IV - Liderança do Departamento e Estrutura Interna.}

O Presidente. O administrador executivo do departamento é o seu presidente ou chefe. $O$ presidente pode ser eleito através do voto, pelo departamento, tendo sua eleição confirmada pelo Diretor da Faculdade, ou pode ser nomeado diretamente pelo gabinete do Diretor. Seu mandato pode ter a duração de dois ou de três anos, ou pode ter duração indefinida, segundo a vontade do Diretor. A 
chamada «presidência rotativa» consiste num rodízio periódico do cargo entre os membros mais experientes do departamento (sénior). O presidente pode receber, embora frequentemente não receba, uma remuneração adicional pela sua função de presidente; mas em qualquer caso sua carga de ensino é normalmente reduzida como compensação por seus deveres administrativos. O termo «chefe» (head) geralmente implica numa nomeação mais permanente do que o uso da palavra «presidente» (chairman). O presidente funciona como porta-voz oficial do departamento nos debates com o Diretor ou Diretor Associado; prepara e reúne todos os relatórios oficiais sobre as atividades e programas de departamento, e dirige toda a correspondência oficial, além de tratar das substituições em potencial ou da expansão do corpo docente do departamento. ${ }^{9}$

A Comissão Executiva. O presidente, como foi demonstrado, é porta-voz oficial do departamento. A autorização para que êle exerça esta função é dada pela Comissão Executiva. Esta comissão usualmente é composta dos membros sénior do corpo docente do departamento (professores titulares e associados). Todos os assuntos de importância para o departamento têm de ser discutidos neste grupo, em reuniões periódicas convocadas pelo presidente ou solicitadas por qualquer membro do grupo. As decisões ou recomendações para promoções, aumentos de salário por mérito, novos programas de ensino, revisão do conteúdo das disciplinas, novas nomeações, e outros assuntos similares somente chegam a uma consideração final após os debates do grupo, e são enviadas pelo presidente ao escalão adequado (geralmente sob a forma de recomendações).

Comissão Departamental. Pode ser composta de todo o corpo docente de tempo integral, incluindo os professônes assistentes e instrutores. Os assuntos são trazidos a este grupo para uma discussão de caráter geral, e as etapas subsequentes são levadas a efeito pela comissão executiva. Neste grupo são nomeadas as comissões departamentais efetivas e ad hoc. Estas podem incluir as Comissões de Disciplinas de Nível Elementar e Intermediário (destinada a selecionar os textos das disciplinas de multiplesection, elaborar o programa de cada disciplina - course Syllabus - formular e supervisionar os exames multiplesection); a Comissão de Biblioteca (destinada a receber, compilar e enviar à biblioteca as solicitações de livros, e a

9 No contexto atual, esta atividade (recrutamento) tornou-se uma das mais onerosas e uma das tarefas que mais consomem o tempo do presidente. A grande mobilidade do corpo docente é um fenômeno mais ou menos recente na Universidade Americana. Hoje não é raro uma instituição contratar todo o corpo docente sénior de um departamento de outra instituição. A intensa competição por professores de alto gabarito, a rápida expansão do professorado ditada pela crescente matrícula, mais as dificuldades orçamentárias internas do departamento ao lado das crescentes va-iações de salários, tornam quase um imperativo para o professor duas ou três transferências em sua carreira. 
manter um arquivo das publicações solicitadas e recebidas) $;^{10}$ a Comissão dos Clubes Estudantis (destinada a funcionar como uma assessoria das organizações estudantis relacionadas ao departamento, tais como «Clube de Economia», «Clube de Espanhol», etc); e outras comissões ad hoc que sejam necessárias.

\section{VI - Aumentos por mérito e normas para promoção.}

Como foi explicado acima, certa percentagem do total do orçamento departamental para ensino é destinado cada ano a aumentos salariais. Suponhamos que temos um departamento com 16 membros em tempo integral, e com US\$200.000 como seu orçamento para ensino, exclusive o salário do presidente. ${ }^{11}$

O Legislativo Estadual ou o Conselho de Curadores votou um aumento salarial de 6\% (a Universidade solicitou 8\%). Uma determinada parcela da verba para aumento de salários fica retida pela Administração e pelos Diretores, a fim de atender a necessidades específicas, tais como a de cobrir uma oferta que um professor de renome recebeu de outra instituição, ou conceder aumentos por mérito para o presidente do departamento, segundo determinação do gabinete do Diretor. Em fevereiro, o departamento é avisado de que o montante para aumento por mérito a ser utilizado no próximo ano letivo, a iniciar-se em setembro, é de $4 \%$ do seu orçamento total (excluindo o salário do presidente), ou seja, US\$ 8.000,00. A comissão executiva do departamento então reunir-se-á para formular recomendações específicas para aumento de salário de cada membro do corpo docente do departamento. Antes de chegar a estas conclusões, cada membro do departamento terá preparado, com detalhes, um Resumo Anual das Atividades, descrevendo suas realizações e trabalho efetuado nas seguintes áreas: I - Ensino (novas disciplinas ensinadas, novas técnicas empregadas, etc); II — Administração (trabalho nas comissões da Universidade e do Departamento, direção de programas, exercício de funções de tempo parcial em comissões extradepartamentais, etc.); III - Publicações (lista de todos os trabalhos publicados durante o ano, por categoria: livros, artigos, monografias, críticas); IV - Pes quisa (projetos em andamento e/ou terminados); V - Organizações Profissionais (comparecimento a encontros de organizações profissionais,

O departamento algumas vezes tem uma verba orçamentária especifica para comp-a de livros. Estes livros serão guardados na biblioteca central e não no departamento. O depa-tamento normalmente disporá de uma coleção de livrostexto atuais, enviados grátis pelas editoras para «exame»; e talvez uma pequena coleção de obras de referência.

Neste departamento, poderíamos ter 1.500 estudantes matriculados em matérias ao nível de graduação, 20 assistentes de pós-graduação (também estudantes de pós-graduação), mais 5 estudantes pós-graduados sem funções de ensino. Teríamos

1 professores (salários de 16.000 a $1 \mathrm{~S} . \mathrm{O} 00) ; 5$ professores associados $(12.000$ a 13.500); 4 professores assistentes $(10.000$ a 12.500$)$ e 3 instrutores $(9.000$ a 9.500$)$. 
cargos ocupados, trabalhos apresentados); VI - Serviços prestados à Comunidade e Serviços Especiais (conferências públicas realizadas, comparecimento a programas de rádio e de televisão, cargos ocupados ou atividades desenvolvidas em organizações comunitárias, tais como Associações de Pais e Mestres, Rotary, e similares).

Em nosso departamento poderíamos encontrar o Professor Associado X (salário de US\$ 13.000) que está neste nível há quatro anos. tendo publicado recentemente um livro notável na sua especialidade; encontraríamos ainda o Instrutor $\mathrm{Y}$, instrutor há dois anos, tendo recebido há pouco seu diploma de doutorado (junho, p. ex.) e tendo também recebido boa oferta como professor assistente, com um salário de US\$ 11.500 em outra instituição (seu salário atual é de $\$ 9.500)$. Pode ser tomada uma decisão preliminar dando a todos os instrutores (2) um determinado aumento $(\$ 200,00)$; o caso do Professor $\mathrm{X}$ é então considerado em reunião à qual êle não comparecerá. Pode ser decidido recomendá-lo para uma promoção a professor titular, recebendo o salário mínimo para este nível (\$14.100). Isto significa um aumento de $\$ 1.100,00$ para esta pessoa. O Instrutor Y será rotineiramente recomendado para promoção a Professor Assistente, pois êle agora tem o doutorado. Se fôr considerado elemento de grande valia, o departamento pode recomendar sua nomeação a um nível salarial que cubra aquela oferta recebida. Isto significará um aumento de \$2.000 para o Instrutor Y. O total já empenhado é agora \$ 3.500; o saldo, \$4.500, deve ser destinado aos 11 membros restantes do deparlamento. Está claro que só podem ser concedidos aumentos moderados a estes membros do corpo docente (uma média de $\$ 410,00$ cada, com uma provável variação de \$300,00 a \$750,00). A distribuição será feita na base do mérito relativo do pessoal, conforme a opinião da comissão e de acordo com os dados fornecidos pelo Resumo Anual.

Deve-se notar que os fatores para promoção e aumentos por mérito constituem-se em incentivos materiais muito poderosos no sentido de estimular a produção de trabalhos de pesquisa e/ou dar contribuição para outras áreas especificadas no Resumo. Mesmo na categoria de professor titular, onde o incentivo da promoção e da estabilidade já não mais existe, a grande variação de salários é, sem dúvida alguma, eficaz. $^{12}$

\section{VI - Estabilidade}

O instrutor, conforme o acima referido, é normalmente um estudante em vias de obter seu doutorado e que é contratado por um ano,

IL Ao lado disso, outro incentivo naturalmente é o reconhecimento e respeito pelos colegas da Universidade. A variação total do salário do professor é quase que inacreditável, partindo dos $\$ 6.003$ pagos por uma pequena Faculdade com cursos de dois anos e atingindo, segundo informações recentes, a casa dos $\$ 45.000$ - salário pago a um notável professor-pesquisador numa grande Universidade. 
podendo este prazo ser renovado. Após ter sido contratado de uma a três vezes, espera-se que êle apresente sua tese e receba seu diploma de doutor. Estará então qualificado para ocupar um cargo de professor assistente, sendo contratado por um ou três anos.

Em muitas Universidades, quando uma pessoa completa seis ou sete anos de serviço, torna-se qualificado para a estabilidade (tenure). Seu contrato é então renovado automaticamente cada ano e só poderá ser demitida em virtude de baixeza moral, atividades criminais, etc. (for canse, como é chamada).

A estabilidade não tem implicações salariais específicas, mas está geralmente relacionada ao nível da carreira. A promoção ou nomeação para o nível de professor associado ou outro nível acima, implica automaticamente em estabilidade. ${ }^{13}$ A concessão de estabilidade a um membro do corpo docente recém-nomeado ou promovido é recomendada pelo departamento, aprovada pelo Diretor, autorizada pelo administrador chefe ou por uma comissão universitária, e homologada pelo Conselho de Curadores. Podo-se observar que o instrutor está sempre sob pressão: primeiro para completar seu doutorado, e depois como professor assistente, para atingir o desenvolvimento necessário, a fim de que lhe seja concedida a estabilidade e que seja promovido a professor associado.

\section{VI - Programa de pós-graduação.}

Um estudo mais profundo da escola de pós-graduação na Universidade Americana está fora do âmbito deste trabalho.

Nossos comentários sobre o programa de pós-graduação limitarse-ão ao âmbito do departamento. Este conduz as atividades de ensino e outras a elas relacionadas na área de graduação, incluindo as disciplinas básicas ou introdutórias, oferecidas em grande quantidade para os alunos do primeiro e do segundo ano, que estão cumprindo os requisitos gerais da Universidade para as áreas de ensino que estão sendo cursadas. ${ }^{14}$ As disciplinas de nível intermediário e avançado destinam-se aos alunos que as escolheram como uma matéria major ou minor, ou que as cursam como uma matéria optativa ( elective).

13 E' claro que é possível para um professor assistente obter estabilidade (com 4 anos de serviço como instrutor e 3 como professor assistente por exemplo). Normalmente, quando um professor assistente se encontra nesta categoria ou se decide que é vantajosa sua promoção a professor associado com estabilidade, ou êle é demitido do corpo docente. A tradição exige que neste caso a pessoa seja notificaca ao final do seu quinto ano de serviço, ou 365 dias antes que seja feita a recomendação para conceder a estabilidade.

Por exemplo, uma matéria sobre geografia física, física ou química preencheria o requisito de trabalho científico em laboratório; uma disciplina sobre sociologia ou antropologia, o requisito de uma disciplina em ciências sociais; uma disciplina sobre línguas estrangeiras, o requisito de uma matéria sobre humanidades. 
Além disso, o departamento oferecerá um programa de estudos pós-graduados destinados à obtenção dos diplomas de Mestre e Doutor. ${ }^{15}$ Para o programa de pós-graduação, teremos um conjunto formal de requisitos e estipulações gerais, que serão publicadas no Boletim da Universidade. Muitos candidatos (frequentemente a maioria) a um diploma de pós-graduação são nomeados assistentes graduados ou assistentes de ensino. ${ }^{16}$ A este grupo de estudantes de pós-graduação são fornecidos seminários ( seminar) e disciplinas ao nível pós-graduação; algumas vezes as disciplinas do quarto ano de graduação também contam crédito para a pós-graduação. A Escola de PósGraduação ( Graduate School - uma divisão separada da Universidade, que funciona englobando os programas de pós-graduação de todos os departamentos, usualmente se encarrega dos formulários e documentos do estudante de pós-graduação. A Escola de Pós-Graduação também pode estabelecer quais devem ser as qualificações de um membro do corpo docente de um departamento para que êle possa ensinar matérias ao nível de pós-graduação. Neste caso, os professores de todos os departamentos que foram «aprovados» para o ensino de pós-graduação constituirão o Corpo Docente de Pós-Graduação ( Graduate Faculty). A carreira do assistente de pós-graduação já foi descrita acima.

Percebe-se através desta descrição resumida e incompleta que a estrutura e o funcionamento do departamento na Universidade americana são bastante complexos. O conceito de departamento está relacionado a um processo de descentralização de considerável importância no funcionamento da Universidade americana. Dentro do departamento, os membros do corpo docente têm um controle básico e direto sobre os currículos de graduação e pós-graduação; dentro do departamento, estes membros controlam o pessoal de ensino; é dentro

15 Existem muitos diplomas conferidos pela Universidade americana. Os de Bacharel em Ciências (B.S.) e Bacharel em Artes (B.A.) são os diplomas comuns de graduação; os de Mestre em Ciências (M.S.) e Mestre em Artes (M.A.) são os primeiros diplomas de pós-graduação, e o de Doutor (Ph.D.) é o diploma de nível avançado em pós-graduação que é o mais frequentemente concedido. O de mestrado exige em média 1 a 2 anos de estudo após o bacharelado; o doutorado 2 a 4 anos além do mestrado.

16 As atividades de ensino destes assistentes normalmente são supervisionadas por um dos membros sénior do departamento. Em alguns programas de supervisão, vários professores sénior visitam, cada semestre, as turmas às quais o assistente está dando aula, preparando, um relatório sobre a qualidade do trabalho realizado. Existem algumas disciplinas especificas sobre métodos de ensino, as quais valem créditos para a pós-graduação e que devem ser cursadas pelo assistente. A disciplina vale geralmente um crédito e consiste em debates com um professor sénior sobre problemas de ensino e sobre objetivos da matéria e assuntos semelhantes. 
do departamento que o sistema de promoções, de recompensas e de aumentos por mérito é levado a efeito. ${ }^{17}$

A coesão e o senso de identidade desenvolvidos pelo departamento dentro da Universidade americana ê, em suma, basicamente o resultado do papel significativo que êle tem tido no desenvolvimento de sua própria área de conhecimento. ${ }^{18}$

Tradução de

JACQUES R. VELLOSO

Março-1968

\section{GLOSSÁRIO}

College (Faculdade): Neste trabalho a faculdade é considerada como uma das principais divisões duma Universidade, um conjunto de departamentos relacionados a uma grande divisão do conhecimento. A Faculdade de Letras e Ciências, por exemplo, incluiria as seguintes divisões: I) Humanidades (departamentos de inglês, línguas estrangeiras, história, filosofia, oratória, etc); II) Ciências Sociais (departamentos de antrolologia, economia, geografia, sociologia, etc), e III) Ciências Naturais (departamentos de botânica, química, matemática, etc) .

Course (Disciplina): Neste trabalho significa um determinado número de aulas dadas por semana, durante um semestre, sobre um determinado assunto, e valendo um número de créditos específico. Por exemplo:

Economia 100 (Designação da disciplina e indicação do nível introdução) .

3 cr. MWF 10:00 (Valor em créditos da disciplina; dias da semana - segundas, quartas e sextas-feiras - e horário da aula).

\section{A Economia Americana (Nome da disciplina)}

Uma introdução às estruturas, métodos e problemas do Sistema Econômico Americano.

\footnotetext{
17 Em cada área citada existem, naturalmente, escalões administrativos mais elevados que revêm os assuntos: os processos de autorização para novas disciplinas podem ser enviados, para aprovação, a uma Comissão de Disciplinas e Currículos (da Escola ou da Universidade) composta de professores eleitos por todo o corpo docente; no caso de matérias para pós-graduação pode também ser necessária a aprovação da Comissão de Disciplinas de Pós-Graduação. A aprovação dos processos de promoção e aumento por mérito foi descrita acima.

Não se deve supor que o departamento tenha grande autonomia. A chave do seu poder jaz na sua capacidade de iniciar $e$ de recomendar através da posição que ocupa, que tem por base o conhecimento íntimo e especializado da matéria e o seu trabalho em regime de dedicação exclusiva.
} 
Course Syllabus (Programa da Disciplina): Um plano de trabalho para as aulas do curso. Nele, normalmente, será encontrado o conteúdo das aulas e das aulas de debates em pequenos grupos (recitation) para cada dia de aula programada. É particularmente útil como um dispositivo de controle para as disciplinas multiplesection.

Elective Subject (Matéria optativa): Dentro dos requisitos exigidos para graduação, existe certa flexibilidade que permite ao estudante optar (ou selecionar) por determinado número de disciplinas de qualquer área que êle julgue interessante. Estas são chamadas de matérias optativas. Dentro das áreas exigidas (tais como humanidades. ciências sociais, ciências naturais, etc. ), o aluno pode selecionar suas disciplinas a partir de uma lista fornecida para cada área (vide acima, nota 14).

Graduate Faculty (Corpo Docente de Pós-graduação): É o conjunto dos professores, de todos os departamentos, que estão autorizados a dar aulas de disciplinas em nível de pós-graduação. Este grupo pode reunir-se como um conselho docente em separado para estudar assuntos relativos ao programa de pós-graduação da Universidade.

Graduate School (Escola de Pós-Graduação): Constitui-se de toda a organização dos programas de pós-graduação da Universidade, incluindo o corpo docente de pós-graduação (q.v.) que é a ela vinculado, do Diretor da Escola de Pós-Graduação, e das várias comissões.

Lecture Sections (Aulas tipo Conferência) : É uma divisão de uma disciplina em que as aulas sobre os assuntos são dadas a grandes grupos de alunos (100 a 500). Normalmente, não há oportunidade para discussões ou debates.

Major (Disciplina de concentração): Uma disciplina selecionada pelo aluno como principal área de ênfase nos seus estudos universitários. $\mathrm{O}$ departamento determina o número e a natureza das disciplinas que são exigidas na categoria major. $\mathrm{O}$ número de créditos permitido para uma matéria major normalmente não pode exceder $30 \%$ do total exigido para graduação (isto é, 40 créditos de um total de 120 exigidos). Isto é uma garantia de que o aluno terá tido, ao graduar-se, bastante contato com outras disciplinas, além da sua major.

Minor (Disciplina de concentração): Normalmente, quando o aluno é júnior (ou terceiranista do curso de graduação), êle deve escolher uma disciplina major e/ou uma minor. Então será exigido que curse certo número de créditos nesta disciplina. $\mathrm{O}$ departamento determina o número e a natureza das disciplinas que constituem uma matéria minor ou major naquela área de conhecimento. Ver também acima major (matéria).

Ph. D. Committee (Comissão de Doutorado): Um grupo de professores (normalmente 3) nomeados para assessorar e supervisionar a tese de um candidato ao doutorado. O presidente deste grupo é geral- 
mente o professor «major», que trabalha em estreito contato com o candidato na preparação da tese.

Quiz Sections (Aulas de debate e provas): Uma divisão da disciplina na qual os alunos são reunidos em pequenos grupos para debates e avaliação do aprendizado. Normalmente estão relacionados às sessões «Lecture e Rccitation», q.v.

Recitation Sections (Aulas de debate): Uma divisão da disciplina na qual os alunos reunidos em pequenos grupos (15 a 30) respondem a perguntas e entram em debates sobre os assuntos acerca dos quais aulas já foram dadas. Normalmente, são combinadas com as conferências (lecture sections), q.v.

School (Escola): Essencialmente a mesma que a definição resumida de Faculdade («College», q.v.). O termo Escola é usado mais frequentemente para um grupo de disciplinas de um campo profissional, como Escola de Educação ou Escola de Medicina.

Scction: Uma aula organizada com capacidade especificada de alunos, duração determinada e instrutor. As disciplinas «multiplesecíion» são aquelas para as quais é necessário organizar vários grupos de alunos. Por exemplo: Economia 100. 3cr. A Economia Americana. Sessão 1: MWF 10:00 A.M.: Sessão II: MWF 2:30 P.M. (o tempo de duração padrão é de 50 minutos) : Sessão III. MW 7:00-8. 15 P.M.

Seminar (Seminário): Uma disciplina em nível de pós-graduação na qual pequeno grupo de estudantes se reúne com um professor «sénior» para debates gerais e críticas dos relatórios individuais apresentados pelos alunos da turma. Normalmente, exige-se que o aluno escreva um relatório razoavelmente extenso sobre os estudos por êle desenvolvidos no período letivo.

\section{GLOSSÁRIO PARA OS ORGANOGRAMAS}

Associate Dean (Diretor Assistente; Vice-Diretor): Nomeados pelo diretor para manter estreitos contatos com cada subdivisão das divisões disciplinares, como as de Humanidades, Ciências Sociais, etc. (vide glossário, s.v. «College»). Cada vice-diretor coordenará os programas dos departamentos de sua subdivisão por intermédio dos respectivos chefes dos departamentos.

Dean (Diretor): É a autoridade executiva de uma ampla divisão disciplinar da Universidade (escola ou faculdade), tal como Ciências e Letras (Artes), Engenharia, Educação, Belas Artes, etc. O diretor desempenha as funções de coordenador e de diretor administrativo (o que inclui programa orçamentário) e do programa de ensino dos vários departamentos de sua escola, agindo por intermédio dos vice-diretores e dos chefes dos departamentos.

Chancellor (Vice-Reitor): A principal autoridade executiva de uma grande unidade regional da Universidade, tal como um «campus» 
separado ou um subsistema de Centros Universitários. Eín algumas Universidades, o «Chancellor» é a mais alta autoridade executiva de toda a Universidade, e neste caso o termo «Provost» ou outra designação é usado para o cargo executivo subordinado.

Vice-President (Vice-Reitor): Nomeado pelo Conselho de Curadores, por indicação do Reitor, com autoridade delegada para desempenhar as funções relativas à administração e controle de uma das áreas do funcionamento da Universidade. Pode haver um Vice-Presidente de Finanças, de Administração, de Assuntos Estudantis, de Serviços de Extensão, de Pesquisa, etc.

President (Reitor): A principal autoridade executiva de uma Universidade ou de um sistema universitário, nomeado pelo Conselho de Curadores ou de Regentes, e permanecendo no seu cargo enquanto fôr essa a vontade do Conselho. O Presidente tem plenos poderes para supervisionar e dirigir todas as atividades da instituição na área do orçamento, do ensino e dos assuntos relacionados à comunidade, bem como para delegar poderes às autoridades subordinadas para dirigirem estas atividades. 

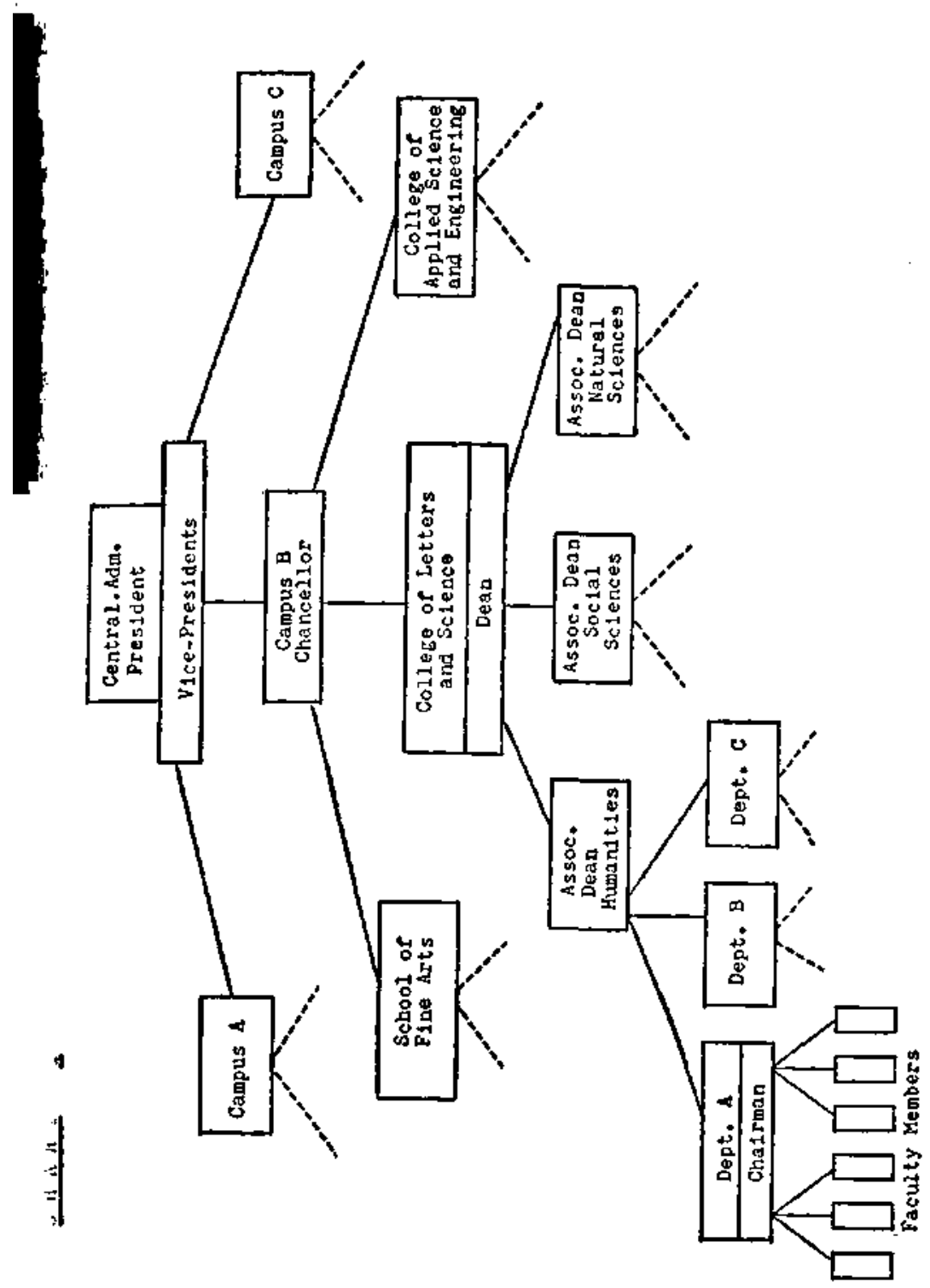

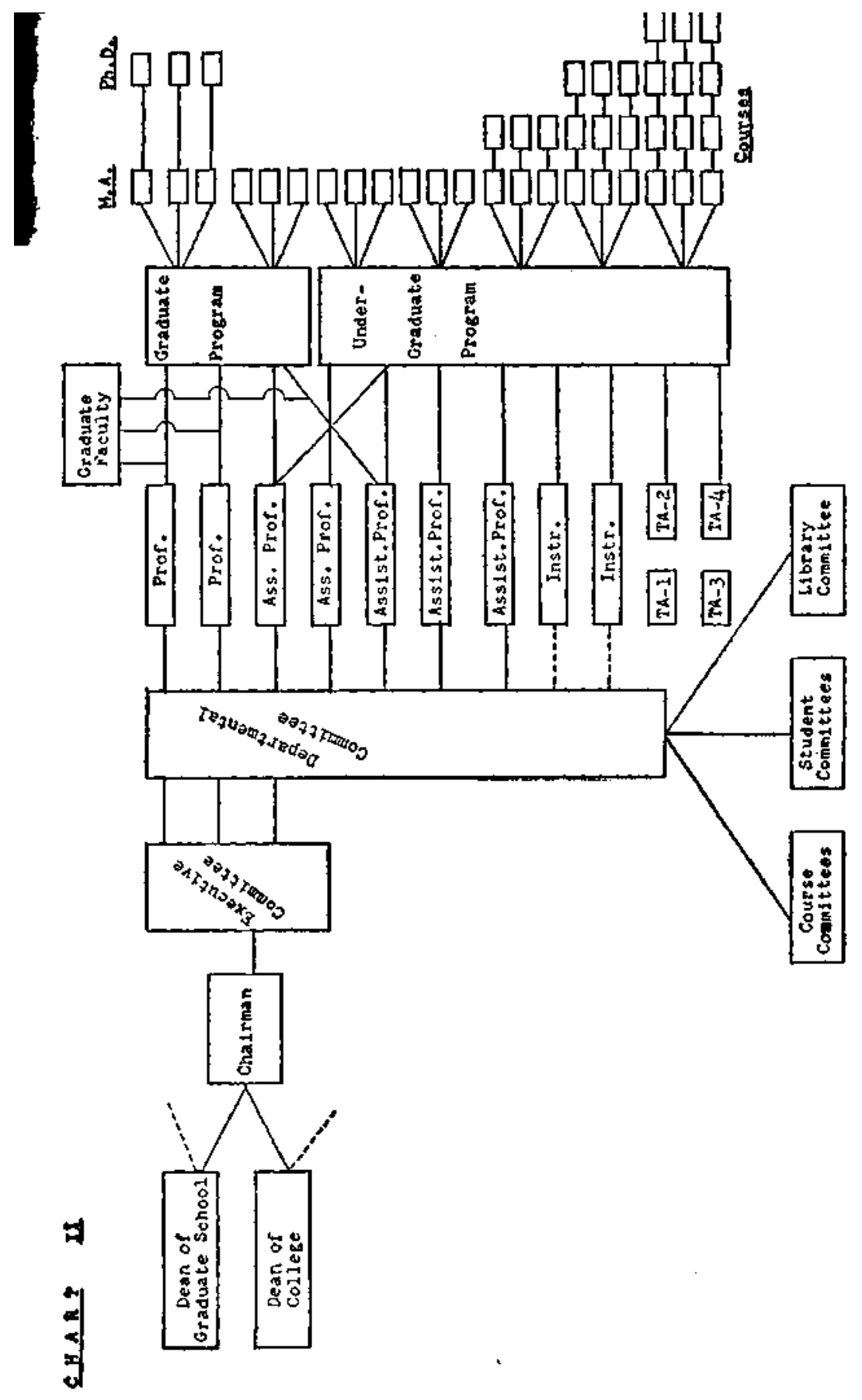
Apendice E. 1

\section{THE UNIVERSITY DEPARTAMENT}

H. W. HOGE

EAPES

This is an attempt to describe the structure and operation of the American University department. It is important to point out at the outset that this paper does not describe the «typical» department of a «typical» U.S. University. The typical American University does not exist. No single, fixed, standard structure is prescribed by legislation or tradition for either the American University or its components. There is consequently a very considerable variation to be observed in the structural and operational characteristics of the department as well as the other component units of the American University.

Despite this variation, there appears to be a certain degree of functional uniformity in the operational role of the department. In the broadest terms, the department may be described as the basic building block of the University structure: it is at once the most elemental administrative unit and the most basic teaching unit of the whole. It must be difficult for the outside observer to become fully aware of the internal processos of the department; even the visiting professor from abroad, with several semesters of contact, might well fail to observe the essential operational principles at work, since he would often be involved almost exclusively in the instructional element of one area (for example, the graduate section) of the departmental program, and since he would frequently be spared the onus of involvement in basic departmental committees.

A fictitious department will therefore be described below. Data on certain structural variations will appear in footnotes. The essential terminology not defined within the body of the text will be listed in an appended glossary. Such terms will be market with an asterisk ( ). It will be assumed that the words «normally» or «usually» are to be applied to all descriptive statements made in this study.

\section{I - COMPOSITION (EXTERNAL STRUCTURE)}

The department may be comprised of a group of faculty members organized to attend to the teaching, research, program development and service needs of a single academic discipline (Geography, Physics, Che- 
mistry, French, etc.); a broader, less specific discipline (Political Science, Zoology, Speech, Linguistics, etc.); or a related set of discipline (Modern Languages, Romance Languages, Fine Arts, Comparative Literature, etc.).

The basic «home» or unit of assignment for the faculty member in the U.S. University is the academic department. The faculty member feels an affiliation directly to this unit, and will cite this as his present position: he will report himself as a professor in the Department of Economics, for example, rather than a professor in the School or

College to which this department may belong. This basic identification with a department arises from and in turn reinforces the departmental role in the selection and appointment process as well as rank promotion and salary adjustment for faculty members.

The department as a whole will consist of all assigned personnel, including secretaries and hourly or part-time student assistants. Confining our description to academic status personnel, we may have the following representation or ranks within a department:

Full Professors (or simply «professors») '

Associate Professors

Assistant Professors

Instructors (full or part-time)

Graduate Assistants.

There is no prescribed table of organization for the department. There are usually several full professors in a single medium-size department. ${ }^{2}$ There is no standard ratio applicable to ranks: there may be two or three full professors in a department with only one associate professors; or there may be several associate professors and only one assistant professor. . It might also be mentioned that faculty members are only exceptionally appointed from the institution's own graduate program. The young $\mathrm{Ph}$. D. will not seek or expect appointment to the department and institution which granted him the degree. In a

1 Other categories -which may be present are a) the Lecturer, or Visiting Professor (a specific rank may be prescribed, such as «Visiting Associate Professor). The Visiting Professor may enjoy all departmental privileges (vote, etc.), but does not acquire time toward tenure, b) The graduate assistant may also be called a teaching associate or «teaching fellow or «research associate (in -which case he will contribute a specific number of hours of work on aproject directed by a senior professor) .

- The number of departmental personnel of the different ranks may well be determined by the recruiting activities of the chairman: an available well quantified full professor may be brought into the department irrespective of the existing rank distribution. 
departament with ten full time faculty members, there might be professors with the $\mathrm{Ph}$. D. degrees from at least six institutions.

The perquisites and conditions of the academic ranks listed, in summary, are as follows:

Professor. The senior position within the department. He will enjoy all privileges accorded to the faculty. The executive officer of the department will often, but not always, be selected or appointed from the professorial rank. The are usually several professors in any given department. Each will teach advanced courses in his own specialty; in departments where there are introductory courses with large enrollments, a full professor may teach the lecture sections, and be placed in supervisory control of the staff of assistants teaching the quiz or recitation sections. The graduate and seminar level courses of a department are usually taught by professors or associate professors. The graduate students working for the $\mathrm{Ph}$. D. will have advisor or a $\mathrm{Ph}$. D. committee selected from this same group. Appointment or promotion to full professor recognizes significant academic achievement in a field of knowledge, usually involving a national reputation and publication of several books and monographs. This rank is seldom accorded for teaching excellence alone.

Associate Professor. The next most senior position. With this rank, the condition of tenure is usually granted, and the faculty member is considered qualified for appointment or inclusion in the Graduate Faculty. If elected or appointed, the associate professor may also serve as the chief executive of the department (even though several «full» professors are on the departmental staff). The promotion or appointment to associate professor is thus a highly significant point in a faculty member's academic career, indicating that the recipient has produced significant research in his field and that he has the potential for further academic growth.

Assistant Professor. The lowest of the «professor» categories. This rank is ordinarily attained more or less automatically by virtue of having received the $\mathrm{Ph}$. D. degree. It is a «trial» phase: the assistant professor has demonstrated that he has received the training and has the potential for significant research and teaching; he is now expected to give evidence of this potential.

3 The academic principle involved here is significant, in that the net result is the dispersion, propagation and fusion of teaching and research techniques throughout the system. The practice of retaining local products is called «in-breeding». The same principle is accepted in the composition of the student body, both undergraduate and graduate. A very considerable percentage (20-30\%) of out-state or foreign students is considered highly desirable. State political factors occasionally exert a reserve pressure in this area, since the state essentially is subsidizing the education of non-state students (out of state tuition, although much higher than in-state charges, does not cover the actual per-student costs of education). 
Instructor. The lowest rank in the full-time teaching staff. In some institutions certain faculty privileges are not accorded to the instructor. The instructor is often a person who has completed all requirements for the $\mathrm{Ph}$. D. degree except the dissertation or thesis. He is therefore free to accept a full-time position at another institution while he prepares or completes the dissertation at his home institution.

Graduate Assistant - Teaching Associate. This is not considered to be a faculty position, and includes part-time teaching or research assistant duties. The teaching assistant or associate is a post-graduate student: he has completed the basic four years of University training and has received the appropriate baccalaureate degree (A.B. or Ph. D. degree. His part-time teaching produces a modest income; ${ }^{4}$ housing is often made available by the University at reasonable rental rates. When the graduate assistant completes all course requirement for the $\mathrm{Ph}$. D. degree, he may move to another institution as an instructor; upon completion of his degree he will routinely be promoted to assistant professor.

\section{II - TEACHING LOAD AND SALARY SCALE}

The teaching load of the faculty is indicated in terms of hours or credits. ${ }^{5}$ Each hour means one hour of lecturing or other activity with a class. It is made clear to the newly appointed professor that his duties consist not only of teaching, but also of research and service to the community. Teaching hours and total hours (including preparation for teaching) devoted to the profession therefore vary enormously.

The teaching load varies by rank: the higher-ranking professors have fewer hours of teaching per week, but in more advanced classes. In many subject matter areas, the professor or associate professor will teach no elementary or introductory sections; in departments with a large graduate program, he may have no undergraduate classes.

4 Ranging from $\$ 3,000$ to $\$ 3,500$ per academic year (nine-months).

6 Courses may vary in value from 1-5 credits. A 2-credit course will usually meet for two hours per week for one semester. Laboratory courses (Chemistry, Physics, etc. may have a different weighting of class hour $v s$ credit. More advanced courses frequently have fewer class meeting per week (credits) than introductory or elementary courses. Elementary course tend to carry 3-5 credits; intermediate, 2-3; and advanced or graduate, 2 .

8 A recent survey at the University of Wisconsin indicated as average number of hours per week in excess of 60 . of this total, about $25 \%$ hours per week, were given to research; about $5 \%$ or 3 hours, to service, and the balance, 42 , was devoted to teaching and preparation for teaching. 
The teaching load in our fictitious department might be as follows, by rank:

\begin{tabular}{|c|c|c|c|}
\hline & Rank & Load & Type \\
\hline Professor & & $10-12$ & $\begin{array}{l}\text { A seminar (2) and two advanced } \\
\text { courses (4-6). }\end{array}$ \\
\hline Associate & Professor & $8-10$ & $\begin{array}{l}\text { Two advanced (4-6) and one or two } \\
(4-6) \text { intermediate. }\end{array}$ \\
\hline Assistant & Professor & $6-8$ & $\begin{array}{l}\text { Two intermediate }(4-6) \text { and one or two } \\
\text { elementary courses }(6-8) \text {. }\end{array}$ \\
\hline Instructor & & $12 \_15$ & $\begin{array}{l}\text { Several introductory courses }(8-10) \text { and } \\
\text { one or two intermediate }(4-6) \text {. }\end{array}$ \\
\hline Teaching & Assistant & $4-6$ & One or two introductor courses. \\
\hline
\end{tabular}

Salaries of University personnel in the U.S. have increased sharply in recent years. The base salary for the teaching staff in calculated on an academic year or nine-months basis; the professor may then be employed in summer school (essentially a half-semester) for an additional $20 \_25 \%$ of his base salary. Faculty with some administrative responsability (associate or assistant dean, director of a research program, etc.) are usually placed on an eleven-months basis. The figures given may thus be increased by $20-25 \%$ to give an annual salary figure.

\begin{tabular}{|c|c|c|c|}
\hline & & Academic & Year \\
\hline Professor & & $13,000-$ & 16,000 \\
\hline Associate & Professor & $11,500-$ & 14,000 \\
\hline Assistant & Professor & $9,500-$ & 12,500 \\
\hline Instructor & & $8,000-$ & 10,000 \\
\hline
\end{tabular}

7 The teaching assistant may teach two introductory courses in one semester and one course in the following semester. The number of courses he may pursue personally toward his advanced degree requirements may be controlled by the amount of teaching. During the semester in which he teaches two courses, he may be permitted to take only courses for graduate credit: during the other semester, he might take four such courses.

The figures given are at considerable variance with official data. As of 1965, the Digest of Educational Statistics National Center for Educational Statistics, U.S. Gov. Printing Office, 1966, p. 76) gives the following information:

\begin{tabular}{|c|c|c|}
\hline & Mean & Range \\
\hline Professor. & $.12,200$ & $9,200-17,000$ \\
\hline Associate Professor. & 9,600 & $7,500-11,600$ \\
\hline Assistant Professor & 7,400 & $6.400-$ \\
\hline Instructor . . . . & 6,400 & $5,200-$ \\
\hline
\end{tabular}

The figures do not give a realistic picture of the current situation in view of the dramatic increase in faculty salaries in the last four years; and since they are the averages of all institutions of higher learning, they do not represent, even as of 1965 . the real situation in the fictious medium-size progressive University taken as the basis for this paper. 
This is not a statistically derived table. The figures are not averages, means or extreme ranges. It is an attempt to describe the current departmental salary picture by rank at a moderately competitive small University in the U.S. The average salary by rank of all U.S. professor is nearly meaningless; the range is an indication only of the lack of a uniform salary scale. The writr's impression is that the «market value» of each rank - the salary which must be offered to obtain a well qualified professor - has been increasing by about $\$ 1,000$ per year. I have no data available which show salary by rank according to years of service; but in a rapidly-changing market, these figures would not be significant. The overlapping salary figures are quite significant: in today' context, it is quite possible that a newly appointed associate professor will receive a higher salary than a more experienced and qualified full professor in the same department.

Occasionaly, an institution wil! establish salary minima for each rank. This means that no new professor is to be brought to the institution for less than the prescribed minimum for his rank. These minimum salaries might be as follows: Professor: \$14,100; Associete Professor: \$12,500; Assistant Professor: \$9,500; Instructor: \$8,000. For promotion within the department, it is then necessary to bring the candidate to the minimum for the next higher rank involved For example: the assistant professor with 4-5 years of service may have a current salary of $\$ 10,500.00$. If his is to be promoted, the department must allocate funds from its budget to bring the candidate to the prescribed minimum for assoiate professor $(\$ 12,500.00$, let us say). Promotion within a department thus becomes a severe strain for the departmental budget. This creates a peculiar (and unfortunate) situation. Is is easier for the assistant professor to make the jump from $\$ 10,500.00$ to $\$ 12,500.00$ by moving to another institution; and since the salary for new appointments is not chargeable to existing departamental fund, it is easier for the department to seek e new associate professor appointment at $\$ 12,500.00$ or more. After this appointment is made, the salary then becomes a part of the departmental budget.

\section{Ill - DEPARTMENTAL BUDGET}

As indicited above, the department has a separate budget, a fiscal identity. This departmental budget constitutes an element of the total budget, of the school or college in which the department is located. This budget consists of the total of salaries of all personnel assigned to the department (teaching staff, clearical and student help), plus funds assigned for supplies, equipment, and services. The total amount of professorial salaries ordinarily supplies the base figure for the calculation of the funds to be made available for merit and/or across-the-board salary increases. In the case of staff expansion to meet rising student enrollment or to enrich the departmental offerings in a certain area, the salary of the aditional personnel is added to the departmental budget. 
The chairman of the department, as spokesman for the executive comimittee. negociates with the Dean of the College on these matters.

\section{IV_ DEPARTMENTAL LEADERSHIP AND INTERNAL STRUCTURE}

The Chairman. The executive officer of the department is the chairman or head. The chairman may be elected by vote of the department and confirmed by the Dean of the College, or he may be appointed directly from the Dean's office. He may serve a fixed two-or three-year term, or he may serve indefinitely at the pleasure of the Dean. The so-called «rotating chairmanship is periodically circulated among the senior members of the department. The chairman may, but often does not receive additional remuneration for serving as chairman; but in any case his teaching load is usually reduced in compensation foi his administration duties. The term «head» often implies a more permanent appointment than the word «chairman». The chairman serves as the official spokesman for the department in discussions with the Dean or Associate Dean; he prepares or assembles all official reports on departmental programs and activities, and conducts all correspondence with potential replacements or expansion faculty for the department.

The Executive Committee. The chairman, as indicated above, is the official spokesman for the department. His authorization for this role comes from the Executive Committee. This committee is usually composed of the senior faculty members of the department (associate and full professors). All departmental matters of substance must be discussed with this group in periodic meetings called by the chairman or requested by any member of the group. Decisions or recommendations for promotion, merit raises, new teaching programs, course revisions, new appointments, and the like are reached only after consideration by this group, and are relayed to the appropriate higher level (usually in the form of recommendations) by the chairman.

Departmental Committee. May consist of all full-time teaching staff, including assistant professors and instructors. Matters may be brought to this group for general discussion, with subsequent action taken by the executive committee. In this group, the standing and ad hoc committees of the department are appointed. These may include Elementary and Intermediate Course Committees (to select the texts for multiple-section courses, plan the course syllabus, formulate and supervise the multiple-section examinations); the Library Committee (to

In today's context, this activity ("recruiting) has become one of the most onerous and time-consuming tasks of the chairman. The increased mobility of the faculty is a fairly recent phenomenon in the American University. It is not now unusual for one institution to hire the entire senior staff of a department in another institution. The keen competition for top-flight scholars, the rapid expansion of the professorate dictated by rising enrollment, plus the internal departmental difficulties in keeping pace with the rising salary ranges, make it almost imperative for a professor to make two or three moves in his career. 
receive, collect and transmit to the library requests for books, and to maintain a local file of items ordered and received; ${ }^{10}$ Student Club Committee (to serve as advisors to the student organizations related to the department, such as the «Economics Club», «The Spanish Club», etc.); and other ad hoc committees as required.

\section{$\mathrm{V}$ - MERIT INCREASE AND PROMOTION PROCEDURES}

As noted above, a certain percentage of the total department budget for instruction is assigned each year for salary increases. Let us assume that we have a department with 16 full time members, and $\$ 200,000$ as its present instructional budget, excluding the salary of the chairman. ${ }^{u}$ A $6 \%$ salary increase has been voted by the State Legislature or Board of Trustees (the University had requested 8\%). A certain amount of the salary increase funds are retained by the Administration and the Deans, to take care of special needs, such as matching the ofter received by a distinguished professor from another institution, and for the merit raises for the Departmental chairman, determined in the Dean's office. In February, the department receives word that its merit-increase sum for the following academic year to begin in September is $4 \%$ of its total budget (excluding the chairman's salary), or $\$ 8,000.00$. The executive committee of the department will now meet to formulate specific recommentations for salary increases for each faculty member of the department. Prior to this, each member of the department will have prepared a detailed Annual Summary of Activities, describing his accomplishments and services in these areas: I. Teaching (new courses taught, new techniques employed, etc.); II. Administration (University and Departmental committee service, program direction, part-time assignment to extra-departmental programs, etc.); III. Publications (list of all publications during the year by category: books, articles, monographs, reviews); IV. Research (projects in progress and/or completed); V. Professional Organization (attendance at meetings of professional organizations, offices held, papers delivered); VI. Community and Special Services (public lectures given, radio or TV appearance, offices held or activies in community organizations, such as Parent-Teacher's Association, Rotary, or the like).

Another factor present in the situation may be that Associate Professor X (salary $\$ 13,000$ ) has been in rank for four years, and has

10 The department will sometimes have a specific budgeted amount for book purchases. These books -will be housed in the central library, and not in the department. The department will usually have a collection of current text-books, sent «for examination by the publishers at no cost, and perhaps a small collection of reference works.

11 In such a department, we might have 1.500 students enrolled in undergraduate courses in the subject matter, 20 graduate assistants (also graduate students) plus 5 non-teaching graduate students. We might have 4 professors (salaries 16,000 to $18,000) ; 5$ associates professors $(12,000$ to 13,000$), 4$ assistants professors $(10,000$ to $12,500)$ and 3 instructors $(9,000$ to 9,500$)$. 
recently published a noteworthy book in the field; also Instructor $\mathrm{Y}$, an instructor for two years, has just received his $\mathrm{Ph}$. D. degree in June, and has received a firm offer as assistant professor at $\$ 11,500$ in another institution (his present salary is $\$, 9,500$ ). A preliminary decision may be made to give all instructors (2) a token raise (\$200.00); then the case of Professor $\mathrm{X}$ is considered (with Professor $\mathrm{X}$ excluded from this meeting). It may be decided that he should be recommended for promotion to full professor, at the minimum salary for that rank.

$(\$ 14,100.00)$. This will mean a raise of $\$ 1,100.00$ for this person. Instructor Y would routinely be recommended for promotion to Assistant Professor, since he now has the Ph. D. If the is considered to be a very valuable person the department may decide to recommend promotion at a salary matching the outside offer. This will mean a $\$ 2,000.00$ raise for Instructor $\mathrm{Y}$. The total allocated is now \$3,500; the balance, $\$ 4,500$, to be assigned to the remaining 10 membrs of the department, It is clear that only moderate raises can be assigned to these faculty members (an average of $\$ 450.00$ each, with the range probably being from $\$ 300.00$ to $\$ 750.00$ ). This distribution will be made on the basis of the relative merits of the personnel, as determined by committee opinion and the data supplied in the Annual Summary.

It will be observed that the promotion and merit raise elements provide very powerful mundane incentives for continuous efforts to produce scholarly research and/or contributions in the other areas specified in the Summary. Even in the full professor category, where the incentive of promotion and tenure has disappeared, the wide range of salaries is surely effective. ${ }^{12}$

\section{VI - TENURE}

The instructor, as noted, is normally a near-Ph. D., appointed for one-year renewable terms. After one three such appointments, he is expected to complete the dissertation and receive his $\mathrm{Ph}$. D. degree. $\mathrm{He}$ is then eligible for an assistant professorship, which may be for either one or three-year terms.

When a person has completed six or seven years of service in many Universities, he becomes eligible for tenure. His contract is then automatically renewed each year, and dismissal can arise only «for cause» (moral turpitude, criminal activities, etc.). Tenure carries no specific salary implications, but it is generally related to rank. Promotion or appointment at the rank of associate professor and above automatically

In addition to the concomitant reward of recognition and respect in the academic profession, of course. The full range of Professorial salary is nearly incredible, ranging from the $\$ 6,000.00$ of a small two-year college to the $\$ 45,000.00$ reported recently for a research professor in a major University. 
implies tenure. ${ }^{13}$ A tenure status for a newly appointed or promoted faculty member is recommended by the department, approved by the Dean, authorized by the chief administrator or a University committee and confirmed by the Board of Regents. It can be seen that the instructor is under pressure, first to complete his $\mathrm{Ph}$. $\mathrm{D}$, and then as an assistant professor, to acquire the stature necessary for approval of tenure and promotion to associate professor.

\section{VII - GRADUATE PROGRAM}

A full consideration of the graduate school in the American University is beyond the scope of this paper. We will limit our comments to the departmental level of involvement in the graduate program. The department will normally conduct teaching and related activities in the undergraduate area, including basic or introductory course work offered largely for first and second year students who are discharging general University requirements in the academic area involved. ${ }^{14}$ The intermediate and upper-level courses serve students who have selected the discipline as a major or minor subject, or who take advanced course work as an elective. In addition, the department will offer a postgraduate program of studies leading to the Master's or Ph. D. degrees. ${ }^{15}$ A formal set of course requirements and general stipulation will exist for this graduate program, and will appear in the University Bulletin. Many (often the majority) of the candidates for a graduate degree will be appointed as graduate assistants or teaching associates. ${ }^{16}$ Separate seminar and graduate-level courses will be provided for this corps of graduate students; at times the fourth-year undergraduate courses will also carry graduate credit. The processing of graduate student appli-

13 It is clear that the possibility of tenure for an assistant professor exists (with 3 years service as instructor and 4 as assistant professor, for example) . Ordinarily an assistant professor in this category is either determined to be worthy of promotion to associate professor -with tenure or he is dismissed from the faculty. Tradition requires that such a person be notified at the end of his fifth year service, or one full year before the recommendation for tenure is to be made.

14 For example, a course in Physical Geography, Physics or Chemistry would discharge a Laboratory Science requirement; a course in Sociology or Anthropology, a Social Science requirement; a course in foreign languages, a Humanities requirement.

'"' There are many degrees conferred by the U.S. University. The B.A. and B.S. are common undergraduate degrees; the M.A. and M.S. are first post-graduate degrees; and the $\mathrm{Ph}$. D. is the most frequently granted second post-graduate degree. The M.A. will require an average of 1-2 years of study beyond the baccalaureate degree; the Ph. D._ an adi'ttional 2-4 years.

16 The teaching activities of these assistants will usually be supervised by one of the senior members of the department. In some supervisory programs, several senior faculty members will visit the classes conducted by the assistant each semester, and will prepare a report on the quality of his work. There is sometimes a specific graduate credit course in teaching methods which the assistant is required to take. The course is generally a one-credit course and consists of discussions with a senior faculty member on teaching problems, objectives of course, and the like. 
cations is usually handled the Graduate School (a separate division of the University serving all departments which have graduate programs) . The Graduate School may also rule on the qualifications of a departmental faculty member to teach graduate courses. In this case, the faculty members of all departments who have been «cleared» for graduate instruction will constitute the Graduate Faculty. The career path of the graduate assistant has been described above.

From this brief and incomplete description, it is seen that the structure and operation of the department in the American University is quite complex. The departmental concept is related to a decentralization process of considerable significance in the operation of American University. From within the department, the faculty members have immediate basic control of the undergraduate and graduate curriculum; from within the department, the faculty members control the teaching personnel; from within the department, the system of promotion, rewards and merit raises is implemented.

The cohesiveness and sense of identity which the department has developed within the American University, in short, is basically a result of the significant role which it has had in the development of its own discipline. ${ }^{18}$

\section{GLOSSARY}

College: In this study, the College is taken to be one of the major divisions of a University, a grouping of departments related to a broad division of (knowledge. The College of Letters and Science, for example, would include departments in I.) Humanities (English, Foreign Languages, History, Philosophy, Speech, etc.), II.) Social Sciences (Anthropology, Economics, Geography, Sociology, etc.) and III.) Natural Sciences, (Botany, Chemistry, Mathematics, etc.).

Course.- As used in this paper, a class in a given subject matter, meeting a prescribed number of times per week for one semester, and carrying a specific number of credits. For example:

Economics 100 (Course designation and indication of level-introductory)

3 cr MWF 10:00 (Weight of course in credits; days and time of class meeting)

The American Economy (Course title) system.

An introduction to the structures, process and problems of the American Economic

In each area cited, of course, there are higher levels of administrate review: new course authorizations may be channeled through a Course and Curriculum Committee (of the School or of the University), consisting of professors elected by the entire faculty; in the case of graduate courses, the proposal may also need to be reviewed by a Graduate Course Committee. The review procedures for promotion and merit raises has been described above.

It should not be assumed that the department has any large measure of utonomy. The key to its control power lies in its ability to initiate and recommend. from a position of knowledgeability, expertise, and full-time professional involvement. 
Course syllabus: A detailed plan for the conduct of a course. This will normally give the lecture or recitation content for each scheduled class meeting. It is particularly useful as a control device for multiple-section courses.

Elective (Subject): Within the prescribed requirements for graduation, a certain flexibility exists which permits the student to elect (or select) a certain number of courses from any field he may find interesting. These are called elective subjects or courses. Within the required areas (such as Humanities, Social Sciences, Natural Sdiences, etc.) the student may select his courses from a list provided for each area (see note 14, above).

Graduate Faculty: The body of professors of all departments authorized to teach graduate - level courses. This group may meet as a separate faculty unit to consider matters relative to the graduate program of the University.

Graduate School: The entire graduate program organization of the University, including the affiliated graduate faculty (q.v.), the Dean of the Graduate School, and the various committees.

Lecture sections: A division of a course in -which lectures on the subject matter are presented to large group of students (100-500). There is ordinarily no opportunity for discussion or debate.

Major (Subject): A discipline selected by the student as a principal area of emphasis in his university studies. The department will prescribe the number and nature of the courses which are required for the major. The number of credits permitted in a major subject will not exceed $30 \%$ of the total required for graduation (i.e.. 40 credits of a total of 120 required). This guarantees that the student will have received an appreciable exposure to several disciplines other than his «majon>.

Minor (Subject): Usually as a junior (or third-year undergraduate), the student must select a major and/or minor subject. He will then be required to take a certain number of credits in this discipline. The department will prescribe the number and nature of its courses which will constitute a minor or major in that subject. See also Major (subject), above.

Ph. D. Committee: A group (usually 3) of professors appointed to advise and supervise the dissertation of a $\mathrm{Ph}$. D. candidate. The chairman of this group is usually the major professors, who works closely with the candidate in the preparation of this dissertation.

Quiz sections: A division of a course in which students are assembled in small groups for discussion and evaluation. Ordinarily related to the Lecture and Recitation sections, q.v.

Recitation sections: A division of a course in which the students, assembled in small groups (15-30) are called upon to respond to question and enter into discussion of the subject matter. Normally combined with Lecture Sections, q.v.

School: Essentially the same as the limited definition of the College (q.v.). The School may be used more frequently for a grouping of disciplines in a professional field, such as the School of Education or the School of Medicine.

Section: An organized class with a specified capacity, time and instructor. Multiple-section courses will be those for which is necessary to organize several groups of students. For example: Economics 100. 3cr. The American Economy. Section 1: MWF 10:00 A.M.; Section II: MWF: 2:30 P.M.; Section III: MWF: 7:00 - 8:15 P.M.

Seminar: A graduate-level course in which a small (3-10) group of graduate students meet with a senior professor for general discussion and critiques of individual reports given by class members. A fairly extensive written term report or individual study is usually required of each student. 


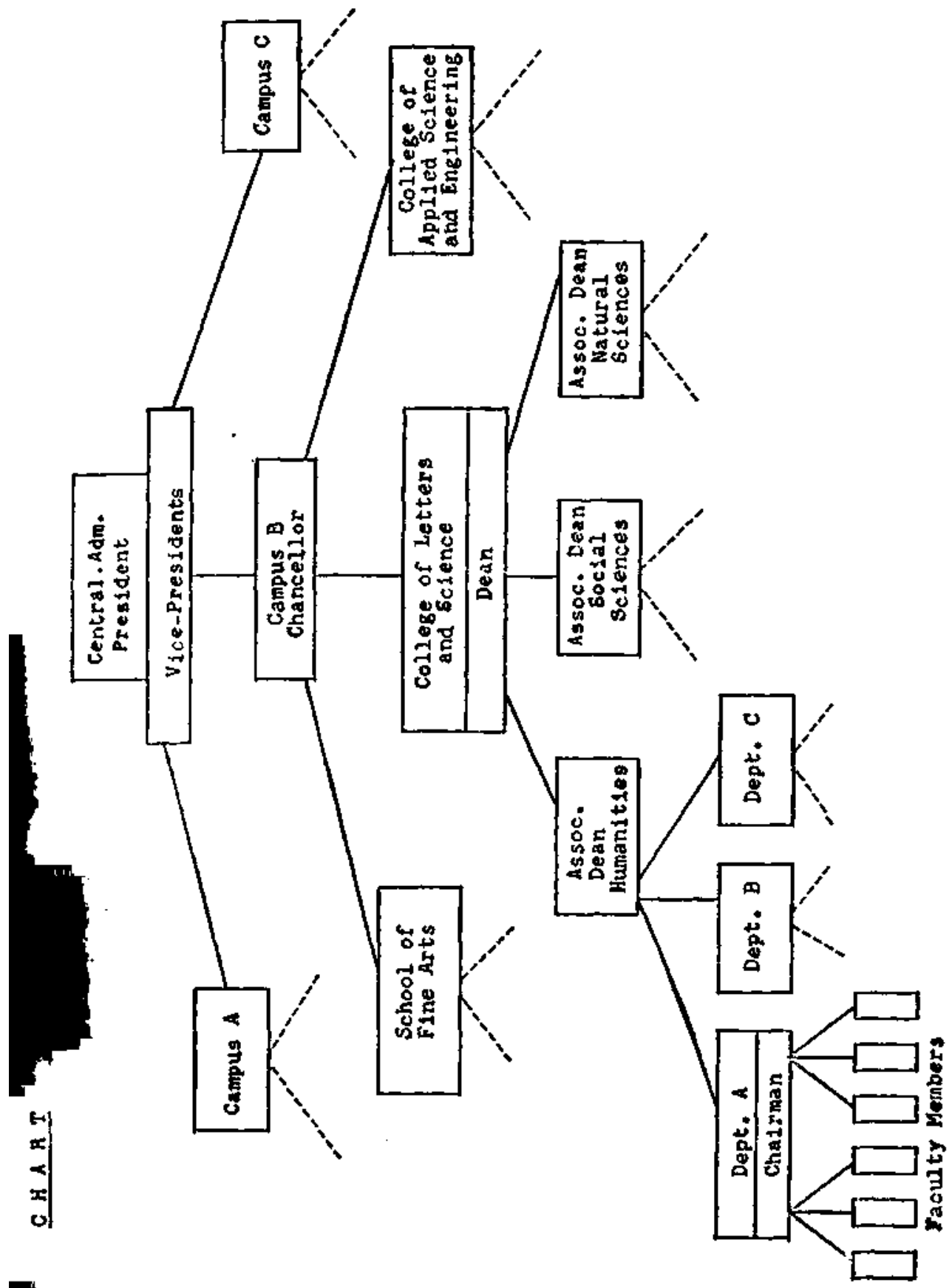




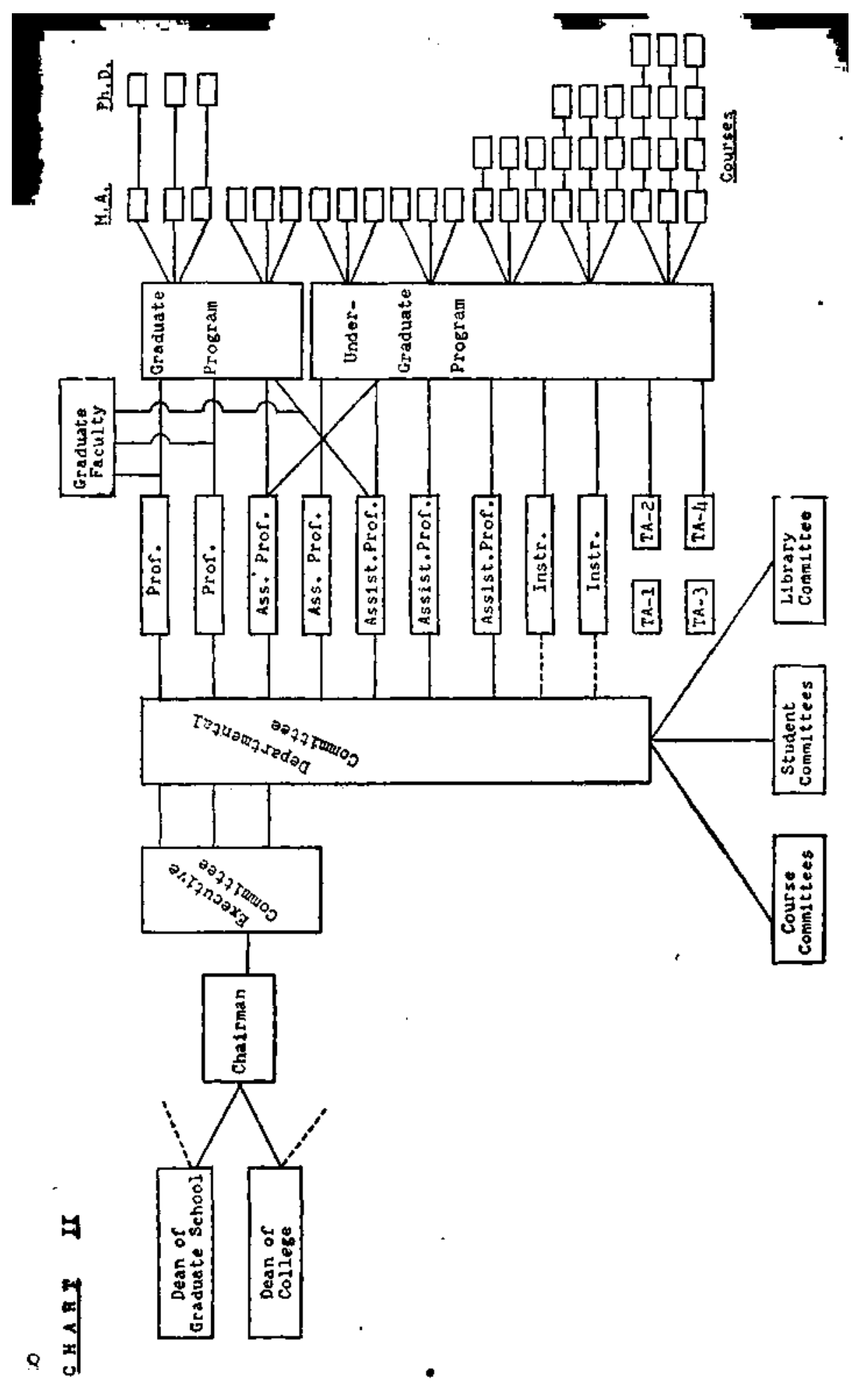


Apêndice E. 2

\section{ESTRUTURA DO CORPO DOCENTE}

HENRY W. HOGE

Outros trabalhos desta série descreveram o sistema de créditos, o departamento na Universidade, e a organização geral da Universidade.

Neste estudo suporemos que o leitor tem conhecimento dos assuntos tratados nos trabalhos mencionados. Este ensaio, portanto, limitar-se-á à descrição e discussão de alguns aspectos da estrutura do corpo docente de uma Universidade americana representativa.

O primeiro problema com que nos defrontamos pode ser um de semântica: a definição do termo «corpo docente» (faculty). A palavra corpo docente (ou Congregação) será empregada, no nosso estudo, no sentido da totalidade do pessoal universitário que possui nivel docente e se dedica ao ensino ou ao ensino juntamente com atividades de pesquisa. Assim, excluímos os diretores das várias escolas ou faculdades. que estarão ligados a um departamento específico e possuirão um título docente (professor de História, professor de Zoologia, etc), mas estarão exercendo atividades de ensino e/ou de pesquisa. Se classificarmos estes diretores segundo a dicotomia administração - corpo docente, eles serão incluídos na administração. Mas esta distinção não será mantida em todas as circunstâncias. $O$ diretor de uma faculdade pode ensinar uma disciplina em nível avançado, dentro de sua especialização; os diretores associados frequentemente ensinam em tempo parcial num determinado departamento, e participam plenamente dos assuntos acadêmicos do departamento. ${ }^{2}$

É preciso que nos refiramos a algumas exclusões da categoria «corpo docente». $\mathrm{Na}$ estrutura de níveis frequentemente encontrada na Universidade americana (associado ou assistente de ensino; instrutor; con-

Mais uma vez, como nos trabalhos anteriores, desejamos evitar o uso do termo «tip:co». Nossos comentários sobre a ampla variação da estrutura das Universidades nos Estados Unidos são igualmente aplicáveis ao presente tema. O problema da definição da «Universidade» e do termo «corpo docente» (faculty) já foi discutido num ensaio do professor John Hunter, intitulado A Estrutura da Educação Superior nos Estados Unidos.

Dando margem, assim, a uma possível situação de interesses conflitantes a qual um diretor associado de Ciências Sociais (digamos) vota as recomendações de aumento ou promoção por mérito, cujo processo mais tarde passará por suas mãos como autoridade administrativa da divisão a que pertence o departamento. 
referencista; professor assistente; professor associado; professor titular), o associado de ensino não é considerado membro do corpo docente, embora certamente seja um membro do «corpo de ensino»; pode-se conceder ou não ao instrutor o status de membro do corpo docente; e normalmente se consideram os que têm nível de «professor» (professor assistente e acima) com direito a todas as prerrogativas do corpo docente. $^{3}$

O departamento, conforme já comentamos anteriormente, é a unidade à qual o membro do corpo docente está basicamente ligado. É no âmbito do departamento que se determina, ou nele se recomenda, através de seus mecanismos operacionais, a designação das matérias que o professor deve ensinar, seus projetos de pesquisas, suas nomeações para comissões departamentais e suas promoções ou aumentos por mérito.

Contudo, um membro do corpo docente também está estreitamente ligado a várias unidades multidisciplinares da Universidade, conforme é mostrado o Diagrama I. O professor A será um membro do Departamento A, como já foi dito; e também pertencerá à Divisão A. Esta divisão consistirá de um grupo de departamentos de disciplinas relacionadas entre si, tais como Humanidades (incluindo os departamentos de história, todas as línguas estrangeiras e clássicas, literatura comparada, filosofia, oratória, história da arte); Ciências Sociais (incluindo os departamentos de antropologia, economia, geografia, história, jornalismo, linguística, ciência política, psicologia, sociologia); e Ciências Naturais (departamentos de astronomia, bacteriologia, bioquímica, botânica, química, geografia, geologia, matemática, meteorologia, filosofia, física, psicologia.

A divisão pode não ter identidade administrativa específica, a não ser a existência de um diretor associado da faculdade trabalhando exclusivamente com os presidentes dos departamentos da divisão. Todavia, o conceito de divisão pode ter um significado vital na área do controle do currículo pelo corpo docente e no processo de promoção e de concessão de estabilidade. Conforme comentamos anteriormente, a

3 Entretanto, a diferenciação entre as prerrogativas pode existir mesmo nos níveis de professor. A comissão executiva do departamento pode ser composta somente de professores associados e titulares. Vide nossa discussão do assunto em O Departamento na Universidade Norte-americana.

4 Não repetiremos os dados já apresentados, anteriormente, nem o funcionamento interno do departamento.

\footnotetext{
5 Deve-se notar que vários departamentos (principalmente História) aparecem em mais de uma divisão. Isto se deve, em parte, ao fato de que somente algumas matérias (História da América, História contemporânea, p. ex.) de um dado ramo do conhecimento (História, no caso), pertencente a um departamento, estão incluídas uma determinada divisão; outras matérias (no sentido empregado) oferecidas pelo mesmo departamento aparecerão em outra divisão. Uma análise rápida e superficial sugere que existe certa falta de lógica na distribuição pelas divisões. A distribuição adequada de uma dada disciplina é, às vezes, ponto discutível, ou mesmo objeto de debates.
} 
recomendação para promoção e estabilidade parte do departamento. ${ }^{\text {fi }}$ Tal recomendação tem um peso considerável, mas não é absolutamente final A recomendação para promoção e/ou estabilidade segue por canais que levam ao diretor associado e ao diretor da escola, e, algumas vezes, simultaneamente, é submetida a uma comissão da divisão que expressa sua opinião oficial e influente. A comissão da divisão usualmente é eleita pelo voto do corpo docente da escola. A distribuição das disciplinas pelas divisões também é de grande interesse para o aluno, pois as exigências para sua graduação, conforme é determinado no Boletim da Universidade, normalmente demandam um número de créditos específicos em matérias pertencentes a cada uma das divisões principais.

O membro do corpo docente também é um membro da Escola (ou Faculdade) A. Assim, êle é controlado pelo diretor de sua faculdade através do diretor associado da Divisão e do seu presidente de Departamento. A relação entre o membro do corpo docente de um Departamento e o diretor de sua escola ou faculdade é pessoal e direta (no caso da discussão de um projeto de pesquisa específico, por exemplo) e indireta (através do presidente do departamento) nos assuntos oficiais acerca dos quais o departamento expressa sua opinião ou faz uma recomendação. O diretor ordinariamente mantém um dossiê sobre cada membro do corpo docente da sua escola. Neste serão incluídas as cópias das propostas de pesquisas e de relatórios, das publicações, e um curriculum vitae atualizado. São raros os contatos entre o membro do corpo docente e as altas autoridades da administração (Chancellor, Provost, Ptesident) e/ou seus assistentes, e quando estes ocorrem são resultado de encontros das comissões do corpo docente com a administração.

Referimo-nos ao «corpo docente» - ou Congregação - como sendo um todo único; entretanto, existem várias «Subcongregações», organizadas separadamente. A Congregação da escola reúne-se periodicamente para tratar de assuntos da sua competência; todo o corpo docente do campus faz o mesmo; todo o corpo docente de Universidade (que frequentemente inclui vários campuses) pode reunir-se para tratar da política de toda a Universidade; e o corpo docente de pós-graduação, que pode ser um para cada campus, ou pode incluir professores provenientes de todos os campuses, constitui outro grupo (vide Quadro II). Na prática, todas as Congregações que abrangem órgão maior do que o departamento provaram ser um instrumento parlamentar incómodo e difícil. Normalmente, existe um sistema de representação: o Senado Acadêmico (faculty senate). ${ }^{7}$ Este órgão tem um membro eleito para cada 30, 50, ou talvez 100 membros de todo o corpo docente da unidade (um único campus) ou do corpo docente total (da Universidade). Um Conselho Acadêmico pode consistir de uma representação proporcional para cada um dos vários campus.

\footnotetext{
6 Vide minha discussão da estabilidade e promoção em $O$ Departamento na Universidade Norte amecicana.
}

7 Que corresponderia, aproximadamente, ao Conselho Universitário no Brasil. 
A chave para a participação do corpo docente nos negócios da Universidade é o sistema de comissões. O membro do corpo docente é também membro de várias comissões, além dos seus deveres de ensino e de outras atividades ligadas aos alunos, e de suas atividades de pesquisa e de serviços para a comunidade.

É de tal ordem a complexidade da estrutura de comissões de uma Universidade de tamanho médio a grande, que é quase impossível sua descrição; na verdade, tornou-se necessário nomear comissões para exercer algum controle sobre uma proliferação de comissões ainda maior (as «comissões das comissões») ou para nomear uma comissão que determina como se pode diminuir o número das atuais comissões. Uma anedota muito antiga no campas é a de que o camelo é um cavalo planejado por uma comissão! Todavia, o membro do corpo docente participa regular e rotineiramente de todas as facetas da vida universitária através dos sistemas de comissões. ${ }^{8}$ Participa dos planos de expansão através da Comissão de Planejamento do «Campus», da Subcomissão de Construções em Geral, e das subcomissões para estudar as reformas dos prédios ou as propostas de construção de novos edifícios (e mesmo através de uma comissão para estabelecer os nomes adequados para os prédios); ${ }^{9}$ dos esportes, através do Conselho de Esportes; da administração do campus, através da Comissão de Estacionamento e Transportes, da Comissão de Segurança e outras; dos assuntos estudantis através da Comissão de Admissões, da Comissão para Auxílios Financeiros aos Estudantes, da Comissão de Visitas às Escolas de Nível Médio, da Comissão de Alojamento, da Comissão ROTC (Treinamento Militar), da Comissão de Conduta e de Apelação dos Estudantes, da Comissão para a Conferência entre Professores e Alanos sobre Assuntos Educacionais, da Comissão de Vida Etudantil e Interesses dos Estudantes. da Comissão para as Fraternidades, Irmandades e Vida Social, da Comissão para as Associações e Organizações Estudantis, da Comissão de Trabalho-Estudo, e da Comissão de Política da União de Estudantes; ${ }^{10}$ da organização das disciplinas e dos currículos através das Comissões de Disciplinas e Currículos (de todo o campus e das divisões); das atividades extracurriculares do corpo docente, através da Comissão de Bem-Estar do Corpo Docente, da Comissão da Sala de Estar do Corpo Docente; das relações comunidade-Universidade, através da Comissão de Atividades Públicas, da Comissão de Relações Públicas, da Comissão de Rádio e Televisão, e da Comissão de Conferências, da pesquisa e obtenção de equipamentos através da Comissão de Doações Anónimas; da política e da legislação da Universidade, através da Co-

8 A estrutura de comissões do departamento já foi descrita noutro trabalho; aqui restringiremos nossa atenção ã estrutura acima do nivel departamental.

9 Que frequentemente recebem o nome de um benfeitor da Universidade.

10 A União de Estudantes é um Centro de Atividades Estudantis, localizado num prédio para este fim, com sala de reuniões, refeitório, salão para jogos e para danças, local para venda de livros, Diretório Acadêmico, etc. 
missão Universitária, da Comissão de Codificação e da Comissão de Nomeações e Eleições; da história da instituição, através da Comissão $A$ <: Arquivos; de atividades de assessoria à administração, através do Conselho Administrativo; das prerrogativas e privilégios do corpo doente através da Comissão dos Direitos do Homem e da Comissão de Estabilidade e Promoções. ${ }^{\text {n }}$

As comissões relacionadas são do tipo permanente e do tipo ad hoc, e ambas podem ser eleitas ou nomeadas. Na maioria dos casos, o período de mandato para os membros das comissões é de um ou dois anos; portanto, durante um período de vários anos, grande número de membros' do corpo docente participará de várias comissões. O interessado não se declara candidato à eleição para uma comissão. Na UWM, solicita-se periodicamente a cada membro do corpo docente que indique três comissões das quais êle desejaria participar. Posteriormente, êle pode ser escolhido, pela Comissão de Nomeações e Eleições, como candidato para uma ou mais destas comissões. Faz parte da ordem do dia das reuniões ordinárias do corpo docente as nomeações adicionais partindo do plenário, e são aceitas se forem por este aprovadas. A congregação mais tarde recebe uma cédula impressa contendo a lista de todos os candidatos para as vagas em cada comissão, devolvendo-a depois para apuração. Os resultados das eleições são computados e distribuídos pelas Comissões de Eleições.

Neste resumo da estrutura do corpo docente, pode-se observar que cada membro da Congregação está forte e intimamente envolvido no funcionamento do departamento, da divisão, da escola, da Universidade e da comunidade: isto se dá através de seu trabalho de ensino e de pesquisa, de sua participação nas comissões da divisão, da escola e da Universidade, e de suas atividades na comunidade. É difícil imaginar que o funcionamento de tal sistema possa ter êxito, a não ser com um corpo docente em tempo integral e intensamente dedicado às suas tarefas na Universidade.

Tradução de

J. R. VELLOSO

Julho/68

11 Esta não é uma lista exaustiva. A descrição feita acima é baseada na estrutura das comissões da Universidade de Wisconsin, Milwaukee, mas, de modo geral, será válida para muitas Universidades americanas. 
DIAGRAMA I

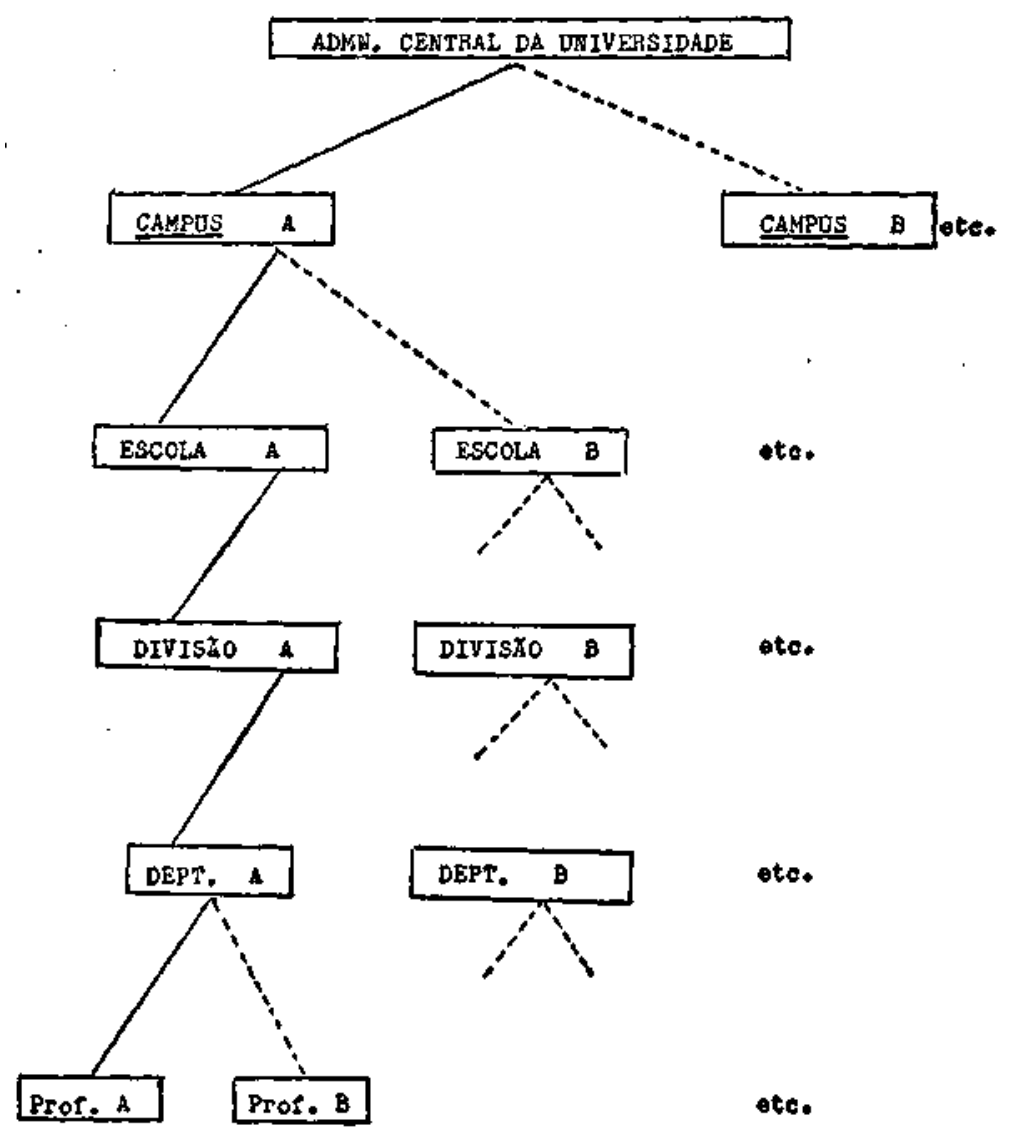


$-569-$

DIAGRAMA.II

CORPO DOCENTS DA DNIVERSIDADE

CORPO DOCENTE DO CAMPOS

CORPO DOCENTE DA FACULDADE

CORPO DOCENTE DA DIVISRO

CORPO DOCENTE DO DEPT: PROF.

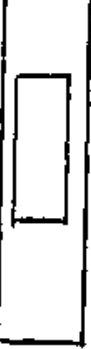


Apendice E. 2

\section{FACULTY STRUCTURE}

HENRY W. HOGE

Other papers in this series have provided a description of the credit system, the university department, and general university organization .

In this study it will be assumed that the reader is acquainted with the subject matter of the works cited. The present essay will consequently confine itself co the description and discussion of certain aspects of the faculty structure of a representative American University. ${ }^{1}$

The first problem we encounter may be one of semantics: the definition of the term «faculty». For the purposes of our discussion, the word faculty is employed to refer to the totality of the university personnel holding academic rank and engaged in teaching or teaching cum research activities. We thus exclude the Deans of the various Schools or Colleges, who will be related to a specific department and will hold an academic title (Professor of History, Professor of Zoology, etc.), but who are not involved in teaching and/or research. Such Deans will be classified with the administration in the administrationfaculty dichotomy. This distinction will not hold for all circumstances, to be sure. The Dean of a College may well teach an advanced course in his discipline; associate deans frequently teach half-time in a given department, and participate fully in department affairs. ${ }^{2}$

It is also necessary 'o refer to certain exclusions in the «faculty» category. Within the rank structure often encountered in the American University (teaching associate or assistant, instructor; (lecturer): assistant professor; associate professor; (professor) the teaching associate is not considered to be a member of the facultv, although he is certainly a member of the teaching staff»; the instructor may or may

Again, as previous papers, we wish to avoid the use of the term «typical». Our comments on the wide variation in University structure in the II. S. are equally applicable to the present topic. The problem of the definition of the «University» end of the term «FacuIty» has been discussed in Prof. John Hunter's essay, The Structure Higher Education in the United States

2 Thus giving rise to a possible conflict of interests situation in which an associate dean of Social Sciences (let us say), votes on departmental recommendations for merit raises or promotion which are later processed through his office ES an administrative officer of the division involved. 
not be accorded faculty status: and the "professorial" ranks (assistant professor and above) are routinely considered to be entitled to all faculty privileges. ${ }^{3}$

The basic affiliation of the faculty member, as noted elsewhere, is the department. His teaching duties, research projects, departmental committee assignments, promotion and salary raises will be determined within or recommended by the department through its operational mechanism. ${ }^{4}$

The faculty member, however, is also closely affiliated with several multi-disciplinary University units, as shown in Table I. Professor A will be a member of Department A, as stated. He will also belong to Division A. This division will be a grouping of departments of related disciplines, such as Humanities (including departments of History, all Foreign and Classic Languages, Comparative Literature, Philosophy, Speech, Art History); Social Sciences (including departments of Anthropology, Economics, Geography, History, Journalism, Linguistics. Philosophy, Political Science, Psychology, Sociology); and Natural Sciences (departments of Astronomy, Bacteriology, Brochemistry, Botany, Chemistry, Geography, Geology. Mathematics, Meteorology, Philosophy, Physics, Psychology, Zoology). ${ }^{1}$

The division may have no separate administrative identity other than the existence of an associate dean of the College who works exclusively with the departmental chairmen of the division. Yet the divisional concept may be vitally significant in the area of faculty control of curriculum and in the process of promotion and award of tenure. As noted elsewhere, the recommendation for promotion and tenure is initiated within the department. ${ }^{6}$ Such a recommendation is submitted to a Divisional Committee which expresses an official carries considerable weight, but is by no means final. The recommendation for promotion and/or tenure proceeds through channels to the associate dean and dean of the College, and, sometimes simultaneously. and influential opinion. The Divisional Committee will usually be a committee elected by vote of the faculty of the College. The disciplinary

Privilege distinction may exist even in the professorial ranks, however. The executive committee of the department may consist only of associate and full professors. See our discussion in «The American University Departments.

4 We will not duplicate the data presented ensewhere or the internal operation of the department.

5 It will be observed that several departments (notably History) appear in more than one division. This is partially due to the fact that only certain departmental courses $\mathrm{a}^{-} \mathrm{e}$ listed for a given division; other courses, offered by the same department, will appear in another, division. A cursory analysis of these suggests that there is a certain lack of logic in the divisional assignment. At times the appropriate divisional assignment for a given discipline is a moot point. or even the subject of polemic.

${ }^{6}$ See my discussion of promotion and tenure in $O$ Departamento na Uni' versidade fsorte-Americana. 
divisional categories are also of great concern to the student, since $U t$ requirements for graduation, as stated in the University Bulletin, will ordinarily involve a specific number of credits in courses listed for each of the major divisions.

The faculty member is also a member of School (or College) A $\mathrm{He}$ is thus, through the appropriate divisional associate dean and his departmental chairman, controlled by the Dean of this College. The relationship bet-ween the departmental faculty member and the Dean of his School or College is both personal and direct (in the case of discussion of a specific research project, for example), and indirect (via the departmental chairman) on official matters in which the department expresses an opinion or makes a recommendation. The Dean will routinely maintain a dossier for each faculty member in his school. The annual summary of professional activities, copies of research proposals and reports, publications, and an up-to-date curriculum vitae will be included in this file. Direct contacts between the faculty member and the higher officers of administration (Chancellor Provost, President and/or their associates) are rare, and usually take place as a result of meetings of faculty committees with the Administration.

We have referred to the «faculty» as a totality; there are, however. several sub-faculties, separately organized. The faculty of the College will meet periodically to consider matters related to its province; the total faculty of the campus will do likewise; the entire faculty of the university (often including several campuses) may meet for consideration of all-university policy; and the graduate faculty, which may be separate for each campus, or include the qualified professors of all campuses, represents another grouping (See Chart II). In practice, all faculty groups larger than department have proved to be unwieldy and cumbersome parliamentary instruments. A representational system usually exists: the faculty senate. This body will have one elected member for each 30, 50, or perhaps 100 members of the total faculty of either the unit (single campus) or the entire faculty. A faculty council may have a proportionate representation from each of several campuses.

The key to faculty participation in University affairs is the committee system. In addition to his teaching and related studentoriented duties, his research and community service activities, the faculty member is usually a member of several committees.

The complexity of the committee structure of a medium to large university is such that it almost defies description; in fact, it has become necessary to appoint committees to exercise some control over the further proliferation of committees (the «committee on committees) or to appoint a committee to determine how the current committees can be reduced. The tired but pointed campus joke is that the camel is a horse, as planned by a committee! Nonethess, the faculty member 
regularly and routinely participates in all facets of university life by virtue of the committee system. ${ }^{7} \mathrm{He}$ is involved in expansion plans through the Campus Planning Committee, the General Building Subcommittee, and the subcommittees for remodeling or for each major new building proposed (and even through a committee to determine the appropriate names for buildings) $;^{8}$ in athletics, through the Athletic Board; in campus management, through the Parking and Transportation Committee, the Safety Committee and others; in student affairs, through the Admissions Committee, the Financial Aids to Students Committee, the High School Visitation Committee, the Committee on Housing, ROTC (Military Training) Committee, the Student Conduct and Appeals Committee, the Student-Faculty Conference Committee on Educational Affairs, the Student Life and Interests Committee, the Fraternities, Sororities and Social Life Subcommittee, the Student Go vernment and Organizations Subcommittee, the "Work-Study Committee, and the Union Policy Board Committee; in the course organization and curriculum, through the Course and Curriculum Committees (allcampus and divisional); in extracurricular faculty activities, through the Faculty Welfare Committee and the Faculty Launge Committee; in university-community relations, through the Public Funcions Committee, the Public Relations Committee, the Radio and Television Committee, and the Lectures Committee; in research data and materials, through the Library Committee, the Gifts and Grants Committee, and the Anonymous Funds Committee; in university policy and legislation, through the University Committee, the Codification Committee and the Committee on Nominations and Elections; in the history of the institution, through the Archives Committee; in an advisory role to the administration, through the Administrative Council; in faculty prerogative and privileges, through the Human Rigts Committee and the Committee on Tenure and Promotion. ${ }^{9}$

The committee listed are both standing (permanent) and ad hoc, and both elective and appointive. In most cases the period of faculty service on a given committee is one or two years; over a period of several years, there is therefore a considerable diffusion of committee service throughout the faculty One does not announce himself as a candidate for elective committees. At UWM, each faculty member is periodically requested to indicate three committees on which he would be willing to serve. He may subsequently be selected as a candidate for one or more of these committees by the Committee on Nominations and Elections. As an item on the agenda of a regular

The committee structure of the department has been described elsewhere; we confire our attention here to the supra-departmental structure.

8 Which often receive the name of a benefactor of the university.

9 This is not an exhaustive list'ng. The descrption given above is based on the committee structure of the University of Wisconsin-Milwaukee, but will be generally valid for many American universities. 
facult meeting, additional nominations are accepted from the floor, faculty The faculty later receives and returns a printed ballot if seconded. The facult candidates listed for each committee vacancy. Results of the election are tabulated and distributed by the Elections Committee.

In this summary of faculty structure, it may be observed that the faculty member is very heavily and intimately involved in the $\mathrm{f}$ uctioning of the department, the division, the college, the university and the community: this through his teaching and research, his participation in divisional, college and university committees, and his communit activities. It is difficult to imagine the sucessful operation of such a system other than a full-time, resident faculty.

\section{CHART I}
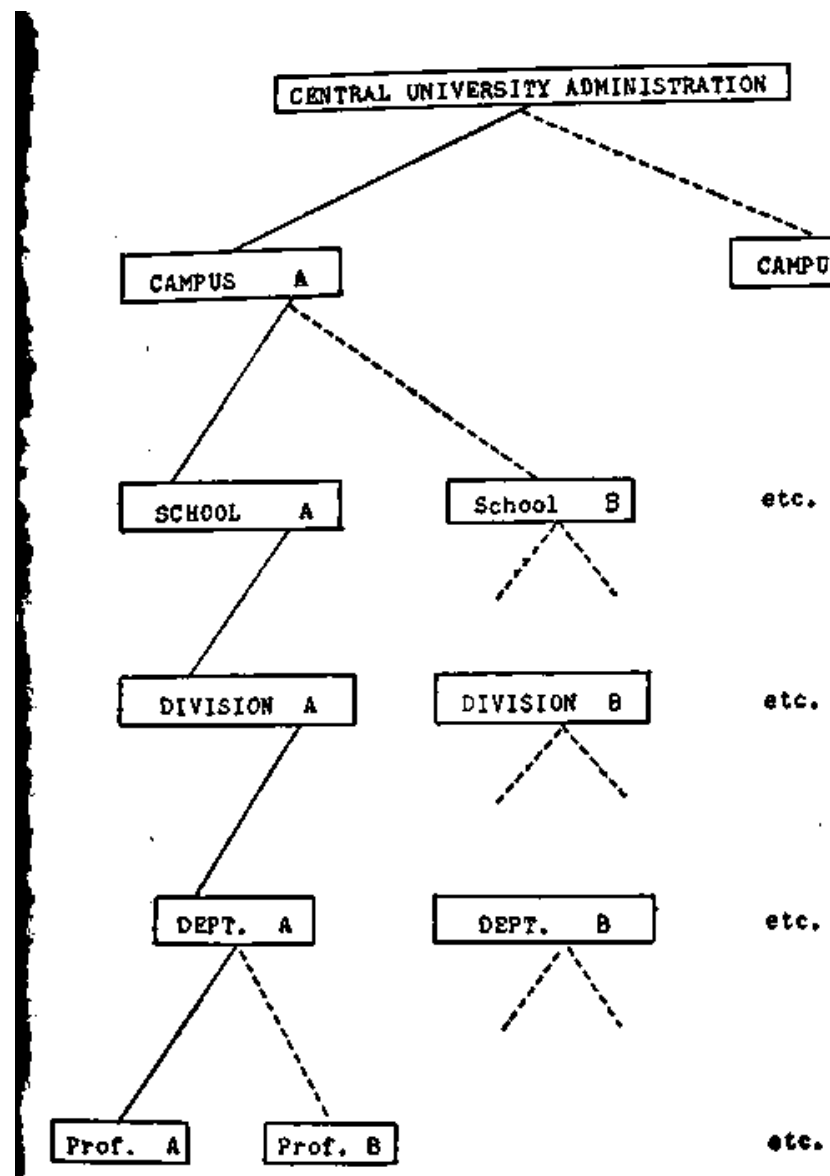

Prof. 


$$
\begin{aligned}
& -576- \\
& \text { CHART II }
\end{aligned}
$$

UNIVERSITY FACULTY

GAMPUS Faculti

\section{CJLLEGE FACULTY}

DIVISION FACULTY

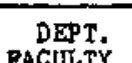

PACULTY

PROP.

PROP.

$\square$

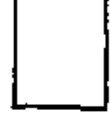

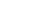


Apêndice E. 3

\title{
REFLEXÕES SOBRE A EDUCAÇÃO SUPERIOR DO BRASIL
}

\author{
H. W. HOGE \\ USEAPES
}

Este ensaio procura descrever brevemente e comentar a atual atuação do ensino superior no Brasil. Excetuando-se as estimativas mais qerais ou globais, este trabalho não se baseia em estatísticas. Isto decorre não só da preferência que tem o autor pelas interpretações filosóficas e sociais em lugar das análises estatísticas, mas também resulta da falta de dados acurados e significativos sobre o sistema educacional brasileiro.

A afirmação descritiva mais exata que se pode fazer acerca da Universidade Brasileira é que ela não existe. Isto quer dizer que o Brasil nunca teve e ainda hoje não tem uma «Universidade» no sentido de um conjunto de cursos profissionais integrados, com um componente preparatório básico e comum. As exceções aparentes não são de fato exceções. A Universidade de Brasília foi estruturada segundo o conceito de institutos centrais destinados a ministrar cursos pré-profissionais, mas fá se desviou, ou retrocedeu, na direção das faculdades separadas e estanques. A atual legislação sobre a reforma estrutural das Universidades decreta a criação de núcleos pré-profissionais comuns; mas esta medida não poderá ser imposta com êxito sobre um grupo de faculdades separadas - e separadas do ponto de vista psicológico e filosófico, e muitas vezes geográfico. Todos os esforços para alterar o padrão estrutural estabelecido estão destinados ao fracasso, enquanto as faculdades isoladas continuarem a existir e a proliferar como instituições que concedem diplomas, e enquanto as novas «Universidades» forcn criadas e reconhecidas pela aglomeração de tais faculdades já existentes. ${ }^{1}$

I - A Estrutura. O sistema de Educação superior do Brasil encontra-se presentemente num estado de fermentação, de instabilidade. Uma estrutura arcaica de cátedras, um processo de admissão altamente

A matéria-prima para a formação de aglomerados adicionais é abundante. Segundo o cálculo oficial da CAPES, o número de faculdades universitárias no período 1964-1967 aumentou de 268 para 372; e o número de faculdades isoladas, de 296 para 305. Mais de $60 \%$ do corpo discente universitário estava matriculado nos estabele-dmentos isolados em 1966. segundo a Análise do Ensino no Brasil (Estudo Preliminar) publicada pela Secretaria-Geral do MEC em maio, 1968 (pág. 47). 
restritivo e seletivo, e a êníase nas tradicionais carreiras profissionais estão cedendo a pressões sociais que demandam por uma Educação superior para amplas parcelas da população e à preocupação primordial com a produção das capacidades profissionais necessárias para o desenvolvimento econômico. Os elementos universitários tradicionais $(\mathrm{Fa}-$ culdades de Direito, de Medicina) possuem influência desproporcional face às atuais necessidades da sociedade, mas proporcional à quantidade dos representantes destas faculdades que atuam na elite dirigente. A necessidade de que uma camada mais ampla da sociedade possua uma Educação de nível superior (ao invés da estreita faixa de líderesfilósofos atualmente existente); a exigência de um corpo de especialistas altamente treinados para construir e manter um complexo industrial competitivo; o clamor do grupo de jovens qualificados para a Universidade, que cresce rapidamente e demanda por sua oportunidade de se unir à classe privilegiada; e a flexibilidade e a diferenciação ditadas pelo potencial de crescimento c pelas variações regionais do interior; estes fatores tornam imperativa a reestruturação da Universidade Brasileira. Esta reforma universitária não pode restringir-se unicamente a uma mudança na terminologia, ou limitar-se à aplicação de novos rótulos a antigos componentes. $\mathrm{Na}$ verdade não pode limitar-se à alteração do mecanismo interno da Universidade. A inflexibilidade e a falta de personalidade das instituições controladas por um núcleo central deve ser substituída por estruturas que possam ter uma relação mais estreita com o seu meio ambiente; que possam se tornar identificadas com a comunidade, orientadas para a comunidade, e mantidas pela comunidade.

Parece-nos evidente que a Universidade Brasileira atualmente se encontra num período de transição. Este não é somente a transformação parcial experimentada na maior parte do mundo pela Universidade, apropriada para ontem, mas inadequada para amanhã; mas é uma adaptação ainda mais radical, partindo de um estágio de evolução que representa um passado morto há muito, para as necessidades do amanhã. A Universidade no Brasil não tem respondido às principais mudanças da sociedade nos ultimes anos; não pode atender à «crescente maré das esperanças sociais»; não pode acompanhar o crescimento da classe média urbana; e não pode dirigir e orientar o desenvolvimento econômico e a evolução social do interior.

A falta de flexibilidade parece ser a maior falha na estrutura da Educação superior. O controle centralizado (federal) da maior parte da estrutura determinou que esta fosse rígida e monolítica, com pouca flexibilidade para permitir adaptações às necessidades locais ou regionais. A legislação federal estabelece currículos mínimos para todas as escolas profissionais, padrões de salário e de desempenho para o corpo docente, e controla a designação das autoridades administrativas mais importantes. Os regulamentos do serviço público impõem entraves burocráticos quanto à estabilidade do pessoal auxiliar, o que prejudica a 
eficiência; os pagamentos atrasam e incertezas financeiras minam a moral. É manifestamente impossível) o controle ou supervisão central das 700 faculdades hoje existentes. A ulterior proliferação de faculdades isoladas é virtualmente garantida pelas pressões políticas e sociais no sentido de expandir as oportunidades da Educação superior. Se as normas ou critérios para esta expansão forem realistas, estes tenderão a tornar-se uma espécie de denominador comum muito baixo, garantindo assim a deterioração da qualidade do todo.

II___ O Professor. Dentro da instituição, o principal problema interno parece ser o de estrutura do corpo docente. $O$ professor de tempo parcial não é necessariamente um fator operacional negativo: pode-se encontrar algumas vantagens, por exemplo, nos serviços docentes de um professor que também trabalhe na sua profissão ou mantém contatos com a indústria. O professor de «tempo dividido», ou aquele que ensina as mesmas matérias ou matérias diferentes em várias instituições, é evidentemente um elemento menos desejável no corpo docente. Seu valor é afetado pelo tempo reduzido de que dispõe para orientar os alunos, para atualizar e rever o material e o conteúdo do programa de sua disciplina, para planejar e realizar programas de pesquisas, e para participar ativa c continuamente nos assuntos internos da instituição.

Não temos absoluta certeza de que realmente existe o problema da escassez de professores qualificados. Se, como acontece frequentemente, o professor A ensina durante uma terça parte do dia em cada uma das instituições $\mathrm{X}, \mathrm{Y}$ e $\mathrm{Z}$; e os pofessôres $\mathrm{B}$ e $\mathrm{C}$ fazem exatamente o mesmo, parece que o professor A poderia ser designado em tempo integral para instituição $\mathrm{X}$, o professor $\mathrm{B}$ para a $\mathrm{Y}$, e o professor $\mathrm{C}$ para a Z. A vida dos professores A, B e C poderia ser menos agitada (e talvez menos interessante): mas sua eficiência aumentaria seguramente, e o fato de se dedicar a uma única instituição poderia acarretar uma benéfica mudança à atitude em face do seu trabalho. Ao refletirmos sobre as causas da presença do professor de tempo parcial em todo o sistema, somos levados a acreditar que o principal fator é a incerteza ou insegurança financeira pessoal que poderia advir da vinculação em tempo integral a uma única instituição. Este é certamente o motivo que é alegado por alguns administradores quando não logram êxito na procura e contratação de um corpo docente de tempo integral. Quaisquer que sejam os fatores econômicos e sociais que deram origem à produção deste fenômeno, ou que até hoje continuam a contribuir para sua ocorrência, não há dúvida alguma de que êle se tornou uma característica padrão do panorama universitário brasileiro, e resistirá à mudança de modo obstinado e até mesmo irracional. E havendo ou não uma escassez crítica na oferta de professores para o presente sistema de Educação superior, é evidente que a fonte de abastecimento $\bullet$ os atuais programas de estudos de pós-graduação no Brasil - é incapaz e fornecer o grande número de professores adicionais que é necessário 
para um sistema universitário ampliado, de dimensões adequadas para atender às necessidades de um Brasil moderno. Portanto, o que é preciso é uma grande expansão dos programas de pós-graduação, produzindo professores que devem convencer-se das vantagens econômicas e filosóficas da vinculação a uma única instituição. Não cabe neste ensaio a discussão dos meios ou da metodologia para efetivar esta mudança. É suficiente afirmar que ela será impossível sem a importação ou adaptação de técnicas, metodologia e pessoal «estrangeiros»..$^{3}$

III - $O$ Estudante. A Universidade tem sido definida como uma «comunidade de professores e alunos», ou seja, uma comunidade de estudiosos composta — é de se supor — daqueles que sabem e daqueles que querem aprender; daqueles, enfim, cuja posição muito especial na sociedade lhes permite o privilégio de ensinar e de aprender. Como professor universitário, eu me definiria como sendo uma pessoa menos ignorante do que meus alunos em algumas áreas do conhecimento; minha tarefa, reduzir esta desigualdade. Espero que eu esteja cônscio da posição privilegiada que me foi concedida pela sociedade, e que eu possa arcar com as responsabilidades inerentes a esta posição; e conclamarei os estudantes a refletirem do mesmo modo sobre seus privilégios e responsabilidades. Não posso acreditar que seu dever seja destruir o sistema organizado em seu próprio benefício; naturalmente é sua responsabilidade adquirir algum conhecimento acerca da instituição que os está servindo, procurar compreender seus mecanismos, e colaborar, dentro dos limites de sua capacidade e das suas outras responsabilidades, para aprimorar sua estrutura e serviços. A Universidade não é estranha à política; mas não deve ser vítima dos inconstantes caprichos e extravagância surgindo de um elemento minoritário de uma única geração. A Universidade deve sobreviver a cada geração, e não pode ser derrubada e reconstruída por cada grupo de pessoas que por ela passam. Na verdade, a Universidade tem a obrigação de se preservar e proteger-se contra a destruição; embora possa parecer que hoje em dia lhe faltam os meios para tanto.

O estudante brasileiro, além da participação desproporcional em atividades periféricas à sua atividade primordial, frequentemente está trabalhando em regime de tempo parcial numa firma industrial ou comercial. 3 Isto significa que uma percentagem bem ponderável dos

\footnotetext{
2 Colocamos aspas na palavra «estrangeiros» porque para o autor parece absurdo que o conhecimento útil e necessário, se adequadamente adaptado ao meio. possa ser considerado «estrangeiro» e portanto indesejável. Nenhuma das chamadas nações «adiantadas» jamais hesitaram em importar o conhecimento técnico necessário para qualquer setor de sua economia.

De fato. a renda do estudante com este tipo de emprego é maior do que o rendimento dos graduados de nível secundário do mesmo grupo etário. Não obstante os impostos que constituirão as verbas para cobrir a maior parte dos custos da formação universitária provêm da classe media. cujos representantes têm pouca ou nenhuma oportunidade de frequenta- a Universidade. $O$ clamor estudantil pela gratuidade do ensino superior não tem lógica à luz destes dados .
} 
recursos e equipamentos da Universidade está ociosa durante grande arte de cada dia, e completamente ociosa durante muitos dias em cada ano. ${ }^{4}$

Portanto, o professor de tempo parcial combina, com o aluno de tempo parcial. Cada fenômeno reforça o outro, e embora possa parecer que com uma utilização eficiente dos recursos existentes o total de matrículas na Universidade pudesse ser aumentado, é muito pouco provável que isto aconteça.

É difícil abandonar o problema do estudante universitário antes de fazer alguma referência aos seus atuais protestos e exigências. Segundo o conhecimento do autor, e excluindo reivindicações puramente políticas, os estudantes são contra: a) a Fundação; b) as anuidades; c) o MEC-USAID; d) o relatório Atcon; e são a favor de: a) maiores verbas governamentais; $b$ ) expansão ou restauração dos restaurante estudantis. Meus comentários sobre estas pretensões se restringirão a mostrar que em primeiro lugar não há no Brasil concordância sobre o que seja a «Fundação» ou sobre o que representa a sua criação: significa muitas coisas para muitas pessoas. A que conceito de Fundação se opõem os estudantes? A peculiar falta de lógica sobre o assunto das anuidades já foi mencionada acima. Com relação ao MEC-USAID, permita-se ao autor dizer o seguinte: o acordo MECUSAID para o planejamento do Ensino Superior (existem muitos outros acordos MEC-USAID) reuniu um grupo de brasileiros e americanos especialistas em Educação para que fosse estudado o sistema de ensino superior brasileiro e para que fossem sugeridos caminhos e meios de aprimorar este sistema. O elemento norte-americano deste grupo de especialistas não tinha quaisquer interesses ou motivações políticas: seu único propósito era utilizar uma determinada quantidade de conhecimentos técnicos e de experiência (adquiridos anteriormente nos E.U.A, e em vários países estrangeiros, combinados com uma compreensão da realidade brasileira adquirida in situ) para analisar a problemática universitária do Brasil c oferecer aos representantes brasileiros uma assessoria técnica para as suas deliberações. Com respeito ao relatório Atcon, o autor nega toda e qualquer vinculação com este documento, e, na verdade, rejeito suas teses principais como irreais e inadequadas para o Brasil. Não temos comentários a fazer sobre a exigência de mais verbas governamentais ou sobre melhores restaurantes. Entretanto, queremos expressar nossa surpresa pelo fato de os estudantes não haverem observado a evidente injustiça que representam os «cursinhos» e o processo de seleção dos exames vestibulares; e que parecem

Não se dispõe de dados estatísticos de confiança sobre utilização de instalações físicas; entretanto, minha estimativa - à primeira vista — é que os recursos da Universidade Brasileira não são utilizados durante pelo menos $50 \%$ do horário de funcionamento de cada dia letivo (i.e., das 8,00 às 17,00 horas, nos dias de aulas normais). 
esquecer a inadequação das bibliotecas para um efetivo estudo independente ou pesquisa; e que eles têm pouco ou nenhum interesse pela modernização ou melhoria dos currículos.

IV - O Círculo Vicioso. Os comentários acima provavelmente terão sido suficientes para transmitir a impressão do autor no sentido de que as áreas-problema da Educação superior brasileira são compostas de fatores inter-relacionados e interdependentes: o professor de tempo parcial oculta a incoerência que é o estudante de tempo parcial, e vice-versa; a combinação professor/estudante de tempo parcial faz com que a falta de uma biblioteca central para pesquisas pareça um defeito menos patente; esta mesma combinação evita uma participação significativa do professor e do aluno no funcionamento da instituição; o controle central ou «remoto» de estrutura universitária faz a instituição menos interessada na comunidade e na região; e a falta de interesse e apoio por parte da comunidade torna a instituição mais dependente de subvenções federais; a colaboração indústria-Universidade depende da pesquisa; a pesquisa depende dos recursos das bibliotecas e de pessoal docente em tempo integral; e assim por diante. Ainda assim, isto é uma super-simplificação, já que os fatores não se relacionam segundo um simples ciclo de causa-efeito. Não será suficiente, por exemplo, dar maior assistência à criação de bibliotecas centrais, julgando que serão resolvidos os problemas de pesquisa, de identificação com a região e com a comunidade e os de apoio por parte da indústria. $\mathrm{O}$ pessoal docente de tempo parcial, a insegurança financeira e os programas de pós-graduação são fatores interrelacionados e permaneceriam negativamente ativos e não solucionados.

As múltiplas áreas-problema devem ser atacadas simultaneamente para obter-se uma real melhoria na Universidade Brasileira - e há poucas dúvidas quanto a isto. Esta tarefa exigirá auxílio estrangeiro, fornecido e recebido de boa-fé; exigirá a ativa colaboração dos órgãos brasileiros de controle central, do corpo discente, do pessoal de ensino, e das autoridades administrativas das instituições; e exigirá o interesse e apoio da sociedade brasileira.

tradução de JACQUES R. VELLOSO Julho - 1968 
Apendice E.3

\title{
REFLECTIONS ON HIGHER EDUCATION IN BRAZIL
}

\author{
H. W. HOGE \\ USEAPES
}

This is an attempt to describe and interpret the current status of higher education in Brazil. Except for the most general or global estimates, this essay is not based on statistics. This arises not only from the writer's predilection for philosophic and social interpretation rather than statistical analysis, but from the unavailability of accurate and meaningful data for the Brazilian educational system.

The most specific descriptive statement which can be made about the Brazilian University is that it does not exist. This is to say that Brazil has never had and today does, not have a «University» in the sense of a close-knit grouping of career courses with a common basic preparatory component. The apparent exceptions are not exceptions in fact. The University of Brasilia was strutured with a Cenrtal Institute pre-professional course concept, but has already drifted, or reverted, in the direction of separated and self-contained faculdades or colleges. The current structural reform legislation decrees the preprofessional common nucleus; but this cannot be sucessfully superimposed upon an existing group of discrete [aculdades. All efforts to alter the established structural pattern are foredoomed to failure as long as the separate [aculdade as a diploma-grating institution exists and proliferates, and as long as new «Universities» are created and accredited by agglomerations of such pre-existing faculdades.

I - The Structure. The higher educational system in Brazil is currently in a state of ferment, of flux. An archaic structure of catedras, highly restricted and selective enrollment, and emphasis on the traditional professional careers or ivory-tower intellectual dilettantism is giving way to social pressures which call for mass higher education and primary attention to production of the professional competencies needed for economic development. The traditional University elements (faculdades de Direito, Medicina) retain and influence disproportionate to the present needs of society, but related to the numbers of representatives

The raw material for the formation of additional agglomerates abounds; the exact number of recognized isolated schools or faculdades isoladas is unknown, but problably lies between 600 and 700 . These faculdades may accommodate as much as $40 \%$ of the entire Brazilian college student body. 
of those faculties active in the ruling elite. The need for a broader stratum of society with a general higher education (as compared to a narrow band of philosopher-leaders); the need for a corps of highly trained technological specialists to construct and maintain a competitive industrial machine; the clamor of a rapidly growing group of collegeeligible youth demanding their opportunity to join the privileged class; and the flexibility and differentiation dictated by the growth potential and regional variations of the interior: these factors make it imperative to revamp and re-structure the Brazilian University. This University reform cannot be merely terminological, or limited to the application of new labels to old components. It cannot be limited, in fact, to the alteration of the internal mechanism of the University. The inflexibility and impersonality of centrally controlled institutions must be replaced by structures which can relate more closely with their immediate ambient; which can become community-identified, community-oriented, and community-supported .

It seems clear that the University in Brazil currently exists in a transitional period. This is not only the transformation phase experienced by the University in the major part of the world, adequate for yesterday, but unsuited for tomorrow; but an even more radical adaptation from a stage of evolution representing a long-dead past to the needs of tomorrow. The University in Brazil has not been responsive to the major societal changes of recent years; it cannot attend to the «rising tide of social expectations; it cannot accompany the growth of the urban middle class; and it cannot direct and orient the economic development and social evolution of the interior.

A key defect in the structure of higher education appears to be inflexibility. Centralized (federal) control of the major part of the structure has prescribed a monolithic and rigid structure, with little flexibility to allow for adjustments to regional or local needs. Federal performance and salary standards for faculty, and controls the designation of key administrative officials. Civil service regulations impose bureaucratic tenure restrictions for support personnel wich impair efficiency; payroll delays and uncertainties undermine morale. Effective centralized control or supervision is manifestly impossible for the 700 isolated faculties now reported to exist. The further proliferation of the isolatel faculty is virtually guaranteed by political and social pressure for expanded opportunities in hightr education. Norms or criteria for this expansion, if realistic, tend to become a type of lowest common denominator, and thus guarantee a deterioration in quality of the whole.

II - The Pro/essor. Within the institution, the chief internal problem appears to be faculty structure. The part-time professor is not necessarily a negative operational feature: one can see some advantage, for example, in the teaching services of a professor who also maintains competency and contact with industry or his profession. The «dividedtime» professor, or one who teaches the same or similar subjects in se- 
1 institutions, is clearly a less desirable faculty membre. His value is $\mathrm{v}_{\text {ffected by the reduced time as his disposal for student guidance and }}$ 'orientation, for up-dating and revision of his course materials, for research planning and execution, and for active and continuous participation in the internal affairs of the institution.

It is not perfectly clear that the problem here is the scarcity of Qualified teachers. If, as is often the case, Prof. A teaches one-third time in institutions $\mathrm{X}, \mathrm{Y}$ and $\mathrm{Z}$; and if Profs. $\mathrm{B}$ and $\mathrm{C}$ do exactly the same, it would seem that Prof. A could be assigned full-time to institutions $\mathrm{X}$, Prof. B to institution $\mathrm{Y}$, and Prof. C to institution Z. Life might be a bit less hectic (and perhaps, less interesting) for Profs. A-B-C; but their efficiency would certainly increase, and the sense of allegiance to a single institution might bring a beneficial change in attitude. In reflecting on the causes for the system-wide presence of the part-time professor, one is inclined to believe that a principal factor is the personal financial unvertainy or insecurity arising from full-time affiliation with a single institution. This is certainly the reason advanced by some administrators for their failure to seek out and hire a full-time teaching staff. Whatever the original or continuing economic or social factors which have produced this phenomenon, there is no doubt but that it has become a standard feature of the Brazilian academic scene, and will stubbornly and even unreasonably resist change. And whether the professor is or is not in critically short supply to staff the present higher educational system, it is clear that the source of supply - the Brazilian graduate-studies program - is incapable of providing the very large number of additional teachers required for a University system expanded to dimensions adequate to serve the needs of a modern Brazil. The need is therefore for a great expansion in graduate study programs, for the production of teachers who must become persuaded of the economic and philosophic advantages of single-institution affiliation. It is not within the province of this essay to discuss the means or methodology to effect this change. Suffice it to state that it will be impossible without the importation or adaptation of «foreign» - techniques, methodology and personnel.

Ill - The Student. The university has been defined as a community of scholars composed, one assumes, of those who know, and those who wish to learn, and whose very special position in society allows them the privilege of teaching and learning. As a college professor, I would define myself as one somewhat less ignorant in certain fields of knowledge than my students; my task, to reduce this disparity. I hope that I am conscious of the privileged position accorded me by society,

2 The quotation marks are used for the word «foreign», since it appears absurd to this writer that useful and necessary knowledge. if appropriately adapted to the milieu, can be considered «foreign» and hence undesirable. None of the so-called «advanced» nations has ever hesitated to import the technical knowledge needed for any segment of its economy, 
and that I can accept the responsibilities which pertain to this position; and I would exhort the student to reflect similarly upon his privileges and responsibilities. I cannot believe that his duty is to seek to destroy the system organized for his benefit; it is naturally his responsibility to acquire some knowledge of the institution which is serving him, to attempt to understand its mechanisms, and to collaborate within the limits of his capabilities and other responsibilities for the improvement of its structure and services. The University is not alien to politics; but it should not be the victim of the shifting political whims and fads of a single generation. It must outlast each generation, and is not be torn down and reconstructed by each group of transients. In fact, the University has the obligation, although it appears that it may lack the means, to preserve and protect itself from destruction.

In addition to the disproportionate involvement in activities peripheral to his primary responsibility, the Brazilian student is often employed part-time in an industrial or business firm. ${ }^{3}$ This means that a very considerable percentage of the facilities and equipment of the Universities stands idle for much of every day, and entirely idle for many days of every year.

The part-time professor is therefore matched by the part-time student. Each phenomenon reinforces the other, and although it would seem that with efficient utilization of existing facilities the university enrollment could be significantly increased, this is very unlikely to happen.

It is difficult to leave the subject of the university student without some reference to the current protests and demands. As far as this writer is aware, the students are against: a) the «fundacao»; b) anuidades; c) the MEC/USAID; $d$ ) the Atcon report; and they are in favor of a) more Government funds; and $b$ ) expanded or restored restaurant services. I will not comment on these demands other than to point out that there is no agreement in Brazil as to what the fundagao is or involves: it means many things to many people. Which concept of the fundação is it that the students oppose? The peculiar lack of logic in the matter of the anuidades has been referred to above. With respect to the MEC/USAID, the writer may be permitted to say this: the MEC/USAID project for Higher Education Planning (there are many other MEC/USAID projects) assembled a group of American and

Indeed, his part-time earnings typically exceed those of the average colegio, graduate of the same age group. Yet the tax contributions which provide the funds to pay the bulk of the costs of university training come from the classe media, whose representatives have little or no opportunity to attend the University. The student clamor for free tuition rings hollow in the light of this data.

4 Reliable space-utilization statiscs are not available; but it is my impressionistic estimate that Brazilian university facilities are unused for fully fifty percent of each scheduled day-time period (i.e. during the hours 8:00 A M. to 5:00 P.M. on regular school days). 
Brazilian educational specialists to study the Brazilian system of higher location and to suggest ways and means of improving this system. This group of specialists was entirely disconnected from political interest and motivations: its only purpose was to apply a certain amount of expertise and experience (acquired both in the United States and in several foreign countries) to the solution of educational problems. With espect to the Atcon report, the writer disclaims any connection with this document, and, in fact, rejects its principal theses as unrealistic and unsuitable for Brazil. We have no comment on the demand for more qovernment funds or better restaurant services. We would venture to express some surprise, however, that the students have not observed the clear inequity of the cursinho and the selection processo of the exame vestibular: and that they seem to be oblivious to the inadequacy of the library holdings of the university for effective independent study or research; and that they have little or no interest in the modernization and improvement of the curriculum.

IV - The Vicious Circle. The comments above will probably suffice to convey the writer's impression that the problem areas of Brazilian higher education are composed of interrelated and interdependent factors: the part-time professor obscures the illogic of the part-time student, and vice-versa; the part-time student/professor combination make the lack of a central research library a less glaring defect; this same combination prevents meaningful participation of professor and student in the operation of the institution; central or «remote» control of the University structure makes the institution less interested in the community and region; and lack of community interest and support makes the institution more dependent upon federal sources; industry-university collaboration depends upon research; research depends upon library resources and full-time staff; and so on. Perhaps a graphic representation of this reciprocal causality gives the bust indication of the interrelationship of factors. (See Chart I). Even so, this is an oversimplication, since the factors are not related in a simples cause-efect cycle. It will not suffice, for example, to give major support to the creation of central libraries with the thought that the problems of research, regional and community identification, and industrial support would thus be solved. The related factors of the part-time staff, financial insecurity, post-graduate programs would remain negatively active and unresolved.

There is little doubt that multiple problem areas must be attacked simultaneously for any real improvement in the Brazilian university. This task will require foreign assistance, provided and received in good faith; it will require the active collaboration of the Bralizian control agencies, the student body, the teaching staff, and the administrative officers of the institutions; and it will require the interest and support of the Brazilian society. 
Apêndice F. 1

\section{A UNIVERSIDADE-FUNDAÇÂO: UMA CAIXA DE PANDORA}

JOHN M. HUNTER

Durante cerca de sete meses, examinando a situação da Educação superior brasileira, e procurando compreendê-la, temos ouvido muito sobre a «Fundação» como sendo um expediente legal para «resolver» ou «atenuar» pelo menos boa parte dos problemas das Universidades. Uma das principais vantagens atribuídas à «Fundação» é a de «libertar» as Universidades de todas as normas, regulamentos e complexidades do DASP particularmente no que toca ao pessoal docente. Encontram-se notáveis exemplos onde o esquema «Fundação» teve êxito, como sejam o IBGE, a Fundação Getúlio Vargas.

O objetivo deste trabalho não é argumentar contra ou a favor da Fundação como um expediente em si, mas sugerir que adotar a Fundação como forma de organização não resolve problemas. Pode facilitar sua resolução ou pode simplesmente converter um conjunto de problemas num conjunto diferente. Até certo ponto - e no mínimo - o novo sistema libertará no organismo universitário toda uma série de novos problemas - a abertura da caixa de Pandora - e são estes que vamos examinar aqui.

Problema do Pessoal Docente - Os problemas de pessoal relacionados ao pessoal profissional das Universidades, traduzidos nos seus termos mais simples, são: 1) Recrutamento - convite e contratação. 2) Fixação - incluindo um sistema de recompensas e a elaboração de um conjunto de critérios para julgar o desempenho profissional. 3) Dispensa - talvez um aspecto especial da fixação. Porém, deve haver condições para a aposentadoria ou simplesmente para a «demissão» em virtude de falta de desempenho ou de algum tipo de má conduta. 4) Proteção - um problema especial da «fixação» e da «dispensa», que implica no reconhecimento da natureza muito especial do papel do magistério na sociedade.

Cada um destes aspectos será mais desenvolvido e melhor explicado posteriormente. Todos os sistemas se defrontam como estes mesmos problemas e, mal ou bem, os resolvem. Primeiro examinaremos

Tradução de Jacques R. Velloso. 
o sistema atual e o tratamento nele dispensado àqueles aspectos do problema do pessoal; em seguida, analisaremos os novos problemas que seriam levantados pela «libertação» do atual sistema.

\section{O SISTEMA ATUAL}

Esta descrição será muito breve, quase caricatural, em parte para poupar a paciência do leitor e em parte devido ao meu conhecimento incompleto do assunto. Além disso, meus comentários são mais pertinentes às instituições federais do que às estaduais, municipais ou particulares .

Recrutamento - No sistema atual, dá-se pouca atenção ao recrutamento de novo pessoal ou de administradores universitários. Estes são eleitos, o que evita um programa de recrutamento segundo o sentido usual da expressão. Por outro lado, o recrutamento de professores não poderia constituir-se em intensa atividade, pois a maioria tem, no que se refere ao trabalho, «condicionamentos externos». Enquanto o pessoal decente trabalhar em regime de tempo parcial e o cargo docente não fôr o principal emprego, os atrativos deste serão provavelmente os fatores determinantes de sua localização geográfica, etc, permanecendo as condições do emprego universitário num plano nitidamente secundário. Além disso, os salários fixos e as condições de trabalho já determinadas permitem pouca flexibilidade para um intensivo programa de recrutamento. O concurso também é expediente muito mais adequado a situações de um excesso de pessoal qualificado procurando cargos altamente desejados do que a uma conjuntura de deficits de pessoal qualificado. $\mathrm{O}$ «condicionamento externo» limita seriamente a mobilidade e portanto restringe ainda mais o número de pessoas que podem ser candidatos efetivos a qualquer concurso.

Fixação - Desde que um professor seja admitido, suas expectativas de salário supõem correções monetárias automáticas, benefícios por tempo de serviço, e salário proporcional ao número de dependentes. Isto lhe é «devido», é um «direito» e não pode ser negado, nem reduzido nem aumentado pela faculdade ou Universidade. Existem outros tipos de gratificações que podem ser consideradas: 1) Diferenciação entre as tarefas destinadas a cada um, embora isto tenha significado limitado sob o sistema de cátedra. 2) Diferenciação na concessão de verbas para pesquisa e na designação de assistentes. 3) Diferenciação na concessão de bolsas, licenças, etc. Em tudo e por tudo, o sistema permite pouca flexibilidade nas negociações para induzir o pessoal a permanecer na Universidade e segundo minhas observações suspeito que mesmo esta pequena flexibilidade é pouco utilizada.

Afastamento ou Dispensa - Com respeito à seleção de professores, o atual sistema funciona baseado em suposições: 1) Ou êle é infalível, ou 2) Admitindo um possível erro, a Universidade - e não o indivíduo - deve arcar com todos os ónus dos erros. A seleção pode ter sido 
mal feita, o professor pode vir a ser ineficiente; em qualquer dos casos, le não pode ser dispensado. Aparentemente, mesmo que a disciplina de sua cátedra se torne obsoleta, êle também não pode ser dispensado. Assim o sistema atual resolve o seu problema do «afastamento», só admitindo ás possibilidades de morte, aposentadoria (incapacidade física prolongada?) ou renúncia voluntária ao cargo. Desconheço até que ponto as pessoas podem ser induzidas a renunciar ou a aposentar-se. Entretanto, de modo geral, existe pouca flexibilidade.

Proteção - Há muito que os professores mantêm uma posição favorecida em virtude da natureza mesma de suas tarefas buscar e ensinar a verdade, seja ela popular ou impopular, onde quer que ela possa ser encontrada. Esta tarefa não pode ser cumprida estando os políticos, sacerdotes, homens de negócio ou soldados supervisionando e revendo o trabalho dos professores, ditando as áreas em que a verdade pode ser procurada ou ensinada. O atual sistema reconhece claramente esta situação e dá o máximo de proteção aos professores.

Esta caracterização talvez seja exagerada e provavelmente existirão exceções ao perfil traçado, mas de modo geral são estas as impressões que um estrangeiro interessado pode obter num prazo de obervação relativamente curto. Suponhamos agora que a Fundação como forma de organização permita que as Universidades estabeleçam sua própria política com respeito aos professores. Como serão e como poderão ser tratados estes mesmos problemas?

\section{SOB O REGIME DA FUNDAÇÃO '}

Recrutamento - Dada a liberdade e flexibilidade inerentes a esta nova organização, as únicas restrições óbvias ao recrutamento são as de ordem orçamentária. Uma dada Universidade - e seus variados componentes - tem apenas que decidir quais são as prioridades a ser concedidas e distribuir os recursos de acordo com esta prioridade. Entretanto, no processo de recrutamento, ela se vai defrontar com muitos e novos problemas, como: 1) Que percentagem do corpo docente deve trabalhar em regime de tempo integral? 2) Esta percentagem deve ser a mesma para todas as subunidades? 3) Uma Universidade teria algumas vantagens naturais que deveriam ser exploradas ou desvantagens que devessem ser superadas? 4) Podem ser descobertos, elaborados ou oferecidos alguns argumentos persuasivos tais como residência para professores, dotações especiais para pesquisas, etc? 5) Até que ponto poderia ser permitida uma competição inter-institucional, isto é, uma instituição poderia «comprar» professores de outras instituições?

Pede-se ao leitor que desculpe as constantes referências aos Estados Unidos nos exemplos que se seguem. A razão é que estou mais familiarizado com o sistema deste país. 
Das perguntas acima depreende-se claramente que a liberdade e a flexibilidade no recrutamento levantam muitos problemas que são evitados pelo sistema atual. Segue-se breve descrição de elementos que têm constituído, numa ou noutra circunstância, aspectos importantes do processo de recrutamento, e que demonstram as várias facetas novas da tarefa de contratação de um professor.

a) Salário - Certamente os salários e as expectativas de salários constituem aspectos importantes na contratação de professores. Isto levanta uma questão crítica, ou seja, a de que os salários devem ou não ser os mesmos para toda a Universidade e para professores mais ou menos equivalentes (assunto a ser discutido abaixo).

b) Residência para o Corpo Docente - especialmente para os novos professores. Talvez isto seja menos importante no Brasil do que nos Estados Unidos, em virtude da mobilidade muito menor dos professores universitários brasileiros. ${ }^{2}$ Neste caso, possivelmente seria mais adequado adotar-se um sistema de residência permanente para os professores, seja êle subvencionado ou não. A Universidade Nacional de Tucumán, na Argentina, por exemplo, fornece residência permanente para professores de outros Estados, reconhecendo a necessidade de encontrar algum meio de atrair pessoal de outras áreas. Isto substitui em parte as diferenças salariais que a Universidade não pode pagar legalmente.

c) Baixa Carga de Ensino - Este método é usado para o pessoal docente com alta prioridade para pesquisa. Pode ser utilizado para reduzir as cargas cada semestre ou ocasionalmente. Suponhamos, por exemplo, que a carga de ensino «normal» é de 3 disciplinas. Poder-se-ia dizer a um professor de prestígio que êle precisava dar somente duas disciplinas ou não precisava dar aula alguma cada terceiro ou quarto semestre. Esta política implica em custos e evidentemente não se pode oferecer cargas reduzidas a todos.

d) Dotações para Pesquisas, tempo de computadores - Todos os auxílios para pesquisas podem ser importantes expedientes no recrutamento - e podem até mesmo ser o item crítico. Um expoente pode ser atraído pela generosidade, ${ }^{3}$ e o pessoal júnior simplesmente pelas facilidades de pesquisa, tais como orçamento adequado para a biblioteca, suficiente ajuda de pessoal de secretaria, etc.

2 Como indicação da mobilidade existente, temos o fato de que a maioria das boas Universidades dos E.U.A, tem por norma não contratar os seus estudantes que nela concluíram cursos de pós-graduação (mestrado e doutorado), senão depois que hajam se afastado da instituição por alguns anos. Esta norma destina-se a evitar a formação de professores dentro do próprio corpo docente. Além disso, os estudantes são aconselhados a que preferivelmente não façam seus cursos de graduação e de pós-graduação na instituição, a fim de travar conhecimento com diferentes abordagens do seu campo de estudo e de ter maior contato com maior número de professores.

Os «melhores» cargos de professor nos Estados Unidos atualmente pagam um salário adequado e, além disso, duas ou três vezes o valor deste salário com a finalidade de financiar o trabalho pessoal de pesquisa do professor. 
e) Política de «Licenças Especiais» e outras licenças - Um professor «produtivo» espera ter cada sétimo ano livre para pesquisa estudd8 e viagens, recebendo pelo menos uma parcela substancial de sei salário.

f) Viagem - A liberalidade no pagamento para participar de conferências, seminários, etc. - especialmente para as instituições isolai___pode auxiliar a superar o isolamento detestado pela maioria dos professores.

q) Consultoria - A autorização para dar consultas particulares com ou sem pagamento pode também ser um atrativo, permitindo que o professor suplemente sua renda e mantenha contatos com o mundo real.

h) Finalmente, nenhum expediente para o recrutamento será mais útil do que possuir um grupo ativo, dinâmico e reconhecido dentro de uma Universidade respeitada.

Um dos principais problemas tem sido e continua a ser o do salário. Discutiremos aqui um dos seus aspectos: o salário deve ou não deve ser o mesmo em toda a Universidade, para o pessoal de tempo integral «igualmente qualificado»? Nos Estados Unidos, empregamos dois sistemas diferentes, e ambos sugerem negativas a esta pergunta, embora um sistema seja o contrário do outro. A essência do problema gira em torno do fato que engenheiros, economistas e químicos não têm maiores dificuldades em obter um emprego bem pago fora da Universidade. Os especialistas em História, Português, Musicologia têm poucas oportunidades fora do âmbito universitário. O resultado é que (quer concordemos ou não com isto) na nossa sociedade um engenheiro ou economista vale mais no mercado do que um historiador. Um grupo de universitários nos Estados Unidos reconhece este fato e explicitamente paga salários distintos para os diferentes ramos profissionais, mas de modo geral procura aplicar os mesmos padrões de promoção para os vários níveis da carreira. Outro grupo de Universidades adotou o sistema de pagar o mesmo salário a todos os instrutores, todos os professores assistentes, etc. A experiência tem demonstrado que também este sistema responde ao mercado, e o progresso através dos diferentes níveis da carreira é mais rápido nas profissões de grande demanda do que nas outras.

Podemos condenar veementemente este aspecto da realidade, mas será insensato ignorá-los. Pagar a todos os professores de acordo com o nível daquelas profissões melhor remuneradas pelo mercado seria extre-

Frequentemente, êle tem um ano inteiro com meio salário ou meio ano com salário integral.

Estes «expedientes» só têm realmente sentido para o corpo docente que é essencialmente de tempo integral, e para alguns casos específicos, como os citados em $g$, mas não têm absolutamente nenhum sentido para o corpo docente de tempo parcial. Existe ainda toda uma série de outras possibilidades. A Universidade poderia criar uma escola modelo ou experimental, reservando, com anuidades reduzidas, vagas para os filhos dos professores de tempo integral. 
mamente dispendioso e reduziria seriamente o número dos professores que poderiam ser admitidos. A política de pagar a todos segundo o preço do mercado para as profissões menos procuradas seria ainda pior, pois resultaria na tendência do ensino universitário ser ministrado pelos piores engenheiros, piores advogados e piores médicos.

A mudança do atual sistema para o da Fundação certamente aumentaria o número e a variedade dos expedientes de recrutamento que a Universidade poderia utilizar. Dispondo de maior número de escolhas, deveria ser mais fácil, para a Universidade, resolver o problema do recrutamento, ou talvez encontrar uma melhor solução para este problema. Mas esta mudança de sistema certamente aumenta a necessidade de julgamento e de tomada de decisões e resultaria num aumento dos erros individuais, altamente prováveis, em lugar dos erros de sistema, também altamente prováveis. Se não se dispõe de escolhas, o processo é simples (embora os resultados possam ser ruins), mas com as possibilidades de escolha o processo torna-se complexo, e espera-se que os resultados sejam melhores.

Nada do que acima foi comentado está em termos de «recomendação»; simplesmente tentou-se examinar pelo menos as principais alternativas que existem, sem que se tivesse pretendido julgar sua validade quer no contexto da Educação brasileira, quer no dos Estados Unidos.

Fixação - Uma vez que o pessoal docente tenha sido recrutado, os problemas restantes referem-se a como manter aqueles que têm um desempenho adequado e como evitar conservar aqueles que não o têm. Nesta parte do texto discutiremos somente o problema da fixação, embora os dois estejam inextricàvelmente interligados.

A primeira decisão real a ser tomada é uma decisão das mais importantes: procurará o sistema distinguir entre aqueles que têm um desempenho adequado e aqueles que não o têm, e com que objetivo? Se fôr decidido que as nomeações são irrevogáveis e para toda vida, a questão está respondida quanto à fixação, mas poderá surgir de novo em outros assuntos.

Quando perguntamos «com que critérios os professores devem ser julgados?», estamos próximos do âmago do problema da Educação superior. O que é desejado, o que é esperado da Educação superior brasileira? Só poderia ser elaborado um conjunto de critérios para medir o desempenho dos professores quando já estiverem delineados os objetivos nacionais para a educação superior. Os professores serão, em última análise, o principal veículo para a execução dos referidos objetivos.

6 Existem, está claro, outros incentivos além do salário para estimular os estudantes a se tornarem professores, mas o salário é, para muitos de nós, uma consideração importante. Muitos jovens deixam o magistério simplesmente porque não podem permanecer nele - da mesma forma que muitos brasileiros atualmente não têm recursos para ser professores universitários de tempo integral, mesmo reunido dois cargos diferentes. 
Seja como fôr, e desde que minha intenção é muito mais levantar problemas do que resolvê-los, permitam-me sugerir alguns critérios que_dados os objetivos gerais — poderiam ser aplicáveis:

a) Uma das principais funções do sistema será certamente a de ensinar aos estudantes universitários, e portanto o desempenho de um professor (uma espécie de combinação da capacidade inata e do interesse) será um importante item para julgá-lo. Infelizmente, não temos nenhuma medida conveniente que permitisse medir, digamos, numa «escala de Dewey», a boa ou má qualidade de um professor; e todo o pessoal universitário esclarecido logo reconhecerá a tarefa extremamente difícil que é julgar os desempenhos.

O professor de quem eu mais gostava, quando estudante, era um cavalheiro minucioso que escrevia no quadro negro o esquema da aula de cada dia; nós ouvíamos, copiávamos, memorizávamos, obtínhamos boas notas, mas hoje dificilmente conseguimos lembrar sobre o que era aquele curso. O professor mais irritante era aquele que nos deixava em dúvida, confundia-nos em vez de esclarecer-nos, levantava mais problemas do que os resolvia. Nós, estudantes, enfrentando as provas, não gostávamos dele. Porém, agora, muitos anos mais tarde, não temos dúvida em ver que foi com êle que fomos estimulados intelectualmente, pois exigia que nós pensássemos, levavanos a procurar os fatos e os problemas importantes. Este exemplo sugere duas ideias: 1) Que os processos externos de ensino podem não ser perfeitamente adequados para um julgamento. 2) Que os atuais estudantes podem trazer uma contribuição positiva para a avaliação do desempenho de um professor, mas não se pode esperar que suas opiniões sejam totalmente dignas de confiança. O verdadeiro teste para o desempenho de um professor é a verificação do resultado do aprendizado do aluno (tomada esta expressão em seu sentido mais amplo) vinte anos após deixar as salas de aula. O que êle ou qualquer outra pessoa pensa enquanto está nas salas de aula é somente um substituto imperfeito para o verdadeiro teste.

Existem ainda outros aspectos complexos: 1) O desempenho de um mesmo professor pode variar de uma matéria para outra. Alguém tem que ensinar as matérias menos interessantes e menos insinuantes. A boa vontade de executar esta tarefa é por si só uma parcela do desempenho do professor? 2) Um indivíduo pode ensinar melhor a pequenos grupos de alunos as fronteiras do conhecimento porque se encontram neste campo as suas capacidades e interesses, enquanto que outro teria melhor atuação dando conferência a grandes turmas de alunos sobre as matérias mais elementares, e encarregando-se dos detalhes administrativos destas turmas. Como pode ser comparado o desempenho dos dois? 3) No mesmo curso, ou disciplina, uma pessoa pode ser mais eficiente usando, digamos, o método de «aula-conferência», 
enquanto que outra se baseia no método «socrático». Um destes métodos é preferível e é um deles mais meritório do que o outro?

$\mathrm{O}$ fato de levantarmos estas questões como imponderáveis não sugere que se deixe de fazer um julgamento acerca da qualidade do ensino. Se c ensino é importante, então parece ser duplamente certo que as Universidades têm que fazer julgamento sobre o desempenho do professor, mesmo se a precisão não puder ser atingida e se forem prováveis os erros ocasionais nestes julgamentos. Recusar-se a cumprir este dever de responsabilidade é fazer funcionar um sistema que presume que todos os professores são: 1) igualmente bons mestres; 2) igualmente interessados nas suas tarefas de ensino. A experiência demonstra que ambas as proposições são falsas. ${ }^{7}$

b) Além do ensino, o sistema universitário provavelmente irá (deve?) incluir a pesquisa nos seus objetivos. Se o fizer, há de esperar que o seu pessoal «profissional» (que pode ser ou não o mesmo que o pessoal de «ensino») realize trabalhos de pesquisa. E, mais uma vez, sendo a pesquisa um dos objetivos, a Universidade tem de estar preparada para avaliar este trabalho (ou para supor que todos são igualmente competentes, igualmente interessados, e trabalhando em problemas igualmente importantes).

Talvez a avaliação de um trabalho de pesquisa seja mais fácil do que a avaliação do ensino, particularmente porque existem algumas medidas externas. Se uma pessoa é repetidamente convidada a apresentar seus achados em congressos nacionais e internacionais, e/ou se estes achados aparecem com frequência em revistas profissionais reconhecidas nacional e internacionalmente, isto normalmente constitui clara evidência de um trabalho de pesquisa de alta qualidade. Mas não resolve, de modo algum, o problema de avaliação dos trabalhos de pesquisa. 1) Como se avaliaria a pesquisa magnum opus que leva anos para ser produzida? 2) Como se avaliaria a pesquisa sólida e honesta, de nível nacional, regional ou local e que pode nunca vir a atrair a atenção internacional? Num certo sentido, isto pode envolver a distinção geralmente estéril entre pesquisa «básica» e «aplicada». 3) Como seria comparado o «valor» do resultado de uma pesquisa em Biologia com o de uma em História?, como o de uma em Economia?

Nos Estados Unidos, geralmente funcionamos segundo o lema «pesquisa e ensino andam de mãos dadas», dando-se a isto um significado bastante amplo. Sugere-se, portanto, que os pesquisadores devem ensinar e os professores devem pesquisar, ponto de vista este que inclui

Logicamente, as hipotéticas distribuições desiguais de 1) e 2) poderiam contrabalançar a ambos (isto é, o incapacitado seria altamente motivado e vice-versa), resultando num igual desempenho de todos nas tarefas de ensino. Por outro lado, nossa experiência sugere que as duas características têm mais probabilidades de ser auto-suficientes (isto é, o incapacitado seria pouco motivado e o capacitado, altamente motivado) . 
certa dose de insensatez, e as Universidades brasileiras devem meditar corri cuidado sobre este axioma. Os bons professores, obviamente, têm que estar atualizados nos campos de suas disciplinas, ${ }^{8}$ mas isto não quer dizer que devam realizar um trabalho original de pesquisa. Esta suposição parece admitir que se eles estão trabalhando numa pesquisa, estão se atualizando, o que pode ser erróneo. E os estudantes certamente têm que ter contato com a pesquisa e com os melhores pesquisadores, roas esta necessidade não significa que todos os pesquisadores devam manter contato com os estudantes.

c) Podemos ainda levar em conta outras atividades ao fazermos o julgamento sobre o professor.

Dentre meus preconceitos, encontra-se o seguinte: parte substancial do sistema universitário (mas não necessariamente todas as Universidades) deve estar estreitamente relacionado com os problemas da sociedade que o criou. A Universidade é um repositório de conhecimentos e de know-how que, até certo ponto, tem que ser colocado imediatamente à disposição da comunidade. Por exemplo: fui designado para ensinar «Fundamentos de Economia» a vários grupos de pessoas, tais como diretores de empresas, líderes sindicais, e todos os empregados de uma fábrica. O exemplo mais amplamente conhecido deste tipo de atividade da Educação nos E.U.A, é o dos cursos de extensão universitária sobre agricultura, levados diretamente ao fazendeiro, cursos que são, em grande parte, responsáveis pelo enorme aumento da produção agrícola neste século.

Este tipo de atividade não é um caminho com uma única direção a ser seguida. No meu caso pessoal, tive que me preparar para atingir uma audiência não obrigada a comparecer (e que compareceria ou não, dependendo de quanto eu pudesse tornar o assunto interessante). Isto fêz com que meus métodos e recursos de ensino melhorassem enormemente, pois exigia que eu elaborasse novas técnicas, fosse mais enfático, que «envolvesse» os alunos, e eliminasse as irrelevâncias e refinamento do assunto. Professores de quase todas as disciplinas podem aprender bastante através de contato constante ou ocasional com o «público».

Não desejo prejulgar os objetivos brasileiros. Estes objetivos poderiam ser importantes, e se o ferem as Universidades teriam que encontrar algum meio de realizá-los - mais uma tarefa para os professores, cuja eficiência necessitaria de julgamento.

d) Finalmente, o professor tem de ocupar-se com muitas outras atividades intra-universitárias, que absorvem seu tempo e exigem seus conhecimentos: elaboração de currículos, constante atenção voltada para as mudanças de curriculares, administração educacional, elaboração e edição de publicações universitárias. Estas e outras são atividades

1 Mesmo campos de estudos «estáveis» como História, Línguas, Literatura, etc, estão constantemente passando por substanciais mudanças pedagógicas. 
profissionais, são valiosas, e podem ser uma parcela dos objetivos da Universidade. Como podem ser avaliadas e comparadas a outras atividades desejáveis?

A discussão dos critérios para julgamento implica num julgamento global do mérito e sugere que o mérito é algo a ser recompensado de algum modo. Se o mérito deve ser recompensado - e o desejo de livrar-se do automatismo do DASP sugere que deve - existe o problema do julgamento (que já foi discutido) e o problema de «recompensar com que»? Temos aí várias possibilidades. Frequentemente sugere aos observadores dos E.U.A, na América Latina que a remuneração para o mérito é o prestígio que se reflete na atividade não universitária de uma pessoa. O arquiteto que é também diretor de uma faculdade poderá receber honorários maiores do que aquele que fôr somente um professor, este poderá receber mais do que o arquiteto que não fôr professor, etc, etc. Isto pode muito bem ser verdade, e o fato de que o prestígio será altamente desejado e procurado no novo sistema tem que continuar também a ser uma verdade. Mas se o trabalho universitário em tempo integral torna-se um desideratum, desaparece a possibilidade de traduzir-se prestígio em termos de feijão. Provavelmente existem vários sistemas que relacionam o mérito à recompensa. Entretanto, desejo levantar questões somente acerca de dois deles: nível. e para dizê-lo cruamente, dinheiro.

Criar um sistema de níveis, é modo de distribuir prestígio. Nos Estados Unidos, temos quatro níveis principais: instrutor, professor assistente, professor associado, professor. Não existe nada de sagrado nestes nomes ou quanto às quantidades especificas existentes. Talvez devesse existir um maior ou menor número de níveis (se é que deve haver algum). A existência de níveis, é claro, implica em critérios para promover as pessoas de um nível para outro. Implica, também. num mecanismo para tomada de decisões. Dois aspectos podem ser rapidamente abordados: 1) A promoção automática como função do tempo negaria a ideia do relacionamento entre nível e mérito. 2) O problema dos critérios e julgamento sobre o assunto níveis não é exatamente o mesmo que o dos aumentos salariais em função do mérito. O primeiro diz respeito ao nível de realizações, enquanto que o segundo está ligado ao aumento de realizações.

Com respeito ao dinheiro, seria bom se chegássemos à conclusão de que os professores não se preocupam com dinheiro, dedicando suas vidas à juventude e à busca do conhecimento. Outros poderiam preferir uma urgente mudança do sistema sócio-econômico, a fim de que estas dedicadas almas não tivessem que se preocupar com objetivos materiais. Contudo, até chegarmos à utopia, o dinheiro desempenhará importante papel e, no nosso caso, em dois relevantes aspectos: 1) Se se pensa que é desejável um ensino e pesquisa em regime de tempo 
integral, então os salários têm que ser suficientes para atrair jovens para o ensino universitário como uma carreira. Isto significa que o jovem que não tenha independência financeira deve poder olhar para o futuro e sentir, com alguma confiança, que pode sustentar razoavelmente a si e a sua família através do trabalho na Universidade. ${ }^{9}$ Se isto não puder ser feito, os únicos que podem ser atraidos para uma carreira universitária com trabalho em tempo integral são os que já possuem independência financeira, e não há muitos motivos para pensar que estes são os melhores. Pode-se talvez contar com o trabalho dos demais no máximo e unicamente em regime de tempo parcial. 2) O dinheiro, e especificamente os aumentos de salários, podem ser utilizados como parte de um sistema de recompensas. $\mathrm{Na}$ instituição em que trabalho, ${ }^{10}$ revemos anualmente o desempenho de cada membro do corpo docente profissional - utilizando critérios bastantes semelhantes aos que discutimos anteriormente - com a finalidade de conceder aumentos salariais (de «zero» para cima). Estes são chamados de «aumentos por mérito». Isto nos dá o «prémio» e o «castigo», meios de recompensar o desempenho meritório e de corrigir o desempenho pernicioso. Sabemos que uma pessoa que «tendo estabilidade» ${ }^{11}$ deixe de progredir, que não assuma sua parte das responsabilidades, que negligencie o ensino, não receberá aumentos de salários, enquanto que o desempenho «médio» trará modestos aumentos e o desempenho excepcional trará grandes aumentos salariais. Este ponto não deve ser super-enfatizado. pois faz com que os professores pareçam crianças de jardim de infância. Talvez cerca de $95 \%$ dos professores tivessem o mesmo comportamento se não existisse este sistema. Talvez o preguiçoso não seja afetado por este sistema, mas é ocasionalmente instrumento útil e frequentemente uma catarse psicológica para saber que o colega negligente não será tratado da mesma forma que os outros. ${ }^{1}$

Desejo esclarecer mais uma vez que este sistema não é necessariamente uma recomendação, e que somente procurei mostrar os tipos de problemas levantados pela flexibilidade.

Dispensa e proteção — Estes dois aspectos do problema do pessoal estão tão estreitamente relacionados que serão discutidos juntos. O problema essencialmente é que o corpo de professores deseja proteger-se das pressões externas no seu trabalho de ensino e pesquisa, e tem bons e justos motivos para tanto. Em última análise, proteger seus

9 Tendo-se a noção de que os professores em potencial geralmente possuem «padrões de vida» razoavelmente elevados.

10 Michigan State University, East Lansing, Michigan.

11 A ser explicado abaixo, e bem separados deste assunto.

12 Supomos que os enganos nas nomeações correrão, mesmo quando as nomeações permanentes forem feitas somente após vários anos de observações, .e de fato esta suposição é correta. É também fato que algumas instituições têm um automatismo muito maior nos seus sistemas de salários do que o aqui descrito. 
membros da eventualidade de uma demissão devida a razões injustas provenientes de qualquer fonte, ou por qualquer motivo derivado de forças de fora da Universidade. Esta é a essência da liberdade de cátedra e fora dos países totalitários poucas pessoas defenderiam posição contrária.

Tendo sido decidido que a «liberdade de cátedra» tem de existir, surge o problema da «liberdade para fazer o quê?» ou da «liberdade para não fazer o quê?». Não se admite que a «liberdade de cátedra» seja uma licença total, e o problema perene é o traçar as fronteiras entre o que é permitido e o que não é. A «incompetência profissional» geralmente não é protegida (embora seja difícil de se provar), a «baixeza moral» (qualquer que seja o significado dado a esta expressão) não é protegida, continuando fracasso de um professor no cumprimento de suas tarefas provavelmente não será protegido. Existem muitas possibilidades que ainda estão pouco obscuras: o que dizer do professor de matemática que usa sala de aula para defender a causa de Barry Goldwater? ou a posição de «parar com o bombardeio», ou os principios de determinado candidato político, durante a época das eleições? O que dizer dos poucos professores que, uma vez assegurada esta proteção, param suas atividades intelectuais? $O$ que dizer do professor que falta constantemente às suas aulas, porque está dedicado a consultas fora da Universidade? Existe grande quantidade de possíveis «pecados» que podem ser acobertados pelo sistema que é destinado somente a proteger os direitos do professor trabalhar em suas pesquisas como julgar mais conveniente e de ensinar a verdade como êle a vê.

Portanto, garantir a «liberdade de cátedra» envolve certo grau de proteção para o professor, isto é, certo grau de segurança em seu trabalho. Mas isto levanta questões importantes, como: 1) Que tipos de atividade devem ser protegidas? Num extremo, poderíamos sugerir «zero» atividades, ou absolutamente nenhuma liberdade de cátedra; no outro extremo, o professor poderia ser protegido contra os aborrecimentos do estacionamento proibido, contra as amolações dos cobradores de impostos, etc. e entre estes extremos está toda uma série de atividades. Deve ser determinado um ponto em algum lugar desta série. 2) Quanto maior fôr a proteção dada, maiores serão as probabilidades do sistema vir a incorporar várias espécies de «indesejáveis»: o preguiçoso, o incompetente, o desmazelado, o desinteressado. Parece-nos evidente que existe uma positiva associação entre estes aspectos, ou seja, quanto maior fôr a liberdade de cátedra maior será a probabilidade de se protegerem atividades com características não imaginadas — ou por certo não desejadas — nos objetivos iniciais. ${ }^{13}$

13 Meditando sôbre o assunto, encarando os fatos cora certa jovialidade, conclui que o sistema de estabilidade do serviço público é ótimo para os" países que não o possuem, mas péssimo para aqueles paises que o têm. 
Se esta proposição fôr correta, então é importante que o pessoal sejaselecionado com cuidado extremo e se encontre algum meio de reduzir ao mínimo os prejuízos potenciais dos «erros».

Suponho que exista uma gama infinita de sistema possíveis. Mais uma vez, e sem nenhum caráter de recomendação, permitam-me descrever o sistema com o qual estou mais familiarizado.

O sistema americano é um «sistema de estabilidade» no qual certo número de professores é nomeado por períodos de tempo definidos (sem estabilidade), enquanto outros são nomeados por tempo indefinido normalmente para toda a vida. Destes, digamos que têm «estabilidade». «Ter estabilidade» significa essencialmente que o professor não pode ser demitido do cargo senão em virtude de certos abusos da liberdade que goza, como baixeza moral, consistente falta de cumprimento dos regulamentos da Universidade, etc.

Para os níveis iniciais da carreira as nomeações são feitas sem implicar em estabilidade. Os instrutores são usualmente nomeados por um ou dois anos e podem ser reconduzidos. Os professores assistentes são usualmente nomeados por três anos e podem ser reconduzidos. Mas, via de regra, o período total em que uma pessoa pode ser contratada sem ganhar estabilidade é de 6 ou 7 anos. Por exemplo, um professor assistente é nomeado por três anos e depois readmitido por mais três anos. Qualquer recondução subsequente automaticamente inclui estabilidade. A promoção de professor assistente a professor associado inicialmente implica em estabilidade. Nomeações de professores (que não pertenciam anteriormente ao quadro da Universidade) implicam em estabilidade. ${ }^{14}$ As nomeações de professores associados são normalmente por 2 ou 3 anos e qualquer recondução subsequente implica em estabilidade. Geralmente não há regras para evitar a concessão de estabilidade antes dos limites máximos sugeridos, e a promoção a professor associado frequentemente ocorre antes do período de experiências de seis ou sete anos.

Este sistema provê um prazo de vários anos para uma tomada de decisão, durante o qual a Universidade presumivelmente poderá observar o indivíduo, a fim de estar apta a fazer julgamentos válidos sobre seu interesse e capacidade de ensinar, sua capacidade de pesquisar, etc. Deve-se notar que a Universidade é obrigada a tomar uma decisão quanto à estabilidade: depois que um professor trabalhar durante o período «probatório», a Universidade tem que decidir se êle é ou não uma pessoa a ser contratada por toda a vida. Este aspecto do sistema é algumas vezes chamado de «promoção ou demissão».

A razão fundamental é que neste nível as nomeações são de pessoas de altos níveis, que já são bastante conhecidas. 
Tem por justificativa o fato de que seis ou sete anos constituem um prazo bastante longo para tomar-se uma decisão, e ninguém deve ser contratado além desse período sem a completa segurança garantida pela liberdade de cátedra. Além disso, a Universidade não deve, de modo algum, contratar uma pessoa por período de tempo maior do que aquele, em bases «provisórias» e sujeita a não-renovação de contrato, não importa por que motivo.

Nenhum sistema é tão perfeito a ponto de predizer as atividades profissionais de um homem por um prazo de trinta anos, ${ }^{15}$ mas existem meios marginais para suavizar os efeitos dos erros. O professor que se recusa a fazer pesquisa e a publicar trabalhos pode receber uma carga de ensino muito pesada (desde que, evidentemente, êle não seja um mau professor). Os maus professores, os velhos, os cansados são designados para períodos de aulas impopulares, onde seu contato com os estudantes é menor. Podem ainda ser designados para fazer trabalho de «pesquisa em casa», ao invés de ensinar, simplesmente para reduzir ao mínimo os danos que podem causar. De certo modo, isto é semelhante às chamadas aulas «paralelas», algumas vezes organizadas em Universidades Latino-Americanas.

Existem processos complicados e elaborados para demitir uma pessoa com estabilidade. O processo é iniciado por alguma autoridade da administração da Universidade. Se o professor quiser entrar em litígio, uma comissão permanente de professores estuda o caso e faz uma recomendação. Se esta conclui contra o professor, não existe apelo para outra instância. Se conclui em seu favor, a administração pode ou não aceitar suas conclusões e arquivar o assunto, ou insistir na demissão simplesmente, através da suspensão do pagamento de seu salário. ${ }^{16}$ No caso de um flagrante abuso de liberdade de cátedra. a «American Association of University Professors» pode finalmente agir, censurando publicamente a Universidade, após cuidadosa investigação. Esta atuação não tem força de lei, mas é encarada seriamente por nosso mundo profissional. O recrutamento de bons profissionais é particularmente difícil para uma instituição «censurada».

\section{CONCLUSÃO}

Espero ter mostrado a grande quantidade de problemas que surgiriam unicamente na administração do pessoal docente, caso o atual sistema viesse a ser extinto. Foi descrito e discutido grande número de alternativas para o atual sistema, mas sempre evitou-se tocar num aspecto: quem se encarregaria de todas as decisões a serem tomadas e de todos os julgamentos a serem feitos?

\footnotetext{
15 Supondo-se que a estabilidade fosse concedida aos 35 anos de idade e que êle se aposentasse aos 65 .

16 Estes casos são extremamente raros. Na verdade, os casos raramente chegam até a comissão de professores.
} 
Esta questão deverá ser objeto de outro trabalho, e desejo somente comentar de modo geral alguns de seus aspectos.

Para uma melhoria do sistema universitário, pode ser que seja desejável e necessário uma segura liderança de um ou mais indivíduos, durante um considerável período de tempo. Não existe nenhuma garantia de que as instituições humanas medíocres venham a passar por rápida melhoria - se é que alguma melhoria - através da utilização do incómodo mecanismo da democracia pura. Não há nada de mágico no processo de somar os votos de pessoas medíocres, que podem muito bem ter velado interesse pela mediocridade. Um todo não é maior do que a soma de suas partes, e não contém qualquer «acréscimo» em termos de dinamismo, sabedoria ou qualidade.

Se a principal tarefa é a reforma estrutural e administrativa da Universidade (como a que vemos em andamento no Brasil), ela deve ser considerada como a renovação extensiva - senão a nova construção - de uma estrutura social importante e complexa, que requer tempo. paciência e liderança firme. Não seria razoável que pedíssemos a um arquiteto para iniciar uma obra importante e lhe disséssemos que dentro de dois meses êle estaria sujeito a novo contrato, e ao fim de seis meses deveria desocupar o cargo. ${ }^{17} \mathrm{Nem}$ se constróem muitos edifícios quando o verdadeiro poder de decisão e a verdadeira autoridade estiverem nas mãos de uma comissão. Mesmo sem as «girafas», ${ }^{1 S}$ já existem problemas suficientes na Educação superior.

Esta é uma posição «não democrática», se vista por determinados ângulos. A concessão de autoridade e a delegação de poderes para tomar e executar decisões representa um compromisso com o que há de fundamental na democracia, na qual cada eleitor participa igualmente em cada decisão. O problema da delegação adequada de autoridade e da proteção contra a usurpação do poder e da autoridade é problema gémeo da democracia. A exclusiva preocupação com este último levará à mediocridade inerte.

Uma pergunta final nesta série de perguntas. Suponhamos que a Organização $X$ é considerada deficiente, e que umas das razões para isso é que todos ou alguns de seus membros, tendo ou não tendo culpa. também são deficientes: incompetentes, sem base, não têm imaginação. são ociosos e muito ocupados com outros afazeres. Qual é o sentido de iniciar-se uma reforma que tem como principal fundamento não incomodar, de modo algum, todos os componentes atuais do sistema?

Neste exemplo os períodos de tempo são curtos, porque uma construção física é muito menos complexa e exige muito menos tempo do que construir toda uma Universidade.

Um sábio, ao ver pela primeira vez uma girafa, comentou: «Parece que foi feita por uma comissão». 
Apêndice F. 2

\section{O VALOR DA DIVERSIDADE EDUCACIONAL}

JOHN M. HUNTER

Com o propósito de trazer subsídios à reforma da Universidade brasileira, iniciamos hoje a publicação de uma série de trabalhos elaborados por especialistas brasileiros e norte-americanos. O estudo, O Valor da Diversidade Educacional, é de autoria de um professor de Economia da Michigan State University. Fala-se muito em nossos dias sobre a notável eficiência do ensino superior norte-americano. O livro de Servan Schreiber, $O$ Desafio Americano, dentro de um contexto global, despertou o interesse da opinião pública para a importância do «sistema» universitário dos E.U.A, na composição dos fatores que geraram a grandeza da presença norte-americana no mundo de nossos dias. Qual é o segredo do extraordinário desempenho das Universidades americanas? O leitor encontrará no presente trabalho do prof. John M. Hunter e nos que publicaremos em seguida a resposta adequada a esta indagação.

Depois de apresentar interessante visão de conjunto do «sistema» de ensino superior nos E.U.A., o prof. John M. Hunter analisa mais de perto as vantagens de uma organização universitária fundamentalmente flexível, variada, heterogénea. «A heterogeneidade da Educação. assinala o ilustre professor, tem demonstrado, na experiência educacional dos E.U.A., três grandes vantagens: 1) a diminuição dos custos através do aproveitamento das vantagens oferecidas pelas economias de escala; 2) uma tendência de elevar ao máximo os benefícios para o estudante através da especialização institucional não em disciplinas, mas de acordo com a votação dos próprios estudantes; 3 ) o progresso, a experimentação e a disciplina através da competição interinstitucional». Redução dos custos operacionais do ensino, adequação de currículos e programas às inclinações vocacionais do estudante e competição que inevitavelmente conduz à incessante elevação dos padrões do trabalho das instituições universitárias constituem as principais vantagens que decorrem, mas também concorrem para fazer do Ensino superior norte-americano uma organização característica, fecundamente heterogénea.

Há na Educação superior brasileira forte tendência para que exista uma identidade entre todos os elementos do sistema, para a tentativa de fazer de cada instituição educacional a imagem das demais. Encontra-se esta tendência nos regulamentos federais e no reconhecimento das profissões, nos vários dispositivos da Lei de Diretrizes e 
Bases, nos poderes e atividades centralizados do Conselho Federal de Educação. Sugere-se neste trabalho que a heterogeneidade entre as instituições é de considerável valia - é uma característica que merece. por si só, ser buscada. Este tópico será desenvolvido em duas partes: na primeira, encontraremos breve caracterização ou descrição da Educação superior nos E.U.A., no que toca a este tema. Escolhi os E.U.A, porque é esta área geográfica com a qual estou mais familiarizado, porque ilustra convenientemente a segunda parte deste trabalho, e porque, através da pouca experiência que possuo, verifiquei que os brasileiros geralmente não estão bem informados sobre a natureza da Educação nos E.U.A. Na segunda parte, veremos algumas das vantagens encontradas na heterogeneidade. Mas antes de tratarmos destes pontos principais, existem alguns aspectos suplementares a serem considerados.

1) A heterogeneidade ocorrerá, até certo ponto, mesmo que não tenha sido planejada ou desejada, ou mesmo que contra ela existam leis. Instituições tais como as Universidades são instituições sociais e suas características são provenientes da legislação básica existente, dos seres humanos que a elas estão ligados, das características nacionais e régio nais, dos recursos disponíveis e das capacidades para utilizar estes recursos etc. Mesmo que existisse uma lei descrevendo minuciosamente as Universidades, e mesmo que esta lei determinasse que todas deveriam ser iguais nos mínimos detalhes, isto simplesmente não ocorreria. Contudo, não é nesta heterogeneidade acidental e marginal que estou interessado.

2) Ainda não está definido até que ponto a heterogeneidade pode ser «planejada». Parece um tanto duvidoso que vários graus de heterogeneidade possam ser criados ou exigidos por meio de leis ou ordens administrativas. Mas se ela não pode ser especificamente planejada, certamente pode-se «criar condições» para que ela ocorra, tendo-se o cuidado de - ao planejar-se a Educação - dar à legislação básica uma natureza geral, que permita experiências, e tendo-se realmente em vista a expectativa de que instituições e circunstâncias não previstas possam desenvolver-se.

3) A heterogeneidade no sistema de Educação superior implica num considerável grau de mobilidade entre os estudantes. Assim, se um país tiver três escolas para especialização em Economia (não confundir com administração de empresas ou contabilidade), isto implica em que os estudantes interessados nesta matéria devem poder e querer ir para as localidades onde se encontram estas escolas. Estou perfeitamente ciente de que esta mobilidade não é, hoje em dia, comum entre os brasileiros, mas desejo frisar que não existe alternativa prática para encontrar meios de desenvolver este tipo de mobilidade. Este assunto será discutido posteriormente, mas permitam-me ilustrá-lo rapidamente, com um simples exemplo. Suponhamos que seja bastante desejável que o Brasil tenha um aumento anual de 40 psicólogos, altamente treinados. Eles poderiam estudar em duas ou três escolas que graduariam 15-20 estudantes por 
ano, ou nas Universidades federais que diplomariam 2 estudantes anualmente, cada uma. O custo da última alternativa será muito maior e a qualidade dos resultados muito menor. Sugiro também que não devemos supor uma falta total de mobilidade: há evidências, desde os dias de Bras Cubas, que os brasileiros estão dispostos a migrar em busca da Educação quando esta migração parece ser compensadora. Embora no passado esta disposição tenha sido amplamente demonstrada pela migração internacional, isto não exclui necessariamente a mobilidade dentro do País em busca da Educação.

Espero mostrar nos próximos parágrafos alguma coisa sobre a heterogeneidade da Educação nos E.U.A. Não porque penso que este seja um padrão que deva (ou que não deva) ser aplicado ao Brasil, mas porque é um padrão de heterogeneidade que auxiliará a esclarecer o que nós, naturais dos E.U.A., temos em mente quando falamos da Educação superior deste país.

\section{CARGOS E OBRAS}

O prof. John Hunter graduou-se em Economia pela Universidade de Illinois. Quatro anos depois obteve seu diploma de Master of Science (1947) na mesma escola, tendo mais tarde concluído seus estudos para o doutorado na Universidade de Harvard, obtendo seu Ph.D. em Economia no ano de 1951.

Sua carreira profissional iniciou-se em 1950 como professor assistente da Universidade Estadual de Michigan (MSU), sendo posteriomente promovido a professor associado e professor titular, cargo que ocupa até hoje. Foi também vice-diretor do Departamento de Economia da mesma Universidade e diretor interino deste departamento por um ano. Exerce ainda as funções de consultor da Fundação Ford.

Sua experiência no estrangeiro é bastante ampla, tendo residido nas Filipinas, no Vietname, na Colômbia e na Argentina, além do Brasil.

Dentre seus trabalhos publicados referentes a assuntos universitários, destacam-se: Alguns Aspectos de la Organización y Operación de In Universidad de los Andes, Bogotá, 1959; Racionalización Integral de la Universidad, Córdoba, 1964; e El Mejoramiento de la Ensenanza de la Economia en la República Argentina, 1965.

A tradução do presente trabalho foi feita por Jacques R. Velloso.

\section{A ESCOLA "SUPERIOR"}

Um tipo de Universidade é aquela instituição pequena, de artes liberais, ${ }^{l}$ de nível superior e de cursos para graduação, tais como o

A função das Faculdades de Artes Liberais se assemelha àquela das Faculdades àc Filosofia no Brasil. 
Swarthmore College, e os de Oberlin, Reed, Pamona, etc. São de nível «superior» no sentido de que aceitam para matrícula somente a elite intelectual. Não possuem cursos de pós-graduação e concentram-se num ensino excelente para os seus estudantes de primeira categoria. O número de alunos por professor é geralmente baixo, mas espera-se que os alunos realizem boa parcela de seu estudo por eles próprios. Em Swarthmore, por exemplo, os estudantes honors do terceiro e quarto anos não frequentam aulas - no sentido usual da expressão - e realizam a maior parte do seu «aprendizado» através de trabalho independente de pesquisa. Grande parte de graduados destas instituições frequentam escolas de pós-graduação para fazerem seus estudos de pós-graduados em Medicina, Administração, Educação etc.

\section{A «LIGA DA HERA» ${ }^{2}$}

Outro grupo de instituições, que poderíamos chamar de «Liga da Hera», é certamente mais conhecido dos brasileiros: Harvard, Yale, Princeton, Columbia, Massachusetts Institute of Technology, John Hopkins, entre outras. Foram, há algum tempo, a elite das instituições para cursos de graduação nos E.U.A., mas atualmente têm importância muito maior como as mais notáveis instituições para estudos de pós-graduação. Sua função mais importante é, evidentemente, a de proporcionar um nível de estudos o mais elevado possível para o preparo dos futuros pesquisadores e professores de todo o País. Todas possuem cursos de graduação e selecionam rigorosamente aqueles que são admitidos, e seus diplomas de graduação são muito procurados. Mas o conjunto de excelentes professores, magníficas bibliotecas, os milhões de dólares destinados a pesquisas (que auxiliam a financiar os estudantes de pósgraduação) são fundamentalmente destinados a manter o setor de pósgraduação. ${ }^{3}$

\section{As INSTITUIÇÕES «LAND GRANT»}

Outro grupo de instituições extremamente importantes são as Universidades estaduais, tais como a Universidade da Califórnia, a Universidade de Minnesota, a Universidade de Wisconsin, a Universidade do Estado de Michigan, a Universidade de Illinois, a Universidade de Pennsylvania, dentre as mais conhecidas. Estas podem ser consideradas como o principal sustentáculo do sistema. Historicamente, tiveram a função de levar a efeito, ao nível do Ensino superior, a filosofia característica da Educação nos E.U.A., ou seja, a de que todos os cidadãos

\footnotetext{
2 Assim chamadas porque as Universidades são antigas, têm prédios de tijolos cobertos de hera. Isto teve uma conotação de riqueza e de elevado nível social que agora está desaparecendo.

3 Os brasileiros que frequentam uma destas instituições como estudantes em nível de pós-graduação aprendem muito pouco sobre as Universidades e sobre a Educação nos Estados Unidos.
} 
capazes têm de ter uma oportunidade de estudar. As principais instituições estaduais são instituições land grant, cuja existência se tornou possível graças à Lei Morrill de 1865, que determinava a doação de terras federais a cada Estado, para que a renda destas terras fosse destinada ao estabelecimento de instituições de ensino superior. Estas deveriam dedicar-se, dentre outras coisas, a ensinar «artes agrícolas e mecânicas» aos filhos e filhas dos fazendeiros e trabalhadores. Nenhuma destas instituições atualmente se considera dentro de limites tão restritos, mas a concepção de uma Universidade em cada Estado, dedicada ao desenvolvimento e ao ensino na área de assuntos tão mundanos como agricultura e artes mecânicas (a precursora da engenharia) foi algo de revolucionário nos dias em que a maioria do conteúdo da Educação era de natureza clássica ou teológica.

Assim, as instituições land grant começaram com uma orientação para a educação vocacional - e para as profissões que se tornaram então da maior importância para o desenvolvimento do País. Estas instituições não eram destinadas a serem unicamente instituições de ensino, mas também de pesquisa, particularmente dedicadas à aplicação dos conhecimentos básicos das ciências para uso prático pelas populações a quem as Universidades, ao serem fundadas, eram destinadas a servir. Não é decorrente de razões acidentais o fato de que a agricultura dos E.U.A., se tornou a mais produtiva do mundo: a base de recursos naturais foi evidentemente importante, mas não a única. As instituições land grant que concentraram recursos na pesquisa agrícola e que desenvolveram o mecanismo para a transmissão dos resultados destas pesquisas às fazendas e fazendeiros (uma outra forma de ensinar) são em grande parte responsáveis por esta revolução agrícola sem precedentes.

Mas este grupo de instituições tem sido a mola mestra de imensa importância também em outras fases da Educação. Até recentemente haviam absorvido, mais por omissão de que por planejamento, o crescente número de jovens que procuram uma Educação universitária. As instituições particulares limitam sua matrícula e assim as instituições públicas tinham de decidir se se expandiam ou não. E com a firme convicção de que a Educação era um «direito da pessoa humana», as instituições estaduais foram compelidas a crescer. Esta pressão decorreu de uma série de fatores: 1) o crescimento da população e especialmente, a partir da II Guerra Mundial, a existência de crescente número de jovens na idade universitária; 2) o crescimento da renda per capita, o que permite que maior percentagem da população possa arcar com as despesas educacionais; ${ }^{4} 3$ ) as maiores demandas da economia que exige e paga mão-de-obra crescentemente especializada, e assim percentagem cada vez maior dos graduados de nível secundário percebe que deve, a todo custo, obter uma Educação superior. Deste modo, estas instituições tiveram a responsabilidade de fornecer Educação

4 Espera-se que as despesas de uma família com a Educação cresçam como um percentual, à medida que aumenta a renda. 
superior a um crescente número de jovens, tentando fazê-lo a um custo mínimo, a fim de que os recursos econômicos limitados fossem uma barreira mínima para obter uma educação universitária. ${ }^{5}$ Inicialmente, a orientação era em grande parte vocacional, mas atualmente o é menos. pois as Universidades compreenderam que também é sua responsabilidade a de preparar futuros cidadãos e líderes, além de formar profissionais.

As Universidades estaduais, íand grant, além da orientação para a agricultura e engenharia (serviços diretos e imediatos, prestados às sociedades que as mantinham) e dos ensinamentos ministrados a um crescente número de estudantes ao nível de graduação, desempenharam importante papel no ensino pós-graduado. As instituições para pósgraduação como Harvard, Yale etc. não podiam atender às necessidades de formação de professores de nível médio e superior e de pesquisadores exigidos pelo Governo, pelo sistema educacional, pela indústria. e assim estas instituições dedicaram parte substancial de suas energias aos estudantes de pós-graduação.

Portanto, em resumo, este grupo de instituições tem como suas multifunções (e daí o termo «multiversidade», atualmente em voga):

1) Educação de grande número de estudantes a um custo relativamente baixo para os próprios estudantes e ao menor custo possível para a população contribuinte.

2) Educação de estudantes pós-graduados para a maioria de cargos de ensino, de pesquisa e do Governo que exigem pessoal com nível de pós-graduação.

3) Pesquisa, tanto básica como aplicada (se esta distinção fôr significativa).

4) Contínua atenção voltada para as necessidades imediatas da sociedade nos seus vários aspectos e para satisfazer a estas necessidades. como é próprio da Universidade. Como resultado disto, foram criados programas de real projeção no setor da Educação de adultos.

\section{As ESCOLAS NORMAIS E ESTADUAIS}

Com o desenvolvimento de escolas normais separadamente das Universidades, a maioria dos Estados criou um segundo sistema estadual de Educação superior com a finalidade de preparar professores primários c secundários. Estas geralmente tendiam a ser menores, fisicamente separadas, sem cursos de pós-graduação e eram reconhecidamente de qualidade inferior. Entretanto, a partir da II Grande Guerra, como muitas

5 É bem possível que anuidades modestas ao lado de uma alta renda per capita não sejam mais - ou menos - pesadas quando comparadas ao orçamento de família de localidades pobres. 
destas instituições expandiram-se rapidamente para que pudessem satisfazer às crescentes matrículas, aumentaram também o número de cursos oferecidos, deixando de ser especializadas unicamente em Educação, e algumas começaram também a oferecer cursos de pós-graduação. O que conhecíamos há alguns anos atrás, como pacatas faculdades para a formação de professores são hoje Universidades com 10-15-20 mil estudantes. Em muitos casos, as diferenças entre estas e as Universidades estaduais, descritas na parte anterior deste trabalho, são muito menores do que eram há duas décadas atrás.

\section{APÊNDICES DO SISTEMA UNIVERSITÁRIO ESTADUAL}

Vários esquemas foram utilizados na «guerra dos números». As instituições simplesmente cresceram; algumas dividiram-se como amebas (a Universidade da Califórnia, cerca de 100.000 alunos, tem atualmente 10 campus); em outros casos, as instituições de nível inferior anteriormente existentes subiram de nível, como é o caso das escolas normais; mas a ocorrência mais importante talvez tenha sido a crescente importância da faculdade júnior (júnior college) ou escola da comunidade (community college). Para todas as especializações (ou para a maioria delas) os primeiros dois anos de estudos na faculdade são comuns, de disciplinas básicas: ciências naturais básicas, história e pensamento político dos Estados Unidos da América, inglês, matemática etc. Estas disciplinas geralmente exigem menos em termos de equipamento de laboratório e em termos de professores que podem ser menos especializados, que não precisam ter formação tão completa. Assim, a experiência que está sendo levada a efeito é a de criar cursos de dois anos nas grandes e médias cidades (que ainda não possuam suas próprias instituições de ensino superior) para que: 1) os estudantes possam viver em suas casas durante os primeiros dois anos de estudos, o que representa economia de despesas; 2) as Universidades que atualmente já enfrentam dificuldades com um grande número de alunos possam concentrar seus recursos nas áreas mais necessitadas - nos estudantes de terceiro e quarto anos, já em desenvolvimento e parcialmente formados, bem como nos trabalhos de pós-graduação. Existem problemas com este sistema e êle é relativamente novo, mas há muito para recomendá-lo. Poderia ter consideráveis atrativos para os brasileiros, pois reduz em muito as exigências de mobilidade do estudante.

\section{INSTITUIÇÕES MENORES, PREDOMINANTEMENTE PARTICULARES}

O quadro é completado por centenas de instituições menores, via de regra particulares - na maioria escolas de graduação, com curso de quatro anos. Algumas destas são - ou foram - relacionadas à Igreja. Existem algumas faculdades municipais que também cabem nesta categoria, e existem algumas escolas mantidas pelos Estados. 
Estas instituições prestam serviço muito útil. O grande número de jovens que aí está matriculado pode não desejar, por uma ou outra razão, frequentar uma das instituições gigante. ${ }^{6}$ Alguns pais e estudantes podem gostar das bases morais e religiosas das escolas ligadas à Igreja e mesmo da instrução religiosa que aí é ministrada. E até certo ponto, a existência destas instituições possibilitou a alguns estudantes a frequência a uma faculdade por causa da proximidade de suas residências, o que talvez não ocorresse, caso ela não existisse. Entretanto, esta última consideração provavelmente não é de grande importância.

\section{As GRANDES OMISSÕES}

Nenhum resumo ligeiro como este poderia incluir todas as instituições, e mesmo algumas categorias gerais se encontram excluídas. O principal tipo de instituição que estou ciente de haver excluído é o dos institutos tecnológicos (Illinois «Tech», Michigan School of Mines, Colorado School of Mines etc). Estes preenchem uma função definida, mas mesmo assim minha impressão é que estão tendendo a se tornarem cada vez mais semelhantes às Universidades, dando atenção à «cultura geral» além da educação técnica. As principais faculdades mantidas por cidades, como o New York City College e algumas das grandes instituições particulares também não foram incluídas, tais como a University of Southern Califórnia, Notre Dame, Northwestern University. Contudo, minha intenção não era a de ser completo, mas a de pintar, em largas pinceladas, o quadro geral.

\section{UMA PALAVRA SOBRE A QUALIDADE}

Deve ser lembrado que um sistema tão vasto como este - se é que podemos chamá-lo de «sistema» - uma grande variedade de instituições está incluída. Esta é, talvez, sua principal característica - a diversidade - e isto torna muito difíceis os julgamentos a seu respeito. Um brasileiro disse-me recentemente que êle não tinha boa impressão acerca da qualidade da Educação nos Estados Unidos da América. Um filho de um amigo seu, que não pôde ingressar numa Universidade aqui (em nenhuma?), ingressou numa Universidade americana e suas notas lá obtidas foram todas «A». Perguntei que instituição este jovem havia frequentado e rapidamente compreendi que de um brasileiro com inteligência suficiente para concluir seu curso secundário aqui (situando-se nos $10 \%$ superiores de sua turma), temos que esperar um bom desempenho naquela instituição que frequentou.

Para fazermos julgamentos com respeito à qualidade, confiamos no método formalista do «reconhecimento» - um tipo de «reconhecimento

6 Embora as instituições possam ser menores, isto não significa necessã"iamente que o número de alunos por professor seja menor, resultando presumivelmente numa maior disponibilidade de tempo do professor por cada aluno. 
diplomático», dado por associações profissionais, indicando que a instituição alcançou determinados padrões mínimos. Além disso, sabemos, a partir de nossa experiência, que os melhores engenheiros provêm de dez instituições, e que se selecionarmos os segundos melhores estudantes de certas instituições, estes serão melhores do que os melhores de outras etc. O mercado, pode-se dizer, aprendeu a selecionar dentre os produtos diferenciados. Certamente, nossos julgamentos não são perfeitos e são perpetradas injustiças, mas, pesados os prós e os contras, o sistema funciona bem razoavelmente. Após cerca de um ano de trabalho, o progresso do graduado na indústria, educação ou no governo depende muito mais do seu desempenho do que da instituição que lhe concedeu o diploma. ${ }^{7}$

Ademais, a qualidade varia dentro das próprias instituições. Uma Universidade é conhecida por ser da mais alta qualidade em, digamos, História, mas é muito fraca em Arte, ou boa em Biologia, mas fraca em Física.

Para dar a estes comentários com respeito à qualidade aspecto prático, tomemos o caso dos latino-americanos, que ao estudarem nos Estados Unidos da América, na sua maioria gravitam em torno das escolas da «Liga da Hera», quer para estudos de graduação, quer de pósgraduação. No tocante ao primeiro caso, não há certeza de que estas sejam as melhores instituições ou que sejam as mais adequadas para os latino-americanos. Além disso, não são sempre as melhores em termos de estudos de pós-graduação, especialmente tendo-se em mente a grande variação com respeito aos campos de estudo. As melhores das Universidades estaduais têm tanto quanto ou mais ainda a oferecer em áreas específicas.

Como modelo, eu pessoalmente estou mais interessado em que os latino-americanos se tornem familiarizados com as instituições land grant do que com Harvard ou Yale. Estas últimas não são realmente importantes para o atual meio latino-americano, nem correspondem à Educação dos Estados Unidos da América como um todo, pois constituem parcela pequena e atípica. As instituições land grant, grandes, mantidas pelo Governo e de anuidades mínimas, «representam» muito mais verdadeiramente a média da Educação nos Estados Unidos da América.

A heterogeneidade da Educação tem demonstrado, na experiência educacional dos Estados Unidos da América, três grandes vantagens: 1) a diminuição dos custos através do aproveitamento das vantagens oferecidas pelas economias de escala; 2) uma tendência de elevar ao máximo os benefícios para o estudante através da especialização institucional, não em disciplinas, mas de acordo com a vocação dos próprios sempenho .

7 Naturalmente, os estudantes das melhores escolas devem ter melhor de- 
estudantes; 3) o progresso, a experimentação e a disciplina através da competição interinstitucional. Examinaremos individualmente estas vantagens e também sugeriremos alguns dos problemas a elas relativos.

Porém, antes de continuarmos, deve ficar claro que não se sugere que o Brasil adote ou mesmo adapte o sistema ou padrão acima descrito. Mas é conveniente sugerir que as vantagens da heterogeneidade são de uma variedade técnica que é aplicável através de fronteiras internacionais .

Deve-se ter em mente um aspecto da vida nacional dos Estados Unidos da América. Aceitamos como um valor nacional (e como tal êle é singularmente nosso e incontestável) a noção de que a Educação não é somente um direito do indivíduo, mas para a população até uma certa idade é uma exigência imposta socialmente. O significado disto é que todos aqueles que completam o nível médio devem ter uma oportunidade para ter assegurada a sua Educação universitária, caso realmente a desejem. De fato, alguns Estados exigem que as Universidades por eles mantidas aceitem todos os graduados de nível médio daquele Estado que queiram frequentar uma Universidade, mas reconhece-se geralmente que nem todos os graduados de nível médio podem ou devem frequentar uma faculdade. ${ }^{8}$

\section{AS ECONOMIAS DE ESCALA}

Ninguém consideraria seriamente a afirmativa de que todas as instituições de ensino superior têm de oferecer os mesmos cursos. Existem importantes diferenças regionais que explicam porque o City College of New York tem cursos sobre as técnicas de comércio e finanças intercionais e não tem nenhum sobre agricultura, porque a University of Illinois é boa em agricultura, mas só tem cursos teóricos sobre a economia do comércio internacional, porque o curso de engenharia de minas é um curso importante no Colorado e não na Flórida. Mas estas diferenças regionais não são suficientes para explicar as diferenças entre as instituições. As economias de escala são uma importante consideração neste aspecto. Por exemplo: o Estado de Michigan tem cerca de 70 instituições de ensino superior públicas e particulares, mas somente duas ou três destas oferecem cursos que levam à obtenção de um diploma em Medicina e somente uma oferece curso em Medicina Veterinária. Uma das razões é que os custos fixos mínimos do ensino médico são elevados (hospitais, laboratórios, professores muito bem pagos, bibliotecas, etc.) e portanto procuramos dividi-los por grande número de estudantes a

8 Para dar uma dimensão estatística a este fato, temos: as matrículas nas Universidades em 1965 eram de 5.526-000 alunos, ou cerca de 2,9\% da população total e cerca de $40 \%$ da população na faixa de 20-24 anos. Em 1960, segundo dados do recenseamento, de todas as pessoas de 25 anos e mais cerca de $8 \%$ haviam frequentado uma Universidade por quatro ou mais anos. FONTE: Statistical Astract of the United States, 1966. 
fim de reduzir o custo por aluno. O mesmo pode ser dito da Engenharia, Fisica, Agricultura, etc, em que os laboratórios, o equipamento e a terra desempenham importante papel. ${ }^{9}$

Se uma instituição produz anualmente 20 estudantes de administração de empresas, é anti-econômico (ou seja, é desperdício) permitirlhes muita escolha de disciplinas, e certamente não se pode pensar em sub-especialização. Mas, se são 200 ou 500 alunos, então, após uma base de estudos comum a todos, pode-se permitir uma considerável escolha de disciplinas, ${ }^{10}$ podendo-se permitir também alguma especialização, dentro do amplo campo da administração de empresas, digamos em marketing ou contabilidade. "

Em resumo, portanto, para muitas especialidades universitárias, tem-se constatado que a alta qualidade da Educação requer custos fixos elevados e que o número de estudantes a serem preparados não garante que cada instituição possa arcar com estas despesas. Consequentemente, as instituições tendem a especializar-se, procurando, sem dúvida alguma, aperfeiçoar a qualidade da Educação, obter custos muito mais baixos e uma maior variedade. Estes são lucros que não são facilmente perdidos.

\section{AJUSTANDO OS ESTUDANTES E AS INSTITUIÇÕES}

Talvez a maior vantagem da heterogeneidade seja a grande variedade oferecida ao estudante em perspectiva. Até certo ponto, este é um serviço prestado ao consumidor, um «balangandã», que talvez não possa

9 Outro aspecto que os brasileiros devem ter em mente é que utilizamos grande número de professores em tempo integral, dos quais exigimos que realizem trabalhos de pesquisa. Assim, se uma instituição quer construir e manter um departamento de Física, ela deve contar com a necessidade de fornecer laboratórios e equipamentos, não somente para os estudantes em nível de graduação - com instalações relativamente elementares - mas também para os estudantes de pós-graduação e para os membros do corpo docente, o que requer equipamento completo e requintado.

"> Uma das grandes vantagens do sistema de «departamentos», e que não existe no sistema de «faculdades», é que no primeiro todas as d sciplinas da Universidade estão disponíveis para todos seus alunos, tornando possível uma variedade muito maior de disciplinas, o que de outro modo não seria possível. Se um estudante em cada 25 cursos, por exemplo, desejasse cursar uma disciplina sobre crítica musical, seria possível, para o departamento de música, fornecê-la, enquanto que em outras circunstâncias não se poderia reunir um número suficiente de alunos para permitir a existência de tal disciplina. Portanto, todas as disciplinas não somente se tornam disponíveis para cada aluno, mas muitas outras se tornam factíveis.

11 Temos s:do justamente criticados pela excessiva especialização e pela demasiada subdivisão das disciplinas ministradas. Mas o que não é usualmente reconhecido por tais críticos é que, via de regra, esta superespecialização é construída sobre base muito ampla. Por exemplo: nos estudos de um aluno de administração de empresas que obteve seu diploma em «vendas a varejo» (uma subdivisão de market ing, que ê por sua vez uma subdivisão de: administração de empresa), provavelmente $25 \%$ das disciplinas cursadas terão sido de matérias, tais como matemática, economia, estatística, outros $25-35 \%$ de suas disciplinas terão sido em administração de empresas, e os 15-25\% restantes, em matérias sobre «vendas a varejo». 
ser oferecido pelos países pobres, mas que de qualquer modo tem seu relevante mérito social.

A maior vantagem provém do reconhecimento de que nem todos os estudantes universitários em potencial são iguais. Eles não somente diferem quanto às preferências intelectuais, mas também são pessoas diferentes quanto a outras características: alguns são brilhantes, enquanto que outros exigem supervisão, alguns são maduros, enquanto outros são infantis, alguns se sentem à vontade e aprendem no meio da multidão da educação de massas, outros aprendem melhor num ambiente mais calmo e com menor número de pessoas. Talvez seja de bom alvitre selecionar os intelectualmente brilhantes (nas escolas superiores), onde possam realizar o aprendizado de acordo com seu próprio ritmo, sem serem atrasados pelo estudante médio. Talvez também o estudante médio se sinta mais à vontade e aprenda melhor sem a dura competição de seus colegas que tiveram a fortuna de serem mais bem dotados. Supondo que é desejável para a sociedade, até certos limites, desenvolver cada indivíduo até um máximo possível, então esta heterogeneidade contribui para este objetivo. ${ }^{12}$

Analogias são constantemente perigosas e algumas vezes úteis. Podemos ilustrar esta afirmativa sugerindo que os estudantes são algo parecidos com a terra. Alguns solos produzem milho, arroz, centeio, etc. etc, melhor do que outros. Alguns exigem grandes quantidades de Investimento e fertilizantes, mas tornam-se então produtivos, enquanto outros produzem prodigiosamente com uma pequena aplicação de adubos. A elevação de uma produção ao seu máximo (com recursos finitos) exige um cuidadoso discernimento na administração da terra. A heterogeneidade das instituições tem-nos permitido, embora de modo imperfeito, ajustar os estudantes às instituições, a fim de nos aproximarmos do máximo de produtividade do sistema educacional. ${ }^{13}$

\section{Os EFEITOS DA COMPETIÇÃO}

Educação, conhecimento, ensino, aprendizado, são todos aspectos dinâmicos do mundo moderno. Há tanto a ser ensinado, tanto a ser aprendido, e sabemos tão pouco, quer sobre o aprendizado, quer sobre o ensino. As instituições educacionais trabalham nas fronteiras do conhe-

12 O economista pode descrever teoricamente estes limites; é vantajoso continuar a investir num individuo enquanto cada aumento no investimento custar menos que o atual valor descontado do futuro fluxo de benefícios, decorrentes destes investimentos. Contudo, as possibilidades práticas de descrever estes limites são muito, muito menores, devido a problemas de mensuração.

13 Uma das principais imperfeições do processo de ajustamento está no fato de que a renda dos pais não é distribuída de acordo com as necessidades dos futuros estudantes. Diante da crescente confirmação deste fato, principalmente no que toca às dispendiosas escolas «superiores», o desenvolvimento de extensivos programas de bolsas de estudo, tanto públicos como particulares, tem reduzido a importância da situação financeira dos pais como determinante de escolha das instituições. 
cimento e preocupam-se - ou deveriam preocupar-se - acerca do que fazer com seus achados. No meio cultural dos Estados Unidos a competição interinstitucional - nunca formal, mas sempre presente - tem levado à experimentação; à inovação; a testar, rejeitar e aceitar novos dispositivos, novas técnicas, novas filosofias. O efeito total tem sido o de um sistema educacional vibrante, dinâmico, tendendo a liderar ao invés de seguir, a antecipar-se ao invés de atrasar-se. Parece provável que este tipo de atmosfera competitiva (com todos seus problemas) de alguma forma é mais capaz de levar ao desenvolvimento de instituições desejáveis do que um sistema cujo controle e leis partem de um poder centralizado, resultando em que grande parte das energias das instituições sejam gastas na luta para alcançar e manter a identidade externamente imposta - que talvez seja pouco desejada e imperfeitamente compreendida .

O Estado de São Paulo - Quinta-feira, 16 de maio de 1968. 
Apendice F. 3

\section{O DEPARTAMENTO NA UNIVERSIDADE}

HENRY W. HOGE

A organização do Ensino superior brasileiro é baseada inteiramente regime de cátedras. Nestes últimos anos, porém, dividindo as opiniões a favor e contra este regime, inúmeros debates se travaram nos órgãos colegiados da administração universitária, nos Conselhos Estaduais de Educação e, naturalmente, no próprio Conselho Federal de Educação. Desses debates, que assumem não poucas vezes aspectos de apaixonada emotividade, a cátedra é apontada como um dos principais fatores da resistência às transformações que se devem operar para que tenhamos um ensino ajustado ao contínuo e incessante processo de renovação cientifica, tecnológico e cultural e ajustado, também, às exigências da vida social e econômica em acelerado processo de mudança. O catedrático, dizem alguns, é o dono, o proprietário exclusivo e absoluto de um domínio do saber; é um senhor feudal, um mandarim, afirmam outros. Não iremos nos alongar na imensa série de afirmações nascidas quase sempre do ressentimento dos que, por motivos diversos, não lograram alcançar o status de catedrático. O certo, porém, é que os assuntos universitários, por força de sua complexidade, tendem progressivamente a ser desenvolvidos dentro de quadros administrativos mais amplos e mais representativos. A cátedra, na medida que é uma entidade unipessoal, não se ajusta harmoniosamente com a natureza das decisões que pressupõem o confronto constante de opiniões desiguais. Decorre daí, talvez, o interesse crescente que a concepção de departamento vem despertando nos nossos meios universitários.

O professor H. W. Hoge, da Universidade de Wisconsin, Milwauke, propõe-se neste estudo descrever a estrutura e o funcionamento de um departamento «ideal» de uma Universidade «ideal» norteamericana. Neste estudo, o professor H. W. Hoge, deixando de lado os aspectos peculiares da organização departamental em suas formas institucionais concretas, procura as características mais gerais e mais comuns da «ideia» de departamento.

\section{CARGOS E OBRAS}

Professor de língua e literatura luso-brasileira e espanhola, tendo obtido seu diploma de bacharel pela Universidade de Indiana, o pro- 
fessor Henry William Hoge realizou seus estudos de pós-graduação (para o Master of Arts e posteriormente para o Doctor of Philosophy) na Universidade de Wisconsin-Milwaukee (UWM), onde hoje exerce suas atividades profissionais.

Ocupou durante cinco anos (1959-1964) o cargo de diretor do Departamento de Espanhol e Português daquela Universidade, tendo sido ainda diretor do Laboratório Linguístico e um dos diretores do Centro de Treinamento do Corpo de Paz da mesma instituição.

Já conhecia o Brasil desde 1964, quando aqui residiu pela primeira vez, tendo residido também em Cuba e na Colômbia.

Além de vários artigos e livros sobre linguística aplicada, dentre suas obras publicadas, ressaltamos:

Oral Brazilian Portuguese, Milwaukee, 1964.

Modem Portuguesc, Austin, 1966. 1966.

A Selective Bibliography of Luso-Brazilian Linguistics, Milwaukee,

A Selective Bibliography oí Contemporary Brazilian Literature, Milwaukee, 1967.

A presente tradução é de Jacques R. Velloso.

Este trabalho é uma tentativa de descrever o funcionamento e a estrutura do Departamento na Universidade norte-americana. E' importante ressaltar, de início, que não descrevemos um departamento «típico» de uma Universidade norte-americana «típica». Esta Universidade não existe. Não há uma estrutura única, preestabelecida ou padronizada, determinada pela legislação ou pela tradição para a Universidade norteamericana ou para seus componentes. Consequentemente, nota-se grande variação quanto às características estruturais e operacionais do Departamento, bem como das outras unidades componentes da Universidade nos Estados Unidos.

Apesar desta variação, parece existir certo grau de uniformidade operacional nas funções desempenhadas pelo departamento. No seu sentido mais amplo, o departamento pode ser descrito como a pedra fundamental da estrutura universitária: é ao mesmo tempo a unidade administrativa mais elementar e a unidade de ensino básico de maior relevância dentro daquela estrutura. Deve ser difícil, para um observador de fora, obter um completo conhecimento dos processos de funcionamento interno do departamento; mesmo um professor visitante estrangeiro, após vários semestres de contacto com uma instituição de ensino, pode muito bem não perceber como funcionam os princípios operacionais mais importantes, já que êle estaria quase que exclusivamente realizando ou/e orientando trabalhos de ensino e pesquisa numa determinada área do programa departamental (na seção de estudos de pós-graduação, por exemplo), e frequentemente evitar-se-ia que êle arcasse com os ónus dos compromissos de atuação nas comissões departamentais básicas. 
Portanto, nossa descrição será a de um departamento fictício. A terminologia essencial não definida no próprio texto será encontrada num glossário em anexo, sendo tais termos marcados com um asterisco. Suporemos que as palavras «normal» e «usual» devem ser aplicadas a todas as descrições feitas neste trabalho.

\section{COMPOSIÇÃo (Estrutura externa)}

O Departamento pode compreender um grupo de membros do corpo docente, organizado para realizar as tarefas de ensino, pesquisa, elaboração de programas e de atividades administrativas de uma única disciplina universitária (geografia, física, química, francês etc); ou de uma disciplina mais ampla e menos específica (ciência política, geologia, oratória, linguística, etc); ou de um grupo de disciplinas relacionadas entre si (línguas modernas, línguas romanas, belas-artes, literatura comparativa) .

O «lar» básico ou unidade de exercício das tarefas dos membros do corpo docente da Universidade norte-americana é o departamento. $\mathrm{O}$ membro do corpo docente considera-se diretamente ligado a esta unidade, e a citará como seu cargo atual: êle dirá que é professor no departamento de Economia (por exemplo), ao invés de dizer que é professor na Escola (School) ou Faculdade ( Coílege) à qual este departamento pertenceria. Esta identificação básica com o departamento decorre do papel que esta unidade desempenha nos processos de seleção e nomeação, no de promoções para níveis superiores da carreira e no de reajustes salariais para os membros do corpo docente.

O departamento como unidade consiste em todo o pessoal contratado, incluindo secretários e estudantes assistentes em regime de tempo parcial e por hora. Restringindo nossa descrição ao pessoal docente, poderíamos ter a seguinte ordem de níveis num departamento:

Professores Titulares (ou simplesmente «professores»);

Professores Associados;

Professores Assistentes;

Instrutores (tempo integral ou parcial);

Assistente de Pós-Graduação (Graduate Assistants).

Não existe nenhum quadro de pessoal prefixado, destinado a organizar um departamento. Em uma destas unidades de tamanho médio, existem usualmente vários professores titulares. Não há uma proporção padronizada que seja aplicável aos diversos níveis: pode haver dois ou três professores titulares num departamento e somente um professor associado; ou pode haver vários professores associados e só um professor titular. Pode-se também mencionar o fato de que só excepcionalmente a nomeação de membros do corpo docente é feita dentre os que realizaram estudos de pós-graduação na própria instituição. 
Damos prosseguimento hoje à publicação - ontem iniciada - do trabalho do prof. Henry W. Hoge, intitulado «O Departamento na Universidade norte-americana".

O jovem que obteve seu doutorado $(P h$. D. $)$ não procurará nem esperará ser nomeado pelo departamento que lhe concedeu o diploma. Um departamento com dez membros do corpo docente em tempo integral teria professores com diploma de doutorado de pelo menos seis instituições diferentes.

Os pré-requisitos e as condições para os niveis docentes estão resumidamente relacionados abaixo:

Professor - O mais alto nível dentro do departamento, gozando de todos os privilégios concedidos ao corpo docente. O administrador do departamento é frequentemente - embora nem sempre - escolhido ou nomeado dentre os elementos deste nível. Geralmente existem vários professores num dado departamento. A estes professores cabe a tarefa de ministrar aulas de disciplinas em nível avançado, cada um dentro de sua própria especialidade: nos departamentos onde existam matérias introdutórias com grande número de matriculados, um professor titular pode fazer conferências sobre $\mathrm{o}$ assunto ( lecture sections) e supervisionar o trabalho da equipe de assistentes que se encarregará das sessões de debates e avaliação do aprendizado ( quiz \& recitation sections). As disciplinas e seminários em nível de pósgraduação, num departamento, são geralmente ministradas e orientadas por professores ou professores associados. Os estudantes de pós-graduação que realizam trabalhos para obter um doutorado têm conselheiros ou uma comissão de doutorado ( $P h$. D. Committce), selecionada dentre este grupo de conselheiros. A nomeação de um professor titular ou a promoção a este nível implica no reconhecimento de um trabalho universitário de significação numa dada área do conhecimento e está usualmente ligada a uma reputação nacional e à publicação de vários livros e monografias. Raramente este nível é concedido unicamente em função de excelente desempenho nas salas de aula.

Professor Associado - O nível logo abaixo do mais elevado. Ao atingir este nível, geralmente concede-se estabilidade ao membro do corpo docente e êle é considerado qualificado para a nomeação ou inclusão no Corpo Docente de Pós-Graduação (Graduate Faculty) . Se eleito ou nomeado, o professor associado pode também ocupar o cargo de administrador-chefe do departamento (embora vários professores titulares façam parte do pessoal do departamento). A promoção a professor associado ou a nomeação para este nível é assim um marco significativo na carreira universitária de um membro do corpo docente, indicando que aquele que o recebeu realizou pesquisas de importância 
na sua área de estudos e é dotado de um potencial que permitirá o futuro desenvolvimento de suas qualidades no mundo universitário.

Professor Assistente - $\mathrm{O}$ menor nivel dentro da categoria de «professor». Este nível é mais ou menos automaticamente atingido em virtude da obtenção do diploma de doutorado. Esta é uma fase do «julgamento»: o professor assistente já demonstrou que recebeu o preparo e que tem o potencial para realizar um ensino e pesquisa de maior valor; espera-se então que êle demonstre, de fato, este potencial.

Instrutor - O nível inicial dentre o pessoal de tempo integral. Em algumas instituições não são concedidos ao instrutor certos privilégios do corpo docente. O instrutor frequentemente é uma pessoa que já preencheu todos os requisitos para obtenção do doutorado, exceto a dissertação ou tese. Portanto, êle tem liberdade para aceitar um emprego de tempo integral numa outra instituição, enquanto prepara ou completa sua dissertação na instituição em que realiza seus estudos.

Assistente de Pós-Graduação - Associado de Ensino. Este cargo não é considerado como pertencendo à Congregação, e compreende ensino em tempo parcial ou trabalho de assistente em pesquisa. $\mathrm{O}$ assistente ou associado de ensino é um estudante de pós-graduação: completou os quatro anos básicos de formação universitária e obteve o devido diploma (B.A. - Bacharel em Letras e Artes; B. S. - Bacharel em Ciências). Portanto, êle está cursando as matérias para obter seu Mestrado (M. A. - Master o[ Arts) ou Doutorado (Ph. D. - Doctor o/ Philosophy). Suas atividades de ensino em tempo parcial dão-lhe modesta renda; frequentemente a Universidade fornece moradia com aluguéis razoáveis. Quando o assistente de pós-graduação tiver cursado todas as matérias exigidas para obter diploma de Doutor, poderá transferir-se para outra instituição como instrutor; após a obtenção do seu diploma, êle será como de rotina promovido a professor assistente.

\section{CARGA DE ENSINO E TABELA DE SALÁRIOS}

A carga de ensino do corpo docente é expressa em termos de horas ou créditos. Cada hora significa uma hora de aula ou de qualquer outra atividade numa sala de aula. O professor recentemente nomeado é informado de que seus deveres não consistem somente em ensinar, mas também em desenvolver trabalhos de pesquisa e prestar serviços à comunidade. Portanto, as horas de ensino e o total de horas (incluindo a preparação das aulas) devotadas à profissão variam grandemente.

As cargas de ensino variam de acordo com o nível da carreira: os professores de nível mais elevado têm menos horas de ensino por semana, contudo, ministram aulas de nível mais adiantado. Em várias disciplinas ou conjunto de disciplinas, o professor ou professor associado 
não dará aulas nas seções elementares ou de introdução; em departamentos nos quais o programa de pós-graduação ocupa a maior parte da unidade, êle poderá até não dar aulas ao nível de graduação.

A carga de ensino em nosso departamento fictício poderia ser, por níveis, a seguinte:

Nível

\section{Carga em \\ Créditos}

Professor.

6 a 8

8 a 10

Professor Associado

.10 a 12

Professor Assistente.

i12 a 15

Instrutor

Assistente de Ensino
Um seminário (2) e duas disciplinas em nível avançado (4 a 6).

Duas matérias em nível avançado (4 a 6) e uma ou duas de nível intermediário (4 a 6 ).

Duas matérias em nível intermediário (4 a 6) e uma ou duas em nível elementar (6 a 8 ).

Várias matérias em nível de introdução (8 a 10) e uma ou duas em nível intermediário (4 a 6 ).

Uma ou duas aulas em nível de introdução.

Os salários do pessoal universitário nos E.U.A, aumentaram nitidamente nos últimos anos. O salário para o pessoal docente é calculado tendo como base o ano letivo, ou seja, nove meses de aulas: o professor pode também dar aulas nos cursos de verão (essencialmente a metade de um semestre) recebendo 20 a $25 \%$ a mais do seu salário básico. O cálculo para o pessoal docente com alguma responsabilidade administrativa (diretor assistente ou diretor associado de uma faculdade, diretor de um programa de pesquisas etc.) é geralmente feito na base de onze meses. O salário pode ser assim aumentado de 20 a $25 \%$ para resultar num salário anual.

Professor

Professor Associado

Professor Assistente

Instrutor.
Ano Letivo

$\begin{array}{lrrr}\text { US\$ } & 13000 & \text { a } & 18000 \\ \text { US\$ } & 11,000 & \text { a } & 14,000 \\ \text { US\$ } & 9,500 & \text { a } & 12,500 \\ \text { US\$ } & 8,000 & \text { a } & 10,000\end{array}$

Esta não é uma tabela derivada de dados estatísticos. Os valores não são médias, medianas ou pontos extremos. É uma tentativa de descrever o atual quadro salarial de um departamento, por níveis, e uma Universidade moderadamente competitiva dos E.U.A. O salário médio por nível de todos os professores nos E.U.A, é quase sem significado; a variação indica somente a inexistência de uma escala salarial uniforme. A impressão do autor é que o «valor do mercado» 
para cada nível - o salário que deve ser oferecido para obter-se um professor bem qualificado - tem aumentado recentemente em torno de US\$ 1,000 por ano. Não dispomos de dados que mostrem o salário por nivel em função dos anos de serviço; mas, num mercado de constantes e rápidas mudanças, estes valores não seriam significativos.

Os valores dos salários que se superpõem são muito significativos: no contexto atual, é bem possível que um professor associado recémnomeado receba um salário mais elevado do que um professor titular mais experiente e mais qualificado do mesmo departamento.

Ocasionalmente, uma instituição estabelece salários mínimos para cada nível. Isto significa que nenhum novo professor será trazido para a instituição por menos de que o mínimo determinado para o seu nível. Estes salários mínimos poderiam ser: Professor, US \$14,100; Professor Associado, \$12.000; Professor Assistente, \$9,500; Instrutor, \$8,000. Para promoções dentro do departamento, é necessário elevar o salário do candidato ao mínimo determinado para o próximo nível em questão. Por exemplo: um professor assistente com 4 a 5 anos de serviço pode ter um salário atual de $\$ 10,000$. Se êle vai ser promovido, o departamento tem de conseguir verba do seu orçamento para dar ao candidato o salário mínimo determinado para um professor associado $(\$ 12,500$, digamos) . A promoção dentro do departamento torna-se, portanto, uma pesada carga para o orçamento departamental. Isto cria uma situação perculiar (e infeliz): é mais fácil para o professor assistente pular de $\$ 10.500$ para $\$ 12,500$ transferindo-se para outra instituição; e uma vez que os salários para novas nomeações não precisam ser incluídos no orçamento departamental existente, é mais fácil, para o departamento, procurar contratar um novo professor associado com um salário de $\$ 12,500$ ou mais. Depois desta nomeação ser efetivada, o salário torna-se então parte integrante do orçamento departamental.

\section{III}

Damos prosseguimento hoje à publicação do trabalho do professor Henry W. Hoge, intitulado «O Departamento na Universidade norteamerícana». Os capítulos anteriores do trabalho foram publicados em nossas edições de ontem e anteontem.

\section{III - ORÇAMENTO DEPARTAMENTAL}

Como foi mostrado acima, o departamento tem um orçamento em separado, uma identidade fiscal. O orçamento departamental constitui-se num elemento do orçamento total da faculdade ou escola onde se localiza aquela unidade. O orçamento consiste no total de salários de todo o pessoal contratado pelo departamento (pessoal docente e pessoal auxiliar de escritório, o que inclui estudantes), mais as verbas destinadas aos gastos com material, equipamento e serviços. O total de salários do pessoal docente normalmente fornece o valor base para 
o cálculo das verbas a serem destinadas aos aumentos salariais por mérito ou por promoção. No caso do crescimento do corpo docente para atender a uma crescente matrícula ou para enriquecer a variedade de disciplinas oferecidas numa determinada área, o salário do pessoal adicional é somado ao orçamento departamental. O presidente do departamento, como porta-voz da comissão executiva, discute e resolve estes assuntos com o Diretor da Faculdade.

\section{IV - LIDERANÇA DO DEPARTAMENTO E ESTRUTURA INTERNA}

$O$ Presidente. O administrador executivo do departamento é o seu presidente ou chefe. O presidente pode ser eleito através do voto, pelo departamento, tendo sua eleição confirmada pelo Diretor da Faculdade, ou pode ser nomeado diretamente pelo gabinete do Diretor. Seu mandato pode ter a duração de dois ou de três anos, ou pode ter duração indefinida, segundo a vontade do Diretor. A chamada «presidência rotativa» consiste num rodízio periódico do cargo entre os membros mais experientes do departamento (sénior). O presidente pode receber, embora frequentemente não receba, uma remuneração adicional pela sua função de presidente; mas, em qualquer caso, sua carga de ensino é normalmente reduzida como compensação por seus deveres administrativos. $\mathrm{O}$ termo «chefe» (head) geralmente implica numa nomeação mais permanente do que o uso da palavra «presidente» (chairman) . O presidente funciona como porta-voz oficial do departamento nos debates com o Diretor ou Diretor Associado; prepara e reúne todos os relatórios oficiais sobre as atividades e programas do departamento, e dirige toda a correspondência oficial, além de tratar das substituições em potencial ou da expansão do corpo docente do departamento.

A Comissão Executiva. O presidente, como foi demonstrado, é porta-voz oficial do departamento. A autorização para que êle exerça esta função é dada pela Comissão Executiva. Esta comissão usualmente é composta dos membros sénior do corpo docente do departamento (professores titulares e associadas). Todos os assuntos de importância para o departamento têm de ser discutidos neste grupo em reuniões periódicas convocadas pelo presidente ou solicitadas por qualquer membro do grupo. As decisões ou recomendações para promoções, aumentos de salário por mérito, novos programas de ensino; revisão do conteúdo das disciplinas, novas nomeações, e outros assuntos similares somente chegam a uma consideração final após os debates do grupo, e são enviadas pelo presidente ao escalão adequado (geralmente sob a forma de recomendações).

Comissão Departamental. Pode ser composta de todo o corpo docente de tempo integral, incluindo os professores assistentes e instrutores. Os assuntos são trazidos a este grupo para uma discussão de caráter geral, e as etapas subsequentes são levadas a efeito pela 
comissão executiva. Neste grupo são nomeadas as comissões departamentais efetivas e ad hoc. Estas podem incluir as Comissões de Disciplinas de Nível Elementar e Intermediário (destinadas a selecionar os textos das disciplinas de multiplesection, elaborar o programa de cada disciplina - course Syllabus - formular e supervisionar os exames multiplesection); a Comissão de Biblioteca (destinada a receber, compilar e enviar à biblioteca as solicitações de livros e a manter um arquivo das publicações solicitadas e recebidas); a Comissão dos Clubes Estudantis (destinada a funcionar como uma assessoria das organizações estudantis relacionadas ao departamento, tais como «Clube de Economia», «Clube de Espanhol», etc); e outras comissões ad hoc que sejam necessárias.

\section{VI_ AUMENTOS POR MÉRITO E NORMAS PARA PROMOÇÃO}

Como foi explicado acima, certa percentagem do total do orçamento departamental para ensino é destinada cada ano a aumentos salariais. Suponhamos que temos um departamento com 16 membros em tempo integral, e com US\$200,000 como seu orçamento para ensino, inclusive o salário do presidente.

O Legislativo Estadual ou o Conselho de Curadores votou um aumento salarial de 6\% (a Universidade solicitou 8\%). Uma determinada parcela da verba para aumento de salários fica retida pela Administração e pelos Diretores, a fim de atender a necessidades específicas, tais como a de cobrir uma oferta que um professor de renome recebeu de outra instituição, ou conceder aumentos por mérito para o presidente do departamento, segundo determinação do gabinete do Diretor. Em fevereiro, o departamento é avisado de que o montante para aumento por mérito a ser utilizado no próximo ano letivo, a iniciar-se em setembro, é de $4 \%$ do seu orçamento total (excluído o salário do presidente), ou seja, US\$ 8,000.00. A comissão executiva do departamento então se reunirá para formular recomendações específicas para aumento de salário de cada membro do corpo docente do departamento. Antes de chegar a estas conclusões, cada membro do departamento terá preparado, com detalhes, um Resumo Anual das Atividades, descrevendo suas realizações e trabalho efetuado nas seguintes áreas: I. Ensino (novas disciplinas ensinadas, novas técnicas empregadas, etc); II. Administração (trabalho nas comissões da Universidade e do Departamento, direção de programas, exercício de funções de tempo parcial em comissões extradepartamentais, etc); III. Publicações (lista de todos os trabalhos publicados durante o ano, por categoria: livros, artigos, monografias, críticas); IV. Pesquisa (projetos em andamento e/ou terminados); V. Organizações Profissionais (comparecimento a encontros de organizações profissionais, cargos ocupados, trabalhos apresentados); VI. Serviços prestados à Comunidade e Serviços Especiais (conferências públicas realizadas, 
comparecimento a programas de rádio e de televisão, cargos ocupados ou atividades desenvolvidas em organizações comunitárias, tais como Associações de Pais e Mestres, Rotary, e similares).

\section{IV}

Concluímos hoje a publicação do trabalho do prof. Henry W. Hoge, intitulado «O Departamento na Universidade norte-americana». Os capítulos anteriores do trabalho foram publicados em nossas edições dos dias 23, 24 e 25 do corrente.

Em nosso departamento poderíamos encontrar o Professor Associado X (salário de US\$ 13,000) que está neste nível há quatro anos, tendo publicado recentemente um livro notável na sua especialidade; encontraríamos ainda o Instrutor $\mathrm{Y}$, instrutor há dois anos, tendo recebido há pouco seu diploma de doutorado (junho, p. ex.) e tendo também recebido boa oferta como professor assistente, com um salário de $\$ 11,500$ em outra instituição (seu salário atual é de \$9,500). Pode ser tomada uma decisão preliminar dando a todos os instrutores (2) um determinado aumento $(\$ 200,00)$; o caso do Professor $\mathrm{X}$ é então considerado em reunião à qual êle não comparecerá. Pode ser decidido recomendá-lo para uma promoção a professor titular, recebendo o salário mínimo para este nível $(\$ 14,100)$. Isto significa um aumento de $\$ 1,100.00$ para esta pessoa. O Instrutor $\mathrm{Y}$ será rotineiramente recomendado para promoção a Professor Assistente, pois êle agora tem o doutorado. Se fôr considerado um elemento de grande valia, o departamento pode recomendar sua nomeação a um nível salarial que cubra aquela oferta recebida. Isto significará um aumento de $\$ 2,000$ para o Instrutor Y. O total já empenhado é agora \$3,500; o saldo, $\$ 4,500$, deve ser destinado aos 11 membros restantes do departamento. Está claro que só podem ser concedidos aumentos moderados a estes membros do corpo docente (uma média de $\$ 410,00$ cada, com uma provável variação de $\$ 300,00$ a $\$ 750,00)$. A distribuição será feita na base do mérito relativo do pessoal, conforme a opinião da comissão e de acordo com os dados fornecidos pelo Resumo Anual.

Deve-se notar que os fatores para promoção e aumentos por mérito constituem-se em incentivos materiais muito poderosos no sentido de estimular a produção de trabalhos de pesquisa e/ou dar contribuição para outras áreas especificadas no Resumo. Mesmo na categoria de professor titular, onde o incentivo da promoção e da estabilidade já não mais existe, a grande variação de salários é, sem dúvida alguma, eficaz.

\section{$\mathrm{VI}-$ ESTABILIDADE}

O instrutor, conforme o acima referido, é normalmente um estudante em vias de obter seu doutorado e que é contratado por um ano, podendo este prazo ser renovado. Após ter sido contratado de uma 
a três vezes, espera-se que êle apresente sua tese e receba seu diploma de doutor. Estará então qualificado para ocupar um cargo de professor assistente, sendo contratado por um ou três anos.

Em muitas Universidades, quando uma pessoa completa seis ou sete anos de serviço, torna-se qualificada para a estabilidade (tenure). Seu contrato é então renovado automaticamente cada ano e só poderá ser demitida em virtude de baixeza moral, atividades criminais etc. (for cause, como é chamada).

A estabilidade não tem implicações salariais específicas, mas está geralmente relacionada ao nível da carreira. A promoção ou nomeação para o nível de professor associado ou outro nível acima implica automaticamente em estabilidade. A concessão de estabilidade a um membro do corpo docente recém-nomeado ou promovido é recomendada pelo departamento, aprovada pelo diretor, autorizada pelo administrador chefe ou por uma comissão universitária, e homologada pelo Conselho de Curadores. Pode-se observar que o instrutor está sempre sob pressão: primeiro para completar seu doutorado, e depois como professor assistente, para atingir o desenvolvimento necessário, a fim de que lhe seja concedida a estabilidade e que seja promovido a professor associado.

\section{VI - PROGRAMA DE PÓS-GRADUAÇÃO}

Estudo mais profundo da escola de pós-graduação na Universidade americana está fora do âmbito deste trabalho.

Nossos comentários sobre o programa de pós-graduação limítarse-ão ao âmbito do departamento. Este conduz as atividades de ensino e outras a elas relacionadas na área de graduação, incluindo as disciplinas básicas ou introdutórias, oferecidas em grande quantidade para os alunos do primeiro e do segundo ano, que estão cumprindo os requisitos gerais da Universidade para as áreas de ensino que estão sendo cursadas. As disciplinas de nível intermediário e avançado destinam-se aos alunos que as escolheram com uma matéria major ou minor, ou que as cursam como uma matéria optativa ( elective).

Além disso, o departamento oferecerá um programa de estudos pós-graduados destinados à obtenção dos diplomas de Mestre e Doutor. Para o programa de pós-graduação, teremos um conjunto formal de requisitos e estipulações gerais, que serão publicados no Boletim da Universidade. Muitos candidatos (frequentemente a maioria) a um diploma de pós-graduação são nomeados assistentes graduados ou assistentes de ensino. A este grupo de estudantes de pós-graduação são fornecidos seminários ( seminar) e disciplinas ao nível pós-graduação; algumas vezes as disciplinas do quarto ano de graduação também contam crédito para a pós-graduação. A Escola de PósGraduação ( Graduate School - uma divisão separada da Universidade, que funciona englobando os programas de pós-graduação de todos os departamentos) usualmente se encarrega dos formulários e 
documentos do estudante de pós-graduação. A Escola de Pós-Graduação também pode estabelecer quais devem ser as qualificações de um membro do corpo docente de um departamento para que êle possa ensinar matérias ao nível de pós-graduação. Neste caso, os professores de todos os departamentos que foram «aprovados» para o ensino de pósgraduação constituirão o Corpo Docente de Pós-Graduação (Graduate Faculty). A carreira do assistente de pós-graduação já foi descrita acima.

Percebe-se através desta descrição resumida e incompleta que a estrutura e o funcionamento do departamento na Universidade americana são bastante complexos. O conceito de departamento está relacionado a um processo de descentralização de considerável importância no funcionamento da Universidade americana. Dentro do departamento, os membros do corpo docente têm um controle básico e direto sobre os currículos de graduação e pós-graduação; dentro do departamento estes membros controlam o pessoal de ensino; é dentro do departamento que o sistema de promoções, de recompensas e de aumentos por mérito é levado a efeito.

A coesão e o senso de identidade desenvolvidos pelo departamento dentro da Universidade americana são, em suma, basicamente o resultado do papel significativo que êle tem tido no desenvolvimento de sua própria área de conhecimento.

\section{GLOSSÁRIO}

\section{O DEPARTAMENTO NA UNIVERSIDADE}

Colíege (Faculdade): Neste trabalho a faculdade é considerada como uma das principais devisões duma Universidade, um conjunto de departamentos relacionados a uma grande divisão do conhecimento. A Faculdade de Letras e Ciências, por exemplo, incluiria as seguintes divisões: I) Humanidades (departamentos de inglês, línguas estrangeiras, história, filosofia, oratória, etc); II) Ciências Sociais (departamentos de antropologia, economia, geografia, sociologia, etc); e III) Ciências Naturais (departamentos de botânica, química, matemática, etc) .

Course (Disciplina): Neste trabalho significa um determinado número de aulas dadas por semana, durante um semestre sobre determinado assunto, e valendo um número de créditos específico. Por exemplo:

Economia 100 (Designação da disciplina e indicação do nivel - introdução).

3cr. MWF 10:00 (Valor em créditos da disciplina; dias da semana segundas, quartas e sextas - e horário da aula).

A Economia Americana (Nome da disciplina): Uma introdução às estruturas, métodos c problemas do Sistema Econômico Americano.

Course Syllabus (Programa da Disciplina): Um plano de trabalho para as aulas do curso. Nele, normalmente, será encontrado o conteúdo das aulas e das aulas de debates em pequenos grupos (recitation) para cada dia de aula programada. É particularmente útil como um dispositivo de controle para as disciplinas multiple-section.

Elective Subject (Matéria optativa): Dentro dos requisitos exigidos para graduação, existe certa flexibilidade que permite ao estudante optar (ou selecionar) por determinado número de disciplinas de qualquer área que êle julgue interessante. 
Estas são chamadas de matérias optativas. Dentro das áreas exigidas (tais como humanidades, ciências sociais, ciências naturais, etc), o aluno pode selecionar suas disciplinas a partir de uma lista fornecida para cada área (vide acima, nota 14).

Graduate Faculty (Corpo Docente de Pós-Graduação): É o conjunto dos professores, de todos os departamentos, que estão autorizados a dar aulas de disciplinas em nível de pós-graduação. Este grupo pode reunir-se como um conselho docente em separado para estudar assuntos relativos ao programa de pósgraduação da Universidade.

Graduate School (Escola de Pós-Graduação): Constitui-se de toda a organização dos programas de pós-graduação da Universidade, incluindo o corpo docente de pós-graduação (q.v.) que é a ela vinculado, do Diretor da Escola de Pós-Graduação, e das várias comissões.

Lecture Sections (Aulas tipo Conferência): É uma divisão de uma disciplina em que as aulas sobre os assuntos são dadas a grandes grupos de alunos (100 a 500). Normalmente, não há oportunidade para discussões ou debates.

Major (Disciplina de concentração): Uma disciplina selecionada pelo aluno como principal área de ênfase nos seus estudos universitários. O departamento determina o número e a natureza das disciplinas que são exigidas na categoria major. O número de cr;ditos permitido para uma matéria major normalmente não pode exceder $30 \%$ do total exigido para graduação (isto é, 40 créditos de um total de 120 exigidos). Isto é uma garantia de que o aluno terá tido, ao graduar-se, bastante contato com outras disciplinas além da sua major.

Minor (Disciplina de concentração): Normalmente, quando o aluno é júnior (ou terceiranista do curso de graduação), êle deve escolher uma disciplina major e/ou uma "minor". Então será exigido que curse certo número de créditos nesta disciplina. O departamento determina o número e a natureza das disciplinas que constituem uma matéria minor ou major naquela área de conhecimento. Ver também acima major (matéria).

Ph. D. Committee (Comissão de Doutorado): Um grupo de professores (normalmente 3) nomeados para assessorar e supervisionar a tese de um candidato ao doutorado. O presidente desse grupo é geralmente o professor major, que trabalha em estreito contato com o candidato na preparação da tese.

Quiz Sections (Aulas de debate e provas): Uma divisão da disciplina na qual os alunos são reunidos em pequenos grupos para debates e avaliação do aprendizado. Normalmente, estão relacionadas às sessões Lecture $e$ Recitation $q . \quad v$.

Recitation Sections (Aulas de debate): Uma divisão da disciplina na qual os alunos reunidos em pequenos grupos (15 a 30) respondem a perguntas e entram em debates sobre os assuntos acerca dos quais aulas já foram dadas. Normalmente, são combinadas com as conferências Alecture setions, q.v.).

School (Escola): Essencialmente a mesma que a definição resumida de Faculdade (College q.v.). O termo Escola é usado mais frequentemente para um grupo de disciplinas de um campo profissional, como Escola de Educação ou Escola de Medicina.

Section: Uma aula organizada com capacidade especificada de alunos, duração determinada e instrutor. As disciplinas multiple-section são aquelas para as quais é necessário organizar vários grupos de alunos. Por exemplo: Economia 100. 3cr. A Economia Americana. Sessão I: MWF 10:00 AM.: Sessão II: MWF 2:30 P.M. (o tempo de duração padrão é de 50 minutos); Sessão III: MW 7:00-8.15 P.M.

Seminar (Seminário): Uma disciplina em nível de pós-graduação na qual pequeno grupo de estudantes se reúne com um professor sénior para debates gerais e críticas dos relatórios individuais apresentados pelos alunos da turma. Normalmente, exige-se que o aluno escreva um relatório razoavelmente extenso sobre os estudos por êle desenvolvidos no período letivo.

O Estado de São Paulo - 26-5-68 
Apendice F. 4

\section{MOEDA UNIVERSITÁRIA：O "CRÉDITO"}

JOHN M. HUNTER

Neste artigo, o professor John M. Hunter, da Michigan State University, procura explicar o uso de um dos institutos mais característicos da organização universitária americana: o crédito universitário. A grande mobilidade estudantil, a enorme flexibilidade dos cursos oferecidos e a necessidade de um denominador comum para a avaliação do desempenho dos estudantes impuseram a adoção de um sistema de contabilidade académica no qual o «crédito» funciona como unidade de cálculo. O crédito é, assim, um «peso» que se relaciona vom o número de aulas semanais durante um período letivo. Associado às notas obtidas, êle permite o cálculo do grade points que é a medida do desempenho do estudante no exercício de suas tarefas académicas.

O sistema de avaliação descrito no presente trabalho apresenta numerosas vantagens. Parece-nos, assim, que nas escolas e Universidades cujos índices de matricula são elevados, o crédito universitário possa ser instrumento adequado para a plena utilização dos recursos humanos disponíveis em seus departamentos.

Os planos de reforma universitária causaram bastante agitação intelectual no Brasil, quando foram amplamente discutidas as várias propostas, contrapropostas, técnicas, ideais etc, nos Corpos Docentes, nos Conselhos Universitários, nos grupos de estudantes, no Congresso e nos jornais. Alguns querem seguir o sistema educacional dos Estados Unidos; outros condenam, a principio, qualquer aspecto da Educação nos E.U.A. - e ambos o fazem sem qualquer exame ou compreensão da realidade educacional daquele país. Existem outras implicações sócio-políticas ao se procurar copiar as Universidades deste país, e não tenho a intenção de discuti-las neste trabalho. Nem proporei qualquer método ou sistema para ser adotado pelos brasileiros. $\mathrm{Na}$ verdade, minha intenção é explicar o uso do «crédito» universitário, sobre o qual existe considerável confusão no Brasil, e sobre o qual várias pessoas me têm perguntado.

O crédito é tão apolítico como o dólar, o rublo ou a piastra. Pode-se atacar os E.U.A., a Rússia ou o Vietname e seus sistemas econômicos, políticos, religiosos e/ou sociais, mas é pouco provável que isso seja feito atacando-se a unidade de cálculo, o meio de troca, 
a moeda. E o crédito é simplesmente, nem mais nem menos, a unidade de cálculo que é largamente utilizada na educação universitária dos E.U.A. E me proponho a explicá-lo como tal: uma unidade-cálculo, que tem provado sua utilidade, num sistema onde ela é necessária. A Universidade brasileira geralmente não tem as características que exigiriam o sistema de créditos. Eu poderia estar ou não a favor de mudanças no sistema que exigiriam um sistema de cálculo semelhante, mas isto é outro assunto, que não será tratado aqui.

As três características que nos levaram a exigir um sistema de contabilidade universitária são as seguintes: 1) Existe grande mobilidade de estudantes entre as instituições e as disciplinas. Nós utilizamos os «créditos» para avaliar o que o estudante pode transferir de uma instituição para outra de um curso de graduação ou pós-graduação para outro. 2) Os cursos têm, via de regra, grande flexibilidade e inclusive a possibilidade de selecionar várias cadeiras optativas. É muito pouco provável que dois estudantes quaisquer venham a cursar exatamente o mesmo conjunto de disciplinas, e portanto é necessário algum dispositivo para estabelecer-se uma equivalência entre eles. 3) Mesmo seguindo um único curso, um estudante normalmente tem aulas em vários departamentos, além daqueles pertencentes ao seu principal campo de estudo. Sempre que isto ocorre, é necessário algum tipo de avaliação do que está sendo oferecido. Estas são as características que deram origem ao sistema de «créditos» ou qualquer sistema semelhante, algo de indispensável, mas parte completamente auxiliar dentro do sistema universitário.

Os «créditos» são simplesmente «pesos»: dados a cada disciplina oferecida pela Universidade. A norma para determinar o número de créditos de uma disciplina é geralmente o seu número de horas de aula por semana. Porém, esta «norma» é modificada de acordo com o conteúdo da matéria. Assim, uma cadeira de Matemática com cinco horas de aula por semana (exigindo uma média de duas horas de estudo além da aula, por cada hora de aula, ${ }^{1}$ teria «cinco créditos», enquanto que uma cadeira de Inglês com três horas de aula por semana teria «três créditos». Ao interpretar-se este fato, pode-se dizer que êle significa que a cadeira de Matemática «vale» 1,67 vezes a cadeira de Inglês. Algumas disciplinas têm horas de trabalho em laboratório, substitutos para o estudo fora da aula, e portanto a norma de hora-deaula exige uma modificação. Uma cadeira de Física com duas horas de aula e seis de laboratório pode ser avaliada como uma disciplina de 5 créditos. Outras, tais como Educação Física, que exigem pouco tempo de estudo fora das aulas, podem ter duas horas de aula por semana mas valer somente 1 crédito ou mesmo $1 / 2$ crédito. Assim, cada

1 Esta é uma parte essencial da definição, embora muito ambígua. 
matéria oferecida pela Universidade tem o seu valor em termos de «crédito» - o seu peso.

As Universidades geralmente descrevem suas exigências para graduação em termos de um mínimo de créditos ' e de um mínimo de grade points, deixando a cada departamento a descrição de suas exigências específicas. Pode-se supor que um estudante normal vai despender cerca de 48 horas por semana com seus estudos. Deste modo, se cada período letivo normal ê de três quartos ${ }^{4}$ de dez semanas, teríamos uma carga «normal» de 16 «créditos» por período letivo (16 horas de aula e 32 horas de estudo além da aula). Três períodos letivos por ano dariam então 48 créditos a serem obtidos por ano. Multiplicando-se este valor pelo número de anos dos cursos (quatro), teríamos um total de 192 créditos. Este total é, pois, a base, para toda uma Universidade, das exigências para graduação. Com respeito unicamente a estas exigências, o objetivo do estudante é cursar. com aprovação, disciplinas cujo valor total em créditos seja igual ou maior do que 192.

Outra parte das exigências da Universidade para a graduação é um mínimo de grade points. Isto requer uma explicação. Essencialmente, é a tentativa de medir, através de um só índice, o desempenho de um estudante, tendo por base o valor explícito das disciplinas em si (isto é, os créditos) e a qualidade do trabalho do estudante. Geralmente atribui-se ao estudante, ao concluir os estudos de uma disciplina num período letivo, notas em termos de letras: A, B, C, D e F. Atualmente já se fixam valores numéricos para estas letras, conforme relação abaixo:

$$
\begin{aligned}
& \mathrm{A}=4 \\
& \mathrm{~B}=3 \\
& \mathrm{C}=2 \\
& \mathrm{D}=1 \\
& \mathrm{~F}=0 \text { e reprovação }
\end{aligned}
$$

Temos, no exemplo que se segue, o cálculo de grade points para um estudante que teria seguido determinado curso durante certo período letivo.

2 Existem também disciplinas que não contam créditos, que podem ser cursadas para fins de suplementação (por exemplo: estudar uma matéria que deveria já ter sido cursada antes ou simplesmente para fins profissionais ou culturais sem relacionar-se aos estudos para graduação).

3 Os currículos podem não ser todos semelhantes entre si. Contudo, a maioria dos cursos de graduação tem quatro anos, o que permite um mesmo número de créditos exigidos para graduação em todos os cursos. Existem somente exceções ocasionais.

4 Muitas instituições funcionam na base de cada semestre com 10 semanas ao invés de três quartos de 10 semanas (ambos os períodos excluem o tempo dedicado a matriculas e exames). Em princípio, estas diferenças não são relevantes. 


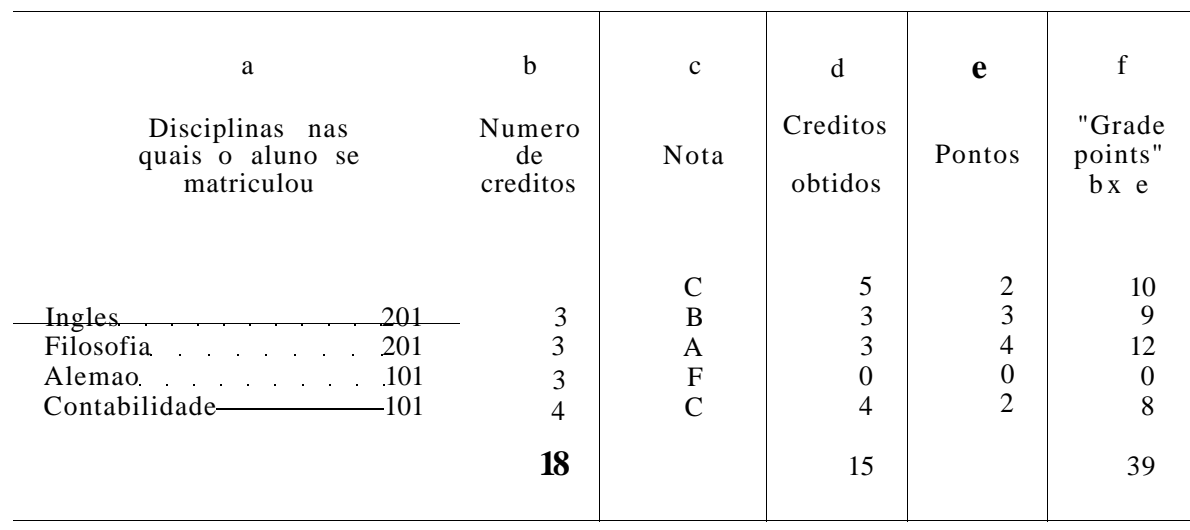

A coluna a contém o nome das disciplinas, identificadas por números, por uma questão de conveniência da instituição. Os valores em créditos das disciplinas que o estudante cursou estão representados na coluna $b$. A coluna $c$ indica $E$ nota que êle recebeu em cada disciplina. Uma vez que êle foi reprovado em alemão, o total de créditos obtidos (coluna $d$ ) foi menor do que o total de créditos das disciplinas nas quais se matriculou. A coluna e simplesmente inclui o valor numérico equivalente às notas obtidas, e a coluna $f$ contém o número de grade points para cada disciplina; é o produto das colunas $b$ e e. Deve-se notar que na cadeira de Matemática, que vale cinco créditos no exemplo acima, êle obteve nota $\mathrm{C}$, o que lhe deu mais pontos do que a cadeira de Contabilidade, que vale quatro créditos, onde êle também obteve nota C. Nosso estudante obteve assim quinze créditos a serem computados para sua graduação, tendo uma média de grade points igual a 2.17 para aquele período letivo (o total de grade points obtidos divididos pelo valor total em créditos das disciplinas, e não pelos créditos obtidos).

Se voltarmos um pouco atrás no seu histórico escolar, verificaremos que este é o quarto período letivo do nosso estudante e que êle obteve anteriormente as seguintes médias:

Valor total em créditos das disciplinas cursadas 51

Créditos obtidos ......................... 51

Grade points .......................... $\quad 117$

Média de grade points .................... 2.29

Os valores acima são facilmente atualizados; incluindo-se o período letivo, que examinamos, há:

Valor total em créditos das disciplinas cursadas

Créditos obtidos.

Grade points.

Média cumulativa de grade points 
A partir desta explicação razoavelmente detalhada, ${ }^{5}$ deve ficar bem claro qual é uma das principais utilidades do sistema de créditos: é possível obter-se, através de cálculos com as notas em termos de números, um resumo numérico do desempenho do estudante. Este resumo de médias de grade points é muito importante para nós. Dentre outras, tem as seguintes finalidades:

a) Os requisitos para graduação numa Universidade são descritos em termos de um mínimo de créditos e de um mínimo de grade points. Por exemplo: pode ser exigida uma média cumulativa de grade points no mínimo igual a 2 .

b) Exige-se que os estudantes mantenham uma média de grade points predeterminada, a fim de poder permanecer na Universidade. Se sua média «fôr inferior a 2.0, por exemplo, o aluno pode passar a uma situação experimental (prohation), durante um período letivo. no qual será exigido que êle obtenha um mínimo de 2.0 ou então deixe a Universidade.

c) Um departamento pode não permitir que um estudante obtenha um diploma na sua especialidade sem que êle tenha um desempenho satisfatório mínimo nas disciplinas daquele departamento, como, por exemplo, ter obtido uma média igual a $2.0 \mathrm{em}$ todas as cadeiras de Física para que êle possa se graduar em Física.

d) Existem algumas finalidades para as quais é importante podermos definir um estudante como primeiranista, segundanista, terceiranista. ${ }^{6}$ Esta definição é obtida simplesmente através do número de créditos que êle obteve. Os estudantes que têm menos de 45 créditos poderiam ser chamados de primeiranistas, os que têm 45 a 89 créditos de segundanistas etc.

e) As cargas máximas das disciplinas são descritas em termos de créditos. Alguns estudantes têm permissão para cursar um maior número de créditos do que o máximo normal, caso tenham um grade points suficientemente elevado. Os estudantes que tivessem uma média de grade points igual a 3.5 poderiam ter permissão para cursar um número de disciplinas que totalizaria até 20 créditos por período letivo, enquanto aqueles que tivessem uma média de grade points menor do que 2.2 poderiam ter o seu número de créditos limitado a 15 .

/) Para algumas finalidades (tais como pagamento de taxas), é necessário classificar o estudante como de «tempo integral» ou de

5 Este não é enunciado definitivo e alguns detalhes foram deixados de lado. Dependendo do motivo, podem ser dadas diferentes notas ao estudante que não consegue terminar uma disciplina. Pode ser dado um tratamento diferente às notas obtidas quando uma disciplina é repetida (o que conta são somente as notas obtidas nas disciplinas, nas quais finalmente passou).

6 Como, por exemplo, na distribuição de entradas, tendo por base a «antiguidade» para, digamos, uma partida de futebol. É necessário um alto grau de não ambiguidade! 
«tempo parcial». O primeiro pode ser definido como o que se matriculou para «13 ou mais créditos», e as taxas seriam pagas «por crédito» para aqueles matriculados com um menor número de créditos.

g) Até certo ponto, os programas da Universidade são divididos em subprogramas: divisão inferior (ciclo básico) e divisão superior ou especializada (ciclo profissional). Para promover um estudante da divisão inferior para a superior, geralmente se exige uma determinada média de grade points - quer numa base global, quer em algumas disciplinas específicas.

h) Além disso, nós o usamos no setor administrativo. Um determinado departamento pode ter 500 alunos frequentando suas aulas, outro cerca de 600. Mas isto pode ser uma medida má em função do tamanho da carga dos departamentos. Se o primeiro tem todas suas disciplinas de 4 créditos e o segundo de 3 , o primeiro tem uma carga de ensino igual a 2.000 créditos e o outro de 1.500. É inútil conhecer estas diferenças para a distribuição de recursos entre as várias unidades.

«O «crédito» como dispositivo de cálculo e de descrição tem ainda outra importante utilidade na elaboração de currículos específicos. Em Economia, por exemplo, exigimos que os estudantes cursem as seguintes disciplinas:

Disciplinas

Créditos

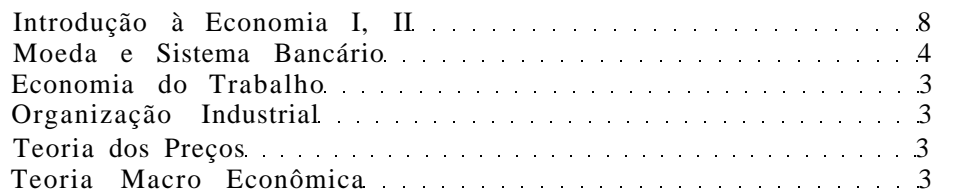

24

Além destas, outras disciplinas do Departamento de Economia devem ser cursadas a fim de totalizar 45 créditos (cerca de $1 / 4$ dos requisitos para a graduação). Exigimos que eles cursem matérias chamadas de «instrumentais» num total de 18 créditos, 12 dos quais devem ser escolhidos de uma única disciplina «instrumental». Temos um curso destinado a tratar de temas atuais para os estudantes de modo geral, mas não para o especialista, e assim, na descrição das cadeiras, acrescenta-se que aquela «não conta créditos para o estudante de economia especializado» (major). ${ }^{7} \mathrm{O}$ Departamento de Matemática ministra aulas sobre uma disciplina específica em

7 Major é o estudante que já escolheu definitivamente seu campo de especialização. Um major em Economia é um estudante do Departamento de Economia que seguiu os requisitos do currículo, a quem o Departamento provê aconselhamento em particular, o que será normalmente indicado para a obtenção de um diploma em Economia pelo Departamento. 
diferentes níveis de intensidade, e portanto caracteriza uma de suas disciplinas como a que «não vale créditos para estudantes com créditos em Matemática 208».

Deve-se mencionar uma utilidade final para o sistema de créditos. Quando o estudante se transfere de uma instituição para outra, seu trabalho na primeira é avaliado em termos das disciplinas que êle cursou, do seu desempenho nestas disciplinas, e finalmente o que êle pode transferir para a nova instituição. Isto é afinal convertido em «créditos de transferência».

Procuramos descrever aqui este animal peculiar, a unidade de cálculo das Universidades dos E.U.A.: o «crédito». Deve ser lembrado que êle é simplesmente isto: um dispositivo de cálculo, uma unidade de cálculo. Teve sua origem num sistema de considerável mobilidade e flexibilidade e na necessidade de lidar com grandes quantidades de estudantes.

É, como afirmam seus críticos, mecanista, mecânico e dá considerável ênfase às notas. Mas, em última análise, o sistema de créditos procura unicamente pesar os cursos, uns em relação aos outros. Neste aspecto deve ser mecânico e não ambíguo. Juntamente com as notas (tentativas para «objetivar» um assunto essencialmente subjetivo), os créditos podem ser utilizados num procedimento lógico para obter-se um resumo ponderado do desempenho individual. É isto o que pedimos seja feito pelo sistema; se seus resultados são ou não tratados adequadamente, é outro assunto muito diferente. 


\title{
RELATÓRIO DA USEAPES
}

\author{
(FORMA PRELIMINAR)
}

\section{Cap. VII - - Recomendações}

Os objetivos do Projeto de Planejamento para o Ensino Superior, conforme estão originalmente especificados no contrato, não demandam unicamente pela formulação de recomendações para uma ação terapêutica nesta área, mas também pela apresentação de um plano específico para a execução destas recomendações.

O projeto não se desenvolveu segundo as linhas estabelecidas pelo acordo. Acreditamos que: 1) os métodos operacionais e os objetivos propostos pela USÂID para este projeto não eram realistas; 2) que demonstravam uma infeliz falta de compreensão dos processos adequados para auxiliar o planejamento e a mudança em Educação; 3) que os métodos originais e a insistência inflexível sobre os mesmos demonstrou notável falta de sensibilidade com relação à realidade brasileira; 4) que a política e as decisões dos E.U.A, foram indevidamente influenciadas pela oposição manifestada ao MEC-USAID; e 5) que, mesmo em face da esmagadora evidência das deficiências do acordo, foi dada atenção insuficiente aos conselhos e recomendações da equipe americana com respeito à modificação do plano original. Bem tarde a equipe pôde seguir por alguns caminhos de cooperação produtiva com os membros brasileiros da equipe; entretanto, quando estas atividades começavam a mostrar resultados positivos e elevado potencial de realizações, o projeto foi interrompido pela decisão unilateral da USAID.

Não apresentamos recomendações exatas para a solução definitiva de problemas específicos da Educação superior no Brasil. É fácil identificar áreas-problema na Educação superior brasileira, e qualquer educador brasileiro pode fornecer uma lista delas. Estes problemas foram completamente identificados e extensas listas foram compiladas em projetos e levantamentos anteriores. ${ }^{1}$ Poderíamos sugerir uma

1 Vide, por exemplo, o relatório da UNESCO sobre uma breve visita a algumas Universidade brasileiras (Lussier, I; J. Lauwerys and D. J. $\mathrm{K}^{\mathrm{r}}$ ienen: Brazil-Advisory Mission on Development of Higher Education. Paris, UNESCO, 1966, 29 págs.); e vide o estudo de Jayme Abreu: «Problemas Brasileiros de Educação», no livro do mesmo título (Rio de Janeiro, Editora Lidador, 1968. págs. 13-38). 
ordem diferente na importância relativa destas compilações. Damos, por exemplo, grande importância à necessidade de um sistema de cursos de pós-graduação aumentado e uniforme, já que isto está tão intimamente relacionado aos problemas do ensino em tempo parcial, de pesquisa, da administração e do planejamento da utilização eficiente de recursos educacionais, e da evasão de capitais para pagar o know-how importado.

A formulação de soluções realistas dos problemas de Educação brasileira é um processo bem complicado. Simplesmente como um exemplo, discutir a «solução» do «problema do reconhecimento» envolveria completa explanação sobre as leis existentes, sobre as instituições e seus métodos, e uma análise exploratória das alternativas. Isto é de alta complexidade e é tarefa muito importante para ser executada superficialmente.

Embora não apresentemos recomendações para a solução de problemas específicos, talvez nossa experiência nos autorizasse a fazer algumas sugestões e recomendações quanto à política para programas de auxílio à Educação superior brasileira. Dois membros da equipe tiveram a oportunidade notável e incomum de se dedicarem intensa e exclusivamente ao estudo e análise da Universidade brasileira durante um período de tempo bem considerável; os outros dois membros, por um período menor, porém ainda considerável. Cada membro da equipe possuía uma identificação intima e de longa data com as Universidades dos E.U.A., e todos tiveram bastante experiência com Universidades estrangeiras em várias regiões do mundo.

Nossas sugestões, com os devidos comentários introdutórios, são as seguintes:

1. Uma estrutura educacional é um complexo de variáveis. Cada variável está intimamente e às vezes inseparavelmente relacionada a muitos outros elementos do todo. Todos os componentes da estrutura da Educação brasileira desenvolveram-se a partir de circunstâncias sociais e históricas singularmente «brasileiras» e a elas estão diretamente ligados. Tal sistema não pode ser subitamente transformado numa estrutura nova e diferente. Certamente mudará através de lento processo de evolução, mais ou menos em resposta às necessidades gerais da sociedade da qual êle faz parte, e mais especificamente em resposta àqueles elementos da sociedade aos quais êle é mais sensível. Através de um planejamento cuidado e esclarecido, deverá ser possível a participação de fontes externas nesta evolução, facilitando-a. Para que isto possa ser feito, as fontes «externas» precisam tornar-se perfeitamente informadas sobre os agentes de controle e órgãos envol-

2 A aritmética aqui é interessante. A equipe compreendia um Chancellor. um Dean e dois ex-presidentes de departamentos, com bem mais de 100 anos de participação coletiva na vida de Universidades americanas, e algo mais de 10 anos de experiências relacionadas a Universidades no estrangeiro. 
vidos nesta evolução. Julgamos que a prolongada associação de educadores americanos e brasileiros em esforços conjuntos para lutar com os problemas que se apresentam trará mais benefícios do que o dispendioso, porém menos produtivo auxílio doado sob a forma de equipamento e materiais.

As soluções para os problemas educacionais brasileiros que envolvem uma transformação radical de um único elemento do sistema (estrutura administrativa, os centros de estudos básicos, a introdução do departamento na Universidade, por exemplo) seriam amplamente ineficazes, uma vez que resultam em «novos rótulos» para os elementos existentes e não na sua «transformação». Não se espera que este procedimento produza componentes universitários funcionando em harmonia com o equilíbrio da estrutura. Esta equipe poderia ter proposto muitas destas mudanças estruturais nos primeiros meses do projeto; entretanto, através de um estudo extenso e intensivo da Universidade brasileira, a equipe convenceu-se da futilidade pragmática de recomendar tais soluções.

Acreditamos que a USAID deva dar apoio à colaboração prolongada e contínua de educadores americanos e brasileiros. Vários fatores relacionados a este apoio são de importância. Consultores a curto prazo importados para estudarem problemas específicos são, por si mesmos, de valor limitado e às vezes negativo; mas podem ser valiosos se adjuntos a uma missão já existente, bem estabelecida, perfeitamente orientada e permanente. A missão ou equipe permanente teria a tarefa crítica e significativa de ajustar e modificar as sugestões dos consultores à luz do índice de factibilidade da situação, e, especialmente, teria a tarefa de participar da execução das recomendações.

2. Descrevemos anteriormente o subprojeto sobre o reconhecimento, levado a efeito durante os últimos meses do projeto pelo Consertium em colaboração com membros do Conselho Federal de Educação, com representantes da equipe brasileira, e com consultores brasileiros. Queremos frisar que o apoio da USAID a este projeto deve continuar. A atividade de continuação inicialmente envolveria uma revisão final e a execução do plano para a pesquisa sobre bibliotecas (vide Parte IV acima; e apêndice A). ${ }^{3}$ Este é somente um elemento do projeto sobre o reconhecimento, de maior envergadura, que incluiria um esquema de pesquisa semelhante para obter dados e eventualmente normas para a administração e finanças universitárias, qualificações do corpo docente, composição do corpo discente, estrutura dos currículos e instalações físicas. A equipe preparou documentos preliminares sobre algumas áreas específicas; contudo, a parte sobre biblioteca encontra-se num estágio mais avançado de desenvolvimento. A situação é altamente favorável para a obtenção de dados significa-

3 Parte IV é o relatório das atividades do grupo de trabalho para o projeto de reconhecimento e autorização; o Apêndice A traz os documentos preparados pelo grupo. 
tivos e de resultados úteis nesta área, porquanto os membros do Conselho Federal de Educação, com os quais trabalhamos, ocupam posições-chave no Conselho (Newton Sucupira é o presidente da Câmara de Ensino Superior, Valnir Chagas é membro desta Câmara; e Rubens Maciel é também um dos membros, bem como relator do subprojeto sobre reconhecimento)- Sentimos que estes conselheiros estão convencidos do valor do projeto sobre reconhecimento e aceitaram a metodologia empregada. A EAPES brasileira participou de várias reuniões de debates, mas o papel de catalisador foi desempenhado pela equipe americana. Consequentemente, é preciso o provimento de pessoal americano adequado, além de verbas para a realização da pesquisa sobre bibliotecas. No presente momento, as circunstâncias são as mais favoráveis para a continuação do projeto; e os resultados podem representar uma contribuição de extrema importância na área do planejamento da Universidade brasileira. Trouxemos penosa e pacientemente estas atividades até o exato limiar de resultados produtivos; se o interesse ativo e o trabalho produzido fôr perdido, a maior contribuição potencial do Consortium também estará perdida. Portanto, insistimos em que as autoridades competentes da USAID estabeleçam sem demora contato com o Conselho Federal e com a equipe de planejamento brasileira, a fim de explorar as possibilidades de maior desenvolvimento do projeto sobre o reconhecimento, conforme o proposto e esquamatizado pelo grupo de trabalho Consortium-EAPES-CFE.

Terminamos expressando nossa posição geral. Endossamos e chamamos a atenção dos planejadores educacionais para os postulados e políticas de auxílio a Universidades estrangeiras, formulados por Burton Friedman, da Fundação Kettering. Resumindo, estes são: a) é de interesse nacional para os Estados Unidos da América estudar, estabelecer entrosamento íntimo e contínuo, e auxiliar Universidades das novas nações ou das nações em desenvolvimento; b) Estas são tarefas a longo prazo. Não levam, por si só, a programas de impacto. As tarefas exigem o esforço ininterrupto de competentes executores; estes exigem o apoio ininterrupto de padrões de confiança; c) as faculdades públicas e privadas nos E.U.A, são os «executores» indicados; d) o estudo e aquele entrosamento com Universidades estrangeiras não é tarefa que possa ser adequadamente realizada por órgãos do Governo federal dos Estados Unidos; e e) mas o Governo dos E.U.A, e as Fundações nos E.U.A, são os patrões indicados, que podem adequadamente financiar as tarefas recomendadas.

\author{
Tradução de \\ Jacques R. Velloso \\ Julho -1968 .
}

Deve ser estudada a completa racionalização desta política; Burton D. Friedman, «Needed: A National Policy Toward llniversities to the Underveloped World», in Public Administration Review, Jan-Fev., 1968, págs. 39-46. 


\title{
USEAPES REPORT
}

\author{
(DRAFT)
}

\section{Chapter VII - Recommendations}

The objectives of the Higher Education Planning Project, as originally specified in the contract, call not only for the formulation of recommendations for remedial action, but also for the presentation of a specific plan for the implementation of these recommendations.

The project did not develop along the lines envisaged in the agreement. We believe that: 1) the proposed operational procedures and objectives for this project were unrealistic; 2) that they displayed an unfortunate lack of comprehension of the appropriate processes for aid to educational planning and change; 3) that the original procedures and the rigid insistence upon them demonstrated remarkable lack of sensitivity for Brazilian reality; 4) that U.S. policy and decisions were unduly influenced by the opposition expressed to MEC-USAID; and 5) that, even in the face of overwhelming evidence of the deficiencies in the agreement, insufficient attention was given to the advice and counsel of the American team with respect the modification and revision of the original plan. Belatedly, the team was allowed to proceed along certain productive paths of collaboration with Brazilian counterparts; yet at the moment when these activities were beginning to show positive results and a high achievement potential, the project was discontinued.

We present no precise recommendations for the definitive solution of specific problems in Brazilian Higher Education. It is easy to identify problem areas in Brazilian Higher Education. Any Brazilian educator can supply such a list; in previous surveys and projects, these problems have been thorouhly identified and extensive listings have been compiled. ${ }^{x}$ We might suggest a different order of relative importance in these compilations. For example, we give a high

1 For example, see the UNESCO report of a brief visit to certain Brazilian Universities: (Lussier, I; J. Lawerys and D. J. Krienen: Brazil-Advisory on Development of Higher Education. Paris, UNESCO, 1966, $29 \mathrm{pp}$; and see the study by Jayrne Abreu: «Problemas Brasileiros de Educacao, in the book by the same title (Rio de Janeiro, Editora Lidador, 1968, pp. 13-38). 
ranking to the need for an expanded and uniform system of postgraduate programs, since this is so intimately related to the problems of part-time teaching, research, the conduct and planning of efficient utilization of educational facilities, and the financial drain of imported technical «know-how».

Realistic problem-solving for Brazilian education is To do this, the «outside» sources need to become fully informed about (and thoroughly identified with) the control agents and agencies involved. We see more benefits arising from the extended association of U.S. and Brazilian educators in joint endeavors to cope with problems than from the expensive but less productive aid granted in the form of equipment and hardware.

Solutions for Brazilian educational problems which involve a radical transformation of a single element of the system (administrative structure, the basic studies centers, the introduction of the academic department, for example) will be largely inneffective, since they result in «relabeling» but not «transforming» of existing elements. This procedure is not expected to produce university components operating harmoniously with the balance of the structure. This team could have proposed many such structural changes in the early months of the project; with extended and intensive study of the Brazilian university scene, however, the team became convinced of the pragmatic futility of recommending such solutions.

We believe that AID should undertake to support a prolonged and continuous collaboration of American and Brazilian educators. Several related factors are of importance. By themselves, short-term consultants imported to study specific problems are of limited and at times of negative value; but they would be valuable adjuncts to a pre-existing, well established, thoroughly oriented, and permanent mission. The permanent mission or team would have the critically significant tasks of adjusting and modifying the suggestions of the consultants in the light of the feasibility-index of the situation, and, especially, of participating in the implementation of the recommendations.

2. We have describel above a sub-project on accreditation undertaken in the final months of the project by the Consortium in collaboration with members of the Federal Council of Education, representatives of the Brazilian team, and Brazilian consultants. We urge that USAID support for this project be continued. Initially, the continuation activity would involve a final revision and execution of the plan for library research (see above, Section IV; and appendix A). quite involved. Simply as an example, a discussion of the «solution» of the «accreditation problem would involve a thorough explanation of existing law, institutions and procedures, and the exploratory analysis of alternatives. This is much too complex and important a task to be undertaken superficially. 
Although we advance no recommendations for the solution of specific problems, it is appropriate to make some policy suggestions and recommendations related to aid programs in Brazilian higher education. Two members of the team had the remarkable and analysis of the Brazilian university for a very appreciable period of a very appreciable period of time; the two other members, for a still appreciable, but lesser period. Each member of the team possessed a long and intimate identification with the U.S. universities, and all had considerable experience with the foreign university in several areas of the world.

Our suggestions, with appropriate prefatory comments, are as follows:

1. An educational structure is a complex of variables. Each variable is intimately and at times inseparably related to many other elements of the whole. All the components of the structure of Brazilian education developed from and are tied directly to uniquely «Brazilian» social and historical circumstances. Such a system cannot be suddenly transformed into a new and different structure. It certainly will change by a slower process of evolution, more or less in response to the general needs of the society of which it is a part, and more particularly to those parts of the society to which it responds and to which it is sensitive. With careful and enlightened planning, it should be possible for outside sources to participate in and to facilitate this evolution. This is only one element of the larger accreditation project, which would include a similar reserach design to produce data and eventually standards for university finance and administration, faculty qualifications, student composition, curricular structure, and physical facilities. Preliminary documents were produced by the team for some of the areas specified; the library section, however, is in the most advanced stage of development. The situation is highly favorable for the production of significant data and useful results in this area, since the Federal Council of Education members with whom we have worked occupy key positions in the Council (Newton Sucupira is the Chairman of the Higher Education Committee; Valnir Chagas is a member of this committee; and Rubens Maciel is also a member as well as relator of the sub-committee on accreditation). These conselheiros, we feel, are convinced of the value of the accreditation project and have accepted the methodology employed. The Brazilian EAPES team has participated in several workshop sessions, but probably would not (and should not) assume the role of catalyst thus far played by the U.S. team. Appropriate

- The arithmetic here is interesting. The team was comprised of a Chancellor, a Dean, and two past departmental chairmen, with well over 100 years of collective participation in American Universities affairs, and something over. 10 years of foreign university-related experience. 
American personnel input is consequently needed, in addition to funds for the implementation of the library research. The circumstances are most favorable at the present moment for continuation; the results can represent an extremely important contribution in the field of Brazilian university planning. We have brought this activity painfully and patiently to the very threshold of productive results; if the active interest and the momentum generated is lost, the most significant potencial contribution of the Consortium project is also lost We therefore urge that the appropriate USAID authorities establish contact with the Federal Council and the Brazilian planning team without delay to explore the possibilities for the further development of the accreditation project along the lines proposed and outlined in the Consortium-EAPES-CFE workshop.

We close with this expression of our general position. We endorse and highly recommend the postulates and policies for aid to foreign universities advanced by Burton Friedman of the Kettering Foundation. Summarized, these are: a) it is the national interests of the United States to study, to cultivate, and to support universities of the new or developing lands; $b$ ) these are long-range tasks. They do not lend themselves to crash programs. The tasks require the uninterrupted effort of competent performers; the performers require the uninterrupted support of reliable patrons; c) the private and public colleges in the United States are the indicated "performers»; d) the study and cultivation of foreign universities is not a task which, with propriety, can be perfomed by agencies of the federal government of the United States; and e) The Government of the United States; and /) The Government of the United States and private foundations in the United States are the indicated patrons that can. with propriety, underwrite the recommended tasks.

3 The complete rationale of this policy should be studied; see Burton D. Friedman, «Needed: A National Policy Toward Universities to the Underdeveloped World, in Public Administration Review, Jan-Fev. 1968, pps. 39-46. 
DEPARTAMENTO DE IMPRENSA NACIONAL 1969 